\title{
From ALbA to AoteAroA: Profiling NEW ZEALAND’s SCOTS MigRANTS, 1840-1920
}

Rebecca A. Lenihan

\author{
A thesis submitted to \\ Victoria University of Wellington \\ in fulfilment of the requirements for the degree of \\ Doctor of Philosophy
}

Victoria University of Wellington

2010 


\section{DECLARATION}

I declare that this thesis is my own work and has not been submitted in any form for a degree at any university or other institute of tertiary education. Information derived from the published and unpublished work of others has been duly acknowledged in the text.

Rebecca Lenihan, January 2010 


\begin{abstract}
While New Zealand has been described as more Scottish than any other country beyond Scotland, and Scots consistently made up nearly 20 per cent of the immigrant population of New Zealand to 1920, as a group New Zealand's Scots migrants have remained relatively blurred. The distinctive national backgrounds of New Zealand's British migrants have seldom been recognised in general histories or in specialist studies of migration to the country, migrants having tended to be categorised as 'British' and 'Non-British', leading to what Akenson aptly described as the 'lumping of all white settlers into a spurious unity.' This thesis, conceived as part of a larger research project investigating the experiences and contributions of Scots in New Zealand, seeks to establish key characteristics of the Scottish migrants arriving between 1840 and 1920. Five core questions are addressed: 'from where in Scotland did they come?', 'who came?', 'when?', 'in what numbers?', and 'where did they settle?'.

While previous studies have suggested partial answers to some of these questions, the present research offers a more full and detailed profile of New Zealand's Scots migrants than has previously been available. Critically, it takes the earlier findings further. Though the investigation has been based primarily upon statistical analysis of a genealogically-sourced database of 6,612 migrants, quantitative analysis has been supplemented by qualitative case studies. Comparison with a second set of data derived from death certificates has enabled a testing of the validity of genealogical data as a source for migration studies.

In addition to the five central questions around which the thesis is structured, the study also addresses issues of internal migration within Scotland, emigration to other destinations prior to arrival in New Zealand, individual and generational occupational mobility, chain and cluster migration among Shetland migrants, and return migration.
\end{abstract}




\section{ACKNOWLEDGEMENTS}

Many debts of gratitude small and large are accrued over the course of a $\mathrm{PhD}$ thesis. Thanks must first and foremost go to my supervisors, Dr Brad Patterson and Dr Rosalind McClean for their time, their comments, and their encouragement throughout the thesis process. Further very special thanks are due to Associate Professor Jim McAloon, not least of all for reading and commenting upon several drafts over the final few months.

Sincere thanks is also owed to the following people, in no particular order, for reasons they know and need not be recited here: Fellow members of the 'New Zealand Scots' Marsden Funded research team; Maureen West; Dr Marjory Harper; Elizabeth Angus and everyone else at the Shetland Family History Society; Brian Smith, Angus Johnson, Joanne Wishart and Blair Bruce at the Shetland Archives; Michelle Gait from the reading room of the special library at Aberdeen University; Professor Cairns Craig, Jon Cameron, Dr Rosalyn Trigger, Dr Michael Brown, and, especially, the late Professor George Watson, at the Research Institute of Irish and Scottish Studies, Aberdeen University; the Stout Centre for New Zealand Studies, not least of all for providing an office with such an inspiring view. Thank you too to Dr Steve Behrendt for his advice and pearls of wisdom regarding, among other things, data entry, storage, and analysis; to Dr Jock Phillips for allowing me the use of the PNZ data, and for the very useful discussions with him early in my own data collection and analysis process.

A thesis such as this one is relies very heavily on the kindness and enthusiasm of strangers. Thank you to all those who contributed to the NZSG Scottish Interest Group's Register of Immigrants arriving in New Zealand prior to 1 January 1921, and to the people who coordinated that register. Also to the many family historians who have published their family trees and other information on such websites as 'roots.web', their own personal family history pages and (especially) bayanne.co.uk; without such information being so readily available this study would have been quite different. Special thanks goes to the many kind people (too many to name) who provided me with their family material and research personally, for taking an interest in my research and assuring me it is of interest to someone beyond myself and my supervisors! Especially notable among these kind folk are Bobbie Amyes, Spin and Joan Sutherland, Janette Godfrey, and Theodora Wickham.

On a more personal level, thank you to:

Mum, Dad, Tara and Gucciana for my sanctuary away from my thesis work. Special thanks to Mum whose steady hand made the maps possible, and who made sure I was eating properly, and generally being taken care of during the final phases of the thesis writing especially.

Margaret McIver, formerly of Portnaguran, Isle of Lewis, for a roof over my head, for providing me with a family far away from home, for her friendship, her encouragement and her wisdom.

My fellow ‘Full Swing’-ers, for regular doses of sanity preservation. 
To Tanja Bueltmann and Gerard Horn must go my final thanks. Thank you both for your comradeship, for listening attentively when I needed to rant, and for joining in those rants when appropriate. Thank you for chatting excitedly with me when a 'lost' migrant was found or a table worked out just as planned and for sharing your moments of research triumph with me. Thank you for being my stalwart companions through the usual and not so usual tribulations that came with the thesis. Thank you for the laughter (albeit some of it hysterical), and the contemplative silences. These four years would have been much more difficult without having you both here beside me going through the same things. Thank you. One hundred times thank you. 


\section{CONTENTS}

List of Maps $\quad$ ix

List of Tables $\quad$ X

List of Figures xii

Abbreviations xiii

Chapter One

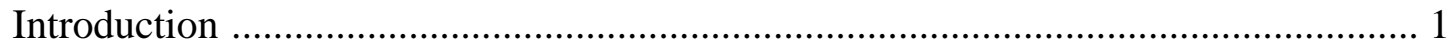

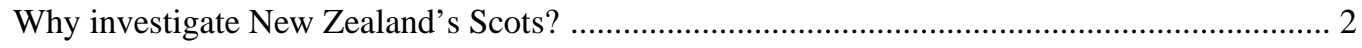

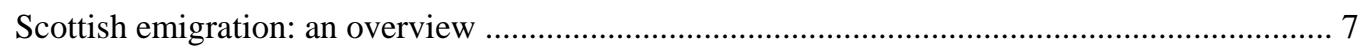

Scottish migrant flows to New Zealand ......................................................................... 13

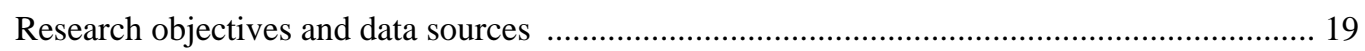

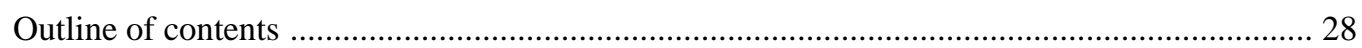

Chapter Two

'Farewell, the bonie banks of Ayr!': The Scottish origins of New Zealand's

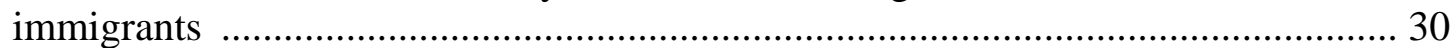

New Zealand's Scottish immigrant's regional and county origins ........................................... 31

An outline of several characteristics of Edinburgh, Aberdeen, Argyll, Glasgow and the

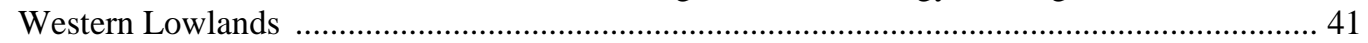

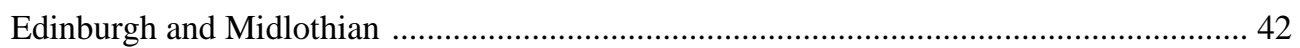

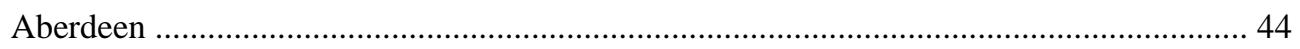

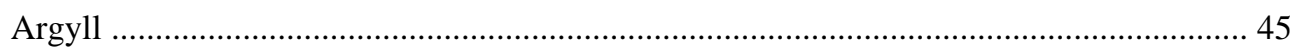

Glasgow and the Western Lowlands .............................................................................. 48

Migration within and outside of Scotland prior to emigration to New Zealand ...................... 51

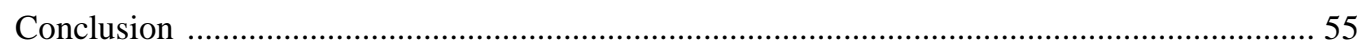

\section{Chapter Three}

From 'the Land of Heather and Thistle' to 'the Land of Kauri and Fern':

Patterns of Scottish settlement in New Zealand ..................................................... 58

New Zealand provincial patterns of Scottish settlement ...................................................... 59

New Zealand county patterns of Scottish settlement .......................................................... 75

Scottish settlement in Wellington Province: case studies ..................................................... 82

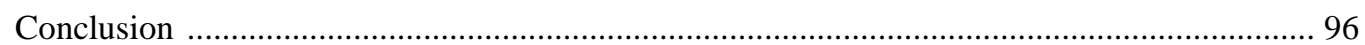

\section{Chapter Four}

Who were New Zealand's Scots?: Analysis of age, gender, and marital status at arrival by origin, settlement and period of arrival

Gender, age and conjugal condition in Scotland, in the New Zealand population, and among

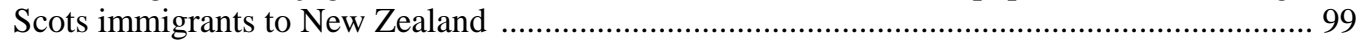

Demographic profile of New Zealand's Scots by origin ...................................................... 105

Demographic profile of New Zealand's Scots by place of settlement .................................. 111

Demographic profile of New Zealand's Scots by period of arrival ....................................... 116

Testing the genealogically sourced data set - comparison with the Peopling of New Zealand

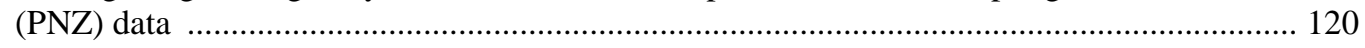

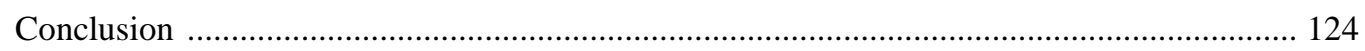




\section{Chapter Five}

'Refugees from the smoke stacks and grime of industry'?: Migrant occupations in

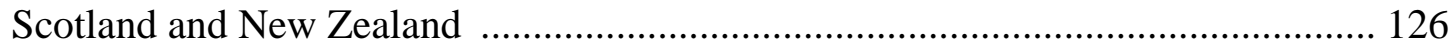

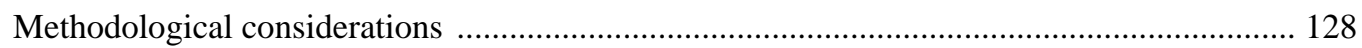

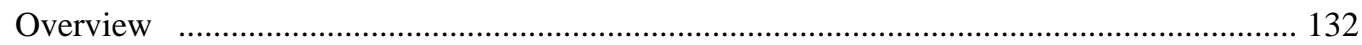

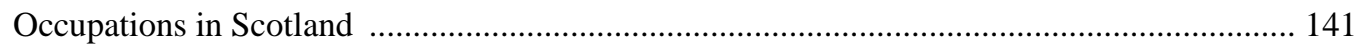

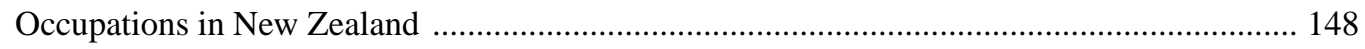

Scottish regional differences within migrants’ New Zealand occupations .............................. 156

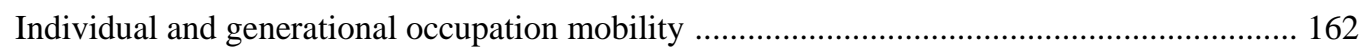

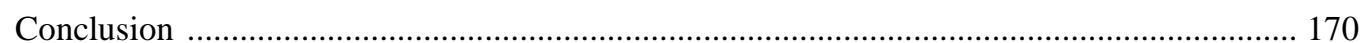

\section{Chapter Six}

'In habits, in character, in fact [in] everything except language... like the

Norwegians': New Zealand's Shetland immigrants - a county case study .............. 172

Background and overview to Shetland migration ………………………………………....... 173

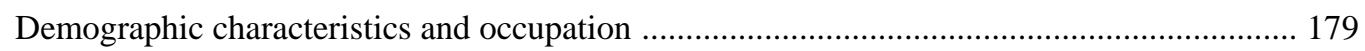

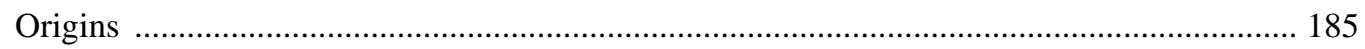

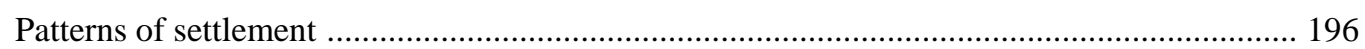

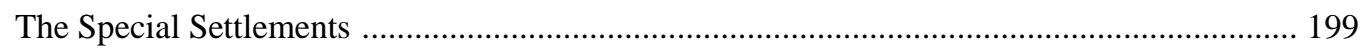

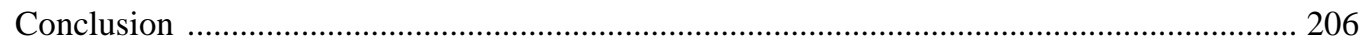

\section{Chapter Seven}

'Empire Settlement' and beyond: an epilogue to the first eighty years of organised

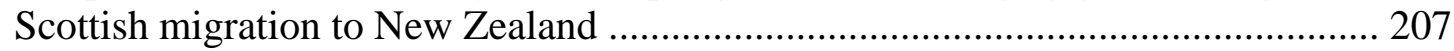

Emigration from Britain between the wars: basic trends ....................................................... 208

Immigration to New Zealand between the wars: basic trends .............................................. 211

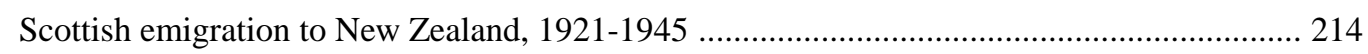

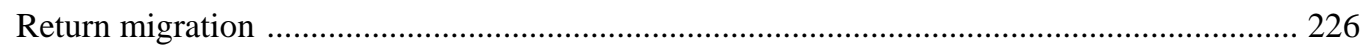

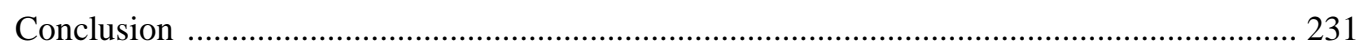

\section{Chapter Eight}

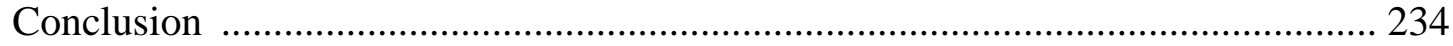

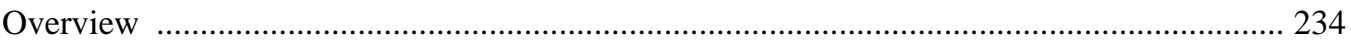

Possible paths for future research ............................................................................ 238

\section{Appendix 1}

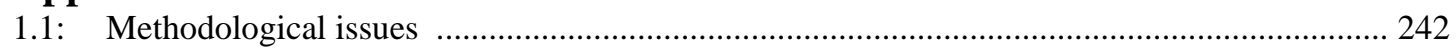

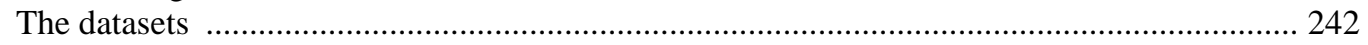

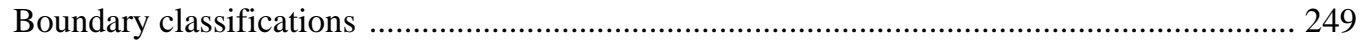

\section{Appendix 2}

2.1: Percentage of the migrants in the NZSG database arriving from each county of Scotland by each period of arrival

2.2: Percentage of the Scotland total population living in each county at the census .................... 253

\section{Appendix 3}

3.1: Proportion of each Scottish county's migrants residing in the provinces of New Zealand ...... 254

3.2: Distribution of the Scottish regional origins of migrants in New Zealand's five principal provinces by period of arrival

3.3a: Proportions of Scots-born living in each NZ county, and the proportions of each NZ county that were born in Scotland including and excluding the NZ-born population of those counties, 1891 Census 
3.3b: Proportions of Scots-born living in each NZ county, and the proportions of each NZ county that were born in Scotland including and excluding the NZ-born population of those counties, 1911 Census

3.4: Diagram of the Cameron family and some of their associates in East Wairarapa .................. 261

3.5: Diagram of connections between the Scottish migrants and New Zealand born individuals of Scottish descent in Fordell, Mangamahu, Turakina and Parewanui

\section{Appendix 4}

4.1: Showing the mean, minimum, maximum, lower quartile, median and upper quartile age statistics for Scots migrants to New Zealand by county and region of birth

4.2: $\quad$ Marital status composition of Scots migrants by county and region of birth arriving in New Zealand between 1840 and 1920

4.3: Proportion of male and female Scots migrants that arrived in New Zealand as children, single or married in each period of arrival

\section{Appendix 5}

5.1: Methodological and classification considerations regarding migrant occupations

Methodology

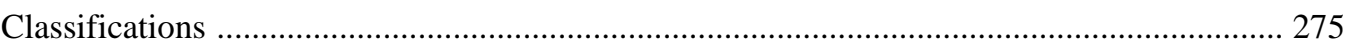

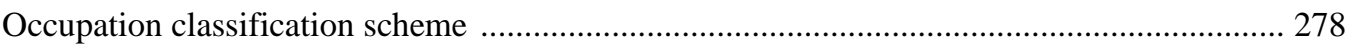

5.1a: Proportion of NZSG Scotland Occupation 1 and NZSG New Zealand Occupation 1 migrants fitting within each occupation sector and occupation type, 1840-1920

5.2: Employment prior to emigration to New Zealand: proportion of Scottish migrants who had been employed in each manufacturing occupational industry and type, by region of birth

\section{Appendix 6}

6.1: Diagram of the Davidson/Nicolson family chain of migration, 1873-1906

6.2: Diagram of the Fordyce/Robinson family chain of migration, 1860-1911

6.3: Diagram of connections between the Harper, Flaws, Mouat, Henderson and Anderson families

6.4: Diagram of connections between the Unst-born migrants to New Zealand 305

6.5: Diagram of connections between the thirty-one Port William Special Settlement settlers, 1874 


\section{MAPS}

Map 1: Thirty-three counties of Scotland (as used in this thesis) .....................................................

Map 2: Six regions of Scotland (as used in this thesis) ........................................................... xvi

Map 3: Sixty-three counties of New Zealand created in 1876 ........................................................ xvii

Map 4: Provinces of New Zealand (as used in this thesis) ........................................................ xviii

Map 5: Showing the distribution of the Scotland born population of New Zealand at the 1916

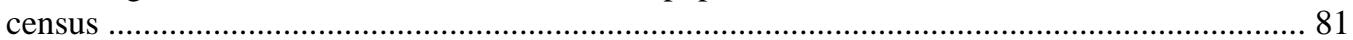

Map 6: Showing the location of Mangamahu, Fordell, Turakina and Parewanui, New Zealand ......... 87

Map 7: Parishes of Shetland (as used in this thesis) ................................................................... 174

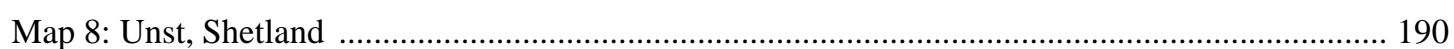




\section{LIST OF TABLES}

2.1: Proportion of New Zealand immigrants from each region of Scotland, with indices of representation based on the Scottish population distribution in 1871

2.2: Indices of representation relating county of birth of NZSG Scottish emigrants to New Zealand by period of arrival to the population of Scotland in those counties at the relevant censuses

3.1: Percentage of migrants from each region of Scotland living in each province of New Zealand

3.2: Proportions of Scots-born living in each New Zealand county, and the proportions of each New Zealand county that were born in Scotland including and excluding the New Zealandborn population of those counties, 1878

4.1: New Zealand Scots immigrant age statistics

4.2: $\quad$ Ratio of females to every 100 males in the 1881 population of Scotland, and in the NZSG data

4.3: Scots migrants arriving in New Zealand aged fifty-plus

4.4: Showing the proportion of the Scottish population and of the NZSG migrants married or single

4.5: Showing the proportion of children who were male and the ratio of female children to every 100 male children in the home population and the NZSG data, from each region of Scotland

4.6: Ratio of females to males in the Scotland-, Ireland- and England-born and the New Zealand total population, 1881

4.7: Showing the ratio of female to male children and proportion of children who were male in the NZSG data and at the 1878 census by New Zealand province

4.8: Ratio of Scottish female migrants to every 100 Scottish male migrants in each period of arrival

4.9: Ratio of Scottish female migrants in each period of arrival to every 100 Scottish male migrants, by region of birth

4.10: Age statistics for Scots migrants in New Zealand by period of arrival

4.11: Ratio of Scottish female child migrants in each period to every 100 Scottish male child migrants

4.12: Ratio of Scottish female migrants to every 100 male migrants in each period of arrival

4.13: Mean ages of Scots migrants to New Zealand arriving between 1840-1920 by region of birth

5.1: Proportion of the occupied population of Scotland employed in each sector

5.2: Proportion of the occupied population of Scotland employed in each sector, by region and gender

5.3: Employment prior to emigration to New Zealand: proportion of Scottish migrants who had been employed in each occupational sector, by region of birth

5.4: Proportion of males and females in the New Zealand population employed in each sector .... 149

5.5: Employment subsequent to emigration to New Zealand: proportion of male and female Scottish immigrants in each sector

5.6: Employment subsequent to emigration to New Zealand: proportion of the Public Service/Professional/Independent sector by occupation type

5.7: Employment subsequent to emigration to New Zealand: proportion of Scots in New Zealand provinces employed in each sector 
5.8: Proportion of the employed population of New Zealand in each province employed in each sector in 1878

5.9: Employment subsequent to emigration to New Zealand: proportion of migrants from each region of Scotland employed in each sector

5.10: Employment subsequent to emigration to New Zealand: proportion of each sector born in each region of Scotland

5.11: Occupational mobility within individual lifetimes: proportion of migrants in each occupational sector of Scotland by subsequent sector in New Zealand

5.12: Occupational mobility within individual lifetimes: proportion of migrants in each occupational sector of New Zealand by former sector in Scotland

5.13: Change subsequent to emigration to New Zealand: proportion of New Zealand Occupation 1 sector totals engaged in by migrants in New Zealand Occupation 2

5.14: Occupational mobility across generations: Proportion of migrants' fathers occupation sector totals migrants were engaged in for their New Zealand occupations

6.1: Showing the ratio of females to every 100 males in Scotland and in Shetland ...................... 179

6.2: Proportion of each age range of Shetland migrants that was female or male .......................... 180

6.3: Showing the percentage of the NZSG Shetland migrants of each marital status by gender compared to Scotland total figures

6.4: Showing the percentage of the NZSG Shetland migrants of each gender by marital status .... 181

6.5: Proportion of Shetland migrant totals employed in each occupation sector in Scotland

6.6: Showing the occupations in Scotland of the twenty Shetland born migrants in the NZSG data with sea-oriented occupations

6.7 Proportion of migrants from each region of Scotland, and from Shetland County, who died in the same New Zealand province they first arrived in

7.1: $\quad$ Proportion of the NZSG pre-1920 migrants and post-1920 PNZ migrants from each county and region, alongside the 1871 and 1921 census of Scotland figures

7.2: $\quad$ Showing the distribution of PNZ post-1920 migrants by province of death, and the distribution of the population of New Zealand by province at the 1921 census

7.3: Ratio of Scottish female migrants in each period of arrival to male migrants, by region of birth

7.4: Showing age statistics from the PNZ data pre-1920 and 1921-1945, and those for the NZSG data between 1840 and 1920

7.5: Showing the proportions of migrants' fathers employed in each occupation sector in each region of Scotland, excluding 'unknown', 'indefinable' and 'other', 1920-1945, PNZ data .. 223

7.6: Proportion of the population of Scotland engaged in each occupation class in 1881 and 1931

7.7: Proportion of migrants employed in each occupation sector in New Zealand, by Scottish region of birth, compared to the proportion of migrants from each Scottish region 


\section{LIST OF FIGURES}

1.1 Diagram showing the proportion of total migrants in the migrant group ('Scotland' or 'Total') arriving in New Zealand in each year from 1840-1920

2.1: Showing the distribution of migrant origins in Scotland in the NZSG (2.1a) and PNZ (2.1b) data 35

2.2: Proportions of Scots residing in only one country other than Scotland prior to emigration to New Zealand

2.3: Last country of residence for Scots with more than one country of residence prior to immigration to New Zealand

3.1: Provincial distribution of the Scots-born population of New Zealand between 1871 and 1911

3.2a: Birth country of emigrants to Auckland Province arriving 1842-1852 ................................... 64

3.2b: Birth country of emigrants to New Zealand Company Settlements arriving 1840-1850 ............ 65

3.3: Provincial distribution of Scots emigrants to New Zealand at time of death ............................ 68

3.4: Distribution of the Scottish regional origins of migrants in New Zealand's five principal provinces

4.1: Showing the proportion of the adult population of Scotland, of New Zealand and of Scottish emigrants to New Zealand who were single, married or widowed

4.2: Proportion of each dataset that was single or married at arrival in New Zealand

5.1: Employment subsequent to emigration to New Zealand: proportion of male migrants in each sector, by period of arrival

5.2: Employment subsequent to emigration to New Zealand: proportion of female migrants in each sector, by period of arrival

7.1: British emigration bound for destinations outside of Europe, 1913-1938 209

7.2: $\quad$ Showing the flow of Scottish migrants to New Zealand between 1921 and 1945

7.3a \& b: Showing the proportion of PNZ migrants arriving 1921-1945 who were children, single and married at arrival by gender 


\section{ABBREVIATIONS}

\section{Counties of Scotland}

The county names and abbreviations listed below and used throughout the thesis are those used by the New Zealand Society of Genealogists. Where county names changed and the new form is used the previous name has been included following the county name.

$\begin{array}{ll}\text { ABD } & \text { Aberdeen } \\ \text { ANS } & \text { Angus (Forfarshire) } \\ \text { ARL } & \text { Argyll } \\ \text { AYR } & \text { Ayrshire } \\ \text { BAN } & \text { Banff } \\ \text { BEW } & \text { Berwick } \\ \text { BUT } & \text { Bute } \\ \text { CAI } & \text { Caithness } \\ \text { CLK } & \text { Clackmannan } \\ \text { DFS } & \text { Dumfriesshire } \\ \text { DNB } & \text { Dunbarton } \\ \text { ELN } & \text { East Lothian (Haddington) } \\ \text { FIF } & \text { Fife } \\ \text { INV } & \text { Inverness } \\ \text { KCD } & \text { Kincardine } \\ \text { KKD } & \text { Kirkcudbright } \\ \text { KRS } & \text { Kinross } \\ \text { LKS } & \text { Lanark } \\ \text { MLN } & \text { Midlothian (Edinburgh) } \\ \text { MOR } & \text { Moray (Elgin) } \\ \text { NAI } & \text { Nairn } \\ \text { OKI } & \text { Orkney Islands } \\ \text { PEE } & \text { Peebles } \\ \text { PER } & \text { Perth } \\ \text { RFW } & \text { Renfrew } \\ \text { ROC } & \text { Ross and Cromarty } \\ \text { ROX } & \text { Roxburgh } \\ \text { SEL } & \text { Selkirk } \\ \text { SHI } & \text { Shetland Islands } \\ \text { STI } & \text { Stirling } \\ \text { SUT } & \text { Sutherland } \\ \text { WIG } & \text { Wigtown } \\ \text { WLN } & \text { West Lothian (Linlithgow) }\end{array}$

\section{Data Sets}

NZSG Dataset constructed for this thesis based upon the New Zealand Society of Genealogists Scottish Interest Group's Register of New Zealand Immigrants of Scottish Birth arriving before 1 January 1921

PNZ Dataset constructed by the Ministry of Culture and Heritage for their 'Peopling of New Zealand' project 


\section{Other}

ANZ

Archives New Zealand

$D N Z B$

Dictionary of New Zealand Biography

AJHR Appendices to the House of Representatives

Napier Commission:

Royal Commission of Inquiry into the Condition of Crofters and Cottars in the Highlands and Islands

Truck Commission:

Commission of Inquiry on the Truck System (Shetland), 1872 
MAP 1

Showing the thirty-three counties of Scotland (as used in this thesis)

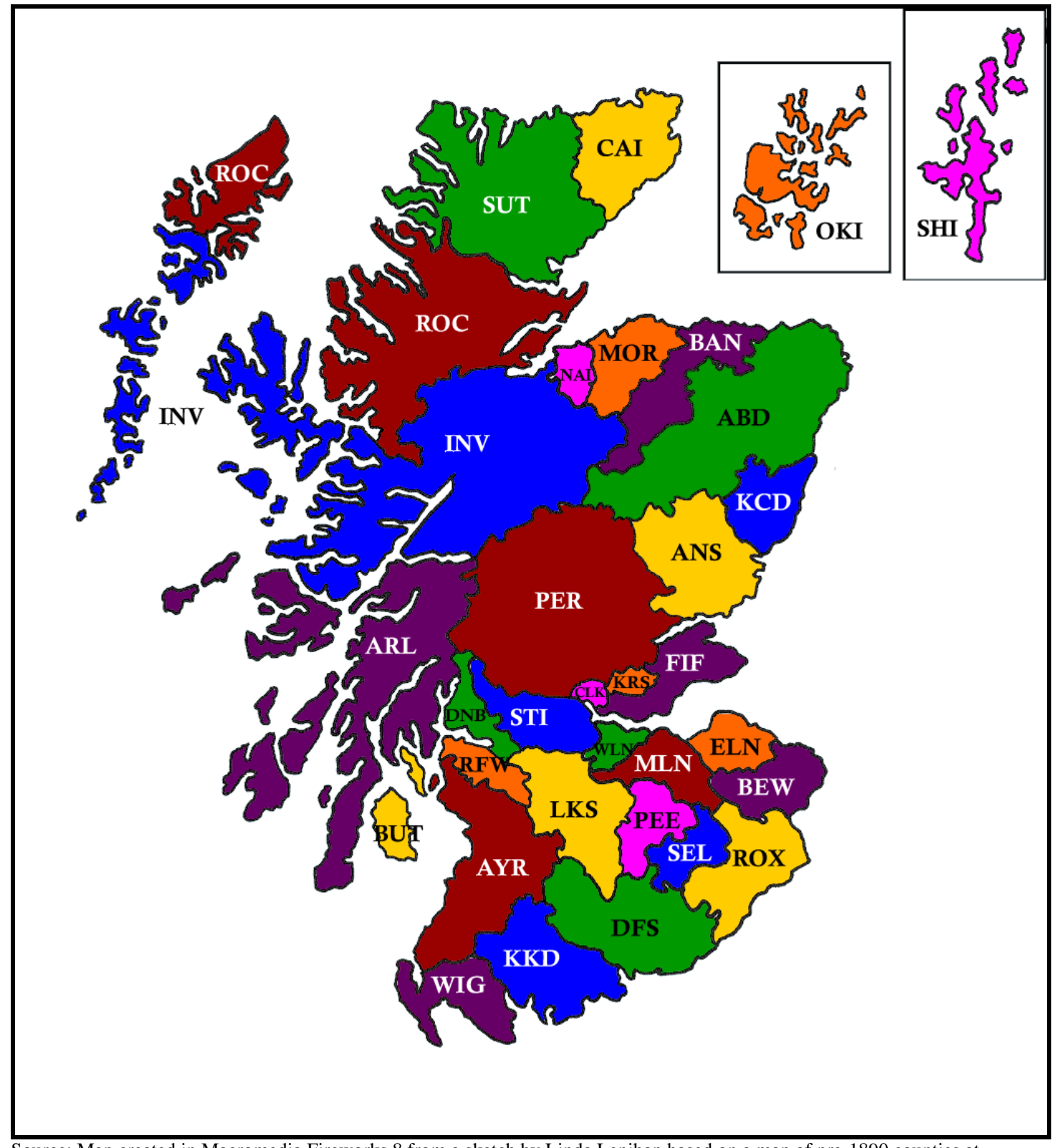

Source: Map created in Macromedia Fireworks 8 from a sketch by Linda Lenihan based on a map of pre-1890 counties at http://www.genuki.org.uk/big/sct/, accessed 16 February 2006

$\begin{array}{llllll}\text { ABD } & \text { Aberdeen } & \text { ANS } & \text { Angus } & \text { ARL } & \text { Argyll } \\ \text { AYR } & \text { Ayrshire } & \text { BAN } & \text { Banff } & \text { BEW } & \text { Berwick } \\ \text { BUT } & \text { Bute } & \text { CAI } & \text { Caithness } & \text { CLK } & \text { Clackmannan } \\ \text { DFS } & \text { Dumfriesshire } & \text { DNB } & \text { Dunbarton } & \text { ELN } & \text { East Lothian } \\ \text { FIF } & \text { Fife } & \text { INV } & \text { Inverness } & \text { KCD } & \text { Kincardine } \\ \text { KKD } & \text { Kirkcudbright } & \text { KRS } & \text { Kinross } & \text { LKS } & \text { Lanark } \\ \text { MLN } & \text { Midlothian } & \text { MOR } & \text { Moray } & \text { NAI } & \text { Nairn } \\ \text { OKI } & \text { Orkney Islands } & \text { PEE } & \text { Peebles } & \text { PER } & \text { Perth } \\ \text { RFW } & \text { Renfrew } & \text { ROC } & \text { Ross and Cromarty } & \text { ROX } & \text { Roxburgh } \\ \text { SEL } & \text { Selkirk } & \text { SHI } & \text { Shetland Islands } & \text { STI } & \text { Stirling } \\ \text { SUT } & \text { Sutherland } & \text { WIG } & \text { Wigtown } & \text { WLN } & \text { West Lothian }\end{array}$


MAP 2

Showing the six regions of Scotland (as used in this thesis)

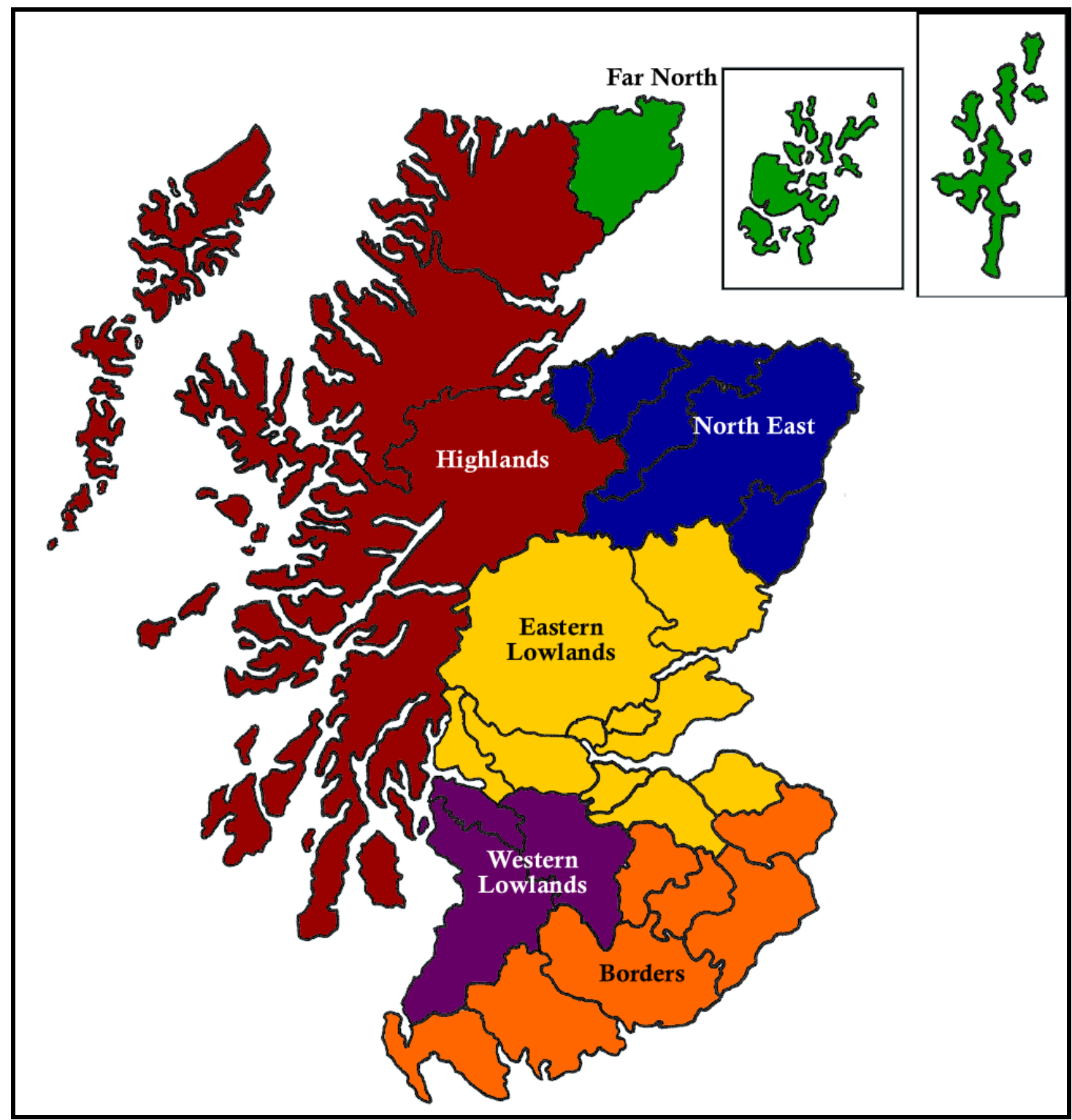

Source: Map created in Macromedia Fireworks 8 from a sketch by Linda Lenihan based on a map of pre-1890 counties at http://www.genuki.org.uk/big/sct/, accessed 16 February 2006 
MAP 3

Showing the sixty-three counties of New Zealand created in 1876

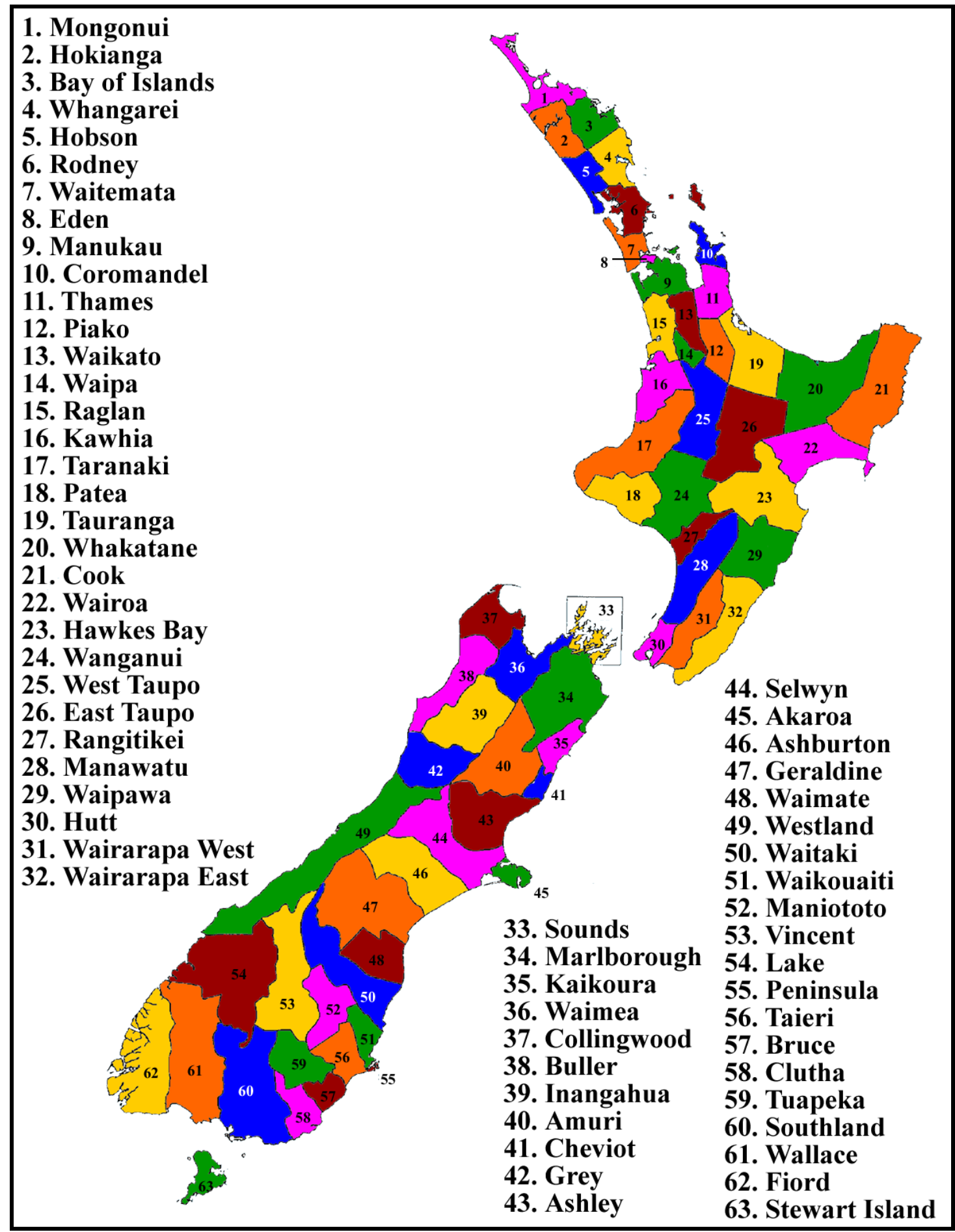

Source: Map created in Macromedia Fireworks 8 based on Brian Marshall and Jan Kelly, Atlas of New Zealand Boundaries, Auckland, 1986, 1.5.3 
MAP 4

Showing the provinces of New Zealand (as used in this thesis)

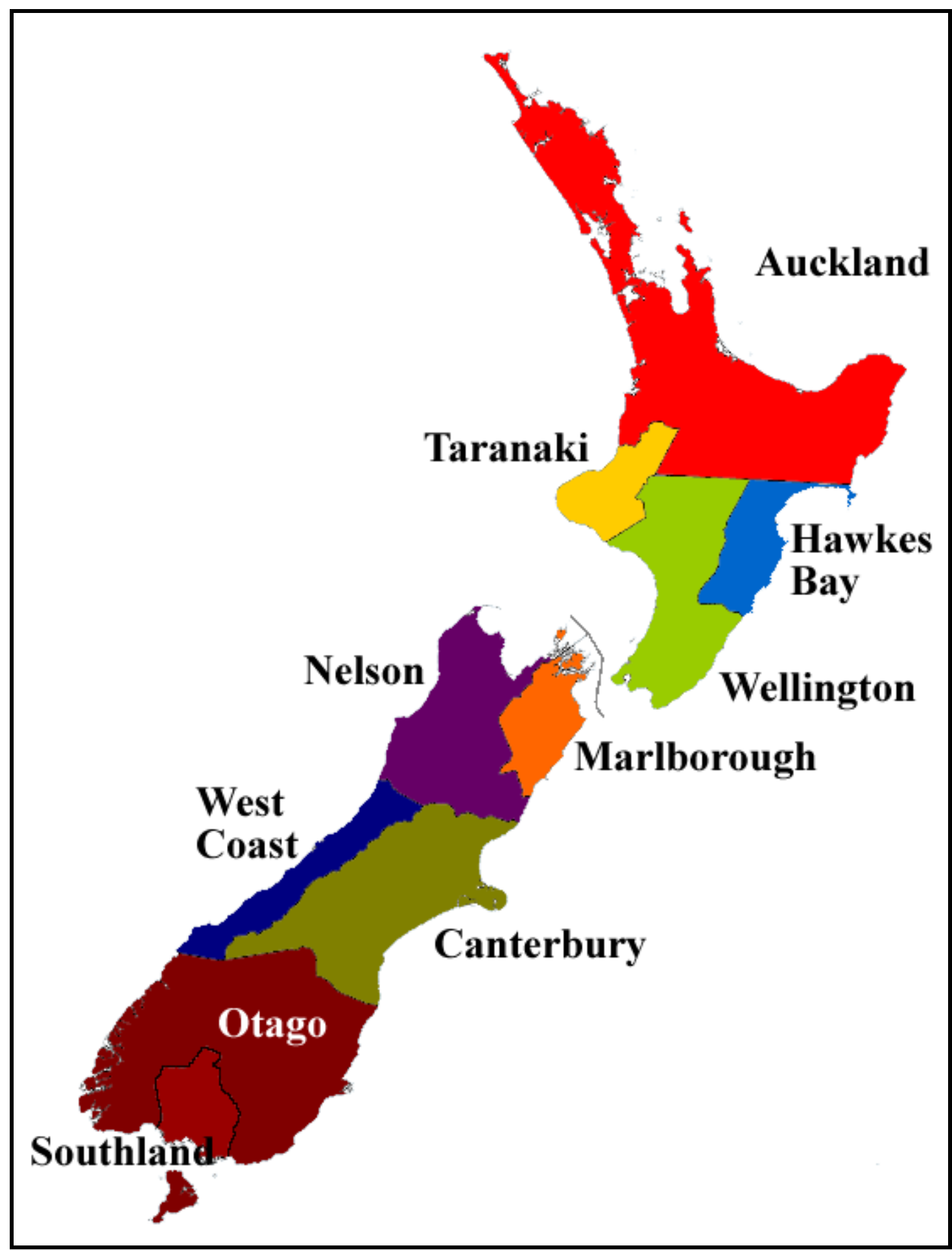

Source: Map created in Macromedia Fireworks 8 based on Brian Marshall and Jan Kelly, Atlas of New Zealand Boundaries, Auckland, 1986, 1.4.2 


\section{Chapter One}

\section{INTRODUCTION}

When Hugh McKenzie left Scotland for Cape Breton Island, Nova Scotia, in 1821, he could not have conceived that he would never see the land of his birth again, or that within forty years he would have a family of his own on the other side of the world. Not quite four years old, his short life had been lived on the croft of his father Donald, in the parish his parents and his siblings had been born in, Assynt in Sutherlandshire. The family sailed on the Perseverance, departing from Loch Inver on 9 July $1821{ }^{1}$ Captained by Hector McKenzie, this was the Perseverance's second voyage taking migrants from Sutherlandshire, the first in 1818 also carrying followers of the charismatic Rev. Norman McLeod across the Atlantic. McLeod had commenced his odyssey the previous year. ${ }^{2}$ Settling in St. Ann's, Cape Breton, where McLeod and his followers had shifted after leaving Pictou in 1820, Hugh's father again took up farming, and five more children were born to the family. The story of McLeod and his followers is perhaps one of the most frequently cited tales of nineteenth-century Scottish emigration. It is sufficient here to note that the community, led by McLeod, remained at Cape Breton until 1851. Then, after seasons of blight and wheat rust, he acted upon glowing reports from his son of the climate and conditions in Australia. New vessels, the Margaret and the Highland Lass, were built and McLeod, with 300 of his followers, set out again. ${ }^{3}$ John Fraser, part owner of the Margaret, and his family were among those accompanying McLeod. Hugh McKenzie, now thirty-three years old and courting Fraser's daughter Mary, aged twenty-one, was told by her father that he could marry Mary only upon the condition that he emigrate to Australia with them. Fearing the climate of Australia, Hugh refused, and the evening before the ship was to sail he and Mary eloped. ${ }^{4}$ It was to be a further six years before Hugh, Mary and their three children emigrated on the Spray to Waipu, New Zealand, where McLeod and many of those following him had made final landfall. The young couple were subsequently joined by Hugh's elderly parents, his brother Alexander,

\footnotetext{
${ }^{1}$ NZSG migrants 03395 and 03880

${ }^{2}$ Neil Robinson, To the Ends of the Earth: Norman McLeod and the Highlanders' Migration to Nova Scotia and New Zealand, Auckland, 1997, p.33

${ }^{3}$ Maureen Molloy, Those Who Speak to the Heart: The Nova Scotian Scots at Waipu, 1854-1920, Palmerston North, 1991, p.9

${ }^{4}$ ibid., p.118
} 
Alexander's wife and their three children, his brother Roderick (who later married Mary's sister Jane in Waipu), his sister Christina (who later married Mary and Jane's brother), and his brother Murdoch (who later married his first cousin, Jessie McGregor, a migrant on the Margaret). Hugh's maternal aunt and her husband had emigrated to Waipu on the Gazelle in 1853, and his maternal uncle followed his sisters to New Zealand on the Ellen Lewis in $1860 .{ }^{5}$ Hugh was the first teacher at the Braigh School in Waipu, and the first registrar of the area; he died in September 1896, aged seventy-nine years. ${ }^{6}$

The migration of McLeod and his followers from Assynt to Pictou, Pictou to St. Ann's, St. Ann's to Australia, finally to Waipu, is among the most widely-known tales of Scottish migration to New Zealand. It has been frequently retold as the story of New Zealand's Scots, challenged only by the Otago settlement. ${ }^{7}$ Yet it is extraordinary. It is indeed the very atypicality of the experiences of Hugh and his fellow McLeod migrants and the mythology that surrounds McLeod's odyssey that makes the tale interesting, and is the primary reason that so much has been written about the group, much more than about any other group of Scots migrants to New Zealand. ${ }^{8}$ This focus on McLeod and Waipu is problematic, as it distorts the perception of the Scottish migrant experience in New Zealand. A more nuanced approach to the study of New Zealand's Scots is required.

\section{Why investigate New Zealand's Scots?}

Few studies of migration to New Zealand, and few general histories discussing immigration to the country have recognised the distinct national backgrounds of New Zealand's British migrants. Instead, scholars have tended to categorise migrants as

\footnotetext{
${ }^{5}$ NZSG database, migrants 03400, 03406, 03718

${ }^{6}$ NZSG migrants 03395 and 03880; Lynne McKenzie, 'McKenzie's from Scotland via Nova Scotia to New Zealand', last updated 31 December 2001, http://wc.rootsweb.ancestry.com, accessed 13 January 2009

${ }^{7}$ See, for example, discussion of these Waipu migrants in G.L. Pearce, The Scots of New Zealand, Auckland, 1976 and Jim Hewitson, Far Off In Sunlit Places: Stories of the Scots in Australia and New Zealand, Edinburgh, 1998

${ }^{8}$ These include Molloy, Those Who Speak to the Heart; Neil Robinson, Lion of Scotland: Being an Account of Norman McLeod's Forty Years' Search for a Land Where He and His Followers Could Live as They Wished; of the Voyage, in 1817, From the Western Highlands to Nova Scotia; to Australia in the 1850s; and Finally to New Zealand; and How They Built a Community for Themselves, London, 1952; Robinson, To the Ends of the Earth; Flora McPherson, Watchman Against the World: The Remarkable Journey of Norman McLeod \& his People from Scotland to Cape Breton Island to New Zealand, Wreck Cove, Cape Breton, 1993; Maureen Molloy, "No inclination to mix with strangers": marriage patterns among Highland Scots migrants to Cape Breton and New Zealand, 1800-1916', Journal of Family History, Vol.11, 1986, pp.221-243.
} 
'British' and 'Non-British', emphasising New Zealand's status as 'Better Britain', consequently not only grouping Gaelic-speaking rural Highland Scots and migrants from urban London together, but also including migrants born anywhere in the rest of the world under a single 'non-British' label. ${ }^{9}$ This simplistic categorisation is not especially useful in establishing where New Zealand's migrants came from, and what influences have shaped New Zealand as a society. Moreover, the distinction between 'British' and 'Non-British' has been exacerbated by many general works that distinguish only between Māori and Pakeha, cementing a tradition of biculturalism that Akenson aptly describes as the 'lumping of all white settlers into a spurious unity. ${ }^{10}$ There had been attempts to separate New Zealand's 'British' migrant streams prior to Akenson's call for the abandonment of a bicultural approach to New Zealand history, however these studies did so seeking answers to quite specific questions - for example investigating the basic profile of the Vogel assisted migrants, or female migration between 1853 and 1871. As a result, these studies do not shed light on the broader issues, for instance the place of the separate 'British' cultures in New Zealand, and their role in shaping 'New Zealand' society. ${ }^{11}$

Since Akenson's influential Half the World From Home several researchers have focused on New Zealand's major 'British' migrant groups. Most notably, there have been an increasing number of studies of New Zealand's Irish migrants, including the South Island Irish settlers, the experiences of Irish women, and migrants from

\footnotetext{
9 Campbell James Gibson, 'Demographic History of New Zealand', PhD Thesis, University of California, Berkeley, 1972; James Belich, Paradise Reforged: A History of the New Zealanders From the 1880s to the Year 2000, Auckland, 2001; Keith Sinclair, A History of New Zealand, Auckland, 2000; King's 2003 history of New Zealand discusses the 'dominant cultural identification of Pakeha' as being 'British', and speaks of the xenophobia in the country in the early twentieth century in terms of British and non-British immigrants. Michael King, The Penguin History of New Zealand, Auckland, 2003, pp.366, 368-370.

${ }^{10}$ Donald Harman Akenson, Half the World from Home: Perspectives on the Irish in New Zealand, 1860-1950, Wellington, 1990, p.6; See, for example, William Pember Reeves, The Long White Cloud, London, 1924; and more recently Peter Gibbons, 'Cultural colonization and national identity', NZJH, Vol.36, No.1, 2002, pp.5-17 and Peter Gibbons, 'The far side of the search for identity: reconsidering New Zealand history', NZJH, Vol.37, No.1, 2003, pp.38-49

11 See, for example, John Morris' thesis that separated the Vogel migrants by country of origin, Charlotte Macdonald's thesis concerning single women migrants to Canterbury, Rollo Arnold's study of English villagers emigrating to New Zealand, and the many works on the Waipu migrants, separated out for their exceptional migration story. John Morris, 'The Assisted Immigrants to New Zealand, 1871-79: a Statistical Study', M.A. Thesis, Auckland University, 1973; Charlotte J. Macdonald, 'Single Women as Immigrant Settlers in New Zealand, 1853-1871', PhD Thesis, University of Auckland, 1986; Rollo Arnold, The Farthest Promised Land: English Villagers, New Zealand Immigrants of the 1870s, Wellington, 1981.
} 
Ulster. ${ }^{12}$ Though it might be argued that as the English made up approximately half of all 'British' migrants to New Zealand, and as such most of what has been written about New Zealand's 'British' migrants was predominantly about the English, this does not explain the paucity of studies regarding English migrants in New Zealand. Hudson's 1996 thesis and Arnold's Farthest Promised Land aside, New Zealand's English migrants still await the attention that has been devoted to the Irish over the past two decades and more recently the Scots. Not to do so would be tantamount to claiming that either New Zealand culture was essentially English - a point debated in works about the Irish and Scots in New Zealand - or that the English in New Zealand do not merit academic attention because they were the majority migrant group. ${ }^{13}$ Unlike the Welsh New Zealand's Scots have not been completely neglected. G.L. Pearce's The Scots of New Zealand is an early example of a popular publication focussed on New Zealand's Scots. ${ }^{14}$ More scholarly is Brooking and Coleman's 2003 edited collection, The Heather and the Fern, which raised important questions about what was actually known about New Zealand's Scots, also suggesting some of the gaps remaining in the body of knowledge about this group. It laid down 'a challenge to other New Zealand historians to carry out further investigations into this rich but often slippery area of discerning ethnic difference within a Pakeha culture'. ${ }^{15}$ McCarthy's work on the Scots, complementing her work on New Zealand's Irish, has

\footnotetext{
${ }^{12}$ Lyndon Fraser (ed.), A Distant Shore: Irish Migration and New Zealand Settlement, Dunedin, 2000; Lyndon Fraser, Castles of Gold: A History of New Zealand's West Coast Irish, Dunedin, 2007; Angela McCarthy, Irish Migrants in New Zealand, 1840-1937: 'The Desired Haven', Woodbridge, 2005; Angela McCarthy, Personal Narratives of Irish and Scottish Migration, 1921-65: 'For Spirit and Adventure', Manchester, 2007; Brad Patterson (ed.), The Irish in New Zealand: Historical Contexts \& Perspectives, Wellington, 2002; Brad Patterson (ed.), From Ulster to New Ulster: The 2003 UlsterNew Zealand Lectures, Coleraine, 2004; Brad Patterson (ed.), Ulster-New Zealand: Migration and Cultural Transfer, Dublin, 2006; Alasdair Galbraith, 'New Zealand's Invisible Irish: Irish Protestants in the North Island of New Zealand 1840-1900', M.A. Thesis, University of Auckland, 1998

${ }^{13}$ Other migrant groups to have their experiences singled out include Chinese and German migrants. Arnold, The Farthest Promised Land; Paul Hudson, 'English Emigration to New Zealand, 1839 to 1850: an Analysis of the Work of the New Zealand Company', PhD Thesis, University of Lancaster, 1996; James Ng, Window's on a Chinese Past, Dunedin, 1993; Manying Ip (ed.), Unfolding History, Evolving Identity: the Chinese in New Zealand, Auckland, 2003; James N. Bade (ed.), The German Connection: New Zealand and German-speaking Europe in the Nineteenth Century, Auckland, 1993; Brigitte Bönisch-Brednich, 'Being German in Wellington: female perspectives', National Oral History Association of New Zealand Journal, Vol.11, 1999, pp.23-29; Brigitte Bönisch-Brednich, Keeping a Low Profile: An Oral History of German Immigration to New Zealand, Wellington, 2002; Brigitte Bönisch-Brednich, 'Gendering German migration experiences in the 1980s and 1990s', in Lyndon Fraser and Katie Pickles (eds), Shifting Centres: Women and Migration in New Zealand History, Dunedin, 2002

${ }^{14}$ Pearce, The Scots of New Zealand

${ }^{15}$ Tom Brooking, 'Introduction', in Tom Brooking and Jennie Coleman (eds), The Heather and the Fern: Scottish Migration and New Zealand Settlement, Dunedin, 2003, p.15
} 
gone some way to addressing the challenge in several areas, but many questions remain unanswered. ${ }^{16}$

Despite the modest recent upsurge of publications dealing with New Zealand's migrants in their separate groups, there has been little statistical analysis of the migrant streams until Phillips and Hearn's recent publications. ${ }^{17}$ Phillips and Hearn's Settlers is remarkable in that it not only investigates the immigrants from every corner of England (and Wales), Ireland and Scotland arriving in New Zealand between 1800 and 1945, but that it does so based on statistical analysis. Their research primarily draws upon a random sample of over 11,800 individual death certificates, providing a high degree of statistical accuracy and their findings are consistent with those based on other sources. ${ }^{18}$ Without such quantitative background to the migrations, the significance of many qualitative findings relating to the shaping of New Zealand society and culture, and for that matter the significance of the migrations to the home countries, must remain largely speculative.

Throughout the period which is the primary focus of the present work, 1840 to 1920, the population of Scotland hovered at around 10 per cent of the population of the United Kingdom and Ireland. ${ }^{19}$ England and Wales accounted for the majority of the population, 74.46 per cent of the combined total in 1881, with Ireland holding 14.83 per cent at that census. In terms of migrants to New Zealand, however, England/Wales represented 53.73 per cent of the British Isles-born population of New

${ }^{16}$ Angela McCarthy, "For spirit and adventure": personal accounts of Scottish migration to New Zealand, 1921-1961', in Tom Brooking and Jennie Coleman (eds), The Heather and the Fern: Scottish Migration and New Zealand Settlement, Dunedin, 2003; Angela McCarthy, 'Personal accounts of leaving Scotland, 1921-1954', Scottish Historical Review, Vol.83, No.216, 2004, pp.196-215; Angela McCarthy, 'Personal letters, oral testimony, and Scottish migration to New Zealand in the 1950s: the case of Lorna Carter', Immigrants and Minorities, Vol.23, No.1, March 2005, pp.59-79; Angela McCarthy (ed.), A Global Clan: Scottish Migrant Networks and Identities Since the Eighteenth Century, London, 2006; McCarthy, Personal Narratives of Irish and Scottish Migration

17 Jock Phillips and Terry Hearn, Settlers: New Zealand Immigrants from England, Ireland and Scotland, 1800 - 1945, Auckland, 2008; Terry Hearn and Jock Phillips, 'Immigration study findings', unpublished manuscript, c.2007, available at: http://www.nzhistory.net.nz/culture/home-away-fromhome/sources; notable among prior works based on statistical investigation of New Zealand's migrants is Morris's thesis concerning Vogel-scheme assisted migrants, Macdonald's study of single women migrants, Galt's article discussing the origins of the New Zealand settlers between 1840 and 1889, and - most importantly for the present study - McClean's $1990 \mathrm{PhD}$ thesis addressing New Zealand's Scots, specifically those arriving between 1840 and 1880. Morris, 'The Assisted Immigrants to New Zealand'; Macdonald, 'Single Women as Immigrant Settlers'; Margaret Galt, 'Who came to New Zealand? New light on the origins of British settlers', New Zealand Population Review, Vol.21, No.1 and 2, 1995, pp.50-71; Rosalind McClean, 'Scottish Emigrants to New Zealand, 1840-1880: Motives, Means and Background', PhD Thesis, University of Edinburgh, 1990

${ }^{18}$ For details of the collection of this data see Appendix 1.1.

${ }^{19}$ Scots constituted 10.71 per cent of the population of England, Ireland, Scotland and Wales combined at the 1881 Census. 
Zealand in 1878, Ireland 22.08 and Scotland 24.19 per cent. ${ }^{20}$ New Zealand could thus be viewed as approximately 13.5 per cent more 'Scottish' than the British archipelago itself. Just who were the Scottish immigrants that consistently made up nearly 20 per cent of the immigrant population of New Zealand over this eighty-year period is the question with which this thesis is primarily concerned.

In 2005, at least partially in acknowledgement of Akenson's call fifteen years previously and of the challenge laid down in The Heather and the Fern, the Marsdenfunded 'Scottish Migration to New Zealand' project was launched. ${ }^{21}$ Led by Dr Brad Patterson and Professor Tom Brooking, an international team of researchers was formed to investigate the extent to which Scottish ways and identity were preserved in New Zealand, for how long, and by what means, as well as the relations between Scots and other ethnic groups, the respective roles of men and women, and areas of settler life in which Scots became disproportionately prominent. The research was structured under three major headings: 'the settling process', 'legacies' and 'a demographic profile'. 22 'The settling process' set out to investigate a number of aspects of the migrant experience, including the creation of distinctively Scottish communities, networks and associations, informal connections between friends and family that may have contributed to the migrants' sense of being part of a Scottish diaspora, and the assimilation of Scots into New Zealand society. 'Legacies' included investigation of discernible Scottish contributions to New Zealand society in terms of business and economic practices, political and legal systems, the spread of political and social as well as religious beliefs and values through the spread of Scottish Presbyterianism, and the transmission of authentic and modified Scottish cultural traits and attitudes. From the outset of the research project, however, it was recognised that the construction of a demographic profile of the New Zealand Scots would provide an indispensable foundation for the study.

It was accepted that the only way in which such fundamental questions as 'from where in Scotland did they come?', 'when?', 'in what numbers?', 'who?' and 'where

\footnotetext{
${ }^{20}$ Migrants from England/Wales constituted 44.32 per cent of the total population of New Zealand born outside of the country at the 1878 Census, Ireland 18.21 per cent and Scotland 19.95 per cent.

${ }^{21}$ Irish-Scottish Studies Programme, research, 'Marsden fund Scottish migration to New Zealand project', http://www.victoria.ac.nz/stout-centre/research-units/issp/projects/projects.aspx, 26 September 2007

${ }^{22}$ Dr Brad Patterson's 'Scottish migration to New Zealand to 1950, and its contributions to the development of New Zealand society' research proposal application to The Royal Society of New Zealand Marsden fund, 2004, 04-VUW-010
} 
did they settle?' could be answered with any degree of confidence would be through the statistical analysis of available datasets. Having statistically-based answers to such fundamental questions would enrich understandings regarding other aspects of settler experiences. These were questions the answers to which had hitherto been largely speculative. McClean's 1990 thesis provided a sound base for some tentative answers, though it primarily addressed 'who' New Zealand's Scots migrants were from a premigration perspective, including 'why' and 'how' they came to New Zealand. Further, its coverage was restricted to just four decades. ${ }^{23}$ Research by Morris on assisted migrants to New Zealand in the 1870s, and by Maxwell for an uncompleted PhD thesis on Otago's pre-1861 settlers, while suggesting some answers also posed further questions relating to the demographic characteristics of the Scots migrants. ${ }^{24}$ It was in an attempt to address these five most fundamental questions that the present study was initiated. It is thus with the statistics of the migrant experience that the present work is primarily concerned, not with questions of ethnicity or cultural legacies, save when they affect the trends and patterns emerging from the statistical analysis. While the study will refer to Scottish migration to other 'overseas' destinations, there will be little direct comparison or contrasting of the New Zealand statistical findings with those from any other country. While Scots had been emigrating for centuries, New Zealand was a latecomer to the list of potential migrant destinations - more than fifty years later than its closest neighbour, Australia, and two hundred behind the United States and Canada. ${ }^{25}$

\section{Scottish emigration: an overview}

Scots have always been a migratory people. In the words of Harper, 'as global wanderers the Scots have a long and impressive pedigree' and as Richards notes, the 'British', including the Scots, all came to Britain as migrants in the first place. ${ }^{26}$ From the Middle Ages Scots were migrating - albeit often temporarily - to parts of Europe, including England and Ireland and further afield, as soldiers, traders, craftsmen and scholars. ${ }^{27}$ Writing in 1812, Thomas Thomson noted 'the principal merchants in

\footnotetext{
${ }^{23}$ McClean, 'Scottish Emigrants to New Zealand, 1840-1880'

${ }^{24}$ Morris, 'The Assisted Immigrants to New Zealand'; Val Maxwell, 'Otago settlers pre-1861'

${ }^{25}$ See discussion below.

26 Marjory Harper, Adventurers and Exiles: The Great Scottish Exodus, London, 2003, p.31; Eric Richards, Britannia's Children: Emigration from England, Scotland, Wales and Ireland since 1600, London and New York, 2004, p.20

${ }^{27}$ Malcolm D. Prentis, The Scots in Australia: A Study of New South Wales, Victoria and Queensland, 1788-1900, Sydney, 1983, p.11; Michael Fry, The Scottish Empire, Edinburgh, 2001, pp.2-3; Gordon
} 
Gothenburg [Sweden] are Scotsmen', while studies of Scots in other parts of Europe indicate that Scots were thriving in such employments by the seventeenth century. ${ }^{28}$ Ulster was a prime destination for Scots from $1607 .{ }^{29}$ Internal migration - especially from rural areas to urban centres - was commonplace by $1750 .{ }^{30}$ Internal migration continued to be an important factor in the distribution of the Scottish population through the nineteenth century and beyond, many migrants embarking upon internal migration as the first step in a movement that would eventually see them settled outside of the United Kingdom. ${ }^{31}$

Although North America and the Caribbean were absorbing the majority of Scots emigrants by 1775 , this was a new phenomenon. One estimate suggests that fewer than 200 Scots had settled across the Atlantic prior to $1640 .{ }^{32}$ Scottish emigration to

Donaldson, The Scots Overseas, London, 1966, pp.23 and 27; Alexia Grosjean and Steve Murdoch (eds), Scottish Communities Abroad in the Early Modern Period, Leiden and Boston, 2005 provides numerous examples of Scottish migration to Europe, and many more references to other works concerning these European Scottish migrations. For background of some of the factors in Scotland that made Scots so ready to migrate in character see R.H. Campbell, 'Scotland', in R.A. Cage (ed.), Scots Abroad, 1750-1914, London, 1985; Jeanette Brock discusses the Scottish 'culture of out-migration' as well as trends concerning Scottish in-migration - Jeanette M. Brock, The Mobile Scot: A Study of Emigration and Migration 1861-1911, Edinburgh, 1999.

${ }^{28}$ Thomas Thomson's 'Travels in Sweden', 1812, reproduced in J. Berg and B. Lagercrantz, Scots in Sweden, Stockholm, 1962, pp.76-78, cited in Alexia Grosjean and Steven Murdoch, 'The Scottish community in seventeenth-century Gothenburg', in Alexia Grosjean and Steven Murdoch (eds), Scottish Communities Abroad in the Early Modern Period, Leiden and Boston, 2005, pp.191-223; see also Nina Østby Pederson, 'Scottish immigration to Bergen in the sixteenth and seventeenth centuries', in Alexia Grosjean and Steve Murdoch (eds), Scottish Communities Abroad in the Early Modern Period, Leiden and Boston, 2005, pp.135-167; Douglas Catterall, 'Scots along the Maas, c.1570-1750', in Alexia Grosjean and Steve Murdoch (eds), Scottish Communities Abroad in the Early Modern Period, Leiden and Boston, 2005, pp.169-189; Rimantas Žirgulis, 'The Scottish community in Kèdainiai c.1630-c.1750', in Alexia Grosjean and Steve Murdoch (eds), Scottish Communities Abroad in the Early Modern Period, Leiden and Boston, 2005, pp.225-247; Kathrin Zickermann, "Briteannia ist mein patria': Scotsmen and the 'British' community in Hamburg', in Alexia Grosjean and Steve Murdoch (eds), Scottish Communities Abroad in the Early Modern Period, Leiden and Boston, 2005, pp. $249-273$

${ }_{29}$ Tom Devine, Scotland's Empire and the Shaping of the Americas 1600-1815, Washington, 2003, p.25; Patrick Fitzgerarld, 'Scottish migration to Ireland in the seventeenth century', in Alexia Grosjean and Steve Murdoch (eds), Scottish Communities Abroad in the Early Modern Period, Leiden and Boston, 2005, pp.27-52; R.J. Dickson, Ulster Emigration to Colonial America, 1718-1775, London, 1966; Philip S. Robinson, The Plantation of Ulster: British Settlement in an Irish Landscape, Dublin, 1984; R. Gillespie, Colonial Ulster: The Settlement of East Ulster, 1600-1641, Cork, 1985; John R. Young, 'Scotland and Ulster in the seventeenth century: the movement of peoples over the North Channel', in W. Kelly and J.R. Young (ed.), Ulster and Scotland 1600-2000: History, Language and Identity, Dublin, 2004

${ }^{30}$ Malcolm Gray, Scots on the Move: Scots Migrants 1750-1914, Glasgow, 1990, p.5; T.M. Devine, The Transformation of Rural Scotland: Social Change and the Agrarian Economy, 1660-1815, Edinburgh, 1994, pp.145-6; See also Charles W.J. Withers, Urban Highlanders: Highland-Lowland Migration and Urban Gaelic Culture, 1700-1900, East Lothian, 1998, Chapters 3 and 4.

${ }^{31}$ Richards, Britannia's Children, p.117; T.M. Devine, The Scottish Nation: 1700-2000, London, 1999, p.162; Withers, Urban Highlanders, pp.3, 4, 8; Harper, Adventurers and Exiles, p.6.

${ }^{32}$ For an overview of early organised ventures into formal Scottish settlements outside of Europe see Harper, Adventurers and Exiles, pp.17-18, 72; Jenni Calder, Scots in Canada, Edinburgh, 2003, pp.23, 
the Americas picked up pace in the eighteenth-century, an estimated 80,000 Scots arriving between 1701 and 1780, settling predominantly in Virginia, North Carolina, Pennsylvania, New York and South Carolina. ${ }^{33}$ Until the 1760 s much of the flow of Scots to the American colonies was from Lowland Scotland, but the 1770s saw a shift from Lowland to Highland Scottish emigration, as well as a move from predominantly individual to group and family emigration. ${ }^{34}$

Canada, the country most often associated with Scots emigration in public consciousness, was only settled by Scots in any great numbers from the late eighteenth century. Yet between 1825 and 1914 an estimated 28 per cent of all emigrating Scots went to Canada. ${ }^{35}$ At the outset the flow was predominantly of Highland Scots, who established settlements rich in Gaelic culture in Upper Canada, Prince Edward Island, Nova Scotia and Cape Breton from the 1770s. ${ }^{36}$ After 1815, and especially from the $1850 \mathrm{~s}$, Lowland migration to Canada became more important, with large numbers of 'Lowland business elites, artisans, farmers and agricultural labourers' as well as a significant number of Scots involved in 'medicine, law, the ministry and journalism' making lives there. ${ }^{37}$ Notwithstanding Canadian recruitment agents complaining in the 1870 s of a considerable number of migrants being diverted as a result of the free passages being offered by New Zealand, Canada remained a favoured destination for Scots migrants up to World War One. ${ }^{38}$ Almost certainly the migrations to Canada in the eighteenth century created a precedent, the distinctively Scottish settlements already established attracting further Scottish migrants. ${ }^{39}$ By the time New Zealand presented as a migrant destination the flow of migrants from Scotland to the United States and Canada was so well-established (and New Zealand

28, 29; Jenni Calder, Scots in the USA, Edinburgh, 2006, p.32; Fry, Scottish Empire, pp.21-22; Devine, Scotland's Empire, 1600-1815, pp.1, 38, 43-48; Donaldson, The Scots Overseas, p.34; Richards, Britannia's Children, p.79; Campbell, 'Scotland', p.2

${ }_{33}$ Devine, Scotland's Empire, 1600-1815, Tables 2 and 3, pp.97, 100; Calder, Scots in the USA, pp.31, 89

${ }^{34}$ Harper, Adventurers and Exiles, p.20. For other works on Scottish emigration to America see also: James Hunter, A Dance Called America: The Scottish Highlands, the United States and Canada, Edinburgh, 1995; Charlotte Erickson, Invisible Immigrants: The Adaptation of English and Scottish Immigrants in 19th Century America, London, 1972; Calder, Scots in the USA, ; Celeste Ray, Highland Heritage: Scottish Americans in the American South, Chapel Hill, North Carolina, 2001; Celeste Ray (ed.), Transatlantic Scots, Tuscaloosa, Alabama, 2005

${ }^{35}$ Harper, Adventurers and Exiles, p.3

${ }^{36}$ Devine, Scotland's Empire, 1600-1815, pp.190-191; Marjory Harper and Michael Vance, Myth, Migration and the Making of Memory: Scotia and Nova Scotia, c.1700-1990 Edinburgh, 1999.

${ }^{37}$ Devine, Scotland's Empire, 1600-1815, p.190

${ }^{38}$ Harper, Adventurers and Exiles, p.137; Calder, Scots in Canada, p.14

${ }_{39}$ Marjory Harper, Emigration from North-East Scotland: Willing Exiles, Aberdeen, 1988, p.191; Richards, Britannia's Children, p.186 
so much further from Britain) that New Zealand posed no serious competition for these countries in the migrant market. ${ }^{40}$

Of greatest comparative significance for New Zealand is the flow of migrants from Scotland to Australia. Scottish immigration to the Australian colonies of New South Wales and Van Diemen's Land was negligible prior to $1820 .^{41}$ Comparatively few Scots came as convicts, the Scottish system of justice resorting to transportation less frequently than was the case in England or Ireland. ${ }^{42}$ Assisted immigration to the eastern Australian colonies began in the 1830s with approximately 10 per cent of British migrants assisted to New South Wales between 1832 and 1836 from Scotland. ${ }^{43}$ Estimates suggest that 20 to 25 per cent of unassisted migrants to eastern Australia between 1832 and 1850 were Scots, approximately 1,500 of these arriving between 1837 and 1842, a peak in Scottish emigration to Australia. Over these same five years some 8,500 assisted Scots migrants also arrived in the colony. ${ }^{44}$ Further estimates suggest that between 1850 and 1900 160,000 to 180,000 Scots arrived in eastern Australia, 14 to 16 per cent of total British migration to the area. ${ }^{45}$ The year 1852 not only saw the end of convict transportation but also the beginning of the Australian gold rushes, with this generating a new stream of Scots migrants, alongside

\footnotetext{
${ }^{40}$ Scots were, of course, migrating to other destinations across the globe during this 'age of migration'. Notable were India, the West Indies and South Africa. India and the West Indies tended to attract temporary migrant Scots, rather than permanent settlers, who used their time abroad to generate the financial grounding they needed to live independently as gentlemen of means upon return to Scotland. In South Africa the Scottish impact was greater in cultural than in numerical terms, Mackenzie noting that the Scottish influence 'in the Cape and the other South African territories.... was out of proportion to their numbers.' Fry, Scottish Empire, pp.70-82, 83-96; Devine, Scotland's Empire, 1600-1815, p.252; Harper, Adventurers and Exiles, pp.283-4; John M. MacKenzie, The Scots in South Africa: Ethnicity, Identity, Gender and Race, 1772-1914, Manchester, 2007, quote from p.8

${ }^{41}$ Prentis, Scots in Australia, p.54. Devine, Scotland's Empire, 1600-1815, pp.278-279; M.D. Prentis, 'The settlers: Scots: the condition of Scotland 1788-1860', The Australian People: An Encyclopedia of the Nation, its People and Their Origins, James Jupp, North Ryde, New South Wales, 1988, pp.759765, p.762

${ }^{42}$ Fry, Scottish Empire, p.109; Devine, Scotland's Empire, 1600-1815, p.278. Just 8,000 of the 150,000 convicts sent to New South Wales or Van Diemen's land between 1787 and 1852 were Scots -4.8 per cent of all male convicts and 9.3 per cent of all female convicts. Appendix 4, pp.184, 188 and p.4 of L. L. Robson's The Convict Settlers of Australia: an Inquiry into the Origin and Character of the Convicts transported to New South Wales and Van Diemen's Land 1787-1852, Melbourne 1965, in Prentis, Scots in Australia, p.48.

${ }^{43}$ Prentis, Scots in Australia, p.58. This figure rose significantly in 1837 to 44.26 per cent, and gradually declined thereafter - 37.14 per cent in 1838; 22.86 in 1839; 25.19 in 1840; and 8.28 in 1841 - though this 'decline' was only proportional to those arriving in total from England, Ireland, Scotland and Wales. Prentis, Scots in Australia, Table 4 'Assisted Immigrants, New South Wales 1832-1850', p.61. David S. Macmillan, Scotland and Australia, 1788-1850: Emigration, Commerce and Investment, London, 1967, p.266.

${ }^{44}$ Prentis, Scots in Australia, p.64; Macmillan, Scotland and Australia, p.302.

${ }^{45}$ Prentis, Scots in Australia, p.68.
} 
migrants of other origins. ${ }^{46}$ As a result of an 'almost accidental accumulation of favourable publicity for Victoria in Scotland', including personal correspondence between friends and relations as well as in newspapers and other publications, Scots migrants tended to favour Victoria over Queensland, and both of these destinations over New South Wales, as places of settlement. ${ }^{47}$ Evidence suggests that 'the bulk of Scots assisted immigrants [to eastern Australia between 1788 and 1900] came from the industrialized Lowland areas such as Glasgow and Clydeside, Edinburgh, Dundee, West Lothian, Fife and Stirlingshire', while in Victoria, 'a slightly higher proportion came from the Highlands', creating the 'rural bias of Scottish-Victorians that continues to this day. ${ }^{48}$ As will be demonstrated, this distribution of migrant origins is similar to that observable among Scottish migrants to New Zealand. Though Australia never attracted migrants in similar numbers to the United States or Canada, an estimated quarter of a million Scots migrated to Australia in the 126 years between the commencement of British settlement in 1788 and $1914 .^{49}$

Being a latecomer on the British migration scene, with no established tradition of migration, was only one of New Zealand's disadvantages in attracting migrants. ${ }^{50}$ As with Australia, additional handicaps were the long travel distance and consequent additional time and costs involved in migrating to this most far-flung of Britain's outposts. By 1840, when New Zealand first received settlers in significant numbers, crossing the Atlantic by steamship took just fourteen days; by 1870 the passage was reduced to eight days, and just five by $1907 .{ }^{51}$ In comparison, ships carrying Scots from British ports to Dunedin in the late 1840s were at sea for anywhere between three and five months, depending on sea conditions. ${ }^{52}$ Due to the distance between coaling stations on the Australian and New Zealand shipping routes, sail was

\footnotetext{
${ }^{46}$ Fry, Scottish Empire, p.109; Devine notes "In 1849 a mere 746 [Scotland] left for Australasian destinations and only 541 in 1851 . The following year this figure soared to 5450,4166 in 1853 and 2699 in 1854." T.M. Devine, The Great Highland Famine: Hunger, Emigration, and the Scottish Highlands in the Nineteenth Century, Edinburgh, 1988, p.204

${ }^{47}$ Prentis, Scots in Australia, p.68; Prentis, 'The settlers: Scots: the condition of Scotland 1788-1860', p.764

${ }^{48}$ Prentis, Scots in Australia, pp.75-6; John McDonald and Eric Richards, 'The great emigration of 1841: recruitment for New South Wales in British emigration fields', Population Studies, Vol.51, No.3, November, 1997, pp.337-355, p.348

${ }^{49}$ Devine, Scotland's Empire, 1600-1815, p.278

${ }^{50}$ Phillips and Hearn, Settlers, p.22

${ }^{51}$ Richards, Britannia's Children, p.13; Devine, The Scottish Nation: 1700-2000, p.475

52 'Appendix F: Vessels dispatched from Great Britain for the settlement of Otago from 1847 to 1850 inclusive; together with a list of emigrants' in T.M. Hocken, Contributions to the Early History of New Zealand, London, 1898, pp.286-296
} 
considered preferable to steamship travel until the 1880s. The first fully steampowered ship to make the voyage to New Zealand from Britain arrived in Dunedin in 1874, fifty-one days after having left Plymouth. Though other fully steam-powered ships were running between Britain and New Zealand from 1879 (the average voyage on one of these being approximately forty days by the 1890s), by the late 1890 s sailing ships were still operating this New Zealand route and the voyage was still around 100 days. ${ }^{53}$ Such protracted voyages not only meant many more weeks living in the discomfort of ship life but also an increased amount of time unemployed between embarkation and settlement. ${ }^{54}$ The average fare to New Zealand tended to be over four times that of the fare across the Atlantic. ${ }^{55}$

Reports of the warlike tendencies of the New Zealand Māori may have been greatly exaggerated, but were almost certainly reinforced and inflated by reports of incidents near newly established settlements. ${ }^{56}$ Though potential migrants to New Zealand may have had their minds turned to other destinations by such reports, as well as by inflated claims about New Zealand's problems purveyed by immigration agents working on the behalf of other destination countries, New Zealand nevertheless tended to be viewed more favourably in Scotland than Australia. It did not, for example, suffer the taint of convict settlement. Moreover while Australia's hot, dry climate was considered by many (such as Hugh MacKenzie) to cause illness, New Zealand's climate was often compared favourably with that of Scotland. ${ }^{57}$ Though many of the pamphlets, emigration handbooks and guides published to encourage

\footnotetext{
${ }^{53}$ John Wilson, 'The Voyage Out - Early Steamers', Te Ara - the Encyclopedia of New Zealand, URL: http://www.TeAra.govt.nz/en/the-voyage-out/6, updated 4-Mar-09; Passenger lists for Ships arriving in Port Chalmers between 1897 and 1900, accessed at $\mathrm{http} / / /$ freepages.genealogy.rootsweb.ancestry.com/ shipstonz/portchalmers5.html

${ }^{54}$ Devine, The Scottish Nation: 1700-2000, p.475

${ }^{55}$ Phillips and Hearn, Settlers, p.22

${ }^{56}$ The Gilfillan massacre at Wanganui in 1847 being a prime example. On 18 April 1847 the Gilfillan family, formerly of Lanarkshire, were attacked at their home in Matarawa by six young Māori men. The attack was considered particularly shocking because women and children were killed, rather than only adult men. Newspaper reports of the massacre were still circulating forty-one years later, an article written by Sarah Gilfillan who was six at the time of the attack, being published to clear up misconceptions about the events that took place that evening. 'The truth about the Gilfillan Massacre', The Wanganui Herald, 6 January 1888, p.2, col.7-8.

${ }^{57}$ For example, The New Zealand "Emigrant's Bradshaw", or, Guide to the "Britain of the South", published in 1856, relates how 'Otago, as regards climate, occupies the same position in New Zealand as Scotland occupies in Great Britain.' Another guide notes 'the climate of New Zealand is cooler and moister than that of New South Wales, and is generally favourable to European constitutions'. Arthur Willis and Gann and Co., The New Zealand "Emigrant's Bradshaw", or, Guide to the "Britain of the South", London, 1856; H. Smith Evans, A Map and a Guide to all the Emigration Colonies of Great Britain and America, London, 1852, p.12; Molloy, Those Who Speak to the Heart, p.118.
} 
emigration to New Zealand were oriented towards English audiences, others were written with the Scottish migrant market specifically in mind - for example Gearrchunntasan air New Zealand: air son feuma luchd-imrich, a guide to New Zealand for potential emigrants published for a Highland audience in Gaelic in $1872 .^{58}$

\section{Scottish migrant flows to New Zealand}

Figure 1.1, below, charts the flow of immigrants from Scotland to New Zealand between 1840 and 1920 alongside the combined flow of immigrants from England, Wales, Ireland and Scotland. In order to examine changes in the profile of the migrants over time, the eighty years with which the present study is primarily concerned have been divided into five distinct 'periods of arrival', each broadly based upon those adopted by Phillips and Hearn in their recent study of migration to New Zealand from all of the counties of the British archipelago. Their periodisation is based upon known trends within New Zealand migration history, these being also inflective of economic and social trends in New Zealand. Migration trends do not occur in isolation and significant social and economic factors seldom fit neatly within decade delineations. ${ }^{59}$ Although Scottish immigration to New Zealand followed a similar flow to immigration to New Zealand generally, there are notable variations of detail in the Scottish flow. The divisions employed in the present study are

\footnotetext{
58 Peter Barclay, Gearr-chunntasan air New Zealand: air son feuma luchd-imrich, Duneideann (Edinburgh), 1872. Other handbooks about New Zealand that circulated in Scotland (viewed at the National Library of Scotland) include: Patrick Matthew, Emigration Fields: North America, the Cape, Australia, and New Zealand; Describing These Countries, and Giving a Comparative View of the Advantages They Present to British Settlers, Edinburgh and London, 1839; John Bright, Handbook for Emigrants and Others: Being a History of New Zealand, its State and Prospects, Previous and Subsequent to the Proclamation of Her Majesty's Authority; also Remarks on the Climate and Colonies of the Australian Continent, London, 1841; Walter Brodie, Remarks on the Past and Present State of New Zealand, its Government, Capabilities, and Prospects; with a Statement of the Question of the Land-claims, and Remarks on the New Zealand Company; also a Description (never before published) of its Indigenous Exports, and Hints on Emigration, the Result of Five Years' Residence in the Colony, London, 1845; George Butler Earp, Handbook for Intending Emigrants to the Southern Settlements of New Zealand, London, 1849; John Hill Burton, The Emigrants' Manual: Australia, New Zealand, America and South Africa, Edinburgh, 1851; Amos John Gann, The New Zealand Emigration Circular for 1852, London, 1852; Thomas S. Forsaith, A Hand-book for Emigrants to New Zealand, London, 1858; John Cargill, Otago, New Zealand: Information for the Guidance of Intending Emigrants, Edinburgh, 1860; Rev. James Baird, The Emigrants Guide to Australasia: Tasmania and New Zealand with a Map of New Zealand, London, 1871; William England, A Pamphlet That All Should Read Before Emigrating to Australia, New Zealand, America, Cape of Good Hope, and Other Places, London, 1877; John Berry, New Zealand as a Field for Emigration. With Map, London, 1879; and John Bathgate, New Zealand: Its Resources and Prospects, London and Edinburgh, 1880

59 A concise outline may be found in Phillips and Hearn, Settlers, pp.30-50; Their unpublished manuscript is organised by these periods of arrival: Hearn and Phillips, 'Immigration study findings', unpublished manuscript
} 


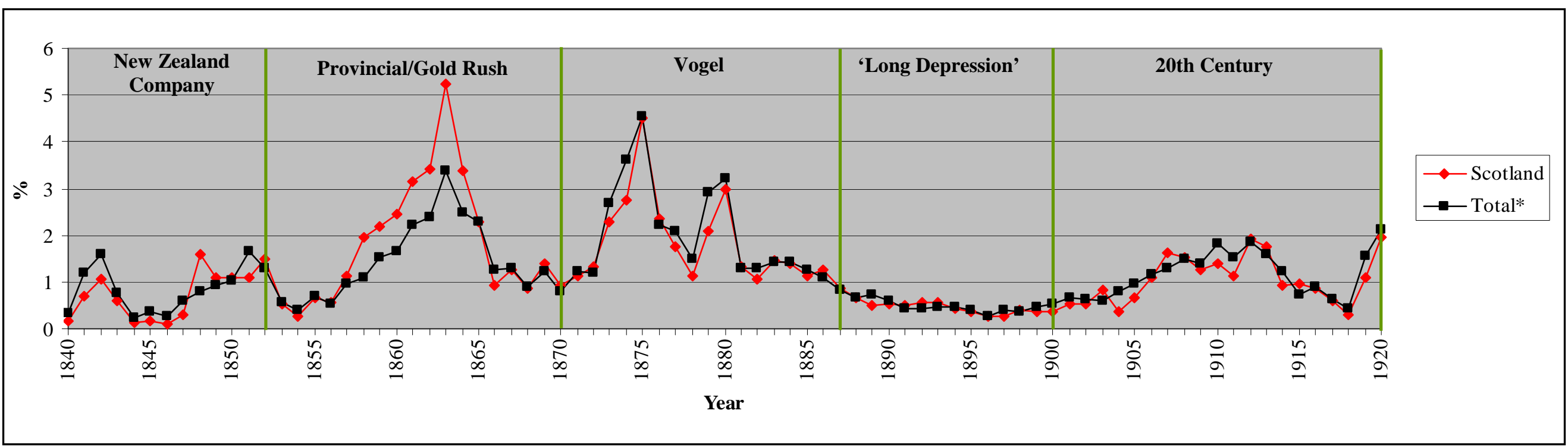

* Total = all migrants in the PNZ data arriving between 1840 and 1920 born in England, Wales, Ireland and Scotland. Source: PNZ data 1840-1920 
Pre-1852, 'The New Zealand Company period'

The systematic colonisation of New Zealand began in 1840 with the arrival of the first New Zealand Company ships at Port Nicholson (Wellington). Over the ensuing decade further New Zealand Company settlements at Wanganui, New Plymouth, Nelson, Otago and Canterbury were established. ${ }^{1}$ Approximately 82 per cent of the migrants to these settlements were from England, just 15 per cent were born in Scotland and less than 2 per cent were from Ireland. ${ }^{2}$ Otago, as will be outlined in greater detail in Chapter Three, was established as a distinctively Scottish settlement in 1848. The first major influx of Scots to Dunedin in 1848 is the primary reason Scots peak above general British immigration to New Zealand in that year in Figure 1.1. Though not a New Zealand Company settlement, Auckland received an earlier influx of Scottish migrants in 1842, predominantly from Paisley and surrounds. ${ }^{3}$ As Figure 1.1 suggests, nearly 6 per cent of all Scots arriving in New Zealand between 1840 and 1920 arrived in this first decade of settlement.

\section{3-1870, 'The gold rush and provincial period'}

Under the Constitution Act of 1852 six provinces were established - essentially based upon five of the New Zealand Company settlements (Wanganui being included within Wellington Province) plus Auckland. Provision was made for the formation of further provinces and alteration of the provincial boundaries as necessary, and eventually ten provinces were created. Each of these provinces was governed by an elected Provincial Council headed by a Superintendant, creating a level of localised government operating below the General Assembly (the sitting of the elected House of Representatives and an appointed Legislative Council, also formed under the Constitution Act) overseen by the Governor of New Zealand. Among the

\footnotetext{
${ }^{1}$ Wellington and Wanganui: 1840; New Plymouth: 1841; Nelson: 1842; Otago: 1848; Canterbury: 1850. Jock Phillips, 'History of Immigration', http://www.TeAra.govt.nz/NewZealanders/NewZealandPeoples/HistoryOfImmigration/en updated 21 September 2007; See also J.S.Marais, The Colonisation of New Zealand, London, 1968; Patricia Burns, Fatal Success: a History of the New Zealand Company, Auckland, 1989

2 Phillips, 'History of Immigration', 'Auckland and New Zealand Company settlers by country of origin, 1840-52'; Terry Hearn and Jock Phillips, "Immigration study findings', unpublished manuscript, Part 2: Immigration during the Crown Colony period, 1840-1852' c.2007, available at: http://www.nzhistory.net.nz/culture/home-away-from-home/sources, p.30.

${ }^{3}$ Many of the early Auckland immigrants were Irish: 35.9 per cent of PNZ migrants arriving in Auckland between 1840 and 1852 were Irish, 17.6 per cent Scottish and 45.7 per cent English. Phillips, 'History of Immigration', 'Auckland and New Zealand Company settlers by country of origin, 184052'; See also Violet Ward, 'Immigrants and Immigration in the Auckland Province 1792-1876', M.A. Thesis, University of Auckland, 1943; J.R. Phillips, 'A Social History of Auckland, 1840-1853', M.A. Thesis, University of Auckland, 1966; John Horsman, The Coming of the Pakeha to Auckland Province, Wellington, 1971; and footnote 17 and Figure 3.2a in Chapter Three of the present work,.
} 
responsibilities and powers allotted to the provincial governments were the promotion of immigration, land sales and development. ${ }^{4}$ Provincial government immigration schemes were the principal recruitment apparatus for the colony to 1870 . Schemes of assisted immigration broadly similar to those devised by the New Zealand Company were introduced, including offers of free passage to labourers and domestic servants. ${ }^{5}$ The primary surge of immigration to New Zealand over this period, however, was largely an outcome of the discovery of gold in the South Island, this drawing large numbers of single male migrants, especially of British birth, many of whom had been living in Australia. Gross immigration figures for 1863 indicate an inflow of over 45,000 individuals landing in New Zealand in that year, a figure not equalled until the 1960s. ${ }^{6}$ Scots loomed large in the influx of prospective miners to Otago, arriving in the province in proportions considerably higher than their share of the 1861 British home population. Hearn notes that the number of Scots travelling directly from Britain to New Zealand exceeded the number of English migrants travelling directly to the colony between 1 January 1860 and 30 June 1863, a pattern that is also clear in Figure 1.1.

\section{1-1886, 'The Vogel period'}

In September 1870 the Immigration and Public Works Act and the Immigration and Public Works Loan Act were passed in the colonial legislature at the instigation of Colonial Treasurer, later Premier, Julius Vogel, the intention being to promote economic and infrastructural growth in New Zealand by stimulating immigration and

\footnotetext{
${ }^{4}$ W.P. Morrell, The Provincial System in New Zealand, 1852-76, Christchurch, 1964, Chapter III.

5 See: ibid.; R.H. Silcock, 'Immigration into Canterbury under the Provincial Government', M.A. Thesis, University of Canterbury, 1963; L.G. Gordon, 'Immigration into Hawke's Bay, 1856-1876', M.A. Thesis, Victoria University of Wellington, 1965; Latiffa Khan, 'Immigration into Wellington Province 1853-1876', PhD Thesis, Victoria University of Wellington, 1968; W.H. Scotter, 'The moderate success of the assisted immigration scheme', in W.J. Gardner (ed.), A History of Canterbury, 1971; Macdonald, 'Single Women as Immigrant Settlers', and Charlotte Macdonald, A Woman of Good Character: Single Women as Immigrants Settlers in Nineteenth-Century New Zealand, Wellington, 1990; Terry Hearn and Jock Phillips, “Immigration study findings', unpublished manuscript, Part 3: The Provincial and Gold-rush years, 1853-70' c.2007, available at: http://www.nzhistory.net.nz/culture/home-away-from-home/sources

6 Phillips and Hearn, Settlers, p.38. See also Murray McCaskill, 'The goldrush population of Westland', New Zealand Geographer, Vol.12, No.1, April, 1956, pp.32-50; James Forrest, 'Population and settlement on the Otago goldfields, 1861-1870', New Zealand Geographer, Vol.17, No.1, April, 1961, pp.64-86; Phillip Ross May, The West Coast Gold Rushes, Christchurch, 1962; Murray McCaskill, 'The South Island goldfields in the 1860s: some geographical aspects', in Murray McCaskill (ed.), Land and Livelihood: Essays in Honour of George Jobberns, Christchurch, 1962; Mike Johnstone, Gold in a Tin Dish: The Search for Gold in Marlborough and Eastern Nelson, Volumes 1 and 2, Nelson, 1992 and 1993

7 Terry Hearn, 'Scots miners in the goldfields, 1861-1870', in Tom Brooking and Jennie Coleman (eds), The Heather and the Fern: Scottish Migration and New Zealand Settlement, Dunedin, 2005, p.72
} 
public works development. The various schemes of assisted immigration subsequently initiated by the New Zealand government drove immigration numbers to a record high. ${ }^{8}$ The introduction of free passages from October 1873 - for married and single male 'agricultural labourers, navvies, shepherds, mechanics' and to 'single women who worked as cooks, housemaids, nurses, general servants and dairy maids who were not under 15 nor over 35 years of age' - was an important contributing factor to the peak inflow observable in the mid 1870s. ${ }^{9}$ Only as the supply of employees began to meet the level of demand were free passages confined to farm labourers of high quality, shepherds, carpenters, bricklayers and female servants. ${ }^{10}$ Finding suitable immigrants during these years was complicated by the fact that immigration to New Zealand was all but closed from November to May. In Scotland, the shepherds, farm labourers and female servants being sought as migrants were just beginning their new yearly or half-yearly contracts. Potential migrants were therefore forced to choose between applying for May immigration, and possibly having their applications turned down, or engaging in new contractual work in Scotland. Many consequently chose to remain in Scotland. ${ }^{11}$ Nevertheless, as Figure 1.1 suggests, the flow of Scottish immigration to New Zealand very closely parallels the flows from all parts of the United Kingdom and Ireland to New Zealand from 1865 and throughout 'the Vogel period'. Although the volume of assisted immigrants arriving was such that little record beyond passenger lists remains extant to examine the flow of unassisted migrants, a significant number of self-funded migrants continued to make their way to New Zealand throughout these years.

\footnotetext{
${ }^{8}$ Morris, 'The Assisted Immigrants to New Zealand', p.21; D.B. Leitch, Railways of New Zealand, Devon, 1972, p.30. While in February 1871 the total population of New Zealand, exclusive of Māori, was approximately 256,000 people, by 1881 the total population had risen to approximately 490,000 . Table No.11. 1871 Census of New Zealand; Part 1, Table VI, 1881 Census of New Zealand, p.3. On Vogel and 'Vogelism' see also: R.M. Burdon, The Life and Times of Sir Julius Vogel, Christchurch, 1948; W.P. Morrell, Vogel and his Public Works Policy, Wellington, 1953; and, in particular, Raewyn Dalziel, Sir Julius Vogel, Wellington, 1968; see also J.P. Dowie, 'The course and character of capital formation in New Zealand, 1871-1900', New Zealand Economic Papers, Vol.1, 1966, pp.38-58; and J.P. Dowie, 'Business politicians in action: the New Zealand railway boom of the 1870s', Business Archives and History, Vol.5, 1965, pp.32-56

${ }^{9}$ Morris, 'The Assisted Immigrants to New Zealand', p.30

${ }^{10}$ ibid., p.45

11 ibid., p.45
} 
1887-1900, 'The Long Depression period', and 1901-1920, 'Early $20^{\text {th }}$ century ${ }^{12}$

From the 1880s through to approximately 1905 immigration to New Zealand was generally at low levels. 'The Long Depression' or the 'Black Eighties', as the period from approximately 1880 to 1892 has been labelled by many New Zealand historians, witnessed soaring unemployment and consequently high levels of emigration from New Zealand. ${ }^{13}$ As one scholar has observed, 'doom clouds wafted along the migration lines to New Zealand' during this period. ${ }^{14}$ Net migration figures for New Zealand indicate an 'exodus' of people from the country between 1888 and $1892 .{ }^{15}$ Though by 1891 the worst of the depression was over, and for at least a decade after 1895 the country experienced full employment and a rise in real wages, immigration figures remained low. ${ }^{16}$ Inflows picked up from around 1906 through to 1914, but World War One effectively halted immigration. While 389,394 people emigrated from Britain to destinations outside of Europe in 1913, only 214,893 left in 1914, and between 1915 and 1918 the figure dropped to just 150,462 in total. ${ }^{17}$ Ships were not generally available for transporting migrants and, besides, travel was dangerous: thirty-seven of ninety-nine ships involved in trade between New Zealand and Britain were sunk by German U-boats during World War One. ${ }^{18}$ As will be outlined in Chapter Seven, an epilogue to the eighty years of New Zealand Scottish immigration to 1920 , immigration flows to New Zealand picked up again in the 1920s, due in part to the revival of schemes of assisted passage. In those years Scottish immigration flows to New Zealand did not vary significantly from the general British flow.

\footnotetext{
${ }^{12}$ It is with this 'depression' period that the periodisation for the present work diverges most sharply from that used for the PNZ analysis by Phillips and Hearn. While their work continues on to 1945, the NZSG data only goes to 1920, making it necessary to alter the periodisation from their '1871-1890', '1891-1915', and '1916-1945'.

${ }^{13}$ R.J. Campbell, "The "Black Eighties": unemployment in New Zealand in the 1880s', Australian Economic History Review, Vol.16, 1976, pp.67-82; John M. Gandar, 'New Zealand net migration in the latter part of the nineteenth century', Australian Economic History Review, Vol.19, No.2, 1979, pp.151-168, p.161; Belich, Paradise Reforged, p.32; Sinclair, History of New Zealand, p.168; King, The Penguin History of New Zealand, pp.234-6; Reeves, The Long White Cloud, pp.242-4

${ }^{14}$ Belich, Paradise Reforged, p.32

15 Rollo Arnold, 'The dynamics and quality of trans-Tasman migration, 1886-1910', Australian Economic History Review, Vol.26, No.1, 1986, pp.1-20; Gandar, 'New Zealand net migration in the latter part of the nineteenth century', p.167

${ }^{16}$ Terry Hearn and Jock Phillips, 'Immigration study findings', unpublished manuscript, Part 5: Economic growth and renewed immigration, 1891-1915, c.2007, available at: http://www.nzhistory.net.nz/culture/home-away-from-home/sources, p.1

${ }_{17}$ Table 1, Appendix I, G.F. Plant, Oversea Settlement: Migration from the United Kingdom to the Dominions, London, 1951, p.174

${ }^{18}$ Belich, Paradise Reforged, p.110
} 


\section{Research objectives and data sources}

The literature about Scottish migrations since the Act of Union is increasingly rich and suggests many questions that may be applied to the New Zealand Scots experience. From where in Scotland did New Zealand's Scots migrants originate were they primarily from Highland or Lowland Scotland, were they from rural areas or urban population centres? Is the distribution of migrant origins in Scotland clustered or dispersed? Arriving later to the immigration game, did New Zealand experience chain and community migration to the same extent as has been reported for other destinations? Who were the migrants? Were they mostly young single men, or were they older married couples, travelling with their children? Did the flow of the migrants change over time in terms of age, gender and marital status, or did the profile remain static? What type of Scottish migrants did New Zealand attract in terms of occupation? Did New Zealand mostly receive Scots with urban-industrial skills, or predominantly those with agricultural, rural backgrounds? How many were 'career migrants' - the soldiers, missionaries, doctors, teachers, clerics, administrators and others capitalising 'on an international demand for their expertise as they pursued their careers around the globe' - who were more likely to emigrate only temporarily and as a part of their working lives? ${ }^{19}$

These are questions that are most clearly answered through statistical investigation. While most previous studies addressing such questions have utilised original census records, shipping records and official emigration records, such sources are either nonextant or of limited availability to historians of New Zealand immigration. ${ }^{20}$ As but one example, though passenger lists for inbound ships to New Zealand are available for those carried on New Zealand Company vessels in the 1840s and for assisted migrants travelling under the auspices of the New Zealand government in the $1870 \mathrm{~s}$,

\footnotetext{
${ }^{19}$ Harper, Adventurers and Exiles, p.282

${ }^{20}$ Erickson, for example, utilised figures recorded in British Parliamentary Papers, from the Census of Great Britain and Census of England and Wales, as well as Statistical Tables Relating to Emigration from and into the United Kingdom in various years, and U.S. Treasury Department statistics recorded in the Annual Report on Foreign Commerce and Navigation in C.J. Erickson, 'Who were the English and Scots emigrants to the United States in the late nineteenth century?' in D.V. Glass and Roger Revelle (eds), Population and Social Change, London, 1972. She makes extensive use of a range of United States inbound vessel ship lists, among other sources, in Charlotte Erickson, 'Emigration from the British Isles to the U.S.A. in 1831', Population Studies, Vol.35, No.2, July, 1981, pp.175-197 and Charlotte Erickson, 'Emigration from the British Isles to the U.S.A. in 1841: Part 1. Emigration from the British Isles', Population Studies, Vol.43, No.2, November, 1989, pp.347-367.
} 
they are deficient for self-funded immigrants and those arriving in other decades. ${ }^{21}$ Sources such as the unpublished Scottish census enumerators' schedules, utilised by McClean in her study of Scots migrating to New Zealand between 1840 and 1880, are of use in a study of migration to New Zealand only when the individuals have already been identified as emigrants from other sources. ${ }^{22}$ Were enumerators' schedules for the New Zealand census available they would prove an invaluable source for migration studies, but all such records prior to 1966 have been destroyed leaving only the published statistics produced from the censuses. ${ }^{23}$

In the absence of these standard sources, two datasets have been employed in the present study. The first, referred to throughout this text as the 'NZSG' dataset, was created specifically for this study and is based upon the New Zealand Society of Genealogists Scottish Interest Group's 'Register of New Zealand Immigrants of Scottish Birth arriving before 1 January 1921'. The aim of the register was to create as complete a list as possible of all Scottish migrants arriving in New Zealand prior to 1921, and it was conceived as an aid to family historians in New Zealand and abroad researching their own Scottish family histories. It was compiled between 1992 and 2005 and consists of over 7,000 individual forms, completed primarily by the descendants of migrants. ${ }^{24}$ The 'NZSG dataset' based on this register is therefore not a random sample of migrants but a self-selected sample. Each entry has been created by a process of record linkage, the contributors of the information individually linking various sources and records before contributing the information to the register. A detailed account of the creation of the dataset is provided in Appendix 1.1.

Because the register was not created with the intention that it become the foundation for a statistical database, fundamental difficulties arise from its use for such a purpose. For example, although the 'guide-lines for contributors' on the registration forms asked that 'one entry form for each New Zealand immigrant born in

\footnotetext{
${ }^{21}$ A notable exception being immigrants to Canterbury under the provincial assisted migration schemes that Macdonald's study of single women immigrants is largely based upon. Macdonald, 'Single Women as Immigrant Settlers', and Macdonald, A Woman of Good Character.

${ }^{22}$ McClean, 'Scottish Emigrants to New Zealand, 1840-1880', pp.67-69.

${ }^{23}$ Len Cook, 'Constraints and conflicts in access to official statistics and statistical records', in Brad Patterson (ed.), New Zealand Archives Futures: Essays in Honor of Michael Hoare, Wellington, 1996, pp.173-180; Rex Sinnott, 'The census and privacy in New Zealand: do privacy concerns justify destruction of name-identified census forms?' Archifacts, April, 2000, pp.25-50; Erik Olssen and Maureen Hickey, Class and Occupation: The New Zealand Reality, Dunedin, 2005, p.29

${ }^{24}$ Other forms in the register have been completed by members of the Scottish Interest Group based upon published works, and by persons unrelated to the migrant who had nevertheless investigated the family history for one reason or another.
} 
Scotland' be completed, often forms were completed for only the father of a family of migrants, with information for the spouse and children filled in on the same form, not separate forms. ${ }^{25}$ It was suspected that the database would be biased toward male heads of households for this reason, including fewer married women and single males, single females and children than if the data were properly representative. Though separate database entries were initially created for each spouse and/or child included on a husband's/father's register form, it was soon recognised that without a separate register entry there was too little information in the spouse and child sections of the registration forms for this to be viable. The likely outcome would be more migrants in the database for whom much of the information was absent.

Entering a number of the spouses and children on to their own forms in the database, however, raised a critical question: who should be included as a Scottish migrant? The first spouse entered in her own right was Sarah Gibson. Wife of a Renfrewshire-born man, Sarah was born in Armagh, Ireland, in 1844. Married at age eighteen, she and her husband migrated to New Zealand eight years later. Even if it is assumed that there was no period of courtship during which she lived in Scotland prior to the marriage, this meant that Sarah was living in Scotland for eight years before migrating to New Zealand with her Scots-born husband and children. ${ }^{26}$ Shortly after, the story of 'Jock' MacFarlane was encountered. Orphaned in England at age eight, George Telfar moved to Scotland to live with two unmarried aunts, residing there until he migrated to New Zealand in his mid-twenties. At that stage he changed his surname to 'MacFarlane', and was known by his contemporaries as 'Jock' ${ }^{27}$ These cases beg the question, should the length of time resident in Scotland alter the perception as to whether a person is Scottish or not? In October 1842 Janet Morris and her husband arrived in New Zealand with their two month old son James McLellan, who was born at sea aboard the Jane Gifford. This child, born into a family of Scots-born parents and siblings, was considered by the contributor of his information to be Scottish, and yet he had never seen Scotland. ${ }^{28}$ Should he be included, while Sarah and 'Jock' are not? In 1858 Catherine Henderson Boyne was

\footnotetext{
${ }^{25}$ In other cases information for both parents was presented, but not the children, or for a child or children but not their parents. As well as other considerations, noted in the text above, this also means the database is smaller than it might have been had registration forms been filled in for additional family members.

${ }^{26}$ NZSG migrant 00012 (Sarah's husband Andrew)

${ }^{27}$ Personal communication with Craig MacFarlane, 2006

${ }^{28}$ NZSG migrants 04061,04062 (no registration form for James' mother)
} 
born in Australia shortly after her family arrived there. She lived less than two years in Australia before migrating to New Zealand with her Scots-born parents, two Scotsborn brothers and one brother born in Australia. Although she knew nothing of life in Scotland, leaving Australia under the age of two, she surely had no perception of herself as an Australian. Should she be considered an Australian or a Scottish migrant $?^{29}$ Elizabeth Connolly was born in Scotland but moved to England shortly after birth, residing there until she migrated to New Zealand thirty-seven years later with her English-born husband and four English-born children. ${ }^{30}$ Though Elizabeth appears to be the least 'Scottish' of the five migrants to New Zealand cited, only she and James McLellan have been included in the NZSG database for the purposes of the present analysis; only those born in Scotland and those born en route from Scotland to New Zealand have been included.

One reason place of birth, rather than place of residence in Scotland, was chosen to determine where in Scotland the migrant was from arose from the registration forms asking for 'up to three places of residence in chronological order'. Many migrants lived in more than three places in Scotland and, though the three listed on many forms may have been in chronological order, no dates are given. It is therefore impossible to determine, based on the forms alone, whether these were the first three places the migrant resided, or the last three before departure. The same holds for places of residence in New Zealand. Although the NZSG registration forms include places of New Zealand residence, there was no indication as to when the individual lived in these places, if these were the only places they resided, or for how long they resided in individual locations. Consequently, place of death has been used as indicative of where the migrant settled in the NZSG as well as the Peopling of New Zealand (PNZ) data, outlined below. Although far from ideal for a number of reasons (see PNZ section below), this was the only variable concerning a place of residence available that was consistent across all entries in the NZSG database.

The register guide-lines also requested that only 'up to two occupations' be recorded for the migrants' time in Scotland and in New Zealand. Again, there is no indication in the returns as to when the occupations were held, for how long, or indeed whether they were held subsequently or concurrently. Some contributors listed

\footnotetext{
${ }^{29}$ NZSG migrant 00115 (Catherine's father)

${ }^{30}$ NZSG migrant 01141
} 
only two occupations, others as many as they could fit onto the form, up to five in some instances. This has made analysis of the migrants' occupations difficult, but it has also afforded richer information than the one occupation of the migrant recorded in death certificates (see Appendix 5.1 for detail).

Notwithstanding the outlined difficulties, the NZSG register has nevertheless proved an invaluable source for demographic research. Although much of the information in the register is also available from official sources, linking the information for each migrant from assorted sources would have been a task for a longterm or team study, not a $\mathrm{PhD}$ thesis research project. Additionally, this ready-made register of migrants was primarily created by their descendants who, it may be assumed, know the linkages between the various aspects of the migrants' lives well. Attempting to link information to tell a migrant's life story is especially difficult in Scotland, where naming practices keep many names cycling through generations. Blindly searching for a 'Donald MacDonald' or 'Gregor MacGregor' becomes an almost impossible task. Descendants with family knowledge of the migrants find the task of tracking down information far easier than a researcher with no family knowledge. The diaries, family bibles, letters, oral tradition and other family records that have been used by many contributors also provide information that is either difficult to find or nearly impossible to link to the correct migrant using official documents alone.

This accepted, while family records and personal documents are the primary strength of the present dataset, they also have the potential to provide unreliable information. Though family tradition may have it that Great Uncle Donald was a farm hand from rural Scotland, it may prove instead that he was a clerk from Glasgow. This is especially the case where the migrant was an assisted passenger to New Zealand and the source of occupation information is an assisted passenger list. The migrant may not have received a free passage as a clerk, but qualified as a farm hand. Further, it was far from unknown for people to reinvent their pasts when embarking on a new life in the new country. Thus stories told to disguise the truth of time in Scotland from New Zealand-born family are passed on through generations, and it is highly probable some have found their way into the register. However, though it must be accepted that such mistakes can slip though in family as well as public records, much of the information in death certificates being based on the information supplied 
by the person registering the death, for the most part family traditions passed down have at least some foundation in fact.

Beyond potentially filling a vital gap, this genealogically-sourced data is important for a second reason. It enables the testing of such collections of data as a foundation for the study of migrants and their movements. The use of genealogical sources in migration studies is not a new idea, Elliott's work on migrants from Tipperary to Canada being an outstanding example of how these methods may be employed. ${ }^{31}$ Elliott's study, of 775 families, is a landmark in migration studies, its primary strength being that he moves beyond faceless aggregate statistics, drawing his conclusions about the migrants and the migration process from a substantial body of data regarding individual migrants. Elliott traced the migrants himself, employing genealogical methods to piece together his dataset. While this ensured a superior level of quality control over the information gathered, Elliott acknowledges that his success in achieving his record linkages on such a grand scale, in a relatively short time, was almost fortuitous: '....in retrospect I can see that the project was just barely manageable. Had I chosen an area of Northern Ireland with its huge Protestant populations, and very common lowland Scottish or borders names... I would be at it still. $^{32}$

Tracing the individuals who made up the flow of migrants from every corner of Scotland to every part of New Zealand, or even to a single province, employing Elliott's methods would be beyond the scope of a single researcher. The utilisation of the NZSG dataset, notwithstanding the necessary reliance on record linkage being individually undertaken by hundreds of family historians, and then compiled by a genealogical group, is a new approach and provides an opportunity to test the validity of using such genealogical sources in migration research. The genealogical foundation of the study has also facilitated the extrapolation of individuals from the aggregate statistics. Hence each of the chapters commences with an outline of the experiences of

\footnotetext{
${ }^{31}$ Bruce S. Elliott, Irish Migrants in the Canadas: A New Approach, Montreal and Kingston, 2004. Other examples include: Colin Pooley and Jean Turnbull, Migration and Mobility in Britain Since the 18th Century, London, 1998 (see pp.28-31 in particular for discussion of the use of genealogical sources in migration research); Harald Runblom and Hans Norman (eds.). From Sweden to America: A History of the Migration, Minneapolis, 1976; Jon Gjerde, From Peasants to Farmers: The Migration from Balestrand, Norway, to the Upper Middle West, Cambridge, 1985; and Walter Kamphoefner, The Westphalians: From Germany to Missouri, Princeton, 1987. In the 2004 edition of Irish Migrants in the Canadas Elliott includes in his 'Epilogue: 2004' what is essentially a short bibliographic essay on other studies of migration that utilise genealogical sources and methods. See pp.249-257.

${ }^{32}$ Elliott, Irish Migrants in the Canadas, p.248
} 
Scots migrants that relate to the theme of the chapter. Wherever possible, further accounts of the experiences of individuals have been included in the text to highlight or illuminate statistical patterns. Though the patterns that emerge when information about individuals is aggregated are meaningful and important, the individuals who created those patterns should not be forgotten. As Elliott notes:

the historical individual assumes meaning as he or she exemplifies or departs from the pattern, and the pattern becomes reality, rather than an analytical abstraction, only when it can be proved to reflect the collective tendencies of individuals. $^{33}$

The second dataset to be interrogated, which serves as a point of comparison and control, is the Scotland-born sub-sample of the extensive dataset based upon death certificates collected for the Ministry of Culture and Heritage's 'Peopling of New Zealand' project, referred to throughout this thesis as the 'PNZ' dataset. ${ }^{34}$ The dataset was made available by Dr Jock Phillips of the Ministry of Culture and Heritage to enable comparison with the NZSG dataset. This data was collected over several years under the supervision of Dr Phillips and Dr Terry Hearn and was based upon information from death certificates from $1876 .^{35}$

Prior to 1876 New Zealand death certificates only contained information regarding when and where the person died, their name and surname, gender, age, profession, and cause of death. When the Registration of Births and Deaths Act 1875 came into effect (on 1 January 1876) the following information was required: when and where the person died; name and surname; sex and age at death; profession or occupation; cause of death, duration of last illness, medical attendant and when they last saw the deceased; name of father, name and maiden surname of mother; occupation of father; when and where buried; name and religion of minister or name of witness; where born and how long they had been in New Zealand; where married, at what age and to whom; how many of their children were still living and how old they were. ${ }^{36}$ The additional information in certificates post-1875 makes them a valuable source for the

\footnotetext{
33 ibid., p.8

${ }^{34}$ Personal communication with Dr Jock Phillips, 21 March 2006; Jock Phillips and Terry Hearn, 'The Peopling of New Zealand project: reflections', Seminar on Ethnic Counting: How Do We Measure Ethnic and Cultural Transfers in the British World?, 2 March 2007

${ }^{35}$ For a summary outline of this project see Jock Phillips, 'Who were New Zealand's founding Pakeha?', in Settling the Waikato and Beyond. Proceedings of the New Zealand Society of Genealogists 2006 Conference, Auckland, 2006, pp.254-269

${ }^{36}$ Death Data Collected, http://bdmhistoricalrecords.identityservices.govt.nz/datacollected/death.aspx
} 
analysis of migrants and patterns of migration to New Zealand. A detailed account of the creation of the dataset is provided in Appendix 1.1.

A fundamental bias of the PNZ data is that a person had to die in New Zealand, and die after 1876 , to be counted. The data is therefore not necessarily representative of all those arriving in New Zealand. Phillips and Hearn argue, however, that it is those who remained in New Zealand, and therefore are included in the dataset, who helped to create and shape New Zealand and its culture. The most serious drawback is that there is no indication from this source as to return migration trends or the actual inflow of migrants.

As previously noted, the only information available in the PNZ data to indicate where a migrant resided in New Zealand is place of death. While this makes analysis simple, there being only one signifier to take into consideration, it is also potentially misleading in respect of the actual pattern of settlement of the migrants. If migrants died away from their usual place of residence, or if they had migrated internally only shortly before death, having lived many years in another part of New Zealand, the place of death provides a misleading indication of the place of settlement. Further, and especially problematic with regard to the first period of arrival, 1840-1852, using place of death as indicative of place of settlement can lead to an implication that the migrant was in that area at arrival. In Chapter Three, for example, Southland is noted as having received a disproportionately high number of Highland Scots noted as having arrived in the colony pre-1852; however Southland was not settled in any great numbers until the $1850 \mathrm{~s}$, so while the high proportion of Highlanders who settled in Southland arrived in New Zealand pre-1852, they did not all settle in Southland pre1852. Despite these conundrums, however, place of death is a fixed point in an individual's history and therefore does allow more sensible, straight-forward statistical analysis than taking account of every place of residence in New Zealand.

Because death certificates only provide useful information from 1876 onwards, the PNZ sample is skewed to those who survived to 1876 . For those arriving in 1840, this meant they had to live at least thirty-six years in New Zealand to be included in the sample. With life expectancy in the colony being relatively low in the formative years, the sub-sample for these years inevitably includes more people who arrived as children and few who arrived aged forty years or older. The data for this early period is also likely to include fewer men than women, accidents being a primary cause of 
death in the early settlement years, and men being more likely to be accidentally killed in the course of their occupations. A further issue regarding the age of the migrants is that the calculation of the age at arrival of the PNZ migrants being age at death minus the number of years spent in New Zealand appears to have 'aged' the migrants, by on average three years. The number of years spent in New Zealand prior to death appears to have been frequently estimated to be less than was actually the case by those filling in the death certificates. For example, if a migrant who had spent fifty-three years in New Zealand had the number of years spent in the country recorded as just fifty years, the migrant would appear to have arrived aged thirteen rather than aged ten. See Chapter Four for further discussion.

The source of the dataset also dictates that migrants are counted and treated as individuals; chains of migration, travel companions and possible group decisions to come to New Zealand are therefore not readily apparent. Without names attached to the information, it is impossible to know whether, for example, the twenty-six migrants from Roxburgh in the data arriving between 1840 and 1920 were related, or if they were twenty-six individuals who made independent decisions to come to New Zealand. As far as seeking possible reasons for migrants leaving Scotland for New Zealand, or looking for patterns of migration from or to a given area in Scotland or New Zealand, there is a significant difference between a single woman migrating on her own and a widowed woman migrating with her five children. The PNZ data does not permit such distinctions to be made.

The PNZ dataset is unique. Based on an official source, it is essentially a random and representative sample including over 11,800 migrants arriving in New Zealand between 1840 and 1945. Of these 11,800, over 3,680 were born in Scotland. The primary strength of the PNZ data as a point of comparison is that its strengths and weaknesses are different to those identified in respect of the NZSG data. The PNZ data permits comment on religion. Information regarding place of birth, places of residence or date of birth are not missing for as many migrants as is the case with the NZSG data. There is only one variable available in the data to answer where the migrant came from, the occupation of the migrant, and where in New Zealand the migrant resided, making analysis straightforward and tidy - even if not particularly rich. The PNZ dataset has allowed quirks in the NZSG data, such as the number of Shetlanders to New Zealand in the 1870 s, to be verified. It has enabled contrary 
interpretations of events to be developed when the patterns coming out of the datasets are divergent - as in the question as to where in Scotland migrants were coming from in the 1890s (see Chapter Two, p.38). Finally, and perhaps most importantly, it has provided reassurance that the NZSG data is robust.

\section{Outline of contents}

The findings of the study are set out in six chapters. Chapter Two examines the origins in Scotland of New Zealand's Scots migrants. Beyond basic analysis of the NZSG and PNZ datasets to establish where in Scotland the migrants were from by period of arrival in New Zealand, it incorporates brief sketches of the key characteristics of several areas in Scotland that sent significant numbers of migrants to New Zealand. The chapter also probes the NZSG data for discernible patterns of internal Scottish migration and immigration to other destinations prior to arrival in New Zealand.

Chapter Three takes findings from Chapter Two and elaborates upon them with regard to where in New Zealand the Scots settled. It seeks to test common wisdoms. Patterns of settlement are explored over time and by region of Scottish origin, at provincial and at county level within New Zealand. Augmenting this statistical analysis, two interconnected Scottish settlements in Wellington Province are examined using genealogically-based qualitative evidence. Statistical analysis in the chapter suggests that, despite past assumptions, parts of New Zealand outside of Otago/Southland and Waipu did receive a significant number of Scots. As well as highlighting the utility of genealogical case studies in illuminating statistical patterns, these case studies explore an area of New Zealand Scots settlement outside of those usually associated with Scots at a greater depth than statistical analysis allows. Wellington has been chosen as a case study as it received Scots throughout the period under investigation, from 1840 with the arrival of several predominantly Scottish migrant New Zealand Company vessels.

Chapter Four examines the NZSG data to determine patterns of gender, age and marital status at arrival. With the factors influencing these demographic characteristics being so varied and multiple, no detailed profiling has been possible in the present work. Instead, the chapter outlines the primary findings pertaining to gender, age and marital status at arrival arising from the NZSG data with regard to 
migrant origins, places of settlement, and period of arrival. It seeks to discover whether these facets of the migrant profile affected the demographic characteristics of the migrants, and in what ways they varied. The chapter concludes by comparing and contrasting the NZSG and PNZ data, testing the genealogical dataset.

Chapter Five turns to the occupational composition of the migrant flows. With occupation being a complex aspect of the migrant profiles, the chapter begins with an outline of some methodological considerations. These are amplified in a separate methodological appendix (Appendix 5.1). Occupation is considered from several angles, including what can be established about the pre- and post-migration occupations of both migrants and their fathers, while there is an attempt to assess both individual and generational occupational mobility. Analysis of occupation by period of arrival, region of birth, province of settlement, gender, age and marital status is also addressed.

Chapter Six is a county case study of Shetland. It investigates the migration flows from Shetland to New Zealand by time, origin, settlement, age, gender, marital status and occupation. It is intended to serve as a further illustration of the greater depth of understanding that is frequently achievable when migration patterns are examined on a smaller scale, and particularly when the locality is relatively distinctive. It enables the tracing of chain migrations, cluster migration and travel companions in ways not feasible when considering the larger migration flows from Scotland to New Zealand.

Chapter Seven is presented as an epilogue to the earlier reported research. While the preceding chapters focus on those migrants arriving in New Zealand prior to 1921, Chapter Seven utilises the PNZ data to briefly sketch the migrant flows between 1920 and 1945. The chapter discusses basic inter-war migration trends and outlines findings from the PNZ data in terms of the region of birth, province of settlement, period of arrival, age, gender, marital status and occupation of Scots arriving in these years. There is also a short discussion of return migration by Scots arriving in New Zealand between 1840 and 1945 .

The study concludes with a summary of its principal findings and suggestions of potentially fruitful avenues for further investigation. 


\section{Chapter Two \\ 'FAREWELL, THE BONIE BANKS OF AYR!' THE ORIGINS OF NEW ZEALAND’s SCOTTISH IMMIGRANTS. ${ }^{1}$}

Born in Edinburgh in 1806, Nathaniel Sutherland was the eldest son of Highland-born parents. His father, Donald Sutherland, was born in 1759 and raised in Clyne Parish, Sutherlandshire. A tailor by trade, Donald served in the British Army from 1777 to 1814, travelling extensively throughout Scotland during that time. Though his wife was also born and raised in Sutherland, the couple settled in Canongate, Edinburgh, after they married in 1805. Nathaniel was thirty-five when he arrived in New Zealand with his siblings, and had spent all of those thirty-five years living in Edinburgh. ${ }^{2}$ Despite his Highland ancestry, Nathaniel was one of New Zealand's many immigrants born in Lowland Scotland.

From where in Scotland New Zealand's Scottish migrants originated is fundamental to consideration of 'who' they were. It is the factor of the migrants' profile that provides the base to which all other elements of the profile are related. Scotland is a land of great contrasts. From its rugged and inhospitable Highland ranges to its fertile Lowland plains, from its coasts to its landlocked valleys - not least from its mainland to its islands - the land cannot help but shape the people living on it. $^{3}$ Discussion in this chapter of from where in Scotland New Zealand's migrants came will provide the necessary framework for later scrutiny of their occupational backgrounds, as well as their demographic characteristics at the time of arrival. In this study, place of birth is the only signifier of 'origin' that has been utilised for statistical purposes. Partly, this is because internal migration featured in the lives of many Scots. ${ }^{4}$ Tracing all of the internal migration movements within Scotland for each subsequent migrant to New Zealand would be a complex task, and one, moreover, that

\footnotetext{
${ }^{1}$ Robert Burns, 'The gloomy night is gath'ring fast', in James Kinsley (ed.), The Poems and Songs of Robert Burns, Oxford, 1968, p.291, line 32.

${ }^{2}$ Sutherland family material provided by Spin and Joan Sutherland of Fordell

${ }^{3}$ Good descriptions of the landscape of Scotland may be found in J.B. Whittow, Geology and Scenery in Scotland, Harmondsworth, Middlesex, 1977; and K.J. Lea, G. Gordon, and I.R. Bowler, A Geography of Scotland, Devon, 1977, chapter 1.

${ }^{4}$ Figures for those enumerated in Edinburgh City and Midlothian, Aberdeen City and Aberdeenshire, Argyll, and the Western Lowlands who were born outside of those areas, noted in the outlines of these areas, below, are suggestive of the prevalence of this internal migration within Scotland. See also Jeanette M. Brock, The Mobile Scot: A Study of Emigration and Migration 1861-1911, Edinburgh, 1999.
} 
would not result in an accurate representation of the internal movements. The movements were often multiple, complex and - especially if the individual migrated internally, and then externally, between census years - unrecorded. The ability to trace such movements in the lives of individual migrants is one primary advantage of the NZSG material over other sources, and as such this will be elaborated upon later in the chapter. Chapter Three will further explore the question of origins, seeking to establish where in Scotland the Scots that settled in each province of New Zealand were from.

This chapter will address two core questions. Firstly, a question in two parts, were the Scots migrants to New Zealand predominantly from Lowland Scotland and was there proportionality in the distribution of migrant origins at the Scottish regional, county and parish levels? Secondly, did the distribution of the migrants origins vary greatly over time ${ }^{5}$ Though the question of how New Zealand's Scots, such as Nathaniel Sutherland, viewed themselves in terms of their personal origins, sense of history and identity is a critical question, it is not an issue that will be addressed in any detail in the present work. ${ }^{6}$ The objective, rather, is to establish the broad patterns regarding where in Scotland the migrants arriving in New Zealand between 1840 and 1920 were from at Scottish regional, county and parish level and to outline the chief characteristics of several key 'sending' areas.

\section{NEW ZEALAND’S SCOTTISH IMMIGRANTS: REGIONAL AND COUNTY ORIGINS}

In the early nineteenth century, Scotland experienced a period of great population movement. Though the Scots had always been migratory people, these first few decades of the nineteenth century witnessed pulses of migration, internal and external, greater than had been seen before. ${ }^{7}$ This period of migration might be described as having been stimulated primarily by the 'four horsemen' of early nineteenth-century Scottish migration: the agricultural revolution, industrialisation, famine and clearance. The details of these upheavals need not be reiterated here, all four having been subject

\footnotetext{
${ }^{5}$ These questions are suggested by findings in previous works: see, especially, Rosalind McClean, 'Scottish Emigrants to New Zealand, 1840-1880: Motives, Means and Background', PhD Thesis, University of Edinburgh, 1990 and Jock Phillips and Terry Hearn, Settlers: New Zealand Immigrants from England, Ireland and Scotland, 1800 - 1945, Auckland, 2008.

${ }^{6}$ This issue is addressed by McClean. See Rosalind McClean, "Writing my history': seven nineteenthcentury Scottish migrants to New Zealand revisit their pasts', Migrations and Identities, Vol.1, No.1, 2008, pp.45-73.

${ }^{7}$ Marjory Harper, Adventurers and Exiles: The Great Scottish Exodus, London, 2003, and Charles W.J. Withers, Urban Highlanders: Highland-Lowland Migration and Urban Gaelic Culture, 1700-1900, East Lothian, 1998, among others, provide good overviews of these flows.
} 
to much scholarly scrutiny. For the purposes of the present work, the brief, very broad summary that follows is sufficient to note the impact these 'four horsemen' had on the population distribution of Scotland in the early decades of the 1800s, prior to the commencement of immigration to New Zealand on any noteworthy scale.

The agricultural revolution saw an unprecedented increase in agricultural productivity, which by the early nineteenth century also led to a large scale reduction in the number of people that needed to be employed in the agricultural sector. People previously engaged in the rural sector were forced to find employment elsewhere, and, by the early nineteenth century, for many this meant moving from rural areas to urban centres in search of employment in the burgeoning industrial sector. In Scotland this meant a considerable number of people migrating from the rural Highlands and islands, the agricultural North East and the farm lands of Lowland Perthshire, as well as the Border counties, into central Scotland - industrial Lanarkshire in particular, though Renfrew, Ayr and Edinburgh also received many internal migrants at this time. The history of the clearances - in particular the move of many land-owners towards sheep farming and the subsequent clearance of the tenants previously living on that land that often followed, in the Lowlands as well as the Highlands, is one of the better known pages of Scotland's recent history. Though many of those 'cleared' from the land emigrated, sometimes assisted by their previous landlords, to Canada, America and Australia, many others migrated within Scotland to the urban, industrial centres of central Scotland. Though not nearly so devastating as the 1840s famine in Ireland, the potato famine in the Highlands of Scotland further accelerated these population movements. In short, the 'four horsemen' of early nineteenth century Scottish migration ensured that by the time of the establishment of Dunedin as a Free Church settlement in 1848, the majority of the population of Scotland lived in what may be termed Lowland Scotland. ${ }^{8}$ It should therefore not be surprising that the

\footnotetext{
${ }^{8}$ For more information see, among others: J.E. Handley, The Agricultural Revolution in Scotland, Glasgow, 1963; G. Whittington, 'Was there a Scottish agricultural revolution?', Area, Vol.7, No.3, 1975, pp.204-206; Dennis Mills and M.L. Parry, 'A Scottish agricultural revolution?', Area, Vol.8, No.3, 1976, pp.237-239; Ian H. Adams and I.D. Whyte, 'The agricultural revolution in Scotland: contributions to the debate', Area, Vol.10, No.3, 1978, pp.198-205; T.M. Devine, The Transformation of Rural Scotland: Social Change and the Agrarian Economy, 1660-1815, Edinburgh, 1994; T.M. Devine, 'Social responses to agrarian improvement: the Highland and Lowland clearances in Scotland, 1500-1800', in R.A. Houston and I.D. Whyte (eds), Scottish Society, 1500-1800, Cambridge, 1989; W.W. Knox, Industrial Nation: Work, Culture and Society in Scotland, 1800-Present, Edinburgh, 1999; I.D Whyte, Scotland before the Industrial Revolution, London, 1995; R.H. Campbell, The Rise and Fall of Scottish Industry, 1707-1939, Edinburgh, 1980; Christopher A. Whatley, The Industrial Revolution in Scotland, Cambridge, 1997; T.M. Devine, The Great Highland Famine: Hunger,
} 
majority of New Zealand's Scotland-born emigrants between 1840 and 1920 were from Lowland Scotland.

An important prefatory clarification relates to the often debated division between 'Highland' and 'Lowland' Scotland. The nature of the NZSG data (and PNZ data for that matter) is such that precise parish level information is not available for a significant number of the migrants. When speaking of 'Highland' or 'Lowland' migrants, this level of precision is necessary, for counties such as Perthshire contain both 'Highland' and 'Lowland' parishes. This is especially important when a distinction is made on the basis of cultural factors, for example the use of Gaelic in parishes. ${ }^{9}$ For this reason, the present work exercises caution in using the terms. It is simply not possible, based on the NZSG and PNZ data, to group the migrants as 'Highlander' or 'Lowlander' using such criteria. However, as no claim has been definitively made for counties here described as in the Eastern and Western Lowlands, or for the Borders regions, being 'Highland' counties or parishes, it is not unacceptable to describe them as Lowland for the purposes of this study. ${ }^{10}$

The NZSG data indicate that 70.03 per cent of the Scots immigrants arriving in New Zealand between 1840 and 1920 were born in a Lowland county. See Table 2.1. The indices in Table 2.1 represent the difference between the distribution of the migrants' origins in the NZSG data over the full eighty-year period (as shown in the 'whole period' column) and the distribution of the population of Scotland as at 1871, the census chosen for this index as the most logical mid-point for comparison with the NZSG data. The closer the index number is to ' 1 ', the less difference there is between the NZSG data and the census distribution. For example, the index number for the Eastern Lowlands is 0.98; the 1871 Census figure shows that 33.4 per cent of the Scottish population lived in this region - very close to the NZSG figure shown above. As may be inferred from Table 2.1, in 1871 over three-quarters of the population of

Emigration, and the Scottish Highlands in the Nineteenth Century, Edinburgh, 1988; Michael Fry, Wild Scots: Four Hundred Years of Highland History, London, 2005, especially chapters 11 and 14; Eric Richards, The Highland Clearances, Edinburgh, 2000

${ }^{9}$ Withers, Urban Highlanders, pp.16-19; Charles W.J. Withers, Gaelic in Scotland, 1698-1981: The Geographical History of a Language, Edinburgh, 1984, examines the changing geography of the Gaidhealtachd - the Gaelic speaking area of Scotland.

${ }^{10}$ The regions and counties of Scotland used throughout this thesis for analysis and discussion are based upon those used by Michael Flinn. See Michael Flinn (ed.), Scottish Population History from the 17th century to the 1930s, Cambridge, 1977, Map 3 (p.xxiii) and discussion, pp.104-106. These divisions are also those used by Rosalind McClean in her 1990 thesis and, largely, by the compilers of the PNZ data. See Map 1 and Map 2. See page of abbreviations for county names and abbreviations. 
Scotland was living in the Eastern or Western Lowlands or the Borders Region, an increase of approximately 10 per cent on the figures for these regions combined in 1801. ${ }^{11}$

Table 2.1

Proportion of New Zealand immigrants from each

region of Scotland, with indices of representation

based on the Scottish population distribution in 1871

\begin{tabular}{ccc}
\hline \hline Region & Whole period & Index \\
\hline \hline Far North & 5.46 & 1.79 \\
Highlands & 13.10 & 1.54 \\
North East & 11.43 & 0.97 \\
Eastern Lowlands & 32.77 & 0.98 \\
Western Lowlands & 27.92 & 0.79 \\
Borders & 9.32 & 1.15 \\
$\boldsymbol{n}$ & $6,243^{*}$ & \\
\hline
\end{tabular}

*Figures exclude those in the data whose birth region is unknown.

Sources: NZSG data 1840-1920; Return Relating to the Population

of Scotland at each Decennial Period, Table II, 1881 Census of

Scotland, pp.2-3

Refining this analysis of where in Scotland the migrants to New Zealand were from, county level is arguably the most useful unit. County level examination enables comparison with the census of Scotland, which used these same territorial divisions of the country, divisions that remained unchanged for more than half of the period of immigration to New Zealand with which the present study is concerned. ${ }^{12}$

The six Scottish counties that sent the largest numbers of migrants to New Zealand were Lanarkshire (15.86 per cent), Midlothian (8.04 per cent), Aberdeenshire (7.37 per cent), Perthshire (6.07 per cent), Ayr (6.50 per cent) and Renfrew (5.56 per cent). Of these, only Aberdeenshire is not located within the Eastern or Western Lowlands or Borders Regions. But nor is Aberdeen, in the North East Region, by most definitions a 'Highland' county. The 'top six' origin counties for migrants to New Zealand may, therefore, all be considered 'Lowland'. These six counties alone supplied 49 per cent of the Scottish migrants arriving in New Zealand during the period 1840-1920, the same proportion as was living in those six counties at the 1841

\footnotetext{
${ }^{11}$ Return Relating to the Population of Scotland at each Decennial Period, Table II, 1881 Census of Scotland, pp.2-3

${ }^{12}$ The county boundaries shifted in some cases as a result of the Boundary Commission, under the Local Government (Scotland) Act of 1889. See Hay Shennan, Boundaries of Counties and Parishes in Scotland as Settled by the Boundary Commissioners under the Local Government (Scotland) Act, 1889, Edinburgh, 1892 for the details of these changes.
} 
Census. ${ }^{13}$ Whether the six counties also contributed nearly half of Scottish emigration is unknown, such county breakdowns of migration to other destinations not being available. As Figure 2.1a and 2.1b show, the PNZ data gives very similar patterns of migrant origin among Scots to New Zealand over the eighty years. ${ }^{14}$

Figure 2.1

Showing the distribution of migrant origins in Scotland in the NZSG (2.1a) and PNZ (2.1b) data

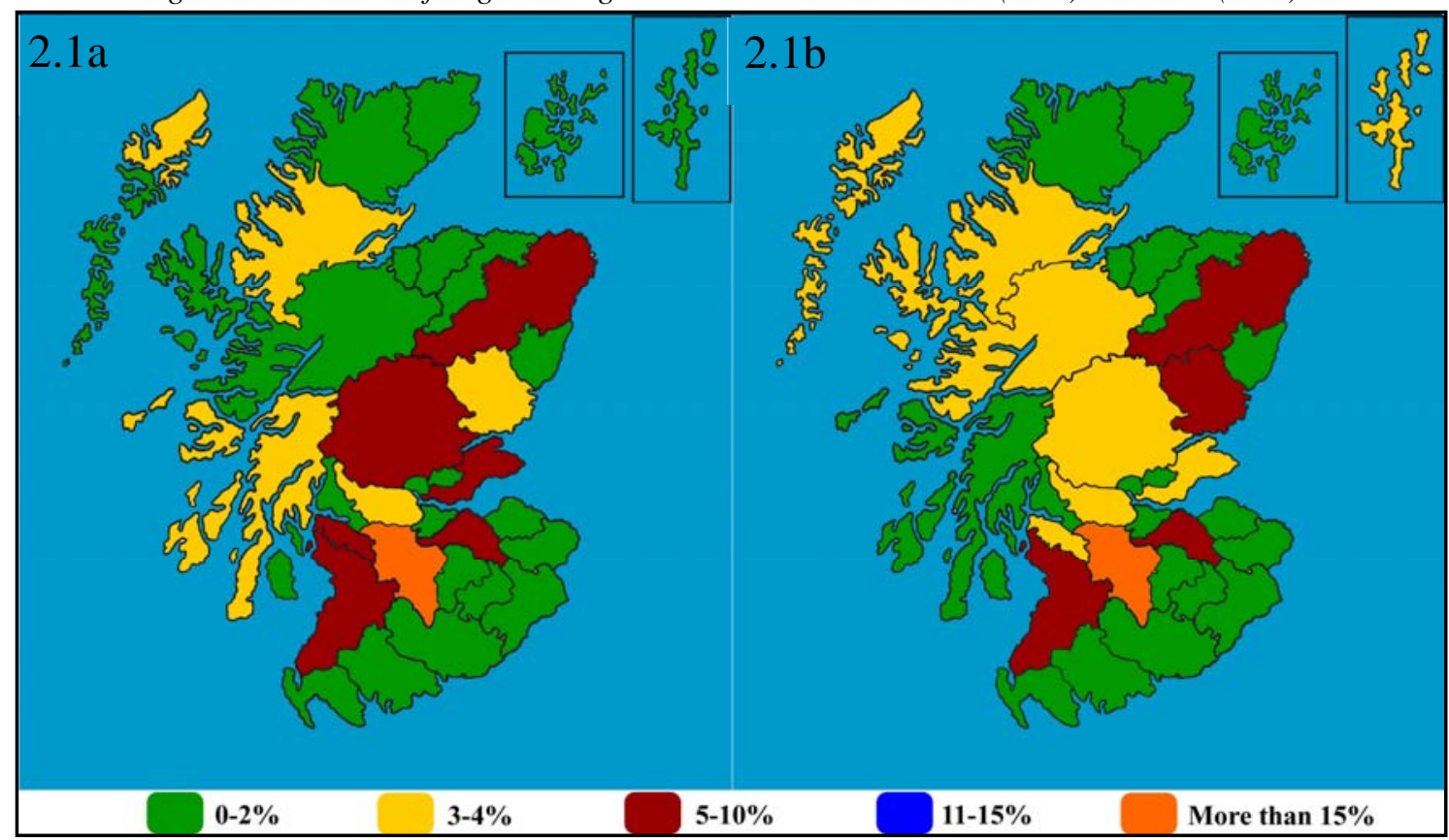

Sources: NZSG \& PNZ data, 1840-1920. Map created in Macromedia Fireworks from a sketch by Linda Lenihan based on a map of pre-1890 counties at http://www.genuki.org.uk/big/sct/, accessed 16 Feb2006

The similarity between the NZSG and the PNZ data for migrant origin distribution follows through into period of arrival. Examining the origins of the migrants by period of arrival in New Zealand, and ranking the six regions in terms of the proportion of migrants from each region, the order of the six regions alters only between the Eastern and Western Lowlands over these periods. Until the Vogel period of immigration (1871-1886) the Eastern Lowlands sent more migrants to New Zealand than the Western Lowlands; thereafter their relative rankings were reversed.

The top source counties also remained largely unchanged over the defined periods of arrival, though their relative rankings varied. ${ }^{15}$ Appendix 2.1 suggests that, pre1852 the top six sending counties of Scots migrants to New Zealand (utilising the NZSG data) were Midlothian, Lanarkshire, Perthshire, Renfrew, Aberdeen and

\footnotetext{
${ }^{13}$ The parishes of Glasgow (see footnote 21 below) contributed 6.87 per cent of total migrants in the database, and is followed by Edinburgh (3.96 per cent), Paisley (1.52 per cent), Dundee (1.19 per cent), Aberdeen - City (1.04 per cent) and Falkirk (1.01 per cent) as the top sending parishes of Scottish migrants to New Zealand for this period.

${ }^{14}$ The PNZ data 'top six' counties are LKS (21.51 per cent), MLN (9.92 per cent), AYR (7.57 per cent), ABD (7.35 per cent), ANS (5.75 per cent), and FIF (4.52 per cent).

${ }^{15}$ These periods are outline in the introduction to the thesis.
} 
Argyll, ${ }^{16}$ whereas in the Vogel years they were Lanarkshire, Ross and Cromarty, Ayr, Aberdeen, Midlothian and Fife. Between 1901 and 1920 Lanarkshire, Aberdeen, Midlothian, Stirling, Renfrew and Ayr were to the fore. ${ }^{17}$ Table 2.2, below, provides indices of representation of the Scottish migrants by county of birth. It compares the percentage of the NZSG total for each period of arrival to the percentage of the Scottish population total for each county thereby indicating whether a county was under- or over- represented among migrants to New Zealand. Zero values in Table 2.2 indicate a county for which no migrants in the NZSG data arrived in that period of arrival. A figure below one indicates the county was under-represented among migrants compared to the population of Scotland, and a figure over one indicates over-representation. For example, the figure for Orkney in the pre-1852 period of arrival is 0.95 . This means the NZSG percentage for Orkney for this period of arrival is 0.95 times that of than the Scottish census percentage for Orkney for $1851-0.95$ times the census percentage (1.09) equals the NZSG percentage (1.03) - thus migrants to New Zealand from Orkney are (slightly) under-represented in this period of arrival. For many counties the figures are close to parity.

Importantly, the indices in Table 2.1 and Table 2.2 reveal that the number of migrants emigrating to New Zealand from each region and county of Scotland was approximately the same as the proportions of the total population of Scotland resident in these regions and counties. ${ }^{18}$ McClean first noted this 'evenness of distribution' of the New Zealand Scots' origins in her 1990 thesis; the present findings therefore reinforce those of McClean and indicate that this trend of even distribution among New Zealand's Scots continued after 1880. This extent of the 'evenness' of the migrant distribution among New Zealand's Scots is significant: although Scots migrants have been noted for the relative evenness of their origin distribution generally, studies of emigration from Scotland do indicate clustering, especially from

\footnotetext{
${ }^{16}$ Ayr contributed just 3.45 per cent of the migrants to New Zealand in this period of arrival.

${ }^{17}$ Although the NZSG results show Shetland as contributing only 4.57 per cent of the total migrants arriving in the Vogel period of immigration (1871-1886), in the 1870s alone Shetland contributed approximately 10 per cent of New Zealand's Scots immigrants in other data sets included the PNZ data. For discussion, see Chapter Six

${ }^{18}$ McClean, 'Scottish Emigrants to New Zealand, 1840-1880', pp.151-157. See also Phillips and Hearn, Settlers, pp.107-8
} 
parishes in the Highlands, and consequently also a degree of clustering of migrant origins among Scots to other destinations. ${ }^{19}$

Table 2.2

Indices of representation relating county of birth of NZSG Scottish emigrants to NZ by period of arrival to the population of Scotland in those counties at the relevant censuses. ${ }^{20}$

\begin{tabular}{|c|c|c|c|c|c|c|c|}
\hline \multirow[b]{2}{*}{ Region } & \multirow[b]{2}{*}{ County } & \multicolumn{6}{|c|}{ Period of Arrival } \\
\hline & & $\begin{array}{l}\text { Pre- } \\
1852 \\
\end{array}$ & $\begin{array}{c}1853- \\
1870 \\
\end{array}$ & $\begin{array}{c}1871- \\
1886 \\
\end{array}$ & $\begin{array}{c}1887- \\
1900 \\
\end{array}$ & $\begin{array}{c}1901- \\
1920 \\
\end{array}$ & $\begin{array}{l}\text { Whole } \\
\text { Period }\end{array}$ \\
\hline \multicolumn{2}{|c|}{ Census compared to } & 1841 & 1861 & 1871 & 1891 & 1911 & 1871 \\
\hline \multirow{3}{*}{ Far North } & SHI & 0 & 0.84 & 5.02 & 0 & 3.18 & 2.15 \\
\hline & OKI & 0.95 & 1.07 & 1.17 & 1.69 & 0.34 & 1.10 \\
\hline & CAI & 1.16 & 1.89 & 2.59 & 0.69 & 0.55 & 2.03 \\
\hline \multirow{5}{*}{ Highlands } & SUT & 0 & 0.18 & 0 & 1.18 & 1.32 & 0.24 \\
\hline & ROC & 0.12 & 0.55 & 0.60 & 0.99 & 1.26 & 0.60 \\
\hline & INV & 0.41 & 0.31 & 0.62 & 1.73 & 1.02 & 0.51 \\
\hline & ARL & 2.56 & 2.53 & 2.95 & 9.29 & 6.50 & 3.27 \\
\hline & BUT & 2.10 & 1.42 & 1.56 & 2.80 & 7.80 & 2.16 \\
\hline \multirow{5}{*}{ North East } & NAI & 7.49 & 5.64 & 1.39 & 5.15 & 1.90 & 4.16 \\
\hline & MOR & 0.51 & 2.93 & 5.51 & 7.13 & 2.45 & 3.52 \\
\hline & BAN & 2.02 & 1.51 & 1.11 & 2.41 & 2.60 & 1.58 \\
\hline & ABD & 0.94 & 0.61 & 0.22 & 0.28 & 0.26 & 0.50 \\
\hline & KCD & 0.43 & 1.01 & 0.53 & 0 & 0 & 0.78 \\
\hline \multirow{10}{*}{$\begin{array}{c}\text { Eastern } \\
\text { Lowlands }\end{array}$} & ANS & 0.55 & 0.49 & 0.46 & 0.84 & 0.63 & 0.52 \\
\hline & PER & 2.51 & 1.55 & 1.29 & 1.43 & 1 & 1.60 \\
\hline & DNB & 1.10 & 0.91 & 1.45 & 0 & 0.95 & 1.11 \\
\hline & CLK & 0.87 & 1.13 & 1.03 & 0 & 0 & 0.88 \\
\hline & KRS & 1.67 & 2.03 & 1.69 & 8.22 & 0 & 2.02 \\
\hline & FIF & 0.97 & 0.99 & 1.05 & 1.24 & 0.76 & 1.06 \\
\hline & STI & 0.46 & 1.49 & 1.12 & 0.21 & 2.31 & 1.38 \\
\hline & WLN & 0.33 & 1.53 & 0.65 & 0.98 & 0 & 1 \\
\hline & MLN & 1.51 & 0.92 & 0.63 & 0.24 & 0.84 & 0.82 \\
\hline & ELN & 0.96 & 1.45 & 1.56 & 0 & 1.84 & 1.44 \\
\hline \multirow{3}{*}{$\begin{array}{l}\text { Western } \\
\text { Lowlands }\end{array}$} & RFW & 2.13 & 0.91 & 0.59 & 0.71 & 1.16 & 0.86 \\
\hline & LKS & 0.67 & 0.63 & 0.86 & 0.52 & 0.79 & 0.70 \\
\hline & AYR & 0.60 & 1.15 & 1.18 & 1.37 & 0.86 & 1.09 \\
\hline \multirow{8}{*}{ Borders } & BEW & 0.27 & 1.64 & 0.39 & 1.59 & 0.60 & 1.09 \\
\hline & PEE & 0 & 1.93 & 0.49 & 3.50 & 2.90 & 1.44 \\
\hline & SEL & 0 & 1 & 1.31 & 0.94 & 0.36 & 0.81 \\
\hline & ROX & 1.06 & 1.28 & 1.93 & 0.48 & 0.75 & 1.41 \\
\hline & DFS & 0.13 & 0.98 & 1.77 & 1.39 & 0.73 & 1.16 \\
\hline & KKD & 0.46 & 1.61 & 0.29 & 1.94 & 0 & 1.04 \\
\hline & WIG & 0.34 & 0.96 & 0.94 & 2.15 & 1.66 & 1.05 \\
\hline & $n$ & 581 & 2,645 & 1,653 & 156 & 537 & 6,243 \\
\hline
\end{tabular}

*Figures exclude those in the data whose birth region is unknown.

Sources: NZSG data 1840-1920; Preliminary report, Table II, 1921 Census of Scotland, p.2

\footnotetext{
${ }^{19}$ See Ian Levitt and Christopher Smout, The State of the Scottish Working-Class in 1843: A Statistical and Spatial Enquiry Based on the Data from the Poor Law Commission Report of 1844, Edinburgh, 1979, Chapter 10 'Emigration'.

${ }^{20}$ These indices of representation have been calculated by dividing the percentage of the migrants arriving in New Zealand in each period of arrival according to the NZSG sample, by the percentage of the population of Scotland living in each county at the census dates stated at the bottom of the table. These census dates were chosen as being the most representative of the Scottish population for each period of arrival. For example 1871 was chosen over 1881 because the primary flow of migrants in this period of arrival was in the early 1870s. This table effectively combines Appendix 2.1 and 2.2.
} 
Comparison of the NZSG data 'whole period' proportions and the census proportions in Appendix 2.1 and 2.2 reveals that for the majority of the Scottish counties these proportions remained in parallel, seldom exceeding a difference of 1 per cent, throughout the period examined. Few counties sent excessively disproportionate numbers of migrants; Ross and Cromarty, Angus, Aberdeen and Lanarkshire sent fewer migrants than was proportionate to their share of the population of Scotland, while Argyll, Nairn and Moray sent more.

At the regional level, between 1841 and 1920 the Far North consistently had the thinnest population - just 3.43 per cent of the Scottish population at the region's population peak in 1861. The Borders region was the second least populated region of Scotland, with the Highlands third and the North East fourth. This ranking very nearly holds as to which region sent the most migrants to New Zealand (see Table 2.1). In 1871 the population of the Western Lowlands first exceeded that of the Eastern Lowlands and, as noted above, it was in the Vogel period, from the 1870s, that the Western Lowlands began to send more migrants to New Zealand than the Eastern Lowlands.

Though some of the aberrations in Table 2.2 are meaningful, others are more likely to be due to small sample numbers. The 2.13 figure for Renfrewshire in the pre-1852 period is significant, indicative of the group of migrants from that county arriving in Auckland in the early 1840s. The figures for Shetland suggest an over-representation of Shetlanders among New Zealand migrants indicative of the ongoing assisted and chain migration of Shetlanders to New Zealand from the 1870s. In contrast, results such as the 7.49 for Nairn pre-1852 are almost certainly reflective of small sample size. The curious figures in the table for the period 1887-1900 are, in all probability, the result of very low immigration to New Zealand in those years. Making statements based on analysis of this period with any confidence is problematic; the small sample sizes reflect the minimal inflows. While the NZSG data indicates migrants arriving in this period were more likely to have come from the Highlands or North East Region, analysis of the PNZ data suggests that even in this decade the make-up of the migrants remained very similar to the pattern of other decades. Less than 2 per cent of all Scots migrants to New Zealand between 1840 and 1920 arrived in the 1890s. The NZSG sample for this decade comprises just ninety-four migrants, the PNZ sample a mere eighty-seven migrants. Although it seems likely that the profile of the migrants was 
not dissimilar from other periods of arrival (as the PNZ sample suggests), it is impossible to generalise with any degree of confidence.

Although precise parish level data have not been located for a significant number of the migrants in the NZSG data, the 'evenness' revealed in Tables 2.1 and 2.2 is also visible at the parish level in the data that is available. In terms of parish populations in Scotland, because it has been necessary to combine the parishes of Glasgow due to the level of information provided by contributors to the NZSG register, analysis shows that the 'combined parishes' of Glasgow, followed by Edinburgh, held the largest proportions of the population between the 1841 and 1881 Censuses, and were thus, unsurprisingly, the top two sending parishes in the NZSG data in nearly every period of arrival. ${ }^{21}$ The largest parishes in Renfrewshire, Angus and Aberdeenshire - Paisley, Dundee and Aberdeen parishes - were all among the top twelve highest population parishes between 1841 and 1881 and were in the top six sending parishes to New Zealand in the NZSG data. Only Falkirk, in Stirling, of the top six sending parishes, sent migrants out of proportion to the number of Scots living in that parish compared to the population of Scotland. Between 1841 and 1881 between 0.537 and 0.673 per cent of Scotland's population lived in Falkirk, but Falkirk parish sent 1.01 per cent of the migrants in the NZSG database. Latheron parish in Caithness also sent migrants to New Zealand out of proportion to the home population. Although this is also apparent when examining the data over the period $1840-1920$ as a whole, 74.36 per cent of Latheron-born migrants in the NZSG data arrived between 1852 and 1870. At the 1851 Census just 0.28 per cent of the population of Scotland lived in Latheron. Migrants born in Latheron constitute 1.10 per cent of migrants in the NZSG data arriving between 1852 and 1870. This is, nevertheless, a small number of migrants twenty-nine migrants in the data arriving in this period. Though it has not been possible to trace all of these migrants to their village of birth, some at least were among those emigrating from Badbea, a clearance village on the east coast of Caithness. This village appears to have been a site of group and chain migration to

\footnotetext{
21 'Nearly every' because in the period 1887-1900 Edinburgh parish supplied only one migrant to the NZSG data, due to this period being one of very low immigration. Too few of the migrants from 'Glasgow' in the NZSG database have the specific Glasgow parish recorded, so they have had to be grouped together as 'Glasgow' as a whole for analysis. The Glasgow parishes in the census are: West St. George; St Enoch; South West, St Mary or Tron; North West, or St David; City; East, Outer Hight, or St Paul; North, Inner Hight, or St Mungo; South, Blackfriers, or College; St John; Middle, or St Andrew; St James; Barony; Calton; Maryhill; Shettleston; Gorbals (part of); Govan (part of); and Springburn.
} 
New Zealand between 1841 and 1911, when the final resident of Badbea left for New Zealand. $^{22}$

New Zealand is not, strictly speaking, unusual in its 'evenness' of Scots migrants. Scottish emigration in general has been noted for this relatively even distribution in terms of migrant origins when compared to other European countries that were concurrently dispatching large numbers of migrants. ${ }^{23}$ This has not always been appropriately recognised in studies of other Scottish migrant destination countries; this is most likely the result of placing a possibly undue emphasis on explanatory factors such as famine or clearance. As well as clusters prompted by, for example, famine and clearance emigration, previous agent or assistance driven emigration from specific parts of Scotland to parts of Canada, America, and Australia - notably Ontario, North Carolina and Victoria, respectively - had created chains of migration that persisted long after the initial assistance schemes had initiated the flows. These chains of migration created a pattern of clusters rather than a dispersed or evenly distributed pattern to the origins of the migrants. Clusters tended to be from parishes in the Highlands of Scotland - for example from Skye, Lewis and Harris, eastern Sutherland, western Argyll, and north-west Perthshire. Yet clusters were not the overriding pattern of emigrant origin distribution within Scotland, which was of a more even distribution. ${ }^{24}$ In New Zealand, due to a relative lack of the cluster and chain migration commonly seen in other Scottish migrant destinations, the evenness in the distribution of migrants' origins is much easier to identify. ${ }^{25}$ Coming later as a potential destination, New Zealand did not have the benefit of a long migration tradition to attract migrants. Partly as a result of this late start and the absence of

\footnotetext{
${ }^{22}$ Personal communication with Nan Bethune, 2 June 2009; see also a website created by descendants of these Badbea immigrants who settled in New Zealand: Badbea Families, http://www.badbeafamilies.com/index.html, 2009; Return Relating to the Population of Scotland at each Decennial Period, Table 3, 1881 Census of Scotland, p.12

${ }^{23}$ C.J. Erickson, 'Who were the English and Scots emigrants to the United States in the late nineteenth century?' in D.V. Glass and Roger Revelle (eds), Population and Social Change, London, 1972; McClean, 'Scottish Emigrants to New Zealand, 1840-1880', p.122.

24 McClean, 'Scottish Emigrants to New Zealand, 1840-1880', p.177, citing Marjory Harper, Emigration from North-East Scotland: Willing Exiles, Aberdeen, 1988 and the Glasgow Sentinel and Journal of the Industrial Interests, 20 March 1869; Harper, Adventurers and Exiles, p.21; Malcolm D. Prentis, The Scots in Australia: A Study of New South Wales, Victoria and Queensland, 1788-1900, Sydney, 1983, pp.75-6.

${ }^{25}$ A 'relative' lack, because the evidence of this even distribution does not mean that there is no evidence of any cluster or chain migration among Scots to New Zealand. A chain of migration from New Deer, Aberdeenshire will be noted in Chapter Three, for example, and, as noted above, migration from Shetland is a notable exception to this 'even distribution' pattern, as will be discussed in Chapter Six.
} 
tradition, as well as the additional distance it was necessary to travel and the costs entailed, chain migration was possibly less common among Scots to New Zealand than elsewhere.

\section{An outline of Several characteristics of Edinburgh, Aberdeen, Argyll,}

\section{GLASGOW AND THE WESTERN LOWLANDS.}

That there was relative evenness in the distribution of Scots immigrant origins does not, however, mean that some areas of Scotland were not of greater importance in supplying New Zealand with emigrants than others. The above analysis has already indicated the areas of Scotland that sent more migrants than others, notwithstanding that this was often in proportion to the population distribution of Scotland. The following brief outline of some of the key characteristics of the home populations of Edinburgh City and Midlothian, Aberdeen City and Aberdeen County, Argyll, Glasgow and the Western Lowlands, is intended to provide sufficient context for the important differences between the various parts of the country to be understood. In conjunction with Chapter Six, which focuses on Shetland, this discussion provides background for at least a part of each of five of the six regions of Scotland (and five of the six top sending counties of migrants to New Zealand). Only the Borders Region is omitted. ${ }^{26}$ Edinburgh and Midlothian were chosen as the Eastern Lowlands example because of Edinburgh's role as Scotland's capital, the large population and the correspondingly large proportion of migrants the area contributed to New Zealand's Scottish population. Aberdeen and Argyll were chosen as representative of the North East and the Highland Regions for similar reasons, while the Western Lowlands as a whole have been discussed in some detail due to the importance of this region as a destination for internal migration within Scotland and as the place of birth for a large proportion of New Zealand's Scots.

\footnotetext{
${ }^{26}$ The seven counties of the Borders having contributed just 9.32 per cent of migrants, this region does not receive as much attention in the present work as, for example, Aberdeen, Edinburgh, Highland counties and the Western Lowlands. The key characteristics of this region are not significantly different to parts of the Eastern and Western Lowlands. In 188131.57 per cent of the population of the Borders was employed in agriculture -49.73 per cent of the population of Berwick and just 9.90 per cent of Selkirk. Industry employed 45.38 per cent of Borders occupied population at that census, 43.31 per cent of those employed in industry being involved in the 'Textile Fabrics' or 'Dress' occupation orders at that census, 16.31 in 'Houses, furniture and decorations' and a further 11.17 per cent in 'Food and lodging'. Commerce employed 4.19 per cent of those in the Borders region, domestic service 13.69 per cent and professional occupations 5.17 per cent. In terms of internal migration, in 184120.61 per cent of those residing in a Borders county had been born outside of that county - just 12.55 per cent of Dumfries residents, but 41.83 per cent of those in Selkirk. Of those living in a Borders county who had been born outside of that county 66.86 per cent had been born within Scotland.
} 


\section{EDINBURGH AND MIDLOTHIAN}

By 1800 Edinburgh, the capital city of Scotland, was not only the cultural centre of the country, as well as the national hub of law and administration, it was also one of the two most urban areas in Scotland. ${ }^{27}$ Although just 2.5 per cent of the population of Scotland resided in Edinburgh City in 1755, by 18415.35 per cent of the Scottish population lived in Edinburgh or its suburbs, 62.18 per cent of Midlothian’s 225,454 inhabitants. $^{28}$

Much of Edinburgh's growth was due to the natural advantages the Water of Leith offered the city as a means of transport (a port) and for manufacturing uses. In terms of manufacturing, for example, in the late eighteenth and early nineteenth century paper made in Scotland was primarily manufactured beside the River Esk and the Water of Leith, with an adequate supply of water thus being assured. ${ }^{29}$ As the city grew, through its roles as the capital and the foremost ecclesiastical, medical, legal and banking centre of Scotland, it also became an increasingly important and large market. The city consequently attracted further industrial growth as manufacturers looked to take advantage of proximity to this market. ${ }^{30}$ Edinburgh relied less on the textile industry than other parts of Scotland, only 13.04 per cent of the city's workforce being employed in the textile industry in 1841 compared to Glasgow's 37.56 per cent and Dundee’s 50.54 per cent. Nevertheless, by the mid-nineteenth century Edinburgh was one of the most industrial cities in Scotland. ${ }^{31}$ Diversifying, Leith had become 'an important centre for ship repairing, sugar refining, and soap and glass making' in addition to paper production. ${ }^{32}$ Yet, despite this core of industrial employment, more of the male workforce of Edinburgh were employed as 'professionals' than in any other city of Scotland: 13.34 per cent of Edinburgh's employed males were in such occupations, compared to just 6.46 per cent of

\footnotetext{
${ }^{27}$ T.M. Devine, The Scottish Nation: 1700-2000, London, 1999, pp.24 and 113; James Buchan, Capital of the Mind: How Edinburgh Changed the World, London, 2003

${ }^{28}$ I.D. Whyte, 'Early modern Scotland: continuity and change', in G. Wittington and I. D. Whyte (eds), An Historical Geography of Scotland, London, 1983, p.130; 'Enumeration abstract: Edinburgh', 1841 Census of Scotland, pp.23-26

29 A.G. Thomson, The Paper Industry in Scotland, Edinburgh, 1974, Chapter Five; G. Gordon, 'Industrial development, c.1750-1980', in G. Wittington and I. D. Whyte (eds), An Historical Geography of Scotland, London, 1983, p.173

30 J. Doherty, 'Urbanization in Scotland, 1750-1914', in G. Wittington and I.D. Whyte (eds), An Historical Geography of Scotland, London, 1983, p.251; Gordon, 'Industrial development, c.17501980', p.173

${ }^{31}$ Devine, The Scottish Nation: 1700-2000, p.160

${ }^{32}$ Doherty, 'Urbanization in Scotland, 1750-1914', p.252
} 
Aberdeen's male workforce and even less in the other cities of Scotland. ${ }^{33}$ By 1831 approximately 5 per cent of the population of Edinburgh were described as 'bankers, professional men and capitalists'. ${ }^{34}$

Though the percentages indicate involvement in industry, professions and commerce were understandably lower among the population of Midlothian than in Edinburgh City, ${ }^{35}$ by 188110.94 per cent of those employed in the county (male and female) were employed in the 'professional' sector, more than in any other county at the 1881 Census. Around 12 per cent of the employed population of Midlothian at that census were engaged in commerce and 54.49 per cent in industry. Though the county was primarily urban - much of the population living in Edinburgh - just under 5 per cent of the population was employed in agriculture in $1881 .^{36}$

Midlothian was the Scottish county with the second highest proportion of the employed population of the county involved in domestic service, behind only Lanarkshire. In 188117.52 per cent of Midlothian workers were employed in that field - and 44 per cent of females in Edinburgh City. ${ }^{37}$ This may account, to some degree, for the gender ratios of Midlothian, high demand for domestic servants in the county possibly encouraging more female migration to the county than male. In 1841 Midlothian contained 8.91 per cent of Scotland's female population and 8.27 per cent of the male population; 57.46 per cent of those aged over twenty were female as were 50.62 per cent of those under twenty; 43.79 per cent of the population was aged under twenty years of age.

Midlothian was also, after Lanarkshire, the second most popular receiving county for internal migration within Scotland. Of the 225,454 people residing in Midlothian at the 1841 Census, 65,855 had, like Nathaniel Sutherland's parents, been born within Scotland but outside of Midlothian, 28.21 per cent of the population of the county.

\footnotetext{
${ }^{33}$ Devine, The Scottish Nation: 1700-2000, p.161; Buchan, Capital of the Mind, provides interesting background.

${ }^{34}$ Doherty, 'Urbanization in Scotland, 1750-1914', p.251, citing L. J. Saunders, Scottish Democracy, London, 1950, p.388

${ }^{35}$ This is due to the urban nature of the occupations and Edinburgh being the urban centre of Midlothian.

${ }^{36}$ Appendix Tables: Table LXX, 1881 Census of Scotland, p.lxi

${ }^{37}$ Gordon, 'Industrial development, c.1750-1980’, p.178; Population, Scotland, Vol.II, Abstracts, 1881 Census of Scotland, pp.555-562.
} 
Between 1851 and 1861 the county experienced a net increase in its population of approximately 22,000 people, with a further 19,063 between 1861 and $1871 .^{38}$

Margaret Wilson and her husband John Fraser were among those migrating within Scotland to Edinburgh. Though born in Dalkeith, Midlothian, Margaret appears to have met her husband in his birth parish, Applecross, in Ross and Cromarty. How long the couple had known each other before their migration to Dalkeith where they were married in 1856 is unknown, as is Margaret's reason for earlier migrating to Applecross. The only occupation recorded for Margaret is 'housewife'. It was in Edinburgh that the couple remained until their migration to New Zealand in $1861 .^{39}$ The migrant flow to Edinburgh was not, however, a one way enterprise. Mary Farquharson's husband Morgan was born in Delting, Shetland, but met Mary while working in Midlothian. The couple moved to Northmaven, Shetland, shortly after the birth of their first child in the parish of Mary's birth, St Cuthberts, Edinburgh, remaining in Northmaven until their immigration to New Zealand in $1876 .{ }^{40}$

\section{ABERDEEN}

Presently a centre of Europe's off-shore oil industry, the growth of Aberdeenshire in the nineteenth century also owed much to its proximity to an abundance of natural resources. Industrial employment opportunities available to Aberdonians in the nineteenth century included granite mining, polishing and other related trades, paper making, and shipbuilding, each of those industries utilising the natural resources and advantages available in the county. ${ }^{41}$ With a relatively long coastline and accessible ports, the fishing industry was also of considerable importance in Aberdeen County, in-shore herring fishing being dominant in the early nineteenth century, and sea trawling from the 1870s when London became a viable market with the development of rail. $^{42}$

\footnotetext{
${ }^{38}$ Calculations based upon information from the Scottish Registrar Generals reports for the 1850s, 1860s and 1870s and Census figures for 1851, 1861 and 1871. The figure of the increase between 1851 and 1861 is an approximation as the Registrar General's reports did not begin until 1855.

39 John worked as a 'carpenter' and a 'boat builder' in Scotland and in New Zealand. NZSG database, migrants 01880, 01906, 01912, and 06456

${ }^{40}$ NZSG database, migrants 01692, 02970, and 06585, 1861 Scottish Census information for Morgan, Mary and George Laurenson, Northmaven Parish, ED: 4, Lines 20, 21 and 22, accessed at Ancestry.co.uk, 13 August 2007.

${ }^{41}$ Doherty, 'Urbanization in Scotland, 1750-1914', p.253; Thomson, The Paper Industry in Scotland, pp. $112-4$

${ }^{42}$ Doherty, 'Urbanization in Scotland, 1750-1914', p.253
} 
As was the case with several other Scottish cities, the textile industry also contributed to Aberdeen's early nineteenth-century growth and prosperity. ${ }^{43}$ From the late seventeenth century one in five men in several Buchan parishes were recorded as weavers. $^{44}$ Despite this long tradition, however, the comparative isolation of the county from the major markets for cotton, linen and woollen products, as well as the higher costs faced by Aberdeen textile manufacturers for the transport of coal from the central Lowlands, put these north-eastern manufacturers at a disadvantage to their Lowland contemporaries. As a result, the textile industry in Aberdeen did not expand with the same rapidity as other Scottish centres of textile manufacture. ${ }^{45}$

The 'regional capital' of the North East, Aberdeen, like Edinburgh, had a relatively large professional base, enhanced from the fifteenth century by graduates from the city's two universities. Yet while Midlothian also had a high proportion of the population employed in commerce and industry, Aberdeen's natural advantages for agriculture ensured that over a quarter of the occupied population were still engaged in agriculture in 1881; 28.43 per cent compared to Midlothian’s 4.93 per cent. ${ }^{46}$

Unlike Midlothian, Aberdeenshire was not a primary destination for internal Scottish and internal United Kingdom migration. Only 13.53 per cent of the population of Aberdeenshire at the 1841 Census had been born outside the county. Significantly, of the non-Aberdeenshire-born in the county in 1841, 61.51 per cent lived in Aberdeen City itself, indicating the primary attraction to Aberdeen County was probably urban/industrial employment or, potentially, tertiary study, rather than agricultural pursuits.

\section{ARGYLL}

Argyll remained predominantly rural throughout the years covered by the present study, with a significant proportion of the population engaged in agriculture as late as 1881. In the census of that year 40.46 per cent of the employed population of Argyll

\footnotetext{
${ }^{43}$ ibid.p. 252

${ }^{44}$ Whyte, 'Early modern Scotland: continuity and change’, p.129

${ }^{45}$ Gordon, 'Industrial development, c.1750-1980', p.177

${ }^{46}$ Ian Carter, Farm Life in Northeast Scotland 1840-1914: The Poor Man's Country, Edinburgh, 1979 gives a good account of the social and economic aspects of the development of agriculture in Aberdeen (and the rest of the North East).
} 
were engaged in farming. ${ }^{47}$ Despite this essentially rural context, 31.57 per cent of the population were employed in 'industrial' (including pre-industrial) occupations. ${ }^{48}$

Like many other parts of rural Scotland, Argyll's population fell into a gradual but steady decline after reaching its peak of 100,973 in 1831, just 75,679 people residing in the county by $1871 .^{49}$ As the nature of farming changed, small plots being consolidated into larger farms and agriculture generally becoming more mechanised and less labour intensive, agricultural districts were increasingly unable to retain their populations. Attempts were made to create employment for those 'displaced' by new farming practices; for example the Duke of Argyll established a woollen mill in Inverary for this purpose. These ventures were seldom successful. While clearance and evictions prompted many to emigrate, unemployment was often circumvented by temporary internal migration. ${ }^{50}$ Temporary out migration had been a feature in Argyll for decades, and it has been suggested that few Argyllshire families in the early nineteenth century could have survived without the income from seasonal work in the Lowlands. ${ }^{51}$ These traditions of temporary migration were often a prompt to permanent migration, bringing familiarity with conditions outside of the home county and loosening bonds with home communities. ${ }^{52}$ For both Agnes Drummond and her sister Isabella the motivation for leaving their Highland home in Argyll was employment. Agnes migrated to Renfrew in the mid-1850s, where she met her future husband while working as a farm servant. The couple migrated to New Zealand in

\footnotetext{
${ }^{47}$ Though, it must be noted, farming of a different sort to, for example, Aberdeen. Though Figure 21 'Type of farming' in Chapter Four 'Rural Scotland' of Lea, Gordon, and Bowler, A Geography of Scotland, (p.131) shows the type of farming most prevalent in each part of Scotland in the mid-1900s, it is also a clear indication as to the type of farming prevalent in those areas in the 1800s. While the North East is described as predominantly 'Rearing with arable', for example, Argyll is predominantly 'Hill sheep', 'Upland (beef and sheep)', with smaller areas in 'Dairying'. See also J.T. Coppock, An Agricultural Atlas of Scotland, Edinburgh, 1976, especially chapter 6 'Types of farm' and chapter 7 'An historical perspective: 1870-1970'.

${ }^{48}$ Occupation Abstract, 1841 Census of Scotland, pp.3-4 and Appendix Tables, Table LLX, 1881 Census of Scotland, p.lxi. 18.48 per cent of the industrially employed population working with 'mineral substances', 16.63 in the 'general or unspecified commodities' order that includes pedlars, general shopkeepers and general labourers, 16.51 employed in the manufacture of dress items - primarily tailors, dressmakers and shoe makers. A further 15.90 per cent were employed in food and lodging and 21.55 per cent in the 'Houses, furniture and decorations' occupation order, most of whom were masons or carpenters. Population, Scotland, Vol.II, Abstracts, 1881 Census of Scotland, pp.515-520

${ }^{49}$ Withers, Urban Highlanders, p.26; R.H. Campbell and T.M. Devine, 'The rural experience', in W. Hamish Fraser and R.J. Morris (eds), People and Society in Scotland, 1830-1914, Edinburgh, 1990, p.46; Preliminary Report, Table IV, 1871 Census of Scotland, pp.10-11

50 J.E. Handley, Scottish Farming in the Eighteenth Century, London, 1953, pp.244, 258-61

${ }^{51}$ T.M. Devine, 'Temporary migration and the Scottish Highlands in the nineteenth century', The Economic History Review, New Series, Vol.32, No.2, August, 1979, pp.344-359, p.344

${ }^{52}$ H. Jones, 'Population from c. 1600', in G. Wittington and I. D. Whyte (eds), An Historical Geography of Scotland, London, 1983, p.106; McClean notes the incidence of this in her thesis.
} 
1857. Four years younger than her sister, Isabella was working as a farm servant in Lanarkshire in 1861 when she too met her future husband, a ploughman on a neighbouring farm. The couple left for New Zealand in $1864 .^{53}$

This familiarity with conditions outside the home county, coupled with 'push' factors - including eviction - and the prospect of greater opportunities in the central Lowlands and abroad, underlay the gradual but steady decline in the population of Argyll post-1831. ${ }^{54}$ The county's already long-standing flow of migrants to near-by Glasgow increased over this period. By 1851, while Edinburgh was drawing most of its migrants of Highland birth from Inverness and Ross and Cromarty, between 61 and 87 per cent of Highland-born migrants residing in Glasgow parishes were from Argyll, 10,575 people from a total Glasgow population of approximately 329,495. This was at a time when the population of Argyll itself was just 89,298. Arguably this was largely due to the proximity of the county to Glasgow, though as Brock notes, Dumbarton (with a population of 45,103) was closer to Argyll and received far fewer Argyll migrants than Glasgow. ${ }^{55}$

Though the outflow of migrants from Argyll, especially to Glasgow, was constant during the nineteenth century, there was nonetheless a (considerably smaller) counter flow of migrants from other Scottish counties into Argyll. In 1841, 89.29 per cent of the population of Argyll had been born in Argyll, and just under 3 per cent had been born outside of Scotland. William Perston and his parents, born in Glasgow, were among those participating in this 'Lowland' to 'Highland' flow of internal migrants. Though William's family had resided in Glasgow for several generations, where William's father had been employed as a power-loom operator, they migrated to Rothesay in Bute when William was just two years old. William's father was based in Rothesay as a carrier of goods between Bute and Glasgow. William's younger brother John was born in Rothesay shortly after the family's migration there. When the

\footnotetext{
${ }^{53}$ Personal communication with Celia Geary, 26 October 2007

${ }^{54}$ Eric Richards, 'Ironies of the Highland exodus, 1740-1900', The Journal of Australian Studies, 'Scatterlings of Empire' volume, No.68, June, 2001, pp.74-85, p.79. Between 1831 and 1841 Argyll’s population decreased by 3.56 per cent, and between 1841 and 1851 the county lost a further 8.29 per cent of its population, a net population decrease of approximately 11,000 people over that decade alone. Withers, Urban Highlanders, Table 2.1, p.26; net population calculations based on Registrar General reports.

${ }^{55}$ Calculations based on tables 4.1 and 4.2 in Withers, Urban Highlanders, pp.88 and 92; Brock, The Mobile Scot, p.100
} 
brothers migrated to New Zealand in the 1870s, separately, both had been residing in Bute until their departure. ${ }^{56}$

\section{GLASGOW AND THE WESTERN LOWLANDS}

Though the three counties making up the Western Lowlands - Lanark, Ayr and Renfrewshire - differed from each other in many respects, the development of the Western Lowlands as a region and the population patterns that subsequently emerged were quite distinctive from the rest of Scotland. The three counties are therefore jointly discussed as 'the Western Lowlands'.

By the end of the eighteenth century the Western Lowlands, and Glasgow in particular, had already emerged as a major British industrial centre. The tobacco trade with America was flourishing; the crossing from the American South to Glasgow taking two weeks less than the voyage to Bristol, Britain's other major tobacco trading port. ${ }^{57}$ This shipping advantage also aided the growth of the Scottish textiles industry in the Western Lowlands. While Angus and Fife continued to produce coarse linen, producers in the Western Lowlands specialised in fine cloth due to the demand for this product in the American market. ${ }^{58}$ From this foundation the cotton industry expanded rapidly in the Western Lowlands; between 1778 and 1788 the importation of raw cotton into Scotland increased by 700 per cent, and by another 500 per cent between 1788 and 1801, the vast majority of these imports entering the country via Glasgow. ${ }^{59}$ Though cotton mills were established in other industrial areas of Scotland, notably Perthshire, by 183991 per cent of Scotland's cotton mills were in the Western Lowlands, the most significant concentration being within thirty kilometres of Glasgow. $^{60}$

The expansion of the textile industry drew further migrants to the already expanding population of the Western Lowlands, with the urbanisation that was the natural concomitant of this population expansion leading, in turn, to further industrial growth. As with Edinburgh, Glasgow provided a growing market for the products produced by local industries: textile finishing trades such as bleaching, printing,

\footnotetext{
${ }^{56}$ Personal communication with Kae Lewis, 21 October 2007

${ }^{57}$ For more on Glasgow's tobacco trade see T.M. Devine, The Tobacco Lords: A Study of the Tobacco Merchants of Glasgow and Their Trading Activities, c.1740-90, Edinburgh, 1975; Gordon, 'Industrial development, c.1750-1980', p.169.

${ }^{58}$ Gordon, 'Industrial development, c.1750-1980', pp.167-8

59 ibid.pp.170-1

${ }^{60}$ ibid.pp.167 and 171
} 
tambouring and weaving; soap-making; sugar-refining; paper-making; and brewing. ${ }^{61}$ Glasgow also provided a ready market for the products of agriculture, often sourced from rural parts of the region. Ayrshire, for example, increasingly specialised in cheese and butter production. ${ }^{62}$ Population growth in Glasgow also stimulated the construction industry in the region as the city grew to encompass its population. ${ }^{63}$

In the early to mid-nineteenth century, as the textile industry in the Western Lowlands began to decline, principally due to increased competition in overseas markets, Glasgow mills began to close. One response was the fostering of greater specialisation, Paisley for example emerging as an important producer of cotton thread, and Glasgow as a producer of carpet. ${ }^{64}$ It was nevertheless fortuitous that, at around the same time as the decline in the region's textile industry, the Western Lowlands commenced excavating and producing vast quantities of pig-iron and coal. While in 1830 the whole of Scotland produced just 40,000 tons of pig-iron annually, by 1848 Lanarkshire alone was producing 426,000 tons, and Ayrshire 60,000 tons, per annum. The expansion of the iron industry necessitated an increase in coal mining. By 1854 pits in Lanarkshire and Ayr (as well as Stirling and Fife) were producing $7,500,000$ tons annually, with the iron industry taking up one-third of this output. ${ }^{65}$

Given this long-standing dominance of industry in the region, it should come as no surprise that by 188165.41 per cent of those employed in Ayr, 71.68 per cent of those in Renfrewshire, and 71.95 per cent in Lanarkshire, were engaged in industry. Though 14.20 per cent of the employed population of Ayr was involved in agriculture, just 4.42 per cent of those in Renfrew were in this type of work and even fewer -2.89 per cent - in Lanark. Less than 5 per cent of the occupied population in these three counties were professionals in $1881 .^{66}$

By 1841 the population of Lanarkshire was more than twice that of the populations of Renfrew and Ayr combined, a result of the location of Glasgow in the county. Glasgow City and its suburbs were home to 59.56 per cent of the Lanarkshire population at this census. More than any other part of Scotland, the Western Lowlands

\footnotetext{
61 ibid.pp.172-3

${ }^{62}$ G. Whittington, 'Agriculture and society, 1750-1870', in G. Wittington and I.D. Whyte (eds), An Historical Geography of Scotland, London, 1983, p.159

${ }^{63}$ Gordon, 'Industrial development, c.1750-1980', p.170

${ }^{64}$ ibid.p. 176

65 ibid.p.174-5

${ }^{66}$ Population, Scotland, Vol.II, Abstracts, 1881 Census of Scotland, pp.527-248
} 
constituted a receiving area for internal migrants and immigrants alike. In 1841 less than 62 per cent of those living in Renfrew and Lanarkshire had been born in those counties, and just 81.17 per cent of those in Ayr. Only 56.57 per cent of the population of Glasgow in 1841 had been born in Lanarkshire; 30.74 per cent had been born elsewhere in Scotland. ${ }^{67}$ Glasgow was home to 77.11 per cent of those residing in Lanarkshire born outside of the county. ${ }^{68}$

Donald McKenzie and his family were among those living in Glasgow in 1841 who had been born outside of Lanarkshire. Donald, wife Catherine and their three children migrated to Glasgow in approximately 1840. All five of them had been born, and had subsequently resided, in Inverness throughout their lives, although Donald had travelled during his service with the $42^{\text {nd }}$ Highland Regiment. The family remained in Glasgow until 1849, with three more children being born in the intervening years. Though family records give no indication as to why the family moved from Inverness to Glasgow, nor why Donald chose to migrate to New Zealand in 1849, the ship they departed on carried a number of other New Zealand Fencibles, and Donald served with that force for a time after his arrival. ${ }^{69}$

Harriet Sydney Hogg was among those making the short-distance migration from the Borders to the Lowland regions. Born in Selkirk in 1827, Harriet did not migrate to New Zealand until she was fifty-one years old. During that half-century she had lived in Yarrow (Selkirk), Linlithgow (West Lothian), Edinburgh (Midlothian), Glasgow (Lanarkshire) and Alloa (Clackmannan), before eventual departing from London on the Forfarshire in 1879. Her husband had been born in Renfrewshire, but worked as a merchant in Glasgow, Lanark. It is unknown where the couple met, but they were married in Linlithgow in June 1855. All of their nine children were born in Glasgow between May 1856 and February 1869, and the family migrated to Alloa sometime in the following decade. ${ }^{70}$

\footnotetext{
${ }^{67}$ A further 2.54 per cent had been born in England and 17.44 per cent in Ireland.

${ }^{68} 72.31$ per cent of the Irish-born population of Lanarkshire resided in Glasgow, 50.18 per cent of the Irish-born residing in the Western Lowlands. 'Enumeration abstracts', 1841 Census of Scotland, pp.182

${ }^{69}$ Personal communication with Linda Dunn, 21 October 2007; for more on the New Zealand Fencibles see Ruth Alexander, Gail Gibson, and Alan J. La Roche, The Royal New Zealand Fencibles, 18471852, Auckland, 1997 - Donald's entry is p.158

${ }^{70}$ NZSG database, migrants 02047, 02048, 02049, 02050, 02051, 02052, 02053, 02055, 02056, 02057, and 02522.
} 


\section{MIGRATION WITHIN AND OUTSIDE OF SCOTLAND PRIOR TO EMIGRATION TO NZ}

Place of birth is the only clear and consistent indicator of 'origin' encompassing all of the migrants in the NZSG and PNZ datasets. Yet, as the examples extrapolated from genealogical material noted in the previous section indicate, basing 'who New Zealand's Scots were' in terms of origins solely on place of birth is problematic. The cited cases, while providing some indication of the various flows of migration within the country, bear this out. Though the frequency of internal migration evidenced by Harriet Sydney Hogg, entailing residence in at least five different Scottish counties over her lifetime, ${ }^{71}$ appears to have been unusual, at least among those Scots who later migrated to New Zealand, multiple moves within the county of birth were not uncommon. ${ }^{72}$ Born in Barony parish in 1829, Margaret McArthur married, had her first two children, and continued to reside in Barony until around 1854. Over the following two decades Margaret and her family moved first to Shettleston in Glasgow, then to the parish of Old Monkland, on to Hamilton parish, then back to Barony, all within Lanarkshire. The family left for New Zealand from London in 1874. ${ }^{73}$ Born in Foveren parish, Aberdeenshire, George Brechin Coull moved within the county at least four times before migrating to New Zealand (via a one year stay in Australia) at the age of thirty-three, shifting from Foveren to Logie Buchan, on to Waterton in Ellon, and then to Aberdeen City itself. ${ }^{74}$ Given the information provided to the NZSG register and available for the present study, it is impossible to accurately assess just how common internal migration within Scotland was among later emigrants. Nevertheless, the genealogical evidence suggests that a significant number of people were migrating within their birth county, birth region, or within the whole of Scotland, before emigrating to New Zealand.

George Brechin Coull was by no means alone in his experience of migrating to a country outside of Scotland on his way to New Zealand. In some instances this step in the migrant chain further complicates the issue of 'origins'. Elizabeth Connely is a very clear example. Born in Dunfermline, Fife, to Scottish-born parents, Elizabeth

\footnotetext{
${ }^{71}$ Contributors were asked not to list more than three places of residence, but in this case the contributor filled the available space on the registration form instead. It is not impossible Harriet had more than these five places of residence in Scotland.

${ }^{72}$ Moves within county of birth do not appear in the basic census enumeration tables of internal movement, at least at county level.

${ }^{73}$ NZSG database, migrants 05437, 05538, 05544, 05553, 05558, and 05561.

${ }^{74}$ NZSG database, migrant 01160
} 
resided in England for all thirty-seven of her years before migrating to New Zealand in 1892. Though her likely motivations for immigration almost certainly had very little to do with push factors in, or pull factors perceived from, Scotland at the time of immigration, her birth in Scotland necessitates her inclusion in the present work as one of New Zealand's Scots, a further illustration of one of the difficulties with using place of birth as a signifier of origin. ${ }^{75}$

Of the 6,612 migrants in the NZSG database, 764 spent some time in another country between their departure from Scotland and arrival in New Zealand, a total of 11.55 per cent of the migrants in that dataset. Information in the NZSG 'Register of New Zealand immigrants of Scottish birth arriving before 1 January 1921' is insufficient to permit any very detailed analysis of the immigration patterns of those Scots spending time in other countries on their way to New Zealand - information as to length of residences being especially scarce - but some basic statistics enable at least an indication of the flows.

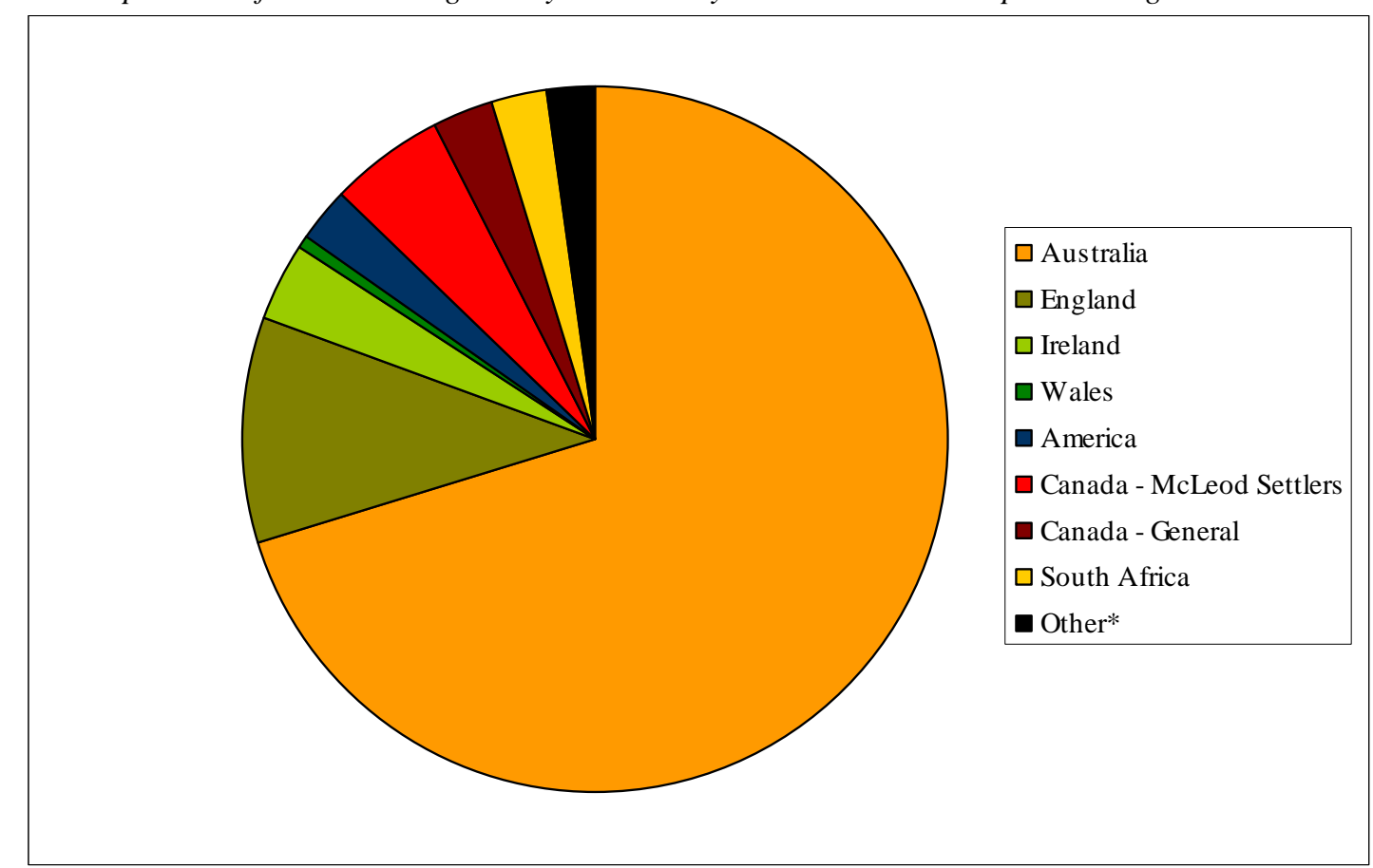

*‘Other’ is India (5), Ceylon (3), Brazil, Chile, Germany, Gibraltar, Russia, Samoa, Singapore, Tonga, and West Indies (1 each). Source: NZSG data, 1840-1920

Of the 764 NZSG migrants who had resided in a country other than Scotland prior to immigration to New Zealand, 720 had resided in one other country only. As Figure 2.2 shows, for the vast majority of these migrants that other country was Australia,

${ }^{75}$ NZSG database, migrant 01141 
70.14 per cent having stopped there before travelling on to New Zealand. This pattern of immigration to New Zealand via Australia was relatively common, ${ }^{76}$ and by no means confined to Scottish migrants, numerous English and Irish migrants also gaining experience of colonial life in Australia before travelling on to New Zealand. ${ }^{77}$ England was the prior country of residence for 10.42 per cent of this sub-sample, Ireland 3.61 per cent and Wales 0.55 per cent, a total of 14.58 per cent for other countries of the United Kingdom. Canada was not far behind England among the stepmigration migrants, but nearly two-thirds of those recorded were followers of the Rev. Norman McLeod who took ship for New Zealand direct from Nova Scotia following McLeod's exploratory travel through Australia and New Zealand. ${ }^{78}$

Among those who first took passage to Australia, then moved on to New Zealand, were John and Mary Edie. Both John and Mary came from coal mining backgrounds Mary's father had died in a mining accident in Fife, and John recorded his occupation as coal miner on the passenger list of the Anna. Shortly after their marriage in July 1854 the couple succumbed to the lure of the Victorian gold rush, setting sail for Sydney from Liverpool in November that year. Working to pay their way to the gold fields through 1855, John was mining in Bendigo from February 1856. The couple remained there until 1862, when they left for the Otago goldfields, joining Mary’s sister Margaret in Dunedin, where she had arrived as an assisted migrant in 1861. Having learnt from his experience in Bendigo that supplying the diggings was a more steady and reliable source of income than mining itself, John worked as a carrier between Dunedin and the diggings at Dunstan. ${ }^{79}$ This move, from the Victorian to the Otago gold fields, is a frequent experience in the stories of Scots arriving in New Zealand in the 1860s. Many of them - like John and Mary - remained in New Zealand after the gold rush had passed. ${ }^{80}$

\footnotetext{
${ }^{76}$ That is, common among those who did not emigrate directly to New Zealand.

${ }^{77}$ Erik Olssen, 'Lands of sheep and gold: The Australian Dimension to the New Zealand past, 18401900', in Keith Sinclair (ed.), Tasman Relations: New Zealand and Australia, 1788-1988, Auckland, 1987, pp.34-51, provides a useful outline of this Australia-New Zealand relationship.

${ }^{78}$ See sections in Chapter One and Chapter Three in the present work for more on this migration.

${ }^{79}$ Desiree Margaret Mulligan, 'Mary Edie’s biscuits and other interesting information about: the Edie family of Edievale', unpublished family history provided by Desiree Mulligan in April 2009, 1996, chapters 1 and 2.

${ }^{80}$ Terry Hearn, 'Scots miners in the goldfields, 1861-1870', in Tom Brooking and Jennie Coleman (eds), The Heather and the Fern: Scottish Migration and New Zealand Settlement, Dunedin, 2005, p.74, 75, 77, and 85
} 
Of the forty-four other NZSG migrants with a prior country of residence recorded, thirty-four had resided in two other countries, seven in three other countries, one in four, and another, a soldier, in six prior to arrival in New Zealand. Of these forty-three migrants, the last stop before immigration to New Zealand for twenty-seven was Australia, 62.79 per cent of the sub-sample (see Figure 2.3 below); thirty-one of the forty-two had spent time in Australia; fourteen had stopped for a time in Canada, six of these being McLeod settlers who followed him to Australia before emigrating to New Zealand; sixteen of the migrants had spent time in England or Ireland before coming to New Zealand.

Figure 2.3

Last country of residence for Scots with more than one country of residence prior to emigration to $\mathrm{NZ}$

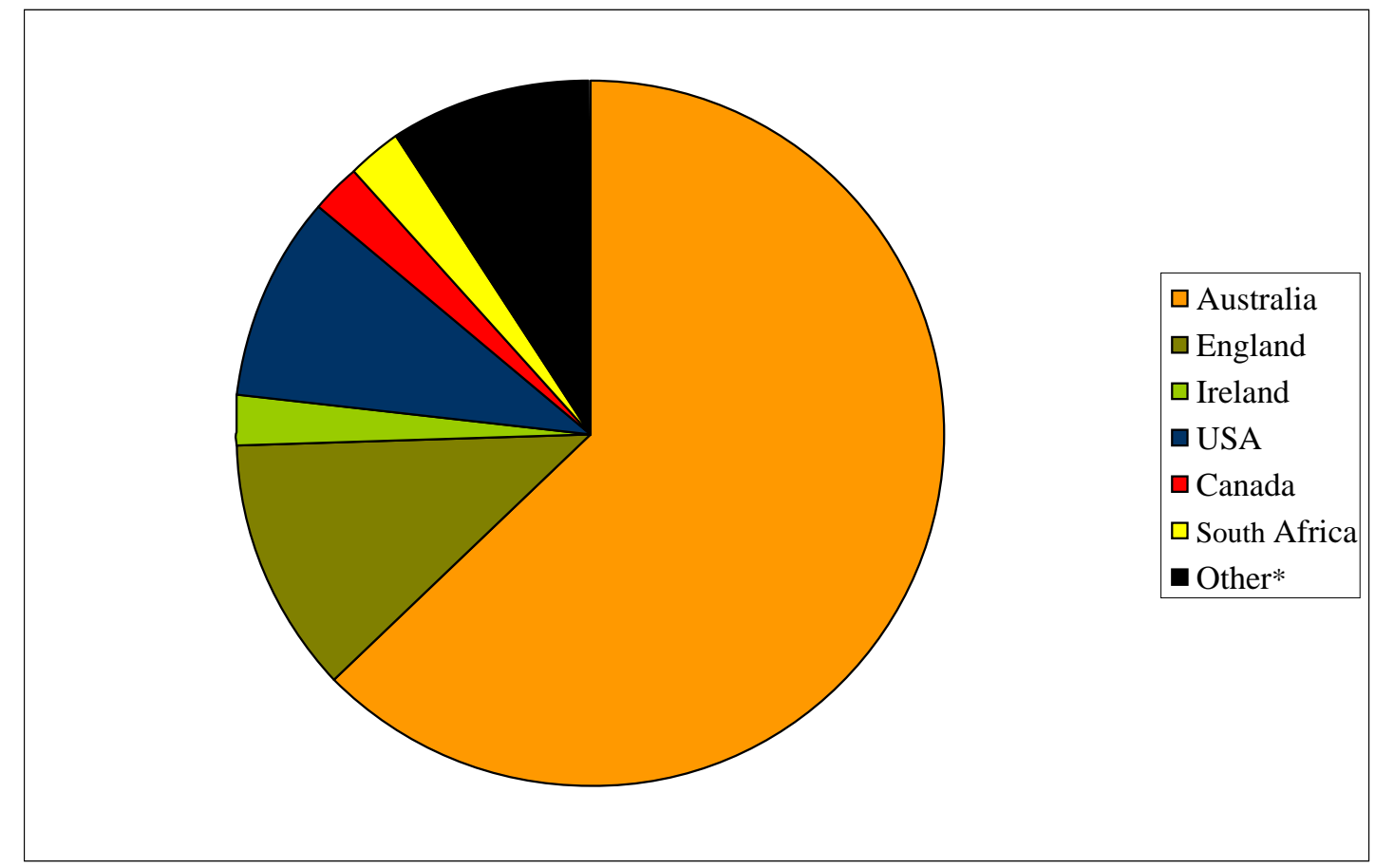

*'Other’ is Ceylon, Malta, New Caledonia, and West Indies (1 each)

Source: NZSG data, 1840-1920

One of the later migrants for whom Australia was the last stop in a series of steps before immigration to New Zealand was William McIntosh. Born in 1884, in his late teenage years William left for Canada where he found work as a horseman before migrating to South Africa. While in South Africa William was offered an assisted passage to Australia, which he accepted, working first in Queensland as a ploughman until the climate there forced him to move south to Burrinjuck Dam, New South Wales. As soon as his assisted passage was repaid, William left Australia for Taranaki, New Zealand, where he worked on a cattle farm at Eltham. ${ }^{81}$ As is

${ }^{81}$ Personal communication with Marlene Williamson, 30 October 2007 
frequently the case for many such migrants, William's motives for his repeated migrations remain unknown, but it is likely he, like so many others, was simply endeavouring to improve his circumstances.

The remaining migrant of the sub-sample of forty-four, Matthew Findlay, differs in an important respect from the others. He is the only individual in the database exhibiting a pattern of migration known to have been common among migrants to New Zealand - temporary migration to Australia post-arrival in New Zealand. Because the relevant space on the NZSG registration forms queries 'If resident in another country before N.Z., where \& for how long', contributors omitted providing information regarding subsequent movements after arrival in New Zealand. Thus this further migration can only be deduced from place of death if the migrant died outside New Zealand. Matthew arrived in New Zealand on the Ionic in 1909, the day before his ninth birthday. In 1928 he left New Zealand for New South Wales with wife Isobel and son Robert James. Isobel died in Australia in 1935, and Robert James in 1941. Matthew remarried in 1936, but his second wife Helen Mary died in 1943, and in 1944 he returned to New Zealand. He married his third wife, Winnifred Annie, in Auckland in $1945 .{ }^{82}$ Though he was in Australia for longer than most New Zealanders spending time across the Tasman Sea, and as such it might be argued that his intention may not have been temporary migration but permanent settlement, it is probable the experience of Matthew Findley of Neilston, Renfrewshire, was more common than the NZSG evidence suggests. ${ }^{83}$

\section{CONCLUSION}

Farewell, my friends! Farewell, my foes!

My peace with these, my love with those:

The bursting tears my heart declare -

Farewell, the bonie banks of Ayr! ${ }^{84}$

The common stereotype of Scots in New Zealand still tends to be the invented 'traditional' Highland image of bagpipes and Highland flings, tartan and claymore

\footnotetext{
${ }^{82}$ NZSG database, migrant 01768

${ }^{83}$ Rollo Arnold, 'Yeomen and nomads: New Zealand and the Australasian shearing scene, 1886-1896', NZJH, Vol.18, No.2, 1984, pp.117-142; and Rollo Arnold, 'The dynamics and quality of transTasman migration, 1886-1910’, Australian Economic History Review, Vol.26, No.1, 1986, pp.1-20 provide a useful introduction to this flow.

${ }^{84}$ Burns, 'The gloomy night is gath'ring fast', in The poems and songs of Robert Burns, Kinsley (ed.) p.292, lines 29-32.
} 
wielding clansmen. ${ }^{85}$ As this chapter has endeavoured to show, far more of New Zealand's Scots immigrants joined Scotland's favourite - and Lowland-born - bard in farewelling the 'bonie banks of Ayr' than farewelled any Highland shore. That this was due to an evenness of migrant origin distribution, mirroring to the population distribution of Scotland, rather than from any particular fondness for New Zealand on the part of Lowland-born migrants, is the principal finding from the collected records of Scottish migrant families.

While discussion of the factors that may have impelled migration flows from particular regions and counties has been implicit rather than explicit, it is clear that the frequently recited tales of the emigration of displaced and impoverished Highland crofters bear little resemblance to the New Zealand experience. New Zealand's Scots did not, by and large, arrive as victims, rather as 'willing exiles'. Though unemployment due to technological advances was a factor that encouraged migrants to come to New Zealand, these individuals tended to be from the industrial Lowlands and from farming districts in the Lowlands and the North East where intensification and mechanisation were obliging people to leave the land. As Akenson has observed 'most individuals who came to New Zealand came from those parts of Scotland most closely linked to the rapidly modernising economy of England and that of the north of Ireland' ${ }^{86}$ As discussion of internal migration has made clear, though migrants came from all over Scotland in numbers proportionate to the population distribution of that country, internal migration and the availability of employment ensured that even those from far-flung Highland parishes often had first-hand experience of the urbanised, industrial centres in the Lowlands. What should also be clear is that this flow from rural to urban to international migration was not the only story.

This chapter has sought to impart a sense of the diversity of Scottish immigrant backgrounds in respect of origins. The descriptions of several locations in Scotland, though brief, provide sufficient information to make plain the essential differences

\footnotetext{
${ }^{85}$ Tom Brooking, 'Sharing out the haggis: the special Scottish contribution to New Zealand history', in Tom Brooking and Jennie Coleman (eds), The Heather and the Fern: Scottish Migration and New Zealand Settlement, Dunedin, 2003; The emblem for the (inaptly named, as may be assumed from what has been discussed thus far) 'Highlanders' Super 14 Rugby team, is of just such a claymore wielding clansman: http://www.highlanders-rugby.co.nz/page.pasp?pageid=2, accessed 13 May 2009

${ }^{86}$ Donald Harman Akenson, 'What did New Zealand do to Scotland and Ireland?' in Brad Patterson (ed.), The Irish in New Zealand: Historical Contexts and Perspectives, Wellington, 2002, p.192
} 
between the various regions of Scotland. This understanding underpins inferences in the following chapters to possible migration motives and pressures.

Finally, this chapter has also set out to demonstrate the importance of disaggregating the statistical mass of migrants to better explore the migration flows. In the absence of an all but unattainable level of detailed information regarding internal migration and step migration between departures from Scotland and arrival in New Zealand, certainly for a sample of migrants of a sufficient size to be meaningful, these aspects of the migrants' experiences can only satisfactorily be examined through case-studies. While statistics are necessary to such a study of migration flows, they are not always sufficient. In exploring the settlement patterns of New Zealand's Scots at destination, genealogically sourced evidence will be employed in a similar manner in the next chapter. 


\section{Chapter Three \\ FROM ‘THE LAND OF HEATHER AND THISTLE' TO ‘THE LAND OF KAURI AND FERN’: PATTERNS OF SCOTTISH SETTLEMENT IN NEW ZEALAND. ${ }^{1}$}

Born in the village of Duntiblae in Lanarkshire in September 1841, Mary Grey left Lanarkshire with her parents and siblings in March 1852. Bound for the Australian goldfields, she arrived in Melbourne in July that year. Although aged just ten years, Mary shouldered the brunt of the responsibility of running the household after her mother fell from a wagon breaking both wrists shortly after arrival. In 1858 Mary and her family moved on again, this time to Otago to join a maternal uncle, Alexander Watson, and his family in Taieri. Mary's father found employment as a farm labourer on 'Ravenscliffe', the estate of English migrants James and Catherine Fulton. The Grey family lived on the estate, where Mary was employed as a maid for Mrs Fulton. When the discovery of gold at Tuapeka led to a gold rush in 1861, the quiet of Mary’s village was shattered as hundreds of men streamed through on their way to make their fortunes. An encounter with one of these men resulted in Mary becoming pregnant, giving birth to a daughter, Phoebe, whose birth certificate reads 'Father Unknown'. The family moved again shortly after Phoebe’s birth, Mary’s father having finally been able to purchase land of his own at Maungatua. In April 1869 Mary married Joseph Cookson, an English migrant who had been employed for some years on the Fulton estate. The couple had nine children over the space of eighteen years, moving to a house built by Joseph at Harvey’s Flat. Mary died of pneumonia in October 1910

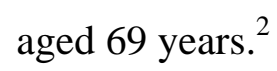

Mary Grey and family, as well as John and Mary Edie encountered in the previous chapter, are valuable case studies of Scots arriving in Otago in these founding decades. Their stories exhibit a number of common characteristics with other migrants. The motivation behind their initial emigrations from Scotland appears to have been the prospect of success on the goldfields of Australia. As noted in the previous chapter, Australia was most frequently the prior country of residence for

\footnotetext{
${ }^{1}$ John Liddell Kelly, 'Heather and Fern', Heather and the Fern: Songs of Scotland and Maoriland, Wellington, 1902, cited in Alan Riach, 'Heather and fern: The Burns effect in New Zealand verse', in The Heather and the Fern: Scottish Migration and New Zealand Settlement, ed. Tom Brooking and Jennie Coleman, Dunedin, 2003, p.156

${ }^{2}$ Phyllis Barnett-Drummuir, 'A lassie from Lanarkshire', unpublished family history presented by Mrs Barnett-Drummuir, pp.1-4 of 4
} 
migrants to New Zealand, particularly in the 1850s and 1860s. Typical of Scots migrants to New Zealand too was the decision of both families to move to Otago because members of their extended families had already established there. Moreover, both families settled in Taieri County, a county with a high proportion of Scottish migrants. Finally, Mary and family were born in Lanarkshire, the Scottish county that contributed the largest number of migrants to Taieri County.

Two key questions will direct the focus of this chapter. Findings presented in Chapter Two suggested that the distribution of the origins of New Zealand Scots at both Scottish regional and county levels was proportionate and that there was limited clustering. Consequently, one of the key questions this chapter will address is did this evenness of distribution continue down to New Zealand provincial level, or did parts of New Zealand attract migrants from parts of Scotland disproportionately? The second key question relates to the pattern of settlement of the Scots generally. New Zealand census birthplace data clearly indicates, and received wisdom relates, that Otago and Southland were the primary locations of Scottish settlement in New Zealand. With that in mind, a second key question is were there identifiable Scottish settlements elsewhere in the colony? These questions cannot be addressed solely through statistical evidence: as in Chapter Two, discussion in this chapter will also utilise genealogical material to explore aspects of the migrant experience.

\section{NEW ZEALAND PROVINCIAL PATTERNS OF SCOTTISH SETTLEMENT}

When New Zealand's Scots have been disaggregated from the general population, and their settlement patterns have been written into general history texts, the emphasis has invariably been on Otago and Southland, with a notable Highland pocket in Waipu, and occasional mention of 'two shiploads of Scottish settlers' arriving in Auckland in 1842. ${ }^{3}$ Scots receive mention in Reeves's 1898 history only with regards to the Otago settlement being the outcome of the Scottish Disruption; writing fifty-six years later, Condliffe and Airey shed little more light on the subject in their Short History of New Zealand. ${ }^{4}$ In his classic History of New Zealand Sinclair notes that 'a few hundred Scottish immigrants' settled in Auckland in 1842 and 'a few more Scottish settlers retreated to Auckland from an unsuccessful settlement on a

\footnotetext{
${ }^{3}$ Michael King, The Penguin History of New Zealand, Auckland, 2003, p.173

${ }^{4}$ William Pember Reeves, The Long White Cloud, London, 1924, p.12; J.B. Condliffe and W.T.G. Airey, A Short History of New Zealand, Auckland, 1954, pp.78-9
} 
neighbouring harbour'. Other settlements receive little attention. ${ }^{5}$ More recently, in Paradise Reforged, Belich writes that 'Scots met some basic criteria for ethnocultural persistence. They had their own church... and some were 'ghettoised'.... The ghetto was rather large: Otago and Southland', again making little mention of settlement elsewhere in New Zealand. ${ }^{6}$ Even Pearce's work dedicated to 'The Scots of New Zealand' largely ignores of Scottish settlements beyond Auckland, Otago, and Waipu, noting only briefly the arrival of several ships carrying Scottish migrants to Wellington in 1840 and a presence of Scots in Canterbury. ${ }^{7}$ Given this scant consideration, it is little wonder the average New Zealander's perception of Scottish settlement is that 'they all went to Dunedin'.

Figure 3.1, below, summarises the provincial distribution of the Scotland-born population of New Zealand between 1871 and $1911 .^{8}$ What this census-based representation reinforces is that, while there were significant populations of Scots in Canterbury, Wellington and Auckland, due to its establishment and continued status as a Scottish settlement the largest proportion of the Scotland-born population of New Zealand did indeed reside in Otago, augmented by its off-shoot, Southland, well into the twentieth century.

\footnotetext{
${ }^{5}$ Keith Sinclair, A History of New Zealand, Auckland, 2000, p.102

${ }^{6}$ James Belich, Paradise Reforged: A History of the New Zealanders from the 1880s to the Year 2000, Auckland, 2001, p.220

${ }^{7}$ G.L. Pearce, The Scots of New Zealand, Auckland, 1976, pp.45-50, chapter 4 and chapter 5.

${ }^{8}$ While Scotland may easily - and not especially controversially - be split into regions, counties and parishes, according to administrative boundaries that were long established by 1840 and remained largely constant throughout the period of this study, New Zealand territorial boundaries were constantly changing between 1840 and 1920, an inevitable consequence of the colonisation and settlement processes. As is detailed in Appendix 1.1, the New Zealand internal boundaries used throughout the present work are the sixty-three counties created in 1876, and the ten provinces used for some or all of the years between 1852 and 1876. Throughout the eighty year period that the NZSG data covers, the New Zealand census states the population of New Zealand by country of origin and New Zealand province from 1871-1916, only separating 'Southland' from 'Otago' in 1871, 1911 and 1916. Though the provincial boundaries were only used up to 1876 for administrative purposes - defining the boundaries of the Provincial Governments jurisdiction - they are used as boundaries for statistical purposes in the New Zealand census throughout this period.
} 
Figure 3.1

Provincial distribution of the Scots-born population of New Zealand between 1871 and 1911

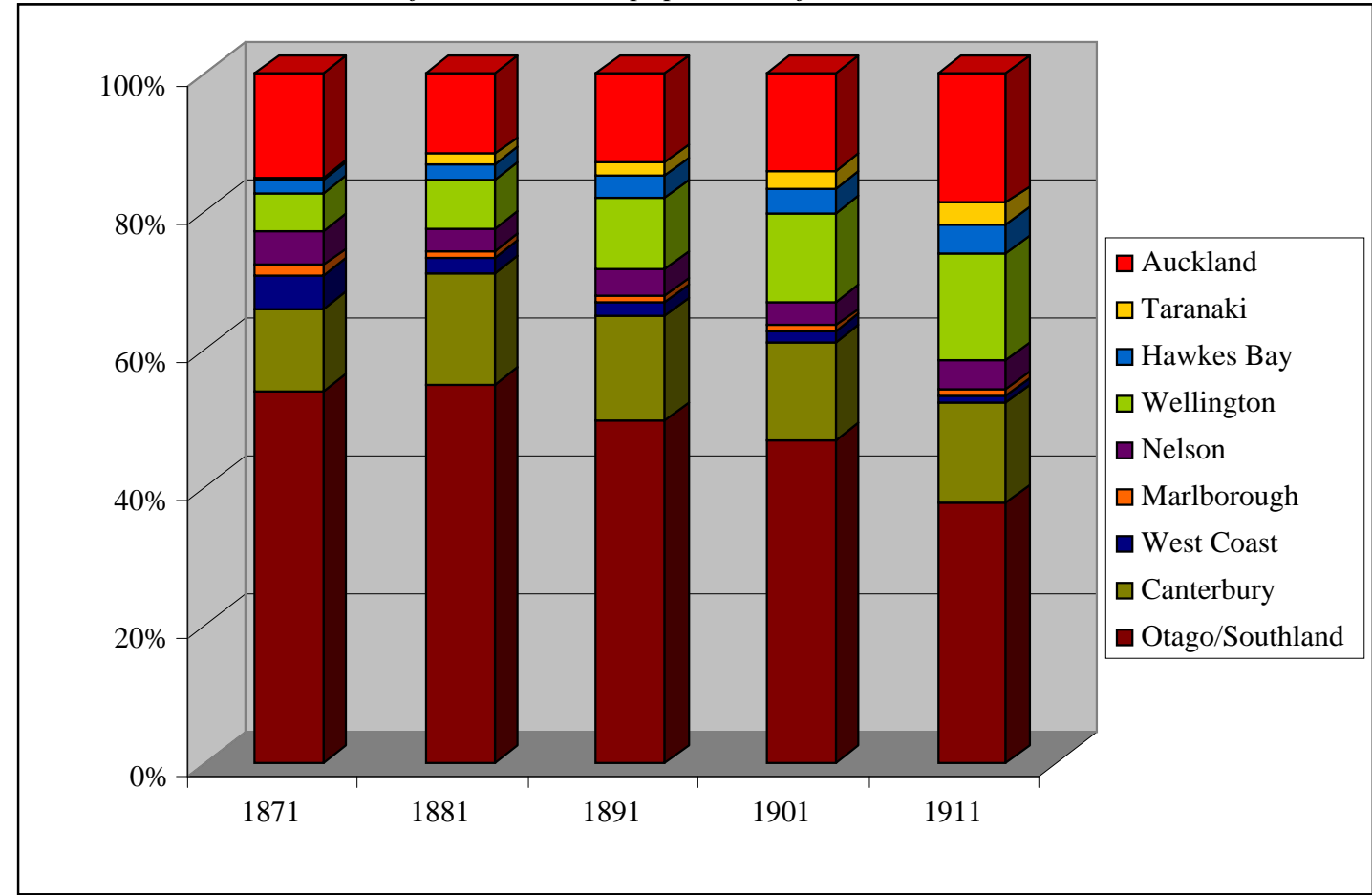

Sources: 1871, 1881, 1891, 1901 and 1911 Census of New Zealand.

The influx of Scots migrants to Otago began in 1848, with the formation of Dunedin as a Scottish Free Church settlement. The notion of forming a distinctly Scottish settlement in New Zealand was first formulated in 1842 and - with modifications by Rev. Thomas Burns, William Cargill and John McGlashan following formation of the Free Church of Scotland in 1843 - the scheme came to fruition with the arrival in Port Chalmers of the John Wickliffe and the Philip Laing in early 1848. ${ }^{9}$ The ideal settlers the sponsors had in mind for the settlement were emigrants “"imbued with the principles and habits of Scottish piety”, preferably - but not necessarily - from the Free Church'. ${ }^{10}$ Around two-thirds of the early Otago settlers were indeed Free Church Presbyterians. ${ }^{11}$

Analysis carried out by Maxwell, investigating the Scottish origins of migrants arriving in Otago between 1848 and 1850 reveals - as might be expected based on the

\footnotetext{
${ }^{9}$ T.M. Hocken, Contributions to the Early History of New Zealand, London, 1898, p.17, chapters 1-6 and chapter 16; A.H. McLintock, The History of Otago: The Origins and Growth of a Wakefield Class Settlement, Dunedin, 1949, chapter 4; Tom Brooking, And Captain of Their Souls: Cargill and the Otago Colonists, Dunedin, 1984, chapters 2 and 3; Erik Olssen, A History of Otago, Dunedin, 1984, chapter 5.

${ }^{10}$ R.R. McClean, 'Scottish piety: the Free Church settlement of Otago, 1848-1853', in Building God's Own Country: History Essays on Religions in New Zealand, ed. John Stenhouse and Jane Thomson, Dunedin, 2004, p.21

11 ibid., pp.26-27
} 
findings presented in Chapter Two - that most of the migrants were from the Lowlands, and the majority of these were from Midlothian, reflecting the promotion of the Otago scheme in that county. ${ }^{12}$ Brooking notes that 'married couples with small families predominated at first, reflecting the desire of the settlement's promoters...', an influx of single men coming to the province later, and especially from $1861 .^{13}$ This was in line with New Zealand Company regulations under which young, childless, married couples were preferred, it being hoped this would 'guard against an excess of males'. ${ }^{14}$ Also in line with New Zealand Company policy, mechanics, craftsmen, agricultural labourers and domestic servants were favoured migrants for the Otago settlement. ${ }^{15}$ The Philip Laing carried thirty couples, ninety-two children and just thirty single migrants, while the John Wickliffe carried thirteen married couples, and sixteen single migrants. Occupations recorded for migrants on the Philip Laing and the John Wickliffe indicate few migrants with agricultural experience, the John Wickliffe including among its passengers five general labourers, four domestic servants and several other migrants with urban occupations, the Philip Laing carrying considerably more agricultural labourers (11.88 per cent of those with an occupation recorded). ${ }^{16}$

Alexander Watson was one of those who took up the offer of an assisted passage to New Zealand on the Philip Laing. Born in 1810 in Kirkintilloch, Dunbartonshire, just north-west of Glasgow, Alexander married Jane Lang in September 1842 and their son Walter was born thirteen months later. A weaver by trade, it is likely the same unemployment pressures that motivated many textile workers from Paisley and surrounds to sail for Auckland in 1842 also motivated Alexander's decision to emigrate. ${ }^{17}$ Possibly in order to secure an assisted passage, Alexander stated his

\footnotetext{
${ }^{12}$ Brooking, And Captain of Their Souls, p.119

${ }^{13}$ Tom Brooking, 'Tam McCanny and Kitty Clydeside' - the Scots in New Zealand', in Scots Abroad, ed. R.A. Cage, London, 1985, p.160.

${ }^{14}$ Marais further notes 'Single women were only accepted if they went out under proper protection, and single men if a corresponding number of single women had been accepted.' 'Regulations to be observed in the selection of emigrants for a free passage dated 1 July 1843' cited in J.S. Marais, The Colonisation of New Zealand, London, 1968, p.62

${ }^{15}$ Regarding New Zealand Company selection policies see also: Tony Simpson, The Immigrants: The Great Migration From Britain to New Zealand, 1830-1980, Auckland, 1997, p.77.

${ }^{16}$ Brooking, And Captain of Their Souls, pp.55-56

${ }^{17}$ See Peter Aitchison and Andrew Cassell, The Lowland Clearances: Scotland's Silent Revolution, 1760-1830, East Linton, 2003, p.118; Ian Levitt and Christopher Smout, The State of the Scottish Working-Class in 1843: A statistical and Spatial Enquiry Based on the Data from the Poor Law Commission Report of 1844, Edinburgh, 1979, p.156-60; Rosalind McClean, 'Scottish Emigrants to
} 
occupation as 'sawyer', this being recorded on the Philip Laing passenger list. Once in Otago, he was employed first as a farm worker, then later as farm manager on the 'Breadalbane' estate in Taieri. In 1865 he was able to purchase twenty-five acres of land neighbouring 'Breadalbane', which he named 'Langsfield'. Alexander, Jane and Walter remained at 'Langsfield' for the rest of their days, Walter buying a section of the property from his father on which to bring up his own family, when he married in 1868. As has already been noted, Alexander was joined in Taieri by his sister and her family in $1858 .^{18}$

The discovery of gold in the province in 1861 and the gold rush that followed brought about a radical transformation in the settlement, the likes of which had been feared by Cargill and his Free Church companions from as early as 1851, when small samples of gold had been discovered. The founding fathers had no desire for the settlement to develop at the 'expense of an invasion of... godless adventurers from overseas. ${ }^{19}$ Between 1860 and 1863 the population of Otago increased six-fold, from 12,691 to 76,965; moreover, an initial gender imbalance was exacerbated, the majority of the new arrivals being single men. ${ }^{20}$

Despite this gold rush driven influx, the Scottish predominance in the population was maintained, in part due to the large number of miners who were of Scottish birth. $^{21}$ According to the 1871 Census, 28.51 per cent of those residing in Otago or Southland were born in Scotland compared to just 16.38 per cent English and 8.95 per cent Irish. $^{22}$ The New Zealand-born population was already 31.84 per cent, and given the very high proportion of Scots in the province in the preceding twenty-three years, it is almost certain that many of the New Zealand-born recorded in the census were the sons and daughters of Scottish migrants. The Scottish population of Otago Province was overwhelmingly settled in Taieri County - the county that included Dunedin within its boundaries - throughout the period: 57.28 per cent of the NZSG

New Zealand, 1840-1880: Motives, Means and Background', PhD Thesis, University of Edinburgh, 1990, p.132.

${ }^{18}$ Phyllis Barnett-Drummuir, 'Notes on the family of William Watson, born Cadder, 1775', family history notes prepared by Mrs Barnett-Drummuir and presented in August 2007, pp.3-4 and 6 (of 7); Barnett-Drummuir, 'A lassie from Lanarkshire',

${ }^{19}$ A.H. Reed, The Story of Otago: Age of Adventure, Wellington, 1947, p.228; H.A. Glasson, The Golden Cobweb (A Saga of the Otago Goldfields, 1861-1864), Dunedin, 1957, p.18

${ }^{20}$ Reed, The Story of Otago, p.265

${ }^{21}$ Terry Hearn, 'Scots miners in the goldfields, 1861-1870', in The Heather and the Fern: Scottish Migration and New Zealand Settlement, ed. Tom Brooking and Jennie Coleman, Dunedin, 2005, pp.7576

${ }^{22}$ Table No.11, 1871 Census of New Zealand. 
Otago Province migrants made homes in Taieri County, 10.89 per cent in Waitaki County and 9.90 per cent in Clutha. The top six 'sending counties' for Otago Province were similar for New Zealand as a whole to 1920: 13.18 per cent of the NZSG migrants in Otago Province had been born in Lanarkshire, 8.97 per cent in Midlothian, 6.78 per cent in Ayr, 6.29 per cent in Perthshire, 5.96 in Aberdeen and 4.65 per cent in Renfrewshire. The county of origin distribution for Taieri County is broadly similar to that for Otago Province as a whole. ${ }^{23}$

While, as Figure 3.1 shows, Otago/Southland remained the most Scottish part of New Zealand throughout, there were always pockets of Scottish settlement elsewhere in the colony. Though Auckland, the only one of New Zealand's six primary migrant settlements not settled by the New Zealand Company, received a much smaller proportion of English immigrants and much higher proportion of Irish immigrants than the four New Zealand Company settlements, it received a similar proportion of Scots. As Figure 3.2a and 3.2b indicate, between 15 and 18 per cent of migrants in both the New Zealand Company settlements and in Auckland arriving between 1840 and 1852 were Scots.

Figure 3.2a

Birth country of immigrants to Auckland Province arriving 1840-1852

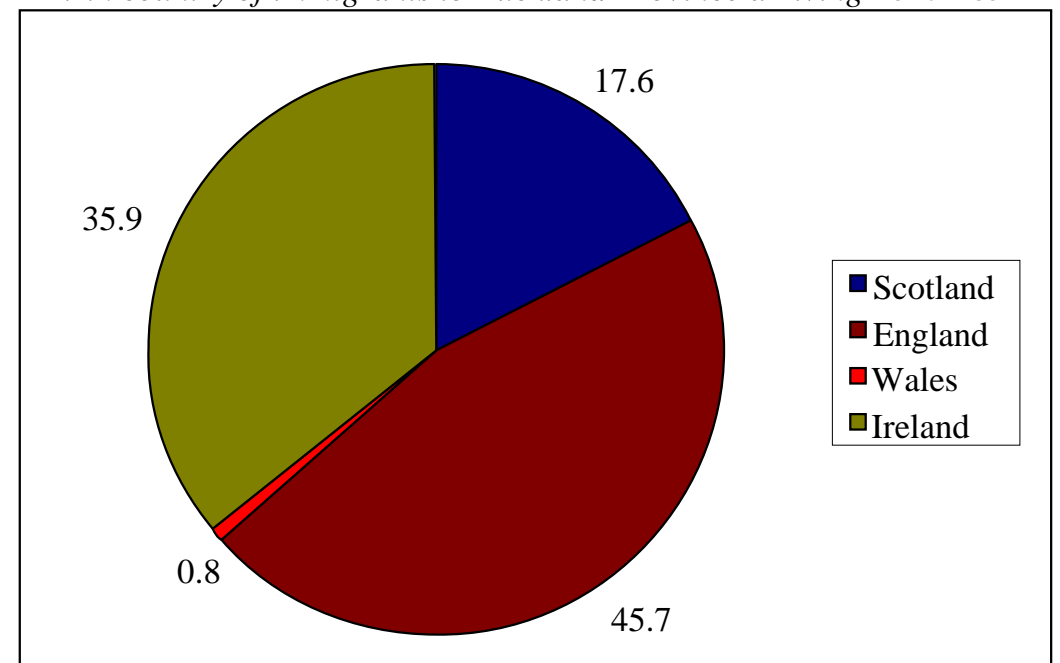

Source: ‘Auckland and New Zealand Company settlers by country of origin, 1840-52', www.teara.govt.nz, based upon sample of death registers, 'Peopling' project, Ministry for Culture and Heritage, Wellington.

\footnotetext{
${ }^{23}$ For more on the Scottish communities and settlements in Otago, Southland see: Olssen, A History of Otago, ; Brooking, And Captain of Their Souls, ; Jane Thomson, ed., Southern People: A Dictionary of Otago Southland Biography, Dunedin, 1998; and The Advance Guard series. This series comprises a collection of biographies contributed to an historical biography competition held by the Otago Daily Times to celebrate the $125^{\text {th }}$ Anniversary of Otago. The series boasts the rescue of 'some of the earliest Otago settlers from near-oblivion'. G.J. Griffiths, ed., The Advance Guard, Series 1, Dunedin, 1973; G.J. Griffiths, ed., The Advance Guard, Series 2, Dunedin, 1974; G.J. Griffiths, ed., The Advance Guard, Series 3, Dunedin, 1974
} 
Approximately one fifth of immigrants to Auckland in this decade were assisted immigrants sponsored by the Colonial Land and Emigration Commissioners. These assisted immigrants included the influx of Scots arriving in the province in 1842 on the Duchess of Argyle and the Jane Gifford, predominantly urban, working folk including many Paisley weavers. ${ }^{24}$ Though the vast majority of the Royal New Zealand Fencibles, who made up approximately 30 per cent of early Auckland settlers, were Irish, Scots were also among this group of immigrants, just under fifty of the 2,581 'Fencible' settlers being Scotland-born. ${ }^{25}$ The inflow of Scots to Auckland continued through the 1850s and 1860s, one in six immigrants to the province being of Scottish birth during these decades, figures boosted by another influx of Scots to the province in 1853 with the settlement of Scots at Waipu with Norman McLeod. ${ }^{26}$ As will be discussed later in this chapter, the flow of Scots to Auckland, having been initiated by the influx of Western Lowland migrants in 1842, remained primarily of Western Lowland, and especially Glaswegian, Scots. ${ }^{27}$

Figure 3.2b

Birth country of immigrants to New Zealand Company Settlements arriving 1840-1852

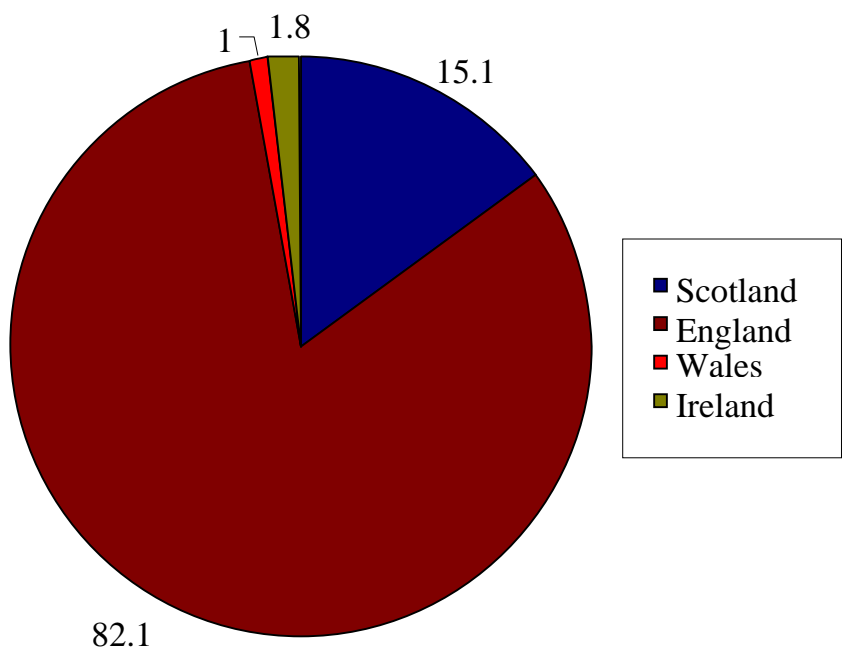

Source: 'Auckland and New Zealand Company settlers by country of origin, 1840-52', www.teara.govt.nz, based upon sample of death registers, 'Peopling’ project, Ministry for Culture and Heritage, Wellington.

\footnotetext{
$24 \quad$ Jock $\quad$ Phillips, History of Immigration', http://www.TeAra.govt.nz/NewZealanders/NewZealandPeoples/HistoryOfImmigration/en updated 21 September 2007; Jock Phillips and Terry Hearn, Settlers: New Zealand Immigrants from England, Ireland and Scotland, 1800 - 1945, Auckland, 2008, pp.1-2

${ }^{25}$ Phillips, 'History of Immigration'; Ruth Alexander, Gail Gibson, and Alan J. La Roche, The Royal New Zealand Fencibles, 1847-1852, Auckland, 1997

${ }^{26}$ Phillips and Hearn, Settlers, p.57

${ }^{27}$ ibid., p.108
} 
Over half of the immigrants coming to New Zealand between 1840 and 1852 were assisted to emigrate by the New Zealand Company or its successors. ${ }^{28}$ As indicated in Figure 3.2b, over 15 per cent of New Zealand Company settlement immigrants those settling in Taranaki, Wanganui, Wellington, and Nelson between 1840 and 1852 - were born in Scotland. The first of the New Zealand Company settlements, Wellington, received an immediate influx of Scots at its inception in 1840 with the arrival of the Blenheim and the Bengal Merchant. While the majority of the 160 passengers on the Bengal Merchant were from Glasgow, most of the 197 immigrants on the Blenheim were drawn from in and around Inverness. ${ }^{29}$ Though infrequently noted as an area of Scottish settlement in New Zealand, pockets of Scottish settlement remained in Wellington Province throughout the period under investigation, much of that stemming from the dispersal and settlement of these early migrants.

As settlement of the colony progressed, and in the later nineteenth century the population as a whole began to move north, Auckland and Wellington became home for an increasingly large proportion of Scots. ${ }^{30}$ This move from the South Island to the North, and from rural communities to urban centres, was not only significant among the Scots-born in New Zealand, but phenomenon shared by the general population. Perceived from the 1890s, the drift of the rural population to urban centres, consequently increasing urban growth, was viewed as an 'evil force that violated the purity of God's Own Country'. ${ }^{31}$ This rural to urban drift was noted in the 1926 New Zealand Census in somewhat alarmist terms:

The term "urban drift" is used to indicate the gradual abandonment of rural life for that of the city and the growth of cities at the expense of their rural hinterland.... In a manufacturing country the tendency is perhaps more natural, but for New Zealand, which is for the greater part a primary producing country, the indications of strong urban drift are viewed by many with alarm. ${ }^{32}$

Though 'the city' was assailed for being 'parasitic and predatory', attracting, trapping and sustaining 'the unfortunate, the degenerate, the weak-willed and the idle', much of this drift was a result of the increasing mechanisation of agriculture that brought about greater levels of production while also requiring less labour and

\footnotetext{
${ }^{28}$ ibid., p.31

29 ibid., p.56

${ }^{30}$ See below regarding the northward drift of the population

${ }^{31}$ Miles Fairburn, 'The rural myth and the new urban frontier: an approach to New Zealand social history, 1870-1940', NZJH, Vol.9, No.1, 1975, pp.3-21, p.4

${ }^{32}$ Vol.1, Introductory notes, 1926 Census of New Zealand, pp.4-5
} 
increasing rural unemployment. ${ }^{33}$ Scots, along with other New Zealanders', were drawn to urban centres by employment opportunities. ${ }^{34}$

The drift of the population from the South to the North Island was not part and parcel of the urban drift of the population, but rather a result of the rural to rural drift from the South Island to land in the North. Between 1886 and 1906, while urban population growth in the North Island was twice as great as that in the South, rural population gain in the North Island was four times that of the South Island, the North Island accounting for approximately 80 per cent of New Zealand's net rural increase over these two decades. ${ }^{35}$ These drifts were, primarily, twentieth century phenomena, notable in the NZSG and PNZ datasets because the place of settlement information is taken at time of death. ${ }^{36}$ This should be borne in mind when reading the 'place of settlement' findings taken from the two data sets, it being likely they are indicative of internal migration within New Zealand after the time period with which the present discussion is concerned (1840 to 1920). ${ }^{37}$

Throughout the period 1840 to 1920 over half of the Scotland-born population of New Zealand lived in the South Island, the North Island Scotland-born population peaking in 1911 with 41.66 per cent of all New Zealand Scots-born living in the North Island at that census. Though Auckland Province received a significant proportion of this population increase, the northward drift is especially clear in Wellington. Nevertheless, while 58 per cent of New Zealand's Scots were living in the South Island at the 1911 Census, the proportion of the total population of New Zealand living in the North Island was 56 per cent, indicating a continued stronghold of Scots in the South compared to the population as a whole.

\footnotetext{
${ }^{33}$ Fairburn, 'The rural myth and the new urban frontier: an approach to New Zealand social history, 1870-1940’, p.4; Sinclair, History of New Zealand, p.208

34 Jock Phillips, 'Rural mythologies - Rural myth lives on, 1945-1975', http://www.TeAra.govt.nz/en/rural-mythologies/6, updated 1 March 09

35 J.S. Duncan outlines this rural to rural movement of the population concisely in J.S. Duncan, 'The land for the people: land settlement and rural population movements, 1886-1906', in Land and Livelihood: Geographical Essays in Honour of George Jobberns, ed. Murray McCaskill, Christchurch, 1962, pp.170-190

${ }^{36}$ Sinclair, History of New Zealand, pp.308-309; R.F. Watters, 'Appendix I: A note on urban growth in New Zealand', in Land and Society in New Zealand: Essays in Historical Geography, ed. R.F. Watters, Wellington, 1965, p.207; R.F. Watters, 'Change and the New Zealand scene', in Land and Society in New Zealand: Essays in Historical Geography, ed. R.F. Watters, Wellington, 1965, Fig.I,: 'The number of towns in various size classes, 1881-1961', p.193

${ }^{37}$ Regarding these South to North Island and rural to urban drifts also see: King, The Penguin History of New Zealand, pp.280-81; also Part I, Seciton III, 1921 Census of New Zealand pp.54-57; Vol.1, Introductory notes, 1926 Census of New Zealand, pp.4-5; Vol.1, Introductory notes, 1936 Census of New Zealand, pp.ix-x; and Vol.1, Introductory notes, 1956 Census of New Zealand, pp.11 and 23-25
} 
Analysing patterns in the NZSG and PNZ data by province of death reassuringly reinforces the broad patterns suggested by census figures. ${ }^{38}$ Even so, these datasets indicate an even smaller proportion of Scots living in Otago and Southland and higher proportions in Auckland and Wellington than the census data indicates. This is a result of the place of settlement recorded in both datasets being based upon place of death, the data collected therefore reflecting domicile in later life. This has intensified the impact of the general northward migration trend of the population, increasing the proportion of the Scots-born population recorded as residing in the north in the datasets compared to the census.

Figure 3.3

Provincial distribution of Scots emigrants to New Zealand at time of death

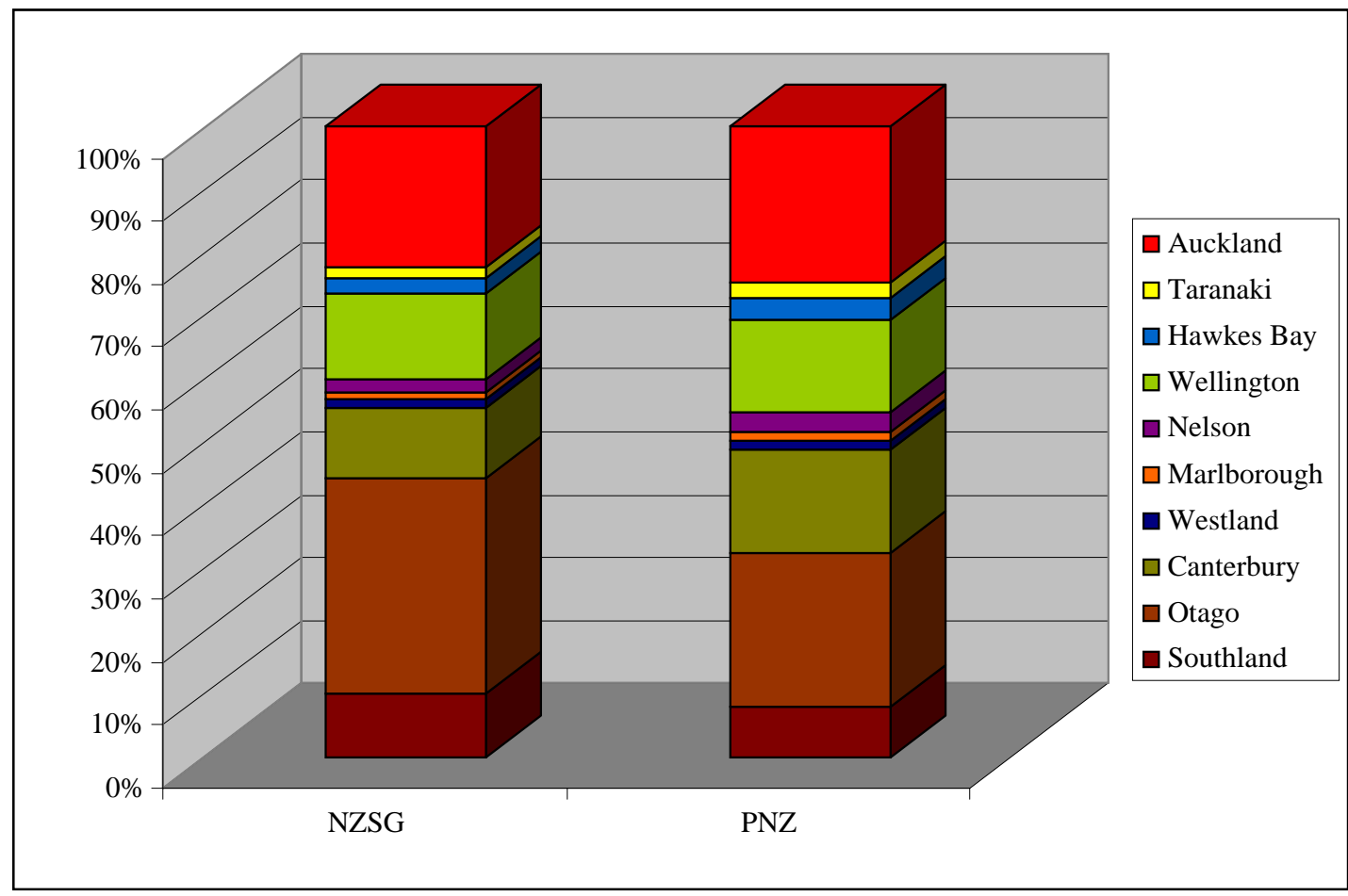

Sources: NZSG and PNZ data, 1840-1920

Table 3.1 displays the percentage of Scots-born in each province of New Zealand according to regional birth place, as recorded in the NZSG data. Taking an average of these percentages for each region of Scotland provides a point of comparison for the New Zealand provincial experience. The average percentage of migrants to New Zealand as a whole from Scotland's Far North, for example, was 5.47 per cent. By comparison, both Auckland and Taranaki held a below average number of Scots from

\footnotetext{
${ }^{38}$ See Appendix 1.1 for the reasoning behind using place of death as the indicator for settlement patterns and some of the issues regarding this.
} 
the Far North with 2.68 and 1.85 per cent respectively, and the West Coast above average with 11.76 per cent. $^{39}$

Table 3.1

Percentage of migrants from each region of Scotland living in each province of New Zealand.

\begin{tabular}{cccccccc}
\hline & \multicolumn{7}{c}{ \% of each province from the regions of Scotland } \\
& $\begin{array}{c}\text { Far } \\
\text { North }\end{array}$ & Highlands & $\begin{array}{c}\text { North } \\
\text { East }\end{array}$ & $\begin{array}{c}\text { Eastern } \\
\text { Lowlands }\end{array}$ & $\begin{array}{c}\text { Western } \\
\text { Lowlands }\end{array}$ & Borders & n \\
\hline \hline Auckland & 2.68 & 10.88 & 12.69 & 33.51 & 35.92 & 4.32 & 1,158 \\
Taranaki & 1.85 & 12.04 & 18.52 & 34.26 & 27.78 & 5.56 & 108 \\
Hawkes Bay & 4.65 & 26.36 & 7.75 & 21.71 & 27.13 & 12.40 & 129 \\
Wellington & 6.33 & 13.08 & 14.63 & 30.1 & 27.29 & 8.58 & 711 \\
Marlborough & 5.56 & 12.96 & 9.26 & 50.00 & 20.37 & 1.85 & 54 \\
Nelson & 4.07 & 7.32 & 6.50 & 43.09 & 34.96 & 4.07 & 123 \\
Canterbury & 5.42 & 16.95 & 11.53 & 32.71 & 23.73 & 9.66 & 590 \\
West Coast & 11.76 & 10.29 & 7.35 & 23.53 & 36.76 & 10.29 & 68 \\
Otago & 6.92 & 10.90 & 9.91 & 35.75 & 24.79 & 11.73 & 1,807 \\
Southland & 5.49 & 16.48 & 11.17 & 26.14 & 25.38 & 15.34 & 528 \\
Average & 5.47 & 13.73 & 10.93 & 33.08 & 28.41 & 8.38 & 5,276 \\
\hline
\end{tabular}

Source: NZSG data 1840-1920

The following analysis of the composition of the Scotland-born populations of the New Zealand provinces by Scottish region of origin considers only Auckland, Wellington, Canterbury, Otago and Southland Provinces, as the sub-samples for these by region of birth in Scotland are sufficient to give socially significant findings. ${ }^{40}$ If the provinces of New Zealand with small Scots sub-samples are excluded from Table 3.1 above (see Figure 3.4 below), the most common pattern is that there was a close correspondence between the provincial and national distributions by Scottish regional origin. In other words, New Zealand's Scottish migrants not only came to the colony proportionately from all over Scotland, but also each region of New Zealand received

\footnotetext{
${ }^{39}$ The likely reason for this is the number of Shetlanders who were settled in 'special settlements' on the West Coast under the Vogel scheme of immigration in the 1870s (See Chapter Six for more detail).

${ }^{40}$ A general 'rule of thumb' for statistical analysis being that samples in which $n=30$ are sufficient for the Central Limit Theorum to hold, a general statement of the CLT being that 'The sum or average of at least 30 independent random variables with the same distribution is approximately normal'. (Megan J. Clark and John A. Randal, A First Course in Applied Statistics - with applications in Biology, Business and the Social Sciences, Auckland, 2004, p.126) In other words, in this case, samples in which $n=30$ are sufficient for the outcome of the analysis not to be too skewed from the proportions that may have been found were this something analysed by the collectors of the New Zealand Censuses. The Scotland region of origin break down of Hawkes Bay gives a clear example of the way in which small sub-samples can be dangerously misleading: 26.36 per cent of Scots to the Hawkes Bay in the sample came from the Highlands. The majority of the Highlanders in the Hawkes Bay were from Ross and Cromarty. Of the Ross and Cromarty-born migrants in Hawkes Bay Province, 70.59 per cent were living in Hawkes Bay County, 13.19 per cent of all Scots living in that county. However, Ross and Cromarty-born migrants living in Hawkes Bay County in the sample number only twelve migrants, and seven of these were cousins, the children of Duncan and Murdoch McKenzie. The only sub-sample below 30 in the analysis below is migrants from the Far North to Southland, 29 migrants in the NZSG sample being in that sub-sample.
} 
a mix of Scots approximately proportionate to their share of the population of Scotland. The PNZ data generally reinforces this finding.

Figure 3.4

Distribution of the Scottish regional origins of migrants in New Zealand's five principal provinces

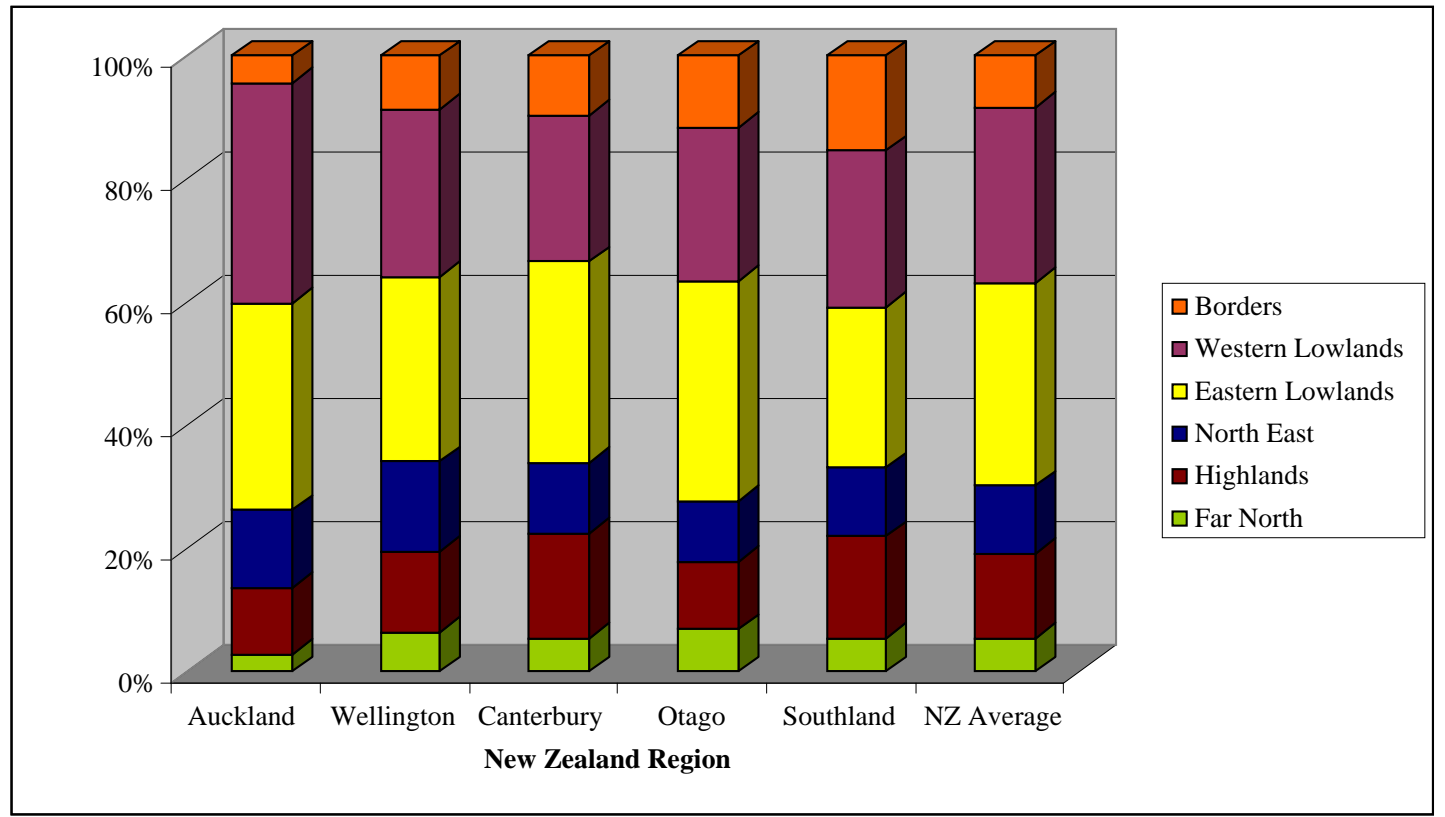

Source: NZSG data $1840-1920$

As may be noted from Figure 3.4, there were exceptions to this 'proportionality' principle. The only 'exception' to not hold true in both datasets is the small number of migrants from the Far North living in Auckland Province. ${ }^{41}$ It is the 'exceptions' that hold true for both datasets that merit further discussion: in Auckland, the below average number of Highlanders and Border migrants and the above average number of Western Lowlanders; in Southland, the above average number of Highlanders and below average number of Scots from the Eastern Lowlands; and in Wellington, the above average number of migrants from the North East.

That Auckland Province should have a below average proportion of Highland migrants seems counter-intuitive, given that 24.34 per cent of all migrants to New Zealand from Inverness County lived in Auckland Province, also 20.85 per cent of migrants to New Zealand from Ross and Cromarty (for a tabulation of the proportion of each Scottish county's migrants living in each region of New Zealand see Appendix 3.1). However, the 'below average' figure for the Highlands and Borders migrants in Auckland is primarily an outcome of the above average number of migrants from the Western Lowlands. Auckland Province accounted for 38.05 per

\footnotetext{
${ }^{41}$ The PNZ data gives the percentage of migrants in this province from the Far North as being 5.28 per cent.
} 
cent of all Renfrewshire migrants to New Zealand, 27.04 per cent of all migrants from Lanarkshire, and 22.63 per cent of those from Ayr. A partial explanation lies in the settlement of many Western Lowlanders, predominantly urban working folk, including weavers from Paisley and surrounds, in Auckland in $1842 .{ }^{42}$ This influx of Scots from the Western Lowlands early in the settlement of the county probably aided the growth of industry and commerce in Eden County, today recognised as Central Auckland, which contained 55.27 per cent of the NZSG Scots in Auckland Province over this eighty year period. ${ }^{43}$ Auckland was a primary site of manufacturing and industrial activity from this first decade of colonisation; of the eighty-five 'manufactories and works' recorded in the Statistics of New Zealand for the Crown Colony Period 1840-1952 in Auckland, Wellington and Nelson, thirty-five were situated in Auckland, including five of the eight sawmills, nine of the sixteen brick kilns and the only iron foundry recorded. ${ }^{44}$ By 1867 Auckland had more people employed in manufacturing occupations and more capital invested in industrial machinery, land and buildings than Canterbury, Otago and Southland Provinces combined; one in every fifty people residing in Auckland was employed in industrial work in 1867, compared to ratios of 1:108 in Canterbury, 1:115 in Wellington and 1:136 in Otago/Southland. ${ }^{45}$ As earlier noted, the Western Lowlands, especially Paisley, Greenock and Glasgow, was a centre of commerce and industrial activity in Scotland. Given the early development of Auckland as an industrial centre, in part thanks to the influx of Western Lowlands with industrial backgrounds in 1842, as well as its role as New Zealand's first capital, consequently leading to the growth of

\footnotetext{
${ }^{42}$ The Duchess of Argyll and the Jane Gifford both departed from Greenock in June 1842 and arrived in Auckland in October that year. Together they carried just over 500 Scots many of whom were assisted by the Paisley New Zealand Emigration Society. Phillips and Hearn, Settlers, pp.1-2; Debra Powell, “It Was Hard to Die Frae Hame': Death, Grief and Mourning Among Scottish Migrants to New Zealand, 1840-1890', M.A. Thesis, University of Waikato, 2007, p.67, McClean, 'Scottish Emigrants to New Zealand, 1840-1880', pp.25-26.

${ }^{43}$ This growth of industry and commerce in the city is noted in James Belich, Making Peoples: A History of the New Zealanders From Polynesian Settlement to the end of the Nineteenth Century, Auckland, 1996, p.368; Una Platts, The Lively Capital: Auckland 1840-1865, Christchurch, 1971, chapter 5; Sinclair, History of New Zealand, pp.226 and 309.

${ }^{44}$ G.J.R. Linge, 'Manufacturing in New Zealand: four years in a century of growth', in Land and Society in New Zealand: Essays in Historical Geography, ed. R.F. Watters, Wellington, 1965, Table I: 'Number and Description of Manufactories and Works in Auckland, Wellington, and Nelson, 1850' based on Statistics of New Zealand for the Crown Colony Period 1840-1852, Auckland, 1954, p.46, p.141 ${ }^{45}$ ibid., p.143
} 
administration and commerce functions, Auckland was a logical destination for further Western Lowland migrants throughout the period under investigation. ${ }^{46}$

One of the Renfrew-born migrants with an industrial background to settle in Eden County was James Allison. Born in Paisley in 1810, James and his Paisley-born wife and children migrated to New Zealand on the Duchess of Argyle in 1842. Having worked as a blacksmith in Paisley prior to his departure, he soon found similar employment in Auckland. His future son-in-law, also born in Paisley and a migrant on the Duchess of Argyle, was from an industrial background and, though just thirteen at arrival, later trained and worked as a brick-maker in New Zealand. ${ }^{47}$ Of all the Renfrew migrants who settled in New Zealand, 23.57 per cent settled in Eden County, as did 16.08 per cent of those from Lanarkshire and 12.01 per cent of Ayr migrants.

In contrast to the Lowlands dominated hub of industrial and commercial activity that Eden County became between 1840 and 1920, Southland Province had an above average number of migrants from the Highlands of Scotland. ${ }^{48}$ Correspondingly, there was a below average number of those from the Eastern Lowlands. Migrants with rural backgrounds were more likely to settle in Southland than those from urban areas of Scotland due to the rural nature of Southland from early in its development. Hence the province attracted an above average number of Scots from the Highlands. ${ }^{49}$ Moreover, land in Southland (in common with some other parts of New Zealand) was perceived as being best suited to pastoralism and sheep farming; as noted in Chapter Two (see footnote 48), this was the type of farming most prevalent in Highland Scotland. ${ }^{50}$ Southland was therefore a logical destination for contemporary Highland agricultural immigrants.

\footnotetext{
${ }^{46}$ For more on the commercial and industrial growth of Auckland see Ian Hunter and Diana Morrow, eds., City of Enterprise: Perspectives on Auckland Business History, Auckland, 2006 (and Gordon Winder, 'Making space: clusters and districts in Auckland manufacturing 1889-1908', in City of Enterprise: Perspectives on Auckland Business History, ed. Ian Hunter and Diana Morrow, Auckland, 2006)

${ }^{47}$ NZSG database, migrants 00222, 00224, 01693, and 02976

48 'Lowlands dominated' only, of course in the sense that Lowland Scotland-born migrants dominated Scots in Auckland Province. The province itself was, in 1878, just 12.44 per cent Scottish excluding the New Zealand-born population (6.66 per cent Scotland-born including New Zealand-born).

${ }^{49}$ Ninety-six of the NZSG migrants were born in the Highland Region and died in Southland Province; sixty-two of these have an occupation recorded in New Zealand, and forty-one of these were engaged in agriculture in New Zealand - 66.13 per cent of Highlanders living in Southland with employment recorded.

${ }^{50}$ R. Ogilvie Buchanan, 'Sheep rearing in New Zealand', Economic Geography, Vol.7, No.4, Oct, 1931, pp.365-379; Kenneth B. Cumberland, 'The agricultural regions of New Zealand', The Geographical Journal, Vol.112, No.1/3, Jul-Sep, 1948, pp.43-63; Howard J. Critchfield, 'The growth
} 
Southland County, containing within its boundaries Invercargill, accounted for 84.15 per cent of Scots in Southland Province. Midlothian provided only 4.93 per cent of Southland County's Scottish migrants. While only 5.01 per cent of all migrants to New Zealand from Midlothian lived in Southland County, the more rural, less populated areas of the Eastern Lowlands contributed higher proportions of their total migrants to Southland. Of all migrants from that arguably half 'Highland', half 'Lowland' county, Perthshire, 7.41 per cent lived in Southland County, as did 7.09 per cent of all those from Fife and 6.50 per cent of migrants to New Zealand from Angus. In the Highlands too, it was the more isolated areas of the region that provided a higher proportion of migrants to Southland County. The Hume brothers of Ross and Cromarty were among those from rural areas of the Highlands to settle in Southland County. James (b.1852), Adam (b.1859), and Walter (b.1861) were all employed as shepherds in Applecross prior to their departure for New Zealand. James emigrated first, arriving in 1880, with Adam and Walter following four years later. All three brothers resided in Southland until their deaths, and all are recorded on their NZSG registration forms as having been shepherds during their time in New Zealand. ${ }^{51}$ Of all migrants to New Zealand from Sutherland, 26.87 per cent lived in Southland County, but the county received only 2.63 per cent of all migrants from the 'capital' of the Highlands, Inverness. In all, 17.04 per cent of Southland County's migrants came from the Highland Region, 4.04 per cent from Sutherland, 5.83 from Ross and Cromarty, 4.71 per cent from Argyll, 1.57 from Bute and just 0.90 per cent from Inverness. ${ }^{52}$

Less easily explicable is the above average number of North East Scots in Wellington Province. Wellington Province received 32.20 per cent of all migrants from Kincardineshire to New Zealand, 19.12 per cent of migrants from Banff, 16.29 per cent from Aberdeen, 9.09 per cent of migrants from Nairn and 8.82 per cent of Moray migrants. However, just 0.14 per cent of the Wellington Province migrants were from Nairn, 0.84 per cent from Moray, 1.83 from Banff and 2.67 per cent from

of pastoralism in Southland, New Zealand', Economic Geography, Vol.30, No.4, 1954, pp.283-300; Robert Peden, 'Pastoralism and the Transformation of the Rangelands of the South Island of New Zealand, 1841 to 1912. Mt Peel Station, a Case Study’, PhD Thesis, University of Otago, 2007.

${ }^{51}$ NZSG database, migrants 02564, 02565, and 02567

${ }^{52}$ For more on Southland see Megan J. Wilson, 'Myth and misunderstanding: the enigma of the Scottish Highland migrants to Otago/Southland, 1870-1879’, M.A. Thesis, University of Otago 1999; M.H. Holcroft, Old Invercargill, Dunedin, 1976; F.G. Hall-Jones, Historical Southland, Invercargill, 1945; and (for biographies of some of the more prominent Southland settlers) F.G. Hall-Jones, Invercargill Pioneers, Invercargill, 1946 
Kincardine. In other words, while migrants from the North East made up a small proportion of the population of Wellington Province, Wellington Province received a high proportion of North East migrants. With 9.14 per cent of Wellington Province's Scottish migrants being from Aberdeen, this may be the county to focus upon for explanations of this 'exception' to the 'proportionality'. The greatest numbers of Scots in the Wellington Province resided in Wanganui, Manawatu and Hutt County. Although Aberdeen only contributed 6.96 per cent of all Scots migrants to New Zealand, 11.67 per cent of the Scots in Wanganui were from Aberdeen, as were 11.02 per cent of those in Manawatu County and 7.96 per cent of those in Hutt. A possible explanation may be found in the immigrants' fields of employment. As will be discussed in greater detail in Chapter Five, a relatively high proportion of the Scots in Wellington were either professionals or employed in the public sector, possibly reflecting the location in Wellington City of the central government from 1865; the North East provided a disproportionately large number of migrants to this sector of work in New Zealand also. ${ }^{53}$ Aberdeen County - as opposed to Aberdeen City - was over 25 per cent agriculturally employed at the 1881 Census and 26.96 per cent of NZSG migrants from Aberdeen had been employed in agricultural pursuits in Scotland, perhaps accounting for the large percentage of Aberdeen migrants in Manawatu and Wanganui Counties, districts that remained predominantly rural throughout the period studied. ${ }^{54}$ Genealogical material regarding several Aberdeenshire families who settled in Wanganui County presented later in this chapter (Howie/Aiken/McWilliam) suggests that more in-depth investigation of individuals and families arriving in Wellington Province from the North East could provide another explanation for this anomaly - chain migration.

Although over the full eighty years studied each province received groups of Scots almost in proportion to their distribution in Scotland, by period of arrival the regional emphasis for each province varied considerably (see Appendix 3.2). Though the figures in Appendix 3.2 are potentially misleading - because breaking this data down by period of arrival, region of birth and province of death produces small sub-samples in the NZSG data - the patterns are still worthy of note. While Auckland's

\footnotetext{
53 Redmer Yska, Wellington: Biography of a City, Auckland, 2006; Brad Patterson, 'A "half Australian, half American” town: the economic foundations of nineteenth century Wellington', in Dynamic Wellington: a Contemporary Synthesis and Explanation of Wellington, ed. Jack McConchie, David Winchester, and Richard Willis, Wellington, 2000

${ }^{54}$ Appendix Tables, Table LXX, 1881 Census of Scotland, p.lxi
} 
disproportionately low Highland figures and high Western Lowland figures were reasonably consistent in all decades, Southland's disproportionately high Highland origin contingent is most evident among those arriving in the colony pre-1852. Wellington too received a comparatively large number of Highland migrants in the early stages of settlement. This early flow of Highland migrants to Wellington had implications for Scottish settlement patterns in the lower North Island in subsequent decades.

\section{NEW ZEALAND COUNTY PATTERNS OF SCOTTISH SETTLEMENT}

As with the discussion of migrant origins in Chapter Two, refining the analysis of settlement locations in New Zealand from the regional/provincial to the county level reveals important and sometimes unsuspected patterns. The Census of 1878 was the only census in which the sixty-three counties established in 1876 were employed as units for the spatial breakdown of the population. ${ }^{55}$ Two approaches to analysis of this census information produce different results. The first, and most obvious, approach is to ask what proportion of the total Scotland-born population of New Zealand lived in each county, thereby revealing density of Scots in county populations (see Table 3.2 column (a)). This approach reveals the patterns that might be expected given the knowledge of provincial patterns of settlement. Counties in Canterbury and Otago/Southland held higher proportions of the Scotland-born population than did those in the North Island. Southland County, for example, held 9.00 per cent of the total Scotland-born population, followed closely by Taieri County on 8.56 per cent. ${ }^{56}$ The settlement of Scots in Waipu made Whangarei County conspicuous among its neighbours, holding 1.12 per cent of New Zealand's total Scotland-born population, while neighbouring counties held only between 0.04 and 0.7 per cent. ${ }^{57}$

\footnotetext{
${ }^{55}$ As with analysis of the NZSG and PNZ data sets by province 1840-1920, analysis of the datasets by county reassuringly gives similar results to that of the census - allowing for the northward shift mentioned above and that the comparison is with only the 1878 Census. Only in two counties are the data sets different by more than 3 per cent regarding what proportion of the Scots resided in which county, the NZSG recording 5.93 per cent and the PNZ 9.47 per cent in Hutt County, and the datasets also disparate in Selwyn County where the NZSG records 6.17 per cent and the PNZ 10.46 per cent. This difference is, most probably, due to the PNZ data capturing more migrants who died in the twentieth century than the NZSG data does (see Appendix 1.1), and therefore capturing more people involved in the early twentieth century internal New Zealand migration to urban areas - Hutt County including Wellington City and Selwyn including Christchurch within its boundaries.

${ }^{56}$ See Map 3 for the location of counties.

${ }^{57}$ Mongonui: 0.14 per cent (41 individuals); Hokianga: 0.04 per cent (12 individuals); Bay of Islands: 0.29 per cent (84 individuals); Hobson: 0.38 per cent (108 individuals); and Rodney: 0.7 per cent (201 individuals). Whangarei County accommodated 320 of New Zealand's Scots-born in 1878.
} 
Table 3.2

Proportions of Scots-born living in each New Zealand county, and the proportions of each New Zealand county that were born in Scotland including and excluding the New Zealand-born population of those counties, $1878 .^{58}$

\begin{tabular}{|c|c|c|c|c|}
\hline NZ County & $\begin{array}{c}\text { \% of Scotland-born } \\
\text { population residing } \\
\text { in the county } \\
\text { (a) }\end{array}$ & $\begin{array}{l}\text { \% of county born } \\
\text { in Scotland } \\
\text { (Incl. NZ-born) } \\
\text { (b) }\end{array}$ & $\begin{array}{c}\text { \% of county } \\
\text { born in Scotland } \\
\text { (Excl. NZ-born) } \\
\text { (c) }\end{array}$ & $\begin{array}{c}\text { County } \\
\text { Population } \\
\text { (d) } \\
\end{array}$ \\
\hline Mongonui & 0.14 & 3.41 & 8.97 & 1,204 \\
\hline Hokianga & 0.04 & 2.86 & 10.71 & 419 \\
\hline Bay of Islands & 0.29 & 5.64 & 12.46 & 1,489 \\
\hline Whangarei & 1.12 & 11.01 & 22.46 & 2,906 \\
\hline Hobson & 0.38 & 4.97 & 8.95 & 2,171 \\
\hline Rodney & 0.70 & 6.44 & 12.27 & 3,122 \\
\hline Waitemata & 0.76 & 6.37 & 11.60 & 3,424 \\
\hline Eden & 2.92 & 5.96 & 11.08 & 13,982 \\
\hline Manukau & 2.80 & 8.75 & 18.11 & 9,152 \\
\hline Coromandel & 0.51 & 7.11 & 12.99 & 2,053 \\
\hline Thames & 1.01 & 5.82 & 11.32 & 4,951 \\
\hline Piako & 0.19 & 11.86 & 17.10 & 447 \\
\hline Waikato & 0.56 & 8.31 & 13.55 & 1,938 \\
\hline Waipa & 0.62 & 6.93 & 11.9 & 2,538 \\
\hline Raglan & 0.20 & 7.15 & 16.62 & 797 \\
\hline Kawhia & 0 & 0 & 0 & 69 \\
\hline Taranaki & 0.64 & 3.92 & 7.53 & 4,689 \\
\hline Patea & 0.93 & 8.87 & 16.48 & 2,988 \\
\hline Tauranga & 0.22 & 4.06 & 6.72 & 1,550 \\
\hline Whakatane & 0.22 & 7.92 & 15.46 & 783 \\
\hline Cook & 0.43 & 8.05 & 14.07 & 1,541 \\
\hline Wairoa & 0.22 & 7.79 & 14.42 & 809 \\
\hline Hawkes Bay & 1.17 & 8.08 & 13.12 & 4,144 \\
\hline Wanganui & 0.92 & 9.94 & 19.35 & 2,647 \\
\hline West Taupo & 0 & 0 & 0 & 0 \\
\hline East Taupo & 0.03 & 8.42 & 12.12 & 95 \\
\hline Rangitikei & 1.25 & 9.65 & 17.78 & 3,690 \\
\hline Manawatu & 0.93 & 5.51 & 9.01 & 4,850 \\
\hline Waipawa & 1.23 & 7.41 & 11.09 & 4,721 \\
\hline Hutt & 1.28 & 5.22 & 11.39 & 7,007 \\
\hline Wairarapa West & 1.03 & 5.34 & 10.90 & 5,490 \\
\hline Wairarapa East & 0.42 & 11.00 & 18.97 & 1,100 \\
\hline
\end{tabular}

\footnotetext{
${ }^{58}$ Appendix 3.3a and 3.3b are comparative tables to Table 3.2, offering this same breakdown of the proportions of the Scots-born population of each county of New Zealand but for 1891 and 1911. Comparison of the three tables allows the movement of the Scots population over this time to be seen more precisely, and the effect on statistical analysis of the increasingly large number of counties the population was divided into to be noted.
} 


\begin{tabular}{|c|c|c|c|c|}
\hline NZ County & $\begin{array}{l}\text { \% of Scotland-born } \\
\text { population residing } \\
\text { in the county } \\
\text { (a) } \\
\end{array}$ & $\begin{array}{c}\text { \% of county born } \\
\text { in Scotland } \\
\text { (Incl. NZ-born) } \\
\text { (b) } \\
\end{array}$ & $\begin{array}{c}\% \text { of county } \\
\text { born in Scotland } \\
\text { (Excl. NZ-born) } \\
\text { (c) } \\
\end{array}$ & $\begin{array}{c}\begin{array}{c}\text { County } \\
\text { Population }\end{array} \\
\text { (d) } \\
\end{array}$ \\
\hline Sounds & 0.12 & 5.96 & 15.18 & 570 \\
\hline Marlborough & 0.85 & 6.54 & 14.52 & 3,713 \\
\hline Kaikoura & 0.25 & 9.08 & 18.83 & 782 \\
\hline Waimea & 0.77 & 3.11 & 9.06 & 7,037 \\
\hline Collingwood & 0.36 & 6.91 & 17.80 & 1,477 \\
\hline Buller & 0.83 & 9.87 & 15.63 & 2,391 \\
\hline Inangahua & 0.95 & 9.12 & 12.37 & 2,970 \\
\hline Amuri & 0.26 & 15.94 & 23.40 & 458 \\
\hline Cheviot & 0.09 & 22.22 & 28.26 & 117 \\
\hline Grey & 1.60 & 9.43 & 12.82 & 4,846 \\
\hline Ashley & 3.11 & 7.55 & 14.00 & 11,759 \\
\hline Selwyn & 6.81 & 7.13 & 12.33 & 27,309 \\
\hline Akaroa & 0.92 & 7.07 & 14.59 & 3,722 \\
\hline Ashburton & 2.28 & 10.65 & 15.56 & 6,123 \\
\hline Geraldine & 3.71 & 10.84 & 17.31 & 9,775 \\
\hline Waimate & 2.32 & 15.53 & 22.40 & 4,269 \\
\hline Westland & 2.00 & 9.42 & 13.24 & 6,061 \\
\hline Waitaki & 6.19 & 26.5 & 39.44 & 6,668 \\
\hline Waikouaiti & 5.25 & 25.35 & 45.94 & 5,918 \\
\hline Maniototo & 1.11 & 14.06 & 20.50 & 2,255 \\
\hline Vincent & 1.69 & 16.13 & 23.07 & 3,001 \\
\hline Lake & 1.56 & 17.14 & 24.34 & 2,596 \\
\hline Peninsula & 2.01 & 26.10 & 50.09 & 2,195 \\
\hline Taieri & 8.56 & 31.87 & 54.38 & 7,674 \\
\hline Bruce & 4.59 & 27.12 & 48.45 & 4,834 \\
\hline Clutha & 4.23 & 32.35 & 56.43 & 3,731 \\
\hline Tuapeka & 3.39 & 17.07 & 28.63 & 5,666 \\
\hline Southland & 9.00 & 25.00 & 40.78 & 10,282 \\
\hline Wallace & 1.89 & 22.56 & 37.42 & 2,394 \\
\hline Fiordland & 0.03 & 69.23 & 69.23 & 13 \\
\hline Stewart Island & 0.10 & 11.43 & 28.28 & 245 \\
\hline
\end{tabular}

The second approach involves asking what proportion of each county's population the Scotland-born comprised in 1878 (see Table 3.2 column (b)). Rather than revealing where Scots were more likely to settle, interrogating the data in this way gives some indication as to the significance of Scots as a proportion of the population of each county. The population of Fiord County was 69.23 per cent Scotland-born though in this case the 'significance' indicated is trifling: one must note that the population of the whole county was just thirteen people at the time. ${ }^{59}$ Extracting the New Zealand-born population from the calculation (see Table 3.2, column (c))

\footnotetext{
${ }^{59}$ All men - three born in England, one born in Ireland and nine born in Scotland.
} 
provides a clearer picture of the proportion of Scots in the immigrant population of New Zealand. Outside of Southland and Otago, only four counties exceeded the mean proportion of Scots-born in the immigrant population of New Zealand as a whole (20.25 per cent): Amuri and Cheviot in Nelson Province (bordering Canterbury), with 23.40 and 28.26 per cent respectively, Waimate in Canterbury Province with 22.40 per cent, and Whangarei.

Bordering Otago Province, and just over 100 kilometres from Dunedin, Waimate is not a surprising pocket of Scots, notwithstanding the fact that it also held the second largest proportion of English-born migrants in the South Island at the 1878 Census. ${ }^{60}$ Besides Waimate, Amuri and Cheviot were by far the most 'Scottish' counties in the South Island outside of Otago and Southland, in terms of the proportion of the county's population that were of Scottish birth, at the 1878 Census. However Amuri and Cheviot were also the smallest in terms of population (see column (d)). The number of Scots-born resident in Amuri in 1878 was seventy-three and there were just twenty-six Scots resident in Cheviot at that census. Given the apparent propensity among Scots for large families, it is possible that these Cheviot Scots comprised just two or three family groups, or one large extended family. Who these particular Scots were has not yet been traced. Besides being numerically very 'Scottish', Amuri in particular 'had a reputation as a Scottish preserve' from the 1860s to the 1900s, the Scottish character in the county being due to many of the runholders and shepherds being of Scottish birth, this 'Scottish leadership and skill [giving] the Amuri its high reputation as a pastoral district'. ${ }^{61}$ Given the small numbers of Scots involved, Scots in these counties would be a logical choice for more in-depth examination, as has been carried out for the area south of Wanganui, presented later in this chapter. ${ }^{62}$

Utilising the second approach to county level analysis reveals the true impact on Whangarei County of the Reverend McLeod's Waipu settlers. While Whangarei County accommodated only 1.12 per cent of the total Scotland-born recorded in the Census in 1878, 11.01 per cent of the population of Whangarei County was born in Scotland. Extracting the New Zealand-born population from the calculations, 22.46 per cent of the immigrant population of Whangarei County was Scotland-born. More

\footnotetext{
${ }^{60} 31.48$ per cent of Waimate having been born in England at this census.

${ }^{61}$ W.J. Gardner, The Amuri: A County History, 2nd ed, Culverden, 1983, p.115

62 ibid., p.115
} 
significantly, however, 9.94 per cent (289 people) of the population of that county in 1878 was born in an 'Other British Possession', which included Canada - 20.28 per cent when the New Zealand-born population is excluded. Only three other New Zealand counties had more than 2 per cent of the population who were born in an 'Other British Possession' at this census: 2.05 per cent of those in Coromandel County (forty-two people), 2.56 per cent of those in Cheviot (just three people) and 5.26 per cent of those in East Taupo (only five people). ${ }^{63}$ The majority of McLeod's followers had arrived in Waipu fourteen years before the 1878 Census and, with most having resided in Nova Scotia for at least thirty years before that, the preponderance of those still alive by 1878 are likely to have been born in Nova Scotia rather than Scotland. The Waipu settlement remained largely isolated, restricted principally to the McLeod settlers, until approximately 1875 when the first long-term settlers who were not McLeod's followers came to the settlement. ${ }^{64}$ Even so, by 1882 just two of the 134 freeholders recorded in Waipu in October were not either McLeod settlers or married to a McLeod settler. ${ }^{65}$

Utilising this second approach also assists in the identification of previously obscured population clusters, in particular the location of distinctively Scottish settlements beyond the boundaries of Otago/Southland. East Wairarapa affords a useful example. In terms of the proportion of the total Scotland-born population of New Zealand, Wairarapa West held 1.03 per cent and Wairarapa East just 0.42 per cent. When the Scotland-born are viewed as a proportion of the county populations, however, Wairarapa West's share rises to 5.34 per cent (10.90 per cent if the New Zealand-born population is excluded) and Wairarapa East's to 11.00 per cent Scotland-born (18.97 per cent excluding those born in New Zealand). ${ }^{66}$ Ireland-born settlers made up just 5.09 per cent of Wairarapa East and the England-born 31.09 per cent. The New Zealand-born constituted 42 per cent of the county population in 1878 and, given the Scottish propensity for larger families, many of these are likely to have been of Scottish descent. That less than 0.50 per cent of the total Scotland-born population in New Zealand lived in this county, but 11.00 per cent of the county was

\footnotetext{
${ }^{63}$ Note, only two other counties held over 100 people who had been born in an 'Other British Possession' - Manakau and Eden counties with 169 and 145 people respectively. For more on the McLeod settlers see the Introduction to the present work.

${ }^{64}$ Maureen Molloy, Those Who Speak to the Heart: The Nova Scotian Scots at Waipu, 1854-1920, Palmerston North, 1991, p.55

${ }^{65}$ A Return of the Freeholders of New Zealand, Wellington, 1884, cited in ibid., p.57

${ }^{66} 293$ and 121 individuals of total county populations of 5,490 and 1,100 people respectively
} 
Scotland-born, suggests a settlement of Scots might be identified there. As evidence presented in the following section indicates, genealogical investigation supports this case.

Map 5 shows the distribution of the Scots-born population of New Zealand at the 1916 Census, utilising the first approach to county level census data described above to analyse later census data. Because this 1916 county level census data is split into twice as many divisions as the 1878 Census, the figures are not directly comparable with those given in column (a) of Table 3.2. Nevertheless, the distribution evident in the map clearly shows the continued predisposition of Scots to reside in the lower South Island into the early twentieth century, and the continued presence of the pockets of Scots elsewhere in New Zealand that were evident in the 1878 data. The northward drift of the population is less evident at the county level, a partial reason being the division of the North Island data into nearly twenty counties more than the South Island. As will be seen in greater detail in respect of the districts south of Wanganui, below, were the data of some of these North Island counties to be aggregated the proportion of the New Zealand Scots-born population residing in close proximity would be more directly observable in the data. 


\section{North Island Counties}

$\begin{array}{ll}\text { 1. } & \text { Mongonui } \\ \text { 2. } & \text { Whangaroa } \\ \text { 3. } & \text { Hokianga } \\ \text { 4. } & \text { Bay of Islands } \\ \text { 5. } & \text { Whangarei } \\ \text { 6. } & \text { Hobson } \\ \text { 7. } & \text { Otamatea } \\ \text { 8. } & \text { Rodney } \\ \text { 9. } & \text { Waitemata } \\ \text { 10. } & \text { Eden } \\ \text { 11. } & \text { Great Barrier } \\ \text { 12. } & \text { Manukau } \\ \text { 13. } & \text { Franklin } \\ \text { 14. } & \text { Raglan } \\ \text { 15. } & \text { Waikato } \\ \text { 16. } & \text { Waipa } \\ \text { 17. } & \text { Kawhia } \\ \text { 18. } & \text { Awakino } \\ \text { 19. } & \text { Waitomo } \\ \text { 20. } & \text { Ohura } \\ \text { 21. } & \text { West Taupo } \\ \text { 22. } & \text { Matamata } \\ \text { 23. } & \text { Piako } \\ \text { 24. } & \text { Ohinemuri } \\ \text { 25. } & \text { Thames } \\ \text { 26. } & \text { Coromandel } \\ \text { 27. } & \text { Tauranga } \\ \text { 28. } & \text { Rotorua } \\ \text { 29. } & \text { East Taupo } \\ \text { 30. } & \text { Whakatane } \\ \text { 31. } & \text { Opotiki } \\ \text { 32. } & \text { Waiapu } \\ \text { 33. } & \text { Waikohu } \\ \text { 34. } & \text { Cook } \\ \text { 35. } & \text { Wairoa } \\ \text { 36. } & \text { Hawke's Bay } \\ \text { 37. } & \text { Waipawa } \\ \text { 38. } & \text { Waipukurau } \\ \text { 39. } & \text { Patangata } \\ \text { 40. } & \text { Dannevirke } \\ \text { 41. } & \text { Woodville } \\ \text { 42. } & \text { Weber } \\ \text { 2anata }\end{array}$

1. Mongonui

slands

Hobson

(aitemata

1. Great Barrier

6. Waipa

19. Waitomo

21. West Taupo

Matamata

4. Ohinemuri

Coromandel

Weber
43. Clifton

44. Taranaki

45. Egmont

46. Stratford

47. Whangamomona

48. Eltham

49. Waimate West

50. Hawera

51. Patea

52. Waitotara

53. Kaitieke

54. Waimarino

55. Wanganui

56. Rangitikei

57. Kiwitea

58. Pohangina

59. Oroua

60. Manawatu

61. Horowhenua

62. Kairanga

63. Pahiatua

64. Akitio

65. Eketahuna

66. Mauriceville

67. Masterton

68. Castlepoint

69. Wairarapa South

70. Featherston

71. Hutt

72. Makara
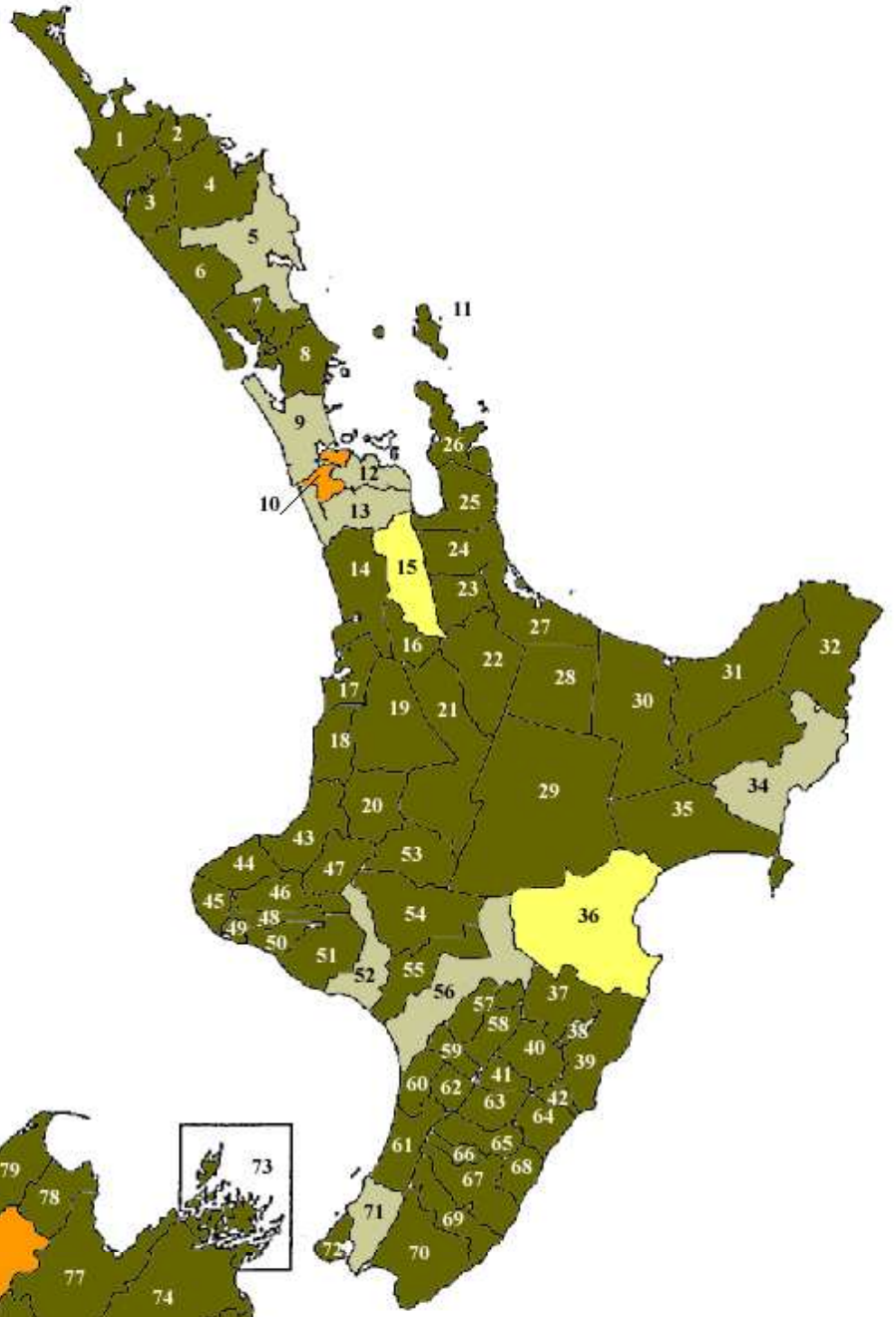

South Island Counties

73. Sounds

74. Marlborough

75. Awatere

76. Kaikoura

77. Waimea

78. Takaka

79. Collingwood

80. Buller

81. Murchison

82. Inangahua

83. Grey

84. Westland

85. Amuri

86. Cheviot

87. Waipara

88. Kowai

89. Ashley

90. Rangiora

91. Eyre

92. Oxford

93. Tawera

94. Malvern

95. Paparua

96. Waimairi

97. Heathcote

98. Halswell

99. Mount Herbert

100. Akaroa

101. Chatham Is.

102. Wairewa

103. Springs

104. Ellesmere

105. Selwyn

106. Ashburton
107. Geraldine

108. Levels

109. Mackenzie

110. Waimate

111. Waitaki

112. Waihemo

113. Waikouaiti

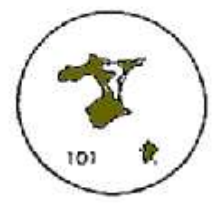

114. Peninsula

115. Taieri

116. Bruce

117. Clutha

118. Tuapeka

119. Maniototo

120. Vincent

121. Lake

122. Southland

123. Wallace

124. Fiord

125. Stewart Island

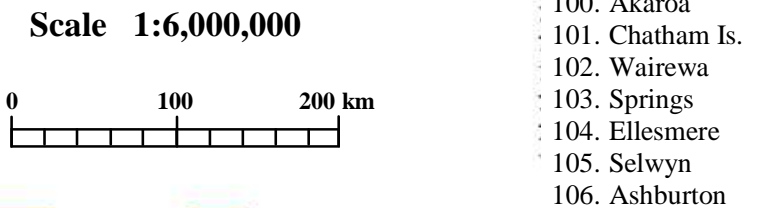




\section{ScotTish SeTtLement in Wellington Province: CASE STUdies}

Although the statistical breakdowns at regional and county level presented above are central to migration studies, in terms of identifying individual Scottish communities the statistics are at best indicative. Qualitative, in this case genealogical, material may augment and clarify patterns that can remain unrevealed utilising statistical analysis alone.

The purpose of the present section is two-fold. Firstly, it investigates two interconnected Scottish settlements outside of the areas most commonly associated with New Zealand Scottish settlement. The statistical analysis presented confirms that New Zealand's Scots were dispersed throughout the country, though to varying degrees, and that Wellington was not unique outside of Otago/Southland in receiving a significant number of Scots. As Figures 3.1, 3.3 and, to a slightly lesser extent, Table 3.2, Appendix 3.3a and 3.3b and Map 5, clearly indicate, Auckland, being the largest province geographically and in terms of population, received many migrants of Scottish birth, and Canterbury also received a significant and sustained influx of Scottish settlers. Because it has not been possible in the present work to explore Scottish migrant settlements in every part of New Zealand in depth, Wellington has been chosen as the focus location for a more detailed case study. Wellington was the first New Zealand Company settlement and continued to receive Scots throughout the entire period under investigation, making it a logical choice. The second purpose of this section is to highlight the way in which qualitative, genealogical, material can and should be used to augment and illuminate statistical patterns. As will be made evident, migrant patterns and flows are more than the sum of their parts.

On 27 December 1840 the Blenheim arrived in Port Nicholson, carrying 197 Scottish immigrants. Known as 'the Scots ship', the Blenheim was not the first New Zealand Company ship, nor was it the first to carry a substantial number of Scots to the colony, the Bengal Merchant having arrived in Wellington on 20 February 1840 with 160 Scots on board. ${ }^{1}$ While many of the Bengal Merchant migrants were from Glasgow and surrounds, a majority of the Blenheim passengers had been recruited at Fort William, Inverness, by Donald MacDonald, who emigrated with the families he

\footnotetext{
1 'Blenheim: Greenock 25 August 1840, Kaiwharawhara 27 December 1840' notes on the passage of the Blenheim including a passenger list, prepared by Donald D. Cameron, 1990, p.1; Louis E. Ward, Early Wellington, New Zealand Electronic Text Centre, 1928, p.28; Phillips and Hearn, Settlers, p.56
} 
had recruited. ${ }^{2}$ Those migrants who had purchased land orders for Wellington and Wanganui from the New Zealand Company arrived to find that not only had the land not been surveyed or divided into sections, but there was also question over the purchase of the land from Māori. ${ }^{3}$ Many of the Blenheim migrants eventually settled at Kaiwarra (Kaiwharawhara) where temporary immigration barracks had been situated and where Donald MacDonald (afterwards known as the 'Laird of Kaiwarra') had purchased land. ${ }^{4}$ It was not until later in the decade that the settlers began to disperse from this 'Scotch settlement' at Kaiwarra in any great numbers, as land became available in the Wairarapa, then in and around Wanganui. The death of Donald MacDonald in 1849 essentially spelt the end of the 'Scotch settlement', though a handful of the Blenheim passengers who had settled with MacDonald at Kaiwarra stayed on. ${ }^{5}$

As the story of the Cameron family, below, demonstrates, the bonds that tied many of the early Scots migrants together were frequently those formed en route to New Zealand and during their initial settlement. Donald ('the weaver') Cameron's family were among the Blenheim passengers, and among the first migrants to settle in east Wairarapa. His sons and daughters who married all wed fellow Scots migrants, thereby creating ties between the properties owned by the Camerons and Scottish owned and managed stations in the county and beyond. Many of the stations' hands employed by the Cameron family and their associates were also Scots or the descendants of Scottish migrants. By 1878 more than 5 per cent of Wairarapa East's Scotland-born population were living on stations owned by the Cameron family; many of these were among those arriving on these first few 'Scots' ships and settling initially at Kaiwarra.

\footnotetext{
${ }^{2}$ Norah Parr, 'Kaiwarra or the village that was', The Onslow Historian: Official Journal of the Onslow Historical Society Inc., Vol.10, No.2, 1980, pp.4-9, p.7; 'Onslow settlers of the 1840s: Donald MacDonald, laird of Kaiwarra', The Onslow Historian: Official Journal of the Onslow Historical Society Inc., Vol.18, No.4, 1988, pp.4-11, pp.4-5; Phillips and Hearn, Settlers, p.56

3 'Onslow settlers of the 1840s: Donald MacDonald, laird of Kaiwarra', pp.4 and 6; Ward, Early Wellington, pp.58-9

4 'Blenheim: Greenock 25 August 1840, Kaiwharawhara 27 December 1840' notes on the passage of the Blenheim including a passenger list, prepared by Donald D. Cameron, 1990, p.5; 'Onslow settlers of the 1840s: Donald MacDonald, laird of Kaiwarra', pp.4 and 6.

5 Brad Patterson, "It brings to mind the wild valleys of lovely Glencoe": The Scots in early Wellington', Workshop on Scottish Immigration to New Zealand, December 2005.
} 
Donald ('the weaver'), formerly of Ardnamurchan, Argyllshire, arrived in Wellington on the Blenheim with wife Christine and seven children. ${ }^{6}$ Donald and his family were known to Donald MacDonald and were recruited due to Cameron's experience in labouring on the construction of the Caledonian Canal; MacDonald noted 'this man and his family have been known to me for many years, he is very industrious'? Setting up a school of weaving in Wellington, Donald taught his craft by day and ran a public house after school hours, building a house on the hill just north of the Kaiwarra stream, along what would become the Hutt Road. ${ }^{8}$ Donald's second son, Alexander (b.1824), worked in Wellington as a book-keeper for fellow Blenheim passenger Hugh Morrison. ${ }^{9}$ Alexander married Hugh's daughter Mary in July $1855 .{ }^{10}$ In 1846 Donald leased a large tract of land from Māori that was part of 'Pahaoa' on the Wairarapa coast. He was joined by his wife, five sons and two daughters soon after. ${ }^{11}$ The station (split in 1882, with part of it renamed 'Glendhu') was run by Donald's sons, Donald ('the piper', b.1825), John (b.1832) and Duncan (b.1834). ${ }^{12}$ Another property purchased by the brothers, 'Blairlogie', was sold in 1878 to John Morrison, the son of fellow Blenheim passenger Hugh Morrison. ${ }^{13}$ At the time of the 1878 Census 'Pahaoa', 'Glendhu' and 'Blairlogie' Stations were home to more than 5 per cent of the county's Scotland-born migrants, including John Cameron and his wife Annie, Duncan Cameron and his wife Mary, also John Morrison and his wife Janet, as well as the Scotland-born labourers employed on the three stations. ${ }^{14}$ Several

\footnotetext{
${ }^{6}$ For a diagram of some of the connections between the Cameron family and their associates as described below see Appendix 3.4a and 3.4b.

7 M.J. Ulyatt, 'The Kaiwarra Camerons: The First Fifty Years in New Zealand: 1840-1890', unpublished family history provided by M.J. Ulyatt, 2007, p.14.

8 ibid., p. 22

9 Tobe Cameron, 'Cameron of Kaiwharawhara: the first three generations in New Zealand', unpublished family history updated by Peter Hargreaves, provided by Jennifer Cameron, p.6.

${ }^{10}$ Frank Fyfe and Bebe Douglas, Morvern to Glenmorven, Masterton, 2000, p.153

${ }_{11}^{1}$ Alex Sutherland, Sutherlands of Ngaipu, Wellington, 1947, p.32.

12 Donald 'the piper' married Isabella Glasgow of Turakina in 1853, creating yet another interconnection, this time between the Cameron family and Scots outside of Wairarapa East. Turakina, detailed below, was another strongly identifiable settlement of Scots. Donald died in 1866, after which time John and Duncan managed the property.

${ }^{13}$ Fyfe and Douglas, Morvern to Glenmorven, p.185; For more on the various land transactions etc in the Wairarapa the Cameron brothers were involved in see Cameron, 'Cameron of Kaiwharawhara', pp.8-9. Ulyatt, 'The Kaiwarra Camerons', pp.35-37, 47-53, 55, 69

${ }^{14}$ Janet Morrison was Hugh Morrison's cousin Alexander's daughter, who had come to New Zealand in 1858 with her family, sponsored by Hugh.

How much more than 5 per cent of the county's Scots-born population was residing on these three stations is unknown, precise records regarding employee's etc being no longer extant. Family records and oral tradition suggest that a significant number of those employed on the Cameron properties may have been Scottish. Personal Communication with Jennifer Cameron, March 2006. The sons of
} 
of the New Zealand-born population counted at that census were first generation New Zealand-born Scots, including the children of the Cameron brothers and of John Morrison.

Linkages between the Cameron family and fellow Scots in Wairarapa East continued to be reinforced with the first generation of the family to be born in New Zealand. John Cameron's eldest son Donald married Elizabeth (Bessie) Sutherland, whose Scotland-born grandfather, Alexander Sutherland (b.1806), had come to Wellington on the Oriental in $1840 .{ }^{15}$ John Cameron's youngest son Ernest married Bessie's cousin, Donalda (Dona) Sutherland. ${ }^{16}$ Dona's father David William was the youngest of Alexander's (b.1806) children, and had married his second cousin, Helen Ross. ${ }^{17}$ Helen came to Wellington from Scotland with her parents and eight siblings on the Douglas in $1873 .{ }^{18}$ Her mother Mary had three brothers and one sister already in New Zealand, as well as her uncle, Alexander (b.1806). Helen's brother Alexander (b.1856c) was seventeen when the family arrived in Wellington and he was immediately employed as a shepherd at 'Pahaoa' for $£ 28$ per year by his Great Uncle Alexander (b.1806). ${ }^{19}$ Far from being an island of Scots in a sea of other British migrants, the Cameron family and their associates are just one example of an identifiable 'pocket' of Scots in Wairarapa East that flourished through generations due to marriage with fellow Scots and descendants of Scots, chain migration and patronage. $^{20}$

The reconstruction of the settlement by Scottish families on lands to the south of Wanganui that include Fordell, Mangamahu, Turakina and Parewanui provides a clearer picture still of the settlement of Scots in Wellington Province on a local scale. Though this area constitutes a significant lower North Island community of Scottish families living in close proximity, working with, assisting and marrying fellow Scots, because they spanned three different 1876 counties they do not readily appear in

Alexander Cameron (b.1824) - Hugh and Alexander - were employed by John Morrison on 'Blairlogie' in the 1880s. Ulyatt, 'The Kaiwarra Camerons', p.55

${ }^{15}$ Sutherland, Sutherlands of Ngaipu, pp.98-99

${ }^{16}$ Cameron, 'Cameron of Kaiwharawhara', pp.14 and 16

17 'Sutherland Genealogical Tree', compiled by Keith N. Lambert

${ }^{18}$ Having spent time in Ross, Caithness, Cromarty, Scapa Flow and Hoy in Orkney, and finally Shetland

${ }^{19}$ Sutherland, Sutherlands of Ngaipu, pp.67-68 and Family Tree at the end of the book.

${ }^{20}$ Further interconnections between Scots in the area can be inferred in such histories as Bagnall, Wairarapa: An Historical Excursion; for example Bagnall notes that Alexander Sutherland (b.1806) employed three brothers, Donald, William and Peter McLaren, as shearers at 'Ngaipu' in 1871. A.G. Bagnall, Wairarapa: An Historical Excursion, Masterton, 1976, p.362. 
statistical analyses of these counties, in census data or collected datasets. Fordell sits just north of the 1876 Wanganui and Rangitikei Counties border, while Mangamahu is north east of Fordell. Turakina, just over ten kilometres south of Fordell, lies completely within Rangitikei County as defined in 1878, and Parewanui, just over twenty kilometres south of Turakina, falls within Manawatu County. ${ }^{21}$ This is one case where it is clear that the story of the Scottish community is more than the sum of its parts. Though descriptions of individuals are interesting in themselves, it is only by noting how these individual parts of the Scottish migration story relate to one another that a depiction of the community may emerge. ${ }^{22}$ The following case studies demonstrate the interconnectedness of the Scottish families and individuals in the area, extending beyond ties of marriage and kinship. It demonstrates too the rich detail available in the genealogical evidence and the greater understanding of the settlement patterns attainable when analysis of these communities moves beyond statistical evidence. $^{23}$

\footnotetext{
${ }^{21}$ See Map 6, below.

${ }^{22}$ These connections being multiple and varied, it is recommended that the following case study be read in conjunction with Appendix 3.5a-f.

${ }^{23}$ For a solid background of this area, and Turakina in particular, including the ways in which Scottish identity have been preserved, and an historiography of the district, see Jessie M. Annabell, "Caledonia, Stern and Wild': Scottish Identity in Wanganui and Rangitikei, 1880-1918', M.A. Thesis, Massey University, 1995 and Jessie Annabell, 'Smoke in the Hills? Representations of Turakina's Past', BA (Hons) Thesis, Massey University, 1993.
} 


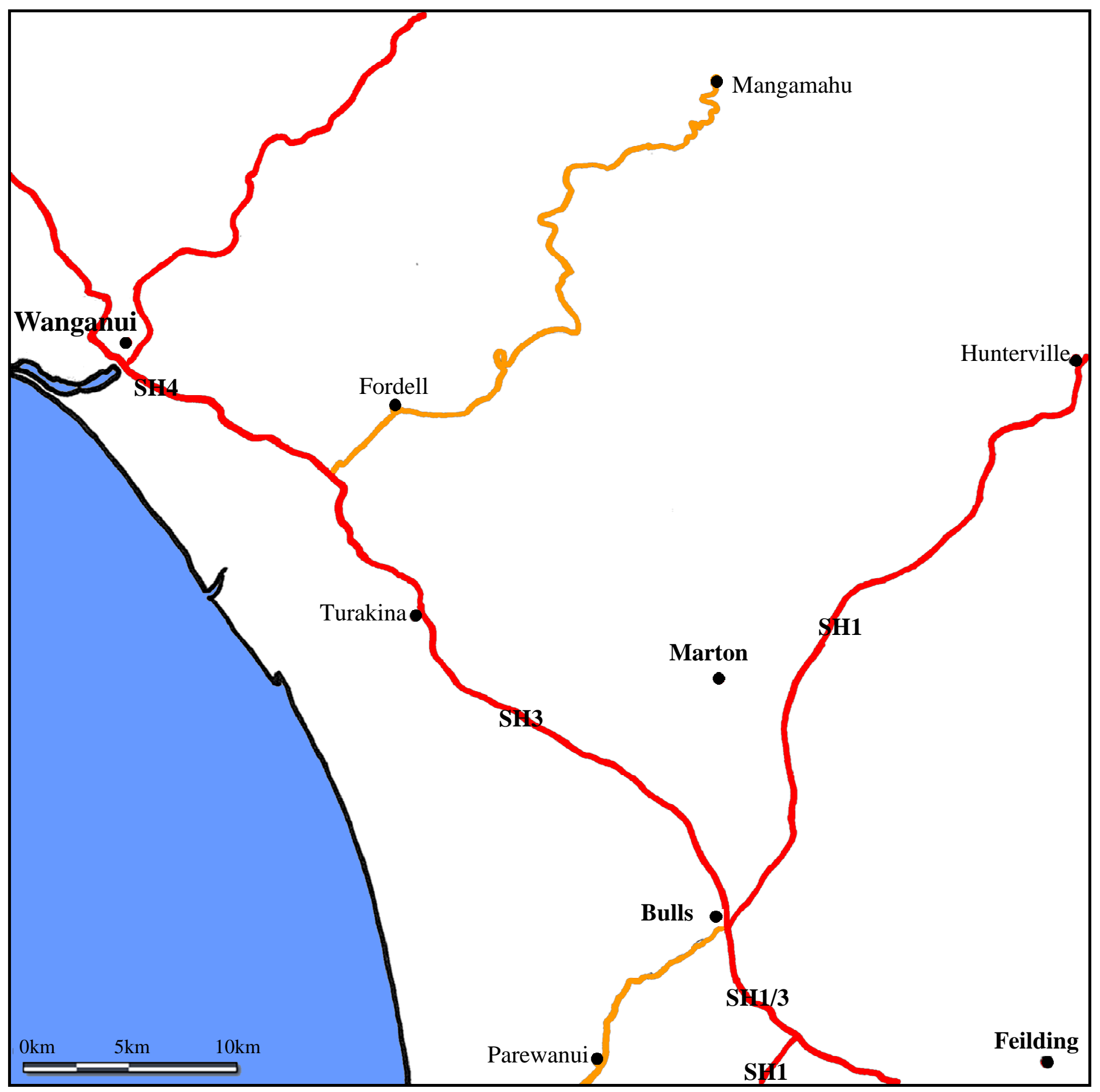

Source: Map created in Macromedia Fireworks from a sketch by Rebecca Lenihan based on a map of New Zealand available at http://maps.aa.co.nz/, accessed 5 June 2008 
Moses Campbell, born in Perthshire in 1787, arrived in Wanganui in November 1841, having spent nearly a year in Petone with his wife Jessie and their children. The family had travelled to Wellington as cabin passengers on the Blenheim. Unable to take possession of the land allocated to him, Moses leased land from local Māori just south of Wanganui until, in 1843, he came to an arrangement to occupy his allocated sections. As a result, when the land purchase dispute was settled in 1848 he was able to take possession of the sections, notably 'Wiritoa', uncontested. ${ }^{1}$ Jessie's cousin, John Cameron, born in Inverness in 1818 , was also a passenger on the Blenheim. ${ }^{2}$ John had preceded the Campbell family to Wanganui, working on survey parties for the New Zealand Company from March 1841, then boarding with his cousin and her family until he took possession of his land at 'Marangai' in $1843 .{ }^{3}$ Arriving early and settling their allocated lands years before the purchase of the lands was finalised, these two men are cited in histories of the region as prominent and successful early settlers, John being described, stereotypically, as 'a fine old Highlander of the best type'. The majority of the Scots migrants arriving in Wellington on the Blenheim, the Bengal Merchant and the Oriental, however, remained in Wellington - notably at Kaiwarra - until their allocated sections were surveyed and made available late in the decade. $^{5}$

Marjory Fraser may be regarded as representative of the Wanganui/Rangitikei, Scottish migrants. In 1917 her family was described as having 'had the greatest influence upon the settlement of the Rangitikei, its descendants some years ago numbering well over a thousand and embracing the McGregors, the McKenzies, the Stevenses, the Campions, and the Richardsons, beside those bearing the name of the clan itself. ${ }^{6}$ Marjory, the daughter of Alexander Fraser and Elizabeth MacDonald, was born in 1803 in Knockie, Inverness, and married Duncan Fraser in Fort Augustus

\footnotetext{
${ }^{1}$ Rex H. Voelkerling and Kevin L. Stewart, From Sand to Papa: A History of the Wanganui County, Wanganui, 1986, p.32

${ }^{2}$ Not one of the 'Pahaoa' Cameron's mentioned above.

${ }^{3}$ Voelkerling and Stewart, From Sand to Papa, pp.87-8; James G. Wilson, Early Rangitikei: A few notes, Collected from Various Sources of the Settlement on the Rangitikei River of a Number of Maoris of Different Tribes. A Short History of the Purchase and Colonization of the Land Between the Turakina and Oroua Rivers, and an Account of the Various Pioneers, Christchurch, Wellington and Dunedin, 1914, p.58; 'Onslow settlers of the 1840s: Donald MacDonald, laird of Kaiwarra', p.6

${ }^{4}$ Wilson, Early Rangitikei, p.58; Voelkerling and Stewart, From Sand to Papa, p.41

${ }^{5}$ Voelkerling and Stewart, From Sand to Papa, pp.27-8, 32

${ }^{6}$ Ian Clapham, Pukehou: The Frasers of Lower Rangitikei: Family Tree of the descendants of Duncan and Marjory Fraser, 1795-1995, Feilding, 1996, (Obituary of Mr Donald Fraser, original source not cited), p.327
} 
at age eighteen. The couple arrived in Wellington on the Blenheim in December 1840 with their ten children (one born in the Bay of Biscay en route) and Marjory's sister. They lived in Wellington initially, where Duncan established 'the Highlander Inn', a smithy on a town section near Tinakori Road and a farm at Section 3, Kaiwarra. ${ }^{7}$ In 1852 Marjory and Duncan followed their daughter Margaret (married to Ross-shire born Thomas Urquhart McKenzie in 1843) and her family up the island, settling in Parewanui, 150 acres being transferred to Duncan for $£ 75$ in July 1857. This land was the basis of the family's property, 'Pukehou' ${ }^{8}$ Marjory and Duncan's children born in New Zealand - Margery and Hugh (twins b.1843), Catherine (Kate) and Jane travelled with their parents to 'Pukehou', all being under nine years old at the time of the move. Hugh married the granddaughter of Donald ('the weaver') Cameron, Christina Annie McDonell, yet another link between the Cameron family and Scots families in the lower North Island. Christina Annie's parents, James McDonell and Annie Cameron, owned 'Inverhoe' at Parewanui. Hugh and Christina moved around this area of New Zealand during their life times, living at one point with Hugh's nephew James at 'Okirae'. (See Appendix 3.5a)

James McDonell married Annie Cameron, daughter of Donald ('the weaver') Cameron, at Donald's home in Kaiwarra on 18 December 1849. Born in Inverness in 1818 , James had first emigrated to Australia in 1840, moving on to Wanganui later in that decade. Through an arrangement with local Māori, James took occupancy of the land that would later become 'Inverhoe' in the late 1840s. When the question of title was finally settled in 1850 and 'Inverhoe' was subsequently purchased from the Crown, it was Annie's father, Donald 'the weaver', not James, who was the registered owner, possibly because the required $£ 200$ was beyond the reach of the young couple. Donald ('the weaver') Cameron's son Donald ('the piper') also married a Scots migrant in Turakina, Isabella Glasgow, in 1853, another indication of the ongoing links between Scottish settlements east and west of the dividing ranges. Though the couple moved to the east coast of the Wairarapa, where they lived on 'Pahaoa' station, their son Robert married a Turakina woman, Eliza Clark. Donald Cameron

\footnotetext{
${ }^{7}$ Julie Bremner, 'The Kai Warra Road and Khandallah in the 1840s', The Onslow Historian: Official Journal of the Onslow Historical Society Inc., Vol.7, Nos.3 and 4, 1977, pp.39-42, p.40

${ }^{8}$ The couple were joined there by their son Donald who remained at 'Pukehou' for most of the rest of his life excluding a few brief intervals on the Australian gold fields in the 1860s. Clapham, Pukehou, pp. 15 and 325

ibid., p.345
} 
(b.1869), the son of John Cameron, the second youngest son of Donald ('the weaver'), was schooled in Turakina, where he stayed with both the Turakina Camerons' and his aunt Mary Glasgow. ${ }^{10}$

Margaret (nee Fraser) and her family had moved to Turakina in 1850 when her husband Thomas Urquhart McKenzie took up land there. Thomas had taken ship to New Zealand on the Oriental in 1840. Having relocated to Turakina, the couple lived there until 1854, when an opportunity arose to buy 800 acres in Parewanui. Margaret, Thomas and family lived with James and Anne McDonell (Margaret's sister-in-law's parents) at 'Inverhoe' until their new home - 'Poyntzfeild' - was built. (See Appendix 3.5b)

In her recollections, Margaret and Thomas Urquhart McKenzie's daughter Eliza Rockel (nee McKenzie) speaks of the trip 'up the coast' from Kaiwarra to Parewanui and the help the family received from Mr and Mrs Scott of 'Scott's Ferry'. ${ }^{11}$ Thomas Scott and his wife Mary arrived in New Zealand in 1841 on the Olympus. Around November 1849 the couple and their children settled at the Rangitikei river mouth, establishing 'Scott's Ferry' and later a store and accommodation house. All but one of Thomas and Mary Scott's children married the children of fellow Scots, their daughter Anne and son David both marrying the children of Thomas and Mary Higgie, formerly of Fife, who had also come to New Zealand in 1841 on the Olympus. ${ }^{12}$ (See Appendix 3.5ci and 3.5cii)

As may be seen in Appendix 3.5cii and 3.5ciii, marriage connections between the Higgie and Scott families and other Scots in the area continued through the next two generations. ${ }^{13}$ It seems likely that these families formed the close bonds indicated by these intermarriages on the voyage to New Zealand and that these bonds were subsequently reinforced upon arrival in the colony, at the Kaiwarra settlement. That the families known to each other from the Kaiwarra settlement continued to intermarry through to the early twentieth century is further evidence of the close bonds and interconnectedness of this settlement of Scots.

\footnotetext{
${ }^{10}$ Ulyatt, 'The Kaiwarra Camerons', p.67.

${ }^{11}$ Eliza Rockel, 'When the World was Young', unpublished recollections compiled for her family, provided by Theodora Wickham, Year Unknown, p.15

12 'Intention to Marry', BDM 20/1868, p.219, ANZ, provided to the present author by Barbara Mariott; Higgie Family Tree, provided to the present author by Barbara Mariott.

${ }_{13}$ Personal Communication with Alexa McPherson, 13 October 2007; Higgie Family Tree, supplied by Barbara Mariott; Clapham, Pukehou, pp.198 and 235.
} 
Thomas and Mary Higgie's daughter Mary and her husband John Hair bought the old 'Okirae' homestead block from the Campion family in $1913 .{ }^{14}$ This section of 'Okirae' was bought in 1916 by recently arrived Scots, the Melville family. Shortly after brothers Andrew and Alexander Melville made the decision to migrate to New Zealand in 1913, Alexander died. His widow Christine and their two sons came with Andrew and his wife in 1914. In 1917 Alexander Sutherland, one of Archibald Sutherland's four sons, exchanged his share of 'Craigie Lea' (a property acquired by Archibald and his brother Nathaniel Sutherland Junior) for three separate sections of 'Okirae'. ${ }^{15}$ (See Appendix 3.5c-iii)

Marjory and Duncan Fraser's second daughter Catherine's seventh child, also named Catherine, married Nathaniel Sutherland Junior in January 1874. Nathaniel, born in Wellington in 1847, was the son of Nathaniel Sutherland Senior (encountered in Chapter Two), born in Edinburgh in 1806, and his wife Marion. ${ }^{16}$ Through Nathaniel Junior's diary, kept between 1868 and 1870, further insights into this community of Scots are provided. They demonstrate that the connections that bound Scots in this area were not simply of marriage and kin, nor only of bonds formed en route to New Zealand. Rather they also included mutual aid and friendship, bonds that appear, in this instance, to primarily have been formed on the basis of a shared Scottish background.

Although he had sought to acquire land in Wellington and Wanganui through the New Zealand Company prior to departure for New Zealand, Nathaniel Senior found employment in Wellington shortly after arrival, and never farmed his Wanganui land himself. ${ }^{17}$ As soon as they were old enough, Nathaniel Junior and Archibald took charge of their father's affairs in Wanganui. In his first full diary entry, 23 December 1868, Nathaniel Junior provides the first evidence of his association with Scots and Scottish descendants in the area:

\footnotetext{
${ }^{14}$ M.H. Campion, The Road to Mangamahu: a History of the Whangaehu River Valley from Reid's Hill to Mt View, Wanganui, 1988, p.97

${ }^{15}$ Moving to the section known today as 'Wharakai' (formerly 'Old Arawhata'), then to 'Te Huia' (2,110 acres) before settling on the section 'Nga Hui' until he retired in 1965. ibid., pp.116, 123

${ }^{16}$ Sutherland family material provided by Spin and Joan Sutherland

${ }^{17}$ ibid.
} 
Shearers arrived sheep not dry enough they Had a sort of hurdle race Geo. Campbell on his own mare. Dick Campbell on his Thurston on Charlie and Mike Mar on Madge. Madge won it in $1^{\text {st }}$ rate to the surprise of the shearers who thought theirs would win. ${ }^{18}$

A few days later, on 1 January 1869 Nathaniel

[d]ined with Andrew [Campbell] and Archie [Sutherland.] Went to join Cameron's with them at night where they [were] singing gaelic Songs \& of the which I could make naught. ${ }^{19}$

Throughout the diary interactions with local Scots are regularly recorded, Nathaniel working with Andrew Campbell, attending William Reid's muster, dining with Gregor McGregor, buying grass seed from Sandy McGregor and meeting Duncan McGregor on his way to meet his sweetheart. He travelled with Robert McIntosh, borrowed equipment from William McWilliam, aided Jack Johnston with his shearing, was visited by Alex Higgie and Dick Campbell, sold a horse to Stewart McGlashan and bought fencing material from Archibald McDowell. ${ }^{20}$ So common were interactions with Scots and their descendants in the life of Nathaniel Sutherland that one of the most notable entries in the diary relates an encounter with two nonScots. On 8 July 1869 Nathaniel records:

Very wet. Went to work when after clearing the fern the rain came down so fast that I was forced to take shelter in a maori whare, at the redoubt close by, where two men -1 an Irishman, the other a Dane - have taken up their abode, employed by W. Reid to erect this part of boundary fence. Had a cup of tea with them. The Dane gives a comical accent to his words. He told me that he saw some sheep sold for six and one pence each. The whare was full of smoke which he said he hated more than de debble. ${ }^{21}$

The following day Nathaniel notes: 'The Dane Bill and Irishman Pat have commenced clearing the fern \&c for the fence which they expect to finish tomorrow

\footnotetext{
18 'Diary of Nathaniel Sutherland (Jnr), 1867-1870', transcribed by Janette Godfrey, Sutherland family material provided by Spin and Joan Sutherland, p.3

19 ibid., p.4. This ignorance of Gaelic is interesting, given both of Nathaniel Junior's paternal grandparents had been born in Sutherland (see Chapter Two). It raises again the question of personal identity among both Lowland Scotland- and first generation New Zealand-born Scots regarding Highland heritage. In contrast to the Sutherlands, Alexander Watson and his wife, mentioned earlier in the chapter, were at least third-generation Lowland Scotland-born - Alexander's father and grandfather were born in Cadder, LKS - yet both were fluent Gaelic speakers and taught their New Zealand-born grandchildren the language. Barnett-Drummuir, 'Notes on the family of William Watson, born Cadder, 1775 , pp.1-4

20 'Diary of Nathaniel Sutherland (Jnr), 1867-1870', Sutherland. See Appendix 3.5d

${ }^{21}$ ibid., p.36
} 
and then on Monday start the fence. ${ }^{22}$ At no other point in the diary is reference made to the ethnicity of those with whom Nathaniel associated.

One Scots family with whom Nathaniel appears to have been in especially regular contact was the Howies. While many of the families living in this locality were of Highland origin, had formed connections through passage on early ships to Wellington or during that first decade of settlement in Wellington, the Howies were one of at least three families who arrived in the Rangitikei from New Deer, Aberdeenshire. ${ }^{23}$ Though the entries referring to this family do not suggest familial connections, or involvement with business and land transactions, their frequency suggests a strong bond of friendship between this first generation New Zealand-Scot and the Aberdeenshire-born family, perhaps indicating ties not only of kin but of 'Scottishness' at work. Entries include 'W. Howie was here' on 14 January 1869; 'went to Mrs Howie's' (probably Mrs Sandy Howie, nee Anne Aiken) on 4 March 1869; 'Called at S Howie's' on 30 April 1869; 'Dined at S. Howie's' on 23 May 1869; and 'Called at Mrs. Howie's and took some letters from her intending to post them but not reaching town left them at Planpin's' on 13 October $1869 .^{24}$

Alexander (Sandy) Howie Junior and his wife Anne (nee Aiken) had arrived in New Zealand in 1854, purchasing property on the No. 2 line in Fordell. Alexander's parents (Alexander and Jane), siblings (Helen, William and John), and the daughters of his sister Jane (Beatrice and Isabelle Robertson), followed the couple to New Zealand between 1855 and $1857 .{ }^{25}$ Anne Aiken's brother George also married a Howie, Sandy's sister Helen. George and Anne Aiken's sister Catherine was the first of their family to arrive in New Zealand, and it appears that her migration with her husband Thomas McWilliam to Fordell, via South Africa and Australia, encouraged their siblings, and consequently also the Howie family, to emigrate to the area. ${ }^{26}$ Catherine and Thomas' son William (recorded by Nathaniel Sutherland as having lent him equipment) and his wife were farming 'Netherdale' by 1869. 'Netherdale' was directly adjacent to 'Fernilea', occupied by the Young family, who were related to the

\footnotetext{
22 ibid.

${ }^{23}$ Personal Communication with Bobbie Amyes, 24 February 2009

24 'Diary of Nathaniel Sutherland (Jnr), 1867-1870', Sutherland and 'Where the Howies were in NZ in 1869', Personal Communication with Bobbie Amyes, 10 July 2009

25 'Where the Howies were in NZ in 1869', Personal Communication with Amyes,

26 'The Aiken Connection to Matarawa in 1869', Personal Communication with Bobbie Amyes, 13 July 2009
} 
Howie family via Jane Young's marriage to John Howie in 1864, and opposite 'Learney', the property occupied by the Howie family. ${ }^{27}$ Catherine and Thomas were joined by her siblings William and Alexander in 1852-3, followed next by Ann and George. Alexander Aiken married his first cousin, Ann McIntosh, and Ann's brother Robert McIntosh (who is recorded by Nathaniel Sutherland as having travelled with him) was also living in the area by $1867 .^{28}$ (See Appendix $3.5 \mathrm{~d}$ )

Both the Aiken family and the McIntoshs had links with New Deer, Aberdeenshire. Though they had purchased the land while in Scotland, what enticed Catherine Aiken and Thomas McWilliam to stay in the area south of Wanganui is unknown, but it is clear that it was their immigration that initiated a chain of migration from New Deer, Aberdeenshire, to Fordell, Wanganui, over the subsequent decade. It is likely there were similar chains among families migrating from other parts of Aberdeenshire to Manawatu, Wanganui and Hutt counties. If this were so, it may go some way to explaining the disproportionate number of North East migrants settling in Wellington Province earlier noted. ${ }^{29}$

After the death of their father in 1883, Nathaniel and Archibald Sutherland remained in Fordell, buying 'Lambhill' from another settler of Scottish descent, Alexander Allison, in 1887. Alexander Allison was the New Zealand-born son of Dr James Allison and Georgianna Gilfillan. James, born in Letham, Strathaven, Lanarkshire, in 1816, acquired approximately 1,632 acres of land in Fordell (that he named 'Lambhill' after his family home in Scotland) through the New Zealand Company. After his death in 1867, James' property was transferred to his son, Alexander. After Georgianna's death in 1887 Alexander sold 1,432 acres of 'Lambhill' to Nathaniel and Archibald Sutherland, remaining in the area on 200 acres he had retained for himself that he renamed 'Letham' and farmed until $1928 .^{30}$ (See Appendix 3.5e)

\footnotetext{
27 'Bobbie Amyes speech for NZSH Hutt branch meeting April 2005', Personal Communication with Bobbie Amyes, 24 February 2009

${ }^{28}$ Personal Communication with Amyes, 'Beatrice Robertson', Personal Communication with Bobbie Amyes, 5 March 2009

${ }^{29}$ As noted in Appendix 1.1, it has not been possible to trace chains of migration for the vast majority of the NZSG migrants; travel companions and chain migration are aspects of the New Zealand Scots experience that merit further attention. Chapter Six, with a focus on migrants from Shetland, explores this issue in more depth.

${ }^{30}$ Marie White, ed., Lakes District of Wanganui, Wanganui, 1997, pp.60-62
} 
Whilst most of the rest of Duncan and Marjory Fraser's family settled in Parewanui and Turakina, their eldest daughter Catherine and her family eventually settled in Wanganui. Having married a fellow Blenheim passenger from North Uist, Inverness, Gregor McGregor, Catherine had moved to Sydney by 1845 with Gregor and their two children. They returned to Turakina within five years with three children (their son James having died in Sydney), moving to Wanganui shortly afterwards. Catherine and Gregor's eldest son, John, married Christina McDonald McGregor in February $1871 .{ }^{31}$ Christina was the adopted daughter of John 'Jock' McGregor. ${ }^{32}$ 'Jock' was born in Perthshire to John and Christen McGregor in 1813 and had come to New Zealand as a sailor in 1836, settling initially at Port William, Stewart Island. ${ }^{33}$ He married Isabella Lockhart, formerly of Glasgow, in Wellington in September 1840. She had arrived on the Bengal Merchant earlier that year. ${ }^{34}$ Isabella and 'Jock' separated in 1853, at which time 'Jock' left New Zealand for Scotland, returning in 1855 with Christina McDonald McGregor, an orphan whom he had adopted. ${ }^{35}$ Christina lived with her adopted father until her marriage in $1871 .{ }^{36}$ (See Appendix 3.5e)

As noted earlier, many of the early settlers south of Wanganui were Scots who had already established relationships with fellow Scots on the voyage to New Zealand and subsequently upon initial settlement in Wellington. The Scottish character of the area was primarily established by those settlers settling there in the late $1840 \mathrm{~s} .{ }^{37}$ As the McWilliam/Aiken/Howie chain of migration indicates, however, the predominantly Highland-born influx from the early ships is by no means the whole story. It is notable too that first generation New Zealanders and later arriving Scots continued to be drawn to the district. Scots were not, of course, the only settlers in this area. There

\footnotetext{
31 'The family of Gregor and Catherine McGregor' family tree, Wanganui Archives.

${ }^{32}$ For more on John 'Jock' McGregor see Felicity Campbell, Making Waves: Captain Jock McGregor Shipmaster, Wanganui Pioneer, Wellington, 2004

${ }^{33}$ Letter from John McGregor to the Rev. R. Taylor, 13 February 1867, John 'Jock' McGregor papers, Wanganui Archives; Campbell, Making Waves, p.33

34 'The late John McGregor' in the Wanganui Chronicle, 5 October 1882, John 'Jock' McGregor papers, Wanganui Archives; Campbell, Making Waves, p.103

${ }^{35}$ It is probable Christina (or Christian, in some sources) was a relation - Felicity Campbell suggests she was his cousin's daughter. 'John, “Jock”, McGregor founders card', John 'Jock' McGregor papers, Wanganui Archives. 'The late John McGregor' in the Wanganui Chronicle, 5 October 1882, John 'Jock' McGregor papers, Wanganui Archives; Campbell, Making Waves, pp.28, 153

36 'A Wanganui Cause Celebre (McGregor versus Boyd)' in the Wanganui Chronicle, 22 October 1883, John 'Jock' McGregor papers, Wanganui Archives

${ }^{37}$ For example Captain Moses Campbell and family, and John Cameron, both of whom left for Wanganui shortly after arrival in Wellington, rather than settling initially in Wellington as their fellow Blenheim passengers did. 'Onslow settlers of the 1840s: Donald MacDonald, laird of Kaiwarra', p.5.
} 
were, surely, as many opportunities to interact with English and Irish settlers as with fellow Scots. By 1878 the population of Manawatu County was 34.23 per cent England-born, 6.10 per cent Ireland-born and just 5.51 per cent Scotland-born. In Rangitikei County the proportions were 27.40, 6.37 and 9.65 per cent respectively and in Wanganui 23.42, 9.56 and 9.94 per cent. It seems, then, that this persistence of Scots in the area, marrying one another, engaging in land transactions, employing fellow Scots, helping one another out, was a deliberate seeking out of Scots by Scots over and above other ethnic groups. To what extent this was due to earlier formed relationships, connections based upon their shared Presbyterian faith (the first Presbyterian Church service in the Rangitikei was held on 15 December 1852), or simply to migrants choosing to live with and by like-minded people who happened on many occasions to be Scots is a matter that cannot, at present, be addressed. It is, perhaps, indicative of the extent of the Scottish community in this area that the Turakina Highland games, reportedly first held in 1864, are New Zealand's longest running Highland games. Focusing on these two settlements of Scots in the lower North Island has served two purposes. Firstly, it has reinforced that the Scottish settlements in Otago/Southland and Waipu were not the only pockets of Scots in New Zealand. Though these were the New Zealand locations most commonly associated with Scottish settlement, New Zealand's Scots were dispersed across the country and distinctive Scottish communities emerged in other localities. It is likely that the patterns that have emerged from the Wellington case studies were common across New Zealand. The Rutherfords of Amuri could as easily have been examined as the Cameron family of Wairarapa East, and a study of the connections between Scots across Amuri and Cheviot would almost certainly have shown similar patterns to the area south of Wanganui. ${ }^{38}$ Secondly, it has very clearly shown that while statistical analysis is indispensable, it cannot tell the whole story of migration flows. Genealogical material and local studies amplify statistical findings and are vital to the understanding of migrant settlement patterns.

\section{CONCLUSION}

The stereotype of Otago/Southland and Waipu as the Scottish settlements of New Zealand is based upon irrefutable fact: Otago and Southland did receive the largest

\footnotetext{
${ }^{38}$ Janet Holm, Nothing But Grass and Wind: The Rutherfords of Canterbury, Christchurch, 1992; Gardner, The Amuri: A County History; John Wilson, Cheviot: Kingdom to County, Cheviot, 1993; W.J. Gardner, A Pastoral Kingdom Divided: Cheviot, 1889-94, Wellington, 1992
} 
proportion of New Zealand's Scottish migrants, and the Scots of Highland origin settling in Waipu were an unusual and noteworthy, if small, group. As this chapter has shown, however, the spread of Scottish settlement throughout New Zealand was much greater than these stereotypes imply. Though settlements in Wellington Province alone were considered in the final section, locally based studies of Scots in other areas of New Zealand would undoubtedly also reveal similar pockets and communities based upon mutual aid, marriage and kin links.

Carrying through from Chapter Two, settlement patterns investigated by origin in Scotland revealed that each of the major provinces of New Zealand also received a proportionate cross-section of the Scottish population, albeit with some New Zealand provincial/Scottish regional variations. At the New Zealand county level, Scots were spread throughout the country in a way that might be expected, based upon the discussed provincial patterns. The distribution of New Zealand's Scots was affected by the move in New Zealand generally towards urban settlement in the twentieth century.

The chapter has also advanced the importance of genealogical evidence in discovering population distribution patterns and processes at the sub-county and supra-county levels in New Zealand. Though statistical evidence suggested the presence of a Scottish community in East Wairarapa, the extension of the apparent community of Scots in Turakina, Fordell, Mangamahu and Parewanui over three county boundaries meant that it was not observable in the absence of genealogical evidence and local knowledge. The case-study of the districts south of Wanganui serves as a reminder that migration flows are more than the sum of their parts. Without dis-aggregating the statistics and focusing on the stories of individuals who made up the migration flows, whenever possible exploring their lives and their interactions with each other, the history of migrants and their migrations are 'captured only in fuzzy outline'. ${ }^{39}$

\footnotetext{
${ }^{39}$ Charles W.J. Withers, Urban Highlanders: Highland-Lowland Migration and Urban Gaelic Culture, 1700-1900, East Lothian, 1998, p.10
} 


\section{Chapter Four \\ WHO WERE NEW ZEALAND's SCOTS? ANALYSIS OF AGE, GENDER, AND MARITAL STATUS AT ARRIVAL BY ORIGIN, SETTLEMENT AND PERIOD OF ARRIVAL}

When Mary Grey and her family arrived in Otago in 1858 they were, statistically, typical Scots immigrants in several ways. As the account of their experiences in Chapter Three outlined, Mary was typical in that she was born in Lanarkshire, settled on the Taieri, and came to New Zealand following extended family members after a period of time on the Australian gold fields. In addition to these features, Mary's family was large: Mary was one of ten children and she had ten children herself; her parents were over forty years old and married at arrival and, although Mary was over sixteen when the family came to New Zealand, there were several children under sixteen; finally, there were more males than females in the family. ${ }^{1}$ As well as place of origin, migration motive and settlement, these demographic characteristics may also be said to be 'typical' of Scots migrants to New Zealand. ${ }^{2}$

Addressing the age, the gender and the marital status at arrival of the migrants is fundamental to shedding light on the over-arching question of the present study 'who were New Zealand's Scots?' Not only do these aspects of the migrants' profiles tell a great deal about the types of migrants coming, they also give an indication as to the impact their departure or arrival may have had on the lands they were leaving or settling in respectively. Examining these aspects of the migrant profile could easily constitute a study in itself. The primary purpose of the present chapter is to outline the main demographic patterns, and to assess the extent of variation in these patterns

\footnotetext{
${ }^{1}$ Phyllis Barnett-Drummuir, 'A lassie from Lanarkshire', unpublished family history presented by Mrs Barnett-Drummuir, pp.1-4 of 4 . Note neither religion nor family size are features of the migrant profile examined in the present work. See Appendix 1.1 for detail.

${ }^{2}$ While Pool et al as well as David Thomson suggest that 'the large family of yesteryear' is, to an extent, a nostalgic myth of 'frontier' New Zealand, a crude examination of the NZSG data suggests that large families (here indicated by migrants with six or more children listed as 'total children' born to the individual) were more common than small families among the Scots migrants. While 2,350 NZSG individuals have five or less children recorded over the eighty years examined, 3,262 NZSG individuals had six or more children, 1,078 of these having ten or more children. It may be noted, however, that migrants with large families were more likely to be entered in the NZSG register, due to the higher likelihood of them having an ancestor to contribute their details. It is primarily due to this assumed bias in the data that this aspect of the migrant profile has not been examined in greater detail in the present research. Ian Pool, Arunachalam Dharmalingam, and Janet Sceats, The New Zealand Family From 1840: A Demographic History, Auckland, 2007, chapter three. David Thomson, 'Marriage and family on the colonial frontier', in Tony Ballantyne and Brian Moloughney (eds), Disputed Histories: Imagining New Zealand's Past, Dunedin, 2006, pp.119-141
} 
according to migrant origins, places of settlement and period of arrival. ${ }^{3}$ Tables and graphs presented in the chapter are augmented by further tables in Appendix 4. The final section of the chapter compares the NZSG migrant age, gender and marital status at arrival profile with the PNZ data in order to identify gaps and biases in the various datasets. This comparative analysis will also serve to test the validity of the genealogical dataset.

GeNDER, AGE AND CONJUGAL CONDITION IN ScotLAND, IN THE NEW ZeALAND POPULATION, AND AMONG SCOTS IMMIGRANTS TO NEW ZEALAND

At the 1881 Census of Scotland the ratio of females to males in the population was marginally imbalanced, there being 107.6 females for every 100 males. Emigration was one reason for this gender imbalance in Scotland's population. ${ }^{4}$ It is therefore logical that there should be more males than females amongst Scottish migrants to New Zealand during the period 1840-1920. Moreover, this is in line with the much discussed gender imbalance of New Zealand's early European population. ${ }^{5}$ Yet what is most striking about the gender imbalance among Scots to New Zealand is not that it was a reversal of the situation in Scotland, but that the ratio of males to females among New Zealand's Scots was greater than among the New Zealand population generally. While there were proportionately more females than males in the population of Scotland than was the case in England/Wales or Ireland (with gender ratios of 105.5:100 and 104.3:100 respectively in 1881), there were proportionately more Scots males than females in the New Zealand population than among these other migrant groups.

\footnotetext{
${ }^{3}$ These demographic characteristics are so affected by external factors that explanation of the patterns is extremely complex. For example, although these features of the migrant profile are examined first by migrant origins, taken as a likely explanatory and independent variable, as Chapter Two has already demonstrated, Scotland is a land of great diversity. Demographic features could, therefore, be examined from a wide range of angles with regard only to the multiplicity of features pertaining to origins in Scotland. This chapter offers insight into broad patterns, indicating aspects of the profile that warrant further elucidation in later studies.

${ }^{4}$ T.M. Devine, The Scottish Nation: 1700-2000, London, 1999, pp.253-4

${ }^{5}$ This gender imbalance and the implications of it for colonial society are discussed in, for example: Judith Elphick, 'What's wrong with Emma? the feminist debate in colonial Auckland', NZJH, Vol.9, No.2, 1975, pp.126-141; Raewyn Dalziel, 'The colonial helpmeet: women's role and the vote in nineteenth-century Auckland', NZJH, Vol.11, No.2, 1977, pp.112-123; Jock Phillips, A Man's Country? The Image of the Pakeha Male - A History, Auckland, 1996; Charlotte Macdonald, 'Too many men and too few women: Gender's 'fatal impact' in nineteenth-century colonies', in Caroline Daley and Deborah Montgomerie (eds), The Gendered Kiwi, Auckland, 1999, pp.17-35.
} 
The ratio of females to males in the general population of New Zealand between 1867 and 1911 rose steadily from just 65.75:100 in 1867 to 89.59:100 in $1911 .^{6} \mathrm{Had}$ male and female Scots come to New Zealand in numbers proportionate to the gender balance in Scotland, at least 105 Scottish females would have arrived for every 100 Scottish males over the period studied. Instead, the greatest female to male ratio in this period (aside from 1916) was the 74.6:100 Scottish females to Scottish males recorded in 1896. In 1881, while there were 70.1 Scots females to every 100 Scots males living in New Zealand, the ratio of English migrants was 71.6:100 and Irish $78.4: 100 .^{7}$ The gender ratio exhibited by the NZSG data for the entire period, 1840 to 1920, lies between the minimum and maximum gender ratios noted in the census for New Zealand as a whole over this period, with a gender ratio among the migrants in that data of 79.03:100.

Age statistics for the home population of Scotland are affected by the comparatively large proportion of older folk in the population, as might be expected in an established society. In 1881, while 24.37 per cent of the population of Scotland was aged over forty years the comparable figure for the New Zealand population (exclusive of Māori) was just 17.07 per cent; while 4.97 per cent of Scots were aged sixty-five plus only 0.28 per cent of those resident in New Zealand fitted within this age cohort. Those under ten years of age constituted 25.47 per cent of the Scottish population at the 1881 Census, but 31.09 per cent of the New Zealand population. ${ }^{8}$ The proportion of the populations of Scotland and New Zealand aged between twenty and forty years in 1881, on the other hand, was remarkably similar: 28.94 per cent of the Scottish population and 29.35 per cent of the New Zealand population.

The Scottish immigrant population of New Zealand exhibited clear differences from the sending population. Generally, those recruiting migrants for New Zealand were seeking healthy individuals aged between sixteen and forty-five years of age -

\footnotetext{
${ }^{6}$ This ratio was $99.25: 100$ in 1916, however this nearly equal figure for 1916 is due to the number of New Zealand men outside of the country on census night 1916 due to World War One service. Excluding 1916 the greatest female to male ratio for the New Zealand population generally was 90.33:100, reached in 1901. These 'New Zealand' population figures, throughout the chapter, are exclusive of Māori, being based on the census statistics available.

${ }^{7}$ Population by gender tables in the published Censuses of Scotland 1801-1881; Population by birthplace tables in the New Zealand Censuses 1871-1916. The ratio of Scottish females to males in the NZSG data is 79.03:100.00 for the 'whole period', 1840-1921. The same ratio in the PNZ data for the period $1840-1945$ is $81.25: 100.00$. See also Table 4.6 below.

${ }^{8}$ This latter figures probably reflects the youthfulness of the settler population in relation to the sending society, rather than any predilection for immigrants to produce large families.
} 
broadly speaking single migrants and couples with young families, people fit for the physically demanding work of settling the country for least another ten to fifteen years. Age restrictions were applied to those travelling on assisted passages offered by the New Zealand Company, provincial government schemes, and under the Vogel scheme, and there is evidence that a number of migrants consequently falsified their age to receive an assisted passage. ${ }^{9}$ When the New Zealand Company began advertising free passages for mechanics, gardeners and agricultural labourers in 1839 they sought married men 'not exceeding 30 years of age'. ${ }^{10}$

The mean age upon arrival of the NZSG migrants over the whole period was 23.5 years (see Table 4.1). One quarter of the migrants were aged under twelve years of age, and one quarter over thirty-two. 'Outliers', the statistical term for anything that lies too far beyond the 'norm', include all migrants aged sixty-three years or over. What this means is that the age structure of New Zealand's Scottish immigrants for the period 1840-1920 exhibits a pattern very similar to what is already known about the age structure of immigrants in general to New Zealand. ${ }^{11}$ Fifty per cent of the NZSG migrants were aged between twelve and thirty-two years of age. ${ }^{12}$ Most of those were aged from twenty-one to twenty-five, the most common age being twentyfour.

\footnotetext{
${ }^{9}$ Falsified ages are found relatively frequently when comparing birth certificate details with shipping passenger list information.

${ }^{10}$ Louis E. Ward, Early Wellington, Wellington, 1928, p.440, citing the Colonial Gazette, 15 June, 1839. In 1843 the New Zealand Company assisted migrant selection policy extended to adults between fourteen and thirty-five years (the upper limit being extended if the person was the parent of 'children' over fourteen who were accompanying them. J.S. Marais, The Colonisation of New Zealand, London, 1968 , p.62

${ }^{11}$ See, for example, 'Diagram 1: Age of the Vogel Immigrants 1871-1879' in John Morris, 'The Assisted Immigrants to New Zealand, 1871-79: a Statistical Study', M.A. Thesis, Auckland University, 1973, and pp.138-150; Charlotte J. Macdonald, 'Single Women as Immigrant Settlers in New Zealand, 1853-1871', PhD Thesis, University of Auckland, 1986, pp.97-102; and Jock Phillips and Terry Hearn, Settlers: New Zealand Immigrants from England, Ireland and Scotland, 1800 - 1945, Auckland, 2008, p.139

${ }^{12}$ This is the inter quartile range - the 50 per cent of the sample that lies between the top and bottom 25 per cent of the group.
} 
Table 4.1

New Zealand Scots immigrant age statistics

\begin{tabular}{ll}
\hline \hline$n^{*}$ & 5,819 \\
Mean & 23.49 \\
Mode & 24 \\
Minimum & 0 \\
Lower Quartile & 12 \\
Median & 22 \\
Upper Quartile & 32 \\
Maximum & 80 \\
'Outliers'** & $63+$ \\
\hline * 793 migrants having no age at arrival information available. \\
** Upper Quartile $+1.5 \times$ the Inter Quartile Range $(20)=62$. \\
Source: NZSG data, 1840-1920
\end{tabular}

While males significantly out-numbered females in the adult New Zealand Scots population, male and female children arrived in approximately equal numbers. At the 1881 Census of Scotland 50.66 per cent of children - those aged under fifteen years of age - were male, and the proportion of male children in the New Zealand population as a whole in 1881 was 50.46 per cent. Males constituted 52.27 per cent of NZSG migrants who arrived under the age of sixteen over the period 1840 to 1920 , 1.61 per cent higher than the Scottish population total. This difference may be due to the inclusion of fifteen-year-olds in the NZSG analysis: 49.87 per cent of NZSG migrants under five years old at arrival were male, as were 50.44 per cent of six to ten year olds, whereas of the eleven to fifteen year olds (inclusive) 57.32 per cent were male, a pattern that is possibly the result of more fifteen year old males than females emigrating to New Zealand unaccompanied rather than with their families, fifteen year old males being more likely to find employment, as agricultural labourers especially, than females of the same age. ${ }^{13}$ While this near parity of male and female children migrating appears logical, studies of Dutch emigrants and of British immigrants to the United States in 1841 suggest that 'families with young sons, even under the age of ten, were more inclined to emigrate than those with daughters' ${ }^{14}$ This even gender ratio among children will be explored further later in the present chapter.

\footnotetext{
${ }^{13}$ While this could be tested by examination of travel companions utilising the NZSG data it has not been in the present study. See Appendix 1.1 for detail.

${ }^{14}$ Charlotte Erickson, 'Emigration from the British Isles to the U.S.A. in 1841: Part 1. Emigration from the British Isles', Population Studies, Vol.43, No.2, November, 1989, pp.347-367, p.360; Robert P. Swierenga, 'Demography of Dutch emigration', Journal of Family History, Vol.5, No.4, 1980, p.395 cited in Erickson, 'Emigration from the British Isles to the U.S.A. in 1841: Part 1. Emigration from the British Isles', p.360. See also Rosalind McClean, 'Scottish Emigrants to New Zealand, 1840-1880: Motives, Means and Background', PhD Thesis, University of Edinburgh, 1990, p.586
} 
Figure 4.1 shows the proportions of the adult populations of Scotland, New Zealand and of NZSG migrants who were single, married or widowed. Immediately obvious is the relatively even distribution of single and married males and females in the Scottish population when compared to the population of New Zealand and to the NZSG sample. The slightly higher proportion of married men than married women in the population of Scotland arises from the higher proportion of widowed women than men that in turn arising from the longer life expectancy of women. The apparently much higher proportion of married women in relation to all women in New Zealand, and in relation to the comparable ratio for men, is an expected outcome of the high proportion of single men in the colony. In real terms, there were 72,798 married women and 73,261 married men. ${ }^{15}$ However, while there were 37,126 single females in the country at this census, there were 81,067 single men; it is this group that so distorts the gender ratio from that of the home population. ${ }^{16}$ The high proportion of both married men and women in the NZSG data is probably indicative of the bias of the data towards married couples, who were more likely to have descendants to fill in the registration forms in the late twentieth century (see Appendix 1.1).

\footnotetext{
${ }^{15}$ This difference of 463 probably being the result of married men coming to the colony ahead of their wives and children, and of men marrying Māori women, who were not included in census figures.

${ }^{16}$ See footnote 5 above regarding references to literature discussing the implications of this large proportion of single men in the colony.
} 
Figure 4.1

Showing the proportion of the adult population of Scotland, of New Zealand and of Scottish emigrants to New Zealand who were single, married or widowed

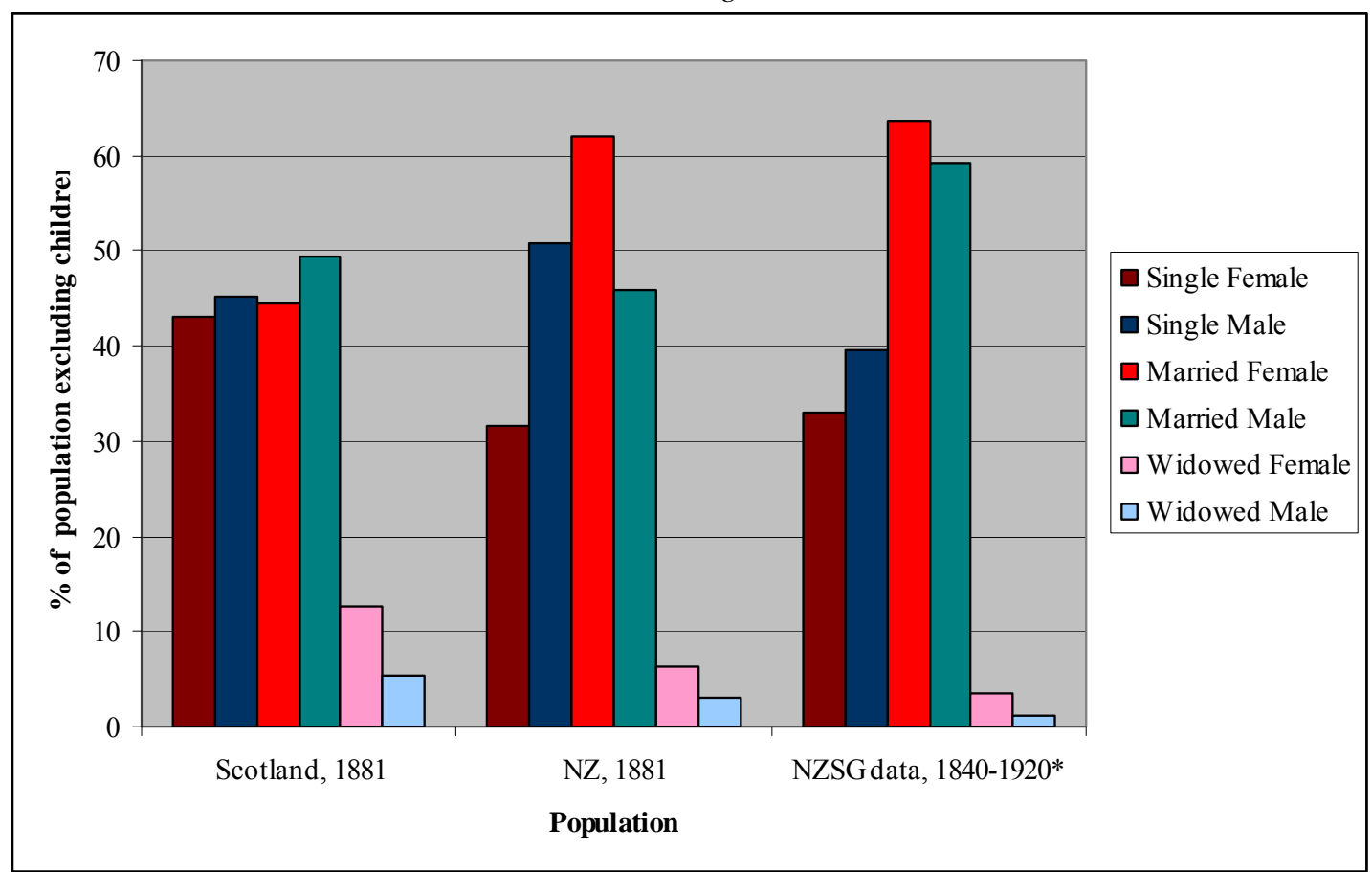

* The NZSG figures exclude children, those recorded as 'either widowed or spouse absent' and those for whom marital status at arrival is unknown $=$ sample of 3,830 .

Sources: Appendix Tables, Table LX and LXI, 1881 Census of Scotland, pp.xlix and 1; Part III, Table III, 1881 Census of New Zealand, p.90; NZSG data, 1840-1920.

In summary, New Zealand was receiving a mix of Scots that, while differing from the sending population in significant ways, was broadly comparable to the contemporary profile of the population of New Zealand. Though the largest Scottish migrant group consisted of single men in their early twenties, a significant number of the migrants were young married couples with children under ten years of age.

Although direct comparison with emigrants to other destinations is problematic due to the different types and date ranges of the data used in studies of migrant patterns, it is nevertheless possible to offer some general observations. For example, Erickson's analysis of British emigrants to the United States is based upon data collected from migrants arriving in five ports in 1831 and 1841. It is therefore not directly comparable with New Zealand immigrant data, immigration to New Zealand being in its infancy in these years. Even so, with 30.90 per cent of the Scottish immigrants arriving in the United States in 1841 aged under fourteen years, the lower quartile age was approximately the same as among NZSG migrants arriving between 1840 and 1920 . With 8.20 per cent of Erickson's sample arriving between fifteen and nineteen years of age, and 16.40 per cent between twenty and twenty-four, the mean age also appears to have been comparable with the NZSG data, and the upper quartile 
age figure of these United States immigrants was probably close to the NZSG figure of thirty-two years. ${ }^{17}$ In terms of gender, however, this sample of Scots immigrants to the United States arriving in 1841 differs significantly from the gender ratio of New Zealand's Scots, with just 57.5 adult females to every 100 adult males in that data. ${ }^{18}$ The gender ratio of Scots arriving in New South Wales, Australia in 1841, by contrast, was much closer to the figure for New Zealand Scots, around 85.82 females arriving for every 100 males. $^{19}$

In the absence of data comparable to the NZSG data for other Scottish emigrant destinations over the same period, the following sections subject New Zealand Scottish immigrant data to further scrutiny by origin, place of New Zealand settlement and by period of arrival.

\section{DEMOGRAPHIC PROFILE OF NEW ZEALAND’s SCOTS BY ORIGIN}

The gender profile of the Scots migrants to New Zealand varies significantly between regions and counties of origin in the NZSG data over the entire period studied. Table 4.2 compares the ratio of females to every 100 males in the 1881 Scottish census data to the NZSG data. Though some speculative conclusions could be reached from comparisons of the NZSG and the 1881 Scottish Census figures, it is apparent that the proportions of males and females sent from each region and county is more likely dependant on influences within the sending communities than on the gender ratio of the communities. Angus and Aberdeen are both coastal counties that, in 1881, were of similar population size with large rural components and significant urban centres. Nevertheless the home population gender ratios were markedly different and while the ratio of females to males in Aberdeen was closer to parity than the ratio in Angus in the home population, the opposite was true among migrants from those counties. In this instance the comparatively high ratio of females in the population of Angus is likely due to the high proportion of women employed in the textile industry in Dundee; the comparatively low ratio of female migrants from Aberdeen is likely also

\footnotetext{
17 Table 6, Erickson, 'Emigration from the British Isles to the U.S.A. in 1841: Part 1. Emigration from the British Isles', p.358.

${ }^{18}$ Though these figures are of emigrants aged over 15 years, and the NZSG data is of all migrants, the figures are still broadly comparable on that basis, the proportion of male and female children in the NZSG data being very close. Table 11, ibid., p.361.

${ }^{19}$ Assisted immigrants of all ages. Table 11, John McDonald and Eric Richards, 'The great emigration of 1841: recruitment for New South Wales in British emigration fields', Population Studies, Vol.51, No.3, November, 1997, pp.337-355, p.346
} 
due to employment conditions in the home population encouraging a higher proportion of males to emigrate.

The results for some counties, such as Kirkcudbright and Wigtown, in Table 4.2 may, though the samples appear sufficiently large, have been unduly skewed by the composition of large families. Kirkcudbright and Wigtown had gender ratios of 112.69 and 112.81 respectively at the 1881 Census, the home populations of the two counties differed by just 3,516 people and the counties were of a similar make up. However, while Kirkcudbright supplied 92.86 females for every 100 male migrants in the NZSG data, the ratio of Wigtown-born migrants in the data is just 46.15:100. Among the twelve members of the Wilson family of Wigtown the gender ratio was just 50:100; the gender ratio of the Thomson family of Kirkcudbright was 125:100 due simply to the birth of one more daughter to the family rather than a son. ${ }^{20}$

Based on the figures in Table 4.2 alone, it is clear that very close analysis of the sending populations, and of the motives that impelled the emigrants to leave their homeland, is necessary to explain the significant differences in gender ratios by county (and region) among New Zealand's Scottish immigrants. However, it is notable that the counties that sent the closest ratio of females to males were often the large industrial centres noted in Chapter Two: Midlothian (98.42:100); Lanarkshire (94.11:100); and Renfrew (91.71:100). In these instances the sub-samples are sufficiently large to avoid the problem of individual family experiences determining the aggregate county ratio. ${ }^{21}$

\footnotetext{
${ }^{20}$ NZSG migrants 04401, 06039, 06049, 06060, 06062, 06063, 06068, 06072, 06083; NZSG migrants 03924, 02017, 06424, 06426, 06429, 06431, 06442, 06443, 06444, 06464, 06470, 06480

${ }^{21}$ In terms of gender Shetland was the most imbalanced of Scotland's counties in 1881, yet exactly 50 per cent of NZSG Shetland migrants were female and 50 per cent male. See Chapter Six for more detail.
} 
Table 4.2

Ratio of females to every 100 males in the 1881 population of Scotland, and in the NZSG data.

\begin{tabular}{|c|c|c|c|c|}
\hline County & $\begin{array}{c}\text { Scotland, } \\
1881 \\
\end{array}$ & $n$ & NZSG & $n$ \\
\hline SHI & 134.71 & 29,705 & 100 & 126 \\
\hline OKI & 113.88 & 32,044 & 45.45 & 64 \\
\hline CAI & 111.33 & 38,865 & 65.93 & 151 \\
\hline Far North & 118.59 & 100,614 & 72.22 & 341 \\
\hline SUT & 108.31 & 23,370 & 75.56 & 79 \\
\hline ROC & 112.13 & 78,547 & 78.48 & 282 \\
\hline INV & 106.27 & 90,454 & 73.33 & 182 \\
\hline ARL & 101.79 & 76,468 & 61.15 & 224 \\
\hline BUT & 117.99 & 17,657 & 85.19 & 50 \\
\hline Highlands & 107.47 & 286,496 & 72.36 & 817 \\
\hline NAI & 109.98 & 10,455 & 83.33 & 11 \\
\hline MOR & 111.28 & 43,788 & 93.62 & 91 \\
\hline BAN & 110.60 & 62,736 & 80.43 & 83 \\
\hline $\mathrm{ABD}$ & 109.21 & 267,990 & 64.29 & 460 \\
\hline $\mathrm{KCD}$ & 102.99 & 34,464 & 38.78 & 68 \\
\hline North East & 109.12 & 419,433 & 66.59 & 713 \\
\hline ANS & 121.80 & 266,360 & 83.33 & 231 \\
\hline PER & 109.59 & 129,007 & 70.72 & 379 \\
\hline FIF & 112.54 & 171,931 & 76.67 & 318 \\
\hline KRS & 115.20 & 6,697 & 125 & 27 \\
\hline CLK & 110.25 & 25,680 & 62.5 & 39 \\
\hline DNB & 101.90 & 75,333 & 57.14 & 121 \\
\hline STI & 100.27 & 112,443 & 81.29 & 252 \\
\hline WLN & 91.29 & 43,510 & 85.37 & 76 \\
\hline MLN & 111.60 & 389,164 & 98.42 & 502 \\
\hline ELN & 104.73 & 38,502 & 68.33 & 101 \\
\hline Eastern Lowlands & 110.90 & $1,258,627$ & 80.42 & 2,046 \\
\hline LKS & 101.29 & 904,412 & 94.11 & 988 \\
\hline RFW & 107.80 & 263,374 & 91.71 & 347 \\
\hline AYR & 103.63 & 217,519 & 65.71 & 406 \\
\hline Western Lowlands & 102.87 & $1,385,305$ & 86.2 & 1,741 \\
\hline BEW & 104.73 & 38,502 & 60.87 & 74 \\
\hline PEE & 108.60 & 13,822 & 73.68 & 33 \\
\hline SEL & 110.25 & 25,564 & 86.67 & 28 \\
\hline ROX & 110.10 & 53,442 & 72 & 129 \\
\hline DFS & 111.36 & 76,140 & 69.47 & 161 \\
\hline KKD & 112.69 & 42,127 & 92.86 & 81 \\
\hline WIG & 112.81 & 38,611 & 46.15 & 76 \\
\hline Borders & 110.37 & 288,208 & 69.19 & 582 \\
\hline Total & 107.55 & $3,738,683$ & 79.03 & 6,610 \\
\hline
\end{tabular}

Source: Appendix Tables, Table VI, 1881 Census of Scotland, p.xix; NZSG data, 1840-1920

Though the profile of the NZSG migrants in terms of age is, as noted in the previous section, not dissimilar to that of Scottish emigrants generally, nor to that of the New Zealand population as a whole, Scottish regional variations are evident. As 
may be seen in greater detail in Appendix 4.1, the age profile of Scots migrating to New Zealand varies significantly from county to county. As with the gender ratio differences mentioned above, this is likely due to factors in the sending communities. Most notable is the youth of Lanarkshire migrants: with an average age for the NZSG data for the whole period of 19.62, one quarter of the migrants from Lanarkshire were under the age of eight, while no more than a quarter were over twenty-eight. The youth of the Lanarkshire migrants is clarified by analysis of the migrants' marital status at arrival. Most of the Lanarkshire migrants were young couples with young children, 43.04 per cent of Lanarkshire migrants being children compared to an average of just 33.19 per cent children for the whole of Scotland. Moreover, 44.40 per cent of children from Lanarkshire were under five years old at arrival, compared to 40.41 per cent of child migrants from the whole of Scotland in the NZSG data. The large proportion of young children in the Lanarkshire migrant population brings the lower quartile age and the mean age for the county down. Comparison of the profile at this county level among migrants to other destinations would allow more confident speculations as to the reasons for the differences, confirming whether the differences are simply due to sample size or if they are socially significant variances. For this reason Appendix 4.1 includes the mean, minimum, maximum, lower quartile, median and upper quartile ages for the migrants in each county and region of Scotland as found in the NZSG data, thereby facilitating comparison with Scots in other destinations at a later date.

In the light of immigrant recruitment policies, the arduous nature of the voyage to New Zealand and the frailty of the elderly, it is unsurprising that while 14.77 per cent of the population of Scotland in 1881 was aged over fifty years, and 7.27 per cent of the New Zealand population was over fifty in that year, just 5.47 per cent of the total NZSG sample was aged fifty-plus at arrival. Also unsurprising is that this fifty-plus sub-sample is primarily made up of those aged between fifty-one to fifty-five - hence 'outliers' in Table 4.1 include those aged sixty-three and above. What is startling in respect of this fifty-plus immigrant group is that the proportion of migrants from each region in this age bracket was by no means uniform across Scotland. For example, although nearly twice as many migrants aged fifty-plus came from the Eastern Lowlands as from the Highlands, a higher proportion of the Highland migrants were aged over fifty (see Table 4.3, below). 
Table 4.3

Scots migrants arriving in New Zealand aged fifty-plus

\begin{tabular}{cccc}
\hline \hline Region & $\begin{array}{c}\text { Proportion of total } \\
\text { Scottish migrants }\end{array}$ & $\begin{array}{c}\text { Proportion of regions } \\
\text { total migrants }\end{array}$ & * \\
\hline \hline Far North & 0.33 & 6.45 & 341 \\
Highlands & 0.94 & 7.58 & 818 \\
North East & 0.53 & 4.91 & 713 \\
Eastern Lowlands & 1.83 & 5.91 & 2,046 \\
Western Lowlands & 0.92 & 3.5 & 1,743 \\
Borders & 0.55 & 6.18 & 582 \\
Total & $\mathbf{6 . 2 2}$ & & $\mathbf{6 , 6 0 8}$ \\
\hline *n for Total is for all migrants with age information, so the total ' $n$ ' does not $=$ sum of the region \\
totals, as these do not include those for whom there is age but not region of birth information. \\
Source: NZSG data, 1840-1920
\end{tabular}

A probable reason for the relatively high number of Highland migrants arriving aged fifty-plus is the apparent tendency of Highland migrants, especially, to migrate with elderly parents rather than have a member of the family remain in Scotland to care for them. ${ }^{22}$ Though this appears to have been less common among 'Lowland' migrants, it was the case with Mary McCaig, born in Kirkcudbright. Widowed and aged eighty years, Mary arrived in Otago in October 1867 on the William Davie, accompanied by her only son, Alexander, her daughter-in-law and youngest grandchild. Though five other grandchildren remained in Scotland, Mary accompanied Alexander to New Zealand, where the four of them joined Alexander's son William in Otago. William had settled in Otago in the early 1860 s, after time on the Australian goldfields. Mary lived with Alexander and his wife until her death at age $87 .^{23}$ As noted in Appendix 1.1, tracing the travel companions for all the migrants in the NZSG database has not been possible for the present study. However, a limited survey of the available data, reveals that many of those aged sixty-plus were travelling to New Zealand with their adult children. ${ }^{24}$ By contrast, many of those in their early fifties had young families, couples often producing children for over twenty years.

Table 4.4 compares the proportion of the 1881 population of Scotland and of the NZSG sample migrants who were married or single. ${ }^{25}$ As the table indicates, while the Far North sent single and married migrants in similar proportions to the 1881

\footnotetext{
${ }^{22}$ McClean, 'Scottish Emigrants to New Zealand, 1840-1880', , pp.384-385

${ }^{23}$ NZSG migrants 01081, 01878, 01885, 01925, 03459.

${ }^{24}$ McClean carried out such a task with a sub-sample of her migrants. See McClean, 'Scottish Emigrants to New Zealand, 1840-1880', chapter seven.

${ }^{25}$ Widowed migrants have been excluded from the proportions because a much greater proportion of the Scottish population was widowed than were NZSG migrants at arrival in New Zealand, and this difference skews the proportions presented making comparison less clear. Appendix 4.2 is a breakdown of the marital status composition of the NZSG Scots by county and region of birth into child, single, married, widowed and 'either widowed or spouse absent' for the whole period, 1840-1920.
} 
sending population, this replicating pattern is not paralleled among the New Zealand Scots from any other region. The table reinforces the earlier finding (see Figure 4.1) that, though single females and single males were actively recruited by various assisted immigration schemes, for most counties and regions in Scotland married Scots were considerably more likely than single adults to emigrate to New Zealand.

Table 4.4

Showing the proportion of the Scottish population and of the NZSG migrants married or single.

\begin{tabular}{ccccc}
\hline \hline & & Single & Married & $\boldsymbol{n}$ \\
\hline \hline \multirow{4}{*}{1881} & Far North & 52.25 & 47.75 & 61,626 \\
Scotland & North East & 50.04 & 49.96 & 235,660 \\
& Highlands & 55.07 & 44.93 & 173,783 \\
& Eastern Lowlands & 48.53 & 51.47 & 728,430 \\
& Western Lowlands & 45.73 & 54.27 & 787,549 \\
& Borders & 51.12 & 48.88 & 165,387 \\
\hline \multirow{4}{*}{ NZSG, } & Far North & 51.34 & 48.66 & 187 \\
$1840-$ & North East & 40.63 & 59.37 & 443 \\
1920 & Highlands & 43.08 & 56.92 & 513 \\
& Eastern Lowlands & 35.21 & 64.79 & 1,119 \\
& Western Lowlands & 36.79 & 63.21 & 927 \\
\hline Source: NZSG data 1840-1920; Appendix Tables, Table LX and LXI, 1881 Census \\
of Scotland, 'pp.xlix and 1
\end{tabular}

Examining the ratio of female to male children by Scottish regions and counties suggests that the New Zealand Scots may in fact have mirrored the patterns observed in studies of Dutch migrants and by Erickson of Scots to the United States in $1841 .^{26}$

Table 4.5

Showing the proportion of children who were male and the ratio of female children to every 100 male children in the home population and the NZSG data, from each region of Scotland.

\begin{tabular}{ccccc}
\hline \hline & \multicolumn{2}{c}{$\%$ of children that were male } & \multicolumn{2}{c}{ Ratio (females to 100 males) } \\
& Scotland, 1881 & NZSG, 1840-1920 & Scotland, 1881 & NZSG, 1840-1920 \\
\hline \hline Far North & 50.08 & 53.41 & 96.86 & 87.23 \\
Highlands & 51.25 & 41.90 & 95.12 & 138.67 \\
North East & 50.74 & 52.02 & 97.07 & 92.22 \\
Eastern Lowlands & 50.69 & 53.50 & 97.26 & 86.92 \\
Western Lowlands & 50.49 & 53.08 & 98.07 & 88.40 \\
Borders & 50.69 & 53.08 & 97.26 & 88.41 \\
Total & 50.66 & 52.04 & 97.39 & 92.16 \\
\hline
\end{tabular}

Sources: NZSG data, 1840-1920; Population, Scotland, Vol.II, Abstracts, 1881 Census of Scotland, pp.4-5

The figures presented in Table 4.5 indicate that the difference between the female to male ratio of 'children' in the home population and among Scots immigrants was significant, possibly indicating a greater tendency of families with male children to

\footnotetext{
${ }^{26}$ See also McClean, 'Scottish Emigrants to New Zealand, 1840-1880’.
} 
emigrate. This is not so obvious in the analysis of migrants from the whole of Scotland (noted in the previous section) because the migrant ratio figure for the country as a whole is brought closer to the population of Scotland ratio by the anomalous figure for the Highland Region. While home population figures for the Highland Region indicate that the proportion of males under fifteen in the region was higher than in any other region of Scotland, NZSG figures suggest that a considerably higher proportion of female children from that region came to New Zealand. This gender imbalance among children is most pronounced among migrants from Inverness, just 30.56 per cent of child migrants in the NZSG sample being male, compared to 51.38 per cent of children in the home population. Individual examples within the sample are illustrative. The MacMillan family of Inverness, arriving in Port Chalmers in 1859, had nine children, six of whom were female, giving a gender ratio among the MacMillan children of 200:100, or 66.66 per cent female. ${ }^{27}$ The gender ratio of the Gillanders' children of Inverness was 133.33:100, or 57.14 per cent female. ${ }^{28}$ There is no readily apparent reason for this pattern, except that it appears to be consistent with the high propensity of young single women from the Highlands to migrate to towns in search for jobs in domestic service. Given the figures available, it may fairly be noted that families with female children in the Highland Region were more likely than those with male children to emigrate to New Zealand.

\section{DEMOGRAPHIC PROFILE OF NEW ZEALAND's SCOTS BY PLACE OF SETTLEMENT}

The ratio of Scotland-born females to males in New Zealand being 74.6:100 at the highest point in 1896 , and 58.68:100 at the lowest in 1867, it might be expected that the ratio of Scots females to males in every province and county of New Zealand over the whole period would lie somewhere within this range. In fact, the ratio of Scotlandborn females to males varied greatly from province to province. The West Coast was the least gender balanced province in terms of Scots migrants over the eight decades. At the 1871 Census just 30.2 Scotland-born females resided in the province for every 100 Scotland-born men. The peak of Scottish females per 100 Scottish males, reached in 1911, was just 53.58:100. Otago had the most even distribution of male and female Scots throughout the period, at the minimum (in 1871) 66.93 females to every 100 Scots males residing in the province, with 85.02 Scots females to every 100 males in

\footnotetext{
${ }^{27}$ NZSG migrants $03275,03276,03277,03278,03280,03281,03282,03283,03284,04173,06602$

${ }^{28}$ NZSG migrants 02062, 02064, 02068, 02075, 02076, 02077, 02079
} 
1911. These gender ratio differences between Otago and the West Coast are predictable, given the nature of the migrations to those two provinces - the Otago flow being relatively family-oriented (despite the gold rushes) and the West Coast attracting large numbers of single men, especially in the gold rush ear of the 1860s. As Table 4.6 indicates, the Scotland-born population of each region of New Zealand was more disproportionately male than the total New Zealand population of the same regions. The region in which the gender ratio of Scots was closest to the region's total population gender ratio was Otago, but this was due to the Scots-born in the region constituting over one fifth of the region population at that census. That the West Coast Scots-born ratio differed most from the region's population ratio generally is probably a remnant of the high proportion of Scots miners to the region, especially single males, this data being collected in $1881 .^{29}$

Table 4.6

Ratio of females to males in the Scotland-, Ireland- and England-born and the New Zealand total population, 1881.

\begin{tabular}{ccccccccc}
\hline \hline Province & Scots & $\boldsymbol{N}$ & Irish & $\boldsymbol{n}$ & English & $\boldsymbol{n}$ & NZ Total & $\boldsymbol{n}$ \\
\hline \hline Auckland & 68.14 & 6,216 & 84.93 & 12,017 & 69.92 & 24,924 & 83.79 & 99,451 \\
Taranaki & 55.24 & 711 & 43.40 & 1249 & 64.58 & 4409 & 74.45 & 14,858 \\
Hawke's Bay & 58.74 & 1,189 & 65.87 & 1,672 & 68.90 & 5,160 & 79.04 & 17,367 \\
Wellington & 71.07 & 3,849 & 87.73 & 4,209 & 77.28 & 17,123 & 87.58 & 61,371 \\
Marlborough & 51.56 & 535 & 69.98 & 719 & 57.82 & 2189 & 77.18 & 9,300 \\
Nelson & 52.66 & 1,664 & 50.20 & 2,208 & 64.63 & 5,739 & 76.18 & 26,075 \\
West Coast & 38.95 & 1,081 & 67.92 & 2,413 & 47.90 & 2,424 & 65.4 & 15,010 \\
Canterbury & 67.80 & 8,499 & 81.28 & 12,494 & 77.99 & 34,992 & 85.15 & 112,182 \\
Otago & $\mathbf{7 5 . 1 6}$ & 28,992 & 81.52 & 12,365 & 68.28 & 22,208 & 79.52 & 134,077 \\
New Zealand & $\mathbf{7 0 . 1 4}$ & $\mathbf{5 2 , 7 5 3}$ & $\mathbf{7 8 . 4 2}$ & $\mathbf{4 9 , 3 4 6}$ & $\mathbf{7 1 . 6 2}$ & $\mathbf{1 1 9 , 2 2 4}$ & $\mathbf{8 1 . 7 2}$ & $\mathbf{4 8 9 , 6 9 1}$ \\
\hline
\end{tabular}

Source: Part V, Table VI, Census of New Zealand, p.196

What Table 4.6 also suggests is that Nelson, Marlborough, Taranaki and Hawkes Bay had considerably less than the national average of females per males, among Scots as well as the English and Irish. This may indicate that females, or families, were more likely to settle in the main centres of New Zealand - Auckland, Wellington, Christchurch and Dunedin - where female employment opportunities were greater and the settlements and facilities therein better established.

The gender balance of Scots in each New Zealand county in the NZSG data reinforces this speculation. Analysing the data by county, it is necessary to exclude

\footnotetext{
${ }^{29}$ Terry Hearn, 'Scots miners in the goldfields, 1861-1870', in Tom Brooking and Jennie Coleman (eds), The Heather and the Fern: Scottish Migration and New Zealand Settlement, Dunedin, 2005
} 
those counties for which the sub-sample is less than thirty for the whole period. ${ }^{30}$ Of those counties remaining there does not appear to be any clear pattern as to the gender ratio of Scots, except that areas of New Zealand with larger populations, with larger urban centres, held a more even male/female distribution of Scottish migrants than counties with smaller populations or little or no urban element. The counties that included within them Auckland, Wellington, Christchurch, Dunedin and Invercargill all had a male to female ratio close to or greater than the national average (81.72:100): Eden 90.93, Hutt 90.64, Selwyn 80.85, Taieri 84.00 and Southland 82.03 Scots females to every 100 Scots males. Wanganui County and Rangitikei County share a border, yet Rangitikei County held only 72.09 Scots females per 100 Scots males in the NZSG sample, while Wanganui County, including the town of Wanganui itself, held 88.06 Scots females per 100 Scots males. Marlborough and Waimea counties also shared a border, but held 67.86 and 108.51 Scots females per 100 Scots males respectively, principally because Waimea incorporated the town of Nelson. Southland and Wallace Counties shared a border but Wallace contained only 56.36 Scots females for every 100 Scots men, while Southland (containing Invercargill) had $82.03: 100 .^{31}$

Examining the age of the migrants by place of settlement in New Zealand, there is great variance on the national average in the NZSG data, with wide discrepancies between males and females and between counties, many of them inexplicable at this aggregate level of analysis. For example, female migrants in Eden County were, on average, 22.4 years old at arrival in New Zealand, while Scots males in that county averaged 32 years of age. This Eden County sub-sample includes 111 female children and 113 male children; 127 of the married adults were female and 126 male. There is no suggestion from the evidence of age distribution that might explain this disparity between the average age at arrival of male and female migrants. While fifty-four of the single migrants were female and seventy-five male, only seven of the single migrants was aged over thirty years and five of these were female. This suggests that the reason for the disparity is attributable to the ages at marriage of Scottish migrants who settled in Eden County.

\footnotetext{
${ }^{30}$ See Chapter Three, footnote 40 for explanation

${ }^{31}$ Oddities in the NZSG data include the counties of Tauranga, Maniototo and Waitaki that all had more Scots females than males (as did Waimea County) with 106.25, 102.78 and 101.98 females per 100 males respectively. Whangarei County - the county that included Waipu - held the lowest ratio of females to males in the NZSG data with just 53.57 Scots females for every 100 Scots men.
} 
In Whangarei the average age for female Scots was 20.57 and for males 27.27 years, a difference caused by the larger proportion of older married male Scots than females - the oldest female in the sample being thirty-nine at arrival, with four males in the sample aged forty-one, forty-four, fifty-four and fifty-six at arrival. Wanganui also exhibited a large age variance between males and females, the average ages there being 26.71 and 18.98 for males and females respectively, though in this case the age disparity arises from the larger proportion of female children, 24.75 per cent of the total sample and 71.43 per cent of children in the sample being female. Waimea County, including Nelson, also exhibited a great difference in age between male and female Scots at time of arrival, the difference being 7.02 years. As for Wanganui, the relatively low female age for Waimea County (compared to that for males) is attributable to the large number of female children who settled in Nelson (see discussion relating to Table 4.7 , below.) $)^{32}$

Scots in Westland County reversed this gender ratio trend, Scots females in the county being, on average, 3.67 years older than Scots males, the average ages being 28.80 and 25.13 years respectively. This Westland figure is due to the larger proportion of single men than women arriving in the county as a result of the gold rushes and the later emphasis in the area on extractive industries such as coal mining and bush felling. While the gender ratio of both children and married Scots arriving in the county was even, just 31.25 per cent of the single migrants were female. Of the single men in this sub-sample, 63.63 per cent were between twenty and twenty-five years of age at arrival. The female average age figure is also affected by the one migrant in the sub-sample over the age of forty-seven, Jane Spence, born in West Lothian, who arrived in New Zealand in 1878 aged $64 .{ }^{33}$

Taieri migrants were older than the migrants in most counties, Scots females there having an average age of 25.34 and males of 26.97 years at arrival. ${ }^{34}$ Migrants in Taranaki County were, on average, nine to ten years younger than in neighbouring county, Patea: males in Taranaki County had an average age of 18.32 years compared to Patea's average of 28.64 and Taranaki female Scots an average age of 17.07 years compared to Patea's 26.63. The difference between Taranaki and Patea is likely to be

\footnotetext{
${ }^{32}$ Waimea female average age 18.78 years, male average 25.8 years

${ }^{33}$ NZSG migrant 05713

${ }^{34}$ Migrants to Otago Province were, on average, the second oldest (behind West Coast), females being 25.83 years of age on average and males 26.68 .
} 
the result of the location of an urban centre, New Plymouth, in Taranaki County. Wellington (Hutt County), Christchurch (Selwyn County) and Invercargill (Southland County) all had average ages near the national average. ${ }^{35}$ It appears that just as counties that included larger urban centres received more female migrants, proportionately, than other more overtly rural areas, urban centres also received younger female migrants, presumably because the urban employment opportunities attracted a greater proportion of young, single female migrants. This proposition appears to be borne out in the case of Taranaki County compared to Patea and in Eden County.

Table 4.7

Showing the ratio of female to male children and proportion of children who were male in the NZSG data and at the 1878 Census by New Zealand province.

\begin{tabular}{ccccccc}
\hline \hline & \multicolumn{3}{c}{ NZSG children } & \multicolumn{3}{c}{ 1878 Census children } \\
& Ratio & \% male & n & Ratio & \% male & $\boldsymbol{n}$ \\
\hline \hline Auckland & 96.77 & 50.82 & 366 & 96.45 & 50.9 & 35,244 \\
Taranaki & 53.85 & 65 & 40 & 96.84 & 50.8 & 4,242 \\
Hawkes Bay & 105.88 & 48.57 & 35 & 99.94 & 50.02 & 6,252 \\
Wellington & 105.83 & 48.58 & 212 & 100.07 & 49.98 & 21,515 \\
Nelson & 164.71 & 37.78 & 45 & 96.99 & 50.77 & 10,064 \\
Marlborough & 100 & 50 & 18 & 103.82 & 49.06 & 3,202 \\
West Coast & 100 & 50 & 8 & 101.29 & 49.68 & 6,250 \\
Canterbury & 77.11 & 56.46 & 147 & 98.24 & 50.44 & 39,791 \\
Otago/Southland & 90.57 & 52.47 & 566 & 98.23 & 50.45 & 48,259 \\
\hline Source: NZSG data 1840-1920; Part II, Table XIV, 1878 Census of New Zealand, pp.61-62.. \\
$n=$ children in the sample/census
\end{tabular}

The ratio of female to male Scots children in Auckland, Hawkes Bay, Wellington, Marlborough and West Coast Provinces was close to the ratio in the New Zealand population in those provinces. Gender ratios for Scots children settling in Taranaki, Canterbury and Otago, however, suggest that Scots families settling in these provinces were, as with Erickson's British migrants to the United States in 1841, more likely to have sons than daughters. It is probable that this is due to the prominence of agriculture in these provinces, and the relative usefulness of male children compared to female children in agricultural work. Families with male children were therefore better suited to these agricultural areas, while families with daughters appear to have been more likely to settle in urban areas where prospects for domestic employment and marriage were better. Nelson Province inverts this pattern. Children in Nelson Province constitute 45.9 per cent of all Scots female migrants to

\footnotetext{
${ }^{35}$ Hutt female average 22.05, male average 23.89; Selwyn female average 22.68, male average 23.54; Southland female average 22.6 , male average 24.5 years.
} 
the province. Female children were the largest group of Scots migrants in Nelson Province generally - 23.73 per cent of the total Scots population. In no other province, according to the NZSG data, did the proportion of Scots migrants classified as female children approach this level. Why this anomaly arises among Nelson's Scots female child migrants is unclear. Given that the province of residence these figures are based upon is derived from stated place of death, a possible explanation is that female children who came to the province were more likely than other groups to remain there for the rest of their lives. If children arriving in Nelson Province came in equal male and female numbers, but male children tended to move away, and/or to die elsewhere, this might explain the anomaly. It is a plausible explanation, as male migrants in the area would have been more attracted than females to move from Nelson to work on the gold and coal fields further south, or to take up labouring elsewhere in the country. James, Joseph, John and William Brown Allen, four brothers from Kilmarnock, Ayr, arrived in Nelson with their family in 1842, aged eighteen, fourteen, eleven and five years old respectively. It is unclear when the brothers moved from Nelson, but the next place of residence recorded for John was Dunstan and for James, Joseph and William Brown, Dunedin. All four brothers have 'farmer' recorded as their New Zealand occupation. Each died in East Taieri in 1891, 1879,1901 and 1867 respectively. ${ }^{36}$

\section{DEMOGRAPHIC PROFILE OF NEW ZEALAND’s SCOTS BY PERIOD OF ARRIVAL}

Examining the demographic profile of the migrants by period of arrival reveals that the age, gender and marital status composition of the Scots differed significantly by time.

Table 4.8

Ratio of Scottish female migrants to every 100 Scottish male migrants in each period of arrival

\begin{tabular}{ccccc}
\hline \hline Pre-1852 & $\mathbf{1 8 5 3 - 1 8 7 0}$ & $\mathbf{1 8 7 1 - 1 8 8 6}$ & $\mathbf{1 8 8 7 - 1 9 0 0}$ & $\mathbf{1 9 0 1 - 1 9 2 0}$ \\
\hline \hline 82.55 & 79.36 & 87.49 & 67.01 & 84.16 \\
$\boldsymbol{n}=659$ & 2,816 & 1,708 & 162 & 558 \\
\hline \multicolumn{2}{l}{ Source: NZSG data $1840-1920$} & & &
\end{tabular}

As indicated in Table 4.8, between 1852 and 1870 and in the period 1887 to 1900 proportionately more Scottish males than females arrived in New Zealand than at other times. The earlier period was marked by increased employment opportunities for men, the gold rushes creating employment for males not only in mining but across

${ }^{36}$ NZSG migrants 00205, 00212, 00213, 00219 
the board, the population boom resulting from the rushes creating a larger market for basic goods and services and a greater need for housing. The consequent influx of male migrants thus reduced the ratio of females in that period. It is conceivable that the decrease in the ratio of females to males in the later period was due to the availability of fewer employment opportunities for female migrants than usual. The period witnessed economic depression in the late 1880s and slow economic recovery in the early $1890 \mathrm{~s}$ and it is likely these economic factors decreased demand for domestic servants and consequently also for female migrants. Certainly there was a decrease in domestic service employment across New Zealand, from 53.6 per cent of all employed females in 1886 to 46.16 per cent in $1891 .^{37}$ The discontinuation of assistance for nominated immigrants in December 1887 also undoubtedly affected the flow of female migrants into New Zealand, more so than the flow of males, further reducing the number of females compared to males arriving over this period. ${ }^{38}$

The highest ratio of females to males is observed for migrant arrivals during the period 1871 to 1886 , almost certainly as a result of the emphasis on family migration and on the recruitment of single female migrants to meet the demand for domestic servants in the colony. Even so, the NZSG data suggests a much higher female to male ratio for this period than that postulated by Morris in his 1973 study. Morris records a $67.76: 100$ ratio of females to males, ${ }^{39}$ whilst analysis of the NZSG data produces a ratio of $90.34: 100$ for the same nine year period (1871-1879). ${ }^{40}$ The reason behind this difference of nearly twenty-three females per 100 males between the samples probably lies with the higher proportions of females contributed by counties in the Highlands compared to Eastern and Western Lowland counties in the NZSG sample for this period. Morris notes that 'the Lowland area of Scotland in which Lanarkshire was the most important recruitment county... sent a considerable number of women'. ${ }^{41}$ While this finding is borne out in the NZSG data for the period 1840 to

\footnotetext{
${ }^{37}$ The decrease in domestic service employment among females in the population of New Zealand as a whole from 53.6 per cent of all employed females in 1886 to 46.16 per cent in 1891 (45.27 per cent in 1896 and 44.18 per cent in 1901) may also indicate this phenomenon. Part VII, Table I (also Table III for 1881 and 1886), 1881, 1886, 1891, 1896 and 1901 Censuses of New Zealand

${ }^{38}$ Terry Hearn and Jock Phillips, 'Immigration study findings', unpublished manuscript, Part 4: The great migration, 1870-1890', c.2007, available at: http://www.nzhistory.net.nz/culture/home-awayfrom-home/sources, p.38

39 40.39:59.61 in his text. Calculation: $59.61 / 100=1.677570877 ; 40.39 * 1.677570877=67.75708774$ females to every 100 males. Morris, 'The Assisted Immigrants to New Zealand', p.154.

${ }^{40}$ For the period 1871 to 1886 the NZSG ratio is $87.49: 100$

${ }^{41}$ Morris, 'The Assisted Immigrants to New Zealand', p.154.
} 
1920 as a whole (see Table 4.2 above and relevant discussion), the NZSG data suggest that females constituted a larger proportion of migrants in the Far North and Highland Region counties than in the Lowland and Border counties in the Vogel period. Table 4.9 shows the ratio of females per 100 males arriving from each region of Scotland for each period under analysis.

Table 4.9

Ratio of Scottish female migrants in each period of arrival to every 100 Scottish male migrants, by region of birth

\begin{tabular}{cccccc}
\hline \hline & Pre-1852 & $\mathbf{1 8 5 3 - 1 8 7 0}$ & $\mathbf{1 8 7 1 - 1 8 8 6}$ & $\mathbf{1 8 8 7 - 1 9 0 0}$ & $\mathbf{1 9 0 1 - 1 9 2 0}$ \\
\hline \hline Far North & 40.00 & 76.47 & 98.65 & 50.00 & 30.00 \\
Highlands & 66.00 & 75.93 & 93.00 & 43.75 & 64.00 \\
North East & 79.41 & 65.19 & 75.76 & 56.00 & 84.00 \\
Eastern Lowlands & 84.25 & 76.46 & 85.94 & 142.86 & 96.55 \\
Western Lowlands & 90.59 & 87.81 & 90.57 & 36.67 & 84.91 \\
Borders & 50.00 & 70.29 & 73.63 & 77.78 & 60.00 \\
$\boldsymbol{n}$ & 659 & 2,816 & 1,708 & 162 & 558 \\
\hline
\end{tabular}

Source: NZSG data 1840-1920

Both the Far North and the Highlands contributed higher proportions of females to males than the Lowland regions or the Borders between 1871 and 1886.

Another contrast between the Morris findings and the results of the NZSG data analysis is the number of counties 'throughout the whole of Scotland' where 'females [were] dominant among the immigrants'. ${ }^{42}$ Morris records female 'dominance' females accounting for more than 50 per cent of the migrants - in Shetland, Kincardine, East Lothian and Midlothian. For the period 1871 to 1886 the NZSG data shows female 'dominance' in twelve counties. Discounting those counties for which the sub-samples are too small for reliable inferences, these counties are, in order of female 'dominance': Midlothian (56.86 per cent); Renfrewshire (55.56 per cent); Ross and Cromarty (52.99 per cent); Shetland (51.28 per cent); Caithness (50.98 per cent); and Inverness (50 per cent). That counties in the Far North and Highlands frequently exhibit ratios of females to males that are higher than the Eastern or Western Lowlands or Borders, indicates that while female assisted immigrants in the Vogel years may have mostly been from 'Lowland' counties, the Far North and Highland counties sent proportionately more females than 'Lowland' counties during that period.

\footnotetext{
42 ibid.,
} 
A notable feature of analysis of age by period of arrival is the relative youth of the migrants arriving prior to 1886 compared to the later periods (see Table 4.10).

Table 4.10

Age statistics for Scots migrants in New Zealand by period of arrival

\begin{tabular}{cccccc}
\hline \hline & Pre-1852 & $\mathbf{1 8 5 3 - 1 8 7 0}$ & $\mathbf{1 8 7 1 - 1 8 8 6}$ & $\mathbf{1 8 8 7 - 1 9 0 0}$ & $\mathbf{1 9 0 1 - 1 9 2 0}$ \\
\hline \hline $\boldsymbol{n}$ & 651 & 2,722 & 1,686 & 160 & 553 \\
Mean & 21.91 & 23.74 & 23.10 & 26.86 & 24.10 \\
Minimum & $4 \& 8$ & 23 & 1 & $26,27 \& 33$ & 23 \\
Lower Quartile & 0 & $-2 *$ & 0 & 0 & 0 \\
Median & 20 & 12 & 11 & 15 & 12 \\
Upper Quartile & 32 & 23 & 21 & 26 & 23 \\
Maximum & 74 & 32 & 32 & 36.75 & 34 \\
'Outliers'** & $65+$ & $62+$ & 75 & 75 & 76 \\
\hline * Two of the migrants recorded in the register have arrival dates that precede their date of birth, one by one year, and \\
one by two years. \\
** Upper Quartile + 1.5 x the Inter Quartile Range (Upper Quartile minus Lower Quartile) \\
Source: NZSG data, 1840-1920
\end{tabular}

The average (mean) ages of those arriving pre-1852 and between 1871 and 1886 are brought down by the modal tendencies (most common age) for these periods; this is very young, the mode being four and eight years old for pre-1852 and just one year old between 1871 to 1886 . Conversely, those arriving between 1887 and 1900 tended to be older, with an average age of 26.85 and a shared most common age of twentysix, twenty-seven and thirty-three. While one quarter of the migrants arriving pre1852 and between 1871 and 1886 were under ten and eleven respectively, this lower quartile figure for 1887 to 1900 is fifteen years of age. The youth of the migrants in the earlier periods was almost certainly a result of the recruitment of assisted migrants, with the inherent age restrictions and emphasis on family migration that assistance implied. During those years in which assistance was not available, or not so readily available, older migrants were proportionately more numerous, probably because they were more likely, relative to families with young children, to be able to access resources to fund their migration themselves. Further, in years during which assistance was not so readily available the flow of migrants from elsewhere, especially from across the Tasman, became proportionately more significant, and many of these step-migrants would have been older.

Table 4.11

Ratio of Scottish female child migrants in each period to every 100 Scottish male child migrants

\begin{tabular}{cccccc}
\hline \hline Pre-1852 & $\mathbf{1 8 5 3 - 1 8 7 0}$ & $\mathbf{1 8 7 1 - 1 8 8 6}$ & $\mathbf{1 8 8 7 - 1 9 0 0}$ & $\mathbf{1 9 0 1 - 1 9 2 0}$ & Total \\
\hline \hline 102.40 & 94.43 & 84.52 & 64.00 & 83.67 & 91.72 \\
$\boldsymbol{n}=253$ & 838 & 596 & 41 & 180 & 1,923 \\
\hline
\end{tabular}

Source: NZSG data, 1840 to 1920 
Analysis of the NZSG data in respect of the ratio of female to male children arriving in each period of arrival (Table 4.11) indicates further significant differences over time. While Erickson's suggestion that families with male children were more likely than those with female children to emigrate appears to be borne out among New Zealand's Scots from the 1870s, the ratio of male and female children was closer in the first two periods of arrival. Though the very low ratio noted in the 1887-1900 period is, once again, more likely due to small sample size than any real difference, the difference between the ratio of female to male children in the Vogel and in the early twentieth-century periods is a significant decrease from that seen in the first two periods. There is no obvious explanation for this divergence. Indeed, it is fair to say that analysis of the variation in demographic indices according to period is in general less fruitful for the NZSG data than spatial analysis according to place of origin or place of settlement. Some of the reasons for why this is so are linked to the ways that methodological issues affect the NZSG data to differing extents depending on period of arrival, as will be discussed in the following section.

TESTING THE GENEALOGICALLY SOURCED DATA SET - COMPARISON WITH THE Peopling of New Zealand (PNZ) data

Comparisons between the PNZ and NZSG datasets with regard to gender, age and marital status make it very clear that both sets of data are significantly biased, albeit in different ways. In terms of providing a representative sample of migrant experience and characteristics, neither set is ideal. Comparison between the two sets of data indicates the validity and reliability of the parallel findings emphasising biases that might otherwise be disguised.

Examining gender by period of arrival there are marked differences in both datasets in the proportions and ratios for each region and county of Scotland in every period of arrival. In every period except 1901 to 1920 (see Table 4.12) the ratio of females to males in the datasets is lower in the PNZ data.

Table 4.12

Ratio of Scottish female migrants to every 100 male migrants in each period of arrival

\begin{tabular}{cc|cc|cc|cc|cc}
\multicolumn{2}{c|}{ Pre 1852 } & \multicolumn{2}{|c|}{$\mathbf{1 8 5 3 - 1 8 7 0}$} & \multicolumn{2}{|c|}{$\mathbf{1 8 7 1 - 1 8 8 6}$} & \multicolumn{2}{c|}{$\mathbf{1 8 8 7 - 1 9 0 0}$} & \multicolumn{2}{|c}{$\mathbf{1 9 0 1 - 1 9 2 0}$} \\
\hline \hline \multirow{2}{*}{ NZSG } & PNZ & NZSG & PNZ & NZSG & PNZ & NZSG & PNZ & NZSG & PNZ \\
82.55 & 69.77 & 78.91 & 73.26 & 87.49 & 85.87 & 67.01 & 59.55 & 84.16 & 84.39 \\
$\boldsymbol{n}=659$ & 219 & 2,816 & 745 & 1,708 & 684 & 162 & 142 & 558 & 496 \\
\hline
\end{tabular}

Sources: NZSG and PNZ data 1840-1920 
While, as noted in the previous section, a lower proportion of females to males is predictable in the pre-1852 period, a consequence both of the requirement that PNZ migrants live to at least 1876 in order to be included in the data, and the higher life expectancy of females in this period of New Zealand history, it might also be expected that during this period the PNZ data would contain a higher proportion of females than males than the NZSG data for that same reason. This is not the case. In fact, in the pre-1852 years the difference between the PNZ and the NZSG samples is most stark, the NZSG data suggesting 82.55 females for every 100 men, the PNZ data just 69.77. A possible reason for the discrepancy between the two datasets may be the bias regarding single men in the NZSG data, men arriving in New Zealand single being less likely than other migrant groups to marry and have children to produce descendants to fill in NZSG register forms. It is also possible that the ratio of females to males was higher in every period (except 1901-1920) in the NZSG data than the PNZ data because single men were under-represented in the NZSG dataset and as such the ratio of females to males in those periods of arrival is consequently comparatively higher.

The PNZ data yields markedly different results with regard to the migrant ages at arrival compared to the NZSG data. Whereas the average age of the NZSG migrants was 23.5 years, the average age of PNZ migrants was 26.4 years. Comparing the average age of the migrants from 1840 to 1920 for each region of Scotland, it is noticeable that the PNZ migrants were between 1.65 and 4.48 years older than the NZSG migrants (see Table 4.13).

Table 4.13

\begin{tabular}{cccccc} 
Mean ages of Scots migrants to New Zealand & arriving between 1840-1920 by region of birth \\
\hline \hline \multirow{2}{*}{ Region } & \multicolumn{2}{c}{ PNZ } & \multicolumn{2}{c}{ NZSG } & Difference \\
& \% & $\boldsymbol{n}^{*}$ & $\%$ & $\boldsymbol{n}^{*}$ & 3.42 \\
\hline \hline Far North & 27.62 & 156 & 24.20 & 288 & 1.65 \\
Highlands & 28.10 & 265 & 26.45 & 709 & 2.28 \\
North East & 26.55 & 218 & 24.27 & 622 & 2.62 \\
Eastern Lowlands & 25.88 & 701 & 23.26 & 229 & 4.48 \\
Western Lowlands & 25.69 & 763 & 21.21 & 1,571 & 1.89 \\
Borders & 26.82 & 164 & 24.93 & 514 & 2.98 \\
Total & 26.44 & 2,428 & 23.46 & 5,819 & \\
\hline $\boldsymbol{n}$ for Total is for all migrants with age information, so the total ' $n$ ' does not $=$ sum of the region totals, as these do \\
not include those for whom there is age but not region of birth information. \\
Sources: NZSG and PNZ data, 1840-1920
\end{tabular}

The frequent inexact recording on death certificates of the number of years spent in New Zealand since immigration potentially affects findings for any data set, such as 
the PNZ data, based on this source alone. A noticeably larger number of migrants in the PNZ sample were recorded as having spent a round number of years in New Zealand: thirty-four of the migrants had lived in New Zealand for twenty-nine years before death, but eighty-seven were recorded as having been in the county for thirty years; fifty-nine migrants had been in New Zealand for forty-nine years, but 129 for fifty years. If the number of years spent in New Zealand was more often rounded down rather than up, then the calculated age at arrival for many of the migrants in the sample would be higher than was actually the case. ${ }^{43}$ This rounding tendency appears to have affected the age pattern exhibited in the PNZ data.

Single, rather than married persons, are the majority marital status group in the PNZ data. The difference between the two sets of data for child migrants is 14 per cent and there is an 18 per cent difference between the proportions of migrants who were 'single' in the datasets. The most important reason for the discrepancy between the two datasets is that single migrants were less likely than married migrants to be entered in the NZSG register. Those arriving in New Zealand married were more likely than their contemporaries arriving 'single' to have children and therefore to have descendants in the late twentieth century to fill in a registration form about them. The PNZ data is therefore not biased towards married migrants as is the NZSG data. Two other factors contribute to the discrepancy. Firstly, the PNZ data classifies all persons not married at arrival as single, not differentiating between someone who was single and someone who was widowed at arrival. Given the probable reason for the average age of PNZ migrants being approximately three years older it is likely too that a number of migrants listed as being sixteen to nineteen years of age at arrival may have actually been under sixteen and should thus have been recorded as children and not as single adults. Both of these factors have decreased the number of migrants recorded as married or as children and consequently inflated the proportion of single migrants in the PNZ data.

\footnotetext{
${ }^{43}$ A similar rounding of ages to the nearest zero or five is noted with regard to 'age-heaping' in Irish census returns in the mid-nineteenth century though in that case it is indicative of high rates of illiteracy rather than vagueness about the information recorded per se. (Cormac Ó Gráda, 'Across the briny ocean: some thoughts on Irish emigration to America, 1800-1850', in T.M. Devine and David Dickson (eds), Ireland and Scotland 1600-1850: Parallels and Contrasts in Economic and Social Development, Edinburgh, 1983, p.122). This 'number of years in New Zealand' information on the death certificates was, like all of the other information on the certificates, provided to the registrar by obviously - someone other than the deceased, so accuracy varied depending on the relationship that person had with the deceased.
} 
The proportions of each gender recorded as single or married also differ in the two datasets. More females in the PNZ data were married than single, as was also the case for the NZSG sample (56.08 per cent of all PNZ adult females were married). However, here the similarities end: 57.13 per cent of all PNZ adult males were single and just 34.77 per cent of all PNZ males were married; 43.92 per cent of PNZ adult females were single. Figure 4.2, displaying each gender/marital status combination as a proportion of the adult sub-sample of each database, also shows this trend.

Figure 4.2

Proportion of each dataset that was single or married at arrival in New Zealand.

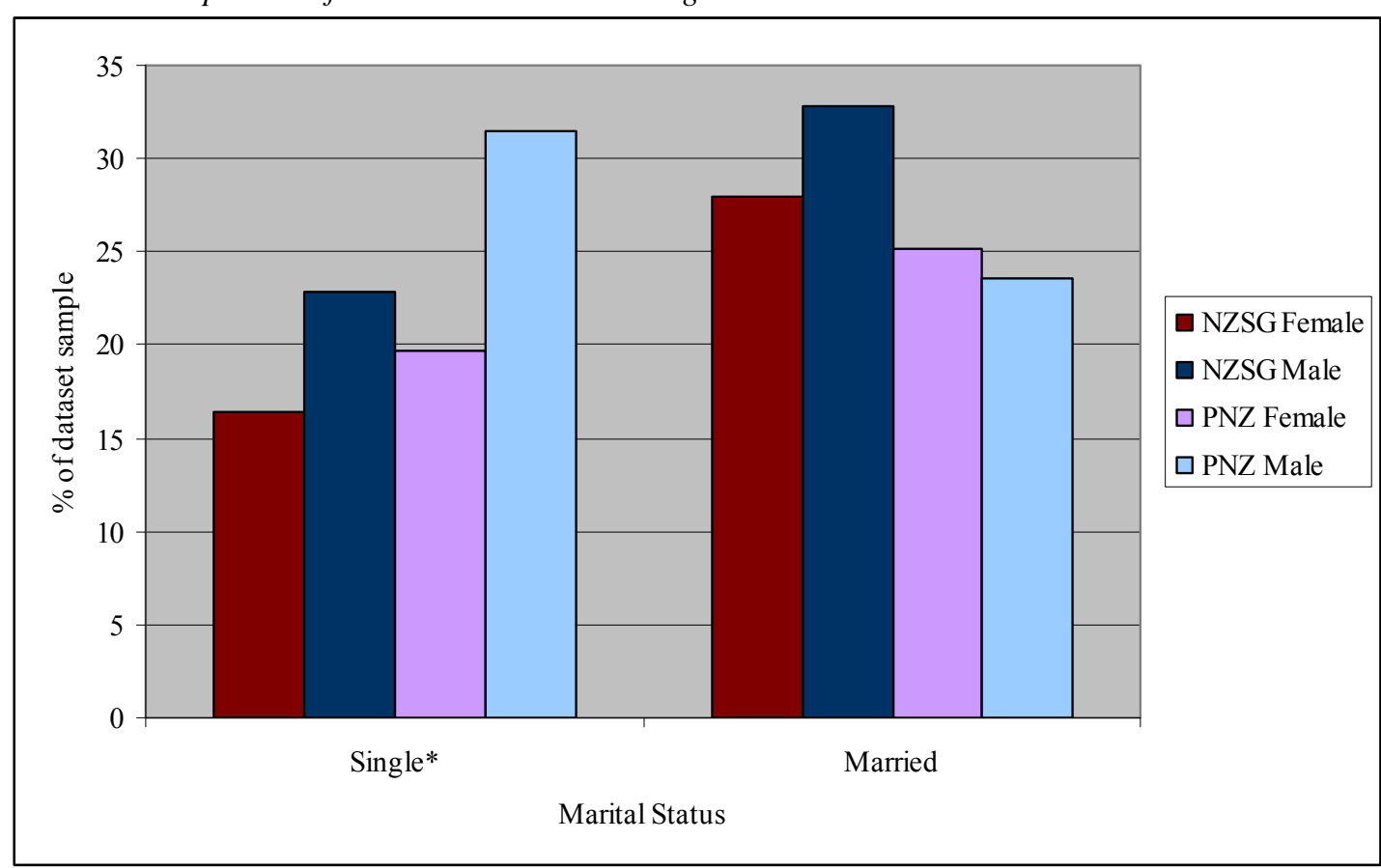

Figures exclude children. * Single includes widowed/widow or spouse absent for NZSG data. Sources: NZSG and PNZ data, 1840-1920

Though male and female children constituted almost exactly the same proportion of their gender totals - 18.92 per cent of females and 18.91 per cent of males females represented only 44.97 per cent of all children in the PNZ data. This may be due to families with male children being more likely to emigrate, in accordance with suggestions made earlier in this chapter. On the other hand, given the overall gender imbalance in New Zealand society at this time, the much larger proportion of single males and male children in the PNZ sample compared to the NZSG sample may also be due to a large number of males in these marital status groups never marrying, not having children and therefore being less likely to be included in the NZSG data (i.e. the NZSG sample under-represents single migrants, and especially single male 
migrants). Thus, with regard to marriage and family indices in particular, both sets of data are highly biased.

The two datasets under discussion each have benefits and disadvantages that complement those of the other. The primary advantage of the datasets, when used in conjunction, is the way in which each highlights the biases inherent in the other. The benefits of complementarity aside, the question remains: are genealogical data valid as a source for such statistical analysis? It is fair to remember here that the NZSG register was not created with statistical uses in mind. The way the information has been recorded is not standardised, and it is not possible to know in detail upon what sources each piece of information is based. Nevertheless, comparison with the PNZ data collected solely from death certificates indicates that the NZSG data is at least as representative as this 'official source' data in terms of demographic as well as other variables. Furthermore, as is apparent in other chapters, this genealogically-sourced data enables individuals to be recovered; case studies may be drawn from the material and conclusions drawn from the data even when statistical analysis is hindered by difficulty with small samples. In short, datasets created from genealogical sources have some validity as statistical sources, even when they are not specifically designed for the purpose; furthermore, it might be argued, datasets based on linked genealogical records are in many ways preferable to datasets based on a single source.

\section{CONCLUSION}

What, then, can be concluded regarding the age, gender and marital status at arrival of the Scots migrants in NZ? Broadly, the gender profile was slightly more unbalanced than that of other contemporary migrant groups coming to New Zealand. While some parts of Scotland sent disproportionately high numbers of females and some disproportionately low ones, there were always more male than female arrivals from Scotland as a whole. Consequently, and when considered in aggregate, the Scots migrant gender ratio was always more disproportionate than the European-born population of New Zealand. In terms of age, New Zealand's Scots tended to be young - in their mid-twenties - and one third of the migrants were children. Among adult migrants, in the NZSG dataset at least, there were significantly more Scots arriving in New Zealand married than single among both males and females, despite the gender imbalance being particularly evident among single migrants. This factor needs to be taken into account in future studies of New Zealand migrants and cultural transfers. 
As Phillips and Hearn have noted, 'families are the vehicles of culture. They teach children traditions, and their members reinforce each others' accents, religious faith, ways of doing things. ${ }^{, 44}$ It is possible that the large number of Scots migrants arriving in New Zealand married with young families was a primary reason for the successful continuation of many Scottish traditions in New Zealand.

${ }^{44}$ Phillips and Hearn, Settlers, p.126 


\section{Chapter Five \\ 'REFUGEES FROM THE SMOKE STACKS AND GRIME OF INDUSTRY'? MigRANT OCCUPATIONS IN SCOTLAND AND NEW ZEALAND. ${ }^{1}$}

Angus Cameron, formerly of Bracadale, Skye, aged eighteen years, arrived in New Zealand on the Blenheim in December 1840 with his mother Catherine and sisters Catherine and Mary. ${ }^{2}$ Having been employed as an agricultural labourer in Skye, he initially worked in road building in the vicinity of Wellington, later travelling with a survey party to Port Chalmers in February $1846 .{ }^{3}$ When this employment terminated in November of that year Angus, unlike many of his colleagues who returned to Wellington, remained in Otago, subsequently taking up employment as a shepherd and stockman at Kelvin Grove, a farm owned by fellow Scot Archibald Anderson, on the Otago Peninsula. It is likely Angus and Archibald already knew each other, the latter having arrived in Wellington in early 1840 and run a shop on Thorndon Beach before turning his attentions to Otago. ${ }^{4}$

By May 1848 Angus was employed in the Armed Police Force and by 1851 he was a senior constable. On 25 June 1852 Angus married Mary Niven, who had arrived on the Philip Laing in 1848, and a child was born to the couple two days later. ${ }^{5}$ Angus left the Armed Police Force in January 1853. It is likely he was dismissed after a drunken brawl on New Year's night that also saw two other constables dismissed. ${ }^{6}$ Whatever the reason for leaving the Armed Police Force, Angus once again took up employment as a shepherd, this time on the Otepopo estate of Charles Suisted, a

\footnotetext{
1 Jock Phillips and Terry Hearn, Settlers: New Zealand Immigrants from England, Ireland and Scotland, 1800 - 1945, Auckland, 2008, p.83

${ }^{2}$ Catherine (jnr) was actually Catherine McQueen at the time of arrival, having married Archibald McQueen in March 1840. Unfortunately further detail regarding Angus' parents is, as yet, untraced. It is known that his mother re-married sometime after immigration, but who she married is unknown. The following pen portrait is based upon Mary Bolland and Bruce Bolland, 'A Forward Pert Sett: a Family History’, privately produced family history, 2005; also NZSG database, migrant 00850 and Personal communication with Mary Bolland, 3 May 2009

3 Passenger list for Blenheim, arrived Port Nicholas (Wellington), 27 December 1840, http://freepages.genealogy.rootsweb.ancestry.com/ ourstuff/Blenheim.htm accessed 30 October 2008; Bolland and Bolland, 'A Forward Pert Sett', p.9

${ }^{4}$ Bolland and Bolland, 'A Forward Pert Sett', p.12

${ }^{5}$ Otago Marriage Register, Certificate Number 1852/146; and Otago Register Folio Number 52/146; cited in ibid., p.14

${ }^{6}$ Richard S. Hill, Policing the Colonial Frontier: The Theory and Practice of Coercive Social and Racial Control in New Zealand, 1767-1867, Part One, Wellington, 1986, p.330; Bolland and Bolland, 'A Forward Pert Sett', pp.12-14
} 
Swedish migrant. ${ }^{7}$ When Suisted sold the property in 1856, Angus and his family moved to the Papakaio Run owned by William and Richard Filleul, where Angus was employed as a shepherd and Mary as a cook. By 1858 Angus was back in Otepopo, having bought ten and a half acres of land from Henry France, a fellow former constable. This was the same land that Suisted had sold in 1856 to Alfred Chetham Strode, a former sub-inspector of police, who later sold it to a Mr Lemon, also expolice, who sold it to Henry France, indicating the existence of an occupational rather than ethnically-based network. ${ }^{8}$ A mortgage agreement Angus witnessed for a local saw miller on 8 June 1858 has him recording his occupation as 'stock drover'.

Angus also purchased a store in Otepoto from France, and in January 1859 he received his Post Office licence. While Angus served as postmaster, Mary ran the store. At the same time, Angus continued to work as a shepherd and stock drover. He also owned seven cows and four calves at the time he wrote his will in October $1859 .^{9}$ While the postmastership was relinquished in 1861, the couple did not sell the store until 1873, the year in which Angus died, apparently of 'congestion of the lungs, bronchial problems and an enlarged heart. ${ }^{10}$

What is significant about this recounting of Angus's employment history is that he was employed in at least seven different occupations during his thirty-three years in New Zealand. From road construction and survey labourer work, he progressed to agricultural labouring, then to farming in his own right. In addition to serving with the Armed Police Force, he also served the community as postmaster and store owner. These occupations varied considerably and are, at least in part, reflective of the need to be flexible as a migrant; as was observed by another Scotsman, George Hendry,

\footnotetext{
${ }^{7}$ Suisted was a founding settler in Otago. See Dorothy McKenzie, 'Suisted, Charles Eberhard (18101860) and Mary Emma (1817-1860)', in Jane Thomson (ed.), Southern People: A Dictionary of Otago Southland Biography, Dunedin, 1998p.489. Cameron is recorded as having worked as a shepherd for Suisted in 1851, not 1853, in Julie A. Bremner, 'Charles Suisted', in G.J. Griffiths (ed.), The Advance Guard: Prize-winning and Other Leading Essays from the Historical Biography Competition Conducted by the Otago Daily Times to Mark the 125th Anniversary of the Otago Settlement. Series Two, Dunedin, 1974, p.126.

${ }^{8}$ Bolland and Bolland, 'A Forward Pert Sett', pp.15-16; 'Strode, Alfred Rowland Chetham (18231890)', in Jane Thomson (ed.), Southern People: A Dictionary of Otago Southland Biography, Dunedin, 1998, p.487

${ }^{9}$ Bolland and Bolland, 'A Forward Pert Sett', p.16

${ }^{10}$ ibid. p.18
} 
migrants would be unwise to only seek out employment that they had 'been in the habit of doing at home'. ${ }^{11}$

Occupation is the final element of the New Zealand Scottish immigrant profile to be investigated in the present study. As has been noted, by the time New Zealand became a destination for immigrants Scotland was already a highly urbanised and industrialised society. In contrast, New Zealand remained a predominantly rural and agricultural society until the early twentieth century. Yet, while a large proportion of Scotland's population was located in the country's industrial heart, the Western Lowlands, with the majority of New Zealand's Scots also coming from that region, Scotland as a whole offered a great diversity of occupational experience. What, then, was the occupational background of New Zealand's Scots? How many were, or had been, people of the land? How many were, in contrast to Angus Cameron, 'refugees from the smoke stacks and grime of industry'? 'Were New Zealand's Scottish migrants predominantly from industrial or agricultural backgrounds' is a primary question addressed in the present chapter. The exploration of this element of the migrant profile will include examination by region of origin, province of settlement and period of arrival.

\section{METHODOLOGICAL CONSIDERATIONS}

Occupation has been described as 'one of the most complex indicators used in social science' because it is 'multi-dimensional, often ambiguous in meaning, and capable of being coded into an infinite number of categories and subcategories. ${ }^{12}$ Appendix 5.1, which underpins the present chapter, begins with an outline of the methodological and classification issues taken into consideration with regard to migrant occupation. This is followed by a detailing of the classification scheme used for the present study, which has been applied to migrant occupations for the NZSG and PNZ datasets, as well as to the results of the 1878 New Zealand Census. ${ }^{13}$ Especially ambiguous

\footnotetext{
${ }^{11}$ Tanja Bueltmann, “'Where the measureless ocean between us will roar”: Scottish emigration to New Zealand, personal correspondence and epistolary practices, c1850-1920', Immigrants \& Minorities, Vol.26, No.3, 2008, pp.242-265, p.251

12 Margo Conk, The United States Census and Labor Force Change: A History of Occupation Statistics, 1870-1940, in Robert Berkhofer (ed.), Studies in American History and Culture, 1978, p.21, quoted in Erik Olssen and Maureen Hickey, Class and Occupation: The New Zealand Reality, Dunedin, 2005, p.30

${ }^{13}$ Part VII, Tables I, III, VI, VIII, IX and X, 1878 Census of New Zealand, pp.279, 280, 283-4, 287-8, 289-95, and 297-307. References to New Zealand Census occupation data throughout this chapter refers to these tables.
} 
occupations have been annotated to demonstrate the inherent difficulties in interpreting historical occupational descriptions.

Even after migrant occupations have been classified, preparing an occupational profile of the migrant group from the available data remains difficult, with many migrants holding several occupations over their lifetimes, as in the case of Angus Cameron. In addition, within many occupations the versatility exhibited by the early settlers cannot be fully conveyed under a single occupational title. Olssen and Hickey note, for example, instances of hospital matrons whose jobs also entailed work as 'cooks, laundresses, charwomen, dispensers, anaesthetists, gardeners, and clerks' ${ }^{14}$ Furthermore, analysis of the occupations of the migrants can only be based upon a 'snapshot' of the migrants' occupational experiences at a single point in time, otherwise the analysis becomes unwieldy and results highly suspect. The NZSG record for Angus Cameron records his occupation in New Zealand as 'settler, policeman, shepherd', and he has consequently been recorded in the database as having been of independent means in his primary occupation, in the 'armed forces 2' category of public service for occupation 2, and as 'farm workers 1' for his third occupation. ${ }^{15}$ Yet, as the case study presented clearly shows, this is an inadequate summary of Cameron's employment history; the snapshot of his employment fails to capture the accuracy or the richness of his occupational experiences.

The 'snapshot' of migrant occupations in the PNZ dataset is likely to have been of the occupation engaged in immediately prior to death. ${ }^{16}$ This is important, as it tends to skew the results towards senior positions within occupational 'sectors'. The agriculture sector provides a useful example. The proportion of males in the PNZ dataset involved in agriculture in New Zealand is just 25.29 per cent, somewhat lower than might be expected based on previous research. In the 1878 Census of New Zealand 35.11 per cent of the male population was employed in agriculture, and analyses of migrant backgrounds carried out by Phillips and Hearn, and earlier by McClean, suggest that Scots were more likely than their English contemporaries to be

\footnotetext{
${ }^{14}$ Pat Sargison, “"Essentially a woman's work”: A history of general nursing in New Zealand, 18301930', PhD Thesis, University of Otago, 2001, pp.70-71; and R. Wright St Clair, Caring for People: Wanganui Hospital Board, 1885-1985, Wanganui, 1987, p.29; cited in Olssen and Hickey, Class and Occupation, p.61

${ }^{15}$ NZSG database, migrant 00850. See Appendix 5.1 for discussion of 'settler' as an occupation.

${ }^{16}$ For further discussion see Appendix 5.1
} 
occupied in agriculture. ${ }^{17}$ Phillips and Hearn note that 30.7 per cent of Scots migrants arriving in Otago between 1840 and 1850 were engaged in agriculture, as were 73.9 per cent of those assisted migrants going to Canterbury and 42.9 per cent of those assisted to New Zealand between 1871 and $1888 .{ }^{18}$ As there were more migrants to New Zealand from England than from Scotland, it should be anticipated that the proportion of the population of New Zealand involved in agriculture in the 1878 Census would be lower than the proportion of Scots agriculturally employed in Scotland. This low proportion of migrants involved in agriculture in the PNZ dataset means that the proportion recorded as being involved in all other 'sectors' is higher than expected. Indeed it is potentially created by this higher proportion recorded as belonging to other sectors. A probable reason is the use of death certificates as a source. Some migrants who had been engaged in agriculture earlier in their lives may have been recorded as 'settler' or 'gentleman' on their death certificates, having 'retired' some years before death.

However, this snapshot effect is not simply an issue for data samples created retrospectively, but also influences census data collection. The date on which the census was taken obviously affects how many were enumerated in seasonal fields of work, respondents giving their occupation as that in which they were currently employed rather than summarising for the enumerator all occupations in which they had been employed during the previous year. This immediate distortion is exacerbated by the fact that during the period studied respondents were asked to record one occupation only on census forms. As Fairburn notes, 'it was customary in nineteenthcentury New Zealand to call a man by one occupational name only, irrespective of how many livelihoods he possessed. ${ }^{19}$ Unlike Britain, which experienced increasing

\footnotetext{
17 Rosalind McClean, 'Scottish Emigrants to New Zealand, 1840-1880: Motives, Means and Background', PhD Thesis, University of Edinburgh, 1990, p.311; Tables 11 and 17, Phillips and Hearn, Settlers, pp.88 and 113

${ }^{18}$ English and Welsh migrants of agriculture background arriving with the New Zealand Company are recorded as being 36.1 per cent of migrants (a higher figure than that noted for Scots above, because this figure is of New Zealand Company migrants generally and the Scots figure is for those going to Otago alone), those assisted to Canterbury just 45.9 per cent and those assisted between 1871 and 1888 just 34.5 per cent. Another consideration regarding these figures is the likely recording of occupations that migrants knew the colony required - if an assisted passage was offered to agricultural labourers but not to blacksmiths, for example, the migrant may have claimed the sought occupation. This would undoubtedly increase the proportion of 'labourers' and 'domestic servants' recorded in a sample of ship lists. Table 18, Phillips and Hearn, Settlers, p.113; p.88

${ }^{19}$ Olssen and Hickey, Class and Occupation, pp.37 and 72; Miles Fairburn, 'Social mobility and opportunity in nineteenth-century New Zealand', NZJH, Vol.13, No.1, April, 1979, pp.43-64, p.44. The pitfalls of occupational enumeration in the census are elaborated upon in detail in chapter 2 of
} 
occupational specialisation during this time, employment in New Zealand required a high degree of versatility. In 1867 New Zealand’s Registrar-General observed that the workforce was filled 'with a 'great number' of jacks-of-all-trades', and it was not only seasonal agricultural labourers who held more than one job over the course of a year'Members of Parliament, Magistrates... persons following combined professional or commercial and agricultural pursuits' were all examples of people likely to have more than one occupation. ${ }^{20}$ As early as 1858 the Registrar-General noted that 'the calling entered in the Census Schedule is not always that in which the person is most habitually engaged or from which he principally derives his maintenance'. ${ }^{21}$ It is highly probable that Angus Cameron would have been enumerated as postmaster at the 1861 Census, this being, if not his primary occupation, at least that with the highest income. ${ }^{22}$ If such was the case, a shepherd, a drover, a store keeper and a liquor licensee (the other occupations embraced by Angus at the time) were, consequently, excluded from the census enumeration in that year. It is in this respect that the NZSG data is strongest in comparison to census data and the PNZ dataset, providing additional information about the migrants' occupations, even when not lending itself to statistical analysis.

Another respect in which the NZSG data is especially strong in comparison to the PNZ dataset is with regard to female employment patterns. Because the source of the PNZ data is death certificates, and because for the most part the occupation recorded was that held immediately prior to death, the majority of females in the PNZ data (over 99 per cent) have no occupation listed. The NZSG data sheds more light on female occupations. Of the 2,915 females in the NZSG database, 1,279 have an 'occupation' recorded. While 632 of these fall within the 'other' sector, including wives, mothers, housewives and other dependants, 647 female migrants have occupations that lend themselves to analysis. Consequently, there are instances in the present chapter where the occupational data for male and female migrants is considered separately. For the most part, however, male and female migrant occupational data has been jointly analysed. Conclusions may be drawn from the

Class and Occupation. See also Fairburn, 'Social mobility and opportunity in nineteenth-century New Zealand', pp.44-45.

${ }^{20}$ Olssen and Hickey, Class and Occupation, p.37; Fairburn, 'Social mobility and opportunity', p.44.

${ }^{21}$ Fairburn, 'Social mobility and opportunity', p.45.

${ }^{22}$ Which occupation Angus recorded at the census cannot be checked, the individual schedules having been destroyed, only the published calculations being now available. 
separated male and female results as to whether, for example, most of the migrants recorded in the combined tables as being engaged in domestic service were male or female. In most cases throughout the chapter tables and figures relating to migrant occupations exclude those recorded as 'other', 'indefinable due to lack of information' and 'unknown'. Migrants occupations were not 'unknown' or 'indefinable' in their own lifetimes, and including 'other' only skews the figures towards dependants without revealing anything useful about the composition of the occupations of the workforce. Therefore it must be borne in mind when reading tables that when the analysis is exclusive of 'other', 'unknown' and 'indefinable' it is primarily, but not solely, of male migrants.

One further consideration regarding methodology is that the occupational profile of the migrants is heavily dependant on the accuracy of the recording of occupations in the original sources (and subsequently). The difference between a baker and a banker is great in real terms, but not in written form, just as millers and miners are only a smudge apart in ink. The profile presented in this study is based on the available evidence. Other data sources will be needed to create a more complete profile of the migrants.

\section{OVERVIEW}

One of the primary hypotheses running throughout the present investigation relates to change over time - did the occupational make-up of the migrants alter between periods of arrival? The preceding chapters have presented evidence that suggests there were changes in other aspects of the profile of the migrants over time. However, there are strong indications that the changes were not radical but actually relatively subtle, and that these subtle changes were dependant upon factors in Scotland and in New Zealand, such as internal migration and the deliberate recruitment of particular categories of migrants at various points of time. The occupational composition of the migrants has proven no exception. Figure 5.1, below, illustrates the occupational sector composition of male NZSG migrants in their New Zealand occupations by period of arrival. 
Figure 5.1

Employment subsequent to emigration to New Zealand: proportion of male migrants in each sector, by period of arrival

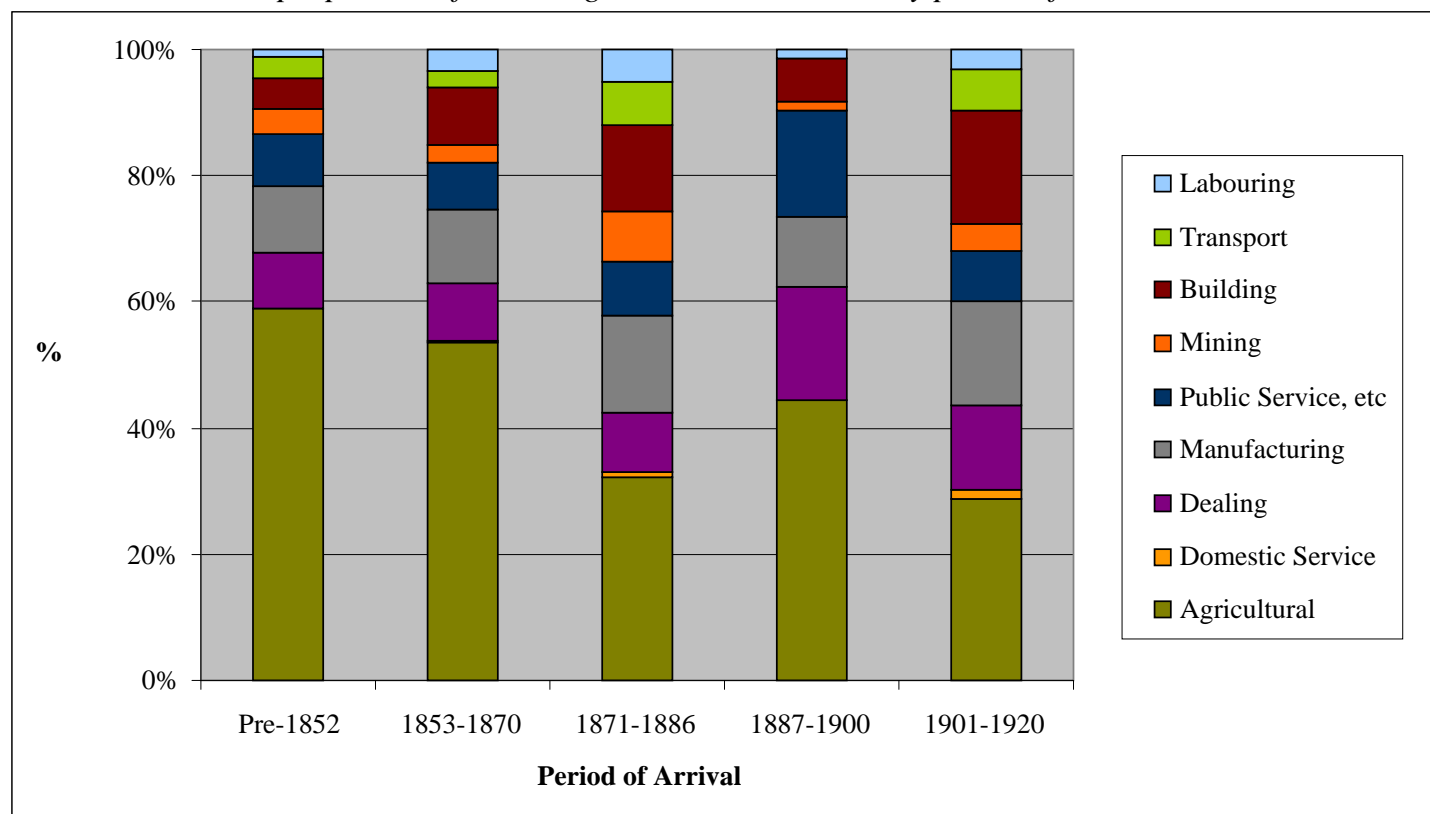

Source: NZSG Data, 1840-1920

Although Figure 5.1 sets out only the occupations of the Scottish-born males in the NZSG data, the changing sectoral shares reflect the shift within New Zealand from an early settler society, with agriculture the cornerstone, to an increasingly industrialised and increasingly urban society from the 1870s through to the early twentieth century. ${ }^{23}$ While the general trend in Figure 5.1 within the agricultural sector is a decline in numbers, there is a consistent trend towards increase within the manufacturing, dealing, and especially building, sectors. ${ }^{24}$ Among Scots males in the NZSG dataset arriving in New Zealand pre-1852, 59.06 per cent were involved in agriculture at some point in their lives. This decreased to 53.48 per cent between 1853 and 1870, and yet again for those arriving between 1871 and 1886 (32.31 per cent).

\footnotetext{
${ }^{23}$ Good general overviews of the economic development of New Zealand include: J.B. Condliffe, New Zealand in the Making: a Survey of Economic and Social Development, London, 1930, (see, especially, chapter one, 'The main periods of development', for the broad trends); J.B. Condliffe and W.T.G. Airey, A Short History of New Zealand, Auckland, 1954, (especially section three); W.J. Gardner, 'A colonial economy' in Geoffrey Rice (ed.), The Oxford History of New Zealand, Auckland, 1992; Tom Brooking, 'Economic transformation', in Geoffrey Rice (ed.), The Oxford History of New Zealand, Second Edition, Auckland, 1992, pp.230-253; and Jim McAloon, 'The New Zealand economy, 17921914', in Giselle Byrnes (ed.), The New Oxford History of New Zealand, Melbourne, 2009, pp.197-218

${ }^{24}$ These figures, for males, are calculated excluding 'other' for reasons mentioned below. Note, the spike in Figure 5.1 for those employed in public service in the period 1887-1900 is probably an aberration caused by the small sample sizes for that period.
} 
Between 1901 and 1920 agriculture represented only 28.72 per cent of occupations recorded among these male migrants. ${ }^{25}$

As the above analysis is based on a sub-sample of migrants in the NZSG dataset, with only one occupation recorded on the NZSG registration forms, it is possible that the apparent decline in agriculture over the eight decades is indicative of migrants holding more than one occupation during their lives in New Zealand, with the contributors of the information recording only the wage-earning forms of employment rather than 'farming'. For some farming may have been a way of life as much as an occupation. Moreover, as the colony grew many migrants were forced to find other employment in addition to farming. This proposition is not supported, however, by analysis of those with more than one occupation recorded on the registration forms; just seventy-six males in the sample arriving between 1901 and 1920 had two or more occupations recorded for their New Zealand years, compared to 128 with two or more occupations among those arriving pre-1852, 520 arriving between 1852 and 1870 and 232 arriving between 1871 and 1886. Only seventeen of the seventy-six with two or more occupations arriving 1901-1920 had an agricultural occupation as their second occupation, suggesting that this was not the primary reason for the decline in the number of migrants involved in agriculture over time.

A more likely explanation lies in the unusually rapid transformation of New Zealand from a primarily agricultural society with a scattering of urban centres to an increasingly urban and industrial society, albeit one still heavily dependant on primary production. In the early twentieth century agriculture was still very important -28.72 per cent is still a considerable proportion of the occupied male population. ${ }^{26}$ While the

\footnotetext{
${ }^{25}$ Hawke notes that 'the labour force in farming [in New Zealand, according to the census] shows much less 'relative decline' than it does in most of the richer counties of the world, a result readily understood in terms of the comparative advantage of New Zealand in the international economy, and the absence of any technical or social reasons for seeking employment opportunities in other activities' and that 'the relative decline of farming as a source of employment, a feature of the developed countries in general, really begins only in the early twentieth century'. G.R. Hawke, 'Disaggregation of the New Zealand labour force, 1871-1936', VUW Working Papers in Economic History, 79/1, January, 1979, p.22. However his analysis for this working paper begins with the 1874 Census; as the analysis discussed here shows, the NZSG data corroborates his findings after that date. This very high proportion of Scots involved in agriculture in the first two periods discussed here, though, may prove to be a Scottish peculiarity; certainly recent work examining the occupations of Wellington's Irish immigrants indicates that, as was the case among Irish immigrants to other parts of the world, New Zealand's Irish were much less inclined towards agriculture than were the Scots.; Gerard Horn, forthcoming PhD thesis, Victoria University of Wellington.

${ }^{26}$ Much has been written regarding the economic and social development of New Zealand over this period. As well as general histories of New Zealand such as William Pember Reeves, The Long White Cloud, London, 1924; James Belich, Making Peoples: A History of the New Zealanders From
} 
proportion of Scots migrants employed in agriculture in New Zealand decreased by 30.34 per cent between the pre-1852 period and 1901-1920, no one other sector accounted for the decline, though the building sector was significant. The increase in those involved in manufacturing between these two periods of arrival was just 5.58 per cent (from 10.53 per cent of those arriving pre-1852 to 16.41 per cent of early twentieth century migrants), and the difference between the two periods of arrival of migrants employed in the dealing sector in New Zealand was just 4.56 per cent. While the building sector accounts for just 4.68 per cent of NZSG male migrants New Zealand occupations among those arriving pre-1852, 17.95 per cent of those arriving between 1901 and 1920 were engaged in that sector. This is a reflection of the relatively rapid urbanisation of New Zealand society over the eighty years examined and consequent demand for construction. Patterson, for instance, notes the amount of housing available in Wellington more than doubled over the course of the 1870s, 'houses... being let before even piles were placed in the ground', and that this demand continued into the twentieth century. ${ }^{27}$

A change in the occupational patterns of female Scots migrants over time also indicates the shift in New Zealand from a rurally oriented settler society to one increasingly urban. Figure 5.2 illustrates the occupational sector composition of female NZSG migrants in their New Zealand occupations by period of arrival.

Polynesian Settlement to the End of the Nineteenth Century, Auckland, 1996; Keith Sinclair, A History of New Zealand, Auckland, 2000; James Belich, Paradise Reforged: A History of the New Zealanders From the 1880s to the Year 2000, Auckland, 2001; and Michael King, The Penguin History of New Zealand, Auckland, 2003 (as well as Condliffe, New Zealand in the Making, Condliffe and Airey, A Short History of New Zealand, Brooking, 'Economic transformations', and McAloon, 'The New Zealand economy 1792-1914', noted earlier), that provide the reader with a good general background as to the basic phases of development, many other works cover more specific aspects of this development. See, for example, C.G.F. Simkin, The Instability of a Dependent Economy: Economic Fluctuations in New Zealand, 1840-1914, London, 1951; G.R. Hawke, The Making of New Zealand: An Economic History, Cambridge, 1985; Margaret Nell Galt, 'Wealth and income in New Zealand c.1870 to c.1939', PhD thesis, Victoria University of Wellington, 1985; H.G. Philpott, A History of the New Zealand Dairy Industry, 1840-1935, Wellington, 1937; G.J.R. Linge, 'Manufacturing in New Zealand: four years in a century of growth', in R.F. Watters (ed.), Land and Society in New Zealand: Essays in Historical Geography, Wellington, 1965; and Muriel F. Lloyd Prichard, An Economic History of New Zealand to 1939, Auckland, 1970, among others.

${ }^{27}$ Brad Patterson, 'A "half Australian, half American” town: the economic foundations of nineteenth century Wellington', in Jack McConchie, David Winchester, and Richard Willis (eds), Dynamic Wellington: a Contemporary Synthesis and Explanation of Wellington, Wellington, 2000, p.195. 
Figure 5.2

Employment subsequent to emigration to New Zealand: proportion of female migrants in each sector, by period of arrival

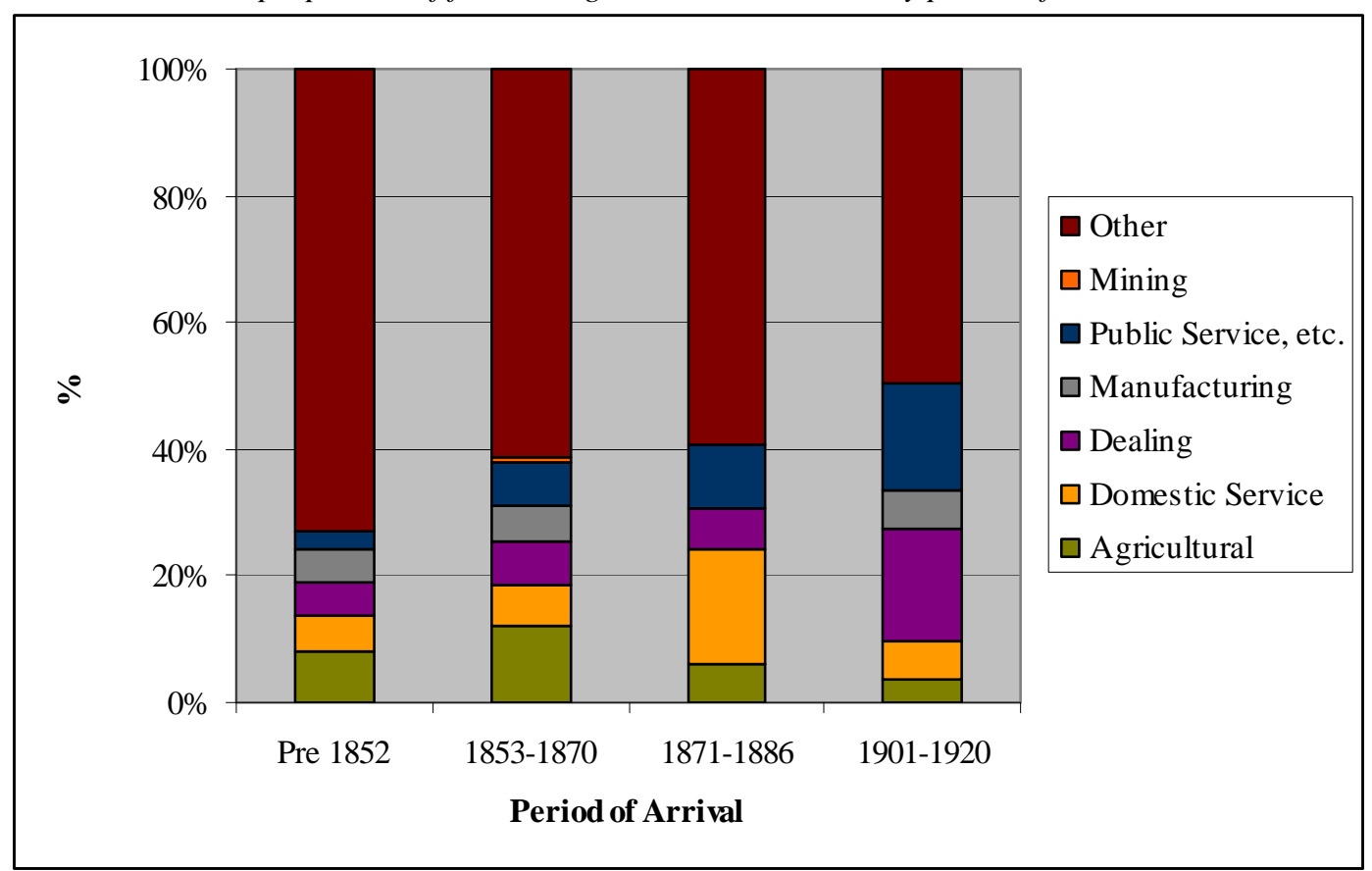

Source: NZSG Data, 1840-1920

Most notable in Figure 5.2 is the majority of female migrants not recorded as being in paid employment - those recorded on the NZSG registration forms in ways that have necessitated their occupation classification as 'other'. Of NZSG females arriving in the pre-1852 period, 72.97 per cent fall within the 'other' category, every one of these women being wives or widows. Though 8.11 per cent of females in the sample arriving in the first decade were involved in agriculture, and only 5.41 per cent each in domestic service, dealing and manufacturing, this was only a difference of one migrant - nine females in agriculture and eight in each of the other categories. From that point (and excluding the period 1887 to 1900, where the sub-sample is a mere thirty-two people) the proportion of females without an occupation recorded continuously decreases: 61.24 per cent of females were in the 'other' sector among those arriving in the period 1853-1870; 54.09 per cent arriving between 1871 and 1886; and 49.56 per cent between 1901 and 1920. A little of this difference may be accounted for by the slight decrease in the proportion of female migrants arriving in New Zealand married over these periods: 42.02 per cent of female Scots immigrants arriving pre-1852 were married, 44.54 per cent arriving between 1852 and 1870, 39.70 per cent in the 'Vogel' period and 39.50 per cent in the first two decades of the 
twentieth century. ${ }^{28}$ As these figures suggest, however, this continuous decrease in the proportion of women working outside recognised paid employment (for it must not be assumed that these women were not 'working' simply because they were not being paid for their labour within the family unit, or because their paid employments were not recognised because they were not the breadwinner) is principally due to the increasing movement of women into the paid workforce in New Zealand over these eighty years.

A significant difference between the NZSG and PNZ datasets regarding migrant occupations should be noted at this point. While the difficulties with the occupations recorded in the PNZ data being almost certainly those held immediately prior to death have been stated, the problem is compounded in respect of female migrants. Though female migrants may have been in paid employment in earlier phases of their lives, as the NZSG data indicates was the case for a large number, the vast majority had no occupation recorded on their death certificates. Those who died while in unpaid employment as wives and mothers, though in most cases performing the same tasks as employed domestic servants, were recorded as having no occupation. The recording of female employment in this manner also affected census results. While a woman may have been employed in part-time work, or in seasonal employment, because her primary role was as housewife or mother this was more likely to be recorded as her occupation for the census, as it was on death certificates. ${ }^{29}$ Over the period 1840 to 1920 the PNZ data records the occupation of 99.09 per cent of females in the dataset as being 'unknown' - i.e. no occupation was recorded. Just six females in the data set - 0.39 per cent of the female total - were employed in the sector encompassing those in public service, professionals and those of independent means, four in manufacturing, two in agriculture and one each in building, transport and commerce, and domestic service. It is evident from these results that a sample of death certificates is of limited utility in eliciting information on female occupations.

\footnotetext{
${ }^{28}$ Based on the NZSG data.

${ }^{29}$ Olssen and Hickey, Class and Occupation, p.38, citing Higgs, 'Women, occupations and work in the nineteenth century censuses’, History Workshop Journal, Vol.23, Spring 1987, pp.63-4; Nancy Folbre and Marjorie Able, 'Women’s work and women's households: Gender bias in the U.S. Census', Social Research, Vol.56, 1980, p.548; Nancy Folbre, 'The unproductive housewife: Her evolution in nineteenth century economic thought', Signs: Journal of Women in Culture and Society, Vol.16, 1991, pp.463-84; Desley Deacon, 'Political Arithmetic: The nineteenth-century Australian census and the construction of the dependant woman', Signs: Journal of Women in Culture and Society, Vol.11, 1985, p.29
} 
The proportions of females involved in agriculture and in domestic service in the NZSG dataset peaked in different arrival periods, and both declined thereafter, although the patterns of decline were different. The proportion involved in agriculture peaked at 12.20 per cent between 1853 and 1870, falling to 3.54 per cent by the period 1901 and 1920. The proportion employed in domestic service peaked at 16.73 per cent in the period 1871-1886 (when the greatest number of women were specifically recruited for employment in domestic service), but this figure declined to 6.19 per cent in the first two decades of the twentieth century. Though this represented a marked decrease (and no females in the NZSG sample arriving between 1887 and 1900 were employed in domestic service) the proportion of females arriving between 1901 and 1920 who were employed in domestic service was only slightly greater than those arriving pre-1852. That these periods of arrival attracted similar proportions of Scots females in domestic service is, however, undoubtedly due to significantly different factors - an initial inability to employ domestic servants as a result of a scarcity of women to employ, and the greater range of employment opportunities available to women in the later period.

Most striking of the sectors, viewed by period of arrival, are dealing and public service/professional/independent. The proportion of females in the sample employed in 'dealing' in the first four periods of arrival was between 5.41 and 6.70 per cent, those involved in public service etc between 2.70 and 9.25 per cent. Between 1901 and 1920, however, the proportion of female migrants involved in these sectors, respectively, was 17.70 and 16.81 per cent, a striking increase in both cases. This is indicative of the more general move towards paid employment among women, a move away from domestic service towards higher status occupations such as nursing and clerical work in the early twentieth century, and of the growth of the state over this time. ${ }^{30}$ Of the 17.70 per cent of occupied females in the public service, etc, sector arriving in New Zealand between 1901 and 1920, eleven were teachers ('Professional 2'), five were 'Assistants to Professionals' (three nurses, one dental nurse and one photographers assistant) and three were of 'Independent Means' (all 'retired'). Within

\footnotetext{
${ }^{30}$ For discussion of the increase of employment in this type of work among New Zealand women in the early twentieth century see Melanie Nolan, Breadwinning: New Zealand Women and the State, Christchurch, 2000; Tim Frank, 'Bread queues and breadwinners: gender in the 1930s', in Caroline Daley and Deborah Montgomerie (eds), The Gendered Kiwi, Auckland, 1999, pp.113-140; Danielle Sprecher, 'Good clothes are good business: gender, consumption and appearance in the office, 19181939', in Caroline Daley and Deborah Montgomerie (eds), The Gendered Kiwi, Auckland, 1999, pp.141-162.
} 
the dealing sector, eight of those who made up the 16.81 per cent for this period of arrival were 'retail proprietors', four were 'retail workers' and eight were involved in 'clerical and financial' work (six clerks/secretaries, one book-keeper and one typist).

Figures 5.1 and 5.2 strongly suggest that the occupational profile of the migrants did vary according to time of arrival. Furthermore, they show a significant difference between the respective employment patterns of male and female migrants generally and by period of arrival, though the occupational profiles of both male and female migrants were affected by underlying factors in the societies in which they were employed. These gender differences will be further elaborated upon in later discussion.

Life cycle considerations - specifically age and marital status - are significant factors to consider when investigating migrant occupations. The point in the migrants' life cycles upon arrival in New Zealand, for example, undoubtedly influenced the type of work they were likely to have taken up post-immigration. Given the hard physical nature of the work involved, it should be no surprise that the majority of the Scottish migrants engaged in mining in New Zealand arrived between the ages of twenty-one and thirty-five (56.63 per cent). Likewise, it is logical that 56.38 per cent of NZSG migrants employed as domestic servants in New Zealand arrived between the ages of eleven and twenty-five. Women employed as domestic servants tended to 'retire' from this paid employment upon marriage and - as discussed in Chapter Four - the majority of those arriving aged over twenty-five were married.

The higher level of financial security generally enjoyed by older migrants is the likely reason that both the PNZ and NZSG datasets suggest that Scots arriving in New Zealand at over forty years of age were more likely to become involved in agriculture (and in particular land ownership, even if only on a small scale) than those in other age cohorts. While agriculture employed less than 34 per cent of NZSG migrants arriving in other age groups, 42.36 per cent of NZSG migrants aged forty-one to forty-five, 42.31 per cent of forty-six to fifty year olds, and 38.10 per cent of migrants aged fifty-plus, were engaged in agricultural pursuits. These older migrants were more likely to have the financial means to invest in land, then to work it themselves, rather than having to enter paid employment. Those arriving at a younger age generally had to adopt different success strategies. Duncan Bell was thirty-five, married, and a father of four, when he arrived in New Zealand in 1867. Though he 
was a 'farmer' at his death approximately twenty-one years later, he was initially employed as a station hand, presumably accumulating the means to purchase land in this employment. Having worked as a cotton and woollens weaver in Scotland at a time when mechanical innovations were making such workers redundant, with a young family to support, Duncan would have been in no position upon arrival in New Zealand to immediately purchase land. ${ }^{31}$ In contrast, of the agriculturally occupied migrants aged forty-plus in the NZSG dataset only 9.68 were employed as farm workers in New Zealand, compared to 18.21 per cent of under-forty year olds (23.73 per cent of 16-25 year olds). This indicates a greater level of farm ownership, or, put another way, seniority in the agricultural sector hierarchy, among those migrating aged forty-plus. David Gibson, for example, arrived in Invercargill newly-wed at age forty-one in 1882. An iron and coal mine owner in Scotland, though his occupation in New Zealand is listed simply as 'Farmer', it is highly probable that in this instance that description does imply farm ownership. ${ }^{32}$

The effect of age upon arrival on the occupations taken up by migrants is particularly evident in the public service/professional/independent sector: While 15.04 per cent of the NZSG migrants subsequently employed in this sector in New Zealand were under five years old at arrival, and 12.39 per cent were over fifty, all other age cohorts contributed less than 12 per cent of migrants to this occupation sector. The occupation types within the sector engaged in by migrants aged fifty-plus and those aged under five at arrival were, understandably, very different. Those deemed 'independent' comprise nearly 90 per cent of the fifty-plus age group, indicating migrants coming to New Zealand with wealth, or being dependant on their children rather than earning their living in New Zealand; 60.70 per cent of this fifty-plus 'independent' group were 'retired', and 21.42 per cent were recorded on the NZSG forms as 'settler'. Those aged fifty-plus comprise 59.52 per cent of all migrants in the database categorised as 'independent'. 33 Of the migrants comprising the remaining 40.48 per cent of this category, it is likely many would have been otherwise classified if another point in the migrants' lives had been available for the occupational snapshot. It seems unlikely, for example, that James Dougal Melville, who arrived as a boy of thirteen in 1862, was solely a mill owner during his time in New Zealand, or

\footnotetext{
${ }^{31}$ NZSG database, migrant 00460.

${ }^{32}$ NZSG database, migrant 02009

${ }^{33}$ See discussion of these categories in Fairburn, 'Social Mobility and Opportunity'.
} 
that Agnes Findlay Johnston, arriving in 1892, age seventeen, was retired from the time she arrived in the country. ${ }^{34}$ Those who arrived under five years of age in the public service/professional/independent sector predominantly fit within the 'professional 2' category, with a few 'assistants', 'professional 1', 'public service 1 and 2', and 'armed forces 2'; no migrants arriving under five years of age were recorded as having been of independent means in their NZSG dataset 'New Zealand Occupation 1'. That more migrants arriving aged five years or under were engaged in this sector than other age cohorts may be a quirk of the NZSG dataset. However, it may indicate that these children were benefiting from their parents' decisions, from generational social mobility strategies, or that rapid assimilation into New Zealand society was an advantage in securing employment in professional occupations. It is likely that children adjusted more quickly, having fewer cultural and emotional ties to the homeland. Another possibility is that, rather than zero to five year olds being more likely, per se, to enter this sector of work, migrants arriving in older age ranges were less likely, there being a stronger inclination to enter the labouring and domestic service jobs that the colony was crying out for workers to fill.

\section{OCCUPATIONS IN SCOTLAND}

Over the course of the nineteenth century there was a gradual but marked shift in Scotland from agricultural to industrial employment. Though this was in part due to the lure of greater employment opportunities in the factories of the burgeoning urban centres, it was also an outcome of shrinking opportunities in the agricultural workforce due in part to technological advances in agriculture. ${ }^{35}$ By 1881 the Census of Scotland records 60.97 per cent of all occupied males and 51.53 per cent of occupied females as being employed in industry (see Table 5.1). Even so, the table also shows that the proportion of the population of Scotland employed in agriculture (16.77 per cent) was higher than that for England and Wales (12.36 per cent).

\footnotetext{
${ }^{34}$ NZSG database, migrants 02682 and 04293.

${ }^{35}$ J.H. Treble, 'The occupied male labour force', in W. Hamish Fraser and R.J. Morris (eds), People and Society in Scotland, 1830-1914, Edinburgh, 1990, pp.167-205; W.W. Knox, Industrial Nation: Work, Culture and Society in Scotland, 1800-Present, Edinburgh, 1999, chapters 2 and 8; T.M. Devine, The Transformation of Rural Scotland: Social Change and the Agrarian Economy, 1660-1815, Edinburgh, 1994, chapter 3.
} 
Table 5.1

Proportion of the occupied population of Scotland employed in each sector*

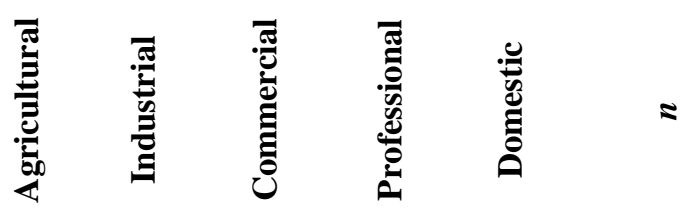

\begin{tabular}{cccccccc}
\hline \hline \multirow{3}{*}{ Scotland } & Male & 19.41 & 60.97 & 11.43 & 5.91 & 2.28 & $1,108,713$ \\
& Female & 10.90 & 51.53 & 1.06 & 6.14 & 30.37 & 498,171 \\
& Total & 16.77 & 58.04 & 8.22 & 5.98 & 10.99 & $1,606,884$ \\
\hline \multirow{2}{*}{ England and } & Male & 16.94 & 61.61 & 12.34 & 5.79 & 3.32 & $7,783,646$ \\
Wales & Female & 1.90 & 46.36 & 0.57 & 5.76 & 45.40 & $3,403,918$ \\
& Total & 12.36 & 56.97 & 8.76 & 5.78 & 16.12 & $11,187,564$ \\
\hline
\end{tabular}

* These figures are based on totals excluding those enumerated as 'unoccupied and non-productive', who in Scotland at this census numbered 690,762 males and 1,437,827 females and in England/Wales numbered 4,856,256 males and 9,930,619 females.

Sources: Appendix Tables, Table LXVIII, 1881 Census of Scotland, pp.lvii-lviii, and Summary Tables,

Table 4, 1881 Census of England/Wales, p.vi.

The pattern of employment varied in each of the six regions of Scotland. While the Far North, Highlands and North East remained predominantly agricultural in employment terms, in the Borders, the Eastern Lowlands, and especially the Western Lowlands, the majority of the occupied population - females as well as males - was employed in industry by 1881. (See Table 5.2). As outlined in Chapter Two, migrants from each region of Scotland came to New Zealand in numbers approximately proportionate to each region's share of the population of Scotland. Had New Zealand's Scottish migrants arrived in equally proportionate numbers in terms of occupation, and if the 1881 Census of Scotland may be taken as broadly indicative of the occupational structure of Scotland over the eighty year period under investigation, a majority of the Scottish migrants would have come from industrial backgrounds. 
Table 5.2

Proportion of the occupied population of Scotland employed in each sector, by region and gender*

\begin{tabular}{cccccccc}
\hline \hline \multirow{5}{*}{ Far North } & & Agricultural & Industrial & Commercial & Professional & Domestic & $\boldsymbol{n}$ \\
& Male & 59.26 & 28.37 & 6.18 & 5.36 & 0.84 & 28,396 \\
& Female & 25.59 & 45.62 & 0.09 & 5.92 & 22.77 & 14,771 \\
& Total & 47.74 & 34.27 & 4.10 & 5.55 & 8.34 & 43,167 \\
\hline \multirow{2}{*}{ Highlands } & Male & 51.62 & 30.84 & 7.08 & 7.71 & 2.75 & 86,529 \\
& Female & 36.87 & 17.21 & 0.20 & 7.61 & 38.11 & 33,416 \\
& Total & 47.51 & 27.04 & 5.16 & 7.68 & 12.60 & 119,945 \\
\hline \multirow{2}{*}{ North } & Male & 41.93 & 41.76 & 8.25 & 5.84 & 2.21 & 118,163 \\
East & Female & 17.16 & 32.12 & 0.80 & 8.67 & 41.25 & 50,194 \\
& Total & 34.55 & 38.89 & 6.03 & 6.68 & 13.85 & 168,357 \\
\hline \multirow{2}{*}{ Eastern } & Male & 14.33 & 63.93 & 11.71 & 7.04 & 2.98 & 366,382 \\
Lowlands & Female & 8.13 & 55.09 & 1.01 & 6.26 & 29.51 & 184,659 \\
& Total & 12.26 & 60.97 & 8.12 & 6.77 & 11.87 & 551,041 \\
\hline \multirow{2}{*}{ Western } & Male & 5.18 & 74.27 & 14.35 & 4.78 & 1.42 & 428,025 \\
Lowlands & Female & 3.89 & 63.02 & 1.62 & 5.23 & 26.24 & 178,870 \\
& Total & 4.80 & 70.96 & 10.60 & 4.92 & 8.73 & 606,895 \\
\hline \multirow{2}{*}{ Borders } & Male & 36.31 & 48.93 & 5.88 & 5.12 & 3.76 & 81,218 \\
& Female & 20.99 & 37.45 & 0.40 & 5.28 & 35.87 & 36,361 \\
& Total & 31.57 & 45.38 & 4.19 & 5.17 & 13.69 & 117,579 \\
\hline
\end{tabular}

*These figures are based on totals excluding those enumerated as 'unoccupied and non-productive', who in this census numbered 690,762 males and 1,437,827 females.

Source: Appendix Tables, Table LXX, 1881 Census of Scotland, p.lxi

Though death certificates make no provision for the collection of information relating to the migrants' occupations in Scotland, fathers' occupations may be substituted as at least indicative of a migrant's occupational 'background' ${ }^{36}$ The PNZ data indicates that agriculture was the occupational sector in which most of the migrants' fathers were involved. ${ }^{37}$ Nevertheless, assuming that the majority of those employed outside agriculture were living in urban areas, previous studies that have argued that 'while most nations drew their emigrants from rural areas, Scotland was unusual in sending many people with an urban and industrial background' are not inaccurate in the claim. ${ }^{38}$ Among migrants in the PNZ data arriving between 1840 and 1920, 26.24 per cent of migrants' fathers had been involved in agriculture in Scotland;

\footnotetext{
${ }^{36}$ For discussion of some of the perceived issues with using father's occupation as recorded on migrants death certificates as indicative of migrants' occupational backgrounds, see Phillips and Hearn, Settlers, p. 80

${ }^{37}$ Table 17, 'Occupational background (Father's Occupation) of Scots immigrants aged 20 and over (Percentages)', ibid., p.113

${ }^{38}$ ibid., p.112. Erickson provides a useful breakdown of the male work force employed in agriculture by county of Scotland, separating the counties into 'agricultural' and 'industrial' counties for 1851 and 1881 (Table 11, p.337). Though most Scottish emigrants to the United States were from industrial areas of Scotland, as was the case with migrants to New Zealand, Erickson found that very few of the emigrants to the United States were from agricultural backgrounds, a contrast to New Zealand's immigrants. C.J. Erickson, 'Who were the English and Scots emigrants to the United States in the late nineteenth century?' in D.V. Glass and Roger Revelle (eds), Population and Social Change, London, 1972, pp.347-381. See also McClean, 'Scottish Emigrants to New Zealand, 1840-1880', Table 6.5, p.320
} 
however manufacturing was the stated occupation sector for 16.65 per cent, public service/professional/independent means accounted for 11.06 per cent and building 9.59 per cent. This suggests that up to 37.30 per cent of migrants' fathers may have lived in non-rural environments. ${ }^{39}$

Of the 6,612 migrants in the NZSG database, 1,922 have an identifiable, and clearly definable, occupation (excluding 'other') recorded in Scotland. ${ }^{40}$ Of these, 1,922 (28.51 per cent), were employed in agriculture in Scotland prior to emigration, and 25.39 per cent in manufacturing. The Scottish census data is not directly comparable to the NZSG and other datasets (see Appendix 5.1). However the fact that the largest proportion of Scottish migrants to New Zealand were employed in agriculture is clearly indicative of a marked deviance between the employment in Scotland of the general population and of those who became New Zealand immigrants. In the 1881 Census of Scotland 58.04 per cent of the population (excluding 'unoccupied and non-productive persons') were employed in industry, and just 16.77 per cent in agriculture. The NZSG data thus confirms that, though Scotland was primarily industrial by the time of the mass transfers to New Zealand, and though it has previously been noted that agricultural labourers 'constituted a relatively small proportion of the British outflow after 1855', a preponderance of the migrants from Scotland to New Zealand were from agricultural backgrounds. ${ }^{41}$ Though Richards notes that the 'haemorrhage' of two million Scots leaving Scotland between 1830 and 1914 was 'primarily out of the industrial sector', this appears not to have been the case among Scots emigrating to New Zealand. ${ }^{42}$ Although one reason for a greater proportion of the Scottish migrants to New Zealand having an agricultural rather than an industrial background may have been the availability of opportunities for industrial labourers within Britain and in North America, the availability of land and the

\footnotetext{
39 'May have' because some men - blacksmiths, storekeepers and such like - have been classified in these non-agricultural sectors but are likely to have been living in a rural environment. These figures are based on analysis of the PNZ data, using the occupational classifications devised for this work and not the Phillips and Hearn classifications. Note also that while Phillips and Hearn excluded from analysis of father's occupation those migrants who died under the age of twenty, 'on the assumption that the father's occupation was probably occupation in NZ, not in [the] UK' father's occupation for these migrants has been included in the present analysis. Personal communication with Dr Jock Phillips, 21 March 2006.

${ }^{40}$ Excluding 'other' from these figures means that the majority of the migrants under discussion are males, as explained in Appendix 5.1

${ }^{41}$ Eric Richards, Britannia's Children: Emigration from England, Scotland, Wales and Ireland since 1600, London and New York, 2004, p.168

${ }^{42}$ ibid., p.213, citing T.M. Devine, The Scottish Nation: 1700-2000, London, 1999, pp.263-4
} 
consequent attractiveness of New Zealand to those with an agricultural background played a more important role. $^{43}$

Consideration of the available occupation data by region of birth yields unsurprising results, given what is already known about the regions. In light of the industrial character of the Eastern and Western Lowlands, manufacturing was predictably the primary former employment of migrants from these regions. Conversely, that sector employed less than 10 per cent of those from the Far North. Agriculture employed more than 28 per cent of migrants from the North East, Borders, and Far North Regions, while 50.56 per cent of Highlands Region migrants had been employed in agriculture. While mining accounted for less than 1.50 per cent of those from the North East, Borders and Highlands and 3.74 per cent from the Far North, 10.72 per cent of those from the industrial Western Lowlands were from a mining background.

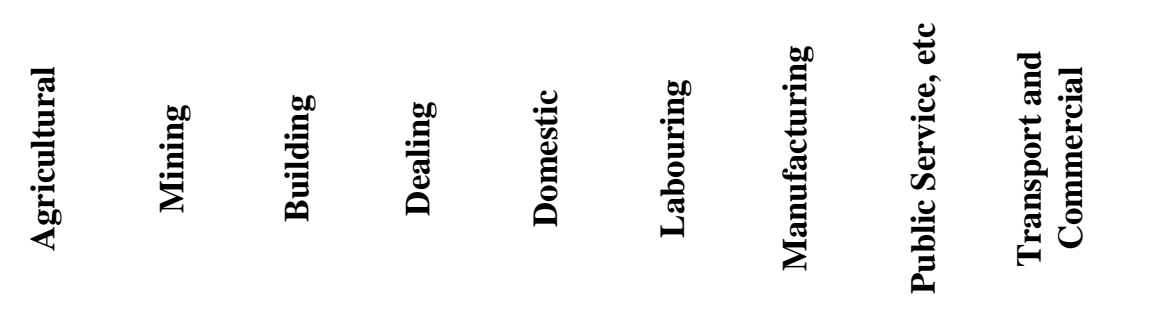

\begin{tabular}{ccccccccccc}
\hline \hline Far North & 40.19 & 3.74 & 7.48 & 3.74 & 15.89 & 2.80 & 9.35 & 5.61 & 11.21 & 107 \\
Highlands & 50.56 & 1.50 & 4.12 & 2.62 & 16.10 & 1.50 & 12.73 & 7.87 & 3.00 & 267 \\
$\begin{array}{c}\text { North } \\
\text { East }\end{array}$ & 28.42 & 0.36 & 13.31 & 7.91 & 11.51 & 3.60 & 20.50 & 9.71 & 4.68 & 278 \\
$\begin{array}{c}\text { Eastern } \\
\text { Lowlands } \\
\text { Western }\end{array}$ & 19.86 & 4.84 & 7.77 & 11.4 & 10.71 & 2.59 & 33.16 & 6.22 & 3.45 & 579 \\
$\begin{array}{c}\text { Lowlands } \\
\text { Borders }\end{array}$ & 19.38 & 10.72 & 9.69 & 9.69 & 7.22 & 3.30 & 30.10 & 5.98 & 3.92 & 484 \\
Total & 28.50 & 4.78 & 8.58 & 8.42 & 11.13 & 2.65 & 25.38 & 6.71 & 3.85 & 1,922 \\
\hline
\end{tabular}

* Excludes 'unknown', 'indefinable' and 'other' sectors

Source: NZSG Data, 1840-1920

\footnotetext{
${ }^{43}$ Richards, Britannia's Children, p.97; Marjory Harper, Adventurers and Exiles: The Great Scottish Exodus, London, 2003, p.95
} 
Further examination of the data by occupation 'type' within each sector produces other interesting patterns. While the largest proportion of (male) migrants from the Eastern Lowlands had been employed in manufacturing prior to emigration, the majority were from 'pre-industrial' occupations, those in which technological innovations had been minimal (see Appendix 5.2). Migrants from the Western Lowlands were equally from 'industrial' and 'pre-industrial' manufacturing backgrounds, but in both instances work with textiles or clothing was the most common former employment. Clothing trades/textile occupations were the primary former employment of migrants with a manufacturing background from every region of Scotland; among the NZSG migrants thirty-four were recorded simply as 'weaver' (industrial, textiles), thirty-six as 'tailor' or 'tailoress', and twenty-six as 'dressmaker' (pre-industrial, clothing trades). This suggests that even the migrants from an 'industrial' background were not necessarily migrating to escape from 'smoke stacks and grime'; or if they were it was from the prospect of such a lifestyle rather than from their present situation.

Of those within the 'armed forces 2' category of the public service, professional and independent sector, 40.74 per cent were from the Eastern Lowlands. The Eastern Lowlands contributed more migrants to both categories of professionals than the Western Lowlands - 33.33 per cent of 'professional 1' and 22.45 per cent of 'professional 2', compared to the Western Lowlands 22.22 and 18.37 per cent respectively. However the North East contributed the most migrants of a 'professional 2' background - 30.61 per cent of the 'professional 2' group. Though it must be conceded that this finding arises from a small - and therefore possibly misleading sub-sample, it is noteworthy that thirteen of the fifteen migrants from the North East categorised as 'professional 2' were teachers. ${ }^{44}$ Half of the migrants employed as 'assistants to professionals' were born in the Western Lowlands, and all but one in Lanarkshire. The eight Lanarkshire-born migrants were nurses, aged between sixteen and thirty-six at arrival. The one 'assistant' born in Renfrewshire was a lay reader in the Presbyterian Church. ${ }^{45}$ David Barker, aged fifty-five at arrival in New Zealand in 1885, was the only migrant in the sample to have been engaged in employment within

\footnotetext{
${ }^{44}$ The other two were accountants. Seven of the nine Western Lowlands 'professional 2' migrants were teachers, and only six of the Eastern Lowlands eleven migrants were in this group.

${ }^{45}$ Though not what would usually be considered an 'occupation', this is what is recorded for his occupation on the NZSG register, and as such it is classified here. NZSG database, migrant 06075
} 
the 'public service 1' category prior to his emigration. He is recorded as having been a Lieutenant Governor in Dumfries. ${ }^{46}$ Perhaps more surprising is that just one migrant in the NZSG data had been employed within the 'public service 2' category prior to emigration; Murdoch McLennan had been an excise officer in Ross and Cromarty before emigrating in 1857, aged twenty-three. ${ }^{47}$ The small number of migrants with a background in public service employment in Scotland suggests that individuals in this line of work had less incentive to emigrate than those in other avenues of employment, perhaps living in comfortable circumstances with financial security. That the New Zealand Government had greater interest in attracting migrants who were highly adaptable to the needs of the colonial occupation market than in migrants who were highly trained and specialised also played a part. ${ }^{48}$

Only four migrants in the sample were of independent means in Scotland. Two were born in the Eastern Lowlands (Clackmannan and Stirling), one in the Western Lowlands (Lanarkshire) and one in the North East (Aberdeen). Although a greater number of migrants were classified as 'independent' in New Zealand, only one of the four remained in this category post-emigration. The migrant of independent means from Aberdeen, Agnes Milne, was recorded as 'Lady' on the NZSG registration form. She was single at arrival in New Zealand, being then aged forty years. Though she died within six years of arrival in New Zealand, she married within this time, to a fellow Aberdonian who had arrived in New Zealand some seven years earlier. Her husband had no occupation recorded in the register for his time in Scotland, but was a farm manager and seed merchant in New Zealand. Agnes had no occupation recorded for her time in New Zealand, but, based on her husband's New Zealand occupations, would not have been recorded as of independent means post-immigration. Furthermore, it might be suggested that if she had the resources to still be considered a 'lady' of independent means, it is unlikely her husband would have been employed in the recorded areas of employment in New Zealand. ${ }^{49}$ Francis Garden Brown, born in Lanarkshire in 1879, is recorded as having been of independent means in Scotland, though he arrived in New Zealand aged just twenty-four. His occupation in New

\footnotetext{
${ }^{46}$ NZSG database, migrant 00404.

${ }^{47}$ NZSG database, migrant 04100.

${ }^{48}$ Fairburn, 'Social mobility and opportunity', p.48

${ }^{49}$ NZSG database, migrant 04408
} 
Zealand is recorded as 'farming' ${ }^{50}$ Alexander MacFarlane, aged only twenty-one years at arrival, was recorded in the register as having been a 'gentleman' in Scotland. He lived only six years in New Zealand before his death in 1880, and was variously employed as a mariner and a publican during that time. ${ }^{51}$ Septimus Leishman, born in Dollar, Clackmannan in 1848, was twenty-nine at arrival and has neither spouse nor children recorded on his registration form. His recorded occupation on the NZSG form for both Scotland and New Zealand is 'independent means'. He died in Edinburgh aged seventy-two. The registration form gives no indication as to when he returned to Scotland. ${ }^{52}$

Over twice as many migrants from the Far North had been involved in the transport sector than were migrants from any other region - 11.21 per cent of Far North migrants compared to less than 5 per cent from other regions. Though this 11.21 per cent was made up of just twelve migrants, eleven of the twelve were either seamen, sailors, seafarers or master mariners. Eight were from Shetland and three from Orkney. ${ }^{53}$ The only migrant of the twelve employed in 'inland transport' was Margaret Doull of Caithness. Margaret was born in 1821 and is recorded on the NZSG form as having worked as a carter prior to her immigration to New Zealand in $1877^{54}$

Aberdeen migrants involved in shipbuilding comprise a significant number of North East migrants engaged in manufacturing, 12.31 per cent of all manufacturing sector migrants from that region being Aberdonian. Four of these Aberdeenshire-men, Adam and David Thompson, Robert Reid and William Craig, were among the Scottish-born employed as shipbuilders in New Zealand. ${ }^{55}$ Another former Aberdeen man, George Fraser, built the first New Zealand-made iron ship. ${ }^{56}$

\section{OCCUPATIONS IN NEW ZEALAND}

To facilitate comparison with the PNZ and NZSG occupation data, the occupations of the 1878 New Zealand Census were reclassified to fit the classification scheme

\footnotetext{
${ }^{50}$ NZSG database, migrant 00659

${ }^{51}$ NZSG database, migrant 03198

${ }^{52}$ NZSG database, migrant 03003

${ }^{53}$ For further discussion of Shetland occupations see Chapter Six

${ }^{54}$ NZSG database, migrant 01497

${ }^{55}$ NZSG database, migrants 06012, 06016, 05113 and 01208

${ }^{56}$ Jim McAloon, 'Scots and the colonial economy', in Tom Brooking and Jennie Coleman (eds), The Heather and the Fern: Scottish Migration and New Zealand Settlement, Dunedin, 2003, p.99
} 
employed to analyse the two data samples in the present study. ${ }^{57}$ Table 5.4 sets out the proportion of males and females in the census data in each sector, including and excluding those for whom occupation is unknown, unable to be classified due to lack of information, or 'other' (not fitting within any other sector).

Table 5.4

Proportion of males and females in the New Zealand population employed in each sector*

\begin{tabular}{|c|c|c|c|c|c|c|}
\hline & \multirow{2}{*}{$\begin{array}{c}\text { Males } \\
\text { (a) } \\
\end{array}$} & \multirow{2}{*}{$\begin{array}{c}\text { Females } \\
\text { (b) }\end{array}$} & \multirow{2}{*}{$\begin{array}{c}\text { Males } \\
\text { (c) } \\
\end{array}$} & \multirow{2}{*}{$\begin{array}{c}\text { Females } \\
\text { (d) } \\
\end{array}$} & \multicolumn{2}{|c|}{$\begin{array}{l}\text { Male and Female } \\
\text { Combined }\end{array}$} \\
\hline & & & & & (e) & (f) \\
\hline Agricultural & 35.11 & 2.63 & 21.35 & 0.3 & 30.86 & 12.03 \\
\hline Mining & 10.18 & 0 & 6.19 & 0 & 8.84 & 3.45 \\
\hline Building & 9.8 & 0 & 5.96 & 0 & 8.52 & 3.32 \\
\hline Labouring & 8.08 & 0.03 & 4.91 & 0 & 7.03 & 2.74 \\
\hline Manufacturing & 11.33 & 19.26 & 6.89 & 2.22 & 12.37 & 4.82 \\
\hline Transport and Commercial & 7.32 & 0.26 & 4.45 & 0.03 & 6.39 & 2.49 \\
\hline Dealing & 11.41 & 5.05 & 6.94 & 0.58 & 10.58 & 4.12 \\
\hline Public Service, etc & 4.65 & 10.27 & 2.83 & 1.19 & 5.38 & 2.10 \\
\hline Domestic Service & 2.13 & 62.48 & 1.29 & 7.22 & 10.04 & 3.91 \\
\hline Other, indefinable and unknown & & & 39.2 & 88.45 & & 61.00 \\
\hline$n$ & 140,436 & 21,180 & 230,998 & 183,414 & 161,616 & 414,412 \\
\hline
\end{tabular}

Including 'unknown', 'other', and 'indefinable' is useful when considering female occupations because, as previously noted, a large number of the migrants were dependants rather than being in paid work. However, it is misleading in respect of male occupations, the group being chiefly made up of those for whom occupations are indefinable due to a lack of information. The majority of males in this category should be included in another, but it is impossible to know which (for example, those recorded as 'apprentice'). Thus column (a) should be considered more meaningful than column (c) and column (d) more meaningful than column (b). Columns (e) and (f) together indicate how significantly 'other' alters the results of the analysis. Because these census results have been re-classified, results in this table may be compared directly with those in Table 5.5.

\footnotetext{
${ }^{57}$ The occupations listed, not the classes, orders or sub-orders, were reclassified. This was occasionally problematic due to several groupings listed under one 'occupation' in the census not being readily separable for reclassification (see Appendix 5.1). Rather than using several sets of New Zealand census data for comparison with occupational data from the samples, the 1878 Census has been chosen as the point of comparison. Although this produces some anachronisms - for example it includes more miners than could be expected in a sample for the eighty years from 1840, and more than may be found in later censuses - 4,492 of the 5,912 migrants in the NZSG database with a date of arrival recorded arrived pre-1878. This makes the Census of 1878 a logical choice.
} 
Analysis of the census data reveals that 61.00 per cent of the population of New Zealand in 1878 were classified as 'other', i.e. they were dependants not in paid employment. Removing this 61.00 per cent of the population from calculations, and then calculating male and females together (column (e)) 30.86 per cent of those who remain for analysis were involved in agriculture, 12.37 per cent in manufacturing, 10.58 and 10.04 per cent in dealing and domestic service respectively and less than 9 per cent in public service/professional/independent, transport/commerce, labouring, building, and mining.

Table 5.5

Employment subsequent to emigration to New Zealand: proportion of male and female Scottish immigrants in each sector

\begin{tabular}{|c|c|c|c|c|}
\hline & $\begin{array}{c}\text { Males } \\
\text { (a) }\end{array}$ & $\begin{array}{c}\text { Females } \\
\text { (b) }\end{array}$ & $\begin{array}{c}\text { Males } \\
\text { (c) } \\
\end{array}$ & $\begin{array}{c}\text { Females } \\
\text { (d) }\end{array}$ \\
\hline Agricultural & 43.83 & 19.32 & 34.26 & 2.88 \\
\hline Mining & 4.55 & 0.97 & 3.56 & 0.14 \\
\hline Building & 10.68 & 0 & 8.35 & 0 \\
\hline Labouring & 3.67 & 0 & 2.87 & 0 \\
\hline Manufacturing & 13.22 & 16.18 & 10.34 & 2.41 \\
\hline Transport and Commercial & 4.8 & 0 & 3.75 & 0 \\
\hline Dealing & 10.24 & 18.84 & 8.00 & 2.81 \\
\hline Public Service, etc & 8.52 & 21.5 & 6.66 & 3.2 \\
\hline Domestic Service & 0.49 & 23.19 & 0.38 & 3.45 \\
\hline Other, indefinable and unknown & & & 21.82 & 85.11 \\
\hline$n$ & 2,042 & 414 & 2,612 & 2,780 \\
\hline
\end{tabular}

The proportion of NZSG females employed in domestic service is lower than might logically be expected (see Table 5.5). In the 1878 Census of New Zealand 62.48 per cent of women were in domestic service if dependants are excluded from the equation, 7.22 per cent when dependants are included - more than twice the NZSG figures. However, the NZSG data covers the eighty years to 1920, and as Figure 5.1 (above) clearly demonstrates, there was a shift in the occupations of females over the eighty years. ${ }^{58}$ The proportion of women in New Zealand employed in domestic service in 1911, for example, was just 23.60 per cent excluding

\footnotetext{
${ }^{58}$ Frank, 'Bread queues and breadwinners: gender in the 1930s', pp.113-140 and Sprecher, 'Good clothes are good business: gender, consumption and appearance in the office, 1918-1939', pp.141-162 also suggest this shift.
} 
dependants and 4.47 per cent including dependants. ${ }^{59}$ This issue of major social changes over the time covered by the data also explains why the NZSG figure for females involved in public service, who were professionals, or were or of independent means, is nearly three times higher than the 1878 Census figure of just 1.19 (including dependants) might suggest. This sector includes hospital matrons, midwives, dental and other nurses, music, sewing and school teachers as well as headmistresses, post mistresses and police matrons. Not all of these occupations were available to the women included in the 1878 Census, but they were all available to those migrants in the NZSG database living in the twentieth century. Dealing is also affected by the dramatic shift in female occupations over the period; the NZSG figure for 'dealing' is more than four times greater than the 1878 Census figure of just 0.58 per cent. ${ }^{60}$

The NZSG dataset includes a much higher proportion of women involved in agriculture than the PNZ data, the New Zealand census data and the Scottish census data. This partly arises from a methodological decision to include in the agricultural sector all those included on registration forms as 'farmer's wife' or 'farmer's daughter', also incidentally 'farmer’s son', as being involved in agriculture rather than as a dependant. (See Appendix 5.1). The contributors of the registration forms who completed the occupation field in this manner likely recognised that wives and children of farmers were almost certain to have contributed their labour to the running of the farm, and were therefore employed on the farm, albeit presumably without wages. Nevertheless, forty-five of the ninety-eight females in the NZSG database included in the agriculture sector were not recorded as farmer's wives or daughters, but as farm workers or farmers in their own right. Though the wives of storekeepers, bakers, grocers, publicans and etc were also likely to have been involved in their husband's work, as was Angus Cameron's wife Mary, ${ }^{61}$ very few women in the NZSG register have been described as 'baker's wife' or 'grocer's wife'. Mary

\footnotetext{
${ }^{59}$ These 1911 figures are based on the sub-order 'Engaged in domestic service and attendance' rather than the class 'Domestic', that also included the sub-order 'Engaged in board and lodging'. Whereas in the 1878 Census 'Domestic' included 'Persons engaged in the domestic offices or duties of wives, mother, mistresses of families, children, relatives (not otherwise returned) - who have been included in my analysis as 'Dependents' - the 1911 Census separated these people into a 'Dependents' category. Part VIII, Tables I and V, 1911 Census of New Zealand, pp.412-413 and 419.

${ }^{60}$ For discussion of this shift in the employment patterns of New Zealand women in the early twentieth century see Frank, 'Bread queues and breadwinners: gender in the 1930s', pp.113-140; Sprecher, 'Good clothes are good business: gender, consumption and appearance in the office, 1918-1939', pp.141-162.

${ }^{61}$ See case study of Angus Cameron at the beginning of this chapter.
} 
Cameron's occupation in New Zealand is recorded as 'domestic, housewife' in the NZSG register. ${ }^{62}$ This phenomenon is not, of course, peculiar to the NZSG data. As Fairburn has noted 'the great majority of work places, [were small scale,] generally owner-operated affairs located in the home where wives and children played a crucial role in productive activity. The distinction the Census made between "breadwinners" and "dependants", therefore, had little basis in reality. ${ }^{63}$

The figure in the NZSG data for males involved in agriculture in New Zealand (43.83 per cent) is closer than the PNZ dataset to the proportion that might be expected based on previously published findings and census data. ${ }^{64}$ The NZSG data is within 2 per cent of the 1878 Census data for the building, manufacturing, dealing and domestic service sectors.

That the Scots were involved in both manufacturing and dealing in New Zealand in proportions similar to their contemporaries throughout the rest of New Zealand (compare Tables 5.4 and 5.5), corroborates McAloon's provisional findings that Scots were disproportionately successful in these sectors. ${ }^{65}$ Had the proportion of Scots involved in these sectors been much higher than the proportion of the general population of New Zealand so engaged, it might be expected that their rate of 'success' would, correspondingly, also be higher, and the apparent success noted by McAloon would be less noteworthy. In several papers on Scots in the New Zealand economy McAloon notes the importance of Scottish networks, especially with regard to woollen merchants and manufacturers. He observes that the small population of Scotland, certainly in comparison with England, 'made networks much easier to form and maintain'. ${ }^{66}$ These networks, he suggests, aided the development of Scots businesses in New Zealand, and it is these networks, and not a peculiarly Scottish technical ability or shrewdness, that set the Scots apart, in terms of success, from their New Zealand contemporaries.

\footnotetext{
${ }^{62}$ NZSG database, migrant 04817

${ }^{63}$ Fairburn, 'Social mobility and opportunity', p.49

${ }^{64}$ See discussion of PNZ agricultural migrants earlier in this chapter

${ }^{65}$ Jim McAloon, 'Scottish Canterbury?' The Jim Gardner Lecture 2007, University of Canterbury, 5 August 2007; Jim McAloon, 'Scots, networks and the colonial economy: the nineteenth-century business relationships of Sanderson and Murray of Galashiels and Murray, Roberts and Co of Dunedin’, in John MacKenzie and Brad Patterson (eds), Scots Abroad: The New Zealand Scots in International Perspective, Forthcoming

${ }^{66}$ McAloon, 'Scots, networks and the colonial economy: the nineteenth-century business relationships of Sanderson and Murray of Galashiels and Murray, Roberts and Co of Dunedin',
} 
The public service, professional, independent means grouping employed 12.99 per cent of PNZ male migrants, 8.52 per cent of NZSG males but just 4.65 per cent of males in the 1878 New Zealand Census (figures exclude those categorised as 'other'). This variance between the Scottish migrant datasets and the New Zealand population at the 1878 Census may have its origin in one or more classification issues, but if this is the case they do not appear to have similarly affected the PNZ and NZSG data (see Table 5.6).

Table 5.6

Employment subsequent to emigration to New Zealand: proportion of the Public Service/Professional/Independent sector

\begin{tabular}{ccc}
\multicolumn{3}{c}{ by occupation type } \\
\hline \hline & NZSG & PNZ \\
\hline \hline Armed Forces 1 & 0 & 0.44 \\
Armed Forces 2 & 5.7 & 22.22 \\
Public Service 1 & 1.14 & 0 \\
Public Service 2 & 7.6 & 20.89 \\
Professional 1 & 17.11 & 17.33 \\
Professional 2 & 33.08 & 15.11 \\
Assistants to Professionals & 17.49 & 5.33 \\
Independent Means & 17.87 & 18.67 \\
$\boldsymbol{n}$ & 263 & 225 \\
\hline
\end{tabular}

Sources: NZSG and PNZ Data, 1840-1920

While the majority of PNZ migrants so classified were in the 'armed forces 2' subdivision, this is a potentially problematic grouping due to the number of unspecified 'seamen' in the category. The PNZ data includes forty-two migrants whose death certificates record their occupation as 'seaman' and these men have consequently been classified as 'armed forces 2', though it is possible they were, more accurately, commercial fishermen or in another sea-based occupation. ${ }^{67}$ Conversely, not one of the NZSG 'armed forces' category migrants were 'seamen' - ten were in the police force, fourteen were in the military, ${ }^{68}$ one was a night watchman, and three were unspecified retired servicemen.

'Independent means' contributed forty-two migrants to both the NZSG and PNZ samples. 'Settler' was the recorded occupation for eleven of the NZSG migrants and twenty of the PNZ migrants; there were two 'gentlemen' in the NZSG sample and nineteen in the PNZ. As noted with regard to migrants aged fifty-plus, however,

\footnotetext{
67 'Seamen' have been classified as 'armed forces 2' in order to afford comparability with McClean's $\mathrm{PhD}$ thesis findings, 'seamen' having been classified in this way in her study because most of the people described as such in her sources were in the armed forces. See Appendix 5.1.

68 'armed constabulary’, 1; 'cavalry’, 1; ‘fencible’, 3; 'military’, 2; ‘soldier’, 7.
} 
whether or not these migrants were otherwise employed is unknown. As Dunstall has cautioned in respect of Fairburn's 1979 propositions, the widely employed 'settler' and 'gentleman' designations are not so much occupational descriptions as markers of self-perceived socio-economic status. ${ }^{69}$

Most notable in Table 5.6 is the disparity between the PNZ and NZSG data for the sub-divisions 'professional 2' and 'assistants to professionals'. The proportion of NZSG migrants employed in each of these categories is very similar to that of the New Zealand population at the 1878 Census. At the 1878 Census 90.38 per cent of 'assistants to professionals' were nurses or midwives, as were 87.04 per cent of the NZSG migrants so classified. ${ }^{70}$ Of the 'professional 2' sub-division, 62.93 per cent of NZSG migrants were teachers or school principals. ${ }^{71}$ This high proportion is almost exactly matched by the New Zealand census figures for 1878: 62.79 per cent of the 'professional 2' sub-group, 2,380 individuals out of a total of 3,790, were school masters/mistresses, music teachers or 'others connected with education'. It is not possible to establish whether this is co-incidence or if it is indicative of the accuracy of the NZSG data for this part of the migrant profile, given the available data. If Scottish migrants were involved in the occupations to the same extent as the population of New Zealand generally, as these figures suggest, it would emphasise the perceived disproportionate impact those Scots who were involved in education (and in making policies relating to education) had on New Zealand's schools and education. ${ }^{72}$

Just as each region of Scotland had distinctive occupational characteristics, so too were some occupation types more evident in particular New Zealand provinces. Table 5.7 shows the occupational sector spread of NZSG Scots in each province. As the table indicates very clearly, the West Coast was the only province in which migrants were not primarily engaged in agriculture; this was due to the influence of mining - of

${ }^{69}$ G. Dunstall, University of Canterbury, comment on Fairburn, 'Social mobility and opportunity', pp.61-2

${ }_{71}^{70}$ Forty-seven of the fifty-four 'assistants' in the NZSG data.

${ }^{71}$ Seventy-three out of the 116 in this occupation type.

72 This 'perceived disproportionate impact' of Scots on New Zealand education systems includes the admittance of females to New Zealand's universities from the inception of the universities, an insistence that girls as well as boys in the colony receive secondary education and the formation of a secular rather than sectarian state system of education in 1877. See Tom Brooking, 'Sharing out the haggis: the special Scottish contribution to New Zealand history', in Tom Brooking and Jennie Coleman (eds), The Heather and the Fern: Scottish Migration and New Zealand Settlement, Dunedin, 2003, pp.59-60. Brooking cites Ian Carter, 'The Scottish Contribution to the development of New Zealand universities', Bamforth Lecture, University of Otago, 1992; Roger Openshaw, Greg Lee and Howard Lee, Challenging the Myths: Rethinking New Zealand's Educational History, Palmerston North, 1993, esp. pp. 81-95; and Erik Olssen, A History of Otago, Dunedin, 1984, p.94 
gold and, later, coal - in that province. Just 7.89 per cent of the migrants were engaged in agriculture, but 31.58 per cent in mining. The trend is not peculiar to Scots, being also reflected in the 1878 Census data. ${ }^{73}$

Table 5.7

Employment subsequent to emigration to New Zealand: proportion of Scots in New Zealand provinces employed in each sector* NZ Occupation Sectors
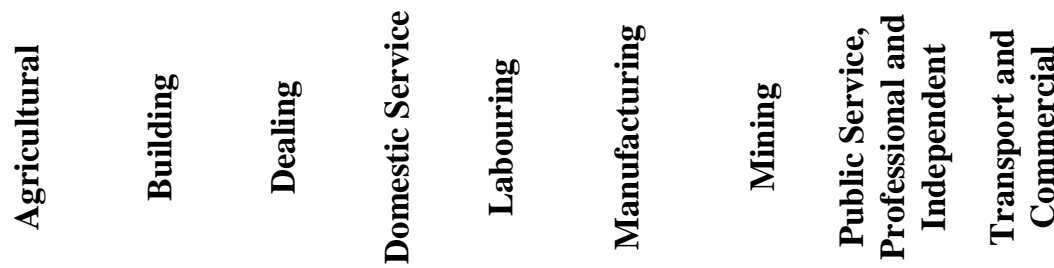

\begin{tabular}{ccccccccccc}
\hline \hline Auckland & 31.68 & 11.59 & 12.84 & 4.14 & 1.45 & 16.56 & 3.93 & 13.04 & 4.76 & 483 \\
Taranaki & 55.10 & 8.16 & 6.12 & 2.04 & 0.00 & 6.12 & 0.00 & 18.37 & 4.08 & 49 \\
Hawkes Bay & 40.63 & 7.81 & 10.94 & 4.69 & 7.81 & 15.63 & 0.00 & 10.94 & 1.56 & 64 \\
Wellington & 38.79 & 8.90 & 14.59 & 2.49 & 1.42 & 12.81 & 2.14 & 15.30 & 3.56 & 281 \\
Nelson & 22.64 & 1.89 & 13.21 & 9.43 & 9.43 & 15.09 & 11.32 & 9.43 & 7.55 & 53 \\
Marlborough & 47.37 & 5.26 & 10.53 & 5.26 & 5.26 & 10.53 & 0.00 & 10.53 & 5.26 & 19 \\
West Coast & 7.89 & 13.16 & 5.26 & 7.89 & 0.00 & 10.53 & 31.58 & 10.53 & 13.16 & 38 \\
Canterbury & 39.92 & 7.36 & 14.34 & 8.14 & 2.71 & 14.73 & 2.33 & 7.75 & 2.71 & 258 \\
Otago & 41.89 & 8.18 & 11.42 & 4.09 & 4.09 & 13.82 & 3.95 & 9.03 & 3.53 & 709 \\
Southland & 57.14 & 6.25 & 4.91 & 3.13 & 2.68 & 12.50 & 3.57 & 6.70 & 3.13 & 224 \\
Total & 39.81 & 8.63 & 11.62 & 4.45 & 2.94 & 14.10 & 3.90 & 10.65 & 3.90 & 2,178 \\
\hline
\end{tabular}

* Excludes unknown, indefinable and other sectors

Source: NZSG Data, 1840-1920

Canterbury and Wellington had the largest numbers, as a proportion of all the Scots in the province, of those engaged in dealing, with retail proprietors making up the majority in both cases, 56.89 per cent of Wellington Scottish migrants in the dealing sector and 66.66 per cent of those in Canterbury. However, while 19.44 per cent of retail proprietors in Canterbury were bakers and 19.44 per cent butchers, 21.21 per cent of the Wellington retail proprietors were store keepers and 15.15 per cent hotel keepers. This may underline the more urban nature of Wellington compared to Christchurch over the eighty years, and the need, as the capital, to accommodate a greater number of transients. ${ }^{74}$ Given the significant early clustering of Europeans in the vicinities of Auckland and Wellington, due to the location of the capital in those centres pre- and post-1865 respectively, the higher than average proportion of

\footnotetext{
${ }^{73}$ Though the figure for mining on the West Coast among the population at large at that census was 51.70 per cent.

${ }^{74}$ In terms of population density, at the 1921 Census of New Zealand the 'urban area' (a division created for statistical purposes at the 1916 Census) of Auckland held 2.53 people per acre and Christchurch 1.32 per acre, Wellington was the most densely populated 'urban area' with 3.31 people per acre. Part I, Section III, 1921 Census of New Zealand, p.45
} 
migrants in those provinces who were of independent means or involved in public service or professional occupations is arguably predictable - 13.04 per cent of Scots in Auckland and 15.30 per cent of those in Wellington were employed in this sector. Nevertheless, as can be seen when comparing Table 5.7 with Table 5.8, this pattern is more clearly apparent among the NZSG Scots than the 1878 population of New Zealand, perhaps reflecting an over-representation of Scots in these occupations. While these two tables are not directly comparable, Table 5.7 being of migrants arriving over an eighty year period and Table 5.8 being a snapshot of occupation in 1878 alone, comparison of the two tables reveals evident occupational clusters of Scots. While the proportions of Scots involved in public service and professional occupations in Wellington and Auckland was higher than elsewhere in the country, the proportion of Scots involved in this sector across the country was significantly higher than among the general population of New Zealand. This was also the case among those in the manufacturing sector and in agriculture. On the other hand, Scots appear to have been under-represented among labourers and domestic servants. This comparison further substantiates McAloon’s findings (see p.152 above).

Table 5.8

Proportion of the employed population of New Zealand in each province employed in each sector in 1878*

\section{NZ Occupation Sectors}

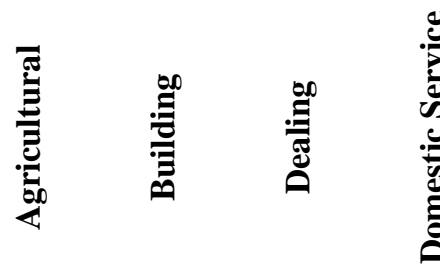

\begin{tabular}{ccccccccccc}
\hline \hline Auckland & 32.81 & 8.46 & 11.41 & 9.58 & 3.56 & 13.85 & 6.22 & 6.73 & 7.38 & 30,720 \\
Taranaki & 42.29 & 7.90 & 9.05 & 8.40 & 10.61 & 8.61 & 0.29 & 8.66 & 4.19 & 3,393 \\
Hawkes Bay & 34.88 & 8.72 & 9.91 & 12.19 & 9.66 & 11.20 & 0.53 & 5.19 & 7.74 & 6,047 \\
Wellington & 27.38 & 11.88 & 12.00 & 11.40 & 9.53 & 12.85 & 0.77 & 7.50 & 6.68 & 19,514 \\
Nelson & 25.88 & 6.51 & 8.95 & 8.59 & 5.23 & 9.42 & 25.25 & 4.38 & 5.79 & 10,193 \\
Marlborough & 41.26 & 6.45 & 7.06 & 10.04 & 10.68 & 9.19 & 2.57 & 4.77 & 7.98 & 2,959 \\
West Coast & 7.65 & 6.60 & 11.81 & 7.52 & 3.32 & 8.61 & 46.89 & 3.57 & 4.04 & 8,021 \\
Canterbury & 36.29 & 8.73 & 9.88 & 11.68 & 9.31 & 12.52 & 0.70 & 4.80 & 6.08 & 35,055 \\
Otago and & 29.91 & 7.91 & 10.54 & 9.10 & 6.74 & 13.03 & 12.13 & 4.39 & 6.27 & 45,616 \\
Southland & & & & & & & & & &
\end{tabular}

* Excludes unknown, indefinable and other sectors

Source: Part VII, Table III, 1878 New Zealand Census 


\section{SCOTTISH REGIONAL DIFFERENCES WITHIN MIGRANTS’ NEW ZEALAND OCCUPATIONS}

Given the outlined Scottish regional differences with regard to occupations, another question that arises is whether the same differences are evident in the migrants' New Zealand occupations. Table 5.9 shows the proportion of migrants from each region of Scotland engaged in each occupational sector post-immigration.

Analysis of the 2,913 NZSG migrants with region of birth information and one occupation recorded in New Zealand produces patterns that might be expected. Migrants born in the Highlands and Borders, for example, were more likely than migrants from other regions to be involved in agriculture in New Zealand. Just over half of Borders migrants were involved in agriculture in New Zealand, and 60.87 per cent of the Highland migrants. Less than 41 percent of migrants from the other four regions were employed in agriculture. The region with the fewest migrants engaging in agriculture in New Zealand was the Western Lowlands, with 30.83 per cent (see Table 5.9 - compare Table 5.3).

Table 5.9

Employment subsequent to emigration to New Zealand: proportion of migrants from each region of Scotland employed in each sector*

\begin{tabular}{|c|c|c|c|c|c|c|c|c|c|c|}
\hline & & 首 & 冓 & 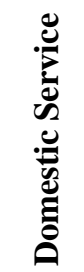 & 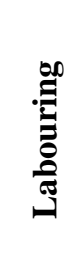 & 兑 & 㔽 & 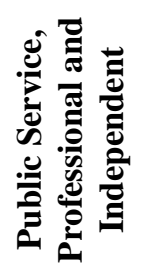 & 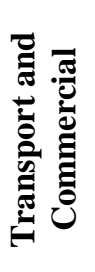 & $=$ \\
\hline Far North & 39.57 & 7.91 & 9.35 & 5.76 & 7.19 & 13.67 & 5.04 & 7.91 & 3.60 & 139 \\
\hline Highlands & 60.86 & 4.61 & 8.22 & 3.62 & 2.30 & 6.91 & 1.97 & 8.22 & 3.29 & 304 \\
\hline North East & 40.82 & 13.11 & 10.11 & 2.25 & 3.75 & 10.11 & 0.75 & 15.73 & 3.37 & 267 \\
\hline $\begin{array}{c}\text { Eastern } \\
\text { Lowlands }\end{array}$ & 35.80 & 7.66 & 13.47 & 5.68 & 2.77 & 15.19 & 3.96 & 10.57 & 4.89 & 757 \\
\hline $\begin{array}{l}\text { Western } \\
\text { Lowlands }\end{array}$ & 30.83 & 11.13 & 13.38 & 4.66 & 2.71 & 15.49 & 6.32 & 10.98 & 4.51 & 665 \\
\hline Borders & 50.22 & 7.11 & 10.67 & 1.33 & 2.67 & 15.56 & 2.22 & 8.89 & 1.33 & 225 \\
\hline
\end{tabular}

The North East provided a relatively large proportion (15.73 per cent) of the migrants involved in the public service, professional or independent sector, followed by Western Lowland migrants, 10.98 per cent of whom were involved in this sector. In line with the pre-emigration occupational backgrounds of the migrants, comparatively few of those from the Highlands were involved in manufacturing in 
New Zealand, while correspondingly high proportions of migrants from the Western Lowlands and the Far North were engaged in mining in New Zealand. Of the Western Lowlands migrants, 6.32 per cent were employed in mining in New Zealand, as were 5.04 per cent of Far North migrants and 3.96 per cent of those from the Eastern Lowlands. Less than 2.3 per cent of migrants from the other regions of Scotland were involved in mining industries in New Zealand. For reasons outlined below, migrants from the Far North were almost three times as likely to be employed as labourers in New Zealand as migrants from other regions in the database, 7.19 per cent of Far North migrants being labourers post-immigration, 3.75 per cent of North East migrants, and less than 2.7 per cent of migrants from other regions. ${ }^{75}$

Table 5.10 gives the percentages of migrants in each sector in New Zealand by region of birth, as well as the percentage of the total Scots migrants from each region. Viewed in this way, the data reveals in which sectors of New Zealand employment the regions were over or under-represented. Several discrepancies are especially notable.

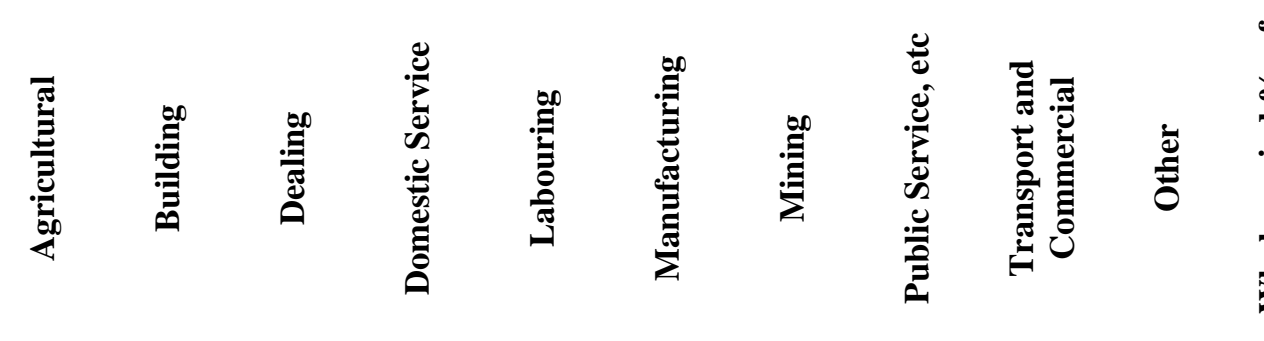

\begin{tabular}{|c|c|c|c|c|c|c|c|c|c|c|c|}
\hline & 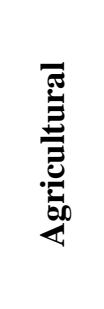 & 晜 & 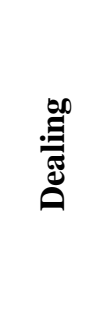 & 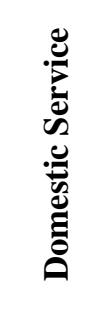 & 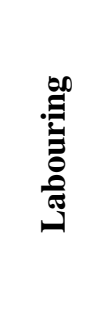 & & 昙 & 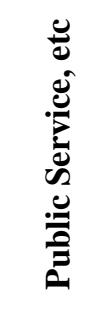 & 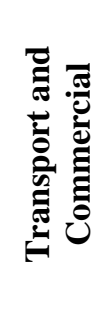 & ఫેّ & 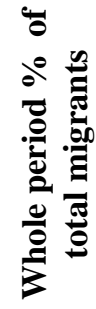 \\
\hline Far North & 5.86 & 5.29 & 4.64 & 7.84 & 13.89 & 5.94 & 7.61 & 4.38 & 5.32 & 5.04 & 5.16 \\
\hline Highlands & 19.72 & 6.73 & 8.93 & 10.78 & 9.72 & 6.56 & 6.52 & 9.96 & 10.64 & 12.41 & 12.37 \\
\hline North East & 11.62 & 16.83 & 9.64 & 5.88 & 13.89 & 8.44 & 2.17 & 16.73 & 9.57 & 14.57 & 10.78 \\
\hline $\begin{array}{l}\text { Eastern } \\
\text { Lowlands }\end{array}$ & 28.89 & 27.88 & 36.43 & 42.16 & 29.17 & 35.94 & 32.61 & 31.87 & 39.36 & 33.81 & 30.94 \\
\hline $\begin{array}{l}\text { Western } \\
\text { Lowlands }\end{array}$ & 21.86 & 35.58 & 31.79 & 30.39 & 25.00 & 32.19 & 45.65 & 29.08 & 31.91 & 25.36 & 26.36 \\
\hline Borders & 12.05 & 7.69 & 8.57 & 2.94 & 8.33 & 10.94 & 5.43 & 7.97 & 3.19 & 8.81 & 8.8 \\
\hline$n$ & 938 & 208 & 280 & 102 & 72 & 320 & 92 & 251 & 94 & 556 & \\
\hline
\end{tabular}

* Excludes ‘unknown', 'indefinable’ and 'other' sectors

Source: NZSG Data, 1840-1920

\footnotetext{
${ }^{75}$ These results are the percentages of the region totals for each sector when 'other', 'unknown' and 'indefinable' are excluded from calculations.
} 
Entirely predictably, given the large proportions of migrants from the Highlands and Borders regions involved in the sector, as indicated in Table 5.8, these two regions were over-represented in agriculture. Though migrants from the Eastern and Western Lowlands contributed a greater number of migrants to the sector, this was simply because overall more migrants came to New Zealand from these regions. The Western Lowlands contributed over 9 per cent more migrants than its share of the migrant total to the building sector, and the North East was also over-represented in building, contributing 16.83 per cent of building sector migrants. While the proportion of Borders and North East migrants involved in domestic service in New Zealand was considerably smaller than their share of the population, the Eastern Lowlands contributed nearly 12 per cent more migrants to domestic service than was proportionate to their share of the total migrants. Far North migrants were disproportionately represented in the labouring classes, contributing 13.89 per cent of labourers compared to the 5.16 per cent share of the migrant total. None of the NZSG Far North migrants employed in labouring in New Zealand had a background in labouring, over half having been employed in fishing or other sea-linked occupations in Scotland. For example, though their father was a fisherman in Shetland and a ropemaker in New Zealand, all three of Laurence and Georgina Robertson's sons, born in Walls, Shetland, were labourers in New Zealand. ${ }^{76}$

The Western Lowlands was heavily over-represented in the mining sector, contributing nearly 20 per cent more than was proportionate to its migrant share perhaps unsurprising given the background in mining many from the Western Lowlands would have had. The North East, on the other hand, contributed just over one fifth of its proportionate share of the migrants to this sector. This underproportionate figure for miners from the North East is, perhaps, surprising, given the relative prominence of the granite mining industry in that region. As Harper observes however, there was a well established flow of granite workers from the North East to America by the mid-nineteenth century, both of temporary and permanent migrants, and it may be that this established flow prevented any great number of North East miners from emigrating to New Zealand. ${ }^{77}$ Moreover, New Zealand is not a reserve of granite, so would not have attracted these miners in particular.

\footnotetext{
${ }^{76}$ NZSG database, migrants 05194, 05199, 05223 and 05225

${ }^{77}$ Marjory Harper, Emigration from North-East Scotland: Willing Exiles, Aberdeen, 1988, pp.254-259.
} 
If the inflows are considered by county rather than region of birth, the patterns above are even more easily explained. The high proportion of Far North migrants involved in labouring was created primarily by migrants from Shetland - while 9.09 per cent of NZSG Orkney migrants and just 1.75 per cent of those born in Caithness turned to this line of work, 12.24 per cent of Shetland migrants were labourers in New Zealand. All of these Shetland migrants who had been employed in Scotland prior to immigration had been seamen/fishermen, whereas three-quarters of the Orkney-born migrants in the sub-sample had been employed in agricultural occupations. The importance of the sea to the Shetland migrants in terms of occupation will be discussed further in Chapter Six. With labouring being the principal colonial occupation requiring little previous experience or training, it was an obvious option for individuals with skills and experience in limited demand. Few of those who had been in sea-oriented occupations would have had experience of paid employment outside of those occupations. Typical was Thomas Mouat. Thomas had worked as a fisherman in Norwick, Unst, where he also worked the croft that he and his family lived on and from. Part of a mass migration from Unst to New Zealand in the 1870s, Thomas, his wife and eight children departed on the Clarence in 1874. Arriving in Napier in 1875, he found work as a labourer in the inland settlement of Waipukurau, where he resided until his death forty-five years later. ${ }^{78}$

Of the thirty-three counties of Scotland, eight had more than 50 per cent of their NZSG migrants engaged in agriculture in New Zealand. All were counties with a high proportion of the home population employed in agriculture. Of these eight counties, three were Highland: 59.82 per cent of Ross and Cromarty migrants to New Zealand were employed in agriculture, 58.33 per cent of those born in Inverness and 63.53 per cent of the Argyll immigrants. The Border region accounted for another three of the counties: 50.00 per cent of Dumfries migrants, 65.63 per cent of those from Kirkcudbrightshire and 63.33 per cent of immigrants born in Wigtown. Migrants from both Orkney and Perthshire were also predominantly employed in agriculture in New Zealand, 63.64 and 53.57 per cent respectively of the migrants from those counties being involved in farming. ${ }^{79}$

\footnotetext{
${ }^{78}$ NZSG database, migrant 04564; Shetland database migrants Chips001-Chips009

${ }^{79}$ The proportion of these counties home populations engaged in agriculture at the 1881 Census of Scotland were: ROC, 59.37 per cent; INV, 44.2 per cent; ARL, 40.46 per cent; DFS, 29.16 per cent; KKD, 33.97 per cent; WIG, 41.86 per cent; OKI, 56.7 per cent; PER 28.45 per cent. Thesis figures
} 
The disproportionate number of migrants from the North East recorded as being involved in public service/professional/independent employment in the NZSG data in part reflects the high percentage of migrants from Moray, 29.03 per cent of Moray migrants being engaged in this sector compared to 15.17 per cent of Aberdeen migrants. While it might reasonably be expected that counties such as Midlothian, East Lothian, Renfrewshire and Lanarkshire would send larger proportions of migrants in these fields of employment than other counties, Shetland contributed a similar proportion to these four counties, and the Moray percentage for this sector was more than twice as high. Though this is probably an aberration due to the small sample size (there being only ninety-one migrants in the NZSG data born in Moray in total), all of the Moray migrants classified in this sector were either 'professional 2', 'public service 2' or 'assistants to professionals' occupation types - none were 'settlers' or 'retired'. Agnes McKnight Anderson Knight, aged fifteen at arrival, and her eighteen-year-old sister Helen Grant Knight were among the Moray migrants working in this sector in New Zealand. While Agnes was employed as a photographer's assistant ('assistant to professional'), Helen was working as a music teacher. $^{80}$

The high proportion of migrants from the Western Lowlands with backgrounds in mining is primarily the result of a very high proportion of migrants from Lanarkshire. While Lanarkshire provided just 14.97 per cent of Scottish migrants to 1920 it, perhaps unsurprisingly, contributed 27.08 per cent of those involved in mining in New Zealand. ${ }^{81}$ Peebles contributed more than four times its share of migrants to the mining sector, being the source of 0.49 per cent of migrants but 2.08 per cent of New Zealand Scottish miners; however this constituted just two migrants. While Shetland contributed just 1.91 per cent of migrants over the period 1840 to 1920 , it contributed 5.21 per cent of miners and 8.00 per cent of labourers. Unsurprisingly, given the high proportion of Far North migrants involved in labouring in New Zealand, Orkney too was over-represented in the labouring sector, contributing 4.00 per cent of labourers but only 0.98 per cent of total migrants.

differ to those given in Table 11 of Erickson, 'Who were the English and Scots emigrants', because her figures are of the male labour force only.

${ }^{80}$ NZSG database, migrants 02885 and 02888

${ }^{81}$ The prevalence of mining in the home population of Lanarkshire was noted in Chapter Two. 
Aberdeen, the birth county of 6.95 per cent of all Scots migrants to New Zealand to 1920, was the birth county of 11.01 per cent of all Scots in the building sector in New Zealand. Building was the pre-emigration occupation of over 13 per cent of the North East migrants, and Aberdeen was the largest county in that region. Engineers made up 24.39 per cent of Aberdeen building sector migrants in the NZSG data, carpenters a further 24.39 per cent and stone masons 14.63 per cent. Though shipbuilders are classified in the present study as 'Manufacturing - industrial and changing skills', it should be noted that Aberdeen also supplied a significant proportion (14.81 per cent) of the NZSG migrants who were employed in shipbuilding in New Zealand. All seven of the Aberdeen NZSG migrants working as stone masons in New Zealand had been stone masons in Aberdeen. The apparent tendency of Aberdeen stonemasons to remain stonemasons after arrival in New Zealand raises the question of occupational mobility - how common was it for Scottish migrants to remain in the same occupations, or at least the same occupational sector, after their arrival in New Zealand?

\section{INDIVIDUAL AND GENERATIONAL OCCUPATION MOBILITY}

Though occupational change is often advanced as an indicator of social mobility, the use of occupation alone as an index can be misleading. ${ }^{82}$ Nevertheless, it is the sole measure available to the present study. The following discussion focuses upon mobility within the migrants' own lives, comparing their employment in Scotland to that in New Zealand, as well as comparing multiple occupations held post-emigration. It also considers generational mobility, matching the employment of migrants in New Zealand to the employment it is believed their fathers held in Scotland.

Table 5.11 is a cross-tabulation of the occupations in Scotland of NZSG migrants with the occupations held by those same migrants in New Zealand. It includes only those migrants with a single occupation recorded in Scotland and a single occupation recorded in New Zealand. This affords a sample of 3,079, of whom 1,394 have only one occupation recorded for either New Zealand or Scotland, leaving a sub-sample of 1,685 migrants for consideration. What is immediately clear is that Aberdeen stonemasons were not the only migrants remaining in the same occupational sector post-migration.

\footnotetext{
${ }^{82}$ Fairburn, 'Social mobility and opportunity’, pp.42-64
} 
Though the very large proportion of migrants who had been engaged in agriculture in Scotland who were also employed on the land in New Zealand (78.30 per cent) was not rivalled in any other field of employment, a clear majority of those in building, dealing, labouring, manufacturing, mining, public service etc and 'other' in Scotland remained in those occupational sectors in New Zealand. Only those who had been domestic servants in Scotland provide a notable exception to the rule, presumably because many women married in New Zealand shortly after arrival and were subsequently classified as 'other'. A majority of the migrants who changed their occupations in New Zealand switched to agricultural employment, indicating the attraction of land in New Zealand to immigrants, and the widespread recruitment of migrants for agricultural labouring.

Table 5.11

Occupational mobility within individual lifetimes:

proportion of migrants in each occupational sector of Scotland by subsequent sector in New Zealand*

\section{Scotland Occupation Sector}

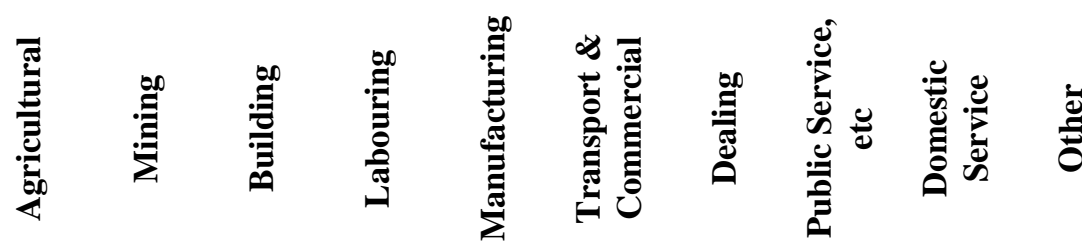

\begin{tabular}{|c|c|c|c|c|c|c|c|c|c|c|c|}
\hline \multirow{10}{*}{ 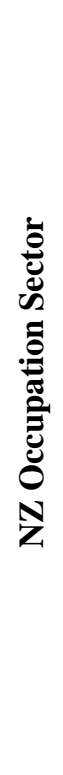 } & Agricultural & 78.30 & 19.64 & 15.63 & 29.73 & 17.65 & 34.00 & 23.08 & 14.81 & 9.52 & 16.53 \\
\hline & Mining & 2.20 & 66.07 & 3.13 & 8.11 & 1.38 & 4.00 & 0.96 & 0.00 & 0.00 & 2.44 \\
\hline & Building & 2.75 & 1.79 & 64.58 & 0.00 & 10.03 & 4.00 & 0.00 & 0.00 & 1.59 & 7.59 \\
\hline & Labouring & 2.47 & 3.57 & 2.08 & 29.73 & 1.73 & 8.00 & 0.00 & 1.23 & 0.79 & 1.08 \\
\hline & Manufacturing & 2.20 & 0.00 & 6.25 & 8.11 & 48.10 & 10.00 & 2.88 & 2.47 & 3.17 & 8.67 \\
\hline & $\begin{array}{c}\text { Transport and } \\
\text { Commercial }\end{array}$ & 1.37 & 3.57 & 1.04 & 18.92 & 1.38 & 38.00 & 1.92 & 1.23 & 0.00 & 1.63 \\
\hline & Dealing & 3.02 & 3.57 & 2.08 & 0.00 & 6.23 & 2.00 & 54.81 & 4.94 & 7.14 & 6.23 \\
\hline & $\begin{array}{c}\text { Public Service, } \\
\text { etc }\end{array}$ & 3.02 & 1.79 & 5.21 & 5.41 & 4.15 & 0.00 & 6.73 & 66.67 & 6.35 & 8.40 \\
\hline & $\begin{array}{l}\text { Domestic } \\
\text { Service }\end{array}$ & 1.65 & 0.00 & 0.00 & 0.00 & 0.35 & 0.00 & 0.96 & 0.00 & 25.40 & 2.71 \\
\hline & Other & 3.02 & 0.00 & 0.00 & 0.00 & 9.00 & 0.00 & 8.65 & 8.64 & 46.03 & 44.72 \\
\hline & $n$ & 364 & 56 & 96 & 37 & 289 & 50 & 104 & 81 & 126 & 369 \\
\hline
\end{tabular}

* Excludes 'unknown', 'indefinable' and 'other' sectors

Source: NZSG Data, 1840-1920

Given that industry was the primary employment sector in Scotland, and agriculture the primary employer in New Zealand, it is noteworthy that only 17.65 per cent of those in the NZSG sample engaged in manufacturing in Scotland turned to 
agriculture in New Zealand. Indeed, just under half of the Scottish manufacturing sector migrants (48.10 per cent) were employed in manufacturing in New Zealand, suggesting that these immigrants were perhaps seeking an environment, not an occupational, change. ${ }^{83}$ Daniel Brown provides an apt example. Born in 1884, Daniel lived in Ayrshire until his emigration with his wife and children at age thirty-five. Having trained and worked as a blacksmith (and thus classified in the present study as 'manufacturing, pre-industrial, metal trades') in Ayrshire, he naturally found employment as a blacksmith when he and his family settled on a farm in Morrinsville, New Zealand. ${ }^{84}$ As the nineteenth century drew to a close there were burgeoning opportunities for skilled mechanics and tradesmen.

Very few of the NZSG migrants involved in manufacturing in Scotland found new lives in labouring, mining, transport and commerce, or in domestic service, these occupational groups representing between 0.35 and 1.73 per cent of migrants who were previously involved in manufacturing. Migrants employed in the public service etc sector in New Zealand represent 4.15 per cent of migrants in a 'manufacturing' occupation in Scotland, 6.23 per cent of immigrants employed in manufacturing in Scotland were in the dealing sector in New Zealand, and 9 per cent were in 'other', all but one of the last being female, and all dependants; 10.03 per cent were employed in a building related trade in New Zealand.

The unexpectedly high proportion of Scottish labourers (18.92 per cent) who were engaged in the transport and commerce sector in New Zealand is conceivably another peculiarity of the small sub-sample, with only nine migrants being in the group. All of these migrants were 'labourers' in Scotland, and four of them went on to work on the railways in New Zealand. There occupations were recorded, respectively, as 'bridge keeper, New Zealand Rail', 'railwayman', 'railway porter', and 'railway ganger', suggesting not so much a change of occupation, these still being 'unskilled' occupations involving some labour, as a change in the type of work involved (and hence a change in occupation title and consequently also occupation sector). ${ }^{85}$

\footnotetext{
${ }^{83}$ Though being a developing rather than developed nation, the nature of New Zealand manufacturing was, of course, different to that in Scotland. G.J.R. Linge provides a good outline of the development of manufacturing in New Zealand between 1850 and 1940 in Linge, 'Manufacturing in New Zealand: four years in a century of growth', pp.139-159.

${ }^{84}$ NZSG database, migrant 00650

${ }^{85}$ NZSG migrants 04432, 04929, 05837, and 06583
} 
Viewing migrants' occupations in Scotland and New Zealand from a different perspective, analysing the figures in terms of the proportion of migrants in each occupational sector of New Zealand who were employed in those sectors in Scotland, only emphasises the significance of manufacturing employment in the country of origin (see Table 5.12).

Table 5.12

Occupational mobility within individual lifetimes: proportion of migrants in each occupational sector of New Zealand by former sector in Scotland*

\section{Scotland Occupation Sector}
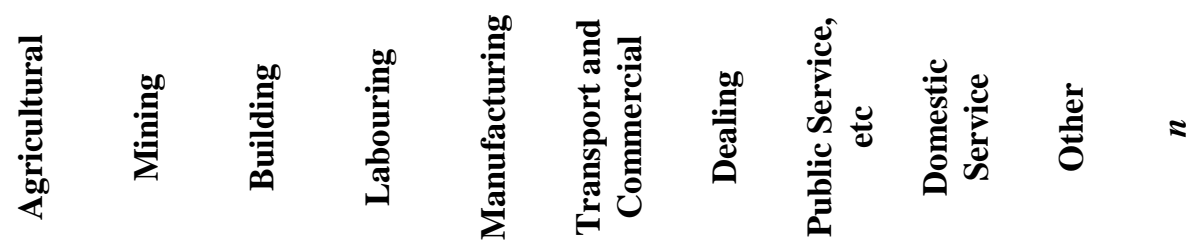

\begin{tabular}{|c|c|c|c|c|c|c|c|c|c|c|c|c|}
\hline \multirow{10}{*}{ 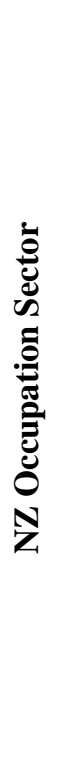 } & Agriculture & 57.11 & 2.20 & 3.01 & 2.20 & 10.22 & 3.41 & 4.81 & 2.40 & 2.40 & 12.22 & 499 \\
\hline & Mining & 11.94 & 55.22 & 4.48 & 4.48 & 5.97 & 2.99 & 1.49 & 0.00 & 0.00 & 13.43 & 67 \\
\hline & Building & 7.46 & 0.75 & 46.27 & 0.00 & 21.64 & 1.49 & 0.00 & 0.00 & 1.49 & 20.90 & 134 \\
\hline & Labouring & 23.08 & 5.13 & 5.13 & 28.21 & 12.82 & 10.26 & 0.00 & 2.56 & 2.56 & 10.26 & 39 \\
\hline & Manufacturing & 3.96 & 0.00 & 2.97 & 1.49 & 68.81 & 2.48 & 1.49 & 0.99 & 1.98 & 15.84 & 202 \\
\hline & $\begin{array}{c}\text { Transport and } \\
\text { Commercial }\end{array}$ & 10.64 & 4.26 & 2.13 & 14.89 & 8.51 & 40.43 & 4.26 & 2.13 & 0.00 & 12.77 & 47 \\
\hline & Dealing & 8.66 & 1.57 & 1.57 & 0.00 & 14.17 & 0.79 & 44.88 & 3.15 & 7.09 & 18.11 & 127 \\
\hline & $\begin{array}{c}\text { Public Service, } \\
\text { etc }\end{array}$ & 8.40 & 0.76 & 3.82 & 1.53 & 9.16 & 0.00 & 5.34 & 41.22 & 6.11 & 23.66 & 131 \\
\hline & $\begin{array}{l}\text { Domestic } \\
\text { Service }\end{array}$ & 12.00 & 0.00 & 0.00 & 0.00 & 2.00 & 0.00 & 2.00 & 0.00 & 64.00 & 20.00 & 50 \\
\hline & Other & 3.99 & 0.00 & 0.00 & 0.00 & 9.42 & 0.00 & 3.26 & 2.54 & 21.01 & 59.78 & 276 \\
\hline
\end{tabular}

* Excludes 'unknown', 'indefinable' and 'other' sectors

Source: NZSG Data, 1840-1920

Manufacturing was the prior occupation of more migrants than even agriculture or domestic service. Of NZSG migrants employed in manufacturing post-migration, 68.81 per cent had a background in manufacturing, as did 21.64 per cent of NZSG migrants involved in building post-migration. Aside from agriculture, no other Scotland occupation sector was represented by much more than 5 per cent of migrants in any New Zealand occupation sector outside of that same sector.

As has been stressed, a primary advantage of the NZSG data for occupational analysis is the availability of information on multiple occupations. Though the reliability of the listings is uncertain, because it is not known in what way the 
information was recorded, ${ }^{86}$ the data is suggestive of a high degree of occupational mobility once migrants landed in New Zealand. ${ }^{87}$ Table 5.13 is a cross-tabulation of the NZSG migrants 'New Zealand Occupation 1' with their 'New Zealand Occupation 2'. Given the dominance of agriculture amongst the New Zealand occupations of the migrants, it is logical that agriculture should be the sector in which most migrant 'second' occupations were classified. Furthermore, it is likely that for a large number an agricultural 'second' occupation was concurrent with other employment. Farming a small block of land, for example, with the primary income being supplemented by other, often seasonal, employment was common, as the case of Angus Cameron well demonstrates. ${ }^{88}$ Census occupation data bears this out. As Fairburn notes, the 1881 Census recorded 30,832 land holdings greater than one acre, but only 20,280 individuals enumerated as 'farmer', 'market gardener', 'runholder', or 'grazier' at that census. This suggests that over 10,000 people who were recorded as being in non-agricultural occupations could, potentially, have been classified as engaged in agriculture. ${ }^{89}$

A significant number of migrants with two occupations were both farmers and retail proprietors. Of the 1,021 migrants with two occupations in the data, 5.78 per cent were 'farmers' and 'retail proprietors' in either occupation one or two, a high proportion given the large number of occupation combinations possible. Of those with a combination of 'farmer' and 'retail proprietor' in occupations one and two, eighteen were butchers and farmers. Only thirty-two of the migrants with two occupations were butchers, making this a noteworthy number. This is perhaps one of the more predictable combinations of occupations, the one occupation providing means to the other, as the case of William Duff Murray appears to show. Born in Aberdeen in 1836, William was a flesher in Scotland prior to emigration at age twenty-seven. It appears that he initially lived at the site of his butcher's shop in Auckland, and there is no evidence that he was farming at that time. After his marriage to Mary Ann Lesley in 1866, the couple moved to Kaeo, Northland, where William farmed and continued

\footnotetext{
${ }^{86}$ Was it, for example, recorded in the order they came to the mind of the contributor?; In order of perceived importance by the contributor?; In chronological order?; In order of the length of time spent in each occupation?

${ }^{87}$ What have been analysed as a secondary occupation of migrants in New Zealand, for the 1,021 migrants with two occupations recorded in the NZSG dataset, are simply those occupations listed second on the registration forms.

${ }^{88}$ Bolland and Bolland, 'A Forward Pert Sett'

${ }^{89}$ Fairburn, 'Social mobility and opportunity’, p.53
} 
to work as a butcher, partly supplying his own stock, until his death at age fifty. ${ }^{90}$ Two of the three market gardeners in the database were also farmers. The second largest combination was of migrants who were farmers and storeowners or general shopkeepers, though this combination of occupations accounts for just fifteen of the fifty-one migrants with 'storeowner' or 'shopkeeper' as one of their two occupations.

Table 5.13

Change subsequent to emigration to New Zealand: proportion of New Zealand Occupation 1 sector totals engaged in by migrants in New Zealand Occupation 2* NZ Occupational Sector 2

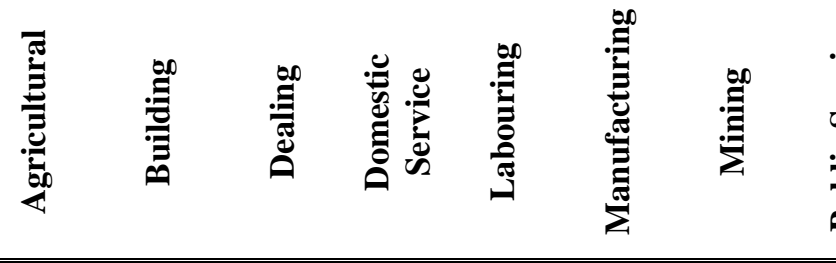

\begin{tabular}{|c|c|c|c|c|c|c|c|c|c|c|c|c|}
\hline \multirow{10}{*}{ 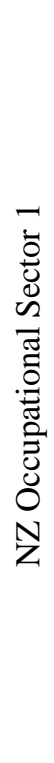 } & Agricultural & 37.68 & 7.39 & 19.01 & 1.06 & 5.99 & 4.58 & 2.82 & 11.62 & 5.28 & 2.11 & 284 \\
\hline & Building & 32.80 & 22.40 & 9.60 & 0.00 & 1.60 & 13.60 & 3.20 & 15.20 & 1.60 & 0.00 & 125 \\
\hline & Dealing & 33.61 & 4.10 & 27.05 & 0.82 & 0.82 & 4.10 & 0.82 & 18.85 & 4.10 & 4.10 & 122 \\
\hline & $\begin{array}{l}\text { Domestic } \\
\text { Service }\end{array}$ & 7.69 & 0.00 & 19.23 & 7.69 & 0.00 & 7.69 & 0.00 & 3.85 & 0.00 & 53.85 & 26 \\
\hline & Labouring & 62.22 & 11.11 & 2.22 & 0.00 & 0.00 & 11.11 & 2.22 & 2.22 & 8.89 & 0.00 & 45 \\
\hline & Manufacturing & 33.33 & 8.81 & 20.13 & 1.26 & 2.52 & 18.87 & 1.26 & 5.66 & 3.77 & 3.14 & 159 \\
\hline & Mining & 37.08 & 12.36 & 17.98 & 1.12 & 6.74 & 7.87 & 5.62 & 7.87 & 2.25 & 0.00 & 89 \\
\hline & $\begin{array}{c}\text { Public Service, } \\
\text { etc }\end{array}$ & 31.82 & 1.52 & 16.67 & 0.00 & 3.03 & 4.55 & 0.00 & 37.88 & 0.00 & 4.55 & 66 \\
\hline & $\begin{array}{c}\text { Transport and } \\
\text { Commercial }\end{array}$ & 41.54 & 4.62 & 15.38 & 0.00 & 3.08 & 9.23 & 4.62 & 10.77 & 9.23 & 0.00 & 65 \\
\hline & Other & 16.67 & 0.00 & 9.26 & 3.70 & 0.00 & 1.85 & 0.00 & 9.26 & 0.00 & 57.41 & 54 \\
\hline
\end{tabular}

* Excludes unknown, and indefinable sectors

Source: NZSG Data, 1840-1920

For others, a second occupation in the agricultural sector was indicative of true occupational mobility, rather than occupational versatility or the supplementing of an income. Moreover, it is clear that this was almost invariably 'upward' mobility. Of those whose primary occupation was in agriculture, 37.68 per cent held another agricultural occupation as their secondary employment; 81.32 per cent were 'farmers' in occupation two, 46.01 per cent of whom had been employed in an occupation within the 'farm workers 1' category and 19.26 within 'farm workers 2' in occupation one. This indicates that mobility within the agricultural sector was primarily upwards

${ }^{90}$ NZSG database, migrant 04705 
over the two occupations recorded (also suggesting that many informants listed the occupations in chronological order).

Upward mobility was not just confined to agriculture: 22.4 per cent of those with a secondary occupation in building, 27.05 per cent of those in dealing, 18.87 per cent in manufacturing and 37.88 per cent in the public service/professional/independent category were only changing jobs within the same sector as their initial employment. The majority of this in-sector mobility was 'upwards'. William Dawson Douglas, for example, who had arrived in New Zealand as an infant at the beginning of World War One, trained and worked initially as an accountant, rising through this career to become the manager of a company. ${ }^{91}$ Though Robert McKinlay had worked as a cotton weaver and letter carrier prior to emigration at age thirty-six, during his time in New Zealand he worked initially as a leather cutter. In 1879 he founded a boot and shoe factory that is still in operation. ${ }^{92}$ This approach to occupational and social mobility employed by Robert, of a gradual accumulation of capital and remaining within ones area of experience, is not an uncommon story among New Zealand's business elite and entrepreneurs. ${ }^{93}$ One notable absence from the data is of those who were in the labouring sector in both occupation one and two; the majority (62.22 per cent) of those who were labourers in their primary occupation fit within the agricultural sector for their secondary occupation.

Upward mobility was not limited to within particular sectors, something that becomes clearer if land ownership is taken as a guide to success, indicated in the NZSG data primarily by the recording of the migrants' occupation as 'farmer'. Of those who were miners in occupation one, 84.84 per cent were farmers in occupation two, while just 15.16 were in 'other rural' in this agricultural category and none were farm workers. This suggests that earnings accumulated, initially on the gold fields but later through other forms of mineral extraction, were often used to purchase land that was then farmed by the migrant. Most of those whose occupations spanned building, then agriculture, fit within building 'operative 1' type in occupation one and were 'farmers' in occupation two. No migrants in the data were 'farm workers 1' in either

\footnotetext{
${ }^{91}$ NZSG database, migrant 01494

${ }^{92}$ NZSG database, migrant 03955; Graeme and David McKinlay, McKinlay’s of Dunedin, Home Page, http://www.mckinlays.co.nz/index.html.

${ }_{93}$ as further examples in Ian Hunter, Age of Enterprise: Rediscovering the New Zealand Entrepreneur 1880-1910, Auckland, 2007 attest. See also Jim McAloon, No Idle Rich: The Wealthy in Canterbury and Otago, 1840-1914, Dunedin, 2002.
} 
occupation 1 or 2 and builders in the other occupation, suggesting that mobility between the building and agricultural sectors was primarily from building workers to land ownership/farming when this became financially possible.

Whereas comparison of NZSG data for migrants' occupations in Scotland and in New Zealand permits a contrasting of migrant occupational backgrounds and postmigration employment, thereby indicating an appreciable level of individual occupational mobility, the PNZ data provides some insight into generational occupational mobility by comparing fathers' occupations with migrant occupations at death.

Unfortunately, father's occupation was not recorded on the death certificates for 12.09 per cent of the migrants for whom data was collected, and 44.66 per cent of migrants had a father's occupation but not the migrant's occupation recorded (a further 5.60 per cent had neither migrant nor father's occupation recorded). Excluding from calculations those 2,089 migrants with either no migrant, no father's, or neither migrant nor father's occupation recorded, leaves a sample of 1,592 migrants. Table 5.13 is a cross-tabulation of migrants' occupations with fathers' occupations, distinguishing the proportion of each father's occupation sector within which migrants were also involved.

Comparison of this table with Table 5.11 suggests that migrant occupations in Scotland provide a clearer indication of occupational 'background' than is suggested by generational analysis. While there is some correlation between a father's occupation in Scotland and the migrant's own occupation in New Zealand, it appears there was significantly more mobility between generations than there was between a migrants pre- and post-emigration occupation. Nonetheless, over one quarter of migrants involved in building, manufacturing, mining and within the public service/professional/independent category were following in their fathers occupational footsteps - at sector level at least - and just over half of the PNZ migrants with a father who had been agriculturally employed were also engaged in that sector in New Zealand (see Table 5.14). Considered from another perspective, the fathers of 26.13 per cent of migrants in the building sector were also in the building sector, 24.11 per cent of those in labouring were in the same sector as their fathers, as were 37.31 per cent of those in manufacturing, 58.75 per cent of miners, 32.14 per 
cent of those in the public service/professional/independent means sector, and 68.16 per cent of the agriculturally-employed migrants.

Table 5.14

Occupational mobility across generations:

proportion of migrants' fathers occupation sector totals migrants were engaged in for their New Zealand Occupations

\begin{tabular}{|c|c|c|c|c|c|c|c|c|c|c|c|}
\hline & & \multicolumn{10}{|c|}{ Father's occupation } \\
\hline & & 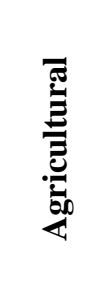 & 些 & 弟 & & 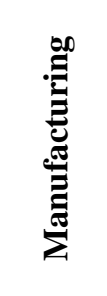 & 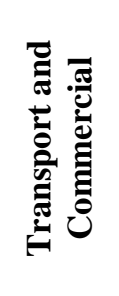 & 祭 & 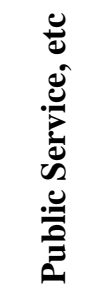 & 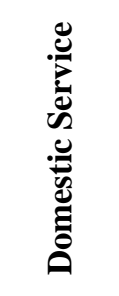 & $=$ \\
\hline \multirow{11}{*}{ 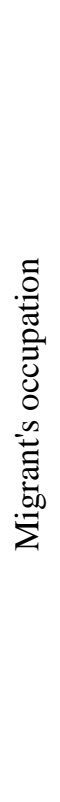 } & Agricultural & 50.98 & 7.14 & 13.66 & 18.68 & 15.26 & 11.48 & 15.38 & 7.93 & 0.00 & 380 \\
\hline & Mining & 1.77 & 41.96 & 0.62 & 3.30 & 2.41 & 13.11 & 2.88 & 0.61 & 16.67 & 80 \\
\hline & Building & 8.27 & 12.50 & 32.30 & 4.40 & 16.06 & 11.48 & 9.62 & 16.46 & 16.67 & 198 \\
\hline & Labouring & 7.48 & 8.93 & 6.83 & 29.67 & 4.82 & 1.64 & 4.81 & 4.88 & 0.00 & 112 \\
\hline & Manufacturing & 7.68 & 6.25 & 14.29 & 16.48 & 28.92 & 18.03 & 12.50 & 7.93 & 0.00 & 193 \\
\hline & $\begin{array}{c}\text { Transport and } \\
\text { Commercial }\end{array}$ & 4.53 & 5.36 & 8.70 & 6.59 & 5.62 & 11.48 & 5.77 & 6.10 & 0.00 & 86 \\
\hline & Dealing & 9.84 & 13.39 & 11.80 & 8.79 & 12.85 & 14.75 & 34.62 & 15.85 & 50.00 & 201 \\
\hline & $\begin{array}{c}\text { Public Service, } \\
\text { etc }\end{array}$ & 9.06 & 2.68 & 10.56 & 10.99 & 12.05 & 18.03 & 13.46 & 38.41 & 16.67 & 196 \\
\hline & $\begin{array}{c}\text { Domestic } \\
\text { Service }\end{array}$ & 0.20 & 1.79 & 0.62 & 0.00 & 0.80 & 0.00 & 0.96 & 0.61 & 0.00 & 8 \\
\hline & Total** & 99.80 & 100.00 & 99.38 & 98.90 & 98.80 & 100.00 & 100.00 & 98.78 & 100.00 & \\
\hline & $n$ & 507 & 112 & 160 & 90 & 246 & 61 & 104 & 162 & 12 & 1,454 \\
\hline
\end{tabular}

\section{CONCLUSION}

The title to the current chapter arises from an observation of Phillips and Hearn: 'New Zealand was not settled by refugees from the smoke stacks and grime of industry' ${ }^{94}$ Though Phillips and Hearn utilised only fathers' occupations in the PNZ dataset, the analysis of migrant occupations in that dataset and in the NZSG dataset supports this contention. Further, the majority of those employed in industrial occupations preemigration were from pre-industrial occupation backgrounds, or had been engaged in textiles. Nearly half of the NZSG migrants from a manufacturing background remained in that form of employment post-emigration. Thus, not only were the

\footnotetext{
${ }^{94}$ Phillips and Hearn, Settlers, p.83
} 
majority of New Zealand Scots migrants not from a background of 'smoke stacks and industry grime', nearly half of those who were were not necessarily emigrating to escape such conditions.

Beyond outlining the patterns and trends extrapolated from the available data, this chapter has highlighted the impact source material may have upon the analysis of datasets pertaining to migrant occupations. While death certificates were demonstrated to be of limited utility as a source for female occupation data, they nevertheless remain valuable as a clear point at which a migrant's life 'snap shot' has been taken. They are also useful in that they allow the probing of generational occupation mobility changes within families. Genealogically-based data are clearly shown to be especially valuable when analysing female occupations, also enabling the pre- and post-emigration occupations of individuals to be considered. Were more sophisticated genealogically-based datasets to be created, with analytical purposes in mind, generational occupation mobility could also be examined in greater detail.

While the evidence presented in this chapter constitutes the most detailed analysis of Scottish migrant employment patterns in New Zealand yet attempted, it may by no means be considered the last word on the subject. Aside from already identified areas in the chapter meriting deeper investigation - for example, individual and generational occupational mobility and concurrent employment patterns - several key questions have yet to be addressed, some of which will be outlined in the conclusion to the present work. 


\section{Chapter Six \\ 'IN HABITS, IN CHARACTER, IN FACT [IN] EVERYTHING EXCEPT LANGUAGE... LIKE THE NORWEGIANS': \\ NEW ZEALAND’s SHETLAND IMMIGRANTS - A COUNTY CASE STUDY ${ }^{1}$.}

Given the small number of Shetland migrants New Zealand received, relative to total New Zealand immigrants, the number of Shetland individuals to leave their mark on New Zealand in memorable ways is remarkable. Foremost amongst them was Sir Robert Stout, who arrived in Dunedin in 1864 and went on to become Premier and Chief Justice. ${ }^{2}$ William Mouat Bolt, a member of numerous Dunedin committees from shortly after his arrival on the Nelson in 1863, was a friend of Stout's. As well as being involved with the New Zealand Tailoresses Union, he was vice-president of the Dunedin Trades Council and in 1892 was called by the Ballance Government to sit in the Legislative Council, remaining there until his death in 1907. ${ }^{3}$ Another noteworthy Lerwick-born migrant, Philadelphus Bain Fraser was a Presbyterian minister with a reputation for unyielding defence of traditional Presbyterian teaching. ${ }^{4}$ A less well known individual who nevertheless left his mark on his new country was a school friend of Stout's in Lerwick between 1859 and 1863, Quintin McKinnon. Mackinnon Pass on the Milford Track was named for this early surveyor who 'found' the route to the West Coast. ${ }^{5}$ Though not all Shetland migrants were able to similarly distinguish themselves, they nevertheless formed a distinctive group.

New Zealand's Shetland immigrants differed from their counterparts from other parts of Scotland in terms of the timing of their immigration flow, their demographic characteristics and their occupations. By describing and explaining this distinctiveness a greater understanding of the variations of the migrant flows from different parts of Scotland may be developed. The consequent deeper knowledge about the individuals

\footnotetext{
${ }^{1}$ Letter to The Honourable The Colonial Secretary from Robert Stout, 18 September 1871, IM 6-10-1, Stewart Island, ANZ, Wellington, p.1

${ }^{2}$ Much has been written of Stout. Works include David Hamer, 'Stout, Robert 1844 - 1930', DNZB, URL: http://www.dnzb.govt.nz/, updated 22 June 2007; D.A. Hamer, 'The Law and the Prophet: A Political Biography of Sir Robert Stout (1844-1930)’, M.A., University of Auckland, 1960; Waldo Hilary Dunn and Ivor L.M. Richardson, Sir Robert Stout: A Biography, Wellington, 1961.

${ }^{3}$ Susan Butterworth, Chips off the Auld Rock: Shetlanders in New Zealand, Wellington, 1997, pp.4546; 'Death of the Hon. W.M. Bolt', Evening Post, Wellington, 30 April 1907, p.5

${ }^{4}$ Allan K. Davidson, 'Fraser, Philadelphus Bain 1862 - 1940’, DNZB, URL: http://www.dnzb.govt.nz/, updated 22 June 2007.

${ }^{5}$ Letter by Sinclair Johnson, New Zealand, to J.J. Haldane Burgess, 16 March 1925, D2/40/8, Shetland Archives. Other sources found that relate to Quintin McKinnon also spell this surname without an 'a'.
} 
and groups of migrants is invaluable to developing an understanding of wider patterns. ${ }^{6}$ Moreover, concentration on the migration patterns of a single Scottish county to one destination country highlights the value of localised studies in migration research. Hence Shetland was chosen as a focus locality. ${ }^{7}$

\section{BACKGROUND AND OVERVIEW TO SHETLAND MIGRATION}

It is debatable whether migrants from Shetland should even be included in a study of 'Scottish’ migrants. For the present study a 'Scottish’ migrant has been defined as one born in Scotland. Shetland migrants are therefore 'Scottish', because Shetland is administratively a county of Scotland. However, this was not always the case, and if 'Scottish' is defined in a strict and purely cultural sense, it may be argued that Shetland is Nordic, or at best 'Shetlandic'.

Until 1469 the Shetland Islands belonged to King Christian of Denmark and Norway. In financial difficulty, and in need of a dowry for his daughter upon her marriage to James the Third of Scotland, King Christian pledged first the royal estates in Orkney, then those in Shetland, to the Scottish Crown. Although Denmark later repeatedly offered to repay the dowry, restoration of the islands to Scandinavian sovereignty was never seriously considered by those who ruled Scotland. ${ }^{8}$ Language and cultural differences ensuing from this Nordic heritage have been maintained in Shetland, in part due the geographical distance of the islands from mainland Scotland and the consequent relative isolation of Shetland from Scottish language and culture both Gaelic and Scots language, Highland and Lowland culture. The resultant perception of Shetland as being part of Scotland but not Scottish has had important implications for the present study, principally due to the NZSG data being a selfselected sample.

\footnotetext{
${ }^{6}$ See, for example, McLean's investigation of migrants from Inverness-shire to Glengarry County, Ontario. Marianne McLean, The People of Glengarry: Highlanders in Transition, 1745-1820, Montreal and Kingston, 1991

${ }^{7}$ Jill Harland is presently carrying out just such a localised study of emigration from another Scottish county, investigating emigration from Orkney to New Zealand, Australia and Canada between 1840 and 1914, at Otago University.

${ }^{8}$ F.T. Wainwright, The Northern Isles, Edinburgh, 1962, p.190
} 


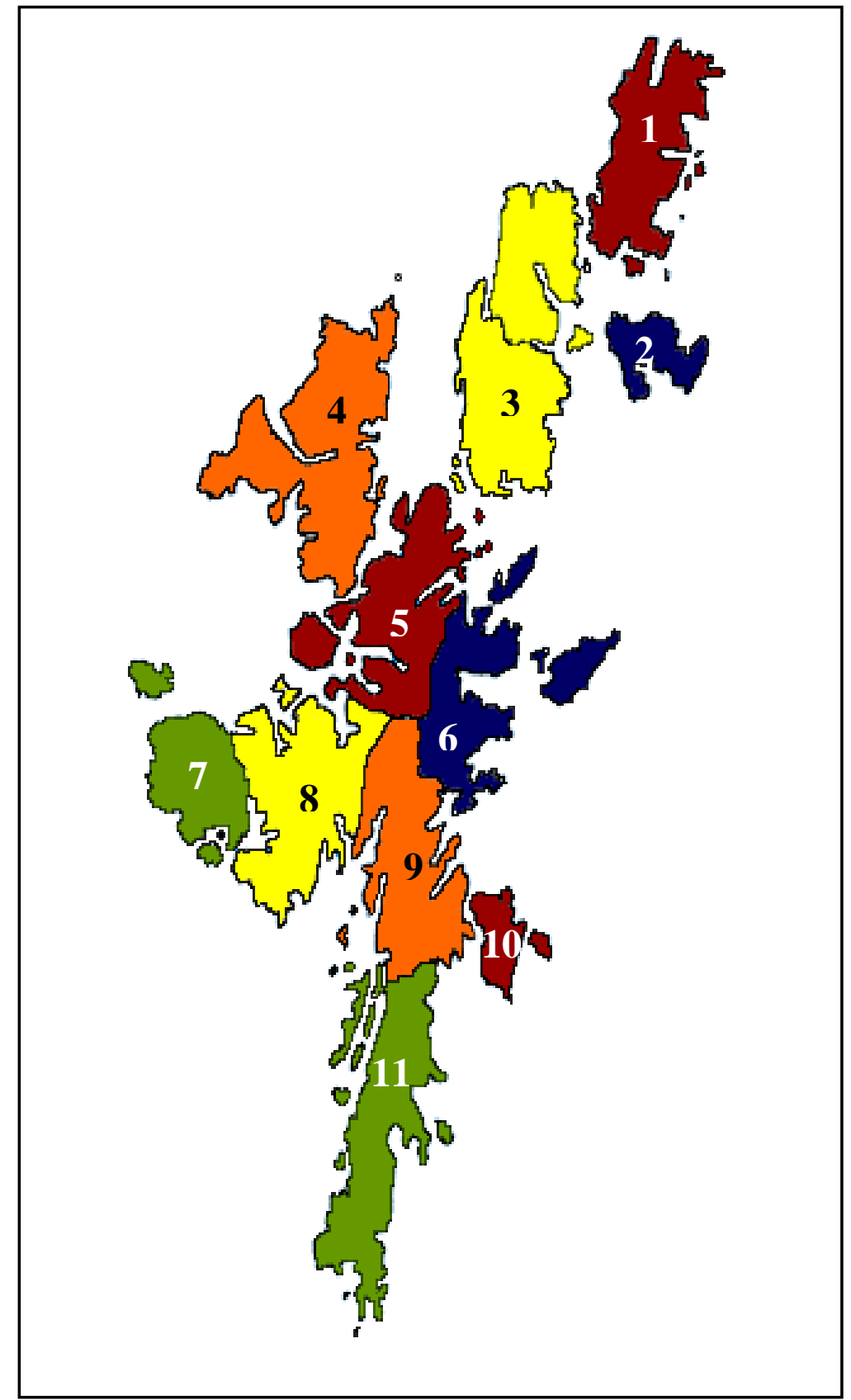

Source: Map created in Macromedia Fireworks based on parish map of Shetland in The Parishes, Registers and Registrars of Scotland, published by the Scottish Association of Family History Societies, 1993; map available online at http://www.scotlandsfamily.com/parish-map-orkney.htm

1. Unst

2. Fetlar, \&c

3. Mid and South Yell

4. Northmavine

5. Delting

6. Nesting, \&c

\section{Walls, \&c}

8. Sandsting and Aithsting

9. Tingwall, \&c and Lerwick

10. Bressay, \&c

11. Dunrossness, \&c

In addition to the conspicuous Nordic heritage, the character of Shetland Islanders has been significantly shaped by the fact that the islands have never been well suited 
to farming. ${ }^{9}$ While crofts have traditionally provided just enough food for individual family needs, there has been little scope for profit to be made from the land. Instead, the traditional mainstay of many Shetland families has been fishing. Indeed 'the lottery-like gains of a fisherman’s occupation' are noted in the Statistical Account of Scotland (1845) as one of the reasons for the 'versatile and sanguine' character of the Shetland people 'more apt for desultory and adventurous, than for regular and continued exertion'.10

Dependence on the sea for their livelihood meant that Shetland men were frequently absent from the home for long periods of time; and many of those who earned their living at sea died there also. Shetland women therefore have a long tradition of independence, as wives left at home to work the family croft while their husbands were at sea, and as widows left to provide for their families after the untimely death of their husbands. The high death toll at sea helps explain why the Shetland population was disproportionately female in the nineteenth century, and also why there was a high proportion of unmarried and widowed women in Shetland.

Preparedness to seek employment elsewhere was another reason for the gender imbalance. The sea-oriented occupations that were claiming the lives of Shetland men were also partly the cause of their emigration from the county. The Statistical Account of Scotland (1845) notes that the attachment of Shetland males 'to country is not very strong, an effect which may, in some measure, arise from the love of a wandering life, induced by sailor habits, and which so many of the young men imbibe, by going

\footnotetext{
${ }^{9}$ One theory as to why Shetland was mortgaged by King Christian for just 8,000 florins compared to Orkney being valued at 50,000 is due to this relative scarcity of arable land. However Shetland historian Brian Smith suspects ‘that the relative values attached to Shetland and Orkney don't concern arable land very much' but agrees that it is possible that the reason Christian held on to Shetland for six months longer than Orkney was because he 'regarded Orkney as self-evidently the most valuable dowry item'. Conversation with Shetland Museum staff, 23 November 2007; Personal communication with Brian Smith, 24 July 2009

10 'General Observations on the County of Shetland', pp.145-174, The New Statistical Account of Scotland, Vol.15, Edinburgh, 1845, p.158. Knitting, too, has always been an important source of household income in the Islands. It appears to seldom have been considered an 'occupation' as such, however, there being no evidence in the NZSG data as to migrants having been employed, or at least making some income, in this way in Shetland. Evidence given before the Truck Commission in 1872 (see footnote 22 in the present chapter for more information on the truck system and Truck Commission) indicates that those knitting goods at home were among those taken advantage of by the truck system - women purchasing wool from the store, knitting goods and taking the articles back to the store, receiving goods from the store in return. 'Minutes of Evidence taken before the Commission on the Truck System (Shetland) 1872', Truck Commission, 1872, transcribed by Angus Johnson, Shetland Archives
} 
annually in the whalers to Greenland." ${ }^{11}$ Though the Account records (arguably erroneously) that 'to no quarter of the kingdom is emigration less applicable; there is ample employment at home for the people, and their habits do not render them fit subjects for the measure' it concedes that because Shetlanders 'make good sailors, and their practice at the oar is as near to perfection as this elegant exercise can approach....most of the men that leave Shetland enter the merchant navy, and few eventually are heard of. ${ }^{12}$ Moreover Shetlanders, in common with their Scottish mainland contemporaries, were migrating to England, Europe, and North America in relatively large numbers from the seventeenth century. The tale has frequently been told of John Harrower, a Lerwick man who emigrated from Shetland to Portsmouth, then to London, in an endeavour to repair his fortunes, before being obliged to ship for Virginia as an indentured schoolmaster in $1774 .{ }^{13}$ Shetland emigrants, as well as their Orcadian counterparts, were frequently employed by the Hudson Bay Company from the eighteenth century. ${ }^{14}$ Shetlanders were among the small number of Scots transported to Australia as convicts, while in 1850, in an attempt to address the gender imbalance in Shetland, Lady Franklin and her associates in Lerwick assisted nineteen young Shetland women to emigrate to Australia, all immediately finding work and commencing new lives. ${ }^{15}$

The population of Shetland reached its peak of 31,670 people in 1861. Even at this point, however, Shetland accounted for only 1.03 per cent of the total population of Scotland. For this reason, the Shetland Islands supplied a similarly small proportion of New Zealand's Scottish immigrants over the eighty years to 1920, just 1.90 per cent of migrants in the NZSG dataset and 3.58 per cent of the PNZ migrants. These figures raise two important questions: why was the proportion of Shetland immigrants to New Zealand higher than the county's share of the Scottish population, and why is the proportion of Shetland migrants in the PNZ data compared to the whole sample considerably higher than the NZSG?

\footnotetext{
11 ibid., p.159

12 ibid., pp.155-156

${ }^{13}$ Eric Richards, Britannia's Children: Emigration from England, Scotland, Wales and Ireland since 1600, London and New York, 2004, pp.101-2; Marjory Harper, Adventurers and Exiles: The Great Scottish Exodus, London, 2003, p.9

${ }^{14}$ Harper, Adventurers and Exiles, pp.22, 306; Richard Blaustein, 'Review of The Crooked Stovepipe: Athapaskan Fiddle Music and Square Dancing in Northeast Alaska and Northwest Canada, by Craig Mishler', American Music, Vol.13, No.4, Winter, 1995, pp.492-494; Ian Maxwell, 'Around the world... The Shetland and Orkney Islands', Your Family Tree, July, 2006, pp.54-57, p.57

${ }^{15}$ Harper, Adventurers and Exiles, pp.35, 275
} 
The proportion of Scottish migrants to New Zealand from Shetland ranged between 0 and 2 per cent in all but one decade between 1840 and 1920 in the NZSG data, and between 3 and 6 per cent of the migrants in the PNZ data. However, in the 1870s the proportions for Shetland were 6 and 10 per cent respectively. The number of Shetland migrants bound for New Zealand in this decade alone accounts for the proportion of Shetland migrants to New Zealand being higher than the county's share of the Scottish population over the eighty years of the study. The most detailed investigation of New Zealand's Shetland migrants to date suggests that approximately 1,200 Shetlanders arrived in New Zealand in the 1870s. ${ }^{16}$ This outflow of migrants equates to 15 per cent of Shetland's net population decrease between 1861 and 1881 arriving in New Zealand, with 3.8 per cent of Shetland's total 1861 population migrating to New Zealand in the 1870s.

The variation between the NZSG and PNZ datasets is explained by the criteria adopted for selection of migrants in the two samples. While the compilers of the PNZ data identified all Shetland-born migrants as Scots, most descendants of Shetland migrants living in New Zealand instead assert their Nordic heritage. This assertion of the cultural difference of Shetland migrants to New Zealand is clearly evidenced by the formation in 1922 of the Wellington Shetland Society. Until the eve of World War Two the society had little to do with Scottish societies, preferring to celebrate a Norse identity over Scottish background. ${ }^{17}$ Even today relatively few descendants of Shetland migrants consider their forebears to have been 'Scottish'. Yet, the NZSG sample is based upon on a register of 'Immigrants of Scottish Birth'. It is possible more descendants of Shetland migrants may have contributed information if the register had been entitled 'Immigrants to New Zealand born in Scotland - including Shetland'.

The surge of Shetland immigration to New Zealand in the 1870s was influenced by factors at both the sending and receiving ends of the flows of that decade, primarily clearance in the islands and New Zealand Government assisted migration respectively. ${ }^{18}$ Though Shetland had not been exempt from the widespread evictions

\footnotetext{
${ }^{16}$ Butterworth, Chips off the Auld Rock, p.64

${ }^{17}$ ibid., p.136

${ }^{18}$ However, it must be noted, the outflow from Shetland was generally high at this time, due to a longer standing problem of over-population and consequent unemployment in the islands. J. Laughton Johnston's forthcoming book notes similar flows to that received by New Zealand in the 1870s arriving in Vancouver especially but also other parts of Canada, the United States and Australia throughout the
} 
throughout the Scottish Highlands in the first half of the nineteenth century, landlords clearing their estates of tenants to make way for more profitable occupants, especially sheep, this process of removal accelerated in the islands in the 1870s. In 1874 twentyseven families were evicted from Quendale, Dunrossness, their houses being stripped and sometimes burned by those officiating to prevent future habitation. ${ }^{19}$ Though in his evidence to the 1883 Napier Commission James Garriock of Reawick noted that the approximately twenty families from Walls who had emigrated to New Zealand had done so of their own accord, it is clear, given the context of the testimony, that they were compelled to leave by the actions of their landlord. ${ }^{20}$ Though Garriock does not state precisely when the migration of these twenty families occurred, it was almost certainly between 1874 and 1876, for it was in these years that Shetland-New Zealand migration peaked. Between 1874 and 1876

the islands were stumped by emigration agents from New Zealand, and a great many people were induced to take advantage of the assisted passages, and went out to that colony. $^{21}$

Under the assisted immigration schemes of the 1870s, the New Zealand Government offered not only passage to New Zealand, but also the cost of transportation to the port of embarkation. This was an important consideration, as many would-be Shetland emigrants were hindered by the truck system prevalent in the islands from making their way to the port of departure to take advantage of other schemes of assisted migration. $^{22}$

Of the various assisted migration schemes devised by the General Government of New Zealand, none were more attractive to Shetland migrants than the policy of free

1860s, 1870s and 1880s. As will be seen later in this chapter, the South Island gold rushes in the 1860s also attracted a number of Shetland migrants, who in turn encouraged friends and relations to emigrate.

${ }^{19}$ Eric Richards, The Highland Clearances, Edinburgh, 2000, pp.285-6

${ }^{20}$ James Garriock, 'Minutes of Evidence, James Garriock, Reawick (49) - examined', Napier Commission, 1883, transcribed by Angus Johnson, Shetland Archives, 22391, p.1416

${ }^{21}$ David Charles Edmonston, 'Minutes of Evidence, David Charles Edmonston (46) - examined', Napier Commission, 1883, transcribed by Angus Johnson, Shetland Archives, 20277, p.1302

22 This system of truck - ‘the payment of wages otherwise than in money' (OED) - was investigated by commissions of enquiry in 1871 and 1872 . Though the 1871 commission received evidence 'tending to show that the existence of Truck in an oppressive form is general in the staple trades of the islands' the commissioners noted that 'no opinion accordingly is offered either as to the extent of, or the remedy for, the alleged evils; but the necessity of some investigation by Her Majesty's Government into the condition of these islands seems made out.' ('Introduction to the Report on the Truck System', Truck Commission, 1872, transcribed by Angus Johnson, Shetland Archives, p.1). Though legislation was passed following the 1872 commission little immediate change occurred in Shetland with regard to the truck system. The full report of this 1872 truck system commission is available online. See also George W. Hilton, The Truck System, Including a History of the British Truck Acts, 1465-1960, Cambridge, 1960; Hance D. Smith, Shetland Life and Trade, 1550-1914, Edinburgh, 1984. 
passages introduced in October 1873. Under this policy passages were offered to both married and single agricultural labourers, navvies, shepherds and mechanics, and to single women who were cooks, housemaids, nurses, general servants or dairy maids, all between fifteen and thirty-five years of age. Migrants were also required to be 'sober, industrious, of good moral character, of sound mind, free from bodily deformity, in good health and must be going to the colony with the intention to work for wages. ${ }^{23}$ Yet, even before these free passages were offered, there had been recommendations from several quarters that Shetlanders would be ideal migrants to improve New Zealand's fishing industry. ${ }^{24}$ In consequence, immigration agents specifically targeted Shetlanders on a large scale for the first time. The first and perhaps best known group of settlers specifically recruited for this purpose was a group of thirty-one migrants carried to Stewart Island in June 1873.

\section{DEMOGRAPHIC CHARACTERISTICS AND OCCUPATION}

Given the acknowledged cultural and geographical differences between the Shetland Islanders and their Scottish mainland contemporaries, it might reasonably be anticipated that this distinctiveness would also be reflected in the demographic characteristics. The available evidence suggests this was the case.

In 188161.34 per cent of the Shetland population was female, compared to 53.27 per cent in Scotland as a whole. While, as shown in Table 6.1, Shetland consistently had an excess of females in the population greater than the 'excess' exhibited by the rest of Scotland, no other county sent a more even number of males and females to New Zealand. Half of the NZSG Shetland migrants were female.

Table 6.1

Showing the ratio of females to every 100 males in Scotland and in Shetland

\begin{tabular}{lccccccccc}
\hline \hline & \multicolumn{8}{c}{ Census year } \\
& $\mathbf{1 8 4 1}$ & $\mathbf{1 8 5 1}$ & $\mathbf{1 8 6 1}$ & $\mathbf{1 8 7 1}$ & $\mathbf{1 8 8 1}$ & $\mathbf{1 8 9 1}$ & $\mathbf{1 9 0 1}$ & $\mathbf{1 9 1 1}$ & $\mathbf{1 9 2 1}$ \\
\hline \hline Shetland & 131.9 & 136.4 & 142.6 & 141.2 & 134.7 & 135.5 & 126.9 & 121.7 & 119.9 \\
Scotland & 111.0 & 110.0 & 111.2 & 109.6 & 107.6 & 107.2 & 105.7 & 106.2 & 108.0 \\
\hline \multicolumn{2}{l}{ Source: Population, Ages, Conjugal Condition, Orphanhood, Birthplaces, Gaelic-speaking, Housing, Scotland, Table 34, } \\
1921 Census of Scotland, p.164
\end{tabular}

This gender parity among Shetland migrants is most probably due to the familial nature of the Shetland migration. A tendency for a large number of the Shetland migrants to come to New Zealand in family groups, nuclear and extended, rather than

\footnotetext{
${ }^{23}$ Regulations for free passages, AJHR, 1874, D-3, p.33.

${ }^{24}$ Letter to The Honourable The Colonial Secretary from Robert Stout, 18 September 1871, p.1.
} 
as single men or women, ensured that the gender ratio was closer than is the case in respect of parts of Scotland from which family migration was less common. In addition, the period during which most of the Shetland migrants arrived - the 1870s was a period of greater gender balance among migrants to New Zealand generally (not only Scots) due to a heavy emphasis on the recruitment of single females and families. $^{25}$

In terms of the age profile of Shetland migrants, the NZSG data sample is too small to facilitate reliable analysis. As Table 6.2 suggests, dividing the Shetland subsample further into age cohorts creates very small sub-samples, rendering the results potentially misleading. This noted, it may be inferred from Table 6.2 that, while the majority of Shetland female immigrants to New Zealand were over fifteen years of age, the majority of Shetland males were children at arrival.

Table 6.2

Proportion of each age range of Shetland migrants that was female or male

\begin{tabular}{cccc}
\hline \hline & Female & Male & $\boldsymbol{n}^{*}$ \\
\hline \hline $\mathbf{0 - 5}$ & 30.00 & 70.00 & 10 \\
$\mathbf{6 - 1 0}$ & 60.00 & 40.00 & 15 \\
$\mathbf{1 1 - 1 5}$ & 38.89 & 61.11 & 18 \\
$\mathbf{1 6 - 2 0}$ & 70.00 & 30.00 & 10 \\
$\mathbf{2 1 - 2 5}$ & 42.86 & 57.14 & 14 \\
$\mathbf{2 6 - 3 0}$ & 71.43 & 28.57 & 7 \\
$\mathbf{3 1 - 3 5}$ & 62.50 & 37.50 & 8 \\
$\mathbf{3 6 - 4 0}$ & 75.00 & 25.00 & 8 \\
$\mathbf{4 1 - 4 5}$ & 42.86 & 57.14 & 7 \\
$\mathbf{4 6 - 5 0}$ & 100.00 & 0.00 & 3 \\
$\mathbf{5 0 +}$ & 41.67 & 58.33 & 12 \\
\hline *age is unknown for 4 Shetland females and 10 \\
Shetland males \\
Source: NZSG data 1840-1920
\end{tabular}

While 44.46 per cent of females over fifteen years of age across all of Scotland were married, just 33.46 per cent of this group were married in Shetland. ${ }^{26}$ Despite the equal gender ratio among Shetland migrants, the NZSG data suggests that in terms of marital status there were not only more single females than males, but also more married females than males. Females constitute 57.89 per cent of Shetland migrants aged over fifteen years who were single at arrival, and 57.69 per cent of married migrants. Table 6.3 compares these gendered marital status figures for Shetland to those for Scotland as a whole.

\footnotetext{
25 Jock Phillips and Terry Hearn, Settlers: New Zealand Immigrants from England, Ireland and Scotland, 1800 - 1945, Auckland, 2008, p.131

${ }^{26}$ Appendix Tables, Table LXI, 1881 Census of Scotland, p.l
} 
Table 6.3

Showing the percentage of the NZSG Shetland migrants of each marital status by gender compared to Scotland total figures.

\begin{tabular}{ccccccc}
\hline & \multicolumn{3}{c}{ Shetland } & \multicolumn{3}{c}{ Scotland Total } \\
& Female & Male & $\boldsymbol{n}^{*}$ & Female & Male & $\boldsymbol{n}^{* *}$ \\
\hline \hline Child & 44.19 & 55.81 & 43 & 47.86 & 52.14 & 1,916 \\
Single & 57.89 & 42.11 & 38 & 39.64 & 60.36 & 1,405 \\
Married & 57.69 & 42.31 & 26 & 45.99 & 54.01 & 2,342 \\
Widowed & 50 & 50 & 2 & 69.72 & 30.28 & 109 \\
\hline
\end{tabular}

* Marital status is unknown for 6 females and 11 males in the sample

** Marital status is unknown for 287 females and 542 males in the sample

Source: NZSG data 1840-1920

Shetland contributed one of the highest proportions of single females for counties in the NZSG sample for the whole period; 34.92 per cent of female migrants from Shetland were single at arrival. ${ }^{27}$

Table 6.4

Showing the percentage of the NZSG Shetland migrants of each gender by marital status

\begin{tabular}{ccccc}
\hline \hline & \multicolumn{2}{c}{ Shetland } & \multicolumn{2}{c}{ Scotland Total } \\
& Female & Male & Female & Male \\
\hline \hline Child & 30.16 & 38.1 & 34.91 & 31.76 \\
Single & 34.92 & 25.4 & 21.2 & 26.96 \\
Married & 23.81 & 17.46 & 41 & 40.22 \\
Widowed & 1.59 & 1.59 & 2.89 & 1.05 \\
\multicolumn{1}{c}{ * } & 57 & 52 & 2,627 & 3,145 \\
\hline * Marital status is unknown for 6 Shetland females and 11 Shetland males \\
in the sample; unknown for 287 females and 542 males from Scotland in \\
total \\
Source: NZSG data 1840-1920
\end{tabular}

Comparing the proportion of migrants from each county of Scotland who were married at arrival, Shetland had the smallest proportions for males and females, just 23.81 per cent of Shetland females and 17.46 per cent of Shetland males (see Table 6.4). The high proportion of single females, also the low proportions of male and female migrants from Shetland who were married, may be explained by the very high proportion of unmarried and widowed women in Shetland, due in part to the high death toll at sea of Shetland men, and the consequent high ratio of females to males in the county (61.34 per cent of the 1881 population). This, together with the familial nature of the Shetland migration to New Zealand, meant that a much higher proportion of the Shetland females than females from the rest of Scotland over fifteen years of age were unmarried and emigrating with their immediate or extended family. They are thus counted as single migrants. Single females constituted 27.72 per cent of the NZSG Shetland migrants. As is evident in Appendices 6.1-5, the tendency to

\footnotetext{
${ }^{27}$ Nairn, Clackmannan and Peebles had a higher proportion of single females in their samples but the samples on which this evidence is based are too small to indicate clear patterns.
} 
migrate in families ensured that a large proportion of the Shetland migrants were children - 54.18 per cent. This, combined with the high proportion of single females in the migrant cohort, created a proportion of married males and females among the Shetland migrants smaller than from any other county of Scotland.

Table 6.5

Proportion of Shetland migrant totals employed in each occupation sector in Scotland*

\begin{tabular}{llllllll|l}
\hline \hline \\
\hline
\end{tabular}

As noted in Chapter Five, analysing data for a migrant occupational profile is rarely straightforward. Notwithstanding the small size of the Shetland sample, the problems related to its snapshot nature still apply. Even so, significant differences between the profile of the Shetland migrants and that of migrants from the rest of Scotland are very clear. Table 6.5 may be compared directly with Table 5.4 (Chapter Five). The proportion of migrants who had been involved in building and labouring is approximately the same as for the rest of Scotland, but the proportion employed in mining is comparable only with the Western Lowlands (see Table 5.4). While coal and granite mining was more common in other parts of Scotland, Shetland mining was primarily for iron and copper. ${ }^{28}$ Due to the limited viability of Shetland for farming, the comparatively small number of Shetland migrants claiming occupations in the agricultural sector in Scotland is unsurprising. However, it is in the 'transport and commerce' sector that the main difference is evident. While less than 5 per cent of migrants from all regions in Scotland except the Far North had been employed in this sector, with the Far North recording 11.21 per cent, 30 per cent of Shetland NZSG migrants were from this occupational background.

Of the 126 Shetlanders in the NZSG sample, just sixty-nine were aged sixteen or over at arrival. Forty of these sixty-nine had an occupation listed in Scotland and sixteen of these forty were female. Twenty of the migrants, 50 per cent of this NZSG

\footnotetext{
${ }^{28}$ Tim Senften, 'Shetland's mining history', The New Shetlander, No.248, Summer, 2009, accessed at http://www.laplandica.com/2009/06/18/shetland\%E2\%80\%99s-mining-history/, 28 July 2009
} 
occupation sub-sample born in Shetland, had a sea-oriented occupation listed among their occupations in Scotland, with only one female. (Table 6.6.)

Table 6.6

Showing the occupations in Scotland of the twenty Shetland born migrants in the NZSG data with sea-oriented occupations

\begin{tabular}{ll}
\hline \hline \multicolumn{1}{c}{ Shetland Occupation } & $\boldsymbol{n}$ \\
\hline \hline Master Mariner & 2 \\
Harbour Master & 1 \\
Sailor/Seaman/Ship Builder & 1 \\
Sailmaker & 1 \\
Ships Carpenter & 1 \\
Sailor/Seaman & 6 \\
Fisherman/Seaman & 2 \\
Fisherman & 3 \\
Fisherman \& farmer & 1 \\
Fish Curer* & 2 \\
\hline * One of whom was female. & \\
Source: NZSG data 1840-1920 &
\end{tabular}

While the majority of Scottish migrants remained in the same sectors of work as they had been employed in prior to their emigration, this was not so among Shetland migrants. This was the combined result of the prevalence of fishing and other seaoriented occupations in Shetland, and their relative scarcity in New Zealand. While nineteen of the twenty-eight males in the sample were in sea-oriented occupations in Shetland, only four continued to earn their livings in this way in New Zealand. In contrast, fourteen of the sixteen female migrants in the sample were employed in the home, in domestic service or in dressmaking in Shetland. All of the women with an occupation recorded in New Zealand were in similar lines of work to those they had followed prior to migration.

Robert Thomson, aged fifty-one at arrival, was one of the four who continued in a sea-oriented occupation in New Zealand: he was a farmer and fisherman in Shetland, and carried on with this in Invercargill. ${ }^{29}$ The sailor/seaman/shipbuilder in Table 6.6, Peter William Mouat, continued shipbuilding in New Zealand, but he also worked as a carpenter and took up farming in Purakanui, and Hamilton Bay, Otago. ${ }^{30}$ William Gilbert Henry was a sailmaker in Shetland and continued to ply this trade in New Zealand, also working at some point drilling wells. ${ }^{31}$ Thomas Ross, a master mariner,

\footnotetext{
${ }^{29}$ NZSG database, migrant 06076

${ }^{30}$ NZSG database, migrant 04563

${ }^{31}$ NZSG database, migrant 02466
} 
continued in this line of work after arrival in New Zealand. ${ }^{32}$ Henry Thomson had no occupation listed in the register for Scotland, but in New Zealand he joined the ranks of Shetland migrants in sea-oriented occupations, becoming a lighthouse keeper. ${ }^{33}$ Barbara Anderina Larnoch prepared herrings in Shetland but worked as a dressmaker in New Zealand. ${ }^{34}$ Other occupations taken up in New Zealand by some of the twenty migrants listed as being in sea-oriented occupations in Shetland included tally clerk, ropemaker, gold miner, hatchery curator, flaxmiller, labourer/contractor, and farmer, several being recorded on the NZSG register under the ever vague title 'settler'. ${ }^{35}$

Fourteen of the NZSG Shetland migrants worked in the home in Scotland ('housewife/wife'), in service, or, in two cases, as dressmakers. All were female, and all remained in this 'domestic' line of work in New Zealand. Laurence Johnstone, a school master in Shetland, was also a school master in Dannevirke. ${ }^{36}$ Robert Fordyce worked as an engineer in Shetland and New Zealand, and also as a fitter and turner in New Zealand. ${ }^{37}$ Henry Ramsay as well as Laurence and Andrew Nicholson Jamieson, brothers from Fladdibister, Dunrossness, all worked in mining in both Shetland and New Zealand. ${ }^{38}$

At best the results from the NZSG Shetland sub-sample may be considered suggestive, but they clearly indicate that the differences between the Shetland migrant occupational profile and those of the migrants from the rest of Scotland are significant. Perhaps more than with any other county of origin, it was the nature of the islands they came from that shaped the occupational background differences of the Shetland migrants.

\footnotetext{
${ }^{32}$ NZSG database, migrant 05315

${ }^{33}$ NZSG database, migrant 06046

${ }^{34}$ NZSG database, migrant 02957

35 The master mariner who did not remain a master mariner in New Zealand has no occupation listed in New Zealand but had also worked as a spirit merchant and a draper in Scotland. The remaining ten migrants with occupations listed in Scotland included one carpenter, one quarryman, two lime makers, one merchant, one labourer, one dairymaid, one engineer, one school master and one male who worked as a mason, crofter and merchant.

${ }^{36}$ NZSG database, migrant 02748

${ }^{37}$ NZSG database, migrant 01848

${ }^{38}$ NZSG database, migrants 05046, 02652, 02660. The three men were employed respectively as a quarryman and gold miner, a lime maker and mine manager and a lime maker and 'miner' in their Shetland and New Zealand jobs respectively.
} 


\section{ORIGINS}

The small population of Shetland, as well as the nature of the flow of migrants to New Zealand from the islands, facilitates a clearer examination of migrant origins within the boundaries of the county, as well as permitting a consideration of the importance of travel companions and chains of migration that has not been possible for migrants from Scotland generally. Shetland's small population makes the tracing of migrants and the noting of connections between individuals and groups prior to and after migration a more possible task.

Caution is nevertheless required when examining migrant origins within county boundaries, such a study inevitably creating small sub-samples from which it may be misleading to draw too explicit conclusions. In a sub-sample as small as that for the NZSG Shetland migrants (126 migrants), and from a county in which large families migrating together was the norm, there is little value in statistical analysis at parish level. For example, ten of the migrants in the NZSG Shetland sub-sample belonged to Morgan and Mary Laurenson’s family. Atypical of families migrating from Shetland, both Mary and the couple's eldest child, George, were born in St Cuthburts, Midlothian. Shortly after the birth of George, in 1857, the family returned to Morgan's birth parish, Delting, Shetland, and the remaining nine children who later migrated with Morgan and Mary in 1876 were born either in Delting or Northmavine. Only seven individuals in the sample were born in Northmavine, and they were all children of Morgan and Mary Laurenson. Only four NZSG migrants were born in Delting, and this included Morgan and two of his children. ${ }^{39}$ A more qualitative approach has thus been adopted to investigate Shetland migrant origins.

A separate database of Shetland migrants has been specifically created to enable this qualitative examination. As explained in Appendix 1.1, the Shetland database has the 126 NZSG Shetland-born migrants as its core, with additional Shetland-New Zealand immigrants included based on information from other sources. Though originally intended as a source for statistical analysis of the Shetland migrants, adequate information for a sufficient number of migrants could not be gathered. ${ }^{40}$ Yet there was enough for 746 of the 1,248 individuals identified to trace something of their migration experiences. While it has not been possible to assign 193 of these 746

\footnotetext{
${ }^{39}$ NZSG database, migrants 01692, 02961, 02962, 02963, 02965, 02966, 02967, 02968, 02969, 02970, 02971, and 06585

${ }^{40}$ See Appendix 1.1 for detail as to the creation of and limitations of this database.
} 
individuals to family groups, there is sufficient information for 553 individuals. These 553 individuals belonged to 195 different immediate family groups, giving a mean of 2.8 individuals per family. However, 104 of the families had five or more people in the family group, while twelve of the families had twelve or more people migrating. Large families migrating to New Zealand together from Scotland was not a phenomenon limited to Shetland migrants; for example, George Burt, his wife Jean Whyte Ramsay and their ten children, all born in New Monkland, Lanarkshire, emigrated to New Zealand together on the Ionic in $1908 .^{41}$ There is evidence, however, to suggest that as a proportion of the migrants migrating from the county of origin, immigrants from Shetland were more likely than their counterparts from other parts of Scotland to migrate in large family groups. Among Shetland migrants emigrating in a familial group were Laurence and Barbara Johnston (born in Lannasting and Unst respectively). Laurence and Barbara took passage on the Howrah in 1876 and were accompanied by their eight children, all born in Sandwick. ${ }^{42}$ Morgan and Mary Laurenceson and their ten children arrived in Lyttleton on the Jessie Osborne in $1876 .{ }^{43}$ In 1874 fifteen members of one extended family arrived in Wellington on the Soukar: James Flaws, his wife Catherine (nee Johnson) and their nine children. Travelling with them was James’ sister Grace, her husband Robert Harper and their two children. ${ }^{44}$ See Appendix 6.3a.

Though chains of migration to New Zealand are evident among migrants from elsewhere in Scotland in the NZSG data, these are nowhere more obvious than among migrants from Shetland. Though chain migration of Shetlanders is most apparent in the 1870s, as subsequent migrants took advantage of the assisted passages having received news and encouragement from friends or relatives who had migrated earlier in the decade, chains spanning decades can also be distinguished. Isabella Robertson, born in Sandness, Walls, appears to have come alone to New Zealand in 1872, as an assisted passenger on the Christian McAusland, but within two years her parents and six siblings joined her in Dunedin, having themselves travelled as assisted passengers on the Invercargill. All of the family lived in or around Dunedin for the remainder of

\footnotetext{
${ }^{41}$ NZSG database, migrants 00766, 00794, 00795, 00797, 00799, 00800, 00801, 00803, 00804, 00805, 00806, 05047

${ }^{42}$ NZSG database, migrants 02653, 02733, 02735, 02738, 02740, 02747, 02748, 02749, 02750, 02753

${ }^{43}$ NZSG database, migrants 01692, 02961, 02962, 02963, 02965, 02966, 02967, 02968, 02969, 02970, 02971, 06585

${ }_{44}$ Shetland database, migrants ANC006, Chips601, Chips603, Chips605, Chips606, Chips607, Chips608, Chips609, Chips610, Other071, Chips643, Chips644, Chips645, Chips646
} 
their lives in New Zealand. ${ }^{45}$ Grace Nicolson also came to New Zealand as an assisted passenger on the Christian McAusland (see Appendix 6.1.). She had worked for the Duthie family of Tingwall prior to her departure, a relationship with the family's nineteen-year-old son having led to her dismissal. Her decision to come to New Zealand as a domestic servant followed. The son concerned, William Ogilvy Duthie, also came to New Zealand on the Christian McAusland, the couple marrying in February $1873 .^{46}$ Grace's sister Mary followed two years later, arriving on the Auckland in 1875, and their mother migrated that same year. A maternal uncle, William Davidson, joined them in 1876, together with his wife, three children and mother (Grace and Mary’s maternal grandmother). In 1894 the sisters' youngest brother Samuel migrated, and he was followed eleven years later by their brother William, his wife and their eight children. This migration chain spanned thirty-four years. $^{47}$

In 1860 Williamina Robinson (formerly Fordyce, nee Spence) left Shetland for Auckland with her husband Robert Robinson, their three children and her daughter to a previous marriage (Mary Jane Fordyce, b.1839). See Appendix 6.2. In 1882 Thomas Fordyce (b.1859), Williamina’s grandson to her daughter Margaret Spence Fordyce (b.1832) joined Williamina and her family in Auckland, where he continued in his trade as a carpenter. Within three years Thomas’ parents, Andrew Bruce Fordyce and Margaret Spence Fordyce (who were also first cousins) and six of their other children joined the exodus, arriving in Auckland on the Aorangi in October 1885. In 1901 Margaret and Andrew Fordyce’s son, William Bruce Fordyce, along with his wife Isabella (nee Anderson) and their two sons, arrived in Auckland. They were followed

\footnotetext{
45 All nine members of the family were born in Sandness, Walls. NZSG database, migrants 05183, 05185, 05194, 05199, 05201, 05223, 05230, 05548

${ }^{46}$ Though emigrating from Shetland, William was born in Perthshire in 1853. It is not clear when his family moved to Shetland, but it was after William's fifth birthday (after the birth of his youngest brother in 1858). Two of William's siblings also emigrated from Shetland to New Zealand, Elizabeth Ogilvy Duthie, born in Angus in 1856 and James Shepherd Duthie born in Angus in 1858 though it is not known when Elizabeth and James came to New Zealand. Elizabeth emigrated with her Shetland born husband - John Ogilvy McPherson. The couple were living in Northmavine in 1881. William's age is recorded as thirty and this place of birth as Kirkcudbright on the Christian McAusland passenger list, proving again that ship lists can not be relied upon for accurate information regarding passengers. Tony Gott, 'Shetland Family History Database', http://bayanne.info/Shetland/, I93431, I93432, I93433, I183408, I204642, accessed 6 April 2009;

Passenger list for Christian McAusland, arrived Otago, December 1872, http://freepages.genealogy.rootsweb.ancestry.com/ ourstuff/ChristianMcAusland72.htm accessed 27 July 2009

47 Extract of email from cousin Les, William Ogilvy Duthie and Grace Nicolson, family history material Val Petrie.
} 
ten years later by William's brother Robert Bruce Fordyce. This chain of migration spanned half a century, from 1860 when Williamina and family left Shetland until 1911 when Robert Bruce arrived in Wellington Harbour, bound for Auckland. ${ }^{48}$

Another chain of migration spanning nearly fifty years began with James Flaws, his sister Grace, and their families, on the Soukar in 1874. (See Appendix 6.3a) Sometime between 1912 and 1926 James and Grace's sister-in-law Barbara Flaws (nee Nicolson), wife to their brother Thomas, arrived in Wellington with five of her children and one daughter-in-law. See Appendix 6.3b. As was often the case with Shetland migrants, two of Barbara's children married other Shetland migrants, a brother and sister in the Henderson family; these were the children of William Robert Henderson and Nicolson Henderson nee Priest, who arrived on the Rotorua in 1913 with their seven children. See Appendix 6.3c. Anne Jessie Henderson was coming to New Zealand to marry John Anderson, who had already been in New Zealand for two years. The rest of her family decided to migrate with her. Nicolson Henderson's mother was Robina Priest (nee Harper) and although Robina did not migrate to New Zealand her four siblings did. See Appendix 6.3d. One of her brothers, James Mouat Harper, married Margaret Yule Anderson in Shetland. They were cousins through their mother's family line (Russell) and their four cousins (the children of their auntin-common, Williamina) also migrated to New Zealand with their spouses. See Appendix 6.3e. Their uncle, Robert Spence Russell, left Unst with his wife and nine children in 1875, arriving in Port Chalmers in November on the Peter Denny. Margaret Yule Anderson's brothers John and Gilbert migrated to New Zealand also. ${ }^{49}$

Nicolson Henderson's great-grandfather, James Priest, born 1764, had another great-grandchild who migrated to New Zealand, William Thomas Priest. See Appendix 6.3f. William Thomas and Nicolson's grandfathers were brothers, and as William Thomas and Nicolson lived just over two miles from each other in north Unst it is highly likely they were well acquainted. William Thomas Priest and his wife Ann Jessie (nee Williamson) left Unst for New Zealand, travelling via Leith in 1923. When Ann Jessie died in Leith before setting out for New Zealand, William Thomas returned to Unst with his two youngest children, leaving them with family there, they

\footnotetext{
${ }^{48}$ NZSG database, migrants 00252, 01838, 01839, 01841, 01842, 01844, 01845, 01846, 01847, 01848, 01848, 01849, 01850, 01851, 01852, 05218, 05229, 05237, 05239, 05716

${ }^{49}$ Her brother William Parsonson Anderson appears not to have come to New Zealand, but to have returned to Shetland after a brief stay in Australia. See Appendix 6.4d.
} 
being too young to travel without their mother. William Thomas subsequently set out for New Zealand with five of his other children, intending to return for the youngest children when they were older. This never happened and the two youngest remained in Shetland. ${ }^{50}$ William Thomas met another Shetland woman on the Tainui on the way to New Zealand, Sunniva Sutherland, and they later married in New Zealand. The number of migrants to New Zealand from these three interconnected families alone (Flaws, Henderson and Harper/Mouat/Anderson/Priest, Appendix 6.3) totalled more than sixty-four.

As the 'trees' compiled to demonstrate the family nature of Shetland migration indicate, there appears to have been no part of Shetland that did not send migrants to New Zealand. However, the island parish of Unst was very clearly the most significant source parish. The extended Harper/Mouat/Anderson/Priest family noted above was a part of a wider chain of migration from Unst to New Zealand. Unst, Scotland's most northerly island, is about nineteen kilometres long, eight kilometres wide, with an approximate land area of $120 \mathrm{~km}^{2} .{ }^{51}$ At its maximum population in 1861, the parish of Unst consisted of 3,060 people. Between 1871 and 1881 the population decreased by 599 - nearly 20 per cent - and much of the decrease was due to emigration. $^{52}$

\footnotetext{
${ }^{50}$ They remained there the rest of their lives. William Thomas' second son William Thomas Junior (born 1900) did not emigrate with the rest of his family either; though it is not evident where William Thomas Junior was living in 1923, he was living in Queensland, Australia, at his death in 1993. Gott, 'Shetland Family History Database', F10043, F23335, F23336, F26645, F27982, F38139, F38178 and I121991

${ }^{51} \mathrm{http}: / /$ www.undiscoveredscotland.co.uk/unst/unst/index.html, accessed 5 June 2008. See Map 6

${ }_{52}$ Return of population of Scotland at each decennial period, Section III, 1881 Census of Scotland, p.39
} 
MAP 8

Unst, Shetland

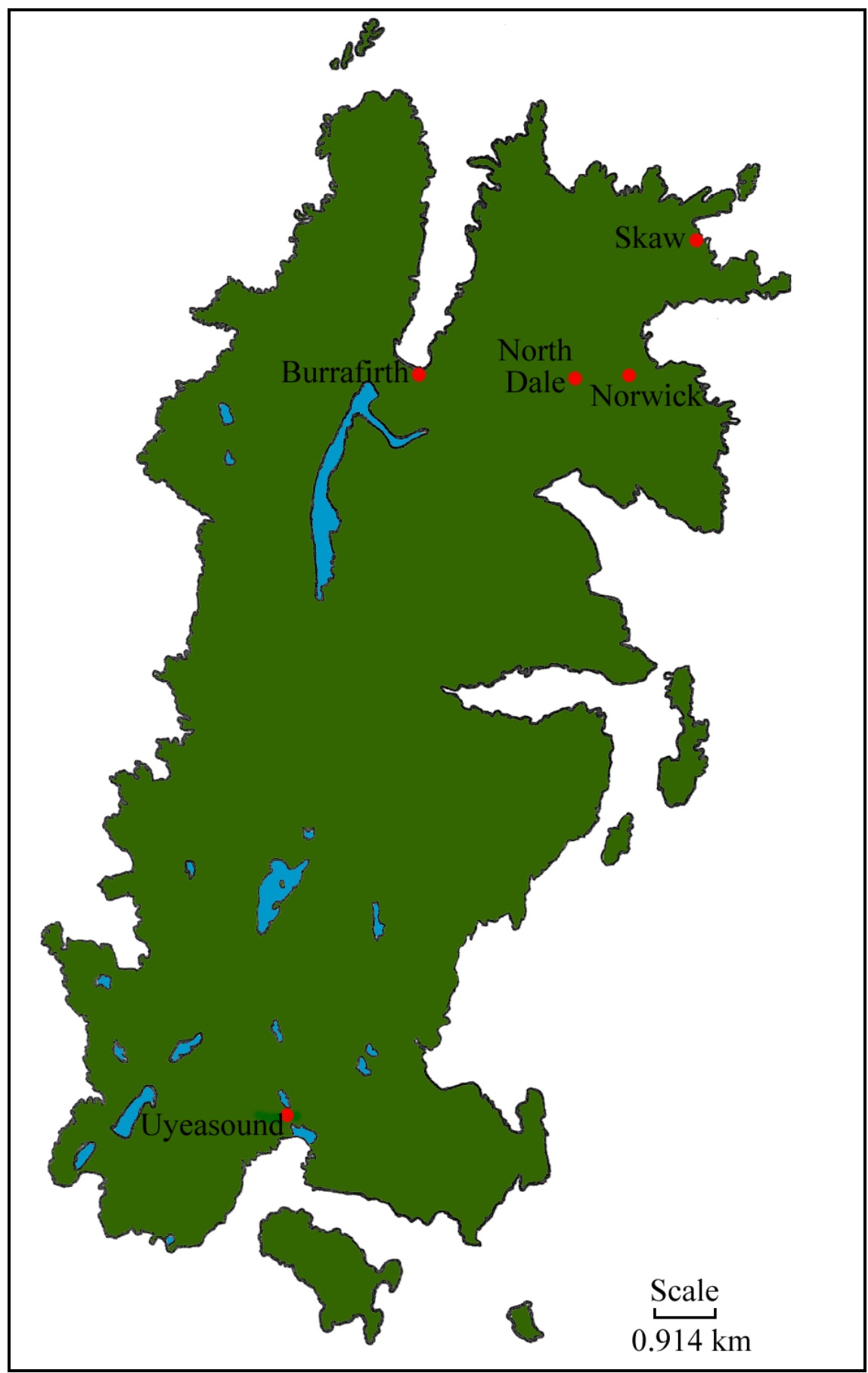

Source: Map created in Macromedia Fireworks based on an ordnance survey map of Unst, Shetland available online at http://uk.multimap.co.uk/world/GB/Scotland/Shetland_Islands/Shetland/Unst 
Nicolson Henderson's father, Nicol Priest, left Unst in 1868 with Magnus and Barclay Mouat, Gilbert Harper, William and Gilbert Anderson and John Johnson, bound for the Australian goldfields. See Appendix 6.4a. ${ }^{53}$ Approximately twelve months later Magnus Mouat and Gilbert Harper made their way to Westport, New Zealand, to try their luck there. ${ }^{54}$ In 1870 , finding profit in beachcombing for gold, they sent for their companions still in Australia and for friends and relatives in Unst. Gilbert Harper was Nicol Priest's brother-in-law (the brother of Nicol's wife Robina), Magnus and Barclay Mouat were Gilbert Harper's cousins, as were William and Gilbert Anderson, and Magnus Mouat's brother-in-law was John Johnson, making this 'exodus' from Norwick, Unst to New Zealand a distinctly family affair. ${ }^{55}$ Nicol's daughter, Nicolson, was born in 1869 and this may have been why (as noted earlier) Robina did not come with her siblings to join her husband and relatives in New Zealand. Nicol Priest was gold mining on Nine-Mile Beach when he died in Nelson in 1873, aged only $37 .^{56}$ It was not until 1914 that his daughter Nicolson left Unst for New Zealand with her family. Her husband's brother Andrew had also been mining on Nine-Mile Beach, though whether he knew Nicol is unknown. He died in 1888 before Nicolson or her husband came to New Zealand. ${ }^{57}$ As may be seen in Appendix 6.4a and 6.3c-f, the chain of migration set in motion by these seven men from Norwick included more than thirty migrants.

The Clarence, sailing for Napier, New Zealand, in 1874, carried at least another forty-five migrants from Unst, all recruited by the New Zealand immigration agent Peter Barclay. ${ }^{58}$ See Appendix 6.4b. Basiell Anderson was one of these passengers,

\footnotetext{
${ }^{53}$ Also present in Appendix 6.4d

54 See Phillip Ross May, The West Coast Gold Rushes, Christchurch, 1962; Phillip Ross May, Hokitika: Goldfields Capital Christchurch, 1964. See also Terry Hearn, 'Scots miners in the goldfields, 1861-1870', in Tom Brooking and Jennie Coleman (eds), The Heather and the Fern: Scottish Migration and New Zealand Settlement, Dunedin, 2005

55 'Some History Notes', William Robert Henderson and Nicolson Priest, family history material Elizabeth Angus

${ }^{56}$ Gott, 'Shetland Family History Database’, I27926, I27927, and F10043

57 'Some History Notes' family history material provided to the present writer by Elizabeth Angus; Letter from Wm R and N Henderson to 'My ever-Dear Cousins', Letter Home from Mornington, Dunedin containing news of family and friends in New Zealand, 16 April 1932 within family history material provided to the present author by Elizabeth Angus. This letter provides evidence that Nicolson kept in touch with her mother's cousins' children in New Zealand after her arrival in 1913. She speaks of a trip she and her husband had been long anticipating to the West Coast to see these relatives as well as the final resting place of William Robert's brother Andrew and Nicol Priest in Charleston Cemetery. ${ }^{58}$ Barclay had previously recruited approximately seventy migrants from Plockton, Lochalsh, Rossshire for the Hawkes Bay, in 1871-2. Peter Barclay, 'Report of Emigration work during the last six months’, 11 June 1872, ACFQ 8226 IM 6/1/1 General 26/03/1873 - 6/06/1876, ANZ, Wellington.
} 
with his wife Barbara and their ten children. Though Barbara and nine of their children were born in Unst, Basiell was actually born in West Yell. Barbara and Basiell were cousins - Basiell's mother, Joan, was Barbara's aunt, her father Laurence's elder sister. Both Joan and Laurence Ramsay were born in Unst, as was their youngest brother James. Possibly it was the migration to New Zealand of James' two sons, Henry and Robert Ramsay, which encouraged their cousins - Barbara and Basiell - to migrate. Henry, born 1832, was one of the few Shetland migrants to come to New Zealand pre-1870, arriving in 1865 . He is reported to have worked as a gold miner in the South Island, dying in Greymouth in 1905. His younger brother Robert (b.1848) followed in 1870 and, also working as a gold miner, remained in the South Island until his death at Brunnerton in 1890. Barbara, Basiell and their family all remained in Napier, their place of arrival on the Clarence in 1874. The fact that they did not join their cousins in the South Island can not be taken as an indication that Henry and Robert's migration was not a factor that encouraged their own decision to migrate. That said, with at least thirty-five other migrants from Unst recruited by Barclay also coming to New Zealand on the Clarence, it may well be that quite other considerations influenced the decision. ${ }^{59}$

Another Clarence passenger from Unst was Ann Ursula Petrie. See Appendix 6.4b. Aged thirty-nine upon arrival, Ann Ursula was a single woman travelling on an assisted passage. She married a fellow Shetland migrant within four years, Thomas Jeromson. Ann Ursula’s twin sister, Agnes Beatrice, had migrated to New Zealand twelve months earlier, arriving in Wellington on the Salisbury in 1873. Also single at arrival, aged thirty-eight, Agnes similarly married a fellow Shetland migrant Mitchell Ridland - in Wellington in 1876. While there is evidence that it was usual for Shetland migrants to remain near their port of arrival in New Zealand, in this case Ann moved from Napier to Wellington, where she lived in Upper Hutt near Agnes. It

There are migrants from Shetland on the Clarence for whom no parish information has yet been traced. Ninety-six of the passengers on the Clarence were from Shetland - the figure has also been recorded as 108, but work by genealogists has since found that twelve of the passengers previously believed to be from Shetland were, actually, born in Ireland. Butterworth, Chips off the Auld Rock, p.76; L.G. Gordon, 'Immigration into Hawke's Bay, 1856-1876', M.A. Thesis, Victoria University of Wellington, 1965, p.266

${ }^{59}$ Also possible, though not proven, is that news of Henry Ramsay's endeavours in the gold fields reached Nicol Priest and company, encouraging them to leave Unst for the gold fields less than three years later. Unst, as mentioned previously, was a very small parish even at the height of its population. It is not unreasonable to assume that very few 'degrees of separation' were in operation there. 
seems likely that in this instance Ann Ursula's migration on the Clarence was a result of encouragement from her twin already in New Zealand. ${ }^{60}$

Other Unst migrants also on the Clarence included: John James Sinclair, his wife and their six children; Thomas Mouat, his wife and their six children; John Laurenson, his wife Elizabeth Margaret (nee Smith) and their four children; also Elizabeth Margaret's brother Lawrence Smith, his wife and their three children. See Appendix 6.4b-c. Each of these migrants was born and lived within approximately five kilometres of each other in the north of Unst - in Burrafirth, North Dale, Norwick and Skaw (see Map 8). Considering that the population of Unst never exceeded 3,060, and the close proximity of these families to one another, it seems all but certain they were all at least known to each other before they were recruited by Barclay. Whether the decision to leave was jointly made, or whether the families took advantage of the available passages on the Clarence separately, of their own volition, remains unclear. Given that this was also the area of Unst that the friends and families of Nicol Priest and his companions were from, it is possible that their example had some influence on the later migration of the Mouat, Laurenceson and Smith families.

Given the Shetland propensity for chain migration and the large number of migrants from Unst arriving in the 1870s, it is not surprising that migrants from Unst continued to flow to New Zealand for many decades after this period of assisted migration. Though it is possible that migrations of extended family groups, of large sections of communities, of chains spanning up to five decades, may well exist among migrants from other parts of Scotland migrating to New Zealand, such movements appear to have been especially pronounced amongst Shetlanders. Indeed there is no evidence that this degree of cluster migration occurred among other Scots migrants to New Zealand. That it was so evident from Shetland was attributable to a specific combination of push and pull factors working simultaneously to bring Shetland migrants to New Zealand from the 1860s but especially during the 1870s. With such a large proportion of the Shetland population coming to New Zealand in that decade, and those migrants encountering mostly favourable conditions, those remaining behind inevitably received favourable reports of the country from a greater than usual range of personal testimonies - siblings, cousins, friends and former neighbours. With

\footnotetext{
${ }^{60}$ NZSG database, migrants 02663, 04946, 05073 and 06648. The story of 'the intrepid Petries and Ridlands' is also detailed in J. Laughton Johnston, A Kist of Emigrants, Shetland, forthcoming (2010)
} 
familial and community support potentially awaiting them in New Zealand, and with assorted schemes of assisted migration to New Zealand available at various times through to the 1960s, there was incentive enough for generations of Shetlanders to prefer New Zealand over other migrant destinations.

Whether or not Shetland migrants were more likely than their Scottish mainland counterparts to keep in touch with family and friends at home, thereby encouraging other family and community members to emigrate, is beyond the present study. Yet, due to the relative ease of tracing Shetland migrants, both pre- and post- emigration, evidence of their activities post-migration is more easily recovered. Migrants sent home news not only of themselves, their family and friends but also of any other Shetlanders encountered, so that news might be passed on to the relatives of that migrant. For example, in a letter home in 1862 Laurence Mathewson wrote that 'Magnus Williamsons Son William’ [sic], who he had seen six weeks earlier, was doing very well on the goldfields. ${ }^{61}$ It was also common for wedding and obituary notices of Shetland migrants to be republished in Shetland newspapers. The obituary notice of Mrs Jane Fea Spence that appeared in the Hokianga County Times on 27 January 1908 was republished in the Shetland Times two months later, while that of William Sievwright, previously of Lerwick, was published in the Shetland Times in 1909. ${ }^{62}$ On 21 February 1891 the Shetland News published 'Death of "Bob Sinclair": A Shetlander's Strange Adventure', an article about a Lerwick-born migrant published by the Taranaki Herald in December the previous year, which had been sent 'home' by a Shetlander in New Zealand. ${ }^{63}$ Maintaining ties with Shetland appears to have been very important to these migrants. The graveyards of Shetland exhibit numerous instances of headstones or memorials to Shetlanders who died in New Zealand, evidence that although the migrants were far from home, family and friends in Shetland considered it important that they be remembered at home after their death. This practice does not appear to have been so common in other parts of Scotland. Only nine monumental inscriptions in the cemeteries of Aberdeen, for example, the county that contributed 7.37 per cent of the NZSG migrants, mention a

\footnotetext{
${ }^{61}$ Letter by Laurence Mathewson, Otago, New Zealand, to 'My Dear Beloved Parents', 29 March 1862, D23/151/28/19, Shetland Archives

${ }^{62}$ Obituary of Jane Fea Spence, Moukaraka (reprinted from Hokianga County Times [New Zealand]), Shetland Times, 28 March 1908, D6/292/14/p45, Shetland Archives; Obituary of William Sievwright, Solicitor, New Zealand, Shetland Times, 19 June 1909, D6/292/15/p88v, Shetland Archives.

63 'Death of 'Bob Sinclair': A Shetlander’s Strange Adventure', Shetland News, 21 February 1891, p.5
} 
person who had died in New Zealand. This is in striking contrast to twenty-five headstones in Shetland, most of which were for whole families, not just one individual. $^{64}$

Even when Shetland migrants felt New Zealand had become home, and knew that it would be their country of residence for the rest of their lives, Shetland was still 'home' too. When William Fraser of Invercargill North wrote 'home' to his uncle and aunt in Shetland in February 1923, he wrote that he had just returned home to Invercargill from having returned home to Shetland and noted that some fellow Shetlanders who resided in Masterton were also just returning home from having been home. ${ }^{65}$ It is suggestive of the enduring bonds that when Shetland migrants in Dunedin heard in 1881 of a fishing disaster in Shetland, in which many Shetlanders lost their lives and property, a subscription list was promptly circulated and every Shetlander in the district was reported to have given to it liberally. ${ }^{66}$

While, as noted in Chapter Two, 11.70 per cent of NZSG migrants born in Scotland's other thirty-two counties came to New Zealand from Scotland via another country, this was the case with only 4.76 per cent of NZSG Shetland migrants. The majority of the Shetland migrants to New Zealand, especially in the 1870s, travelled on assisted passages, many of those paying for their own passages being parts of established migration chains. Having connections with New Zealand already in place, and a means of getting to New Zealand, there was little need - or incentive - for migrants from Shetland to stop elsewhere along the way. The 4.67 per cent of Shetland migrants choosing to do so comprised just six of the 126 Shetlanders in the NZSG sample. For five of these six migrants the prior country of residence to New

\footnotetext{
${ }^{64}$ Monumental inscription transcriptions for every cemetery in Aberdeen and Shetland, published by the Aberdeen and Shetland family history societies respectively, were examined for references to deaths occurring in New Zealand. Only those that included such references in Aberdeenshire are cited here. The Shetland monumental inscription's are published by parish over twenty-seven volumes with sections within the volumes for individual cemeteries. Volumes 3, 4, 6, 7, 10, 11, 14, 15 and 25 did not include reference to New Zealand. See bibliography for full list of these Shetland monumental inscription transcription publications. Gordon Johnson (ed.), The Kirkyard of Peterculter, Aberdeen, 1988, pp.4, 14, 24 and 29; Sheila M. Spiers (ed.), The Kirkyard of St. Clements (Aberdeen), Aberdeen, 1988, p.12; A. Strath Maxwell (ed.), Monumental Inscriptions, St. Nicholas Churchyard, Aberdeen, Scotland, Sections E, F, etc, Aberdeen, 1973, p.1; Sheila M. Speirs (ed.), The Kirkyard of Alford, Aberdeen, 1991, p.24; Sheila M. Spiers (ed.), The Kirkyard of Foveran, Aberdeen, 2005, not paginated, inscription 242; Bill and Eileen McHardy (ed.), The Cemetery of Peterculter, Aberdeen, 2006, not paginated, inscription 179.

${ }^{65}$ Letter by William Fraser, Invercargill North, to 'Dear uncle John and Aunt': a voyage by sea from Southampton to New Zealand, 19/02/1923, D38/29, Shetland Archives

${ }^{66}$ Letter by Laurence Mathewson, Otago, New Zealand, to 'My Dear Beloved Parents', 1 December 1881, D23/151/47/14, Shetland Archives
} 
Zealand was Australia, and for all five the place of residence in Australia was Victoria, indicating that gold mining was the probable attraction. The only migrant in the NZSG sample to differ from this pattern was Robert Fordyce. His prior country of residence was not Scotland, or Australia, but England. Born in Uyeasound, Unst, in 1857, Robert lived for a time in Leith, Midlothian, before migrating to London, where he worked as an engineer, prior to following his large extended family to Auckland in $1910 .^{67}$

\section{Patterns of Settlement}

The limited sizes of the Shetland sub-sample, and of the Shetland population, are extremely useful when tracing individual origins within Shetland, the data being used qualitatively rather than quantitatively. In quantitative terms, the smallness of the Shetland sub-sample presents problems when considering where in New Zealand Shetland migrants settled. ${ }^{68}$ Analysis of the sub-sample reveals that 7.94 per cent of Shetland migrants settled in Dannevirke, unsurprising given that Dannevirke was a Scandinavian settlement, with likely cultural affinities for the Shetland migrants. ${ }^{69}$ What these bare figures do not reveal is that the 7.94 per cent of the sample settling in Dannevirke was made up of just ten migrants, Laurence and Barbara Johnstone and their eight children. Nevertheless, it is known that other Shetland immigrants settled in the general area of southern Hawkes Bay. ${ }^{70}$

Notwithstanding the inclination of Shetland migrants and their descendants to claim their Nordic rather than Scottish heritage, they tended to follow a Scottish pattern of settlement. However, while migrants from Scotland as a whole appear to

\footnotetext{
${ }^{67}$ NZSG database, migrant 01848. Present in Appendix 6.3

${ }^{68}$ As outlined in Appendix 1.1, the extended Shetland database was created to facilitate quantitative analysis, but insufficient evidence has been gathered for this to be possible.

${ }^{69}$ Dannevirke, Makaretu, Makotuku, Mauriceville, Mellemskov (now Eketahuna), and Norsewood, situated along what is now State Highway 2, were settled under the Vogel immigration initiatives of the early 1870s as 'Special Settlement's' of Scandinavian migrants, recruited to this area of New Zealand specifically in order to clear the '70 Mile Bush' that separated Wellington from Hawkes Bay. 3,327 Scandinavians arrived under this scheme in just three years. Organised Scandinavian immigration into New Zealand ceased in 1875. For more information see G.C. Petersen, Forest Homes: The Story of the Scandinavian Settlements in the Forty Mile Bush, Wellington, 1956; Rob McDonald, Dannevirke: The Early Years, Hastings, 2002;

${ }^{70}$ NZSG database, migrants 02653, 02733, 02735, 02738, 02740, 02747, 02748, 02749, 02750, and 02753. At least 112 Shetland immigrants settled in the Hawke's Bay - the ninety-six arriving on the Clarence have been noted earlier, and Gordon records one Shetland migrant arriving in Napier on the Hudson in 1874, another on the Hudson in 1875, one on the Waitara in 1875 and thirteen on the City of Auckland in 1878. Given the chain migration figures of Shetland immigration, it is highly likely more Shetland migrants settled in the province than these numbers suggest. Gordon, 'Immigration into Hawke’s Bay, 1856-1876', pp.266-267.
} 
have settled in almost every part of New Zealand, case study evidence suggests that Shetland migrants did not spread throughout the country to the same extent. As with Scots generally, there was a clear preference for the lower South Island as place of New Zealand residence among Shetland migrants: Invercargill, Dunedin and surrounding areas, areas with a relatively high concentration of Scots. Beyond these southern locations, only Auckland City and environs, Hutt County and Hawkes Bay appear to have received any significant number of Shetland migrants. That the Shetland migrants did not spread throughout New Zealand to the same extent as the Scots generally is probably due simply to the smaller numbers involved. Were the population of Shetland itself larger, and therefore the actual numbers involved in Shetland-New Zealand migration also larger it is likely Shetland migrants would also have been spread throughout New Zealand.

There also appears to be a clear correlation between where migrants settled and their port of arrival. The Johnstone family of Shetland, who settled in Dannevirke, arrived in Wellington, as did the Tait family who settled in Featherston and the Williamsons and Ridlands who settled in Upper Hutt. ${ }^{71}$ Of the NZSG Shetland migrants for whom both place of death and port of arrival are noted, 72.22 per cent made homes near their ports of arrival. As Table 6.7, below, indicates, however, correlation between port of arrival and place of settlement was by no means unique to Shetlanders amongst migrants arriving from Scotland.

\footnotetext{
71 NZSG database, migrants 05947, 05949, 05955, 05956, 05959, 05962; 06368; 05073, 05153. Though Napier could also be considered a logical port of arrival for those settling in Dannevirke, Dannevirke is included within Wellington Province. These observations and calculations are based upon comparing port of arrival and province of death.
} 
Table 6.7

Proportion of migrants from each region of Scotland, and from Shetland County, who died in the same New Zealand province they first arrived in.*

\begin{tabular}{ccc}
\hline \hline & \% & n** \\
\hline \hline Shetland & 72.22 & 90 \\
Far North & 79.11 & 225 \\
North East & 73.06 & 412 \\
Highlands & 70.7 & 529 \\
Western Lowlands & 70.21 & 1,168 \\
Eastern Lowlands & 72.42 & 1,396 \\
Borders & 78.42 & 380 \\
Scotland total & $\mathbf{7 2 . 5 5}$ & $\mathbf{4 , 1 1 0}$ \\
\hline * Lyttelton has been included as being the same port of arrival as \\
province of death for both the West Coast and for Canterbury \\
Province. \\
** Figures exclude those for whom there is no port of arrival \\
information, no province of death information, and/or no place of \\
birth information. \\
Source: NZSG data
\end{tabular}

The smallness of the Shetland sample again permits deeper insights. All of the NZSG Shetland migrants with place of death and port of arrival information available lived either in the same province as arrival (72.22 per cent) or near family who had earlier settled near their own ports of arrival (27.78 per cent). Thus, although Robert and Margaret Johnston and family moved to Invercargill after arriving in Wellington, thereby seeming to break the pattern of settling near the port of arrival, this was because Robert had lived briefly in Bluff two years earlier before returning to Shetland for his family. ${ }^{72}$ Likewise, when Robert Fordyce settled in Auckland, having arrived in Wellington via England, he did so because of extended family already in Auckland. ${ }^{73}$ Ann Ursula Petrie arrived in Napier on the Clarence in 1874 and shortly afterwards moved to Wellington. Her sister Agnes Beatrice had arrived in Wellington as an assisted passenger thirteen months earlier. ${ }^{74}$

From the 1860s Stewart Island, the most southerly of New Zealand's three principal islands, attracted independent migrants from Scotland's most northerly county. Robert Scollay arrived on Stewart Island with his wife and three children in 1861. Scollay came to the island with saw-milling machinery, was later involved in the fishing industry in the area, and ran his own schooner on the coast until $1899 .^{75}$ James Robertson Thomson, born in Tingwall in 1848, arrived in Port Chalmers on the

\footnotetext{
${ }^{72}$ NZSG database, migrants 01277, 02683, 02703, 02718, 02722, 02725, 02730, 06582

${ }^{73}$ NZSG database, migrants 01848. Present in Appendix 6.3

${ }^{74}$ NZSG database, migrants 04946, 06648. Present in Appendix 6.5b

75 'Mr. Robert Scollay', The Cyclopedia of New Zealand, Christchurch, 1905, New Zealand Electronic Text Centre 3 April 2009, p.892; Graeme Laurenson, A Kiwi in the Shetland Scattald, New Plymouth, 1980, p.53
} 
Jessie Readman with his Shetland-born wife Barbara and one-year-old daughter Robina in $1873 .{ }^{76}$ He and his family settled on Stewart Island in 1876. Purchasing land there, he farmed, fished and mined, and in 1886 opened the Greenvale Accommodation House at Half Moon Bay. ${ }^{77}$

\section{THE SPECIAL SETTLEMENTS}

Beyond the unregulated flows, Shetland migrants were singled out as ideal for the 'special settlements' launched in the 1870s by the New Zealand Government on several occasions. Conceived as a means of promoting rapid settlement and development, the 'special settlements' devised under the Immigration and Public Works Act 1870, were not the first of their kind in New Zealand, previous settlements including Waipu, Albertland, Puhoi and military settlements in the Waikato. ${ }^{78}$ As well as promoting infrastructural growth in the regions the settlements were located, another purpose of the 1870s 'special settlement' scheme was to populate parts of the colony that were relatively remote and generally less attractive. ${ }^{79}$ The first, and perhaps best-known, group of Shetland settlers specifically recruited for New Zealand was the group of thirty-one who arrived in June 1873, secured to settle at the Port William special settlement site in Stewart Island.

In 1871 Robert Stout, a Dunedin lawyer, later Minister of Lands and Immigration as well as Premier, himself a Shetland migrant, wrote to the New Zealand Government suggesting that, in light of the recent Government-sponsored recruitment of Scandinavian immigrants, it would perhaps also like to assist the migration of some British migrants who were 'in habits, in character, in fact [in] everything except language...like the Norwegians' - i.e. Shetland migrants, or those from Orkney. ${ }^{80}$ Stout noted that a 'large number' of such people in Shetland especially, were 'anxious to change their address' as a result of a recent spate of 'extensive evictions' ${ }^{81}$ As well as highlighting their expertise in fishing, an underdeveloped industry in nineteenth-

\footnotetext{
76 Passenger list for Jessie Readman, arrived Port Chalmers, December 1873, http://freepages.genealogy.rootsweb.ancestry.com/ ourstuff/JessieReadman.htm accessed 3 April 2009; Gott, 'Shetland Family History Database’, I46787, accessed 3 April 2009

77 'Mr. James Robertson Thomson', The Cyclopedia of New Zealand, 3 April 2009, p.893

${ }^{78}$ R.P. Hargreaves and T.J. Hearn, 'Special Settlements of the South Island New Zealand', New Zealand Geographer, Vol.37, No.2, 1981, pp.67-72, p.67

${ }^{79}$ ibid., p.68

${ }^{80}$ Letter to The Honourable The Colonial Secretary from Robert Stout, 18 September 1871, p.1. Regarding special settlements of Scandinavian immigrants see footnote 70 in the present chapter.

81 ibid., p.1
} 
century New Zealand, he assured the Government of the suitability of the migrants, noting particularly the scarcity of liquor in Shetland and the need for only two policemen for a population of 33,000..$^{82}$ Less than a month later Stout had been asked for further details and suggestions regarding the prospective migrants. In reply, he outlined the criteria he believed needed to be addressed if a special settlement of Shetland migrants was to succeed. A point on which he placed stress was the careful selection of migrants in Shetland, ensuring at least one boat builder and one blacksmith were among the colonists, with many 'Jacks-of-all-Trades' among the rest. Further, he urged that migrants be picked up directly from Lerwick Harbour, thus reducing the cost of the transfer to the migrants themselves and increasing the likelihood that a greater number would apply for passage. In a postscript Stout emphasised 'the evil that the barter or as it is called 'truck' system has wrought in Shetland' ${ }^{83}$ Realistically, he outlined the potential problems the migrants would face if settled on Stewart Island, as had been proposed, noting their lack of experience in clearing bush, there being no 'timber' whatsoever in Shetland. Further, they would need provisions for the first two years, and some land should be cleared for them in advance of their arrival. ${ }^{84}$

Stout's recommendations encouraged the Government to act. In December 1871, in response to a request from the Otago Provincial Superintendant James Macandrew, Walter Pearson, the Commissioner of Crown Lands at Invercargill, submitted a report that comprehensively described Stewart Island and the seemingly endless opportunities it presented to intended colonists. ${ }^{85}$ Though the existing settlers of Stewart Island had managed to 'subsist' on fishing, Pearson noted that they laboured under several disadvantages unlikely to be shared by the Shetland migrants. The Shetland migrants were 'men whose life training has rendered them adepts at the occupation, masters of the position' and so 'the undertaking could be conducted to a most successful issue' ${ }^{86}$ This comment is interesting, given that there were several Shetland migrants already settled on Stewart Island and involved in the fishing

\footnotetext{
82 ibid., p.2

${ }^{83}$ ibid., pp.1-3. See footnote 22 in the present chapter for more on the Truck System.

84 ibid., pp.5-7.

${ }^{85}$ Letter to His Honor the Superintendant, Otago from W.H. Pearson, 11 Dec 1871, IM 6-10-1, Stewart Island, ANZ, Wellington. This overblown account of the island lead to later reference to Stewart Island as 'Pearson's Paradise.' Basil Howard, Rakiura: A History of Stewart Island, New Zealand, Wellington and Dunedin, 1940, p.242

${ }^{86}$ Letter to His Honor the Superintendant, Otago from W.H. Pearson, 11 Dec 1871, p.10
} 
industry. ${ }^{87}$ Pearson believed that, although the curing of fish was still in its infancy in New Zealand, these enterprising and highly skilled colonists would quickly raise it to the level of a great and lucrative industry, supplying products in great quantities to the local (Invercargill and Dunedin) and Australian markets. ${ }^{88}$ It would not be necessary, however, for the future colonists to confine their attention to fishing. In their spare time they could set their hand to building 'vessels of any tonnage', there being ample standing timber on the island to provide raw materials. Those who sought to escape from the sea in their leisure time would find profit in prospecting and mining, or in the loading of Otago wool-ships. ${ }^{89}$ In fact, Pearson continued,

Stewart Island is so singularly favourably situated for the proper class of settlers, that it is difficult to determine what they could not do.... While trawling, if he sees a whale he can, if prepared give chase, and if he gets his monster fish, tow it home and try it out at his leisure: if he loses it, go on trawling; always sure of a return of some sort. He lives in a genial climate, with a means of subsistence, nay wealth at command, and surrounded with such comfort as few of his calling experience, either in the home country or in the bitter winters of Nova Scotia. ${ }^{90}$

On the back of this most favourable description, Macandrew proposed to settle at least 1,000 migrants on the Island. ${ }^{91}$

Not everyone was as effortlessly convinced as Macandrew that the settling of Shetland migrants on Stewart Island would be so easy or successful. In July 1872 the Resident Minister for the Middle Island, William Pember Reeves, wrote to Macandrew on behalf of the New Zealand Government. He recognised 'a considerable amount of extra care and assistance' would be necessary, and asked if the necessary surveys were going to be carried out. Reeves further noted that 'before undertaking the grave responsibility of introducing population to these settlements, the government would be glad to be definitely informed what steps [Macandrew] propose[d] to take, to supply the various wants of the people, until such time as they can reasonably be expected to provide shelter for themselves and to carve their own

\footnotetext{
${ }^{87}$ Butterworth, Chips off the Auld Rock, pp.46-51

${ }^{88}$ Letter to His Honor the Superintendant, Otago from W.H. Pearson, 11 Dec 1871, pp.13-17

${ }^{89}$ ibid., pp.8, 14, 21-22

${ }^{90}$ ibid., pp.24, 26-7

${ }^{91}$ Memo on Special Settlements, Stewart's Island, from His Honor the Superintendant Otago, 17 January 1872, AJHR, 1872, D-7A, p.3
} 
living. ${ }^{92}$ Issues raised by the Minister included: the extreme poverty of the migrants the government proposed to recruit; the fact that they would be out of the reach of private employers; that there would be no public works offering supplementary employment nearby; and that the settlers would be highly dependent upon their own efforts. They would not only have to clear their allotted land and build their own houses, they would also have to rapidly begin to make a living, as government provisions were to be allocated for one year only. ${ }^{93}$ Despite the raising of these concerns, Macandrew persisted with his plans. The recruitment of suitable migrants went ahead, although initially only thirty-one migrants, rather than 1,000, were enticed to the Port William settlement.

The thirty-one who arrived in 1873 comprised six families and three single adults. ${ }^{94}$ Twenty-six of these thirty-one settlers almost certainly knew each other before they departed for New Zealand. For a diagram of their connections, see Appendix 6.5. Twenty of the twenty-six traceable settlers were from Dunrossness: sixteen were from Scatness, and four from Virkie, and, although the other six settlers are recorded as being in Wilhoul, Sandwick, in the 1871 Census, the mother/wife of this family was the sister of the head of one of the Scatness families. ${ }^{95}$ Laurence Garriock and Laurence Young, the two traceable single men, were both boarders with the Mail family of Scatness in 1871. Garriock was the brother of Janet Gilbertson. Eighteen of the twenty-six travelled to New Zealand on the Euterpe, the eight members of James Harper's family following just six months later on the Dover Castle. The gender split was even (fifteen males and thirteen females), as was the age distribution (nine males and six females were over fourteen and the oldest adult was just thirty-eight.) 'Fisherman' was the recorded occupation of every head of household bar one, James Harper, who worked as a house carpenter in Shetland. ${ }^{96}$

\footnotetext{
${ }^{92}$ Letter to His Honor the Superintendant, Otago from W. Reeves, 25 Jul 1872, IM 6-10-1, Stewart Island, ANZ, Wellington

93 ibid.

94 The number of people in this group is noted in other sources as twenty-four or twenty-six. Butterworth records thirty-one, based on Chris Ingram's study of the group. It is this count and this list of the settlers that has been utilised here. Butterworth, Chips off the Auld Rock, p.69

${ }^{95}$ There is insufficient information about the Johnson Family and Andrew Henry the Barrack Master on Stewart Island to trace them to their Shetland Parish. Shetland Islands Census 1851, 2007, Transcribed by the Shetland Family History Society; Shetland Islands Census 1861, 2007, Transcribed by the Shetland Family History Society; Shetland Islands Census 1871, 2006, Transcribed by the Shetland Family History Society.

${ }^{96}$ There were three James Harpers in this group - The James Harper on the Euterpe was the house carpenter in Shetland. The other two arrived on the Dover Castle and were father and son.
} 
Despite the contingent being an apparently well-mixed and seemingly well-suited group of settlers, there were significant problems from the very beginning, arguably the most considerable being difficulties with fishing. The method of fishing that the Shetlanders had employed successfully at home, set line fishing, was of little use in Foveaux Strait, the settlers reportedly regularly returning to their lines to find that sharks had eaten most of the catch, leaving only heads. ${ }^{97}$ Moreover, despite there being an abundance of fish when other fishing methods were eventually used, the only means of preservation was time-consuming salting or smoking. Ultimately, the return was not worth the work involved. Some 800 pounds of fish shipped to Melbourne brought just $£ 1$ in payment to each of the four men involved, and no payment at all was received for the several boatloads of fish sent to Bluff. Howard notes 'their attempts to obtain money from their agent [for the boatloads of fish] were fruitless, and the impossibility of dealing with the matter satisfactorily from their isolated village induced them to give up all hope'; fishing was soon abandoned altogether by the group. ${ }^{98}$

A further pall was cast on the new settlement when Robert Thomson became ill and had to be taken to Invercargill Hospital, where he eventually died. ${ }^{99}$ Shortly afterwards Henry Gilbertson 'suffered a severe tooth abcess [sic] and also had to be transferred to Invercargill hospital', meaning a population loss to the settlement of seven people within the first few months as families followed their men folk to the mainland. ${ }^{100}$ Within fourteen months of arrival every one of the thirty-one migrants had left the island for the mainland. Though the local press insisted that this was because they were 'a very lazy lot', only remaining so long as the government provisions lasted, several houses were built by the settlers within six months of their arrival. ${ }^{101}$ They had cut the timber themselves, imported doors and sashes from the mainland and, in at least one case, employed a labourer to help with the construction. ${ }^{102}$ Having spent such energy and finances in attempting to settle on the

\footnotetext{
${ }^{97}$ Olga Sansom, In the Grip of an Island: Early Stewart Island History, Invercargill, 1982, p.128

98 ibid., p.128; Howard, Rakiura, p.249

${ }^{99}$ Butterworth, Chips off the Auld Rock, p.70. Note, this is not the Robert Thomson noted earlier in this chapter who was fifty-one at arrival and who worked as a fisherman in Invercargill after arrival in New Zealand.

${ }^{100}$ ibid., p.70

101 Southland News, 26 August 1874, quoted in Howard, Rakiura, p.249

102 ibid., p.249
} 
island it seems unlikely that the migrants would have easily decamped. An account by one of the children in this group captures its mood:

The final straw was when my father's violin gave up singing. It hung on the wall damp and useless like the harp on Tara's walls. The whole place seemed damp all the time. Severe illness forced one family then another to the mainland. No one felt much like singing any more since the violin had gone dumb. ${ }^{103}$

The extent to which the families stayed in contact with each other after the break up of the settlement is unclear, although it is known that Christina Thomson married one of the single men - Laurence Young - after the death of her husband. ${ }^{104}$

Karamea, on the West Coast of the South Island, was another special settlement that attracted a number of Shetland migrants. The Shetlanders who settled in the Karamea special settlement have been estimated as numbering approximately fifty. ${ }^{105}$ As with the Port William special settlement, the gender split in the group was even: twenty-six of the fifty migrants were female, as were ten of the twenty-one children and sixteen of the twenty-nine adults. The group was generally older than the Port William group; twenty-nine of the fifty Shetland settlers in Karamea were more than fifteen years old and fifteen of these adults were over thirty-eight. Though the Karamea Shetlanders were not intermarried in the same way as the Port William settlers, it is likely that again many of them knew one another before they left Shetland. Certainly three of the families are listed in the 1871 Census as having been neighbours: the families of John Sinclair, Bessie Coutts and James Moffatt, were living at 1 West Thistles, Number 1 Dykes and 1 Roadside, Walls respectively, in that census. ${ }^{106}$ There were no single people in the Karamea Shetland group, rather eight families. Occupation in Scotland is known for five of the seven heads of households; four were fishermen. ${ }^{107}$ This settlement was no more successful, though Shetlanders remained at the site of the settlement a few years longer than at Port William. This was partly because it was a larger settlement (thirty families to begin with in total, not

\footnotetext{
${ }^{103}$ Laurence Young, Junior, quoted in Sansom, In the Grip of an Island, p.128

${ }^{104}$ Butterworth, Chips off the Auld Rock, p.70

105 ibid., p.73-74

${ }^{106}$ Shetland Islands Census, 1871, Transcribed by the Shetland Family History Society

${ }^{107}$ One of the family groups consisted of six siblings, all of whom worked as farm servants in Shetland. The other head of household for whom 'occupation' is known is Bessie Coutts who was a widow at the time of immigration.
} 
only from Shetland), in part due to the location, and because there was work available clearing bush and constructing roads. ${ }^{108}$

Other unsuccessful special settlements that involved a small cluster of Shetland migrants included Jacksons Bay and Martins Bay, both on the West Coast. ${ }^{109}$ While Martins Bay was the first of the settlements mentioned here, formed prior to the passing of the Immigration and Public Works Act 1870, due to its isolation it remained very small - fifty settlers at its peak population in January 1871, and just twenty remaining by $1880 .{ }^{110}$ Five members of the Dalziel family, formerly of Shetland, left the settlement in 1878. Jeremiah Dalziel and his son James were among the seven men lost at sea on a trip to Jacksons Bay in June 1878, leaving Mrs Dalziel - the only woman remaining at the settlement - to support her four remaining children. A collection was taken to send the family to Dunedin where they remained, under the care of Robert Stout. ${ }^{111}$ Jacksons Bay, only proclaimed a 'special settlement' in February 1875, was arguably the most troubled of all. A primary difficulty at Jacksons Bay was the mixed origins of the migrants and the consequent communication difficulties that arose - settlers hailing from England, Ireland, and Scotland as well as Germany, Italy, Poland and Scandinavia. From a peak population of 402 in 1878, the settlement had been reduced to just 160 individuals by 1881 and by 1884 only twenty-four families remained. ${ }^{112}$ How many were originally from Shetland is unknown; among them, though, were the already noted Dalziel family, who had come to Martins Bay via the Jacksons Bay settlement. ${ }^{113}$

\footnotetext{
${ }^{108}$ For more information on this special settlement see Laurenson, A Kiwi in the Shetland Scattald, pp.55-57; Butterworth, Chips off the Auld Rock, pp.72-76; Hargreaves and Hearn, 'Special Settlements of the South Island New Zealand', p.71; ACFQ 8226 IM6/6/1 Karamea 12 August 1875 - 27 February 1878, National Archives, Wellington.

${ }^{109}$ For more information see Butterworth, p.75-79; John Hall-Jones, Martins Bay, Invercargill, 1987, pp.77-83; Mrs Peter Mackenzie, Pioneers of Martins Bay: The Story of New Zealand's Most Remote Settlement, Christchurch, 1952; Hargreaves and Hearn, 'Special Settlements of the South Island New Zealand', pp.67-72; Irvine Roxburgh, Jacksons Bay: A Centennial History, Wellington, 1976; ACFQ 8226 IM6/5/2 Jackson's Bay 4 August 1876 - 18 August 1877, and ACFQ 8226 IM6/5/3 Jackson's Bay 29 October 1877 - 28 May 1878, ANZ, Wellington

${ }^{110}$ Hargreaves and Hearn, 'Special Settlements of the South Island New Zealand', pp.68-9

${ }^{111}$ Butterworth, Chips off the Auld Rock, pp.75-6

${ }^{112}$ Hargreaves and Hearn, 'Special Settlements of the South Island New Zealand', pp.69-71

${ }^{113}$ Butterworth, Chips off the Auld Rock, p.76
} 


\section{CONCLUSION}

That the Shetland immigrants were 'in habits, in character, in fact [in] everything except language... like the Norwegians' is clearly an overstatement. ${ }^{114}$ It is necessary only to compare the migrants recruited for the Scandinavian special settlements of the lower North Island in the early 1870s to the settlement of Shetland migrants at Port William to note at least one important difference between the groups: the Scandinavian aptitude for bush-felling, and the almost complete lack of knowledge regarding tree and bush clearance among migrants from the remote and tree-less Shetland archipelago. ${ }^{115}$ Indeed, comparing New Zealand's Shetland immigrants to those from the rest of Scotland, and to Norwegian settlers, it appears that the Shetland immigrants were in habits, character, and even to a degree in language, rather more like the settlers from the other counties of Scotland. As well as tending to settle in New Zealand near fellow Scots, they were, like their Scottish contemporaries, preferred over other migrants by government recruitment agencies; further, they spoke English - even if a dialect not found in mainland Scotland.

Nevertheless, as this chapter has demonstrated, in terms of the specificities of the migrant profile, for example their occupational profiles, the age, gender and marital status structure of the migrants, and the specific way in which they were singled out by New Zealand Government schemes, Shetland migrants were as different from their Scottish mainland contemporaries as Shetland was from Scotland itself. The patterns evident among Shetland migrants to New Zealand outlined in this chapter provide a point against which the characteristics of the migrants from the rest of Scotland can be compared and contrasted, thereby accentuating the trends and broad patterns evident among Scots generally and among the divergent Shetland migrants.

The chapter has served one further purpose; the focus on the emigrants from one Scottish county to one migrant destination has emphasised the importance of such localised studies in the study of migration patterns. Though much remains to be explored regarding Shetland-New Zealand migration, the depth of understanding this case-study has provided about the Shetland migrants, certainly compared to migrants from the rest of Scotland, is evidence of the value of such studies.

\footnotetext{
${ }^{114}$ Letter to The Honourable The Colonial Secretary from Robert Stout, 18 September 1871, p.1

${ }^{115}$ See footnote 69 and the section above regarding the Port William Settlement.
} 


\section{Chapter Seven}

\section{'EMPIRE SETTLEMENT’ AND BEYOND: AN EPILOGUE TO THE FIRST EIGHTY YEARS OF ORGANISED SCOTTISH MIGRATION TO NEW ZEALAND.}

John Williamson, born in Ayrshire in 1883, was married at age twenty-four in Kilmarnock. Though both he and his wife Jessie were employed at the Rowallan Creamery in Kilmarnock prior to emigration in 1926, John servicing the engines and Jessie working as a buttermaker, they were emigrating, apparently unassisted, in search of a better life for their family. They had been married nineteen years and had nine children with them on their voyage to New Zealand. Seeing plumes of what appeared to be factory smoke on the evening he and his family approached Eltham by train from Wellington, John was relieved, as it held the promise of employment. Discovering the following morning that the smoke was from the burning-off of bush, not from busy factories, he became downhearted; but he soon found employment in road construction and, later, worked for himself on land he and Jessie leased. John returned to Scotland for a short visit after Jessie's death in 1954, to see his younger brothers, no one else in his family having emigrated. John died in New Zealand in 1967. ${ }^{1}$

Migrating apparently unassisted during a period that witnessed a high level of assisted immigration, arriving as a married man at a time when only 41 per cent of adult Scottish males migrating to New Zealand were married, settling in Taranaki where only 3.2 per cent of Scottish migrants arriving in this period settled, and refusing to buy land - the aspiration of many migrants to New Zealand - John might be considered an atypical migrant. However, in a number of other respects his experiences were characteristic of New Zealand's post-World War One Scottish immigrants. As this chapter will also demonstrate, Jessie was just one of the migrants making up the 51 per cent of adult Scottish female immigrants arriving during this period who were married. That John and Jessie were accompanied by their older (and adult) children, rather than primarily children under five years, was also 'typical' of the post-war Scottish migrants. John's employment in agriculture was also a common experience, and he was just one of an increasingly large number of post-war migrants who eventually made their way back to Scotland.

\footnotetext{
${ }^{1}$ Personal communication with Marlene Williamson, 30 Oct 2007
} 
This chapter is essentially an epilogue to the primary focus of the present research, Scottish immigration to 1920. It nevertheless serves to highlight and reinforce patterns already discerned, while at the same time broadly outlining post-World War One trends in the flow of Scots to New Zealand. The more limited discussion is dictated by the non-inclusion in the available volume of the NZSG register of migrants arriving after December 1920, this precluding a direct comparison with earlier arrival phases. ${ }^{2}$ Moreover, Scots migrating after World War One were migrating in a vastly different world to those who had left earlier. Different factors influenced both potential migrant decisions to emigrate, and decisions regarding destination. In recognition of these factors the present chapter commences with a consideration of the issues influencing emigration from Britain and immigration to New Zealand in the 1920s and 1930s, and then presents a profile of the Scottish migrants based essentially upon the PNZ data. It concludes with a brief consideration of the significance of return migration. In this respect John Williamson was far from exceptional. As international travel became increasingly easy in the twentieth century, more of New Zealand's Scottish immigrants returned 'home', whether temporarily, as Williamson did in 1954, or on a permanent basis. ${ }^{3}$

\section{EMIGRATION FROM BRITAIN BETWEEN THE WARS: BASIC TRENDS}

The number of emigrants from Britain to destinations outside of Europe totalled 389,394 in 1913 and 214,893 in 1914. Between 1915 and 1918 the figure dropped to just 150,462 in total, an outcome of World War One. Figure 7.1 indicates that although emigration figures rose again immediately after the war, they did not again reach pre-war heights before World War Two.

\footnotetext{
2 'Volume 2, with a cut-off date of arrival before 1 January, 1931, is being compiled, and will be published as soon as enough completed entry forms have been returned'. Cover of registration form for 'Register of New Zealand Immigrants of Scottish Birth Arriving before 1 January, 1931'. This volume of microfiches has not yet been released.

${ }^{3}$ Marjory Harper, 'Introduction', in Marjory Harper (ed.), Emigrant Homecomings: The Return Movement of Emigrants, 1600-2000, Manchester, 2005 and Alistair Thomson, "My wayward heart': homesickness, longing and the return of the British post-war immigrants from Australia', in Marjory Harper (ed.), Emigrant Homecomings: the Return Movement of Emigrants, Manchester, 2005. Both authors briefly discuss the impact of air travel on return immigration from Australia.
} 
Figure 7.1

British emigration bound for destinations outside of Europe, 1913-1938

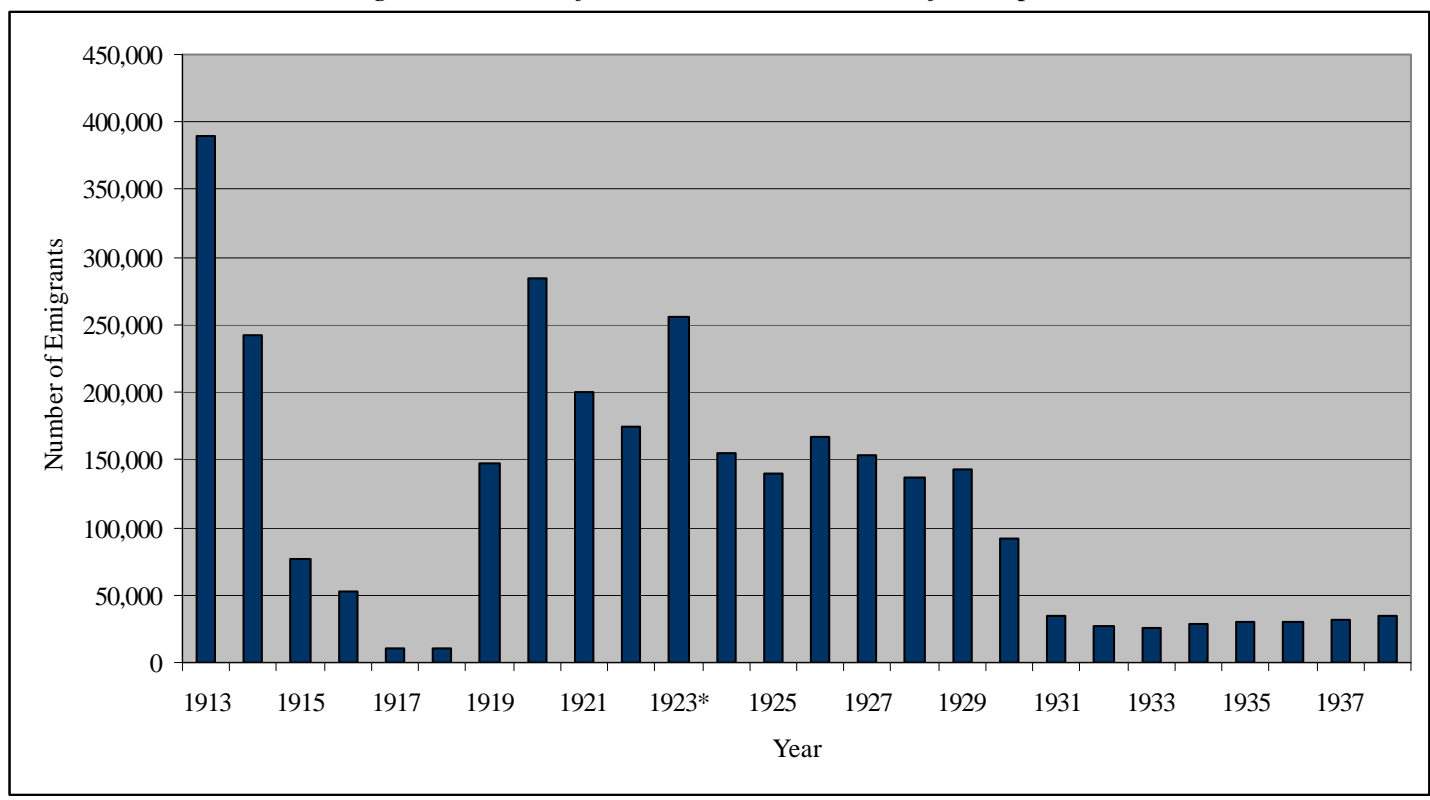

*Figures are exclusive of passengers who departed from ports of the Irish Free State from 1 April 1923.

Source: Plant, Oversea Settlement ${ }^{4}$

The peaks observable in Figure 7.1, in 1920 and 1923, were linked to, respectively, an emigration scheme of free passages for ex-servicemen introduced by the British Government in 1919, and the introduction of immigration quotas in the United States, these coming into effect from July 1924. Co-ordinated by the Oversea Settlement Committee, the emigration scheme for ex-servicemen was established in 1919 and, beginning on 1 January 1920, was intended to operate for one year. Free passage to the British dominion of their choice was offered to British men and women (and their dependants) who could prove war service. ${ }^{5}$ Though the greatest surge was in the first year of the scheme, it was in operation until March 1923, assisting 39,419 exservicemen and their dependants (86,027 migrants in all) to emigrate. ${ }^{6}$ Restrictions on immigration to the United States commenced in 1921, primarily in response to fears that a flood of European migrants would swamp the already depressed post-war American labour market. The quota system introduced restricted the number of immigrants allowed to enter the United States from each nation to 3 per cent of the number of people of that nationality in America at the 1910 Census. In 1922 it was decided to tighten the quota to 2 per cent, with a cap to immigration of 150,000 per year, beginning July 1924. Thus, from July 1924 only 84,007 emigrants per annum

\footnotetext{
${ }^{4}$ Table 1, Appendix I, G.F. Plant, Oversea Settlement: Migration from the United Kingdom to the Dominions, London, 1951, p.174

${ }^{5}$ Marjory Harper, Emigration from Scotland Between the Wars: Opportunity or Exile?, Manchester, 1998, p.15

${ }^{6}$ Plant, Oversea Settlement, p.74
} 
from the whole of the United Kingdom would be permitted. This helps explain the post-war peak of immigration to the United States from Britain in 1923, people rushing to beat the introduction of the tighter quota system. ${ }^{7}$

What is also emphasised by Figure 7.1 is the impact of the worldwide depression of the 1930s on emigration from Britain. While 143,686 emigrants left Britain for the dominions in 1929, the total dropped to 92,158 in 1930, with even fewer emigrating in 1931 than in 1916, the midst of World War One. In contrast, emigration figures soared once again post World War Two, reaching 166,586 in $1946 .{ }^{8}$

In 1911 a peak of 88,852 emigrants departed from Scotland for non-European destinations. Scotland's share of the 150,462 British emigrants departing between 1915 and 1918 was just 13.69 per cent - 20,602 emigrants. ${ }^{9}$ Over the ensuing decade, however, while the populations of England and Ireland increased (by 6 and 0.5 per cent respectively between censuses), Scotland experienced a rate of emigration that exceeded natural increase; this produced an overall fall in Scotland's population of 39,517 people between 1921 and 1931. The absolute decline in the population (of 0.8 per cent) between successive census years is the only such decline ever recorded in Scotland. ${ }^{10}$ While England was experiencing a loss of five people in every 1,000 as a result of emigration in the 1920 s, the figure was eighty to every 1,000 in Scotland. ${ }^{11}$ Just over a quarter of all United Kingdom emigrants departing between 1920 and 1930 were from Scotland. ${ }^{12}$ Between 1919 and 1938, 494,053 Scots departed for Canada, the United States, South Africa, Australia or New Zealand with 19.7 per cent of these Scots opting for Australasia. ${ }^{13}$ While 88,584 emigrated in 1923 alone, between 1931 and 1938 only 33,595 emigrants were recorded, and, simultaneously, 76,869 immigrants, many of whom were probably returning migrants. ${ }^{14}$

\footnotetext{
${ }^{7}$ Harper, Emigration from Scotland Between the Wars, pp.7, 17 and 31

${ }^{8}$ Plant, Oversea Settlement, p.175

${ }^{9}$ Harper, Emigration from Scotland Between the Wars, p.6

${ }^{10}$ ibid., pp.6-7

11 ibid., p.7

12 ibid.; Plant, Oversea Settlement, p.174

${ }^{13}$ Harper, Emigration from Scotland Between the Wars, p.7

14 ibid., p.7. How many of these were returning emigrants is unknown.
} 


\section{IMMIGRATION TO NEW ZEALAND BETWEEN THE WARS: BASIC TRENDS}

Of the 1,958,488 United Kingdom emigrants leaving for non-European destinations between 1919 and 1930, 120,000 emigrated to New Zealand. ${ }^{15}$ Though, in absolute terms this was a relatively small figure, just over 6 per cent of all emigrants from Britain, it represented an addition of nearly 11 per cent of the 1916 population of New Zealand (just 1,099,449 people). ${ }^{16}$ In keeping with the overall drop in British emigration in the 1930s, so too did arrivals in New Zealand decrease, with only around 31,000 migrants arriving between 1930 and 1939. ${ }^{17}$

More than 70,000 of the British migrants to New Zealand between 1919 and 1938 were assisted. ${ }^{18}$ Though the details of who were assisted, by whom, why and when, are more difficult to ascertain than is the case for assisted and nominated passengers in the mid-nineteenth century, whether under New Zealand Company, provincial governments or the Vogel schemes of assistance, several strands of this assisted migration are clearly identifiable.

Of the 86,027 ex-servicemen and their dependants sponsored by the British Government in partnership with the relevant dominion governments between 1920 and 1923, 13,349 departed for New Zealand. ${ }^{19}$ One such, John Fife of Drummore, had been a stoker in the Royal Navy. Arriving in Auckland in 1921, he moved to Hokianga shortly after, there meeting and marrying a local girl. John was the only member of his family to emigrate from Scotland, and returned to visit his siblings in 1983 with his wife and one of his children. ${ }^{20}$ The Empire Settlement Act of 1922 assisted approximately 44,700 further migrants to leave for New Zealand between 1922 and $1936 .{ }^{21}$ Supporters of emigration as a means of social reform in Britain, as well as in the dominions, noted that while the population density in England was 650 people per square mile, in New Zealand the comparable density was just 11.7 people

\footnotetext{
${ }^{15}$ Table 1, Appendix I, Plant, Oversea Settlement, p.174; Jock Phillips and Terry Hearn, Settlers: New Zealand Immigrants from England, Ireland and Scotland, 1800 - 1945, Auckland, 2008, p.47. How many of these 120,000 were from Scotland is presently unknown.

${ }^{16}$ Part I, 1916 Census of New Zealand, p.1

${ }^{17}$ Table 1 'Immigrants intending permanent residence, 1918-1939', Stephen Constantine, 'Immigration and the making of New Zealand, 1918-1939', in Stephen Constantine (ed.), Emigrants and Empire: British Settlement in the Dominions Between the Wars, Manchester, 1990, p.139

${ }^{18}$ Phillips and Hearn, Settlers, p.47

${ }^{19}$ Plant, Oversea Settlement, p.74.

${ }^{20}$ Personal communication with Marilyn Richer, 17 Oct 2007

${ }^{21}$ Constantine, 'Immigration and the making of New Zealand, 1918-1939', p.140
} 
per square mile. ${ }^{22}$ An obvious conclusion was that the latter was under populated and therefore also under developed. ${ }^{23}$ The Act was designed to alleviate the pressures of a growing metropolitan population, including increasing unemployment, to 'consolidate the empire... generate development in the dominions and expand intra-empire trade. ${ }^{\text {,2 }}$ It made provision for $£ 3$ million of British Government funds to be spent each year for fifteen years, augmented by funds from the various dominion governments, on assisted passages, land settlement schemes and occupational training courses for migrants. ${ }^{25}$ However, the scheme was more ambitious than it was successful. Between May 1922 and March 1936 only £6,099,046 was spent, substantially less than the $£ 42$ million proposed, indicating that far fewer emigrants were dispatched from Britain than had been hoped. Nevertheless, the scheme underpinned 36 per cent of all migration to the 'Empire' over that period. ${ }^{26}$ As well as these government sponsored schemes of assistance, numerous voluntary organisations - predominantly church-based - also operated schemes of assisted migration. ${ }^{27}$

Three classes of migrants were targeted for assistance, whether by the voluntary societies or the government schemes: women, children and single men. ${ }^{28}$ As had been the case in the nineteenth century, single men were primarily recruited to fill labour shortages in New Zealand. As had also been the case in the nineteenth century, women were preferred assisted migrants, due in part to the gender imbalance of the British population, further amplified by the war, and by the supposed 'surplus' of men in the dominions. ${ }^{29}$ The shortage of domestic servants was decreed to be 'a matter of "national importance”" in New Zealand, the New Zealand Minister for Agriculture in 1920 stating unequivocally that an important factor in the decline in the country's

${ }^{22}$ The population density of Scotland in 1921 was approximately 160.53 people per square mile $\left(4,882,497 / 30,414 \mathrm{mi}^{2}=1921\right.$ population of Scotland / area of Scotland in square miles.)

${ }^{23}$ Stephen Constantine, 'Empire migration and social reform, 1880-1950', in Colin G. Pooley and Ian D. Whyte (eds), Migrants, Emigrants and Immigrants, London, 1991, p.65

${ }^{24}$ Eric Richards, Britannia's Children: Emigration from England, Scotland, Wales and Ireland since 1600, London and New York, 2004, p.244

${ }^{25}$ Harper, Emigration from Scotland Between the Wars, p.16

${ }^{26}$ Approximately 405,000 migrants. Plant, Oversea Settlement, p.75

${ }^{27}$ Many such organisations were in operation during this time, some assisting only a few migrants, others more prolific. Not all of these schemes of assistance offered assistance with the transportation of the migrants, some instead offering support upon arrival at the migrants' destination. Among the most successful (in terms of the volume of migrants assisted) of these schemes were those run by the Salvation Army. In New Zealand, for example, the Salvation Army ran a training farm for assisted migrants in Putaruru. ibid., pp.135-140, and 144;

${ }^{28}$ ibid., p.136

${ }^{29}$ Harper, Emigration from Scotland Between the Wars, p.17; Dane Kennedy, 'Migration in post-war reconstruction: the role of the Oversea Settlement Committee, 1919-1922', Albion: A Quarterly Journal Concerned with British Studies, Vol.20, No.3, 1988, pp.403-419, p.407 
wheat production was the lack of domestic labour in farmers' homes. ${ }^{30}$ Of all the dominions, New Zealand offered the most generous assistance to women under the Empire Settlement Act: free passages and a £2 gratuity to 'bona fide' domestic servants, that is women between eighteen and forty years of age who had been employed in such work prior to making their application for assistance, who would promise to work in such service for at least one year after arrival in New Zealand, and who pledged not to marry during that time. ${ }^{31}$ New Zealand welcomed 4,504 British women as domestic servants under the legislation. ${ }^{32}$ The three eldest daughters of George Moyes might be considered typical of this group. Isabella (b. 1904), Agnes (b. 1905), and Christina Moyes (b. 1907), all of Fife, departed together on the Ruapehu from Liverpool in May 1925, bound for Wanganui via Wellington. Though three uncles of the girls were already in New Zealand, Isabella, Agnes and Christina were each bonded to employers for three years under the assisted immigration scheme. Within one year they had organised a house for their parents and nine siblings, who arrived in March 1926. All three girls married within twelve months of being released from their employment obligations. ${ }^{33}$

Though the immigration of juveniles, travelling without friends or family, was not something new for New Zealand - a celebrated early case being the several parties of Parkhurst boys in the early 1840s - the 1920s witnessed much greater interest in this class of immigrant. ${ }^{34}$ The 1926 annual report of the New Zealand Immigration Department endorsed that the greatest encouragement should be given to 'that most important of all immigration policies, juvenile and child migration'. ${ }^{35}$ From the viewpoint of concerned Britons, it was feared that many boys were living on city streets, and it was hoped that by removing them to the healthy, open spaces of Canada, Australia and New Zealand they might improve their morals and contribute

\footnotetext{
${ }^{30}$ Janice Gothard, “The healthy, wholesome British domestic girl': single female migration and the Empire Settlement Act, 1922-1930', in Stephen Constantine (ed.), Emigrants and Empire: British Settlement in the Dominions Between the Wars, Manchester, 1990, p.77, citing Report... of the Delegates Appointed to Enquire as to Openings in New Zealand for Women from the United Kingdom, Cmd.933, XXII, 1920, p.4

${ }^{31}$ Katie Pickles, 'Pink cheeked and surplus: single British women's inter-war migration to New Zealand', in Lyndon Fraser and Katie Pickles (ed.), Shifting Centres: Women and Migration in New Zealand History, Dunedin, 2002, p.63

${ }^{32}$ ibid.p.74

${ }^{33}$ Personal communication with Peter J Moyes, 26 Oct and 1 Nov 2007

${ }^{34}$ Gillian Wagner, Children of the Empire, London, 1982, pp.20-21 and 238

${ }^{35}$ ibid., p. 238
} 
constructively to their new communities, thereby also strengthening the Empire. ${ }^{36}$ Contemporaries believed that youth immigration would greatly benefit New Zealand, it being argued that young people would assimilate more quickly than other migrants. ${ }^{37}$ Yet, though policy makers hoped that up to 40 per cent of all immigrants to New Zealand in the 1920s would be children, only around 1,400 were assisted to New Zealand under the Empire Settlement Act, the 'New Zealand Sheepowners' Acknowledgement of Debt to British Seamen Fund', and other schemes, including those operated by the Salvation Army and the Church of England, over the inter-war years. $^{38}$ The Sheepowners' Fund alone assisted 429 male and ninety-four female children between June 1924 and December 1928. This Fund ran Flock House, a 9,000 acre training farm near Palmerston North. It had been set up to bring 'the sons and daughters of British seamen, killed or wounded during the war' to New Zealand for training in farming, then establish them on farms, and finally to aid them to obtain farms of their own. ${ }^{39}$

Although immigration to New Zealand between the wars was not restricted to British immigrants, legislation such as the Immigration Restriction Acts of 1908 and 1920 kept convicted criminals, those with contagious diseases, the deaf and the blind from entering the country, as well as those not of European stock. ${ }^{40}$ Both the assisted and non-assisted flows of immigrants to New Zealand were therefore unsurprisingly primarily British throughout this period.

\section{SCOTTISH EMIGRATION TO NEW ZEALAND, 1921-1945}

In 1878 Scots made up 31.05 per cent of the New Zealand population born in England, Wales or Scotland. ${ }^{41}$ This was 18.48 per cent higher than the proportion of

\footnotetext{
36 Stephen Constantine, 'Introduction: Empire migration and imperial harmony', in Stephen Constantine (ed.), Emigrants and Empire: British Settlement in the Dominions between the Wars, Manchester, 1990, p.9 Phillips and Hearn, Settlers, p.49

${ }^{37}$ Wagner, Children of the Empire, p.238

${ }^{38}$ ibid., pp.238-9. Phillips and Hearn, Settlers, p.49.

${ }^{39}$ Wagner, Children of the Empire, pp.238-9; Harper, Emigration from Scotland Between the Wars, p.161

${ }^{40}$ Constantine, 'Immigration and the making of New Zealand, 1918-1939', p.135. See also F.A. Ponton, 'Immigration Restriction in New Zealand: A Study of Policy from 1908 to 1939', M.A. Thesis, Victoria University of Wellington, 1946; P.S. O’Connor, 'Keeping New Zealand white, 1908-20', NZJH, Vol.2, No.1, 1968, pp.41-65; G.R. Warburton, 'The Attitudes and Policies of the New Zealand Labour Movement Towards Non-European Immigration, 1878-1928', M.A. Thesis, University of Canterbury, 1982

${ }^{41}$ Excluding the Irish-born in these figures as they are for comparison with 1921 figures in New Zealand and in the UK, and population figures for 1921 in Ireland are not available. Scots constituted 24.19 per cent of the United Kingdom and Ireland-born population of New Zealand at the 1878 Census.
} 
the population of the three countries of mainland Britain in 1881 who were Scots (that was just 12.57 per cent of the United Kingdom population). By 1921, though the proportion of the England/Wales/Scotland-born population of New Zealand born in Scotland had decreased to 21.70 per cent, Scots were still vastly disproportionate compared to the population of the United Kingdom itself. The population of Scotland was only 11 per cent of the combined population of England, Wales and Scotland in 1921.

Figure 7.2, below, records the flow of emigrants from Scotland to New Zealand between 1921 and 1945. A comparison of this graph with Figure 7.1 (the emigration flow from Britain ${ }^{42}$ between 1913 and 1938) reveals similar patterns. High post-war flows in the boom years of the 1920s were followed by a decade of very low immigration, lesser flows still during World War Two. Two differences, however, stand out.

Figure 7.2

Showing the flow of Scottish migrants to New Zealand between 1921 and 1945

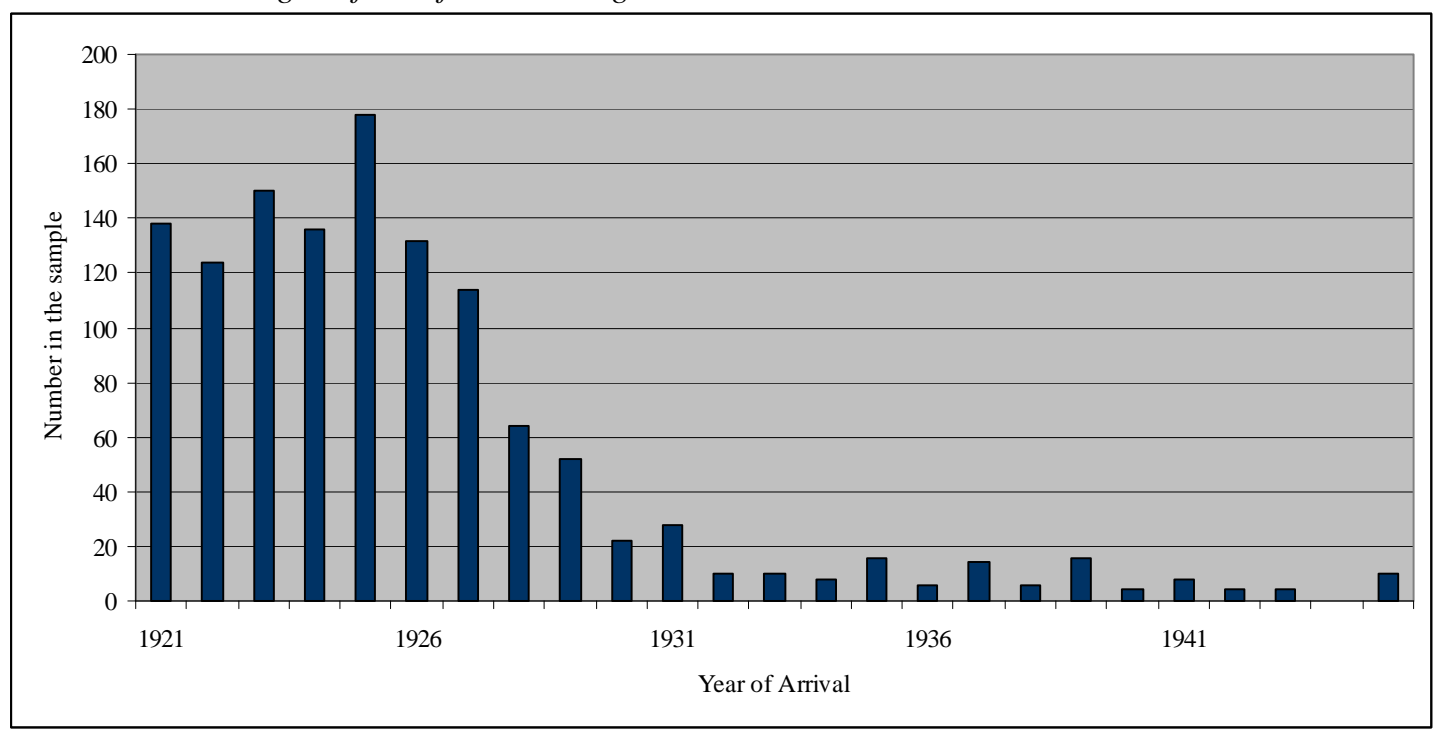

Source: PNZ data 1840-1920

While 1925 is indisputably a peak year of Scotland-New Zealand migration, it is a trough in the British emigration pattern. In contrast, 1928 evidences a more significant drop in numbers of Scots migrants to New Zealand than is visible among total British emigrants. The 1925 peak is possibly a result of the quota system for immigration introduced to America from 1924. No such quota scheme governed the movements of British migrants to New Zealand at this time, making it possible that New Zealand (along with other dominions) picked up the overflow from the American immigration

\footnotetext{
${ }^{42}$ Exclusive the Irish Free State from 1 April 1923
} 
stream. The greater drop in 1928 for New Zealand immigrant figures compared to British emigrant numbers appears to have been due to low agricultural prices and unemployment in New Zealand from 1927, heralding the on-coming depression. Assisted migration to New Zealand was offered almost exclusively to migrants with relatives already residing in New Zealand, and the number of immigrants dropped significantly as a consequence. ${ }^{43}$ This decline in movements to New Zealand was not restricted to Scots but is apparent for all immigrant groups to New Zealand.

Table 7.1, below, compares the origins in Scotland of the NZSG migrants arriving pre-1920 with migrants in the PNZ data arriving 1920-1945. Although the counties and regions of origin of the post-1920 Scots emigrating to New Zealand differ from those of the pre-1920 migrants, the trends remain broadly in line with the population distribution of Scotland, as was the case with the pre-1920 immigrants (compare column (a) with (c), and (b) with (d)).

While 13.11 per cent of pre-1920 NZSG migrants had been born in the Highlands, and just 6.68 per cent of post-1920 PNZ migrants, the proportion of the home population of Scotland living in the Highlands had also decreased between the 1871 and 1921 Censuses (from 8.51 per cent to 5.77 per cent). The proportion of the population of Scotland living in the Eastern Lowlands had increased by just over 1 per cent over the fifty years between the 1871 and 1921 Censuses, and the proportion of migrants from the Eastern Lowlands had also increased by nearly 1 per cent between the pre- and post-1920 periods of arrival. In a continuation of the shift of the population of Scotland to the industrial Lowlands that had begun in the eighteenth century, the proportion of the population living in Lanarkshire between the two censuses increased by 8.75 per cent. The proportion of migrants from Lanarkshire post-1920 also increased on pre-1920 figures, by 13.93 per cent. That Shetland continued to send more migrants to New Zealand than its share of the Scottish population post-1920 confirms the ongoing significance of the familial and chain migration trends noted in Chapter Six.

\footnotetext{
${ }^{43}$ Campbell James Gibson, 'Demographic History of New Zealand', PhD Thesis, University of California, Berkeley, 1972, p.132
} 
Table 7.1

Proportion of the NZSG pre-1920 migrants and post-1920 PNZ migrants from each county and region, alongside the 1871 and 1921 Census of Scotland figures. ${ }^{44}$

\begin{tabular}{|c|c|c|c|c|c|}
\hline & & $\begin{array}{l}\text { NZSG pre-1920 } \\
\text { (a) }\end{array}$ & $\begin{array}{l}\text { PNZ 1920-1945 } \\
\text { (b) }\end{array}$ & $\begin{array}{l}\text { Scot Census } 1871 \\
\text { (c) }\end{array}$ & $\begin{array}{c}\text { Scot Census } \\
1921 \\
\text { (d) } \\
\end{array}$ \\
\hline \multirow{4}{*}{ Far North } & SHI & 2.02 & 2.91 & 0.94 & 0.52 \\
\hline & OKI & 1.03 & 1.03 & 0.93 & 0.49 \\
\hline & CAI & 2.42 & 1.37 & 1.19 & 0.58 \\
\hline & & 5.47 & 5.31 & 3.06 & 1.60 \\
\hline \multirow{6}{*}{$\begin{array}{l}\text { North } \\
\text { East }\end{array}$} & NAI & 0.18 & 0.00 & 0.30 & 0.18 \\
\hline & MOR & 1.46 & 0.34 & 1.28 & 0.85 \\
\hline & BAN & 1.33 & 1.71 & 1.85 & 1.17 \\
\hline & ABD & 7.37 & 8.90 & 7.28 & 6.17 \\
\hline & KCD & 1.09 & 0.34 & 1.03 & 0.86 \\
\hline & & 11.43 & 11.30 & 11.74 & 9.23 \\
\hline \multirow{6}{*}{ Highlands } & SUT & 1.27 & 0.51 & 0.72 & 0.36 \\
\hline & ROC & 4.52 & 1.71 & 2.41 & 1.45 \\
\hline & INV & 2.92 & 1.71 & 2.62 & 1.69 \\
\hline & ARL & 3.60 & 1.37 & 2.25 & 1.57 \\
\hline & BUT & 0.80 & 1.37 & 0.51 & 0.69 \\
\hline & & 13.11 & 6.68 & 8.51 & 5.77 \\
\hline \multirow{11}{*}{$\begin{array}{l}\text { Eastern } \\
\text { Lowlands }\end{array}$} & ANS & 3.70 & 6.85 & 7.07 & 5.55 \\
\hline & PER & 6.07 & 2.23 & 3.80 & 2.57 \\
\hline & DNB & 1.94 & 2.05 & 1.75 & 3.09 \\
\hline & CLK & 0.62 & 0.34 & 0.71 & 0.67 \\
\hline & KRS & 0.43 & 0.17 & 0.21 & 0.16 \\
\hline & FIF & 5.09 & 6.68 & 4.78 & 6.00 \\
\hline & STI & 4.04 & 2.23 & 2.92 & 3.31 \\
\hline & WLN & 1.22 & 2.05 & 1.22 & 1.72 \\
\hline & MLN & 8.04 & 10.62 & 9.77 & 10.37 \\
\hline & ELN & 1.62 & 0.51 & 1.12 & 0.97 \\
\hline & & 32.77 & 33.73 & 33.37 & 34.42 \\
\hline \multirow{4}{*}{$\begin{array}{l}\text { Western } \\
\text { Lowlands }\end{array}$} & RFW & 5.56 & 3.25 & 6.46 & 6.12 \\
\hline & LKS & 15.86 & 29.79 & 22.78 & 31.53 \\
\hline & AYR & 6.50 & 5.48 & 5.98 & 6.13 \\
\hline & & 27.92 & 38.53 & 35.21 & 43.78 \\
\hline \multirow{8}{*}{ Borders } & BEW & 1.19 & 0.34 & 1.09 & 0.58 \\
\hline & PEE & 0.53 & 0.86 & 0.37 & 0.31 \\
\hline & SEL & 0.45 & 1.03 & 0.55 & 0.46 \\
\hline & ROX & 2.07 & 0.34 & 1.47 & 0.92 \\
\hline & DFS & 2.58 & 1.03 & 2.23 & 1.54 \\
\hline & KKD & 1.30 & 0.34 & 1.25 & 0.76 \\
\hline & WIG & 1.22 & 0.51 & 1.16 & 0.63 \\
\hline & & 9.34 & 4.45 & 8.10 & 5.21 \\
\hline$n$ & & 6,243 & 1,168 & $3,360,018$ & 4,882,497 \\
\hline
\end{tabular}

Sources: NZSG data 1840-1920; PNZ data 1920-1945; Return Relating to the Population of Scotland at each Decennial Period, Table II, 1881 Census of Scotland, pp.2-3; Population, Ages, Conjugal Condition, Orphanhood, Birthplaces, Gaelic-speaking, Housing, Scotland, Table 1, 1921 Census of Scotland, p.3

\footnotetext{
${ }^{44}$ The NZSG rather than the PNZ pre-1920 figures are used here in order to facilitate comparison with previous chapters, the NZSG data being the primary dataset utilised throughout the present work so far.
} 
As was evident when comparing the NZSG and PNZ data by province of death to the distribution of New Zealand's Scotland-born population in census figures pre1920, the northward drift of the population of New Zealand is highlighted when the PNZ data is compared to the 1921 Census data. This is especially the case in Auckland and Otago provinces. See Table 7.2, below.

Table 7.2

Showing the distribution of PNZ post-1920 migrants by province of death, and the distribution of the population of New Zealand by province at the 1921 Census

\begin{tabular}{cccc}
\hline \hline & PNZ & \multicolumn{2}{c}{$\mathbf{1 9 2 1}$ Census of NZ } \\
Scotland- & $\begin{array}{c}\text { Total NZ } \\
\text { bopulation }\end{array}$ \\
\hline \hline puckland & 34.88 & 24.33 & 30.34 \\
Taranaki & 3.20 & 3.13 & 5.08 \\
Hawkes Bay & 4.16 & 4.51 & 5.00 \\
Wellington & 20.96 & 18.17 & 20.43 \\
Nelson & 2.72 & 3.74 & 3.91 \\
Marlborough & 0.48 & 0.82 & 1.46 \\
West Coast & 1.92 & 0.76 & 1.16 \\
Canterbury & 14.72 & 14.28 & 16.34 \\
Otago & 12.48 & 22.31 & 11.17 \\
Southland & 4.48 & 7.95 & 5.1 \\
$\boldsymbol{n}$ & 1,250 & 51,654 & $1,218,067$ \\
\hline
\end{tabular}

Sources: PNZ data 1920-1945, Part III, 1921 Census of New Zealand, p.18

The higher proportion of PNZ Scots than Scots in the population in Auckland in 1921, and lower proportion for Otago and Southland, is arguably due to the continued drift of the population to the North Island in the twentieth century, accentuated by the fact that the PNZ data was recorded at time of death. Even so, while in 192160.86 per cent of the population of New Zealand lived in the North Island (30.34 per cent in Auckland Province), just 50.14 per cent of the Scotland-born population of New Zealand lived in the North Island (24.33 per cent in Auckland), this suggesting the continuing dominance of Otago and Southland as the major provinces of Scottish settlement into the twentieth century. If provinces of first settlement were available in the PNZ data, rather than being confined to provinces of death, the distribution may have been closer to that in the 1921 Census.

That the Scots migrating to New Zealand post-1920 were from a different world, motivated by different considerations, is reflected in the demographic profile of the later migrants. In terms of gender, what is most noticeable initially (Table 7.3, below) is the extent to which the gender composition of the migrants from each region 
differed according to period of arrival. If the regions from which most migrants came are considered, the post-1920 gender ratios are remarkably similar to those of the 1871-1886 flow. This is probably due to both periods being times of high levels of assisted migration.

Table 7.3

Ratio of Scottish female migrants in each period of arrival to male migrants, by region of birth. ${ }^{45}$

\begin{tabular}{ccccccc}
\hline \hline & Pre 1852 & $\mathbf{1 8 5 3 - 1 8 7 0}$ & $\mathbf{1 8 7 1 - 1 8 8 6}$ & $\mathbf{1 8 8 7 - 1 9 0 0}$ & $\mathbf{1 9 0 1 - 1 9 2 0}$ & $\mathbf{1 9 2 1 - 1 9 4 5}$ \\
\hline \hline Far North & 30.00 & 68.00 & 75.00 & 100.00 & 53.33 & 29.17 \\
North East & 128.57 & 72.09 & 50.00 & 50.00 & 73.53 & 94.12 \\
Highlands & 50.00 & 59.15 & 87.5 & 66.67 & 100.00 & 62.50 \\
Eastern Lowlands & 61.82 & 83.87 & 96.63 & 77.78 & 70.87 & 95.05 \\
Western Lowlands & 86.67 & 83.50 & 101.89 & 54.29 & 117.65 & 100.89 \\
Borders & 16.67 & 45.24 & 82.76 & 100.00 & 94.44 & 73.33 \\
Total & 68.24 & 73.26 & 86.10 & 61.29 & 90.45 & 88.39 \\
$\boldsymbol{n}$ & 248 & 745 & 684 & 150 & 599 & 1,168 \\
\hline Source: PNZ data 1840-1945 & & & & & &
\end{tabular}

In both periods of arrival (1871-1886 and post-1920) the ratio of females to males from the Eastern and Western Lowlands was approximately 95:100 and 100:100 respectively. Overall, the ratio was 86.1:100 in the earlier period and 88.39 in the latter. Although not replicated in the North East flow as a whole, the flow from Aberdeen in the post-1920 years was very even in terms of gender. This reflects the tendency of the most populated counties of Scotland to send approximately even numbers of male and female migrants; Aberdeen was the third most populated county behind Lanarkshire and Midlothian, both of which also contributed male and female migrants in roughly even numbers. Females made up 51.92 per cent of Aberdonian immigrants, while 53.45 per cent of Lanarkshire migrants and 50 per cent of Midlothian migrants in the PNZ data were female. The very low ratio of Far North females to males after 1920 is attributable to the flows from both Shetland, with a ratio of 30.76:100 females to males, and Caithness, which recorded no female migrants in these years. ${ }^{46}$ The reasons for this gender ratio disparity for Shetland, a marked contrast to the 1870s pattern, are not readily apparent. Case studies suggest that the flow of Shetland migrants appears to have remained broadly of the family and chain migration varieties. There is thus no obvious reason why so few Shetland females should have come to New Zealand. It is possible that the disparity is a quirk of the data rather than representative of an actual gender imbalance among Shetland migrants. Conversely, the Shetland pattern reflects the Far North pattern of male

\footnotetext{
${ }^{45}$ Only the PNZ data pre-1920 is compared here due to methodological issues, discussed previously.

${ }^{46}$ The data includes only twelve migrants from Orkney in this period, six male and six female.
} 
dominance among migrants. The absence of Caithness-born females in the data may indicate a very low ratio of females to males migrating to New Zealand from that county, but should not be taken as indicative of there having been no female migrants at all.

Table 7.4, compares the age profile of the migrants arriving post-1920 in the PNZ data with those of the PNZ and the NZSG pre-1920 migrants, facilitating comparison with results presented in Chapter Four.

Table 7.4

Showing age statistics from the PNZ data pre-1920 and 1921-

1945, and those for the NZSG data between 1840 and 1920

\begin{tabular}{|c|c|c|c|}
\hline & $\begin{array}{c}\text { PNZ } \\
\text { pre-1920 }\end{array}$ & $\begin{array}{c}\text { PNZ } \\
1921-1945\end{array}$ & $\begin{array}{c}\text { NZSG } \\
1840-1920\end{array}$ \\
\hline$n$ & 2,423 & 1,254 & $5,819 *$ \\
\hline Mean & 25.47 & 30.47 & 23.49 \\
\hline Mode & 22 & 28 & 24 \\
\hline Minimum & 7 & 1 & 0 \\
\hline Lower Quartile & 17 & 21 & 12 \\
\hline Median & 25 & 28 & 22 \\
\hline Upper Quartile & 33 & 39 & 32 \\
\hline Maximum & 78 & 76 & 80 \\
\hline 'Outliers’** & $57+$ & $66+$ & $63+$ \\
\hline
\end{tabular}

The results suggest that migrants arriving post-1920 were markedly older than earlier migrants. One quarter of the post-1920 PNZ migrants were under twenty-one at arrival - nine years older than the lower quartile figure for the pre-1920 NZSG migrants. While 50 per cent of pre-1920 NZSG migrants were between twelve and thirty-two, this middle section of post-1920 PNZ migrants ranged from twenty-one to thirty-nine years. Females in the PNZ dataset arriving post-1920 were marginally older than their male counterparts; the mean age for females in the sub-sample is 31.53, for males 29.54 years. Although, as noted in Chapter Four, the average age for migrants in the PNZ data is approximately three years older than migrants in the NZSG data, the former is the only data available for the later period. It should be assumed that if NZSG data were available for the post-1920 migrants the average age would still be approximately three years younger. Why the post-war migrants were significantly older, on average, than their counterparts arriving prior to 1920 is at least partially explainable by marital status. 
As also discussed in Chapter Four, there are more 'single' migrants recorded in the PNZ data than might be expected. Nevertheless, the post-1920 PNZ figures indicate an even greater number of single migrants arriving. As both Figure 7.3a and 7.3b show, the proportion of post-1920 migrants arriving single significantly exceeded the proportion of migrants who were children. This was especially the case among male migrants, 44.64 per cent of whom were single, compared to 36.77 per cent of females. Moreover, 40.48 per cent of 'children' in the sample were aged eleven to fifteen years, and just 25 per cent of 'children' were under five years of age. This possibly indicates the influence on the figures of the juvenile immigration schemes that targeted older children. It also suggests that the majority of married couples arriving in New Zealand from Scotland who had children were not at an early point in their family cycles, in contrast to the majority of pre-1920 married migrants.

\section{Figures 7.3a and b}

Showing the proportion of PNZ migrants arriving 1921-1945 who were children, single and married at arrival by gender.

\section{3a: Female Migrants}

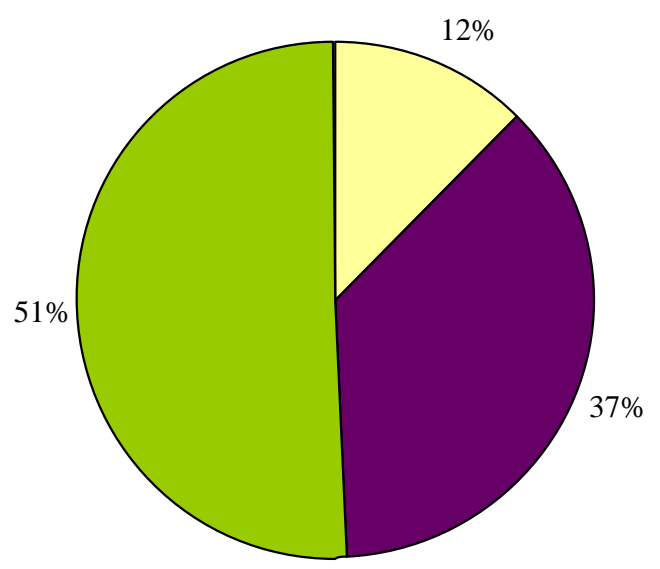




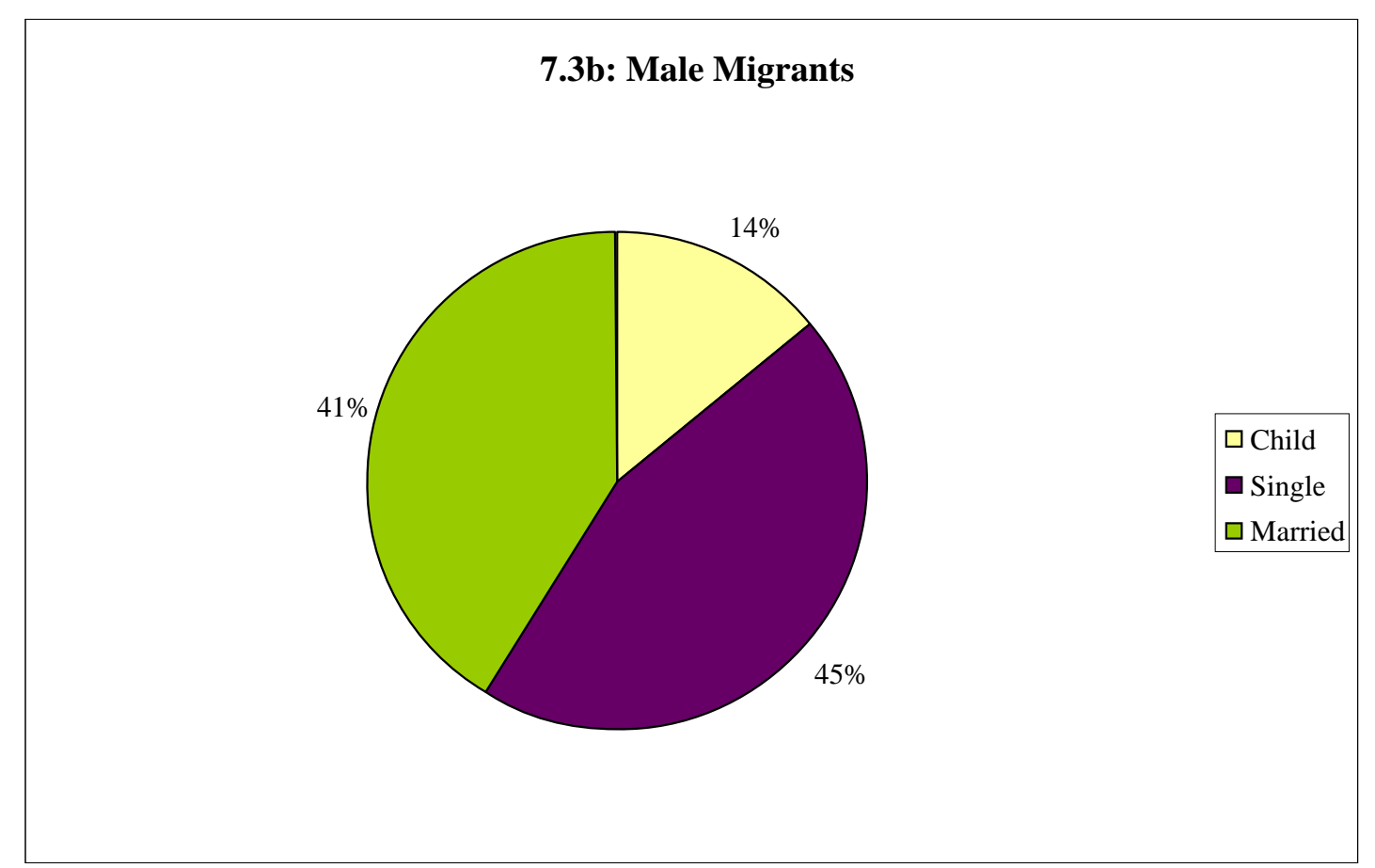

Source: PNZ data 1920-1945

The high proportion of single migrants and the higher average age of the migrants post-1920 are both possibly the result of the assisted migration schemes that operated in the early 1920s. Inevitably, the scheme to assist ex-servicemen and their dependants drew mostly single men in their twenties, as well as (relatively) recently married men and their young families. As approximately 28 per cent of those assisted under the scheme were children, however, this scarcely accounts for the very low 'child' figure among New Zealand's post-1920 Scots. ${ }^{47}$ The Empire Settlement Act 1922 assisted many more single men and women than those married with children. The scheme to assist 'bona fide' domestic servants, for example, supported only single women aged between eighteen and forty years, such as Isabella, Agnes and Christina Moyes. ${ }^{48}$ The New Zealand government was also eager to recruit a significant number of young single men, so many young New Zealand men having been lost to the war. $^{49}$ Although approximately 1,400 children were assisted to relocate to New Zealand under the various post-war assisted migration schemes, the

\footnotetext{
${ }^{47}$ Kent Fedorowich, citing the Report of the Oversea Settlement Committee for 1922, Cmd. 1804, X11, 1923, p.29, notes that 23,325 of those assisted under the ex-servicemen scheme up to 1922 were children - approximately 28 per cent. Kent Fedorowich, 'The assisted emigration of British exservicemen to the dominions, 1914-1922', in Stephen Constantine (ed.), Emigrants and Empire: British Settlement in the Dominions between the Wars, Manchester, 1990, p.70 n.64

${ }^{48}$ Pickles, 'Pink cheeked and surplus: single British women's inter-war migration to New Zealand', p.63; Personal communication with Moyes, 26 Oct and 1 Nov 2007

${ }^{49}$ Gibson, 'Demographic History of New Zealand', p.132
} 
majority of these appear to have been from England rather than Scotland. ${ }^{50}$ The very high 'single' migrant figure among New Zealand's Scots post-1920 suggests that unassisted migrants too were predominately single, many perhaps migrating with their families as adult children, as was the case with John Williamson's family. ${ }^{51}$

Despite the large number of single female migrants in the data being possibly due to the extensive recruitment of domestic servants in the 1920s, this is not an occupation that is well represented in the PNZ data. In terms of migrant 'backgrounds', this is due to the PNZ data utilising migrants' fathers' occupations for 'occupation background' analysis. ${ }^{52}$ Comparing Table 7.5 with Table 5.4 (Chapter Five), it is evident that the background of the migrants from each region of Scotland changed in subtle but significant ways in the post-1920 period.

Table 7.5

Showing the proportions of migrants' fathers employed in each occupation sector in each region of Scotland, excluding 'unknown', 'indefinable' and 'other', 1920-1945, PNZ data

\begin{tabular}{|c|c|c|c|c|c|c|c|c|c|c|}
\hline & & 血 & 窇 & 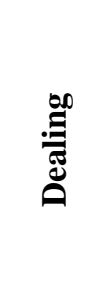 & 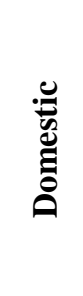 & 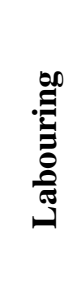 & 串 & 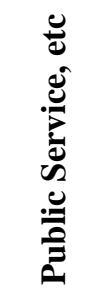 & 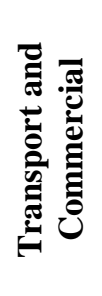 & $=$ \\
\hline Far North & 48.39 & & 3.23 & 3.23 & 0 & 6.45 & 6.45 & 19.35 & 12.90 & 62 \\
\hline Highlands & 43.24 & 2.70 & 2.70 & 8.11 & 0 & 5.41 & 16.22 & 16.22 & 5.41 & 74 \\
\hline North East & 41.67 & 1.67 & 13.33 & 5.00 & 1.67 & 6.67 & 16.67 & 10.00 & 3.33 & 120 \\
\hline $\begin{array}{l}\text { Eastern } \\
\text { Lowlands }\end{array}$ & 12.12 & 17.58 & 15.76 & 7.88 & 0.61 & 7.88 & 19.39 & 10.91 & 7.88 & 330 \\
\hline $\begin{array}{l}\text { Western } \\
\text { Lowlands }\end{array}$ & 11.17 & 15.53 & 13.11 & 11.17 & 1.94 & 4.37 & 22.33 & 13.11 & 7.28 & 412 \\
\hline Borders & 27.27 & 0 & 4.55 & 4.55 & 0 & 4.55 & 40.91 & 13.64 & 4.55 & 44 \\
\hline Total & 20.15 & 12.09 & 12.28 & 8.45 & 1.15 & 5.95 & 20.15 & 12.67 & 7.10 & 1,042 \\
\hline
\end{tabular}

Though the majority of Far North, Highland and North East migrants still came to New Zealand from agricultural backgrounds, and those from the Eastern and Western Lowlands and Borders continued to be from manufacturing backgrounds, the

\footnotetext{
50 A breakdown of the origins of these juvenile migrants assisted to migrate to New Zealand is unavailable, however the available evidence suggests recruitment was primarily from England. Wagner, Children of the Empire, Harper, Emigration from Scotland Between the Wars, and Plant, Oversea Settlement, certainly, imply this.

51 Personal communication with Williamson,

${ }^{52}$ As noted in Chapter Five, occupational data relating to migrants fathers recorded in the PNZ data, and NZSG data sets do not have a close correspondence.
} 
proportions of each region with backgrounds in public service, professional occupations, or who were of independent means, significantly increased. While numbers in the 'dealing' sector occupations remained very similar, the proportion of migrants with 'transport and commerce' backgrounds was significantly higher than amongst NZSG migrants’ occupations in Scotland prior to 1920. These figures are not necessarily indicative of a shift in the types of migrants coming to New Zealand from Scotland per se, rather they were reflective of changes in the employment people tended to be engaged in, that is they were indicative of a continuation of the move away from an agriculturally-based society to one increasingly urbanised, in which more people were employed in commerce, public service and professional occupations. Table 7.6, comparing 1881 Census figures with those from 1931, clearly demonstrates this shift in the employment of the occupied population of Scotland. ${ }^{53}$

Table 7.6

Proportion of the population of Scotland engaged in each occupation class in 1881

\begin{tabular}{ccc}
\multicolumn{3}{c}{ and 1931 } \\
\hline \hline & $\mathbf{1 8 8 1}$ & $\mathbf{1 9 3 1}$ \\
\hline \hline Professional & 5.98 & 11.85 \\
Domestic & 10.99 & 10.84 \\
Commercial & 8.22 & 20.12 \\
Agricultural & 16.77 & 9.05 \\
Industrial & 58.04 & 38.22 \\
Other & 0 & 9.92 \\
n & 1,606,984 & $2,201,310$ \\
\hline Sources: Population, Scotland, Vol.II, Abstracts, 1881 \\
Census of Scotland, p.lvii; and Occupations and \\
industries, Scotland, Vol. III, Table C, 1931 Census of \\
Scotland, p.xi
\end{tabular}

The apparent paucity of domestic servants among the migrants is due to the PNZ data bias in respect of female occupations, the principal source of the data being death certificates, which recorded few female occupations. ${ }^{54}$ Table 7.7 indicates the share of migrants in each occupational sector in New Zealand by region of birth, as well as the percentage of the total Scots migrants from each region, for the post-1920 period (for a comparative table, see Table 5.10). Most immediately noticeable is the low number

\footnotetext{
53 The way occupations were enumerated at these two censuses is quite different. For the present purpose the two have only been compared at an 'occupation order' level - i.e. the occupation 'orders' of the 1931 have been reclassified to fit the 1881 Census occupation 'classes'. The figures presented here may well vary if this re-classification were done at a sub-order or individual occupation level. The 1931 occupation orders were reclassified thus: Professional includes orders 24, 25 and 28; Domestic: order 27; Commercial: 22 and 23; Agricultural: 1 and 2; Industrial: orders 3-21, 29 and 30. 'Other' was included in the 1931 figures also, and incorporates orders 26 ('Entertainments and Sport Occupations') and 31 ('Other and undefined workers').

${ }^{54}$ See Chapter Five for detail.
} 
of migrants in mining occupations in New Zealand, and the fact that those in the data employed in mining in New Zealand were exclusively from the Eastern or Western Lowlands. This is predictable given that coal mining was the most common type of mining in twentieth-century New Zealand and that those from the Eastern and Western Lowlands were more likely than their contemporaries from elsewhere in Scotland to have been employed in coal mining prior to departure. ${ }^{55}$

Table 7.7

Proportion of migrants employed in each occupation sector in New Zealand, by Scottish region of birth, compared to the proportion of migrants from each Scottish region.

\begin{tabular}{|c|c|c|c|c|c|c|c|c|c|c|c|}
\hline & 苞 & 昜 & & 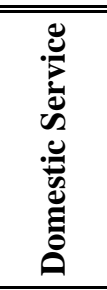 & 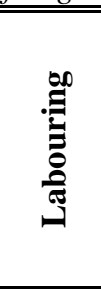 & 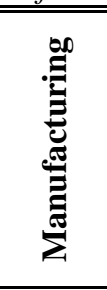 & 面 & 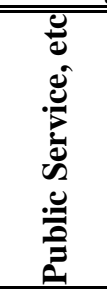 & 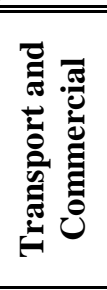 & ప્๋ & 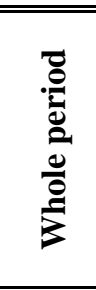 \\
\hline Far North & 13.89 & 7.41 & 7.84 & 0 & 4.35 & 8.70 & 0 & 17.65 & 6.90 & 2.43 & 5.31 \\
\hline Highlands & 13.89 & 7.41 & 9.80 & 0 & 8.70 & 8.70 & 0 & 5.88 & 6.90 & 5.90 & 6.68 \\
\hline North East & 19.44 & 12.35 & 5.88 & 0 & 4.35 & 8.70 & 0 & 8.82 & 17.24 & 12.15 & 11.3 \\
\hline $\begin{array}{c}\text { Eastern } \\
\text { Lowlands }\end{array}$ & 19.44 & 33.33 & 33.33 & 50.00 & 30.43 & 27.54 & 68.42 & 26.47 & 31.03 & 34.72 & 33.73 \\
\hline $\begin{array}{l}\text { Western } \\
\text { Lowlands }\end{array}$ & 27.78 & 37.04 & 39.22 & 50.00 & 43.48 & 37.68 & 31.58 & 32.35 & 34.48 & 40.97 & 38.53 \\
\hline Borders & 5.56 & 2.47 & 3.92 & 0 & 8.70 & 8.70 & 0 & 8.82 & 3.45 & 3.82 & 4.45 \\
\hline$n^{*}$ & 72 & 81 & 102 & 4 & 46 & 69 & 38 & 68 & 58 & 576 & \\
\hline
\end{tabular}

Source: PNZ data, 1920-1945

Another notable variation from the proportion of total migrants each region represents is the spread of place of origin of the migrants employed in agriculture. There are disproportionately few from the Eastern and Western Lowlands, and more than their share of migrants generally from the Far North, Highlands and North East. These figures bear out what is already known about the occupational make up of the regions mentioned - the industrial nature of the Lowlands, and the reliance on

\footnotetext{
55 Simon Nathan, 'West Coast', Te Ara - the Encyclopedia of New Zealand, URL: http://www.TeAra.govt.nz/Places/WestCoast/WestCoast/en, updated 2 February 2009; Alan Sherwood and Jock Phillips, 'Coal and coal mining', Te Ara - the Encyclopedia of New Zealand, URL: http://www.TeAra.govt.nz/EarthSeaAndSky/MineralResources/CoalAndCoalMining/en, updated 4Dec-2008; 'Mining and mineral resources: Coal', from An Encyclopaedia of New Zealand, edited by A. H. McLintock, originally published in 1966, Te Ara - The Encyclopedia of New Zealand, URL: http://www.TeAra.govt.nz/1966/M/MiningAndMineralResources/en, updated 18-Sep-2007; W.W. Knox, Industrial Nation: Work, Culture and Society in Scotland, 1800-Present, Edinburgh, 1999, pp.85-6; Christopher Harvie, No Gods and Precious Few Heroes: Scotland 1914-1980, London, 1981, pp.3-4
} 
agriculture in the Highlands and Far North especially. Nevertheless, these post-1920 figures are less disproportionate compared to the home population than are the respective figures in the NZSG pre-1920 data, as seen in Table 5.10. This suggests that, while earlier Scottish migrants to New Zealand were predominantly from agricultural backgrounds, no matter from where in Scotland they hailed, post-1920 the occupational structures of the regions of Scotland began to have a much greater influence on the occupational composition of the immigrants from those regions. The fundamental economic base of each region began more directly to dictate what sectors migrants from those regions were likely to be employed in post-migration. This suggests that twentieth-century migrants were less likely than their nineteenth-century counterparts to experience occupational mobility at an occupation sector level. Though they may have been 'mobile' within their occupations, they were more likely than those arriving in the nineteenth-century to have remained working within their previous fields of employment.

\section{RETURN MIGRATION}

Tracing return migration flows on any scale greater than individuals is a difficult task. Estimates relating to the return migration of United Kingdom emigrants suggest that 40 per cent of those who emigrated from England and Wales between 1870 and 1914, and approximately one third of Scottish emigrants over the same span, returned permanently to their countries of origin. ${ }^{56}$ Whether these estimates are mirrored amongst those who had emigrated to Australia and New Zealand is as yet unknown. Given the 'tyranny of distance' faced by emigrants departing for New Zealand and Australia, and the costs involved, it seems unlikely. As Richards has noted 'the real and psychic distances between Europe and Australia [and, it may be added, New Zealand] were much greater than those between Europe and America, and it seems unlikely that many migrants before the First World War... would have regarded emigration to Australia as a temporary move. ${ }^{, 57}$ Furthermore, the large numbers of migrants assisted to emigrate to Australasia as domestic servants or as agricultural labourers were unlikely to have 'prospered so quickly that they could afford a double

\footnotetext{
${ }^{56}$ Harper, 'Introduction', p.2, citing Dudley Baines, Migration in a Mature Economy: Emigration and Internal Migration in England and Wales, 1861-1900, Cambridge, 1985, p.128-40; T.M. Devine, The Scottish Nation: 1700-2000, London, 1999, p.475-6

${ }^{57}$ Eric Richards, 'Running home from Australia: Intercontinental mobility and migrant expectations in the nineteenth century', in Marjory Harper (ed.), Emigrant Homecomings: The Return Movement of Emigrants 1600-2000, Manchester, 2005, p.79
} 
passage', having needed heavy subsidisation to emigrate to the antipodes in the first place. ${ }^{58}$ Nevertheless, whether or not the rate of return migration from Australasia was as high as amongst immigrants to, for example, the United States or Canada, there was undeniably a flow of return migration. What complicates the tracing of return migration is identifying the various streams making up the flow; not all of those returning, for instance, were intending to return permanently. Richards states the dilemma succinctly: there is no way of knowing whether migrants were 'first time emigrants, re-emigrants, holidaymakers... “transients”... “double migrants”, “sojourners”, “pensionados”... or “quasi-migrants”.' Return migrants, both temporary and permanent, 'were part of the statistical awkward squad. ${ }^{59}$

In terms of the return migration of New Zealand immigrants of Scottish birth to their homeland, very little data is readily available. Though it is theoretically possible to track ships departing New Zealand bound for Scotland, it is almost impossible to establish whether those on board were returning temporarily or permanently, indeed whether they were from Scotland in the first place, without compiling life histories for each passenger. This is another instance in which genealogical material could potentially be of great value. Unfortunately, however, the NZSG data is not especially revealing. The majority of the contributors of information to the NZSG register were members of the New Zealand Society of Genealogists; thus the migrants included in the register were overwhelmingly those who remained in New Zealand, those who left descendants able to fill in forms about their ancestors. Further, the NZSG forms sought no information about travel outside of New Zealand post-arrival. There is one variable in the NZSG data which may be used to indicate permanent return migration - twenty of the 6,612 listed NZSG migrants died in Scotland. Though this sub-sample of twenty migrants is obviously too small to draw any firm conclusions, it may nevertheless be useful to consider briefly what is known about the individuals involved.

Place of birth is known for nineteen of the migrants; four were born in the Borders, four in the Western Lowlands, five in the Eastern Lowlands, four in the Highlands and two in the North East. No Far North NZSG migrants appear in the sub-sample. This NZSG sub-sample includes fourteen males and just six females. Age at arrival of

\footnotetext{
${ }^{58}$ ibid.p.79

${ }^{59}$ ibid.p.78
} 
the migrants is relatively even: four arrived under twenty years of age, five migrated aged twenty-one to thirty, and five were aged over forty. ${ }^{60}$ The parents and siblings of the three migrants in the sub-sample who arrived in New Zealand as children all died in New Zealand, probably indicating return migration of these child immigrants in their adult years, rather than their being the only member of their family to return to Scotland and not re-migrate to New Zealand.

Marital status upon arrival in New Zealand is unknown for five of the migrants, seven were already married, while five were single. Only two of the migrants did not marry at some point before death: Septimus Leishman, mentioned in Chapter Five, and William Hannah, who had arrived in New Zealand as a one-year-old and returned to Scotland at some point between his twenty-third birthday and his death in Glasgow three-and-a-half years later. ${ }^{61}$ Of the migrants who were single at arrival, all but Septimus married in New Zealand - two, Donald McLennan and Jane McDonald, married each other. It is likely Donald and Jane knew each other prior to immigration to New Zealand; both were born in Fodderty, Ross and Cromarty. It is unknown when Donald arrived in New Zealand, but Jane arrived in June 1872 and they married four months later. The couple had one child in New Zealand, born in 1875. At some point in the following two years the young family returned to Strathpeffer, Ross and Cromarty, where three more children were born. All six members of the family appear to have subsequently lived and died in Scotland. ${ }^{62}$ What motivated the couple to return to Scotland is unknown, but quitting the colony may have been prompted by economic factors - perhaps Donald's work as a publican was not sufficiently providing for his young family - or by a desire or need to raise their children nearer to kin and the support network a family can provide.

Robert Mailer appears to have returned to Perthshire after the death of his wife. Married in 1868, Robert and Margaret, with their sixteen-year-old son William, migrated to New Zealand in 1884. In 1903 Margaret died, aged fifty-four. Robert was sixty years old at her death, and, despite having a son, daughter-in-law and four grandchildren in New Zealand, he appears to have returned to Perthshire between the

\footnotetext{
${ }^{60}$ Three have no age at arrival information.

${ }^{61}$ William was still in New Zealand when his family moved to Domett when his youngest sibling was born in 1897, and he died in Glasgow in January 1901. NZSG data, migrant 02320

${ }^{62}$ NZSG data, migrants 03597, 04080
} 
time of Margaret's death and his own in $1915 .^{63}$ It is possible Robert wished to see his former home once more before he died, then became too ill to return to New Zealand, or he decided for other reasons not to return to his adopted country. It is equally possible that he had no intention of returning to New Zealand when he departed for Scotland.

More revealing when considering who might be more likely to return permanently to Scotland is occupation. While those working in low-income occupations, for instance labourers and domestic servants, were always less likely to have the means to fund a return trip to home, they might nevertheless have had more incentive to return to Scotland if New Zealand was not providing them with the opportunities they had anticipated through immigration. Those who became very successful in New Zealand would have had the means to take passage to Scotland, but were probably less likely to return permanently, already enjoying comfortable lifestyles. Without a much larger statistical base, speculations as to who were likely to permanently return to Scotland must be tentative.

Occupation is unknown or unclear for five of the females in the sample and one male. Agriculture had been the occupation for four of the migrants in New Zealand, only one of whom was recorded as having been a 'farmer' rather than a 'farm labourer'. Of the remaining males, two were builders, one was a blacksmith, one a coal miner (William Hannah, who returned to Glasgow, as noted above, before his twenty-seventh birthday), and three were involved in dealing (a publican, a coal merchant, and a draper). The three other migrants were of independent means (Septimus Leishman) and medical practitioners.

One of the medical practitioners, and the one female in this sub-sample, is Isabella Carr. Born in Auchtermuchty, Fife, in October 1867, it is unknown when Isabella migrated to New Zealand. It is therefore also unknown whether she migrated before returning to Scotland to study, or if immigration came after she became a Licentiate at the Royal College of Physicians and Surgeons in Edinburgh. Whatever the case, when Dr Isabella Hardie Carr died in Auchtermuchty, Fife, in October 1944, aged seventy-

${ }^{63}$ NZSG data, migrants 02021, 03296, 03297 
six years, her working life in New Zealand had been relatively short, she having been in charge of the McLeod Hospital in Ceylon for forty-two years. ${ }^{64}$

It would not be unreasonable to assume that migrants in professional occupations were more likely than others to be involved in return migration. At the higher end of the income scale, professionals were more likely to have the means to return to Scotland. Not being tied to the country, unlike business owners or runholders, they were also able to pick up and re-emigrate with their skills to Scotland, or to any other part of the world. Analysis of the Rolls of Graduates of the University of Aberdeen to 1925 suggest that those who emigrated to New Zealand as teachers were more likely than their colleagues in other professions to return to Scotland. Of the eighty-two Aberdeen University graduate immigrants to New Zealand, it is possible to establish for sixty-two of them whether they settled permanently or only temporarily in New Zealand. Sixteen of the graduate emigrants definitely returned to Scotland postmigration to New Zealand, and place of birth is known and identified as Scotland for eleven of them. Of the eleven Aberdeen University graduates born in Scotland who emigrated to New Zealand, then returned to Scotland, one was a nurse, one a missionary and one a church minister. For two, occupation in New Zealand is unknown. Six were involved in education in New Zealand: two were school teachers, three were school principals, and one a lecturer in Classics at Otago University. ${ }^{65}$

The Aberdeen graduate rolls also reveal next-generation return migration for the purpose of tertiary education. Of the eighty-two Aberdeen University graduates who

\footnotetext{
${ }^{64}$ NZSG migrant, 00958. While the sub-sample of migrants the 'profile' above is based upon consists of those who - purposefully or not - returned permanently to Scotland, as indicated by place of death, a qualitative sample of solely temporary migrants recently compiled by Bueltmann shows similar patterns. She notes that New Zealand Scots who returned temporarily to Scotland primarily returned for three reasons: for leisure, for business and for education. 'Leisure' returnees, such as Robert Mailer may be considered to be, were returning to visit family and to 'explore the country', often in a fashion that may be considered 'early roots-tourism'. Those travelling for 'business' included Ministers returning 'to re-educate themselves by attending Church meetings and meeting former teachers', and may be compared with the likes of Dr Isabella Hardie Carr, returning in the course of her work. Bueltmann notes that 'education' returnees especially included those returning to study medicine. Examination of University Rolls of Graduates below corroborates this finding. Bueltmann's sample is based upon thirty-two travel accounts. Tanja Bueltmann, “Brither Scots Shoulder tae Shoulder': Ethnic Identity, Culture and Associationism among the Scots in New Zealand to 1930', PhD Thesis, Victoria University of Wellington, 2008, pp.203-217

${ }^{65}$ P.J. Anderson (ed.), Fasti Academiae Mariscallanae Aberdonensis: Sections from the records of the Marischal College and University MDXCIII - MDCCCLX, Aberdeen, 1898; Colonel William Johnston (ed.), Roll of Graduates of the University of Aberdeen 1860-1900, Aberdeen, 1906; Theodore Watt (ed.), Roll of the Graduates of the University of Aberdeen 1901-1925 with supplement 1860-1900, Aberdeen, 1935; John MacKintosh (ed.), Roll of the Graduates of the University of Aberdeen 19261955 with Supplement 1860-1925, Aberdeen, 1960; Louise Donald and W.S. MacDonald (eds), Roll of the Graduates of the University of Aberdeen 1956-1970 with supplement 1860-1955, Aberdeen, 1982
} 
emigrated to New Zealand, three, in fact, had been born in New Zealand. Rae McRae, born in Otago in October 1882, was the son of John McRae, a woollen manufacturer. Between 1908 and 1910 Rae received his M.B.Ch.B, D.P.H and M.D. from Aberdeen University. Post-graduation Rae returned to New Zealand, where he married Alice Hall Wolverhampton in Timaru in 1922. He died in New Zealand in $1927 .{ }^{66}$ Gray Hassell, born in Oamaru in October 1860, also 'returned' to Scotland for his university training. Hassell left New Zealand for Aberdeen in 1873 to complete studies begun in New Zealand, graduating from Aberdeen University with an M.B.C.M in 1881 and an M.D in 1890. He returned to New Zealand in 1882 and in 1895 became Medical Superintendant of the Government Lunatic Asylum in Porirua, Wellington, a role he continued in until his retirement in $1920 .^{67}$ With Edinburgh University being considered the foremost medical training institute of its time - 'the seat of the medical muses' - a survey of the graduates would likely exhibit similar next-generation 'return’ migration patterns. Otago University’s medical school had a strong connection to Edinburgh University from its earliest days, due to this enviable reputation. Initially Otago taught only a partial course, two years in duration, students then completing their studies in Edinburgh. ${ }^{68}$ What is clear is that the migration and return migration of professional migrants in both the nineteenth and twentieth centuries merits further attention.

\section{CONCLUSION}

The present chapter, while providing an outline of post-World War One patterns in the flow of Scots to New Zealand, is intended as a point of comparison with the profile of the Scots who had arrived in the previous eighty years. A key point emerges with respect to the place of origin distribution of the migrants pre- and post-1920; while the distribution within Scotland did differ post-1920, the distribution was still

\footnotetext{
${ }^{66}$ Watt (ed.), Roll of the Graduates 1901-1925, p.388; Aberdeen University Review, Vol. XX, No. 58, November 1932, p.93

${ }^{67}$ Johnston (ed.), Roll of Graduates 1860-1900, p.228; Watt (ed.), Roll of the Graduates 1901-1925, p.800; The Cyclopedia of New Zealand, Wellington, 1897, New Zealand Electronic Text Centre 22 May 2009, pp.357-8

${ }^{68}$ Dorothy Page, Anatomy of a Medical School: A History of Medicine at the University of Otago, 1875-2000, Dunedin, 2008, pp.20-21 and chapter 2. James Buchan, Capital of the Mind: How Edinburgh Changed the World, London, 2003, pp.273-4, and citing Dr William Buchan to Mr William Smellie, 20 August 1761, in Memoirs of Smellie (Ch.1, n. 13), Vol. 1, p.238; This 'return' of the descendants of migrants, rather than of the migrants themselves, is explored in terms of roots tourism by Basu: Paul Basu, 'Roots tourism as return movement: semantics and the Scottish diaspora', in Marjory Harper (ed.), Emigrant Homecomings: The Return Movement of Emigrants, 1600-2000, Manchester, 2005.
} 
proportionate to the population of Scotland. In terms of distribution within New Zealand, the northward drift among Scots arriving after 1920 is clearer than among those arriving pre-1920, this drift north was not as pronounced among the Scots-born as among the general population of New Zealand, suggesting the continued dominance of Otago and Southland as the major provinces of Scottish settlement into the twentieth century. Due to the nature of the migration flow post-1920, and especially the emphasis on assisted migration, the gender ratio was remarkably similar to that described for the Vogel period migrant flow, the migrants tended to be older than earlier migrants, and comparatively fewer children were among the migrants. In terms of occupation, the profile suggests little fundamental change by region of origin, but an increasing proportion of Scots employed in commerce, the public service, and in professional occupations from across Scotland. This is indicative not of a fundamental shift in the types of migrants coming to New Zealand from Scotland, but rather changes in the employment structure of Scotland and New Zealand generally, reflecting the move in both societies away from an agriculturally-based society to one increasingly urbanised, in which more people were employed in commerce, public service and professional occupations. Possibly the major difference between the later Scots and those arriving before 1920 was the greater incidence of return migration. This was largely due to the comparative ease and reduced cost of travel in the twentieth century.

The story of Scottish migration to New Zealand does not end with the outbreak of World War Two, but it is at that point that the present study terminates. ${ }^{69} \mathrm{New}$

\footnotetext{
${ }^{69}$ There has been little study of British immigration to New Zealand in the post-war period, much less disaggregation of the Scots from the 'British' mass. Megan Hutching, Long Journey for Sevenpence: Assisted Immigration to New Zealand from the United Kingdom 1947-1975, Wellington, 1999, provides a useful overview of the governments assisted immigration schemes, but does not distinguish the Scots from the general flow. For discussion of specifically Scottish immigration to New Zealand in the post-war period see Claire Toynbee, 'Kinship and the decision to migrate: the experience of Scots migrants to New Zealand', New Zealand Population Review, Vol.26, No.1, May, 2000, pp.23-44; while this is Toynbee's only currently published work on the subject, it is the focus of her present research. A book manuscript (provisionally entitled 'Of Longing and Belonging: Scots Migrants' Talk') discusses the social backgrounds, social networks and experiences of post-World War Two Scots migrants to New Zealand; Claire Toynbee, 'Looking Forward, Looking Back': Scots Migrants Talk', Nations, Diasporas, Identities, 29 March 2008; Personal communication with Claire Toynbee, 21 May 2009. Angela McCarthy's work on twentieth-century Scots migrants to New Zealand provides further qualitative descriptions of their experiences: Angela McCarthy, 'Personal accounts of leaving Scotland, 1921-1954', Scottish Historical Review, Vol.83, No.216, October 2004, pp.196-215; Angela McCarthy, 'Personal letters, oral testimony, and Scottish migration to New Zealand in the 1950s: the case of Lorna Carter', Immigrants and Minorities, Vol.23, No.1, March 2005, pp.59-79; Angela McCarthy, "“For spirit and adventure”: personal accounts of Scottish migration to New Zealand, 19211961', in Tom Brooking and Jennie Coleman (eds), The Heather and the Fern: Scottish Migration and
} 
Zealand immigration policy post-1945 continued to favour immigrants from Britain, schemes of assistance operated by the New Zealand Government continuing to have a significant impact on the scale and composition of the flows of migrants. Criticism of New Zealand's 'white' immigration policy in the early 1970s, among other principally economic factors, led to a review of policy in 1973, many of the schemes of assistance that had aided 76,673 Britons to emigrate to New Zealand since 1947 coming to an end in $1975 .^{70}$

New Zealand Settlement, Dunedin, 2003; Angela McCarthy, Personal Narratives of Irish and Scottish Migration, 1921-65: 'For Spirit and Adventure', Manchester, 2007.

${ }^{70}$ Hutching, Long Journey for Sevenpence, pp.11, 74. See Chapter One, especially, of Hutching for an outline of the various schemes of assistance offered. How many of these 76,673 British migrants were Scots is presently unknown. 


\section{Chapter Eight \\ CONCLUSION}

'Scotsmen' observed Chambers' Edinburgh Journal, 'are proverbially inclined to roam abroad in quest of fortune. ${ }^{1}$ Keen to seize imperial opportunities, their wanderlust has been a notable feature of the Scottish character. Yet, while New Zealand has been described by one of the country's leading historians as the most Scottish country outside of Scotland itself, as a group New Zealand's Scots migrants have remained relatively indistinct. ${ }^{2}$ Until recently, even basic statistical outlines of the Scottish inflows have been scarce, McClean's 1990 thesis being the only previous work to statistically examine the movements of Scots to New Zealand, and that covering only the period 1840 to $1880 .^{3}$ Conceived as one part of a larger research project that seeks to add significantly to the current body of knowledge regarding the Scots abroad, covering an underexplored part of the Scottish diaspora, the present thesis has sought to build upon McClean's findings and to provide a foundation upon which future demographic studies of the New Zealand Scots may be based. In profiling those who had 'better hope of New Zealand than the old country' five core questions have been addressed: 'where in Scotland did they come from?', 'who came?’, ‘when?’, ‘in what numbers?’, and 'where did they settle?'4

\section{OVERVIEW}

Previous studies, notably those by McClean and Phillips and Hearn, found that, contrary to popular wisdom, most of New Zealand's Scots had been born in lowland Scotland and that this was proportionate to the home population of Scotland at the time. Those same studies also suggested that the timing of the Scots flows to New Zealand paralleled the broad United Kingdom flows and that Scots were especially numerous after the establishment of Otago as a Free Church settlement. Comparison of census figures had shown that New Zealand was 'more Scottish' than the United

\footnotetext{
${ }^{1}$ Chambers's Edinburgh Journal, No.302, October 1849, p.225.

2 James Belich, Paradise Reforged: A History of the New Zealanders From the 1880s to the Year 2000, Auckland, 2001, p.221

${ }^{3}$ Rosalind McClean, 'Scottish Emigrants to New Zealand, 1840-1880: Motives, Means and Background', PhD Thesis, University of Edinburgh, 1990

${ }^{4}$ Dunedin, 12 August 1880, Letters from Edgar \& Alice Clarke, Otago Settlers Museum Archive, DC0576
} 
Kingdom itself, while analysis of shipping lists and death registers had indicated that many of New Zealand's Scots were agricultural labourers, notwithstanding a number of Paisley weavers and other such pre-industrial workers settling in Auckland in the early 1840s. In other works the greatest emphasis has often been upon assisted migration and the recruitment of single migrants, leaving an overall impression that most of New Zealand's Scots were aged 20-35 and single at arrival. In terms of settlement, Otago, Southland and Waipu have been the destinations most in the spotlight, though analysis of census figures confirmed that Scots settled throughout New Zealand to varying degrees.

The present study has taken these and other previous findings regarding the characteristics of the New Zealand's migrant Scots considerably further, utilising quantitative and qualitative sources to present a more full and detailed profile than has previously been available. While, as Harper rightly reminds us, 'the uniqueness of each individual's experience defies generalization', it is only by generalising that even tentative answers to these questions may be posited. ${ }^{5}$ In this research answers have been suggested based upon analysis of the aggregated qualitative information of 6,612 individuals, where possible the aggregate analysis has been supplemented by qualitative case studies of these individuals. While Hugh McKenzie, Nathaniel Sutherland, Mary Grey, Angus Cameron and John Williamson had relatively little in common, their experiences, outlined at the beginning of several of the preceding chapters, exemplify characteristics common among many of New Zealand's Scots.

An important aspect of the present study has been a testing of the validity of genealogical data as a source for migration studies. As noted, the principal limitations of the NZSG dataset arise primarily from the fact that the data was not collected with statistical analysis in mind. Were such a dataset to be created, based upon contributions from genealogists about their ancestors, with statistical analysis the intended purpose, a higher level of detail might be attained and the sample would therefore be more statistically sound. Regardless, the NZSG data has proven to be a valuable representative sample, so far as comparison with other data sources can confirm. Furthermore, it has enabled the migrants to be rescued from statistical obscurity, at the same time facilitating the identification and exploration of problems in other datasets. The investigation has powerfully demonstrated the potential value of

\footnotetext{
${ }^{5}$ Marjory Harper, Adventurers and Exiles: The Great Scottish Exodus, London, 2003, p.279
} 
genealogical sources and methods in the study of migrants and migrant flows, strongly suggesting that many future studies might benefit from the use of, or at least incorporation of, such sources and methods.

Despite the evenness of the distribution of the origins of New Zealand's Scots noted in previous works, the almost exact geographical cross-section of Scotland that came to New Zealand is perhaps the most striking finding of the study. Though Scots were less prone than other ethnic groups to cluster migration, no other Scottish migrant destination received such an even cross-section of the Scottish population as New Zealand. In this study the 'evenness' findings of previous studies have been taken several steps further. An examination of the available information regarding migrant origins at parish level found that proportionality continued down to that level in the available data, though a larger - and therefore more robust - sample is required to test the finding further. Even more significantly, examination of the origins of the migrants by place of settlement in New Zealand has revealed that each province of New Zealand also received a mix of Scots geographically proportionate to the home population of Scotland. The divergences between counties within those provinces in respect of Scots migrant origins nevertheless suggest significant differences between the types of migrants rural and urban New Zealand were attracting.

A further significant finding, in addition to confirming that there were concentrations of Scots in parts of New Zealand outside of Dunedin and Waipu (Fordell/Mangamahu/Turakina/Parewanui and the eastern Wairarapa being the examples particularly advanced), is that migrants from Shetland aside, ties of 'Scottishness', rather than of Scottish county, community or family background, appear to have bound Scots within New Zealand. Communities of Scots living beside, working with, inter-marrying and helping one another, even in localities such as Fordell/Mangamahu/Turakina/Parewanui, where the Scots-born were out-numbered by English-, Irish- and New Zealand-born residents, are likely to be found elsewhere in New Zealand.

While previous studies had identified the surge in Shetland migration in the 1870s, more detailed examination in the present research has identified patterns not previously noted that appear to be peculiar to Shetland. The analysis of the Shetland migrants in terms of parish level origins, for example, indicates a hitherto undetected concentration of migrants from Unst. Qualitative investigation of travel companions 
and the incidence of family migration indicated a relatively high level of chain migration, a phenomenon spanning decades and generations, families and communities, a pattern not immediately evident among migrants from other Scottish counties. This county case study has emphasised the importance of localised investigations if wider migration patterns are to be fully understood. The focus on the movements of migrants from one Scottish county to one destination country has enabled idiosyncrasies in the migrant flows to be seen more clearly.

While the analysis of migrant occupations supports Phillips and Hearn's findings in respect of the types of work migrants were primarily engaged in, the present study has again taken the investigation several steps further. While Phillips and Hearn utilised only fathers' occupations in the PNZ dataset (upon which the Settlers occupation data is based), in the present study fathers' occupations were compared to migrants' own occupations in the PNZ data to enable a study of generational occupational mobility. The availability of more than one occupation listing for many migrants in the NZSG data has facilitated analysis of individual occupational mobility. Comparison of the NZSG and PNZ data has highlighted the impact of source material on occupational analysis, the analysis of female occupations especially demonstrating the deficiency in reliance upon death certificate based data alone. Though many aspects of the migrants' occupational profile merit deeper investigation, and several key questions remain to be addressed, the evidence presented constitutes the most detailed study of Scottish migrant employment patterns in New Zealand yet attempted.

Examination of data relating to age, gender, and marital status has also confirmed patterns found in previous studies, but at the same time has underlined inherent biases in the NZSG and PNZ datasets. Most significant of these was the finding that the use of death certificates to estimate age at arrival may lead to an increase in average migrant ages of approximately three years when aggregated. While investigation of aspects of the migrant profile relating to origins, place of settlement and period of arrival has yielded few completely new insights, the analysis has been pursued at a depth not offered in previous studies. The figures presented offer a point of comparison for future investigations of the migrant profile of other New Zealand settler groups. As well as providing some precision regarding the Scots migrant 
profile, it is intended that the tables and graphs presented, augmented by further tables in the appendices, will provide a foundation for future statistical analysis.

Despite the breaking of much new ground in the statistical understanding of the Scots migrant experience in New Zealand, there are still many aspects of this experience remaining to be examined. In many instances the use of genealogical sources and methods could add considerable depth.

\section{POSSIBLE PATHS FOR FUTURE RESEARCH}

Related to addressing 'who' the migrants were, there are a number of aspects of the migrant profile that would benefit from further investigation.

As the Shetland case-study indicated, tracing the experiences of migrants from specific localities to one destination country may be a powerful tool in exploring patterns of migrant settlement. The additional depth of information attainable through such a focused study is invaluable and, were such studies to be carried out for each Scottish county, subtle but significant differences among the migrants at the regional, county and parish levels may be highlighted. These might offer important clues as to the particular push and pull factors operating in the various parts of Scotland at different times. Further examination of Scots in specific New Zealand localities, considering communities in terms of origins, the bonds (or not) of 'Scottishness', or intermarriage with other ethnic groups, would undoubtedly extend knowledge of New Zealand's Scots.

A deeper investigation of the 'origin' backgrounds of the migrants, tracing the parents and grandparents of the migrants insofar as is possible, could promote a new level of understanding for Scots migrants at their ultimate destination. Nathaniel Sutherland was not, by any means, unusual in being a lowland Scotland-born child born to highland-born parents and grand-parents. Such an investigation would facilitate not only the analysis of internal migration within Scotland but would also lead to a greater appreciation of the cultural baggage the migrants may have brought with them.

Many questions relating to fertility and nuptiality among New Zealand's Scots preand post-migration remain to be answered. How common was Mary Grey's experience of bearing a child out of wedlock, yet bringing that child up as her own and remaining among her family? Was it common among the mid-nineteenth century 
settlers in New Zealand generally? Was this a particularly Scottish acceptance of prenuptial fertility, as is suggested by analysis of pre-nuptial fertility in Scotland compared to other parts of Britain, or was it in fact uncommon, both generally and among Scots? ${ }^{6}$ Did migration affect family size among Scots families, or the spacing of children within a family? How did infant mortality rates among Scots in New Zealand compare to the home population? Further, how often were Scots marrying outside of their ethnic group in New Zealand, as in the case of Mary Grey? How did this compare to Scots in Scotland, and to other groups, especially the English and the Irish, within New Zealand? How did migration to New Zealand effect the average age at marriage of Scots compared to the home population, and were the same patterns observable among their English and Irish contemporaries? Such questions, especially if examined alongside other ethnic groups within New Zealand, would offer new and interesting insights.

Several key questions regarding Scots migrant occupations await further research. For example, with respect to the impact of Scots on New Zealand's social and economic development, what were the implications of the varying degrees of Scottish migrant involvement in each sector of employment in New Zealand, and how did Scottish participation in each sector compare to participation by their English, Irish and Welsh contemporaries? Is the perception of a peculiarly Scottish contribution to New Zealand's educational and commercial spheres deserved, or is it a myth arising from the disproportionately high number of Scots in New Zealand compared to the home population of the United Kingdom and consequently the comparatively greater influence of Scots in all spheres of New Zealand life? Further, how does Scottish migrant involvement in the economic development of New Zealand compare to their involvement in other countries of Scottish migrant settlement? Quantitative analysis should underlie the investigation of such issues, and the present research provides some foundation for such future research.

Religion, entirely absent from the NZSG data, is an aspect of the New Zealand Scots migrant experience that calls for much deeper investigation. Besides, obviously, meeting spiritual needs and providing comfort and advice in this new land far from home, religion offered migrants entry into a community of like-minded people. This

\footnotetext{
${ }^{6}$ Pool et al note that the Scottish rate of pre-nuptial fertility was fives times higher than the Irish and twice the English rate. Ian Pool, Arunachalam Dharmalingam, and Janet Sceats, The New Zealand Family From 1840: A Demographic History, Auckland, 2007, p.66
} 
was important for the formation of social and business networks. The popular notion that all Scots were Presbyterian requires further clarification, significant numbers of Anglican and Methodist migrants appearing in the Scottish PNZ data and evidence suggesting that Shetland migrants particularly were primarily Baptist and Methodist. While birth, marriage, death and parish records indicate to which religious denominations the migrants nominally adhered, genealogical information could provide valuable qualitative information. For example family knowledge that, though a family primarily attended a Presbyterian church, the mother's extended family were all Anglican, and therefore family members attended Anglican services on significant days. Such information, if available, would usefully elaborate on statistical findings.

With respect to migration dynamics, motives and strategies, a tracing of travel companions and chain migration, linking the records of family members, friends and members of communities, would add considerably to current knowledge. Such an investigation would potentially also provide further information on those who did not migrate, suggesting reasons for their remaining behind. It would permit the analysis of families who migrated to more than one destination country, offering clues to their motives and perhaps indicating the relative importance of pull factors at the various destinations. A tracing of internal migration within New Zealand, migration to other countries post-arrival, also return migration, would provide further insights.

The examination of Scots migrant flows to New Zealand after World War One suggests several further avenues of study. Little as yet is known, for example, of the details of the various schemes of assistance offered, much less the individuals who came to New Zealand in the 1920s. These post-1920 migrants should prove easier to trace than those arriving earlier, official documentation capturing the migrant at more stages in their life in the twentieth century. Further the children of these migrants, if not the migrants themselves, are in many cases still living. A survey of these migrants created for statistical analysis would prove a useful and unique statistical source.

Return migration being much easier to trace for these twentieth-century migrants, this should be a research priority. The United Kingdom received many more migrants than it sent in the 1930s, indicating the probability of a high level of return migration in that decade, but the details as to how many were returning 'home' from New Zealand are not known. Did these migrants intend to return to New Zealand? What was their motive in coming to New Zealand in the first place, and what impelled them 
to return to Britain? Genealogical material and resources (including the skills of genealogists themselves) may offer further insights regarding their motives. A compilation of individual returnees' stories arising from a questionnaire/survey of these migrants and/or their children combined with (or forming) a statistical base would be invaluable, providing a rich sample that could also be successfully examined in aggregate as a statistically sound sample. Living migrants should not be considered useful to historians only in terms of oral histories.

Ultimately, in terms of European settlement and immigration, New Zealand is a young country. Of all the countries settled by the British during the age of mass migration it should be possible to tell the story of the migrants in much greater depth than has been previously attempted for British immigrants to any destination. While localised studies of migrant origins, such as the Shetland case study, are one way forward, basic statistical analysis of all the migrants, based on a process of record linkage on a grand scale, incorporating as many of New Zealand's migrants as may be found in the historical record, would move studies to a new level. Such a collation of migrant details would, to some extent, compensate for the census information that was lost by the systematic destruction of the enumerators' reports in New Zealand. If funding and time permitted, such a project would prove invaluable not only to the study of migration patterns and the creation of migrant profiles along ethnic lines, but also to many other aspects of New Zealand social history. 


\section{Appendix 1.1}

\section{METHODOLOGICAL ISSUES}

In a study in which methodological issues and decisions significantly shape the final outcome it is essential that the reader have an understanding of those issues and decisions. While points regarding methodology that are fundamental to the understanding of specific parts of the analysis presented have been included in the body of the thesis, the purpose of this appendix is to outline some matters that more broadly underlie the study. It begins with discussion of the creation of the datasets utilised. Decisions regarding which boundaries within Scotland and New Zealand have been chosen to analyse the origins and destinations of the migrants are also discussed.

\section{THE DATASETS}

\section{NZSG DATA}

As outlined in Chapter One, the NZSG dataset was created specifically for this study. It is based upon the New Zealand Society of Genealogists Scottish Interest Group's 'Register of New Zealand Immigrants of Scottish Birth arriving before 1 January 1921', a register conceived as an aid to family historians researching their own Scottish family histories. The completed register forms were published on microfiche in 2005, with an index, and it is from the microfiche copies that the electronic database underpinning this study has been created. Any errors in transcription from the original forms to the electronic database are, therefore, my own.

The first step in the construction of the electronic database was the creation of an entry for each individual listed in the register index in FileMaker Pro 7, this being considered the most appropriate available software for the project. The given name, surname, gender, county of birth, year of birth, year of baptism and year of arrival of the migrants were all entered from the index, as well as the NZSG ID number assigned to them. From this point, the entries were searched for individuals who were in the database more than once, their second, third, and in some cases fourth, NZSG ID numbers being then attached to one Filemaker entry. Due to some migrants having multiple entries in the NZSG register, it is the ID number created for the migrants in 
the electronic database, not the NZSG register ID numbers, that are referred to throughout the present text. ${ }^{1}$

The second phase of data entry, carried out over the following seven months, involved the entering of the following data from the registration forms for every individual in the database:

Full date of birth

Full date of baptism

Town/village of birth

Parish of birth

Father's name

Mother's name

Place of residence in Scotland

Country of residence prior to New Zealand (if not Scotland) and length of residence

Residences in New Zealand

UK port of departure

Full date of departure

Name of ship departed on

Port of arrival in New Zealand

Full date of arrival

Name of ship arrived on

Occupation(s) in Scotland

Occupation(s) in New Zealand

Full date of death

Place of death

Age at death (calculated based on date of birth and date of death)

Age at arrival (calculated based on date of birth and date of arrival) in years and months

Marital status at arrival (based on date of arrival, age at arrival, date and/or place of marriage, and date of death of spouse)

Total number of children (in Scotland and New Zealand combined)

Given name, surname and Database ID number, if available, of spouses listed.

Information available from the registration forms not included in the database included the birth details of spouses and the date and place of marriage, as well as the birth and death details of the children. Spouse and child information was entered for the first 113 and 106 individuals respectively, at which point it was decided to

\footnotetext{
${ }^{1}$ Though the number of migrants in the dataset is 6,612 the ID numbers run through to 6,665, these additional 53 migrants being found to already have entries in the database when a later check was carried out and their multiple records then combined.
} 
discontinue the entering of that information. This decision was primarily based on the potential value of the information, with consideration of the additional time that would be required for data entry if these details were included. The total number of children born to each migrant was recorded, based on a count of the children listed on the form plus the number recorded as 'number of children who are or could be still alive'. There was no differentiation in the count between those born in New Zealand and outside of New Zealand. Collection of the spouse information would allow analysis of where migrants were marrying - possibly providing clues to the patterns of internal migration within Scotland and New Zealand, also potentially offering further insights as to religious adherence, based on the churches in which people were marrying, when the migrants married in a church and not in a private home. It would also allow analysis of marriage patterns, especially whether the Scots migrants were marrying fellow Scots or outside of their ethnic group and whether patterns changed if they married in Scotland or after arrival in New Zealand. Collection of the child information would allow some analysis of infant mortality among the children of the migrants in Scotland compared to New Zealand, as well as fertility patterns in Scotland compared to New Zealand. Although the additional data collected would provide answers to important questions regarding the profile of the migrants - marital patterns especially being of interest - the additional time required to input this information forced a decision to be made, and it was decided that only the basic profile of the migrants would be examined, leaving other aspects, such as marriage patterns, to be examined at a later date.

After the second phase of data entry was completed the database was 'tidied' to ready it for analysis. SPSS, the programme used for the basic statistical computations of analysis, only recognises entries as being in common if they are exactly alike. Therefore all place, port, ship and occupation names had to be standardised. Parishes of birth given in the registration forms were checked against a list of Scotland's parishes and where, for example, the contributor listed the migrant as having been born in Lanarkshire County but a Renfrewshire parish, the county recorded was altered so that the parish of birth recorded was within the county of birth. The date and port of departure and arrival of ships was also checked against other information - where available - and standardised. Where alternative information on transit was not available, the date/port was standardised to whatever the majority of registration 
forms had recorded for that ship and sailing. Occupations were categorised according to a template devised for this thesis, the categories being based upon those used by Rosalind McClean in her 1990 thesis. For more information, and a list of these categories see Appendix 5.1.

Place of birth, rather than places of residence in Scotland, was chosen as the signifier of origin within Scotland, and place of death rather than places of residence in New Zealand was chosen to signify place of settlement. Each place of birth was further categorised by Scotland region, according to the boundaries utilised, and each place of death first by 1876 county, then by pre-1876 province (see below for detail on these boundary classifications). A number of 'places of death' as recorded on the registration forms have not been located on maps or in gazetteers of New Zealand, and have therefore not been classified or analysed. ${ }^{2}$

Marital status demarcations were also checked in this third data entry phase. During data entry all those under twelve years of age had been designated as 'child'. This age limit was subsequently raised to include all those up to, but not including, sixteen years of age. Sixteen was chosen as no individual in the database aged under sixteen years was married at time of arrival or had an occupation recorded in Scotland. Although other migrants aged sixteen years or over may also have been dependant upon their parents or guardians, certainly all those in the data arriving under the age of sixteen were dependants and thus have been classified as children. The remaining migrants (those noted as 'single' 'married' or 'widow') were then checked and some classifications altered to 'either widowed or spouse absent'. In these instances the migrants had a spouse listed, but there is no evidence of the spouse having migrated and a date of death is not recorded. Though the number of these migrants in the data is small, making the distinction was important so as not to potentially incorrectly inflate the number of migrants recorded as having arrived widowed.

A further classification was added to the profile of each migrant based on the year of arrival. A modified period of arrival breakdown, based upon the model used by Phillips and Hearn for their 'Peopling of New Zealand' project and subsequent publications, was used to group the migrants chronologically (see Chapter One). Of

\footnotetext{
${ }^{2}$ Using place of death as a signifier of place of settlement is somewhat problematic; discussion of these issues are outlined below with discussion of the PNZ data.
} 
the 6,612 migrants in the database, 5,912 had a year of arrival recorded and were able to be so grouped.

\section{SHETLAND DATASET}

After the decision was made to focus on migrants from Shetland as a county level case study (see Chapter Six), an extended Shetland dataset was constructed to develop a more complete picture of the experience of these migrants. The NZSG dataset contains information on 126 Shetland-born migrants. These 126, plus the spouses and children of Shetland-born migrants born outside of Shetland who were in the NZSG sample, formed the basis of the extended dataset. As the next step, details were entered from the list of assisted passengers from Shetland in Appendix 1 of Butterworth's Chips off the Auld Rock. ${ }^{3}$ Further individuals were added as a result of a search of records on Ancestry.co.uk, noting individuals born in Shetland who had died in New Zealand. ${ }^{4}$ Details for many of the Chips migrants were also found in the Ancestry.co.uk records. The records available through this Ancestry website have been contributed by genealogists and family historians and come with many of the problems inherent in the entries of the NZSG register. Several other sources were used in the creation of the extended database, including the Shetland Family History Society database of migrants, (available only at the research rooms of the Shetland Family History Society in Lerwick, Shetland), and a database constructed and maintained by Tony Gott of Shetland, available at http://bayanne.info/Shetland/. ${ }^{5}$ The Shetland Family History Society database has been compiled by family historians and is updated and amended frequently. It contains information about most of the Shetland families who have lived in the islands at any point in the past 200 odd years. Tony Gott's database is also frequently updated and amended. It has been created from a wide range of sources, including newspaper reports, census information, naval records, church records and family information from descendants. Both of these databases were searched for individuals with New Zealand recorded as their place of death. In addition, a number of migrants were added as a result of an examination of family histories held by the Shetland Family History Society during a visit in

\footnotetext{
${ }^{3}$ Susan Butterworth, Chips off the Auld Rock: Shetlanders in New Zealand, Wellington, 1997

${ }^{4}$ 'Public Member Trees', available at ancestry.co.uk; 'RootsWeb's WorldConnect Project', available at http://www.rootsweb.ancestry.com/

${ }^{5}$ Shetland Family History Society database of Shetland migrants, available at the Shetland Family History Society research rooms Hillhead, Lerwick, Shetland; 'Shetland Family History Database', compiled by Tony Gott, accessed at http://bayanne.info/Shetland/
} 
November 2007. Additional information relating to individuals in the extended database has been added as it is found.

It was originally intended that this Shetland dataset would also be used for extended statistical analysis. However, though it currently includes 1,118 individuals in addition to the 126 NZSG migrants, few of these 1,244 migrants have a full profile available. For example, port of arrival is known for only 225 migrants. Only 245 have information regarding parish of birth, 496 regarding place of death and 226 have information entered for both parish of birth and place of death. While therefore of limited immediate utility for statistical analysis, this extended database has been valuable for establishing connections between the individuals in terms of family and community relationships. As outlined in Chapter Six, the database has provided insights into migrant clusters in terms of origin and patterns of chain migration from Shetland not observed from other parts of Scotland. It is hoped the dataset may be used for its originally intended purpose in the future, when full profiles of the individuals are acquired.

\section{PEOPLING OF NEW ZEALAND DATA}

As noted in Chapter One, the PNZ dataset is based upon information from death certificates from 1876. ${ }^{6}$ The additional information in certificates post-1875 makes them a valuable source for the analysis of migrants and patterns of migration to New Zealand. $^{7}$

From the death certificate information the following datasets were compiled: 179 people arriving in New Zealand prior to 1840 (dying after 1876) 1,061 people arriving in New Zealand between 1840 and 1852 (dying after 1876) 2,464 people arriving in New Zealand between 1853 and 1870 (dying after 1876) 3,446 people arriving in New Zealand between1871 and 1890 (dying after 1876) 2,109 people arriving in New Zealand between 1891 and 1915 2,570 people arriving in New Zealand between 1916 and $1945^{8}$

These datasets are relatively random samples, being extracted from death registers for every second year and every consecutive month throughout New Zealand - for

\footnotetext{
${ }^{6}$ For an outline of this project see Jock Phillips, 'Who were New Zealand's founding pakeha?', in Settling the Waikato and Beyond, 2006: Proceedings of the New Zealand Society of Genealogists 2006 Conference, Auckland, 2006

${ }^{7}$ Information about the creation etc of the database based upon meetings and correspondence with Dr Jock Phillips and Dr Terry Hearn from March 2006 to July 2007

${ }^{8}$ These totals are not of Scots alone but of the total number of people arriving in each time period subsample.
} 
example January 1876, February 1878, and so forth. The ideal sample size proposed by Phillips and Hearn prior to commencing the exercise was 1,000 people for each time period and for each of the English, Irish, Scottish and New Zealand born subsamples, these being the largest population groups. When the initial run of every second year and every consecutive month did not reach these minimum levels, every other year and consecutive month was taken until the sub-samples reached acceptable sizes. The country distribution of the people in the data was then checked against that of New Zealand census data for the UK-born and against other bodies of data, including the Waikato Military Immigrants, to check that the data was representative. The Scotland migrant sub-sample to 1945 is 3,682.

The following information was collected from the death registration forms for each individual:

Year of Death

Place of Death (to which a province of death was added, based upon regional council boundaries. This was recoded for use in the present study to the New Zealand county and provincial boundaries described below)

Occupation at Death (this was not coded by Phillips, so has subsequently been classified according to the scheme created for the present study; see Appendix 5.1)

Gender

Age at Death

Father's occupation (and 'class' of the occupation, as coded by Phillips, and since recoded to the scheme created for the present study)

Birth Country

Birth County

Birth Region (for Scotland the division of regions was as has been used throughout this thesis, except for the inclusion in the PNZ data of Kincardine in the Eastern Lowlands rather than the North East. This was recoded for analysis of the data for the present study)

Year at Arrival (based on year of death minus the number of years stated as the person having been in New Zealand)

Age at Arrival (based on age at death minus the number of years stated as the person having been in New Zealand)

Marital Status at Arrival (single or married, for migrants over fifteen years at arrival, recorded to child (under sixteen years), single and married for the present study)

Country of Marriage

Religion of person officiating at the funeral

One of the conditions of the collection of information from the registers was that the names of the individuals not be recorded, meaning that the data is useful solely for statistical analysis. No additional qualitative information can be added to the entries for individuals. 


\section{Boundary Classifications}

Boundaries chosen to delineate place of origin and of settlement may significantly influence the results of analyses ultimately presented. Including any given locality within the boundaries of a county and assigning that county to a region or province alters the proportions of migrants that appear to have come from or gone to that county or region/province. The boundary distinctions described below were, therefore, decided upon prior to any data collection in order to keep the analysis of origin and settlement as unbiased by expectations as to how many should be included in a given area as possible.

\section{Scotland}

The county names used throughout this thesis were dictated by the NZSG Scottish Interest Group's use of the 'Pre-1974 Scottish Counties' division of Scotland, stated on the registration form. Contributors were asked to record migrants' counties of birth according to these county boundaries. However, as noted in Chapter Two, the county boundaries of Scotland shifted, in some cases as a result of deliberations of the Boundary Commission created by the Local Government (Scotland) Act of $1889 .{ }^{9}$ It is therefore possible that the location specified by the contributor of the information and the location analysed in the present study may in some cases different. The region and county boundaries in Scotland used throughout this thesis for analysis and discussion are based upon those employed in Michael Flinn (ed.) Scottish Population History from the 17th Century to the 1930s for the nineteenth and twentieth century section. These divisions of Scotland were also used by Rosalind McClean in her 1990 thesis and, apart from Kincardineshire, by the compilers of the PNZ data. For analysis of the PNZ data carried out for the present research Kincardineshire was reclassified to be a North East county, whereas in work published on the PNZ data it is included as an Eastern Lowlands county. For discussion of the reasons for this division of Scotland see Michael Flinn, ed., Scottish Population History from the 17th century to the 1930s, Cambridge, 1977, pp.104-106 (and Map 3, pp.xxiii).

See Maps 1 and 2.

\footnotetext{
${ }^{9}$ See Hay Shennan, Boundaries of Counties and Parishes in Scotland as Settled by the Boundary Commissioners under the Local Government (Scotland) Act, 1889, Edinburgh, 1892
} 


\section{New Zealand}

While Scotland may be easily and not especially controversially split into regions, counties and parishes, divisions that remain largely constant throughout the period this study is concerned with, New Zealand boundaries were changing every few years.

From its inception as a British colony to 1846 New Zealand was divided into three provinces: New Ulster, New Munster and New Leinster. In 1846 New Leinster Stewart Island - was incorporated into New Munster and the provinces of New Ulster and New Munster remained the principal territorial divisions until 1852 and the New Zealand Constitution Act. Under the terms of this legislation six, ultimately ten, provinces were established, these remaining the primary political units until 1876, when the provinces were abolished in favour of sixty-three counties. ${ }^{10}$ With each census, as the population grew and settlement pushed into the hinterlands, new counties and boroughs were formed. Within ten years, in the 1886 census, seventytwo counties are listed and by the census of 1916 New Zealand was split into 123 county divisions. ${ }^{11}$ For the sake of sensible analysis a single set of regional and county divisions was necessary.

Because the New Zealand census continued to enumerate the population in terms of provinces through the period studied, the ten provincial boundaries have been retained for analysis of the NZSG and PNZ data. See Map 4. With New Zealand only being divided into counties from 1876, and the county boundaries changing frequently thereafter, any one county level division used would be anachronistic. The sixty-three 1876 county boundaries were chosen for several reasons. The majority of the migrants arriving over this eighty year having arrived prior to 1878, it was logical to use the first available county level division in terms of time, these being the first county division maps outlining the boundaries of the counties readily available. ${ }^{12}$ It is the smallest county division available of the country, making analysis less fragmentary than might otherwise be the case. See Map 3.

Although several of these counties overlap the provincial boundaries used, this was not a major concern. The majority of the 'borderline' county populations resided on

\footnotetext{
${ }^{10}$ Mary Boyd, 'Government', in New Zealand Atlas, ed. Ian Wards, Wellington, 1976, p.58; R.J. Lowe, 'Administrative divisions', in New Zealand Atlas, ed. Ian Wards, Wellington, 1976, p.66

${ }^{11}$ Table VI, 1886 Census of New Zealand; 1916 Census of New Zealand, pp.31-36

12 The map used throughout this study is based upon map 1.5.3 in Brian Marshall and Jan Kelly, Atlas of New Zealand Boundaries, Auckland, 1986
} 
one side or another of provincial boundaries, only a few residual settlers being counted in counties inside another province. For example, Wairoa County lies across the Auckland and Hawkes Bay Provincial boundary. Just five of the NZSG settlers resided in Wairoa County, four in Hawkes Bay Province and one in Auckland Province. When county analysis is carried out within provinces the one Wairoa NZSG migrant in Auckland Province is recorded as resident in Wairoa County, Auckland Province. This level of precision is not afforded by the census data, so census county data has not been analysed within provinces. 


\section{Appendix 2.1}

Percentage of the migrants in the NZSG database arriving from each county of Scotland by each period of arrival.

\begin{tabular}{|c|c|c|c|c|c|c|}
\hline & \multicolumn{6}{|c|}{ Period of Arrival in New Zealand } \\
\hline & $\begin{array}{l}\text { Pre- } \\
1852 \\
\end{array}$ & $\begin{array}{c}1853- \\
1870 \\
\end{array}$ & $\begin{array}{c}1871- \\
1886 \\
\end{array}$ & $\begin{array}{c}1887- \\
1900 \\
\end{array}$ & $\begin{array}{c}1901- \\
1920 \\
\end{array}$ & $\begin{array}{l}\text { Whole } \\
\text { Period }\end{array}$ \\
\hline SHI & 0 & 0.87 & 4.72 & 0 & 1.86 & 2.02 \\
\hline OKI & 1.03 & 1.13 & 1.09 & 1.28 & 0.19 & 1.03 \\
\hline CAI & 1.55 & 2.53 & 3.09 & 0.64 & 0.37 & 2.42 \\
\hline SUT & 2.58 & 1.85 & 0.42 & 1.28 & 0.37 & 1.27 \\
\hline ROC & 0.69 & 4.08 & 7.08 & 7.69 & 2.23 & 4.52 \\
\hline INV & 3.79 & 2.91 & 2.06 & 3.85 & 3.35 & 2.92 \\
\hline ARL & 6.88 & 4.39 & 1.57 & 1.92 & 1.68 & 3.60 \\
\hline BUT & 0.52 & 1.13 & 0.54 & 0 & 0 & 0.80 \\
\hline NAI & 0 & 0.15 & 0 & 0.64 & 0.56 & 0.18 \\
\hline MOR & 0.34 & 1.47 & 1.45 & 1.92 & 2.05 & 1.46 \\
\hline BAN & 1.38 & 0.91 & 1.63 & 3.85 & 1.86 & 1.33 \\
\hline ABD & 7.92 & 6.58 & 6.65 & 17.31 & 9.68 & 7.37 \\
\hline KCD & 1.20 & 0.76 & 0.79 & 1.28 & 2.98 & 1.09 \\
\hline ANS & 3.61 & 3.25 & 3.27 & 5.77 & 3.72 & 3.70 \\
\hline PER & 12.05 & 6.77 & 4.90 & 4.49 & 2.61 & 6.07 \\
\hline DNB & 1.72 & 1.55 & 2.54 & 0 & 2.79 & 1.94 \\
\hline CLK & 0.69 & 0.79 & 0.73 & 0 & 0 & 0.62 \\
\hline KRS & 0.52 & 0.53 & 0.36 & 1.28 & 0 & 0.43 \\
\hline FIF & 5.16 & 4.99 & 5.02 & 5.77 & 4.28 & 5.09 \\
\hline STI & 1.38 & 4.46 & 3.27 & 0.64 & 7.82 & 4.04 \\
\hline WLN & 0.34 & 1.93 & 0.79 & 1.28 & 0 & 1.22 \\
\hline MLN & 13.6 & 8.24 & 6.17 & 2.56 & 8.94 & 8.04 \\
\hline ELN & 1.20 & 1.78 & 1.75 & 0 & 1.68 & 1.62 \\
\hline RFW & 11.88 & 5.26 & 3.81 & 5.13 & 7.64 & 5.56 \\
\hline LKS & 12.22 & 12.93 & 19.66 & 13.46 & 24.02 & 15.86 \\
\hline AYR & 3.96 & 7.49 & 7.08 & 7.69 & 4.84 & 6.50 \\
\hline BEW & 0.34 & 1.97 & 0.42 & 1.28 & 0.37 & 1.19 \\
\hline PEE & 0 & 0.72 & 0.18 & 1.28 & 0.93 & 0.53 \\
\hline SEL & 0 & 0.34 & 0.73 & 0.64 & 0.19 & 0.45 \\
\hline ROX & 1.89 & 2.27 & 2.84 & 0.64 & 0.74 & 2.07 \\
\hline DFS & 0.34 & 2.42 & 3.93 & 2.56 & 1.12 & 2.58 \\
\hline KKD & 0.69 & 2.23 & 0.36 & 1.92 & 0 & 1.30 \\
\hline WIG & 0.52 & 1.32 & 1.09 & 1.92 & 1.12 & 1.22 \\
\hline$n$ & 581 & 2,645 & 1,653 & 156 & 537 & 6,243 \\
\hline $\begin{array}{l}\text { Missing, } \\
\text { unknown } \\
\text { or at sea }\end{array}$ & 85 & 173 & 55 & 6 & 21 & 369 \\
\hline
\end{tabular}

Source: NZSG data 1840-1920 


\section{Appendix 2.2}

Percentage of the Scotland total population living in each county at the census

\begin{tabular}{|c|c|c|c|c|c|}
\hline & \multicolumn{5}{|c|}{ Scotland Census } \\
\hline & 1851 & 1861 & 1871 & 1891 & 1911 \\
\hline SHI & 1.08 & 1.03 & 0.94 & 0.71 & 0.59 \\
\hline OKI & 1.09 & 1.06 & 0.93 & 0.76 & 0.54 \\
\hline CAI & 1.34 & 1.34 & 1.19 & 0.92 & 0.67 \\
\hline SUT & 0.89 & 0.82 & 0.72 & 0.54 & 0.42 \\
\hline ROC & 2.86 & 2.66 & 2.41 & 1.93 & 1.63 \\
\hline INV & 3.34 & 2.90 & 2.62 & 2.22 & 1.83 \\
\hline ARL & 3.09 & 2.60 & 2.25 & 1.86 & 1.49 \\
\hline BUT & 0.57 & 0.53 & 0.51 & 0.46 & 0.38 \\
\hline NAI & 0.34 & 0.33 & 0.30 & 0.25 & 0.20 \\
\hline MOR & 1.35 & 1.39 & 1.28 & 1.08 & 0.91 \\
\hline BAN & 1.88 & 1.93 & 1.85 & 1.59 & 1.29 \\
\hline ABD & 7.34 & 7.24 & 7.28 & 6.99 & 6.54 \\
\hline KCD & 1.20 & 1.13 & 1.03 & 0.89 & 0.86 \\
\hline ANS & 6.62 & 6.68 & 7.07 & 6.90 & 5.91 \\
\hline PER & 4.80 & 4.36 & 3.80 & 3.13 & 2.61 \\
\hline DNB & 1.56 & 1.70 & 1.75 & 2.35 & 2.94 \\
\hline CLK & 0.79 & 0.70 & 0.71 & 0.71 & 0.65 \\
\hline KRS & 0.31 & 0.26 & 0.21 & 0.16 & 0.16 \\
\hline FIF & 5.32 & 5.05 & 4.78 & 4.65 & 5.63 \\
\hline STI & 2.99 & 3.00 & 2.92 & 3.12 & 3.38 \\
\hline WLN & 1.04 & 1.26 & 1.22 & 1.31 & 1.67 \\
\hline MLN & 8.98 & 8.95 & 9.77 & 10.78 & 10.67 \\
\hline ELN & 1.26 & 1.23 & 1.12 & 0.93 & 0.91 \\
\hline RFW & 5.58 & 5.80 & 6.46 & 7.22 & 6.61 \\
\hline LKS & 18.35 & 20.62 & 22.78 & 25.98 & 30.41 \\
\hline AYR & 6.57 & 6.50 & 5.98 & 5.62 & 5.64 \\
\hline BEW & 1.26 & 1.20 & 1.09 & 0.80 & 0.62 \\
\hline PEE & 0.37 & 0.37 & 0.37 & 0.37 & 0.32 \\
\hline SEL & 0.34 & 0.34 & 0.55 & 0.68 & 0.52 \\
\hline ROX & 1.79 & 1.77 & 1.47 & 1.33 & 0.99 \\
\hline DFS & 2.70 & 2.48 & 2.23 & 1.84 & 1.53 \\
\hline KKD & 1.49 & 1.39 & 1.25 & 0.99 & 0.81 \\
\hline WIG & 1.50 & 1.37 & 1.16 & 0.90 & 0.67 \\
\hline$n$ & $2,888,742$ & $3,062,294$ & $3,360,018$ & $4,025,647$ & $4,759,445$ \\
\hline
\end{tabular}

Source: Scotland Census, 1851, 1861, 1871, 1891, 1911 


\section{Appendix 3.1}

Proportion of each Scottish county's migrants residing in the provinces of New Zealand

\begin{tabular}{|c|c|c|c|c|c|c|c|}
\hline & \multicolumn{6}{|c|}{ New Zealand Provinces } & \multirow[b]{2}{*}{$n$} \\
\hline & Auckland & Wellington & Canterbury & Otago & Southland & Other* & \\
\hline SHI & 16.96 & 19.64 & 9.82 & 29.46 & 9.82 & 14.29 & 112 \\
\hline OKI & 3.64 & 10.91 & 1.82 & 65.45 & 16.36 & 1.82 & 55 \\
\hline CAI & 8.40 & 14.29 & 16.81 & 46.22 & 8.40 & 5.88 & 119 \\
\hline Far North & 10.84 & 15.73 & 11.19 & 43.36 & 10.49 & 8.39 & 286 \\
\hline NAI & 36.36 & 9.09 & 9.09 & 45.45 & 0 & 0 & 11 \\
\hline MOR & 29.41 & 8.82 & 8.82 & 47.06 & 4.41 & 1.47 & 68 \\
\hline BAN & 29.41 & 19.12 & 7.35 & 29.41 & 8.82 & 5.88 & 68 \\
\hline ABD & 22.81 & 16.29 & 12.53 & 27.32 & 11.78 & 9.27 & 399 \\
\hline KCD & 20.34 & 32.20 & 8.47 & 23.73 & 5.08 & 10.17 & 59 \\
\hline North East & 24.30 & 17.19 & 11.07 & 29.75 & 9.75 & 7.93 & 605 \\
\hline SUT & 11.94 & 8.96 & 11.94 & 28.36 & 28.36 & 10.45 & 67 \\
\hline ROC & 20.85 & 9.79 & 17.87 & 28.09 & 12.77 & 10.64 & 235 \\
\hline INV & 24.34 & 15.79 & 11.84 & 32.89 & 4.61 & 10.53 & 152 \\
\hline ARL & 14.37 & 18.97 & 12.64 & 28.74 & 13.79 & 11.49 & 174 \\
\hline BUT & 15.56 & 15.56 & 22.22 & 26.67 & 15.56 & 4.44 & 45 \\
\hline Highlands & 18.72 & 13.82 & 14.86 & 29.27 & 12.93 & 10.40 & 673 \\
\hline ANS & 20.50 & 14.50 & 14.00 & 29.50 & 10.50 & 11.00 & 200 \\
\hline PER & 22.22 & 11.11 & 13.58 & 34.88 & 8.33 & 9.88 & 324 \\
\hline DNB & 20.39 & 10.68 & 22.33 & 33.98 & 8.74 & 3.88 & 103 \\
\hline CLK & 24.14 & 6.90 & 0 & 55.17 & 6.90 & 6.90 & 29 \\
\hline KRS & 23.08 & 3.85 & 0 & 53.85 & 3.85 & 15.38 & 26 \\
\hline FIF & 20.52 & 15.67 & 13.06 & 30.22 & 9.70 & 10.82 & 268 \\
\hline STI & 23.81 & 10.00 & 10.00 & 46.67 & 6.19 & 3.33 & 210 \\
\hline WLN & 21.88 & 7.81 & 6.25 & 53.13 & 4.69 & 6.25 & 64 \\
\hline MLN & 23.46 & 13.67 & 7.06 & 37.36 & 7.06 & 11.39 & 439 \\
\hline ELN & 24.68 & 9.09 & 9.09 & 41.56 & 6.49 & 9.09 & 77 \\
\hline Eastern Lowlands & 22.30 & 12.30 & 11.09 & 37.13 & 7.93 & 9.25 & 1740 \\
\hline RFW & 38.05 & 13.80 & 9.09 & 28.62 & 3.70 & 6.73 & 297 \\
\hline LKS & 27.04 & 13.89 & 8.77 & 29.11 & 10.11 & 11.08 & 821 \\
\hline AYR & 22.63 & 10.89 & 11.45 & 34.36 & 11.45 & 9.22 & 358 \\
\hline Western Lowlands & 28.18 & 13.14 & 9.49 & 30.28 & 9.15 & 9.76 & 1,476 \\
\hline BEW & 14.93 & 1.49 & 13.43 & 49.25 & 17.91 & 2.99 & 67 \\
\hline PEE & 20.69 & 13.79 & 3.45 & 48.28 & 3.45 & 10.34 & 29 \\
\hline SEL & 8.33 & 0.00 & 25.00 & 58.33 & 4.17 & 4.17 & 24 \\
\hline ROX & 4.63 & 12.04 & 12.04 & 55.56 & 7.41 & 8.33 & 108 \\
\hline DFS & 10.61 & 16.67 & 11.36 & 31.82 & 21.97 & 7.58 & 132 \\
\hline KKD & 11.11 & 18.06 & 15.28 & 33.33 & 18.06 & 4.17 & 72 \\
\hline WIG & 7.81 & 12.50 & 6.25 & 39.06 & 26.56 & 7.81 & 64 \\
\hline Borders & 10.08 & 12.30 & 11.90 & 42.74 & 16.33 & 6.65 & 496 \\
\hline
\end{tabular}

*Other = Taranaki, Hawkes Bay, Nelson, Marlborough, and Westland Province

Source: NZSG data, 1840-1920

Colours highlighting Scottish regions here corresponds with key used in Figure 3.4. 


\section{Appendix 3.2}

Distribution of the Scottish regional origins of migrants in New Zealand's five principal provinces by period of arrival ${ }^{1}$

Figure A3.2a: Arrival Whole Period, 1840-1920

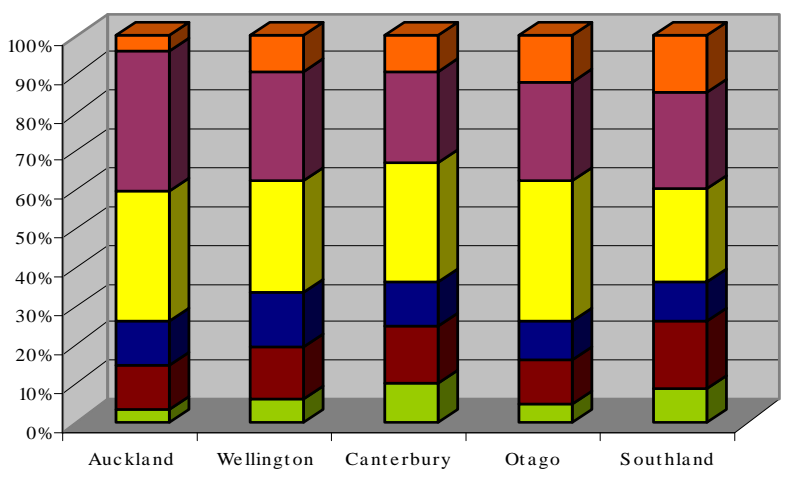

Figure A3.2b: Arrival Pre-1852

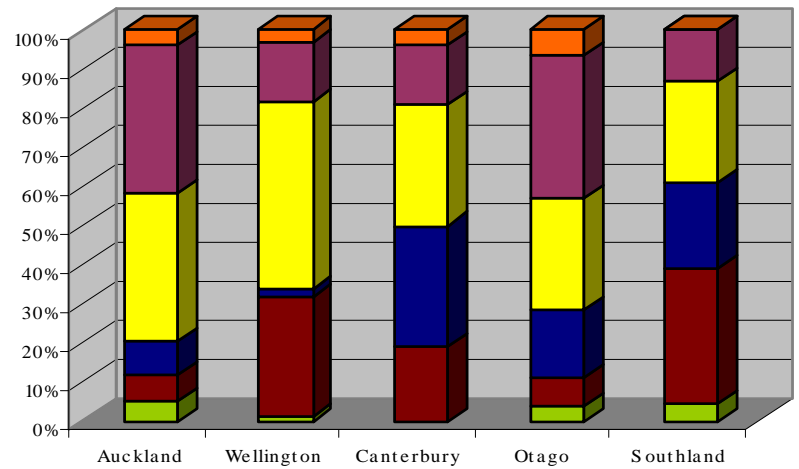

Figure A3.2d: Arrival 1871-1886

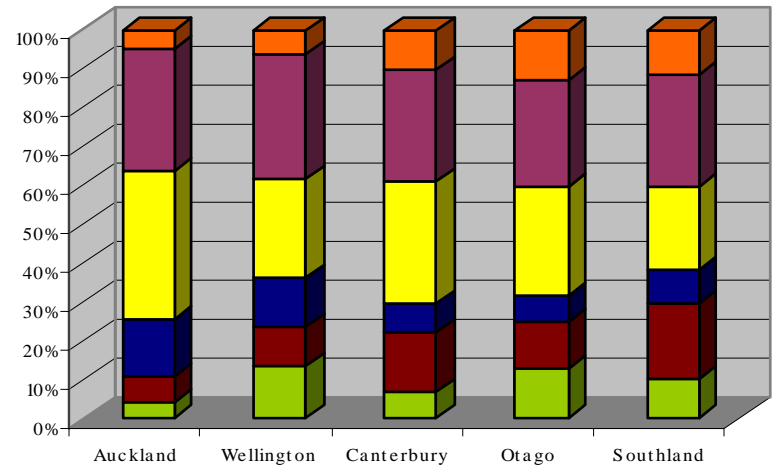

Figure A3.2c: Arrival 1853-1870

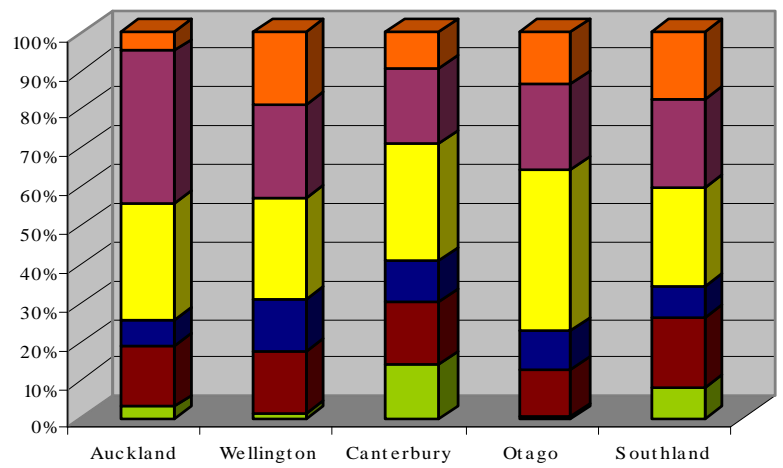

Figure A3.2e: Arrival 1900-1920

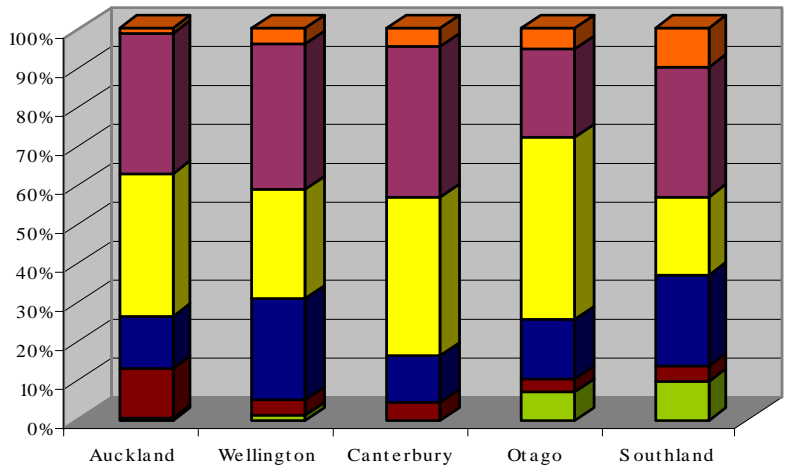

Source: NZSG data, 1840-1920, excluding 1887-1900

Though these figures show quite striking patterns, it should be noted that the numbers involved are relatively small, because the data have been split by, firstly, period of arrival, then region of birth and province of death. So, for example, the number of migrants in the sample for the period 1901-1920 from the North East settled in Wellington is just twenty-seven, and the number for Highlanders in Southland in the pre-1852 period just eight, compared to Wellington's twenty-eight for that same group in the same period of arrival.

\footnotetext{
${ }^{1}$ Excluding the period $1887-1900$ for which the sample is too small.
} 


\section{Appendix 3.3a}

Proportions of Scots-born living in each New Zealand county, and the proportions of each New Zealand county that were born in Scotland including and excluding the New Zealandborn population of those counties, 1891 Census.

\begin{tabular}{|c|c|c|c|c|}
\hline $\begin{array}{l}\text { New Zealand } \\
\text { County }\end{array}$ & $\begin{array}{l}\% \text { of Scotland-born } \\
\text { population residing } \\
\text { in the county } \\
\text { (a) }\end{array}$ & $\begin{array}{c}\text { \% of county } \\
\text { born in Scotland } \\
\text { (Incl. NZ-born) } \\
\text { (b) }\end{array}$ & $\begin{array}{l}\% \text { of county born } \\
\text { in Scotland } \\
\text { (Excl. NZ-born) } \\
\text { (c) }\end{array}$ & $\begin{array}{l}\text { County } \\
\text { Population } \\
\text { (d) }\end{array}$ \\
\hline Mongonui & 0.15 & 3.24 & 9.55 & 1,389 \\
\hline Whangaroa & 0.08 & 2.51 & 9.95 & 878 \\
\hline Hokianga & 0.25 & 4.95 & 11.94 & 1,494 \\
\hline Bay of Islands & 0.38 & 4.37 & 11.64 & 2,562 \\
\hline Hobson & 0.48 & 4.28 & 9.44 & 3,298 \\
\hline Whangarei & 1.49 & 7.09 & 17.03 & 6,120 \\
\hline Otematea & 0.33 & 4.72 & 10.97 & 2,054 \\
\hline Rodney & 0.38 & 3.53 & 9.44 & 3,170 \\
\hline Waitemata & 1.13 & 5.35 & 11.86 & 6,184 \\
\hline Eden & 2.25 & 4.77 & 10.72 & 13,782 \\
\hline Manukau & 2.56 & 6.27 & 16.30 & 11,925 \\
\hline Coromandel & 0.49 & 4.99 & 12.93 & 2,846 \\
\hline Thames & 0.64 & 4.31 & 12.47 & 4,340 \\
\hline Ohinemuri & 0.20 & 3.83 & 9.76 & 1,516 \\
\hline Piako & 0.48 & 5.56 & 13.08 & 2,517 \\
\hline Waikato & 0.66 & 7.01 & 16.47 & 2,738 \\
\hline Waipa & 0.46 & 3.95 & 9.83 & 3,395 \\
\hline Raglan & 0.20 & 5.41 & 13.98 & 1,090 \\
\hline Kawhia & 0.02 & 1.62 & 6.10 & 308 \\
\hline West Taupo & 0.01 & 3.36 & 7.69 & 119 \\
\hline East Taupo & 0.04 & 7.24 & 11.11 & 152 \\
\hline Rotorua & 0.10 & 6.70 & 12.02 & 418 \\
\hline Tauranga & 0.18 & 3.73 & 7.55 & 1,393 \\
\hline Whakatane & 0.29 & 5.51 & 14.26 & 1,524 \\
\hline Waiapu & 0.09 & 6.60 & 14.37 & 379 \\
\hline Cook & 0.88 & 6.49 & 16.74 & 3,945 \\
\hline Clifton & 0.10 & 3.19 & 8.90 & 908 \\
\hline Taranaki & 0.90 & 3.31 & 9.11 & 7,905 \\
\hline Stratford & 0.36 & 4.13 & 9.52 & 2,521 \\
\hline Hawera & 1.00 & 6.69 & 17.32 & 4,347 \\
\hline Patea & 0.64 & 7.13 & 17.71 & 2,608 \\
\hline Waitotara & 0.47 & 6.12 & 15.33 & 2,255 \\
\hline Wanganui & 0.66 & 8.46 & 21.78 & 2,281 \\
\hline Rangitikei & 1.17 & 7.66 & 19.62 & 4,438 \\
\hline Oroua & 1.15 & 4.53 & 11.59 & 7,418 \\
\hline Manawatu & 0.48 & 5.17 & 14.11 & 2,725 \\
\hline Horowhenua & 0.37 & 4.72 & 11.27 & 2,289 \\
\hline Wairoa & 0.30 & 7.14 & 17.02 & 1,246 \\
\hline Hawkes Bay & 1.37 & 6.65 & 14.76 & 6,028 \\
\hline Waipawa & 1.38 & 5.10 & 11.84 & 7,906 \\
\hline Patangata & 0.75 & 10.71 & 22.12 & 2,044 \\
\hline Pahiatua & 0.44 & 5.37 & 12.61 & 2,365 \\
\hline Wairarapa North & 1.06 & 6.01 & 15.14 & 5,143 \\
\hline Wairarapa South & 0.91 & 5.36 & 15.82 & 4,980 \\
\hline Hutt & 0.89 & 4.27 & 13.13 & 6,114 \\
\hline
\end{tabular}




\begin{tabular}{|c|c|c|c|c|}
\hline $\begin{array}{l}\text { New Zealand } \\
\text { County }\end{array}$ & $\begin{array}{l}\% \text { of Scotland-born } \\
\text { population residing } \\
\text { in the county } \\
\text { (a) }\end{array}$ & $\begin{array}{l}\text { \% of county } \\
\text { born in Scotland } \\
\text { (Incl. NZ-born) } \\
\text { (b) }\end{array}$ & $\begin{array}{l}\text { \% of county born } \\
\text { in Scotland } \\
\text { (Excl. NZ-born) } \\
\text { (c) }\end{array}$ & $\begin{array}{l}\text { County } \\
\text { Population } \\
\text { (d) }\end{array}$ \\
\hline Sounds & 0.10 & 3.89 & 13.46 & 720 \\
\hline Marlborough & 1.06 & 4.75 & 14.85 & 6,520 \\
\hline Kaikoura & 0.35 & 7.05 & 20.81 & 1,460 \\
\hline Collingwood & 0.32 & 4.47 & 17.77 & 2,103 \\
\hline Waimea & 0.68 & 2.21 & 9.23 & 8,942 \\
\hline Buller & 1.64 & 10.26 & 21.58 & 4,659 \\
\hline Inangahua & 0.97 & 6.09 & 12.39 & 4,648 \\
\hline Grey & 0.85 & 5.75 & 10.26 & 4,330 \\
\hline Westland & 1.30 & 7.55 & 14.68 & 5,031 \\
\hline Amuri & 0.37 & 11.07 & 21.57 & 967 \\
\hline Cheviot & 0.08 & 14.02 & 25.84 & 164 \\
\hline Ashley & 2.54 & 5.99 & 16.03 & 12,396 \\
\hline Selwyn & 6.27 & 5.03 & 12.46 & 36,375 \\
\hline Akaroa & 0.63 & 4.85 & 15.29 & 3,771 \\
\hline Ashburton & 2.48 & 7.63 & 17.36 & 9,501 \\
\hline Geraldine & 3.45 & 6.91 & 17.67 & 14,588 \\
\hline Mackenzie & 0.65 & 16.19 & 36.11 & 1,180 \\
\hline Waimate & 1.78 & 12.84 & 28.21 & 4,043 \\
\hline Waitaki & 5.29 & 18.45 & 43.08 & 8,375 \\
\hline Waihemo & 1.52 & 21.76 & 50.23 & 2,040 \\
\hline Waikouaiti & 2.85 & 19.22 & 42.63 & 4,334 \\
\hline Peninsula & 1.56 & 16.85 & 45.68 & 2,701 \\
\hline Taieri & 5.05 & 20.82 & 51.57 & 7,079 \\
\hline Bruce & 3.40 & 21.12 & 55.17 & 4,696 \\
\hline Clutha & 4.47 & 23.39 & 55.02 & 5,574 \\
\hline Tuapeka & 3.13 & 14.43 & 32.30 & 6,327 \\
\hline Maniototo & 1.17 & 11.65 & 26.39 & 2,927 \\
\hline Vincent & 1.58 & 12.40 & 25.25 & 3,718 \\
\hline Lake & 1.37 & 13.70 & 27.42 & 2,919 \\
\hline Southland & 11.56 & 17.41 & 41.69 & 19,373 \\
\hline Wallace & 2.73 & 15.02 & 33.49 & 5,306 \\
\hline Fiord & 0.06 & 23.94 & 29.31 & 71 \\
\hline Stewart Island & 0.09 & 13.37 & 38.03 & 202 \\
\hline
\end{tabular}




\section{Appendix 3.3b}

Proportions of Scots-born living in each New Zealand county, and the proportions of each New Zealand county that were born in Scotland including and excluding the New Zealand-born population of those counties, 1911 Census.

\begin{tabular}{|c|c|c|c|c|}
\hline $\begin{array}{l}\text { New Zealand } \\
\text { County }\end{array}$ & $\begin{array}{l}\% \text { of Scotland-born } \\
\text { population residing in } \\
\text { the county } \\
\text { (a) }\end{array}$ & $\begin{array}{l}\text { \% of county born } \\
\text { in Scotland } \\
\text { (Incl. NZ-born) } \\
\text { (b) }\end{array}$ & $\begin{array}{l}\text { \% of county born in } \\
\text { Scotland } \\
\text { (Excl. NZ-born) } \\
\text { (c) }\end{array}$ & $\begin{array}{l}\text { County } \\
\text { Population } \\
\text { (d) }\end{array}$ \\
\hline Mongonui & 0.25 & 1.96 & 2.11 & 3,105 \\
\hline Whangaroa & 0.05 & 1.68 & 10.32 & 775 \\
\hline Hokianga & 0.29 & 2.26 & 7.70 & 3,096 \\
\hline Bay of Islands & 0.30 & 2.32 & 7.83 & 3,147 \\
\hline Whangerei & 1.06 & 3.28 & 12.10 & 7,873 \\
\hline Hobson & 0.32 & 1.87 & 6.01 & 4,128 \\
\hline Otamatea & 0.43 & 2.96 & 9.55 & 3,548 \\
\hline Rodney & 0.37 & 2.13 & 8.38 & 4,264 \\
\hline Waitemata & 1.27 & 3.54 & 10.11 & 8,692 \\
\hline Eden & 3.68 & 3.84 & 10.76 & 23,258 \\
\hline Manukau & 2.73 & 4.10 & 14.37 & 16,180 \\
\hline Coromandel & 0.28 & 2.43 & 10.29 & 2,760 \\
\hline Thames & 0.56 & 3.12 & 12.31 & 4,388 \\
\hline Waikato & 1.75 & 6.44 & 19.45 & 6,610 \\
\hline Raglan & 0.44 & 3.72 & 12.65 & 2,907 \\
\hline Waipa & 0.94 & 3.27 & 10.71 & 6,971 \\
\hline Kawhia & 0.08 & 2.29 & 8.62 & 875 \\
\hline Waitomo & 0.51 & 3.48 & 12.01 & 3,595 \\
\hline Awakino & 0.16 & 6.45 & 21.31 & 605 \\
\hline Ohinemuri & 0.61 & 2.47 & 8.95 & 6,044 \\
\hline Piako & 0.46 & 3.47 & 13.09 & 3,200 \\
\hline Matamata & 0.39 & 3.22 & 11.23 & 2,946 \\
\hline Tauranga & 0.50 & 4.12 & 12.94 & 2,936 \\
\hline Rotorua & 0.58 & 3.95 & 11.18 & 3,544 \\
\hline East Taupo & 0.10 & 4.55 & 10.48 & 528 \\
\hline West Taupo & 0.20 & 5.03 & 15.91 & 974 \\
\hline Ohura & 0.32 & 5.36 & 17.46 & 1,436 \\
\hline Kaitieke & 0.25 & 3.05 & 11.03 & 1,966 \\
\hline Whakatane & 0.31 & 4.43 & 16.89 & 1,717 \\
\hline Opotiki & 0.35 & 3.48 & 12.74 & 2,441 \\
\hline Waiapu & 0.37 & 5.13 & 14.04 & 1,734 \\
\hline Cook & 1.03 & 3.91 & 13.86 & 6,420 \\
\hline Waikohu & 0.44 & 3.61 & 10.15 & 2,963 \\
\hline Clifton & 0.17 & 1.91 & 9.74 & 2,198 \\
\hline Taranaki & 0.88 & 2.29 & 9.54 & 9,327 \\
\hline Egmont & 0.46 & 3.43 & 14.04 & 3,264 \\
\hline Stratford & 0.59 & 2.76 & 11.41 & 5,226 \\
\hline Whangamomona & 0.27 & 4.02 & 10.78 & 1,615 \\
\hline Eltham & 0.28 & 2.07 & 7.74 & 3,339 \\
\hline Waimate West & 0.39 & 3.99 & 13.06 & 2,358 \\
\hline Hawera & 0.56 & 3.72 & 12.95 & 3,659 \\
\hline Patea & 0.66 & 4.52 & 17.46 & 3,565 \\
\hline Wairoa & 0.35 & 4.48 & 15.44 & 1,876 \\
\hline Hawkes Bay & 2.08 & 5.01 & 15.18 & 10,114 \\
\hline Waipawa & 0.56 & 4.51 & 16.61 & 3,041 \\
\hline
\end{tabular}




\begin{tabular}{|c|c|c|c|c|}
\hline $\begin{array}{l}\text { New Zealand } \\
\text { County }\end{array}$ & $\begin{array}{l}\% \text { of Scotland-born } \\
\text { population residing in } \\
\text { the county } \\
\text { (a) }\end{array}$ & $\begin{array}{l}\text { \% of county born } \\
\text { in Scotland } \\
\text { (Incl. NZ-born) } \\
\text { (b) }\end{array}$ & $\begin{array}{l}\text { \% of county born in } \\
\text { Scotland } \\
\text { (Excl. NZ-born) } \\
\text { (c) }\end{array}$ & $\begin{array}{l}\text { County } \\
\text { Population } \\
\text { (d) }\end{array}$ \\
\hline Waipukurau & 0.33 & 5.06 & 18.22 & 1,581 \\
\hline Patangata & 0.54 & 6.77 & 22.05 & 1,936 \\
\hline Dannevirke & 0.58 & 2.99 & 11.47 & 4,683 \\
\hline Weber & 0.19 & 8.56 & 31.25 & 526 \\
\hline Woodville & 0.41 & 5.32 & 19.01 & 1,880 \\
\hline Pahiatua & 0.62 & 4.44 & 18.99 & 3,398 \\
\hline Akitio & 0.25 & 4.29 & 14.77 & 1,421 \\
\hline Eketahuna & 0.14 & 1.83 & 7.74 & 1,914 \\
\hline Waimarino & 0.58 & 3.37 & 11.40 & 4,151 \\
\hline Waitotara & 0.74 & 4.08 & 15.09 & 4,390 \\
\hline Wanganui & 0.65 & 4.42 & 16.94 & 3,549 \\
\hline Rangitikei & 1.58 & 4.26 & 16.47 & 9,042 \\
\hline Kiwitea & 0.39 & 3.38 & 15.38 & 2,781 \\
\hline Pohangina & 0.19 & 2.62 & 11.87 & 1,797 \\
\hline Oroua & 0.35 & 2.34 & 8.83 & 3,588 \\
\hline Manawatu & 0.39 & 2.15 & 9.02 & 4,461 \\
\hline Kairanga & 0.39 & 2.45 & 8.88 & 3,877 \\
\hline Horowhenua & 0.74 & 2.98 & 11.87 & 6,064 \\
\hline Masterton & 0.63 & 3.81 & 15.72 & 4,020 \\
\hline Mauriceville & 0.07 & 1.79 & 7.14 & 950 \\
\hline Castlepoint & 0.18 & 7.10 & 19.82 & 620 \\
\hline Wairarapa South & 0.34 & 3.02 & 14.07 & 2,745 \\
\hline Featherston & 0.77 & 4.74 & 16.85 & 3,965 \\
\hline Hutt & 0.65 & 3.04 & 11.39 & 5,189 \\
\hline Makara & 0.80 & 5.37 & 14.00 & 3,632 \\
\hline Sounds & 0.09 & 1.78 & 11.54 & 1,181 \\
\hline Marlborough & 1.02 & 3.08 & 14.85 & 8,056 \\
\hline Collingwood & 0.29 & 5.78 & 25.83 & 1,212 \\
\hline Takaka & 0.14 & 1.92 & 10.57 & 1,824 \\
\hline Waimea & 0.45 & 1.28 & 9.05 & 8,626 \\
\hline Buller & 2.38 & 8.64 & 20.59 & 6,698 \\
\hline Inangahua & 0.57 & 3.06 & 7.18 & 4,503 \\
\hline Murchison & 0.13 & 3.16 & 13.91 & 1,014 \\
\hline Amuri & 0.41 & 5.84 & 18.33 & 1,695 \\
\hline Cheviot & 0.32 & 5.64 & 20.00 & 1,383 \\
\hline Kaikoura & 0.28 & 3.48 & 16.46 & 1,926 \\
\hline Grey & 1.68 & 5.68 & 15.15 & 7,202 \\
\hline Westland & 0.77 & 4.38 & 14.03 & 4,274 \\
\hline Waipara & 0.57 & 7.07 & 25.23 & 1,966 \\
\hline Tawera & 0.29 & 5.72 & 16.95 & 1,241 \\
\hline Ashley & 1.27 & 3.29 & 14.36 & 9,417 \\
\hline Selwyn & 0.26 & 5.05 & 20.71 & 1,267 \\
\hline Waimairi & 1.95 & 3.50 & 11.35 & 13,582 \\
\hline Malvern & 0.46 & 3.24 & 13.51 & 3,458 \\
\hline Paparua & 0.42 & 2.47 & 9.83 & 4,092 \\
\hline Heathcote & 0.53 & 3.13 & 10.24 & 4,154 \\
\hline Halswell & 0.25 & 3.16 & 10.79 & 1,898 \\
\hline Springs & 0.27 & 3.49 & 14.25 & 1,891 \\
\hline
\end{tabular}




\begin{tabular}{|c|c|c|c|c|}
\hline $\begin{array}{l}\text { New Zealand } \\
\text { County }\end{array}$ & $\begin{array}{l}\text { \% of Scotland-born } \\
\text { population residing in } \\
\text { the county } \\
\text { (a) }\end{array}$ & $\begin{array}{l}\text { \% of county born } \\
\text { in Scotland } \\
\text { (Incl. NZ-born) } \\
\text { (b) }\end{array}$ & $\begin{array}{l}\text { \% of county born in } \\
\text { Scotland } \\
\text { (Excl. NZ-born) } \\
\text { (c) }\end{array}$ & $\begin{array}{l}\text { County } \\
\text { Population } \\
\text { (d) }\end{array}$ \\
\hline Ellesmere & 0.62 & 4.03 & 17.10 & 3,773 \\
\hline Mount Herbert & 0.14 & 7.54 & 30.70 & 464 \\
\hline Akaroa & 0.29 & 3.11 & 18.47 & 2,251 \\
\hline Wairewa & 0.15 & 4.03 & 17.39 & 894 \\
\hline Ashburton & 2.49 & 4.91 & 17.55 & 12,313 \\
\hline Geraldine & 1.08 & 4.58 & 15.73 & 5,741 \\
\hline Levels & 1.32 & 6.03 & 21.36 & 5,319 \\
\hline Mackenzie & 0.64 & 6.66 & 25.32 & 2,341 \\
\hline Waimate & 1.65 & 5.97 & 22.40 & 6,730 \\
\hline Waitaki & 4.18 & 10.45 & 41.43 & 9,733 \\
\hline Waihemo & 0.87 & 12.87 & 49.19 & 1,647 \\
\hline Vincent & 1.09 & 7.12 & 28.82 & 3,734 \\
\hline Maniototo & 0.94 & 8.14 & 29.47 & 2,812 \\
\hline Lake & 0.81 & 10.01 & 33.79 & 1,958 \\
\hline Tuapeka & 2.24 & 9.51 & 35.09 & 5,732 \\
\hline Waikouaiti & 2.21 & 12.46 & 38.40 & 4,318 \\
\hline Taieri & 3.08 & 12.08 & 47.74 & 6,202 \\
\hline Peninsula & 0.64 & 5.28 & 18.26 & 2,937 \\
\hline Bruce & 2.81 & 14.13 & 52.90 & 4,835 \\
\hline Clutha & 3.54 & 11.93 & 47.39 & 7,226 \\
\hline Southland & 9.97 & 9.16 & 37.24 & 26,460 \\
\hline Wallace & 3.03 & 7.83 & 30.45 & 9,422 \\
\hline Fiord & 0.02 & 9.52 & 25.00 & 42 \\
\hline Stewart Island & 0.17 & 11.48 & 28.67 & 357 \\
\hline Chatham Islands & 0.07 & 6.20 & 17.58 & 258 \\
\hline $\begin{array}{c}\text { Main Trunk } \\
\text { Railway }\end{array}$ & 0.02 & 3.50 & 9.43 & 143 \\
\hline
\end{tabular}


Appendix 3.4a

Diagram of the Cameron family and some of their associates in East Wairarapa

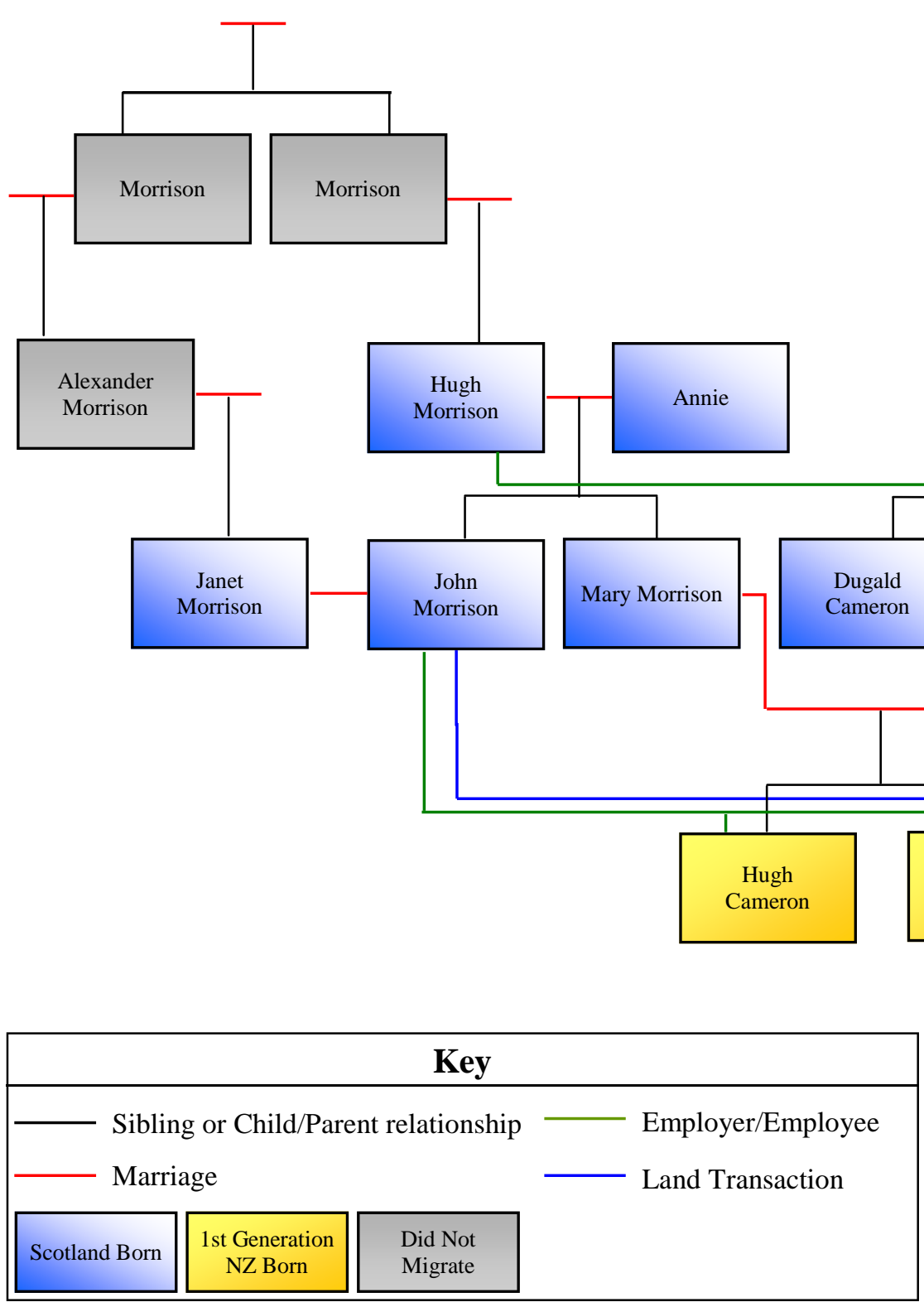


Appendix 3.4b

Diagram of the Cameron family and some of their associates in East Wairarapa

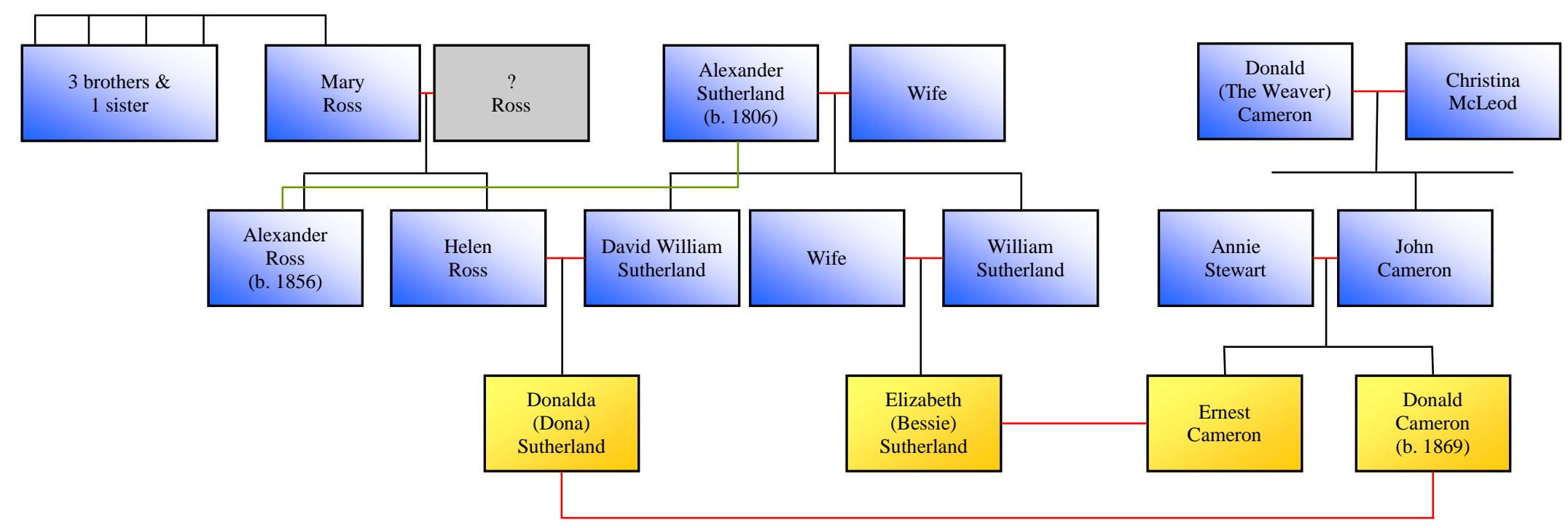

\section{Key}

\begin{tabular}{|c|c|c|c|}
\hline \multicolumn{4}{|c|}{ Кеу } \\
\hline \multirow{2}{*}{\multicolumn{3}{|c|}{$\begin{array}{l}\text { Sibling or Child/Parent relationship } \\
\text { Marriage }\end{array}$}} & \multirow{3}{*}{$\begin{array}{l}\text { Employer/Employee } \\
\text { Land Transaction }\end{array}$} \\
\hline & & & \\
\hline Scotland Born & $\begin{array}{l}\text { 1st Generation } \\
\text { NZ Born }\end{array}$ & $\begin{array}{l}\text { Did Not } \\
\text { Migrate }\end{array}$ & \\
\hline
\end{tabular}




\section{Appendix 3.5a}

Diagram of connections between the Scottish migrants and New Zealand born individuals of Scottish descent in Fordell, Mangamahu, Turakina and Parewanui

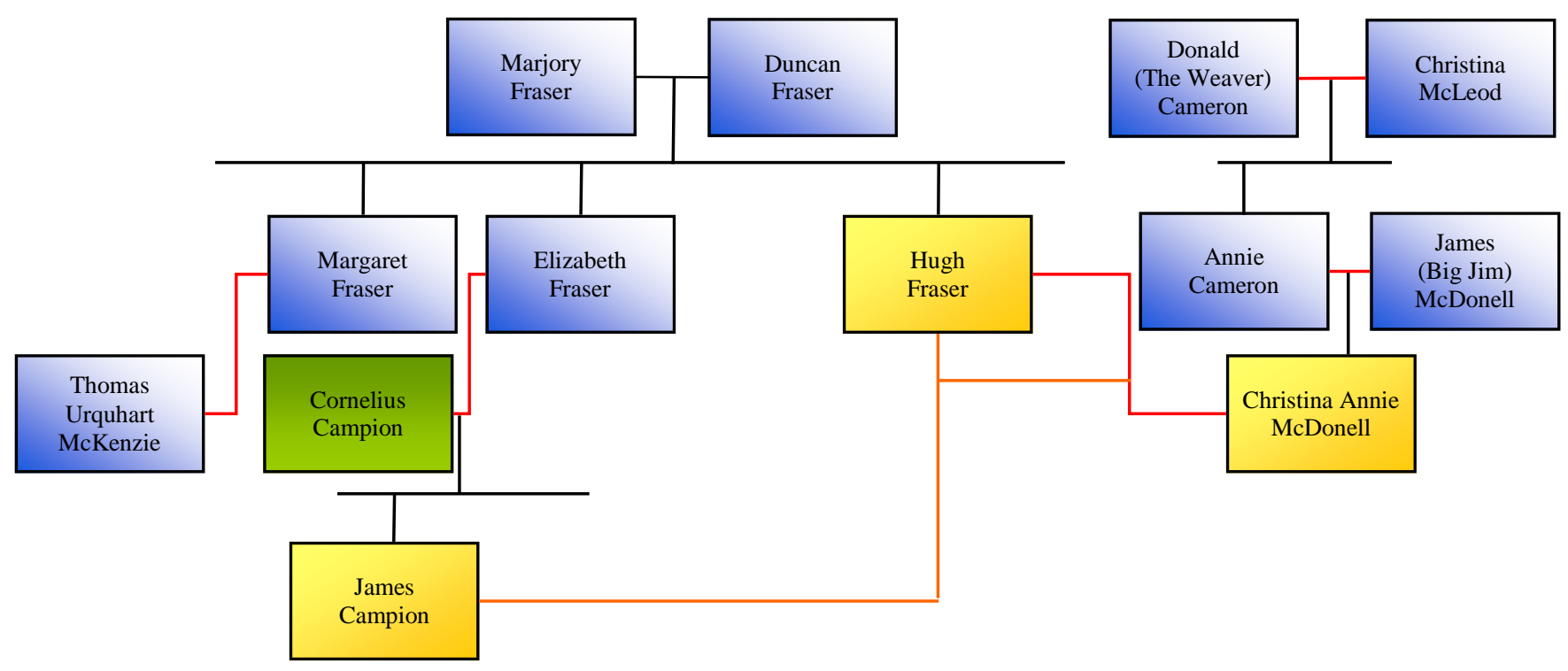

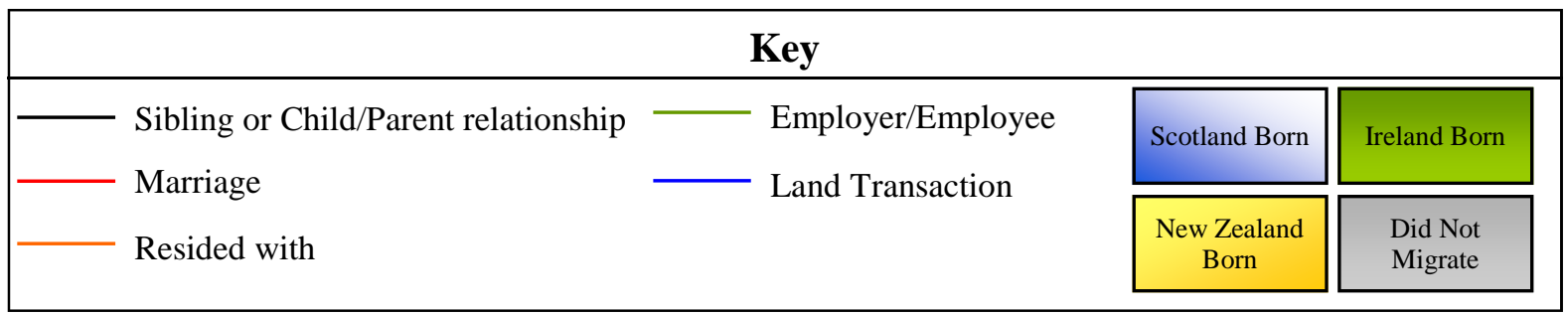


Appendix 3.5b

Diagram of connections between the Scottish migrants and New Zealand born individuals of Scottish descent in Fordell, Mangamahu, Turakina and Parewanui

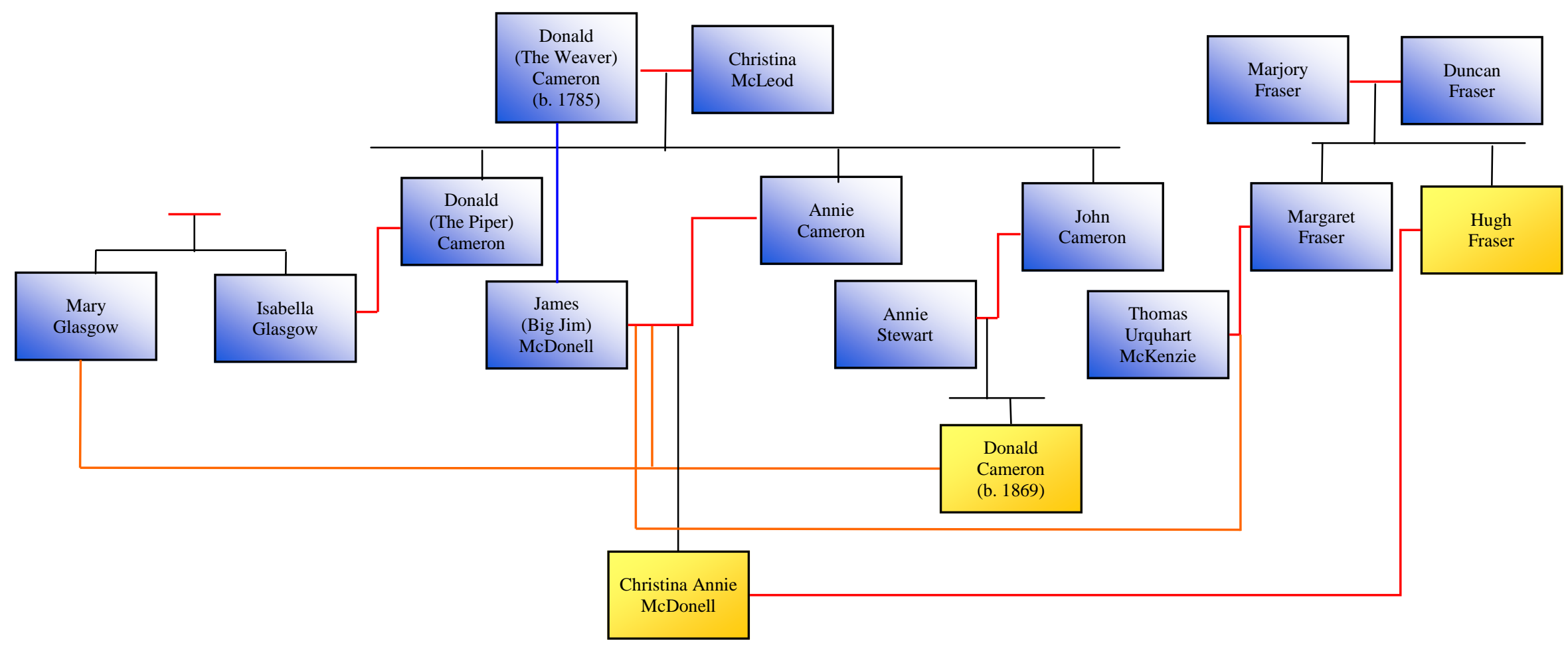

\begin{tabular}{|c|c|c|c|}
\hline \multicolumn{4}{|c|}{ Key } \\
\hline Sibling or Child/Parent relationship & Employer/Employee & Scotland Born & Ireland Born \\
\hline & & $\begin{array}{l}\text { New Zealand } \\
\text { Born }\end{array}$ & $\begin{array}{l}\text { Did Not } \\
\text { Migrate }\end{array}$ \\
\hline
\end{tabular}




\section{Appendix 3.5c-i}

Diagram of connections between the Scottish migrants and New Zealand born individuals of Scottish descent in Fordell, Mangamahu, Turakina and Parewanui

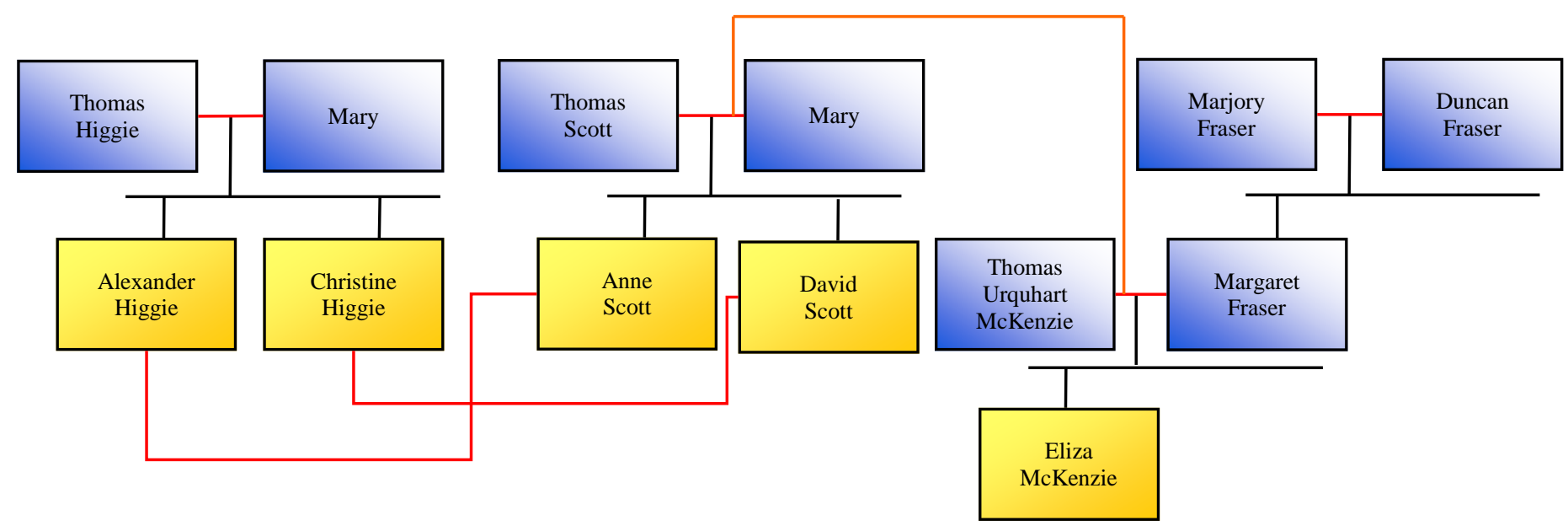

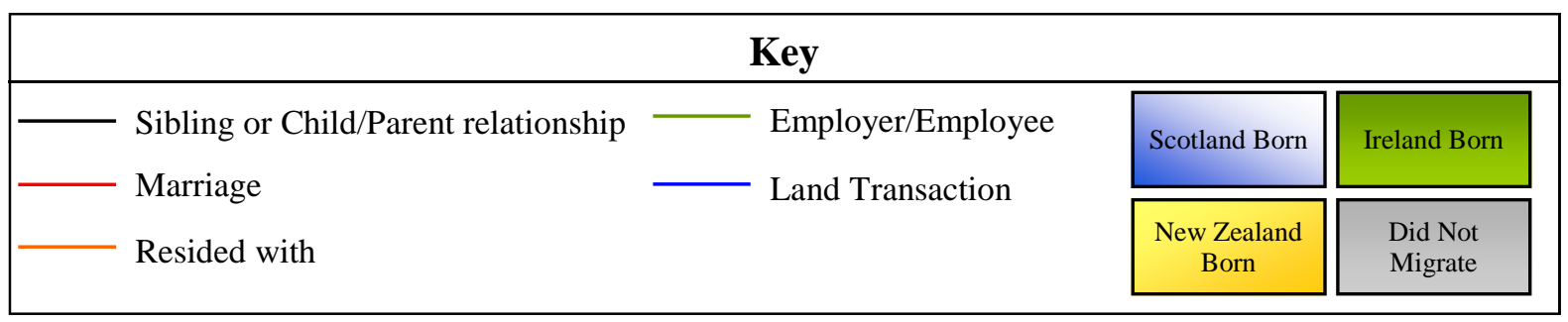


Appendix 3.5c-ii

Diagram of connections between the Scottish migrants and New Zealand born individuals of Scottish descent in Fordell, Mangamahu, Turakina and Parewanui

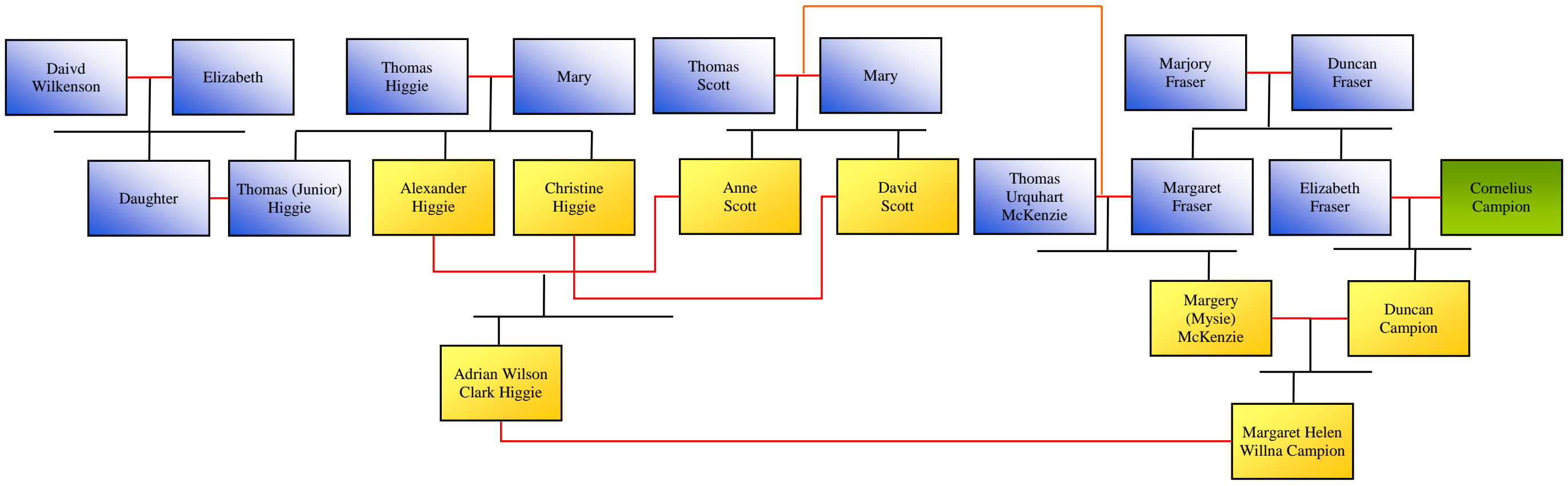

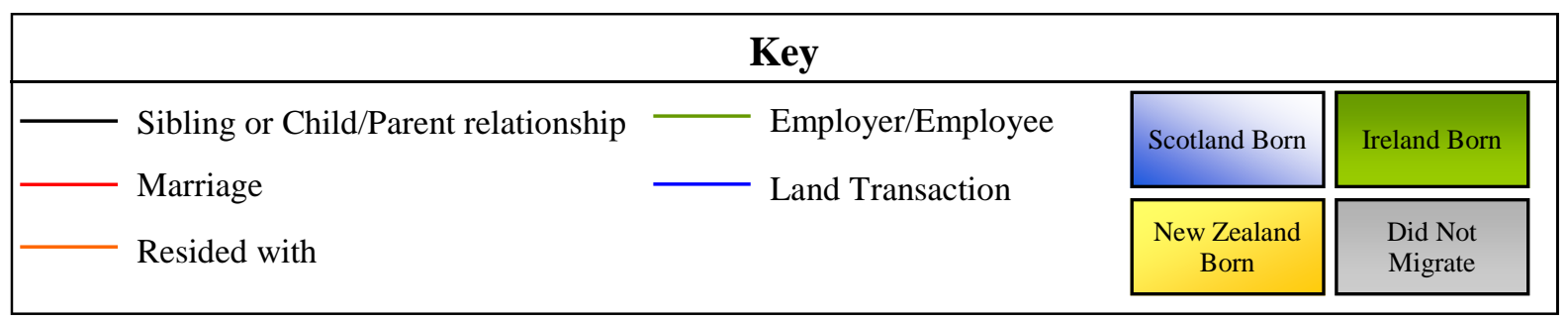


Appendix 3.5c-iii

Diagram of connections between the Scottish migrants and New Zealand born individuals of Scottish descent in Fordell, Mangamahu, Turakina and Parewanui

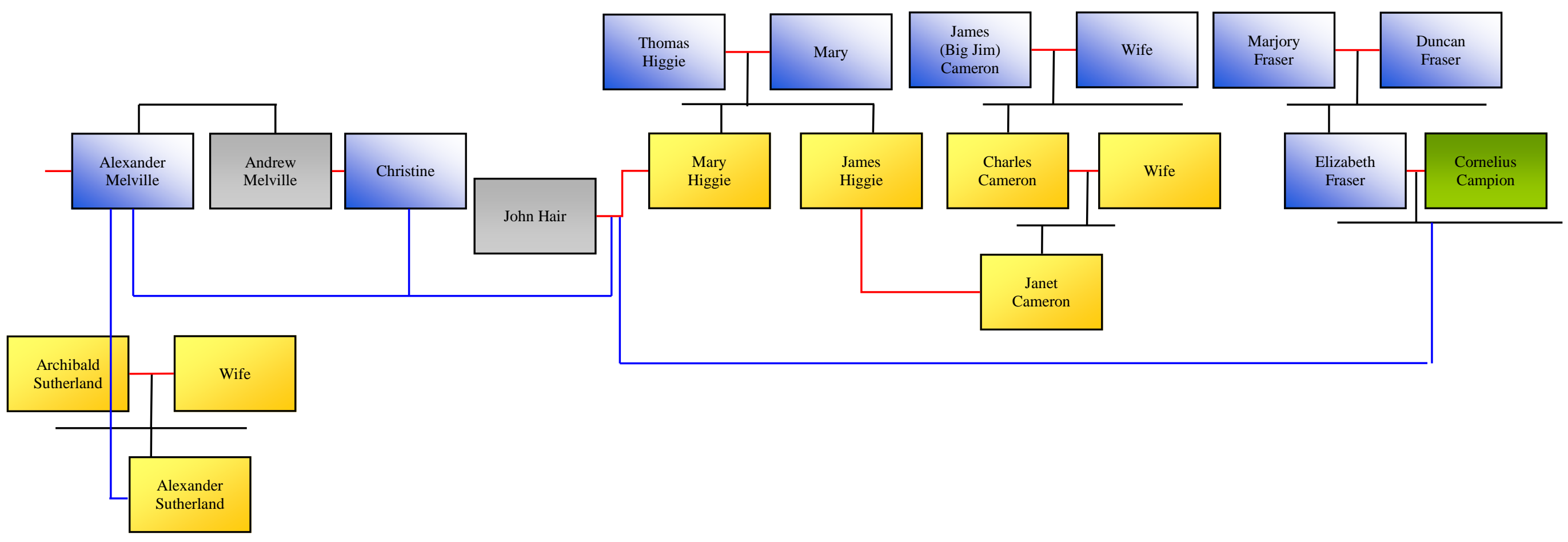

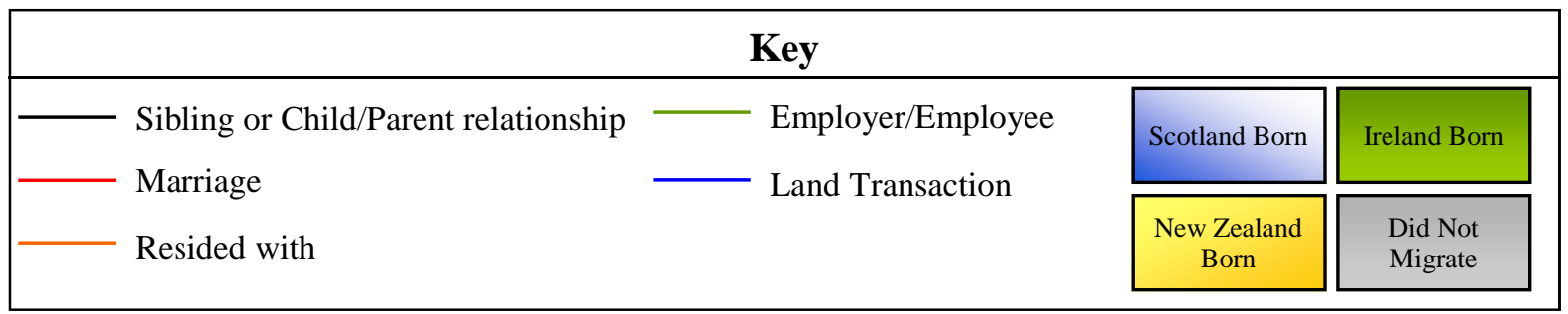




\section{Appendix 3.5d}

Diagram of connections between the Scottish migrants and New Zealand born individuals of Scottish descent in Fordell, Mangamahu, Turakina and Parewanui

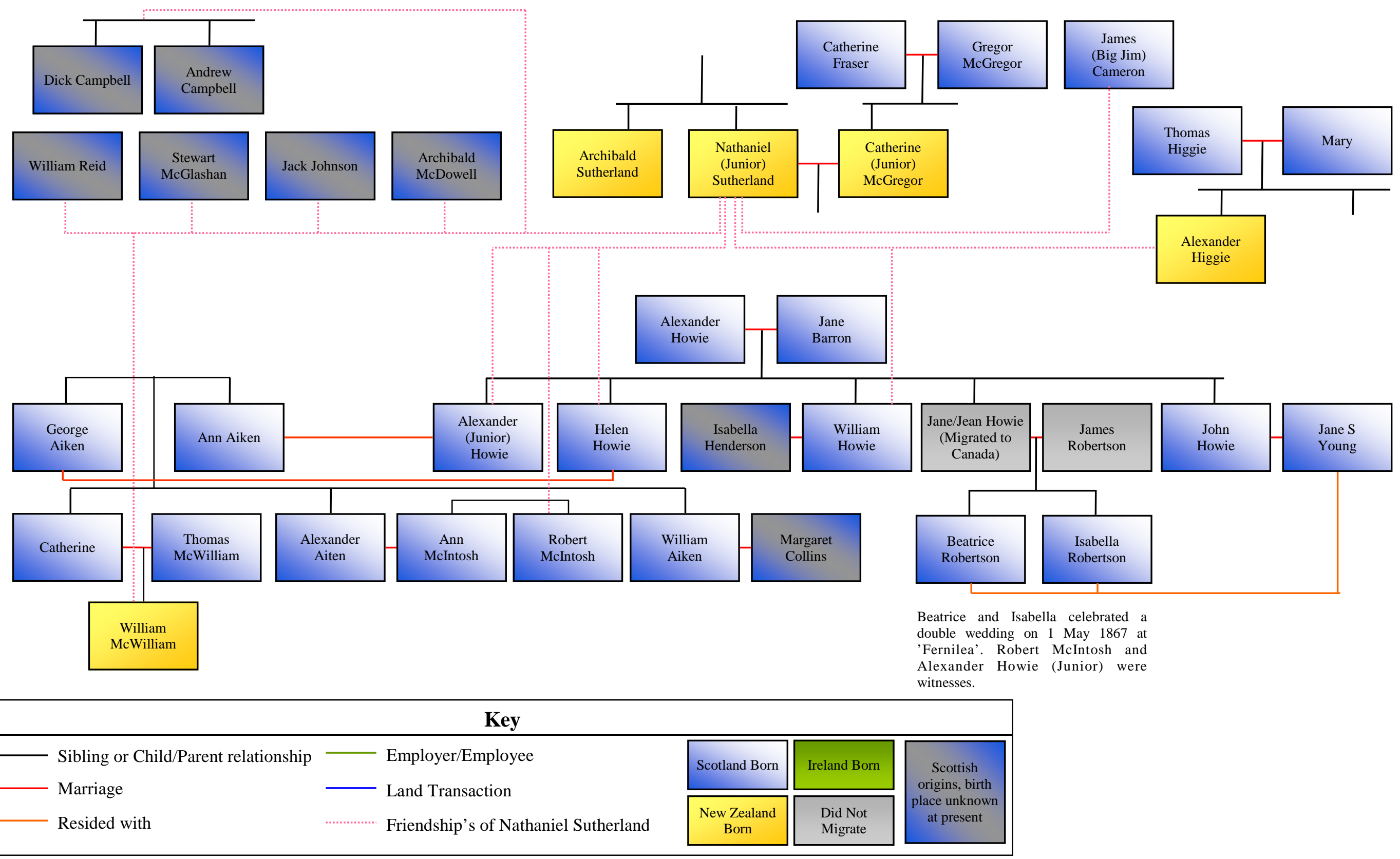




\section{Appendix 3.5e}

Diagram of connections between the Scottish migrants and New Zealand born individuals of Scottish descent in Fordell, Mangamahu, Turakina and Parewanui

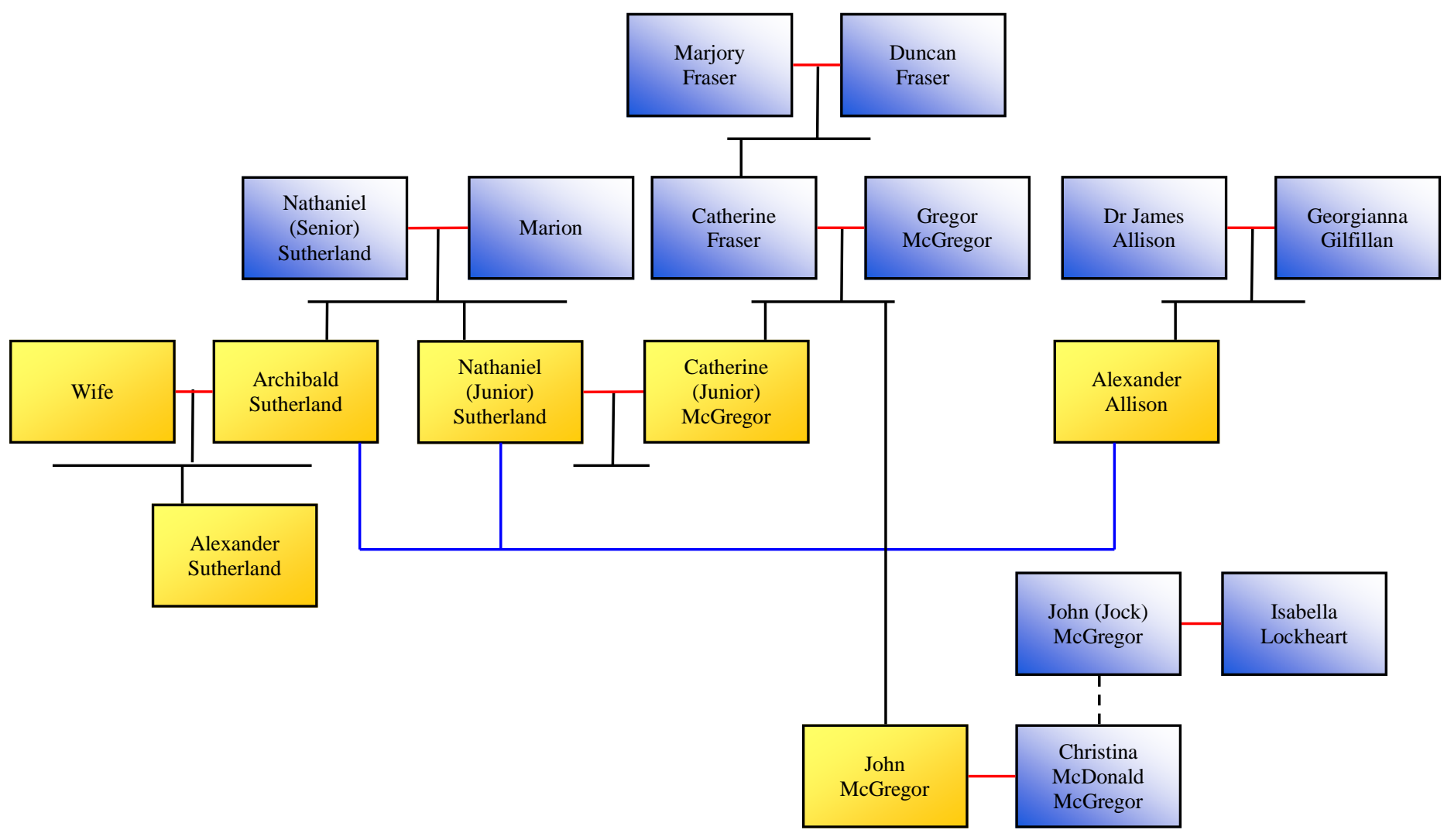

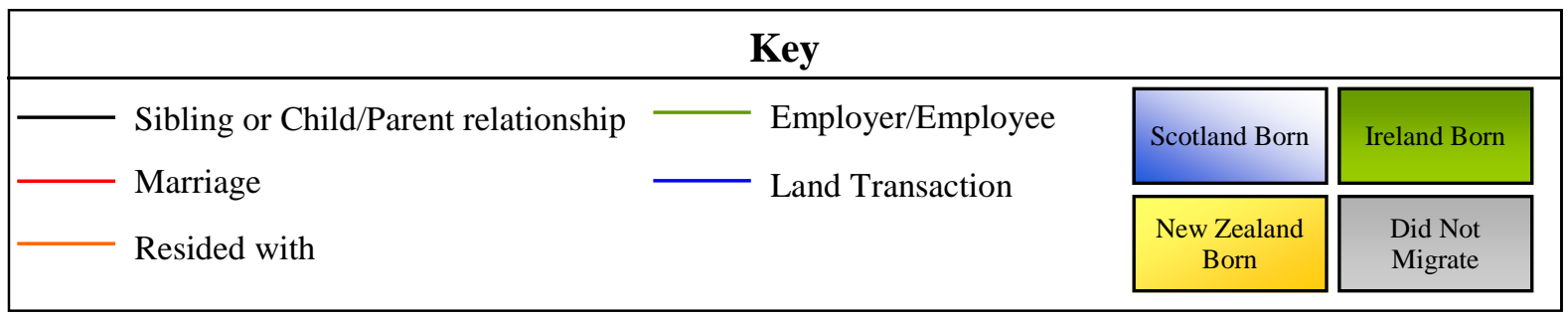




\section{Appendix 4.1}

Showing the mean, minimum, maximum, lower quartile, median and upper quartile age statistics for Scots migrants to New Zealand by county and region of birth.

\begin{tabular}{|c|c|c|c|c|c|c|c|c|}
\hline & & Mean & Minimum & LQ & Median & UQ & Maximum & $n$ \\
\hline \multirow{4}{*}{ Far North } & SHI & 24.69 & 2 & 11 & 21 & 38 & 56 & 111 \\
\hline & OKI & 26.00 & 1 & 20 & 24 & 29.75 & 62 & 56 \\
\hline & CAI & 22.91 & 1 & 12 & 22 & 29 & 67 & 121 \\
\hline & Total & 24.20 & 1 & 13 & 22 & 31 & 67 & 288 \\
\hline \multirow{6}{*}{$\begin{array}{l}\text { North } \\
\text { East }\end{array}$} & NAI & 25.50 & 4 & 21 & 23.5 & 36.5 & 40 & 8 \\
\hline & MOR & 22.31 & 0 & 9.75 & 20.5 & 31 & 64 & 78 \\
\hline & BAN & 26.96 & 1 & 20.75 & 25 & 35.25 & 65 & 74 \\
\hline & ABD & 23.96 & 0 & 13 & 23.5 & 32 & 68 & 404 \\
\hline & KCD & 25.45 & 0 & 13 & 24 & 34.25 & 64 & 58 \\
\hline & Total & 24.27 & 0 & 13 & 23.5 & 32 & 68 & 622 \\
\hline \multirow{6}{*}{ Highlands } & SUT & 27.96 & 1 & 17 & 26 & 36 & 65 & 75 \\
\hline & ROC & 25.78 & 0 & 14 & 23 & 36 & 71 & 247 \\
\hline & INV & 26.65 & 1 & 17 & 24 & 36 & 68 & 155 \\
\hline & ARL & 27.33 & 0 & 16 & 26 & 37 & 73 & 190 \\
\hline & BUT & 23.51 & 1 & 11.5 & 22 & 33 & 69 & 41 \\
\hline & Total & 26.45 & 0 & 15 & 24 & 36 & 73 & 709 \\
\hline \multirow{11}{*}{$\begin{array}{c}\text { Eastern } \\
\text { Lowlands }\end{array}$} & ANS & 23.42 & 0 & 11 & 23 & 32 & 75 & 191 \\
\hline & PER & 25.69 & 0 & 13 & 23 & 35 & 76 & 349 \\
\hline & DNB & 21.69 & 0 & 8 & 19 & 33.5 & 69 & 106 \\
\hline & CLK & 22.53 & 1 & 10 & 21 & 31.25 & 64 & 36 \\
\hline & KRS & 28.48 & 5 & 14 & 25 & 45 & 54 & 25 \\
\hline & FIF & 24.62 & 0 & 13 & 24 & 35 & 74 & 277 \\
\hline & STI & 22.27 & 0 & 8.5 & 22 & 33 & 72 & 225 \\
\hline & WLN & 23.38 & 0 & 10 & 20 & 35.5 & 76 & 69 \\
\hline & MLN & 21.40 & 0 & 10 & 21 & 30 & 74 & 450 \\
\hline & ELN & 21.68 & 0 & 9 & 17.5 & 30 & 67 & 90 \\
\hline & Total & 23.26 & 0 & 11 & 22 & 32 & 76 & 1,818 \\
\hline \multirow{4}{*}{$\begin{array}{l}\text { Western } \\
\text { Lowlands }\end{array}$} & RFW & 22.00 & 0 & 9 & 20 & 33 & 70 & 315 \\
\hline & LKS & 19.62 & 0 & 8 & 19 & 28 & 66 & 882 \\
\hline & AYR & 24.30 & 0 & 14 & 23 & 33 & 66 & 369 \\
\hline & Total & 21.21 & 0 & 10 & 20 & 29 & 70 & 1,571 \\
\hline \multirow{8}{*}{ Borders } & BEW & 28.78 & 1 & 19 & 25 & 39 & 67 & 65 \\
\hline & PEE & 27.20 & 2 & 19.75 & 25 & 35.25 & 53 & 30 \\
\hline & SEL & 24.46 & 1 & 12 & 20.5 & 34.5 & 62 & 24 \\
\hline & ROX & 23.62 & 0 & 11.75 & 24 & 31.25 & 70 & 122 \\
\hline & DFS & 23.98 & 0 & 15 & 24 & 31 & 72 & 137 \\
\hline & KKD & 25.43 & 0 & 11.25 & 23 & 36.25 & 80 & 72 \\
\hline & WIG & 24.08 & 0 & 16.25 & 24.5 & 30.75 & 56 & 64 \\
\hline & Total & 24.93 & 0 & 15 & 24 & 33 & 80 & 514 \\
\hline
\end{tabular}

Note: LQ = lower quartile i.e. 25 per cent of the migrants in the sub sample were under that age. Median = 50 per cent were under that age. UQ = upper quartile, i.e. 75 per cent were under that age.

Source: NZSG data 


\section{Appendix 4.2}

Marital status composition of Scots migrants by county and region of birth arriving in NZ between 1840 and 1920

\begin{tabular}{|c|c|c|c|c|c|c|}
\hline & \multicolumn{4}{|c|}{ Marital Status } & \multirow[b]{2}{*}{$\begin{array}{c}\text { Either } \\
\text { Widow or } \\
\text { Spouse } \\
\text { absent } \\
\end{array}$} & \multirow[b]{2}{*}{$n$} \\
\hline & Child & Single & Married & Widowed & & \\
\hline SHI & 39.45 & 34.86 & 23.85 & 1.83 & 0.00 & 109 \\
\hline OKI & 13.46 & 34.62 & 50.00 & 1.92 & 0.00 & 52 \\
\hline CAI & 34.15 & 32.52 & 31.71 & 1.63 & 0.00 & 123 \\
\hline Far North & 32.39 & 33.80 & 32.04 & 1.76 & 0.00 & 284 \\
\hline SUT & 21.62 & 28.38 & 50.00 & 0.00 & 0.00 & 74 \\
\hline ROC & 27.35 & 30.20 & 40.82 & 0.82 & 0.82 & 245 \\
\hline INV & 23.68 & 38.82 & 35.53 & 1.97 & 0.00 & 152 \\
\hline ARL & 24.08 & 29.84 & 43.46 & 1.57 & 1.05 & 191 \\
\hline BUT & 33.33 & 23.81 & 42.86 & 0.00 & 0.00 & 42 \\
\hline Highlands & 25.43 & 31.39 & 41.48 & 1.14 & 0.57 & 704 \\
\hline NAI & 12.50 & 62.50 & 25.00 & 0.00 & 0.00 & 8 \\
\hline MOR & 35.80 & 25.93 & 37.04 & 1.23 & 0.00 & 81 \\
\hline BAN & 15.38 & 38.46 & 39.74 & 5.13 & 1.28 & 78 \\
\hline ABD & 29.10 & 27.86 & 42.79 & 0.00 & 0.25 & 402 \\
\hline KCD & 26.79 & 21.43 & 50.00 & 1.79 & 0.00 & 56 \\
\hline North East & 27.84 & 28.80 & 42.08 & 0.96 & 0.32 & 625 \\
\hline ANS & 31.79 & 28.72 & 37.44 & 1.54 & 0.51 & 195 \\
\hline PER & 33.14 & 21.60 & 42.31 & 2.66 & 0.30 & 338 \\
\hline DNB & 46.23 & 17.92 & 34.91 & 0.94 & 0.00 & 106 \\
\hline CLK & 34.29 & 34.29 & 28.57 & 2.86 & 0.00 & 35 \\
\hline KRS & 0.00 & 20.00 & 75.00 & 0.00 & 5.00 & 20 \\
\hline FIF & 30.40 & 23.81 & 44.32 & 1.10 & 0.37 & 273 \\
\hline STI & 39.11 & 19.56 & 39.11 & 2.22 & 0.00 & 225 \\
\hline WLN & 40.58 & 13.04 & 42.03 & 2.90 & 1.45 & 69 \\
\hline MLN & 36.24 & 22.60 & 38.70 & 2.01 & 0.45 & 447 \\
\hline ELN & 45.65 & 11.96 & 39.13 & 2.17 & 1.09 & 92 \\
\hline Eastern Lowlands & 35.44 & 21.89 & 40.28 & 1.94 & 0.44 & 1,800 \\
\hline RFW & 39.63 & 19.50 & 37.46 & 2.17 & 1.24 & 323 \\
\hline LKS & 43.04 & 22.04 & 34.11 & 0.81 & 0.00 & 862 \\
\hline AYR & 27.99 & 23.91 & 46.47 & 0.54 & 1.09 & 368 \\
\hline Western Lowlands & 38.76 & 21.96 & 37.73 & 1.03 & 0.52 & 1,553 \\
\hline BEW & 15.38 & 23.08 & 61.54 & 0.00 & 0.00 & 65 \\
\hline PEE & 9.68 & 38.71 & 51.61 & 0.00 & 0.00 & 31 \\
\hline SEL & 33.33 & 25.00 & 41.67 & 0.00 & 0.00 & 24 \\
\hline ROX & 32.17 & 25.22 & 40.87 & 0.87 & 0.87 & 115 \\
\hline DFS & 27.41 & 29.63 & 40.00 & 2.96 & 0.00 & 135 \\
\hline KKD & 30.56 & 22.22 & 45.83 & 1.39 & 0.00 & 72 \\
\hline WIG & 20.31 & 32.81 & 45.31 & 1.56 & 0.00 & 64 \\
\hline Borders & 25.69 & 27.47 & 45.26 & 1.38 & 0.20 & 506 \\
\hline Total & 33.19 & 24.34 & 40.58 & 1.44 & 0.45 & 5,472 \\
\hline
\end{tabular}




\section{Appendix 4.3}

Proportion of male and female Scots migrants that arrived in New Zealand as children, single or married in each period of arrival

\begin{tabular}{|c|c|c|c|c|c|}
\hline & & Child & Single & Married & $n$ \\
\hline \multirow{3}{*}{ Pre-1852 } & Male & 36.98 & 20.71 & 41.72 & 338 \\
\hline & Female & 44.44 & 14.24 & 38.54 & 288 \\
\hline & Total & 40.42 & 17.73 & 40.26 & 626 \\
\hline \multirow{3}{*}{$1853-1870$} & Male & 29.58 & 27.87 & 41.46 & 1,457 \\
\hline & Female & 34.2 & 21.01 & 41.93 & 1,190 \\
\hline & Total & 31.66 & 24.78 & 41.67 & 2,647 \\
\hline \multirow{3}{*}{$1871-1886$} & Male & 37.34 & 25.78 & 36.07 & 865 \\
\hline & Female & 35.64 & 23.5 & 37.6 & 766 \\
\hline & Total & 36.54 & 24.71 & 36.79 & 1,631 \\
\hline \multirow{3}{*}{$1887-1900$} & Male & 27.17 & 32.16 & 36.96 & 92 \\
\hline & Female & 25 & 15.63 & 54.69 & 64 \\
\hline & Total & 26.28 & 25.64 & 44.23 & 156 \\
\hline \multirow{3}{*}{$1901-1920$} & Male & 34.75 & 27.3 & 36.88 & 282 \\
\hline & Female & 33.61 & 26.23 & 38.52 & 244 \\
\hline & Total & 34.22 & 26.81 & 37.64 & 526 \\
\hline
\end{tabular}

*Excludes widowed and widowed or spouse absent

Source: NZSG data, 1840-1920 


\section{Appendix 5.1 \\ METHODOLOGICAL AND CLASSIFICATION CONSIDERATIONS REGARDING MIGRANT OCCUPATIONS.}

As noted in Chapter Five, occupation is an aspect of the migrant profile that is significantly affected by methodological and classification issues, thereby inviting additional comment to that included in the primary methodological appendix (Appendix 1.1) and in the methodological section of Chapter Five itself.

\section{Methodology}

A strength of the NZSG data is that is often provides richer occupation information than might otherwise be possible, contributors having recorded up to seven occupations held by a migrant. This rich data indicates very clearly that a 'snapshot' of occupation, such as is available from a birth, marriage or death certificate, or from the census, may reveal only a small part of a migrant's occupational story. Although contributors to the register were asked to list 'up to two occupations', many fortunately (from the point of view of the present study) chose instead to list three, four and sometimes five occupations held by the migrant in Scotland and/or in New Zealand. ${ }^{1}$ To facilitate statistical analysis, however, it became necessary to examine only one pre-emigration occupation for each migrant, and, except where multiple occupations held post-migration were compared, one occupation held in New Zealand. The snapshot of migrant occupations in the PNZ data was prescribed, and that snapshot is likely to be of the occupation engaged in immediately prior to death. Consequently, the PNZ dataset might be expected to include more migrants in senior positions within their occupational 'sectors' than would be likely if the data was extrapolated at an earlier point in the migrant's life. Because of the way in which the NZSG register was compiled, it is unknown from which point in any individual's life history that snapshot was taken. Moreover, because death certificates are utilised by genealogists in tracing their ancestors, it is likely that the most senior or prestigious position occupation by an individual has also unduly affected the NZSG data. The fact

\footnotetext{
${ }^{1}$ Sixteen migrants have three occupations recorded for their time Scotland, 267 have two occupations recorded pre-emigration, and 2,758 have only one Scotland occupation recorded. In the New Zealand occupation variable, three NZSG migrants have five occupations recorded on the registration form; sixteen migrants have four occupations recorded; 144 migrants have three occupations recorded; 1,053 had two occupations; and 3,212 appear to have been employed in only one occupation in New Zealand.
} 
that it is unknown when a death certificate was the contributor's only source of occupation information makes the NZSG data even more problematical.

Information from registration forms was entered into the NZSG database in the order it was recorded on the forms. The first occupation recorded in the Scotland occupation variable became 'Scotland Occupation 1' and the first and second occupations recorded in the New Zealand occupation variable for each migrant in the database have been entered as 'New Zealand Occupation 1', and 'New Zealand Occupation 2' respectively. However, whether contributors generally noted occupations in chronological order, or perhaps the order in which they found them in their research notes is unknown. Therefore, while the analysis of individual occupational mobility was based upon migrants New Zealand Occupation 1 and New Zealand Occupation 2 (see Table 5.14 and discussion) it should be recognised that the findings are indicative only. There is no evidence as to whether occupations were held concurrently, consecutively, or if other occupations were taken up between holding the two jobs.

An issue that plagues the census data as well as the PNZ and NZSG datasets relates to the recording of the occupations. Often in the PNZ and NZSG data the migrant's occupational experience is generalised, included within such terms as 'farming', 'building', or 'mining', rather than specifying the particular positions the migrant held. ${ }^{2}$ This clumping of occupations under general terms is exacerbated further in the census data by the aggregation of occupations in the published reports into groups that do not take status differences or the nature of the work into account. Olssen and Hickey note, for example, the aggregation of 'Mine proprietor, overseer, miner, clerk and others engaged in coal-mining' at the 1891 census, the destruction of the enumerators returns not allowing this group to be disaggregated to serve other purposes or address other questions. ${ }^{3}$ This non-specificity is impractical from a statistical, as well as a qualitative, point of view. It further intensifies the effect of the snapshot of the migrant's occupation being taken from death certificates, and this is especially noticeable in the NZSG data. In the classification scheme devised for the study, agricultural occupations have been divided into 'farmer', 'farm labourer 1',

\footnotetext{
${ }^{2}$ Among migrant's Scotland occupations: 'farming' - eighteen migrants, 'building' - one migrant, and 'mining' - five migrants; migrant's New Zealand occupations: 'farming' - thirty-three migrants, 'building' - six migrants, and 'mining' - four migrants.

${ }^{3}$ Erik Olssen and Maureen Hickey, Class and Occupation: The New Zealand Reality, Dunedin, 2005p.43
} 
'farm labourer 2' and 'other rural'. In the PNZ dataset the proportion of those classified as 'farmer' is much higher than would probably have been the case if census data had been available for analysis, i.e. if the snapshot included migrants at all stages of their working lives and not merely at the end. For example, 77.96 per cent of the PNZ 'agricultural' sector migrants fall within the 'farmer' category, rather than being recorded as farm labourers or as working in another rural occupation. Though it may be that many people providing information for death certificates somewhat misleadingly recorded the occupation of people employed as farm labourers as 'farmer', indicating a proprietorial rather than labouring role, it is also likely that by the time of death many of the migrants had become farmers in their own right even if only on small freehold plots. The NZSG data is potentially skewed not only by the use of death certificates as the basic information source for migrant occupations, but also by the generalising of migrant occupational experiences. 'Farmer' is the listed occupational type of 85.74 per cent of NZSG agricultural migrants, just 5.74 per cent of NZSG agricultural migrants are recorded as 'farm workers 1' and 3.9 per cent as 'farm workers 2'. 'Others rural' constitute the remaining 4.62 per cent, and includes gardeners as well as fishermen.

\section{ClASSIFICATIONS}

Because New Zealand census occupation information for the study period is not provided by country of birth, the available data can only be used as a very general guideline when investigating the Scots. Consequently, data sampled from other sources, in this case the NZSG and PNZ datasets, must be utilised, and in order to enable meaningful analysis this data must be classified.

Migrants must be fitted to a set of classifications rather than classifications being fitted to the sample of migrants. The classifications, however, must be devised with the migrant group in mind; a classification system created for analysis of contemporary migrants would be of limited value in the study of those migrating pre1920. ${ }^{4}$ Categories of occupation cannot be too broad nor too narrow. While 'agricultural' appears, at face value, to be a useful delineation, it is too broad to reveal much of significance about the livings of the migrants; both the owner/manager of a large sheep run and a first-time farm hand may be included in the same classification.

\footnotetext{
${ }^{4}$ The number of computer technicians employed in the nineteenth century, for example, was zero.
} 
On the other hand, classifications that are too specific tend to make data too fragmentary for useful analysis.

Classifications employed for both the contemporary Scotland and New Zealand censuses were quickly dismissed as possibilities for the present research. Those used in the Scotland census would have required considerable alteration to accommodate New Zealand occupations. The New Zealand census would also have needed significant modification; occupations were often curiously classified and the classifications are not intuitive: pottery makers, railway labourers and night men/scavengers were all included in Class V, Order XI, Sub-Order 3 at the 1878 census; both basket makers and kauri gum diggers were included in Class V, Order XI, Sub-Order 2. With the PNZ data made available, fathers' but not migrants' occupations had been categorised. ${ }^{5}$ Phillips and Hearn employed the following occupation categorisation: ${ }^{6}$

1. Agricultural
a) Farmers
b) Agricultural Labourers

2. Labourers (not otherwise stated)

3. Servants

4. Occupations with relatively little technical change

a) Building

b) Mining

c) Other pre-industrial

5. Occupations with relatively great technical change

a) Mechanics (not otherwise stated)

b) Others

6. White Collar

7. Other Occupations

Not being defined beyond these descriptions, this classification was also rejected for the present research, it being considered that it grouped the migrants too broadly for the desired level of analysis.

Another classification system considered for adoption is that used by McAloon in his studies of individuals listed in the Cyclopedia of New Zealand. McAloon employed fifteen categories for his analysis of occupation and class: Farming, Manufacturing, Maritime, Mercantile, Military, Mining, News/Printing, Official, Professional, Rural Wage, Self Employed, Skilled Trades, Unskilled, White Collar,

\footnotetext{
${ }^{5}$ Publications based on this data have not utilised migrant occupations to date.

${ }^{6}$ This is based upon the classification scheme presented in Appendix C, C.J. Erickson, 'Who were the English and Scots emigrants to the United States in the late nineteenth century?' in Population and Social Change, ed. D.V. Glass and Roger Revelle, London, 1972, p.378
} 
and Wholesale/Retail. ${ }^{7}$ With the primary objective of the present study being to present basic figures on the occupations of the migrants, not to study class more particularly, McAloon's scheme was also deemed to be not wholly appropriate.

For the present research the occupation classification scheme finally adopted was broadly based upon that utilised by Rosalind McClean in her 1990 thesis. The primary reason was to facilitate easy comparison between the present study and McClean's earlier research, the only previous work to focus statistically on New Zealand's Scots. ${ }^{8}$ The list below is a compression of the classifications adopted. The full list includes every occupation recorded on NZSG registration forms within the categories to which they were assigned; this abbreviated list is less specific, but will help explain how occupations were classified. The classification was subsequently applied to the PNZ dataset, and the results of the 1878 New Zealand census have also been reclassified accordingly. The classification of some occupations proved more difficult than others and these have been annotated. Categories within occupational sectors have been further sub-divided, in some cases to reflect the perceived skill involved in the job and in others simply to disaggregate occupations of a dissimilar nature within sectors from one another with no intention of hierarchy.

The reclassification of the New Zealand census presented difficulties. Even at the lowest level of disaggregation occupations were occasionally apparently incongruously clustered. 'Reporter, shorthand writer', occupation titles that appear to describe two quite different jobs, were included in the reclassification as 'professional 2', rather than 'clerical'; 'irregular medical practitioners' were also classified as 'professional 2'. 'Auctioneer, Appraiser, Valuer' could not be disaggregated, being thus included within 'miscellaneous retail'. While 'umbrella, parasol and stick' makers, dealers and menders might otherwise have been grouped separately into retail and manufacturing, this occupation group was classified as 'manufacturing, textiles'. 'Animal and bird' dealers and keepers were also grouped together in the census, as were all 'farmers, market gardeners'. 'Railway officer, clerk, stationmaster' was

\footnotetext{
${ }^{7}$ Jim McAloon, 'The Scottish Diaspora and the Colonial Middle Class', Nations, Diasporas, Identities, 29 March 2008

${ }^{8}$ This explicit comparison was possible, as McClean made her original data available for the present work. Thus it could have been recoded and compared, alongside the PNZ data and the 1878 census data, with the NZSG data. It was eventually decided not to follow this course. The extra comparative dimension may have added a further layer of complexity to the present study, but not necessarily a further layer of elucidation.
} 
another census grouping hard to disaggregate, clerks not being separated into 'clerical and financial' for the 1878 census data.

Appendix 5.1a follows this classification scheme. It shows the proportion of NZSG migrants employed in each occupation sector and type in Scotland Occupation 1 and New Zealand Occupation 1 over the period 1840-1920.

\section{OCCUPATION CLASSIFICATION SCHEME}

\section{Agricultural}

\section{Farmer}

Agriculturalist/Agricultural settler

Breeder

Crofter

Farmer/Dairy farmer/Poultry farmer/Sheep farmer

This occupation, though difficult to classify under any other heading, has considerably increased the number of migrants in the 'Farmer' occupation type. It could be that many of those recorded as 'Farmer' were, in reality, farm hands or labourers rather than 'farmers' in their own right.

Farmer's daughter/son/wife

The decision to include these migrants in this category is potentially controversial, but - as the contributors of the information have also concluded by recording occupation in this way - the 'dependants' of farmers were likely to also have been employed on the farm and were therefore not purely 'dependants' as the wives and children of men with other occupations may have been. The 1878 New Zealand census information also disaggregated such individuals from 'dependants', with separate 'occupation' listings for 'Farmer's wife, assisting on farm', 'Farmer's son, daughter, or other relative over 15 years of age living on farm, if not otherwise described, or under 15 if stated to be assisting on farm', as well as this same description for

Run holder runholder's and grazier's sons, daughters and other relatives.

Stable proprietor

Tenant crofter

\section{Farm Worker 1}

Estate manager

Factor

Farm bailiff/manager/overseer

Run manager

Shepherd

Station manager

Stable keeper/manager

Stock inspector

\section{Farm Worker 2}

Agricultural contractor/labourer

Cow herd

Dairy maid 
Dairy worker/man

Farm hand/labourer/servant

Grazier

Horse breaker/driver/trainer

Shearer

Station hand

Stock man

Others Rural

Agricultural pursuits

Bee keeper

Bush feller

Bush man

Fellmonger

Fisherman/Fishing

Forestry overseer/Forester

Hunter

Gardener

Green keeper

Horticulturalist

Kauri bushman

Orchardist

Park keeper

Rabbiter/Rabbit agent/catcher

Saw doctor/Sawmill hand/Saw miller

Due to the larger number of migrants described as being in these occupations in New Zealand, they have been allocated to this category. They could have been allocated to a manufacturing or industrial classification if more were known about the nature of their work.

Travelling botanist

Without further information, this migrant was classified as 'other rural', Whaler although 'professional' may have been a more accurate designation..

\section{Mining}

\section{Mining Managerial}

Coal company manager/proprietor

Mine/Quarry manager

\section{Miners}

Brick maker

As with lime makers, brick makers were clearly not miners. They were working with the products of mines, however, and were at risk of some of the dangers involved with these products. Possible alternative classifications may have been in Building; Pre-industrial and Unchanging Skills - Miscellaneous Crafts and Unspecified; or Industrial and Changing Skills - Miscellaneous Manufacture

Coal emptier

It has been assumed that this occupation description refers to someone working in a coal mine. 
Coal miner

Gold assayer/miner/prospector

Gum sorter/digger

Iron miner

Lime maker

See 'brick maker'

Miner

Quarrier/Quarry labourer

\section{Building}

This sector has been categorised broadly hierarchically, from those in the most highly-skilled building sector occupations in 'management' to the least skilled in 'operative 2' - separating out road and rail construction workers from other builders, and separating those involved in other trades connected to building who were not involved in actual construction work.

\section{Building Management}

Architect (and assistants)

Building inspector

Civil engineer

Draughtsman

Engineer (and apprentices and assistants)

This classification was especially problematic, as the meaning of 'engineer' varied over time. A migrant so described in 1840 in Scotland may have been involved in different work to a migrant described as such in $1920 \mathrm{New}$ Zealand. Thirty-four migrants were described simply as 'Engineer' in the Scotland occupation field and seventy-four in the New Zealand occupation field.

Master builder

Master plumber

Merchant carpenter

Surveyor (and assistants)

\section{Operative 1}

Bricklayer

Carpenter

Carpenters might also have been classified under 'Pre-industrial and Unchanging Skills - Woodworking Trades' as for example cabinet makers have been.

Mason

Plasterer

Plumber

Slater

\section{Operative 2}

Bricklayer's labourer

Builder

Contractor

Drain layer

Engineer's labourer

Fencer 
Shingle splitter

Stone cutter/hewer

Surveyor's chainman/labourer

Operative 2 - Road and Rail Construction

Bridge builder

Council road worker

Platelayer

Railway builder/construction/ganger/labourer/platelayer/surfaceman

Roading labourer/contractor/maker/worker

Tunnel worker

\section{Other Building Related Trades}

Decorator

House painter

Glazier

Paper hanger

\section{Labouring}

\section{Skilled Labourers}

Those labourers who would have required additional competencies to those engaged in general labouring occupations

Dredge engineer/master

\section{Labourers}

Ditchdigger

Dredge-hand

Labourer

This is another problematic occupation, in that depending on the type of work the migrant may well have fitted within another grouping.

\section{Manufacturing}

Manufacturing Management and Ownership

Co-Owner, Flour Mill

Co-Founder of company

Manager (Boot maker/Dairy factory/Flour mill/Motor Firm/Meatworks/Mill/Wollen mill/Timber mill)

Manufacturer (Cordial/Hosiery/Plough/Rug/Tapestry)

\section{Pre-industrial and Unchanging Skills - Clothing Trades}

Occupations in the Pre-industrial and Unchanging skills categories are those in which technological advances had been minimal.

Boot finisher/maker/trade

Clothier

Cobbler (and apprentice)

Darner

Dressmaker

Knitter

Leather cutter 
Milliner

Needlewoman

Pattern maker

Seamstress

Sewer

Shawl designer/weaver

Shoemaker/master (and apprentice)

Straw-hat maker

Tailor/Tailoress

Tweed designer

Weaver/Hand weaver/Tartan weaver

Pre-industrial and Unchanging Skills - Food Preparation and Manufacture

Bacon curer

Brewer

Cheesemaker

Distiller/Distillery worker

Fish curer/preparation

Flesher

All six of the fleshers recorded in the NZSG data were so employed in Scotland, and five of them are subsequently recorded as butchers in New Zealand. The reason fleshers have been placed in this category rather than as retail proprietors, as with butchers, is the probability that they worked for someone else in Scotland, whereas 'butcher' in New Zealand generally implies that the individual was owner and operator of a butchery.

Flour mill worker

Maltster

Meat inspector

Miller

Pre-industrial and Unchanging Skills - Metal Trades

Blacksmith (and apprentice)

Brass engineering/finisher/founder/moulder

Founder/Foundry worker

Galvanizer

Iron founder/puddler/worker

Jeweller

Silversmith

Smith - tin/copper/stove

Pre-industrial and Unchanging Skills - Woodworking Trades

Bedmaker

Cabinet maker

Carriage builder

Cart and plough wright (and apprentice)

Coach builder

Cooper

French polisher

Joiner (and apprentice)

Lathe splitter 
Shop carpenter

Wheelwright

Wood turner

Wood boilerman

Pre-industrial and Unchanging Skills - Miscellaneous Crafts and Unspecified

Basket maker

Candle maker

Cane worker

Compositor

Curier

Dutcher

Embosser

Fishing net weaver

Gem engraver

Gilder

Skinner

Paper maker

Potter

Saddlemaker/Saddler (and apprentice)

Sailmaker

Sheep skin dresser

Tile maker

Tobacco pipe finisher

Upholsterer

Industrial and Changing Skills - Miscellaneous Manufacture

Occupations in the Industrial and Changing skills categories are those in which technological advances had impacted greatly on the work involved, and the skills required of those employed in the occupations had changed alongside.

Book binder/folder

Bottle maker

Engine fitter/keeper

Freezing works

Gas fitter

Iron store porter

Lithographer/apprentice/assistant

Meter repairer

Printer (and assistant)

Publisher

Industrial and Changing Skills - Shipbuilders

Boat builder

Ship builder/wright/carpenter/chandlery/riveter/smith

Shipyard worker

Industrial and Changing Skills - Textiles

Beater-man in papermill

Bleacher 
Calico maker/printer

Clicker

Cloth lapper

Cotton reeler/spinner/mill worker

Flax cutter

Flax dresser/miller/spinner/Flax mill labourer/worker

Handloom weaver

Hosier

Piecer

Power loom weaver

Rope spinner/maker

Sewing machinist

Stocking maker

Threadmill worker

Weaver - canvas/cotton/damask/stocking/wool/hand woollen

Weft winder weaver

Wool - buyer/classer/ darner/dyer/finisher spinner/warper/yarn twister

Industrial and Changing Skills - Toolmakers, etc.

Boiler maker

Clock repairer

Engine maker

Fitter and turner

Gunsmith

Iron pattern maker

Iron moulder/turner

Machine maker

Master watchmaker/watchmaker

Scale maker

Toolmaker

Industrial and Changing Skills - Unspecified Mechanics

Cycle mechanic

Factory operative/worker

Machinist

Mechanic

Wright

\section{Transport and Commercial}

\section{Inland Transport}

Those engaged in transport on land and inland - i.e. all those involved in transport not at sea, hence the inclusion of those working on river steamers, inland ferries, harbour workers, jetty and lighthouse keepers

Assistant General Manager, New Zealand Railways

Bridge keeper, New Zealand Rail

Cab proprietor

Carrier

Carter

Coach driver

Harbour master 
Dock worker

Driver/Engine driver

Ferry boatman

Fireman, Waikato Steamer

Guard

Harbour ferry skipper

Jetty keeper

Lighthouse keeper

Lorryman

Mail carrier

Rail - employee/engine driver/fireman/foreman/messenger/officer/pointsman/ porter/shunter/stock-keeper/ticket inspector/worker/workshop employee

Shipping manager

Station master

Tram - cashier/conductor/driver/inspector

Truck driver

Waggoner

Waterside worker

Wharf stevedore

\section{Ocean Transport 1}

Captain

Master mariner

Pilot

Ship owner

The only other categorisation that ship owners could have been placed in is 'independent means', but, in the absence of further information, they have Ships officer been included under 'Ocean Transport 1'

\section{Ocean Transport 2}

At sea

Cook - on ship

Mariner

Ropeman

Sailor

Sea Farer

Ship crew

Shipping

Ships porter

\section{Dealing}

\section{Clerical and Financial}

Agent

Bank - agent/clerk/officer/Banker

Book agent/keeper

Businessman

Buyer

Clerical assistant/worker

Clerk 
Commerce

Insurance agent/broker/clerk/manager/salesman

Land agent/valuer

Lawyer's clerk/office

Manager North Auckland Farmers/Union Insurance Company

Mercantile cashier/clerk

New Zealand Rail clerk

Secretary

Not placed under 'inland transport' because of the clerical nature of the work.

Stockbrokers cashier/clerk

Typist

\section{Merchants 1}

The distinction between merchants 1 and 2 is not hierarchical, but merely to separate general merchants from East India merchants, due to the different nature of their work. There was only one migrant in the NZSG database employed as an East India merchant.

East India merchant

\section{Merchants 2}

Book seller

Dealer - car/cattle/coal/horse/provision/spirit/stock/wood

Coal merchant

Distributor

Implement salesman

Importer

Merchant - general/grain and seed/gun/hardware/leather/spirit/sugar/tea/timber/wine/ wood

Trader

Miscellaneous Retail (Includes service industries)

Auctioneer

Cellerman

Commercial traveller

Funeral director

Land speculator

Masseur

Picture framing

Salesman

Travelling draper

Valuer

\section{Retail Worker}

Draper's assistant/traveller

Barmaid/Barman

Baths/Spa custodian

Grocer's assistant

Hotel waiter

Sales person

Stationer's salesman 
Waitress

Window dresser

\section{Retail Proprietors - Food and Beverage}

Baker

Classification is difficult as it is unclear, given only 'baker' as the occupation, whether the individual was employed as a baker, or if they operated their own bakery. Therefore all those recorded as 'baker' have been classified as bakery Butcher proprietors.

The problem that occurred with the classification of bakers also applies to butchers. See also 'flesher', under 'Pre-industrial and Unchanging Skills Food Preparation and Manufacture'

Cake shop owner

Confectioner

Corporate/Market gardener

Eating house keeper

Fruit shop owner

Greengrocer

Milk vendor

Publican

"Ran tea rooms"

Retailer of spirits

Tobacconist

Victualler

Retail Proprietors - Lodging

Accommodation House keeper

Boarding House keeper/operator/owner

Hotel keeper/licencee/manager/owner/proprietor/Hotelier

Inn keeper

Livery business/Livery stable keeper

\section{Retail Proprietors - Other}

Barber

Commercial cleaner

Drycleaner

Ironmonger

Laundry owner/manager/proprietor

Newspaper proprietor

\section{Retail Proprietors - Outlet}

Antiques shop owner

Clothing store

Garage proprietor

General Store keeper

Grocer

Haberdashery shop owner

Hardware store manager

News agent 
Retailer

Shoe and boot retailing

Shop/Store keeper/manager/proprietor

\section{Public Service, Professional and Independent Means}

This sector is divided hierarchically, ' 1 ' being those of high rank or greater skill than ' 2 ' etc for each categorisation group.

\section{Armed Forces 1}

Army Officer

Troop Sergeant Major

\section{Armed Forces 2}

Armed Constabulary

Army

Cavalry

Fencible

Imperial Pensioner

Medical corps

Military

As with 'Navy', 'Royal Marine' and 'Soldier', those recorded as 'military' are Militia categorised thus because they were recorded with no other designation.

Navy

Night watchman

Police constable/matron/sergeant/man/Police force

Prison warden

Royal Marine

Seamen

'Seamen' are here assumed to have been employed within the Armed Forces, probably in the Navy. It is more than likely, however, that this was not what was meant by those recording this occupation, especially in the NZSG register. 'Seaman' may describe someone who was working at sea as a commercial fisherman or in another sea-oriented occupation, in which case they would more accurately be classified as Agricultural - other rural, for example. With no more information than the occupation stated available, all 'seamen' have been classified within this sub-division in order to afford comparability with McClean's $\mathrm{PhD}$ thesis findings.

Soldier

Women’s Army

\section{Public Service 1}

Borough/County Councilmen/Local Government

Court Judge

Government inspector/labour agent/overseer

Justice of the Peace

Lieutenant Governor

Magistrate 
Mayor/Mayoress

The two migrants described as 'Mayoress' in the NZSG data have been classified thus due to their social roles, (thus being married to the Mayor has been considered an employment and they have not been classified as 'dependants').

Members of Parliament/Government Minister/Politician

Provincial Legislator

\section{Public Service 2}

Public Service 1 and 2 is a hierarchical division, a distinction being made between those of a higher standing (Public Service 1) and all those in the public service below this level. It could be argued that a third level is required, it being tricky to place a pound keeper for example on the same occupational hierarchical level as an immigration or customs agent, or a linesman on the same level hierarchically as a public accountant. Separating public service into three (or more) sub-categories would divide the samples used in the present study too far, however, and so these two levels of hierarchy have remained.

Civil servant

County clerk/engineer/overseer/surfaceman

Customs agent

District valuator

Excise officer

Field officer, Ministry of Agriculture

Fireman

Government valuer

Health and food inspector

Immigration agent

Inspector of schools

Inspector of works

Lineman

Night fireman

Post master/mistress/office

Pound keeper

Public accountant/servant/works inspector

Quarantine officer

Registrar

School building inspector

Telegraph linesman

Town clerk

\section{Professional 1}

Academic

Bank manager

Barrister and Solicitor

Clergy

Doctor (Medical/Psychiatric), and medical students

Editor

Interpreter

Lawyer, and law students 
Minister, and ministry students

Missionary

Optician

Preacher

Professor

Surgeon

Veterinarian

Writer

\section{Professional 2}

Accountant

Artist

Deaconess

Engraver

Headmaster/mistress

Instructor of weaving

Instructoress of youth

Journalist

Music teacher

Musician

Opera singer

Photographer

Prioress

Reporter

School master/mistress/principal/teacher

Sewing teacher

Social worker

University student/tutor

Water colour artist

\section{Assistants to Professionals}

Accounts clerk

Attendant in asylum

Chemist's labourer

Church officer

Clerk of the court

Dental nurse

Grave digger

Hospital attendant/matron/orderly/porter

Law clerk/writer

Lay reader

Lunatic keeper

Maternity nurse/Midwife

Matron

Nurse

Given the inclusion of teachers in 'professional 2', and the greater degree of skill required for nursing than teaching in the twentieth century and beyond, the placement of nurses in this category is, perhaps, curious. The decision to place nurses in this category arises from nurses in the period covered being regarded as assistants to doctors, in the main. 
Nursemaid

Photographer's assistant

Precentor

Psychiatric nurse

Salvation Army officer

Surgical orderly

Sexton

Surgeon's servant

Shorthand typist

\section{Independent Means}

Those individuals for whom the following descriptions were given for their occupations were probably otherwise employed during their life times, but, given only these descriptions, they have been categorised as of independent means.

Colonist

Explorer

Farm owner

Gentleman

Independent

Lady

Land owner/Landed proprietor

Not having any other information, it has been assumed that these individuals, as with 'station owners', were not working the land themselves.

Landlord

Owner

Plantation owner

Retired

Settler

It has been assumed that when a migrant has been recorded only, or primarily, as a settler that this is because they held no other occupation but only 'settled' the land, implying they had the financial means to do so. It is a term that could, however, apply equally well to a migrant of meagre means who was granted land that he then worked himself or a migrant for whom the contributor of the information to the NZSG register has no other occupational information and so they recorded 'settler'. See, also, discussion of this Station owner designation in Fairburn's 'Social Mobility and Opportunity'. 9

Traveller

\section{Domestic Service}

Private, Indoor

Butler

Children's nanny/nurse/Nursery maid

Cook

Domestic servant/worker

Footman

\footnotetext{
${ }^{9}$ Miles Fairburn, 'Social Mobility and Opportunity in Nineteenth-Century New Zealand', NZJH,

Vol.13, No.1, April, 1979, pp.43-64
} 
Governess

Home help

House servant/keeper/maid

Kitchen maid

Lady's companion/help/maid/nurse

Maid

Servant

Private, Outdoor

Chauffeur

Foreman

Gamekeeper

Although this could have been classified as Agricultural, outdoor domestic service was deemed more appropriate. Only eleven migrants were described thus, ten in Scotland and one in New Zealand, so the classification of these Groom migrants in one category or another has not significantly affected analysis.

Nursery man

Outside servant

\section{Other Service}

Those in commercial domestic service employment and those for whom it was

Caretaker not clear whether they were in private or commercial employ.

Charwoman

Chef

Cleaner

Hairdresser

Hotelmaid

Janitor

Laundress/Laundry maid/man

Service

Washerwoman

\section{Other}

\section{Dependents}

'At home'

Baby/Infant

Caregiver

Child/Daughter/Son

Home duties/maker

Housewife

Invalid

Married

Mother

Mother's companion

Pupil/Scholar/Student

Widow

Wife 


\section{Miscellaneous}

Remittance man

\section{Indefinable due to lack of information}

Those for whom, as the sector title suggests, it was not possible to classify under any other categorisation due to a lack of information.

Apprentice

\section{Checker}

Domestic

Those with no other indication at all as to whether this was in domestic service or in the home. Unfortunately this is a large number of the migrants in the NZSG database (72 in Scotland and 139 in New Zealand) but with no other information it was deemed inappropriate to assume that these Drafter individuals were in domestic service and not at home or vice versa.

Foreman

Manager

Overseer

Spectator

Spinster

Probably an unmarried woman but, especially in Scotland, possibly a spinner of wool.

Steward

Van man

Warden

Appendix 5.1a, below, is a breakdown of the occupations recorded for NZSG data migrants in Scotland and in New Zealand. It is provided so that the reader may judge how the classification system above has potentially impacted upon analysis - i.e. so it is possible to see, for example, whether a potentially controversially classified occupation has a significant presence in the dataset to warrant concern over its classification. 
Appendix 5.1a

Proportion of NZSG Scotland Occupation 1 and NZSG New Zealand Occupation 1 migrants fitting within each occupation sector and occupation type, 1840-1920

\begin{tabular}{|c|c|c|c|c|}
\hline Sector & Industry & Occupation Type & $\begin{array}{c}\text { Scotland } \\
\text { Occupation } 1 \\
\% \\
\end{array}$ & $\begin{array}{c}\text { NZ } \\
\text { Occupation } 1 \\
\% \\
\end{array}$ \\
\hline \multirow{5}{*}{ Agricultural } & & Farmer & 7.97 & 22.70 \\
\hline & & Farm Worker 1 & 3.65 & 3.04 \\
\hline & & Farm Worker 2 & 7.24 & 1.97 \\
\hline & & Others Rural & 1.89 & 1.90 \\
\hline & & & 20.76 & 29.60 \\
\hline \multirow{3}{*}{ Mining } & & Mining Managerial & 0.07 & 0.18 \\
\hline & & Miners & 3.69 & 4.33 \\
\hline & & & 3.75 & 4.51 \\
\hline \multirow{6}{*}{ Building } & & Building Management & 1.33 & 2.42 \\
\hline & & Operative 1 & 4.19 & 4.01 \\
\hline & & Operative 2 & 0.50 & 1.06 \\
\hline & & $\begin{array}{c}\text { Operative } 2 \text { - Road and Rail } \\
\text { Construction }\end{array}$ & 0.17 & 0.45 \\
\hline & & Other Building Related Trades & 0.23 & 0.32 \\
\hline & & & 6.41 & 8.27 \\
\hline \multirow{3}{*}{ Labouring } & & Skilled Labourers & 0 & 0.02 \\
\hline & & Labourers & 1.86 & 2.90 \\
\hline & & & 1.86 & 2.92 \\
\hline \multirow{12}{*}{ Manufacturing } & & $\begin{array}{c}\text { Manufacturing Management and } \\
\text { Ownership }\end{array}$ & 0.03 & 0.36 \\
\hline & \multirow{5}{*}{ 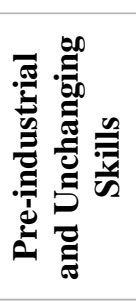 } & Clothing Trades & 4.05 & 3.22 \\
\hline & & Food Preparation and Manufacture & 1.00 & 0.72 \\
\hline & & Metal Trades & 2.43 & 2.47 \\
\hline & & Woodworking Trades & 2.52 & 1.38 \\
\hline & & $\begin{array}{l}\text { Miscellaneous Crafts and } \\
\text { Unspecified }\end{array}$ & 1.10 & 0.68 \\
\hline & \multirow{6}{*}{ 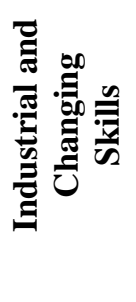 } & Miscellaneous Manufacture & 0.93 & 0.41 \\
\hline & & Shipbuilders & 1.23 & 0.61 \\
\hline & & Textiles & 4.22 & 0.68 \\
\hline & & Toolmakers, etc. & 1.03 & 0.91 \\
\hline & & Unspecified Mechanics & 0.96 & 0.23 \\
\hline & & & 19.50 & 11.66 \\
\hline
\end{tabular}




\begin{tabular}{|c|c|c|c|c|}
\hline Sector & Industry & Occupation Type & $\begin{array}{c}\text { Scotland } \\
\text { Occupation } 1 \\
\% \\
\end{array}$ & $\begin{array}{c}\mathrm{NZ} \\
\text { Occupation } 1 \\
\% \\
\end{array}$ \\
\hline \multirow{4}{*}{$\begin{array}{l}\text { Transport and } \\
\text { Commercial }\end{array}$} & & Inland Transport & 1.30 & 2.92 \\
\hline & & Ocean Transport 1 & 0.33 & 0.29 \\
\hline & & Ocean Transport 2 & 1.66 & 0.68 \\
\hline & & & 3.29 & 3.90 \\
\hline \multirow{10}{*}{ Dealing } & & Clerical and Financial & 1.73 & 1.43 \\
\hline & & Merchants 1 & 0.03 & 0 \\
\hline & & Merchants 2 & 0.60 & 1.11 \\
\hline & & $\begin{array}{c}\text { Miscellaneous Retail (Incl. service } \\
\text { industries) }\end{array}$ & 0.30 & 0.34 \\
\hline & & Retail Worker & 0.47 & 0.39 \\
\hline & & $\begin{array}{c}\text { Retail Proprietors - Food and } \\
\text { Beverage }\end{array}$ & 1.99 & 2.85 \\
\hline & & Retail Proprietors - Lodging & 0.07 & 1.16 \\
\hline & & Retail Proprietors - Other & 0.17 & 0.23 \\
\hline & & Retail Proprietors - Outlet & 1.30 & 2.31 \\
\hline & & & 6.64 & 9.81 \\
\hline \multirow{9}{*}{$\begin{array}{l}\text { Public Service, } \\
\text { Professional and } \\
\text { Independent } \\
\text { Means }\end{array}$} & & Armed Forces 1 & 0.07 & 0.00 \\
\hline & & Armed Forces 2 & 1.16 & 0.63 \\
\hline & & Public Service 1 & 0.03 & 0.07 \\
\hline & & Public Service 2 & 0.07 & 0.57 \\
\hline & & Professional 1 & 1.06 & 1.22 \\
\hline & & Professional 2 & 1.86 & 2.63 \\
\hline & & Assistants to Professionals & 0.70 & 1.22 \\
\hline & & Independent Means & 0.13 & 1.38 \\
\hline & & & 5.08 & 7.72 \\
\hline \multirow{4}{*}{ Domestic Service } & & Private, Indoor & 6.91 & 2.51 \\
\hline & & Private, Outdoor & 0.40 & 0.18 \\
\hline & & Other Service & 0.47 & 0.41 \\
\hline & & & 7.77 & 3.10 \\
\hline \multirow{3}{*}{ Other } & & Dependents & 21.63 & 14.63 \\
\hline & & Miscellaneous & 0 & 0.02 \\
\hline & & & 21.63 & 14.65 \\
\hline \multirow[t]{2}{*}{ Indefinable } & & & 3.29 & 3.85 \\
\hline & & Total $(\boldsymbol{n})$ & 3,010 & 4,415 \\
\hline
\end{tabular}




\section{Appendix 5.2}

Employment prior to emigration to New Zealand:

proportion of Scottish migrants who had been employed in each manufacturing occupational industry and type, by region of birth

\begin{tabular}{|c|c|c|c|c|c|c|c|}
\hline & & 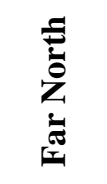 & 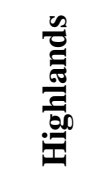 & 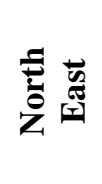 & 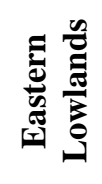 & 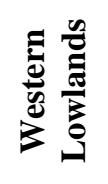 & 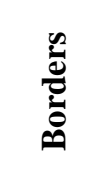 \\
\hline \multirow{7}{*}{ 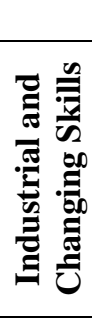 } & Management and ownership & 0 & 0 & 0 & 0 & 0.61 & 0 \\
\hline & Miscellaneous Manufacture & 8.33 & 4.76 & 4.62 & 6.33 & 3.68 & 0 \\
\hline & Shipbuilders & 8.33 & 23.81 & 16.92 & 3.62 & 1.84 & 0 \\
\hline & Textiles & 0 & 9.52 & 7.69 & 21.72 & 31.29 & 25.00 \\
\hline & Toolmakers etc & 0 & 7.14 & 7.69 & 4.52 & 6.75 & 5.36 \\
\hline & Unspecified Mechanics & 0 & 0 & 0 & 4.98 & 6.13 & 7.14 \\
\hline & Total & 16.67 & 45.24 & 36.92 & 41.18 & 49.69 & 37.50 \\
\hline \multirow{6}{*}{ 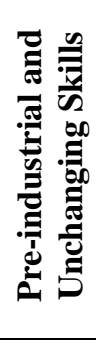 } & Clothing Trades & 25.00 & 19.05 & 18.46 & 22.17 & 20.86 & 21.43 \\
\hline & $\begin{array}{c}\text { Food Preparation and } \\
\text { Manufacture }\end{array}$ & 16.67 & 7.14 & 13.85 & 5.43 & 1.84 & 0 \\
\hline & Metal Trades & 0.00 & 11.90 & 16.92 & 11.31 & 13.50 & 10.71 \\
\hline & Unspecified & 8.33 & 0 & 6.15 & 5.43 & 6.75 & 5.36 \\
\hline & Woodworking Trades & 33.33 & 16.67 & 7.69 & 14.48 & 6.75 & 25.00 \\
\hline & Total & 83.33 & 54.76 & 63.08 & 58.82 & 49.69 & 62.50 \\
\hline & & 12 & 42 & 65 & 221 & 163 & 56 \\
\hline
\end{tabular}

Source: NZSG data 1840-1920 


\section{Appendix 6.1}

Diagram of the Davidson/Nicolson family chain of migration, 1873-1906

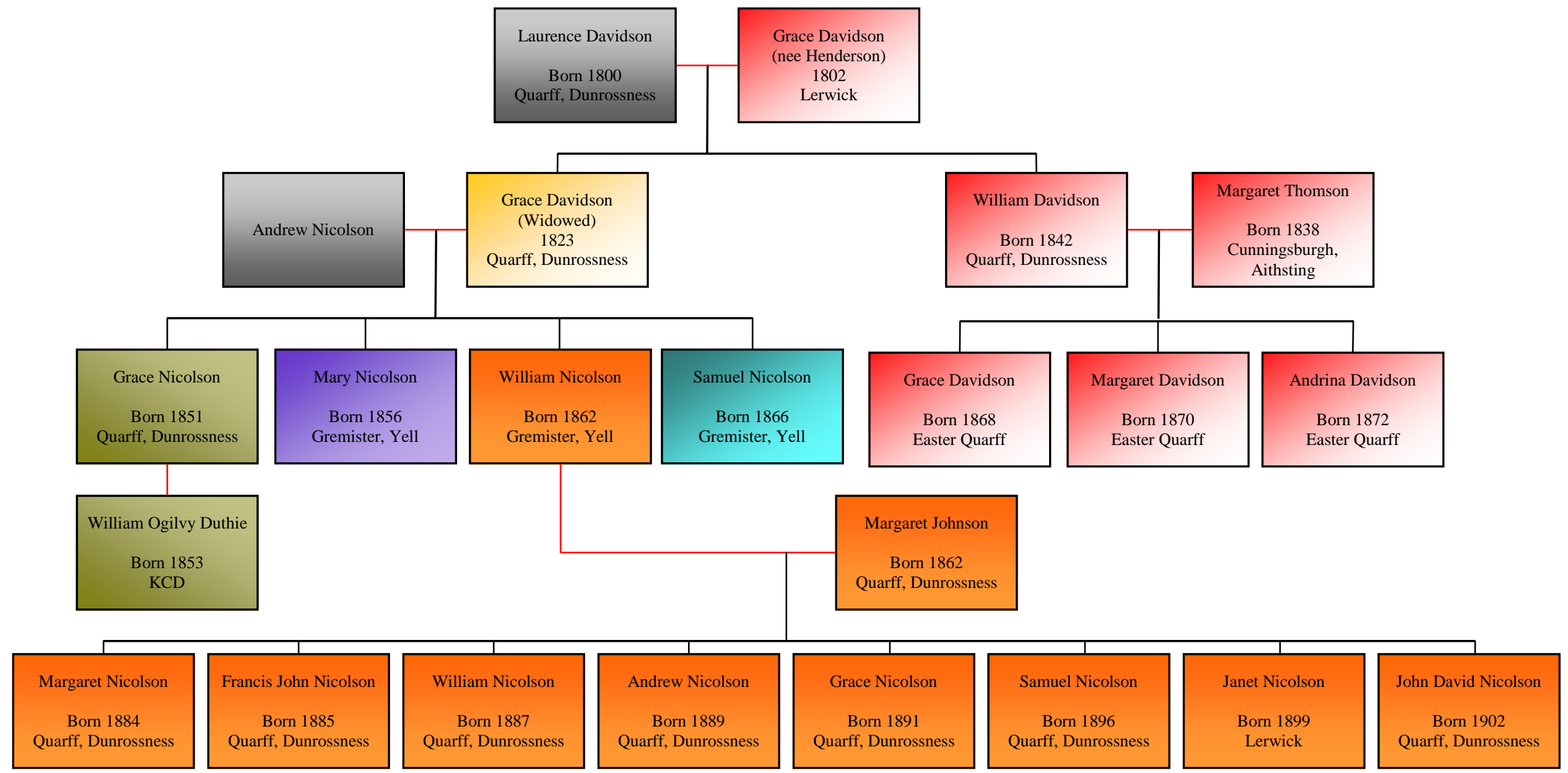

\section{Key}

Sibling or Child/Parent relationship

Marriage

\begin{tabular}{|l|c|c|c|c|c|}
\hline $\begin{array}{l}\text { Did Not } \\
\text { Migrate }\end{array}$ & $\begin{array}{c}\text { Christian McAusland } \\
1872\end{array}$ & $\begin{array}{c}\text { Auckland } \\
1875\end{array}$ & $\begin{array}{c}\text { Nelson } \\
1875\end{array}$ & 1876 & 1894 \\
\hline
\end{tabular}


Appendix 6.2

Diagram of the Fordyce/Robinson family chain of migration, 1860-1911

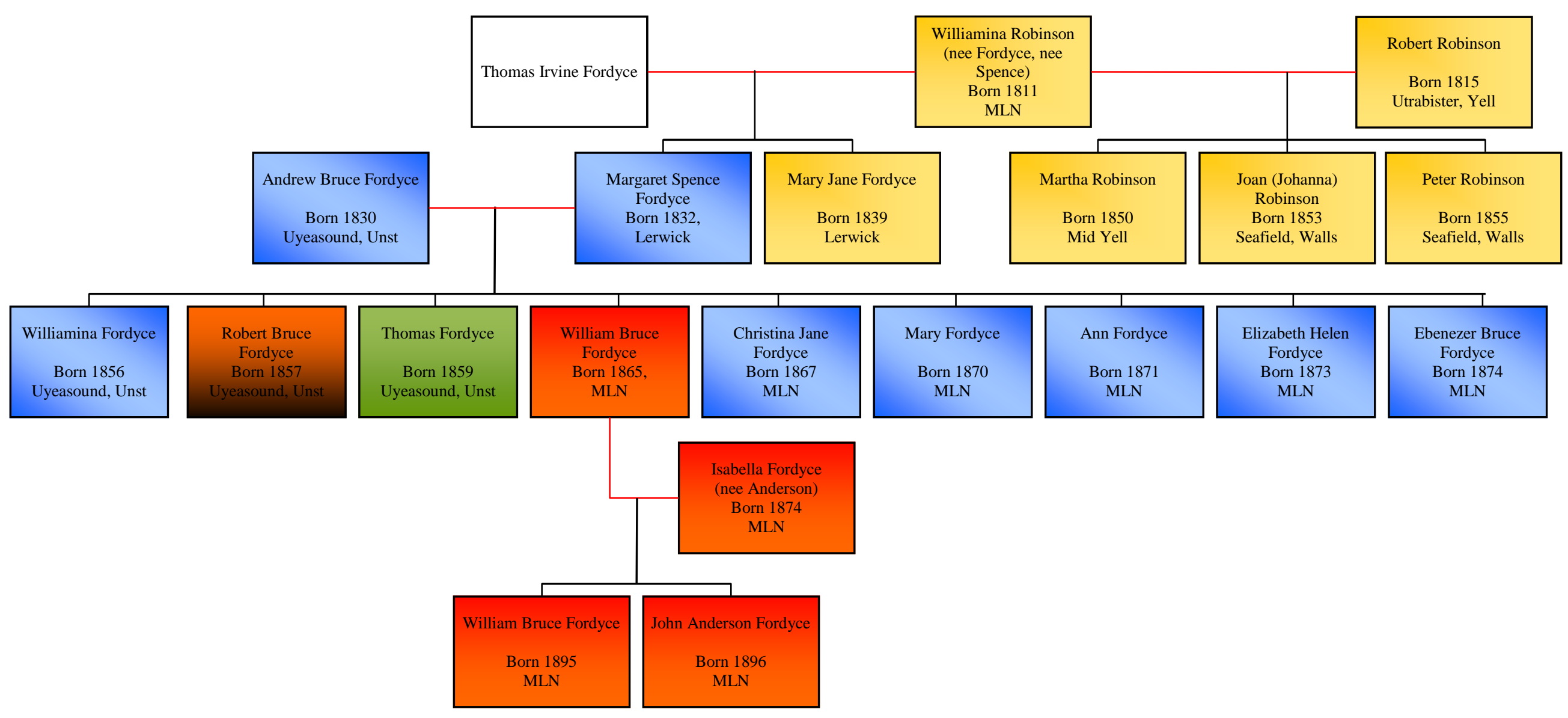

\section{Key}

Sibling or Child/Parent relationship

Marriage

\begin{tabular}{|c|c|c|c|c|c|}
\hline $\begin{array}{c}\text { Zealandia, } \\
1860\end{array}$ & $\begin{array}{c}\text { Rangitiki, } \\
1882\end{array}$ & $\begin{array}{c}\text { Aorangi, } \\
1885\end{array}$ & $\begin{array}{c}\text { Gothic, } \\
1901\end{array}$ & $\begin{array}{c}\text { Turakina, } \\
1911\end{array}$ & $\begin{array}{c}\text { Did Not } \\
\text { Migrate }\end{array}$ \\
\hline
\end{tabular}




\section{Appendix 6.3a}

Diagram of connections between the Harper, Flaws, Mouat, Henderson and Anderson families, part 1 of 6

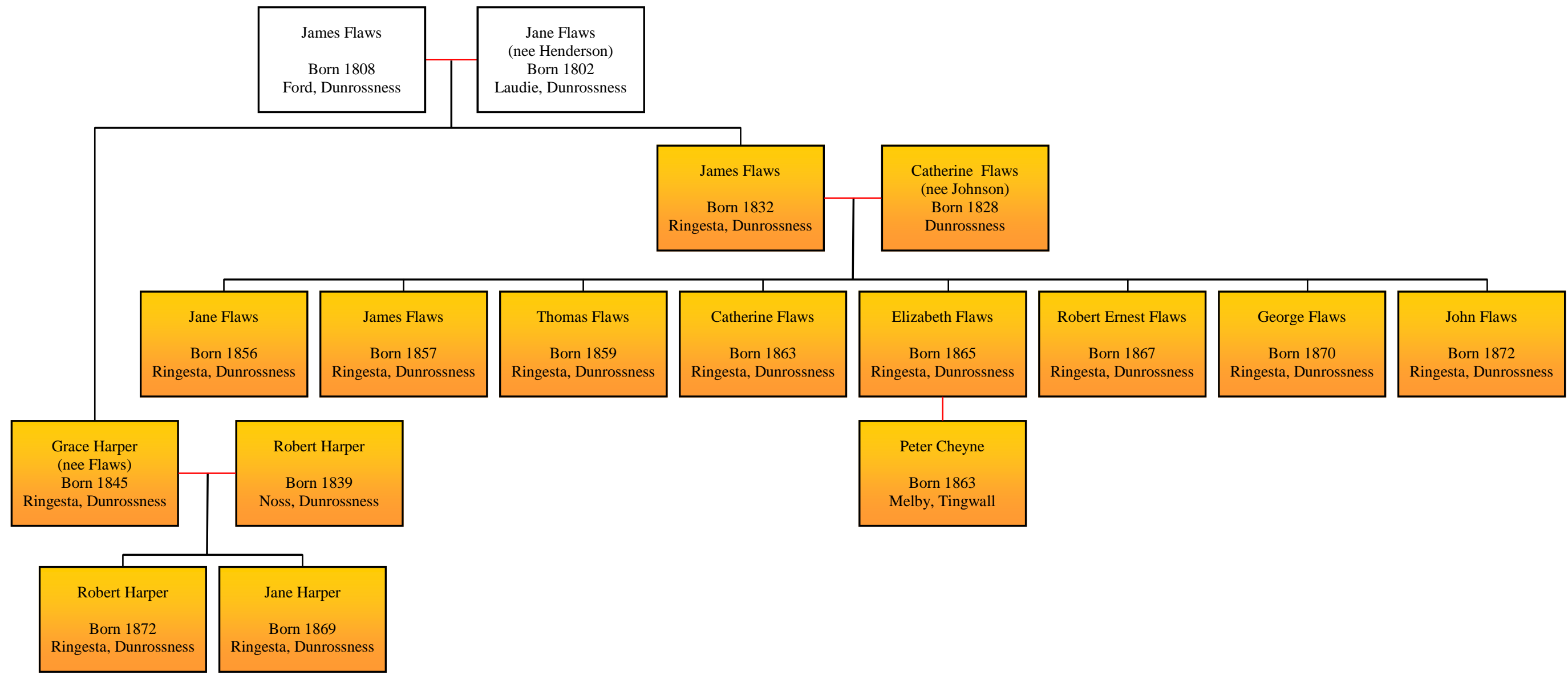

\begin{tabular}{|c|c|c|c|c|c|c|c|c|c|}
\hline \multicolumn{10}{|c|}{ Key } \\
\hline - $\mathrm{Sib}$ & Child & $\mathrm{t}$ relationsh & $\longrightarrow \mathrm{M}$ & & & & & & \\
\hline $\begin{array}{l}\text { Did Not } \\
\text { Migrate }\end{array}$ & $\begin{array}{l}\text { Soukar } \\
1874\end{array}$ & $\begin{array}{l}\text { To Australia } \\
\text { c. } 1868\end{array}$ & $\begin{array}{l}\text { To NZ via } \\
\text { Aust., c. } 1868\end{array}$ & $1870 \mathrm{~s}$ & $\begin{array}{l}\text { Peter Denny } \\
1875\end{array}$ & c. 1912 & $\begin{array}{l}\text { Rotorua } \\
1913\end{array}$ & $\begin{array}{l}\text { Tainui } \\
1923\end{array}$ & Unknown \\
\hline
\end{tabular}




\section{Appendix 6.3b}

Diagram of connections between the Harper, Flaws, Mouat, Henderson and Anderson families, part 2 of 6

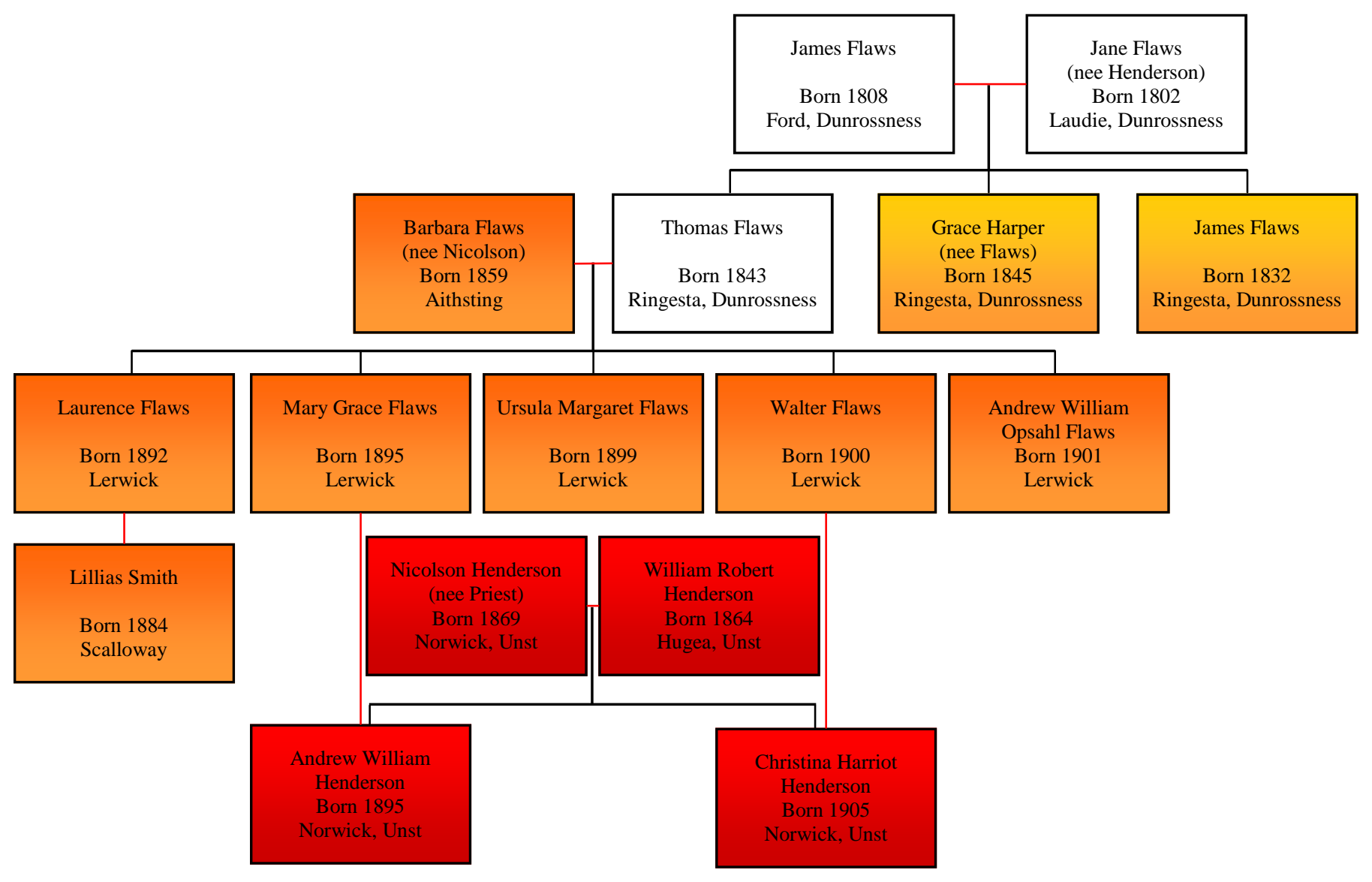

Key

Sibling or Child/Parent relationship — Marriage

\begin{tabular}{|l|c|c|c|c|c|c|c|c|c|}
\hline $\begin{array}{l}\text { Did Not } \\
\text { Migrate }\end{array}$ & $\begin{array}{c}\text { Soukar } \\
1874\end{array}$ & $\begin{array}{c}\text { To Australia } \\
\text { c.1868 }\end{array}$ & $\begin{array}{c}\text { To NZ via } \\
\text { Aust., c.1868 }\end{array}$ & 1870 s & $\begin{array}{c}\text { Peter Denny } \\
1875\end{array}$ & c.1912 & $\begin{array}{c}\text { Rotorua } \\
1913\end{array}$ & $\begin{array}{c}\text { Tainui } \\
1923\end{array}$ & Unknown \\
\hline
\end{tabular}


Appendix 6.3c

Diagram of connections between the Harper, Flaws, Mouat, Henderson and Anderson families, part 3 of 6

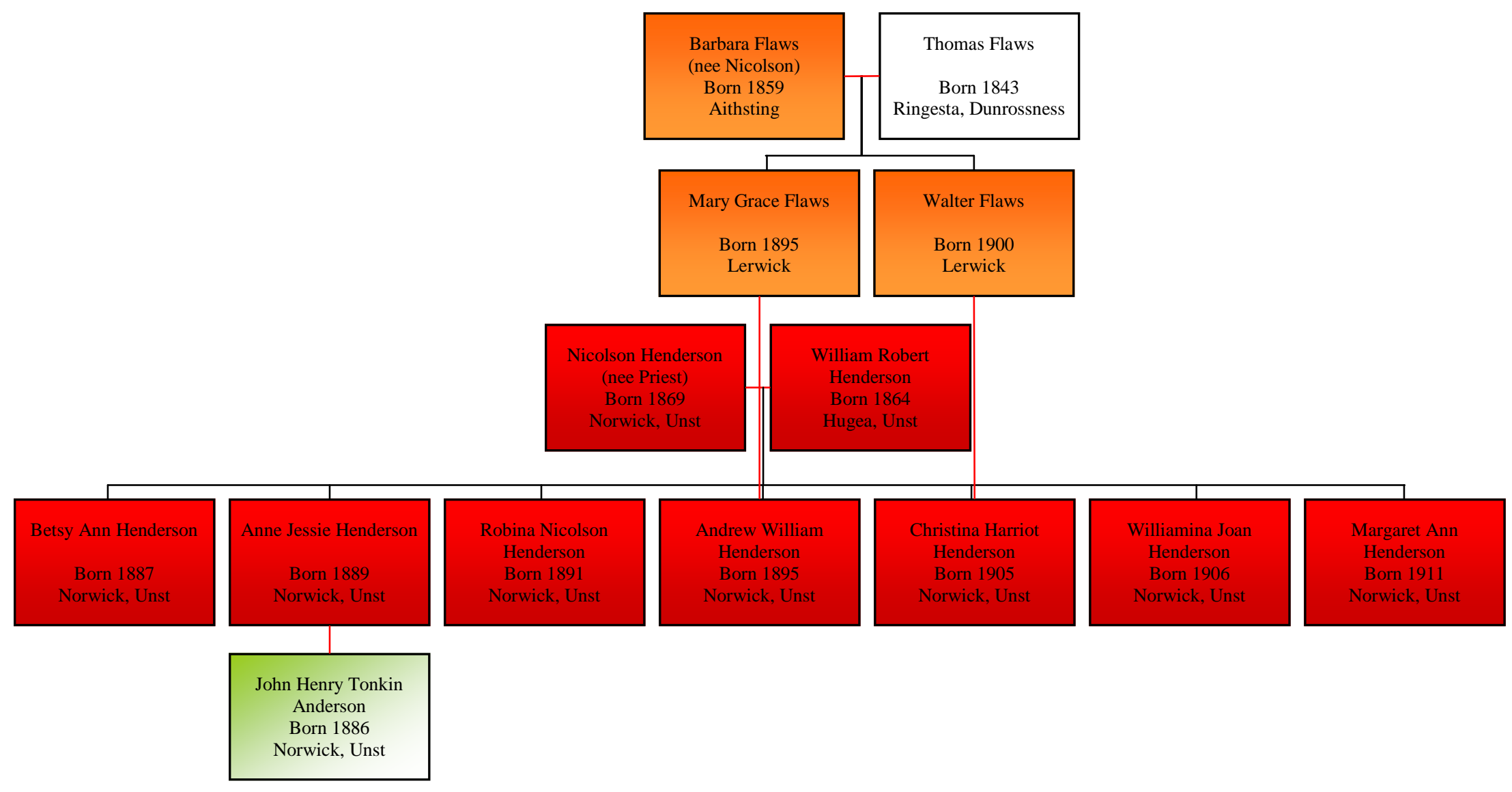

\begin{tabular}{|c|c|c|c|c|c|c|c|c|c|}
\hline \multicolumn{10}{|c|}{ Key } \\
\hline - Sit & r Child/ & at relationsh & $\longrightarrow \mathrm{M}$ & & & & & & \\
\hline $\begin{array}{l}\text { Did Not } \\
\text { Migrate }\end{array}$ & $\begin{array}{c}\text { Soukar } \\
1874\end{array}$ & $\begin{array}{l}\text { To Australia } \\
\text { c. } 1868\end{array}$ & $\begin{array}{c}\text { To NZ via } \\
\text { Aust., c. } 1868\end{array}$ & 1870 s & $\begin{array}{c}\text { Peter Denny } \\
1875\end{array}$ & c. 1912 & $\begin{array}{c}\text { Rotorua } \\
1913\end{array}$ & $\begin{array}{c}\text { Tainui } \\
1923\end{array}$ & Unknown \\
\hline
\end{tabular}




\section{Appendix 6.3d}

Diagram of connections between the Harper, Flaws, Mouat, Henderson and Anderson families, part 4 of 6

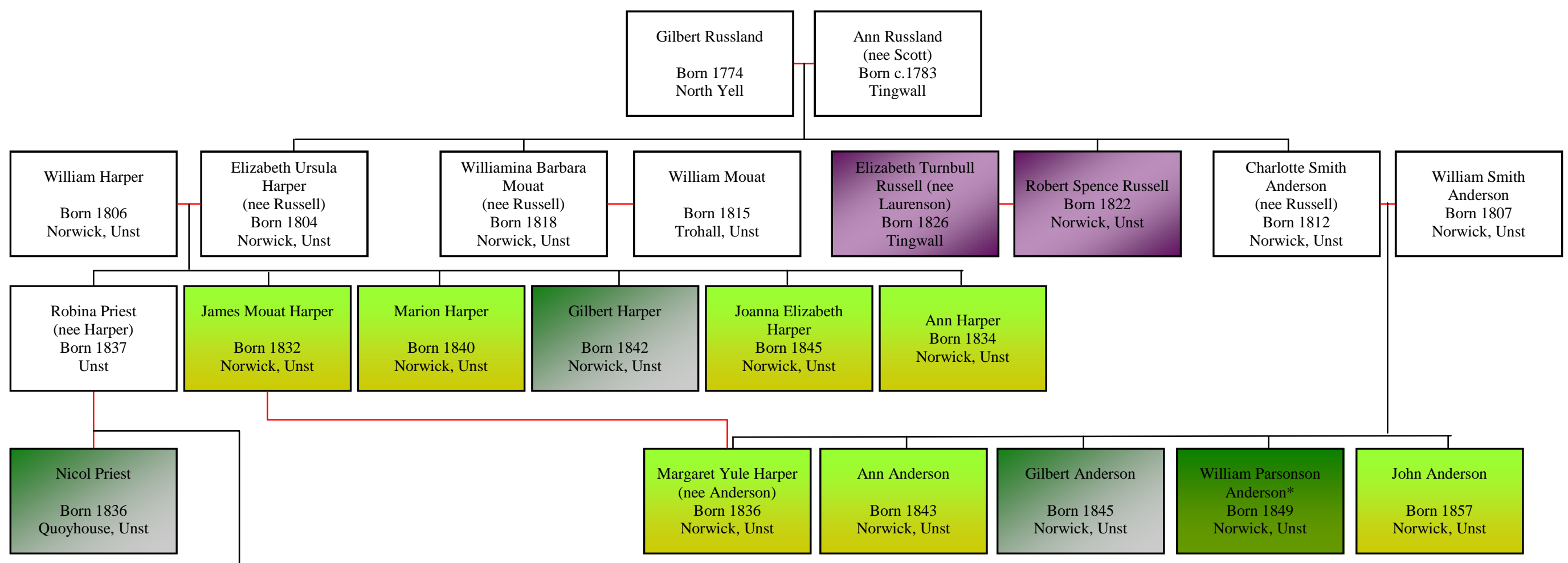

\begin{tabular}{|c|c|c|c|c|c|c|c|c|c|}
\hline \multicolumn{10}{|c|}{ Key } \\
\hline$-\mathrm{Sil}$ & r Child/ & At relationshi & $\longrightarrow \mathrm{M}$ & & & & & & \\
\hline $\begin{array}{l}\text { Did Not } \\
\text { Migrate }\end{array}$ & $\begin{array}{c}\text { Soukar } \\
1874\end{array}$ & $\begin{array}{l}\text { To Australia } \\
\text { c. } 1868\end{array}$ & $\begin{array}{c}\text { To NZ via } \\
\text { Aust., c. } 1868\end{array}$ & 1870s & $\begin{array}{c}\text { Peter Denny } \\
1875\end{array}$ & c. 1912 & $\begin{array}{c}\text { Rotorua } \\
1913\end{array}$ & $\begin{array}{c}\text { Tainui } \\
1923\end{array}$ & Unknown \\
\hline
\end{tabular}


Appendix 6.3e

Diagram of connections between the Harper, Flaws, Mouat, Henderson and Anderson families, part 5 of 6

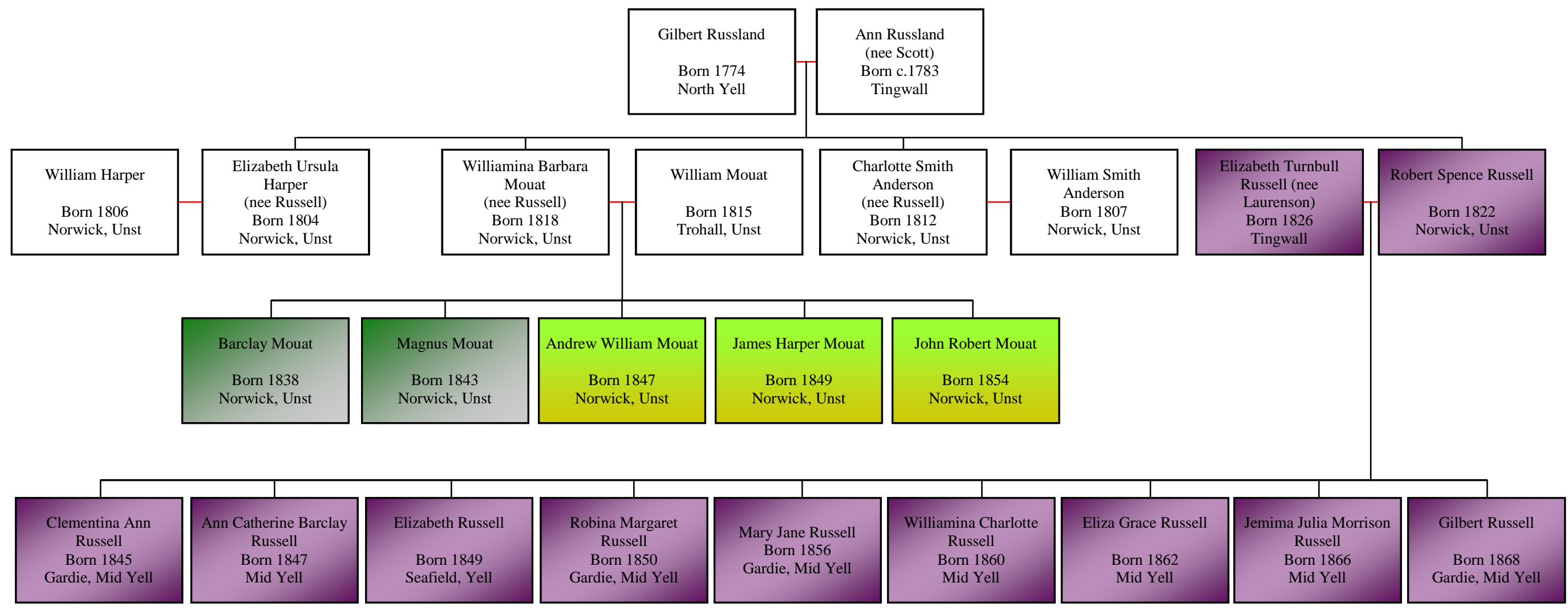

\begin{tabular}{|c|c|c|c|c|c|c|c|c|c|}
\hline \multicolumn{10}{|c|}{ Key } \\
\hline - Sit & r Child/ & at relationshi & $\longrightarrow \mathrm{M}$ & & & & & & \\
\hline $\begin{array}{l}\text { Did Not } \\
\text { Migrate }\end{array}$ & $\begin{array}{c}\text { Soukar } \\
1874\end{array}$ & $\begin{array}{l}\text { To Australia } \\
\text { c. } 1868\end{array}$ & $\begin{array}{c}\text { To NZ via } \\
\text { Aust., c. } 1868\end{array}$ & $1870 \mathrm{~s}$ & $\begin{array}{c}\text { Peter Denny } \\
1875\end{array}$ & c. 1912 & $\begin{array}{c}\text { Rotorua } \\
1913\end{array}$ & $\begin{array}{c}\text { Tainui } \\
1923\end{array}$ & Unknown \\
\hline
\end{tabular}




\section{Appendix 6.3f}

Diagram of connections between the Harper, Flaws, Mouat, Henderson and Anderson families, part 6 of 6

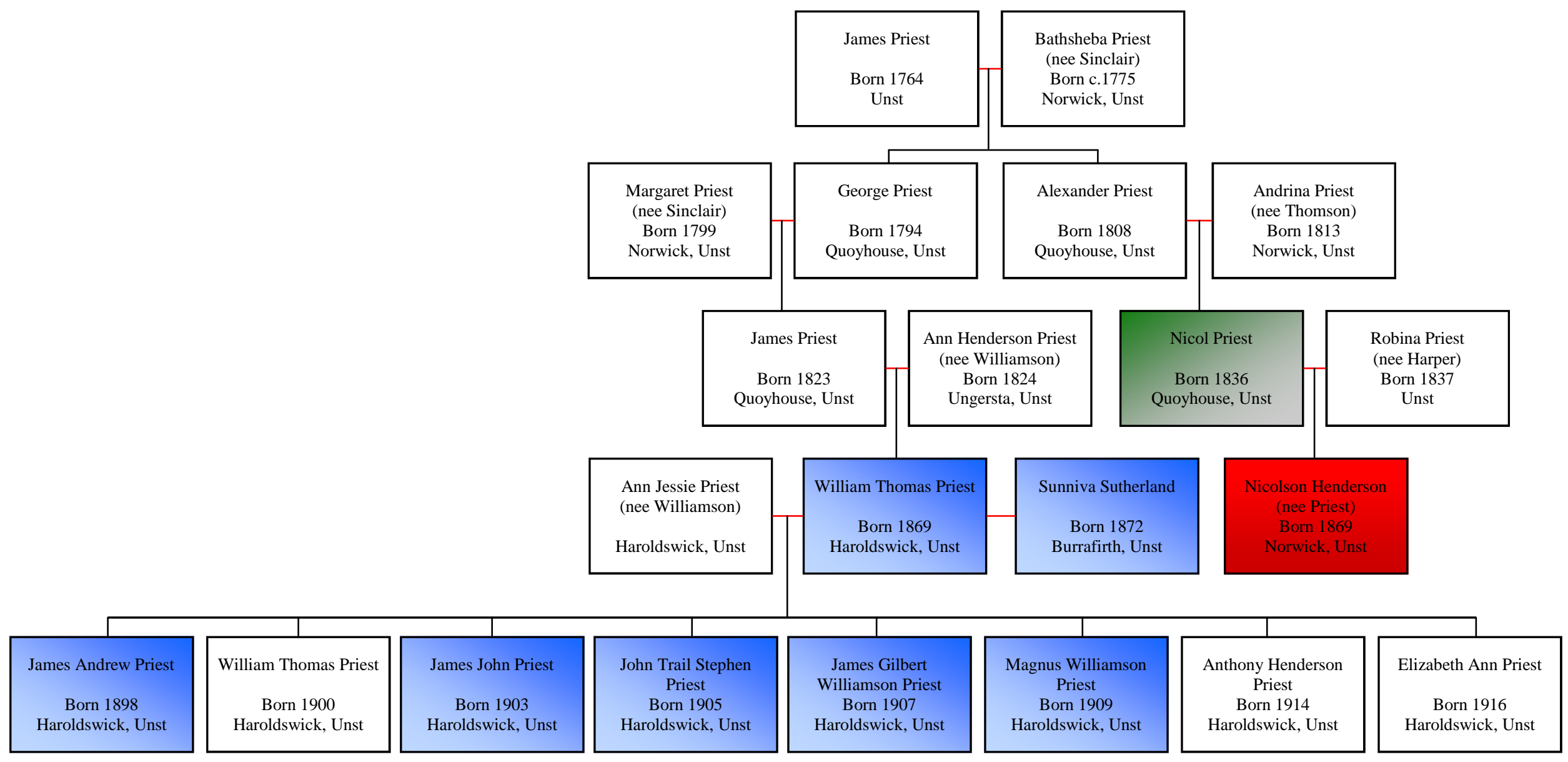

Key

Sibling or Child/Parent relationship $\longrightarrow$ Marriage

\begin{tabular}{|c|c|c|c|c|c|c|c|c|c|}
\hline $\begin{array}{l}\text { Did Not } \\
\text { Migrate }\end{array}$ & $\begin{array}{c}\text { Soukar } \\
1874\end{array}$ & $\begin{array}{l}\text { To Australia } \\
\text { c. } 1868\end{array}$ & $\begin{array}{c}\text { To NZ via } \\
\text { Aust., c. } 1868\end{array}$ & $1870 \mathrm{~s}$ & $\begin{array}{c}\text { Peter Denny } \\
1875\end{array}$ & c. 1912 & $\begin{array}{c}\text { Rotorua } \\
1913\end{array}$ & $\begin{array}{c}\text { Tainui } \\
1923\end{array}$ & Unknown \\
\hline
\end{tabular}


Appendix 6.4a

Diagram of connections between the Unst-born migrants to New Zealand, part 1 of 3

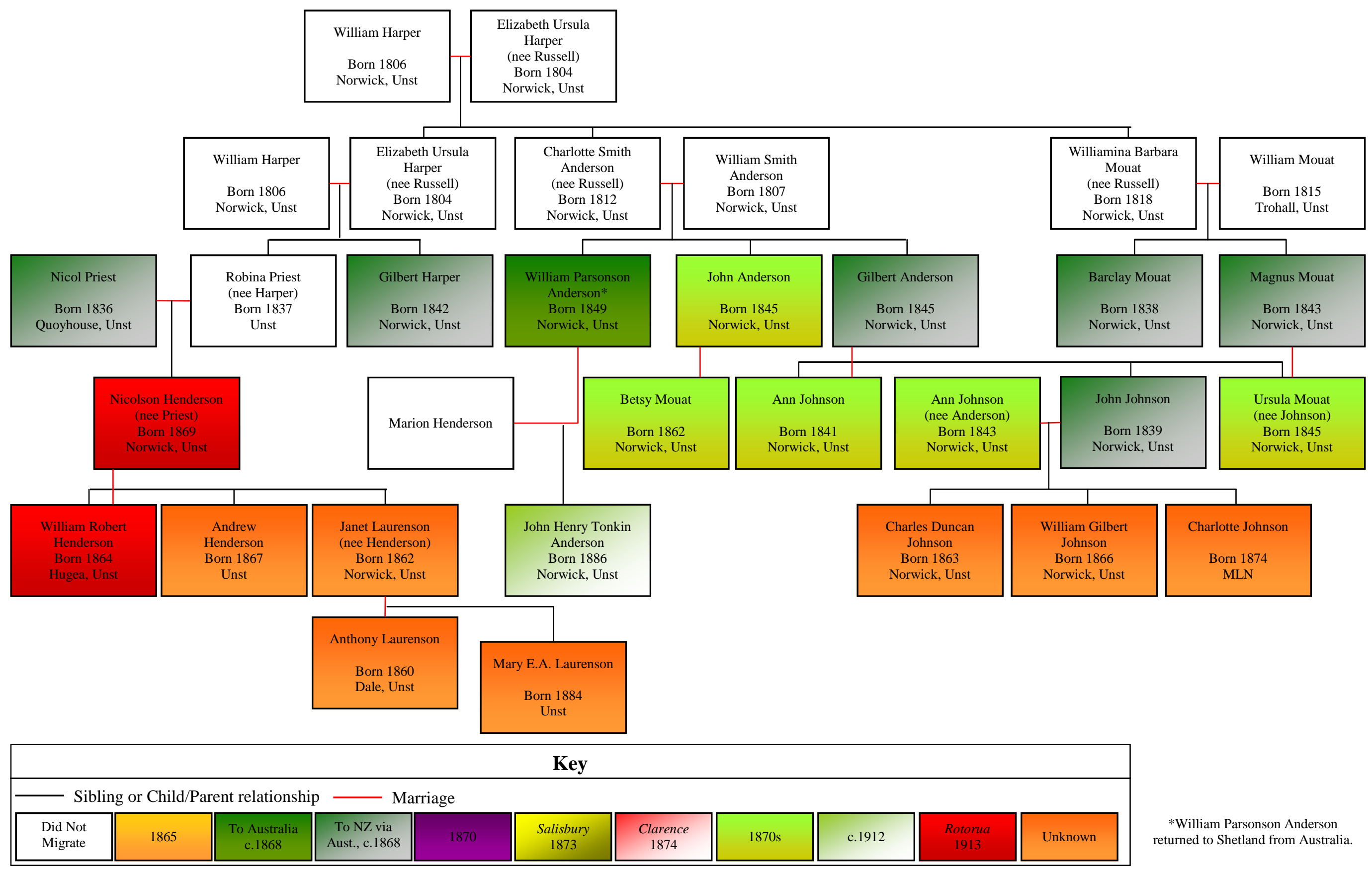


Appendix 6.4b

Diagram of connections between the Unst-born migrants to New Zealand, part 2 of 3
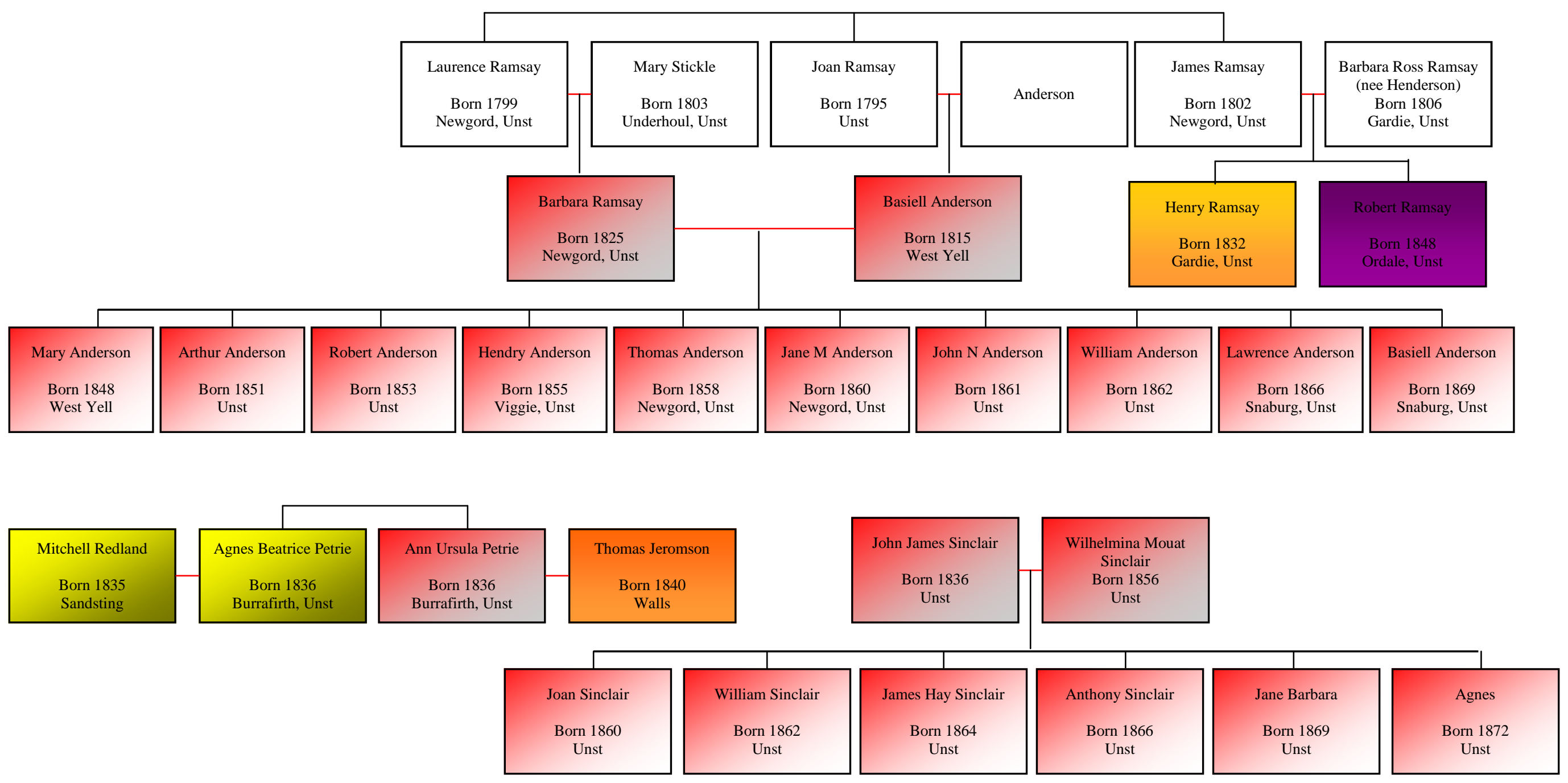

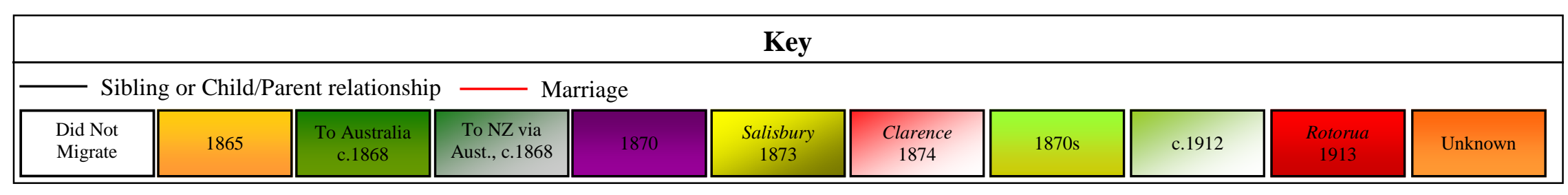


Appendix 6.4c

Diagram of connections between the Unst-born migrants to New Zealand, part 3 of 3
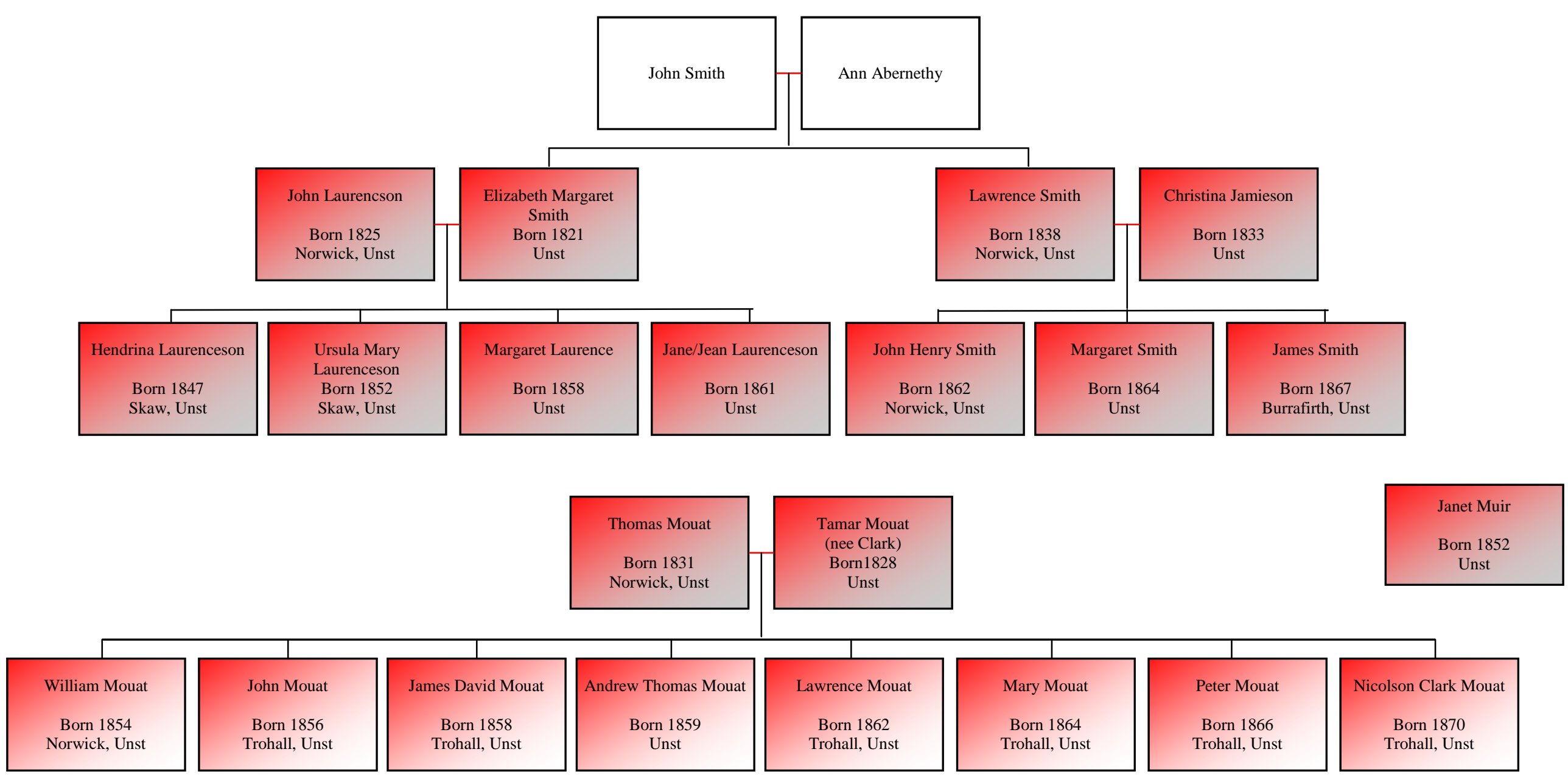

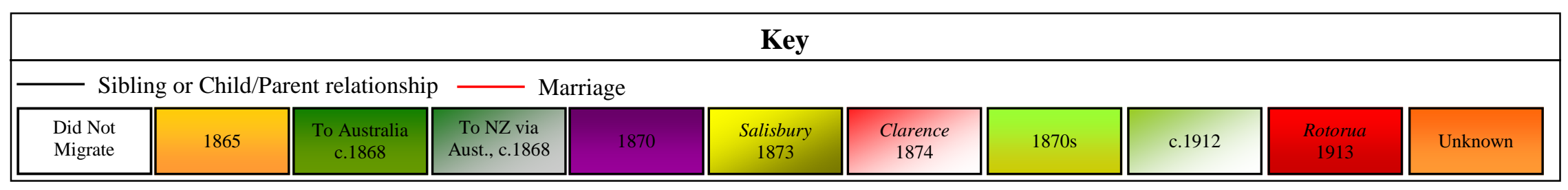




\section{Appendix 6.5}

Diagram of connections between the thirty-one Port William Special Settlement settlers, 1874.

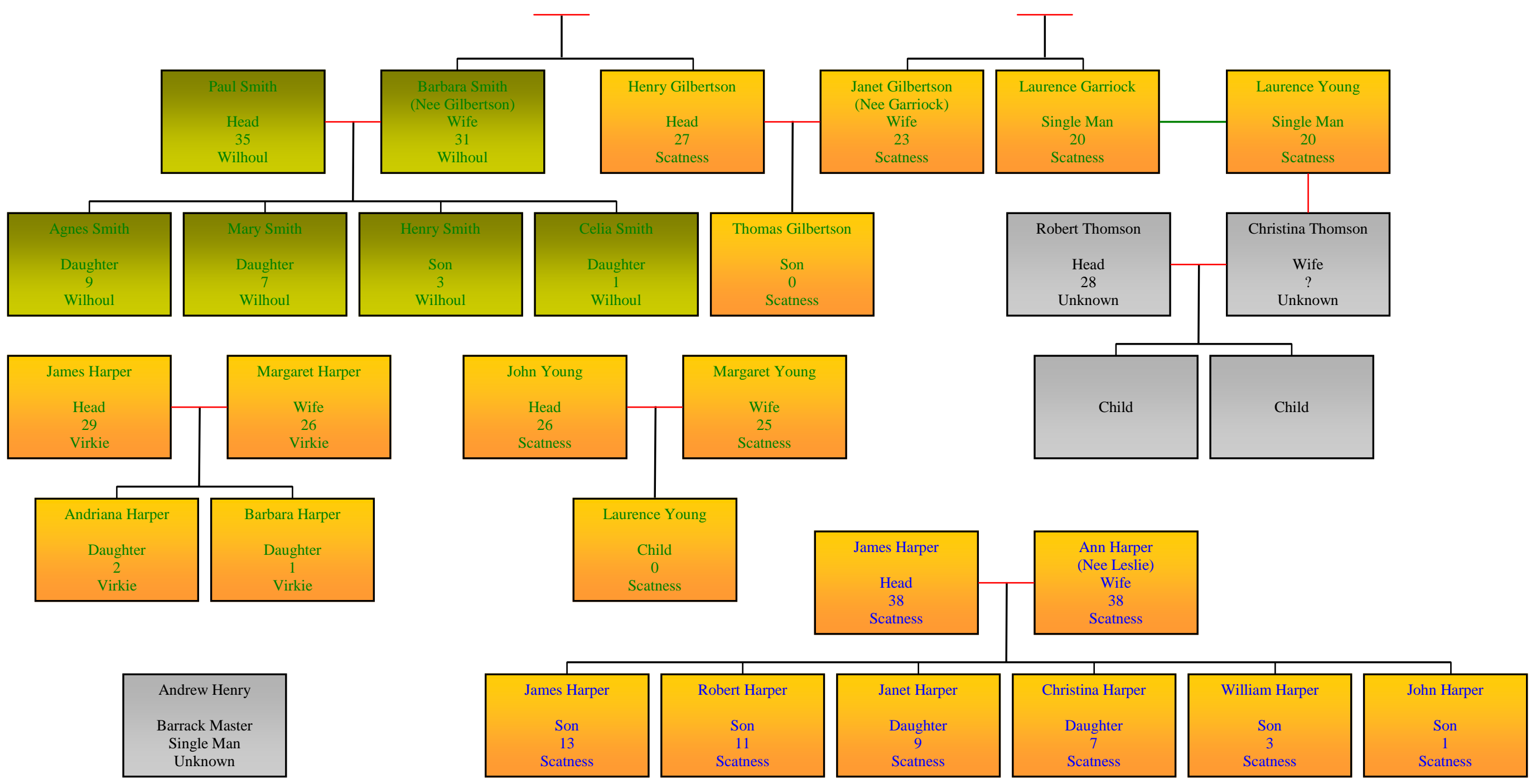

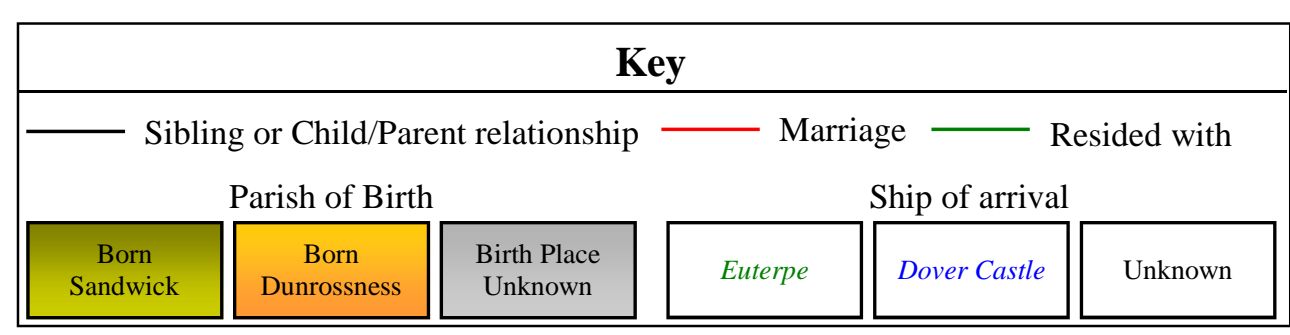




\section{BIBLIOGRAPHY}

This bibliography is arranged under the following headings:

\section{PRIMARY SOURCES}

UNPUBLISHED

ARCHIVES NeW ZEALAND, WELLINGTON

SHETLAND ISLANDS COUNCIL ARCHIVE

WhANGANUI REgIONAL MUSEUM ARCHIVE

PRIVATE OWNERSHIP

Letters, Diaries and other miscellaneous family material

Published

Official Sources

Unofficial Sources

Newspapers and Periodicals

Monumental Inscriptions

\section{SECONDARY SOURCES}

PUBLISHED

Books

Book Sections

Articles, Working Papers, Conference Proceedings

\section{UNPUBLISHED}

Manuscripts and Unpublished Research

Theses and Research Essays

Conference Papers, Lectures, Seminars

Family Histories etc.

Personal Correspondence

WEBSITES AND ONLINE DATABASES

Databases

Online Databases

Family Material

Passenger Lists

Other

\section{PRIMARY SOURCES}

Where an item is part of a collection of papers, full reference to the individual item may be found in footnotes. Citation here is to the collections themselves.

\section{UNPUBLISHED}

ARCHIVES NEW ZEALAND, WELLINGTON

ACFQ 8226, IM 6/1/1, General 26 March 1873 - 6 June 1876

ACFQ 8226, IM6/5/2, Jackson's Bay 4 August 1876 - 18 August 1877

ACFQ 8226, IM6/5/3, Jackson's Bay 29 October 1877 - 28 May 1878

ACFQ 8226, IM6/6/1, Karamea 12 August 1875 - 27 February 1878

ACFQ 8226, IM 6/10/1, Stewart Island 


\section{SHETLAND ISLANDS COUNCIL ARCHIVE}

D2/40/8, Letter by Sinclair Johnson, New Zealand, to J.J. Haldane Burgess, 16 March 1925

D6/292/14/p45, Obituary of Jane Fea Spence, Moukaraka (reprinted from Hokianga County Times [New Zealand]), Shetland Times, 28 March 1908

D6/292/15/p88v, Obituary of William Sievwright, Solicitor, New Zealand, Shetland Times, 19 June 1909

D23/151/28/19, Letter by Laurence Mathewson, Otago, New Zealand, to 'My Dear Beloved Parents', 29 March 1862

D23/151/47/14, Letter by Laurence Mathewson, Otago, New Zealand, to 'My Dear Beloved Parents', 1 December 1881

D38/29, Letter by William Fraser, Invercargill North, to 'Dear uncle John and Aunt': a voyage by sea from Southampton to New Zealand, 19 February 1923

WHANGANUI REGIONAL MUSEUM ARCHIVE

John 'Jock' McGregor papers

'The family of Gregor and Catherine McGregor' family tree.

PRIVATE OWNERSHIP

\section{Letters, Diaries and other miscellaneous family material}

William Robert Henderson and Nicolson Priest, family history material, provided by Elizabeth Angus

'Intention to Marry', BDM 20/1868, p.219, ANZ, Wellington, provided by Barbara Marriott

William Ogilvy Duthie and Grace Nicolson family history material, provided by Val Petrie

Sutherland family material, provided by Spin and Joan Sutherland

Sutherland family material, 'Diary of Nathaniel Sutherland (Jnr), 1867-1870', transcribed by Janette Godfrey, provided by Spin and Joan Sutherland

\section{Published}

\section{Official Sources}


'Introduction to the Report on the Truck System', Truck Commission, 1872, transcribed by Angus Johnson, Shetland Archives

'Minutes of Evidence taken before the Commission on the Truck System (Shetland) 1872', Truck Commission, 1872, transcribed by Angus Johnson, Shetland Archives

'Minutes of Evidence', Napier Commission, 1883, transcribed by Angus Johnson, Shetland Archives

Reports in the Appendices to the Journal of the House of Representatives Papers relating to Special Settlement on Stewart's Island, 1872, D-7A Regulations for free passages, 1874, D-3

Published results of the New Zealand Census, 1874 - 1936, 1951 and 1956

Registrar General Annual Reports of Births, Deaths and Marriages, Scotland, 1855 1910, accessed online at 'Histpop - The Online Historical Population Reports Website', http://histpop.org.uk/ohpr/servlet/

Published results of the Scotland Census, 1831 - 1931, accessed online at 'Histpop The Online Historical Population Reports Website', http://histpop.org.uk/ohpr/servlet/

Scotland Census individual household enumeration reports, $1841-1881$, accessed at ancestry.co.uk

Shetland Island Census 1851, Transcribed by the Shetland Family History Society, Lerwick, 2007

Shetland Island Census 1861, Transcribed by the Shetland Family History Society, Lerwick, 2007

Shetland Island Census 1871, Transcribed by the Shetland Family History Society, Lerwick, 2006

\section{Unofficial Sources}

'General Observations on the County of Shetland', The New Statistical Account of Scotland, pp.145-174, Vol.15, Edinburgh, 1845

Anderson, P.J., (ed.), Fasti Academiae Mariscallanae Aberdonensis: Sections from the records of the Marischal College and University MDXCIII - MDCCCLX, Aberdeen, 1898 
Baird, Rev. James, The Emigrants Guide to Australasia: Tasmania and New Zealand with a Map of New Zealand, London, 1871

Barclay, Peter, Gearr-chunntasan air New Zealand: air son feuma luchd-imrich, Duneideann (Edinburgh), 1872

Bathgate, John, New Zealand: its resources and prospects, London and Edinburgh, 1880

Berry, John, New Zealand as a Field for Emigration. With Map, London, 1879

Bright, John, Handbook for Emigrants and Others: Being a History of New Zealand, its State and Prospects, Previous and Subsequent to the Proclamation of Her Majesty's Authority; also Remarks on the Climate and Colonies of the Australian Continent, London, 1841

Brodie, Walter, Remarks on the Past and Present State of New Zealand, its Government, Capabilities, and Prospects; with a Statement of the Question of the Land-claims, and Remarks on the New Zealand Company; also a Description (never before published) of its Indigenous Exports, and Hints on Emigration, the Result of Five Years’ Residence in the Colony, London, 1845

Burton, John Hill, The Emigrants' Manual: Australia, New Zealand, America and South Africa, Edinburgh, 1851

Cargill, John, Otago, New Zealand: Information for the Guidance of Intending Emigrants, Edinburgh, 1860

Donald, Louise, and W.S. MacDonald, (eds), Roll of the Graduates of the University of Aberdeen 1956-1970 with Supplement 1860-1955, Aberdeen, 1982

Earp, George Butler, Handbook for Intending Emigrants to the Southern Settlements of New Zealand, London, 1849

England, William, A Pamphlet That All Should Read Before Emigrating to Australia, New Zealand, America, Cape of Good Hope, and Other Places, London, 1877

Evans, H. Smith, A Map and a Guide to all the Emigration Colonies of Great Britain and America, London, 1852

Forsaith, Thomas S., A Hand-book for Emigrants to New Zealand, London, 1858

Gann, Amos John, The New Zealand Emigration Circular for 1852, London, 1852 
Johnstone, Colonel William, (ed.), Roll of Graduates of the University of Aberdeen 1860-1900, Aberdeen, 1906

MacKintosh, John, (ed.), Roll of the Graduates of the University of Aberdeen 19261955 with supplement 1860-1925, Aberdeen, 1960

Matthew, Patrick, Emigration Fields: North America, the Cape, Australia, and New Zealand; Describing These Countries, and Giving a Comparative View of the Advantages They Present to British Settlers, Edinburgh and London, 1839

Scottish Interest Group, New Zealand Society of Genealogists, Register of New Zealand Immigrants of Scottish Birth Arriving Before 1 January 1921, Volume 1, Part 1, 1999

Scottish Interest Group, New Zealand Society of Genealogists, Register of New Zealand Immigrants of Scottish Birth Arriving Before 1 January 1921, Volume 1, Part 2, 2005

Shennan, Hay, Boundaries of Counties and Parishes in Scotland as Settled by the Boundary Commissioners Under the Local Government (Scotland) Act, 1889, Edinburgh, 1892.

Watt, Theodore, (ed.), Roll of the Graduates of the University of Aberdeen 1901-1925 with Supplement 1860-1900, Aberdeen, 1935

Willis, Arthur, Gann and Co., The New Zealand "Emigrant's Bradshaw”, or, Guide to the "Britain of the South", London, 1856

\section{Newspapers and Periodicals}

Aberdeen University Review, Vol.XX, No.58, November 1932

The Wanganui Herald, 6 January 1888

Shetland News, 21 February 1891

The New Zealand Tablet, Supplement, 20 December 1895

Evening Post, 30 April 1907

\section{Monumental Inscriptions}

Johnson, Gordon, (compiled by), The Kirkyard of Peterculter, Aberdeen, 1988 
Maxwell, A. Strath, (compiled by), Monumental Inscriptions, St. Nicholas Churchyard, Aberdeen, Scotland, Sections E, F, etc, Aberdeen, 1973

McHardy, Bill and Eileen, (compiled by), The Cemetery of Peterculter, Aberdeen, 2006

Shetland Family History Society:

Parish of Northmavine: Monumental Inscriptions, Vol.1, 1999.

Parish of Bressay: Monumental Inscriptions, Vol.2, 2000.

Parish of North and South Nesting: Monumental Inscriptions, Vol.3, 2000.

Parish of Burra: Monumental Inscriptions, Vol.4, 2000.

Parish of Delting: Monumental Inscriptions, Vol.5, 2000.

Parish of Whalsay and Skerries: Monumental Inscriptions, Vol.6, 2000.

Parish of Whiteness and Weisdale: Monumental Inscriptions, Vol.7, 2000.

Parish of Sandsting: Monumental Inscriptions, Vol.8, 2000.

Parish of Aithsting: Monumental Inscriptions, Vol.9, 2000.

Parish of Lannasting: Monumental Inscriptions, Vol.10, 2000.

Parish of Unst: Monumental Inscriptions, Vol.11, 2000.

Parish of Tingwall: Monumental Inscriptions, Vol.12, 2000.

Parish of Dunrossness (south) and Fair Isle: Monumental Inscriptions, Vol.13, 2000 .

Parish of Dunrossness (north): Monumental Inscriptions, Vol.14, 2000.

Parish of Sandwick: Monumental Inscriptions, Vol.15, 2000.

Parish of Cunningsburgh: Monumental Inscriptions, Vol.16, 2000.

Parish of Quarff and Gulberwick: Monumental Inscriptions, Vol.17, 2001.

Parish of Lerwick (1) (Knab Road, Queen's Lane and Sound): Monumental Inscriptions, Vol.18, 2001.

Parish of Lerwick (2) (New Cemetery - Lower Section Town Side): Monumental Inscriptions, Vol.19, 2001.

Parish of Lerwick (3) (New Cemetery - Lower Section Knab Side): Monumental Inscriptions, Vol.20, 2001.

Parish of Lerwick (4) (New Cemetery - Upper Section Town Side): Monumental Inscriptions, Vol.21, 2001.

Parish of Lerwick (6) (New Cemetery - Upper Section Knab Side): Monumental Inscriptions, Vol.22, 2001.

Parish of Walls (Including Vaila and Foula): Monumental Inscriptions, Vol.23, 2001.

Parish of Sandness (Including Papa Stour): Monumental Inscriptions, Vol.24, 2002. 
Parish of North Yell and Fetlar: Monumental Inscriptions, Vol.25, 2002.

Parish of Mid and South Yell: Monumental Inscriptions, Vol.26, 2002.

Monumental Inscriptions from printed sources and early transcriptions, Vol.27, 2003.

Spiers, Sheila M., (compiled by), The Kirkyard of St. Clements (Aberdeen), Aberdeen, 1988

Spiers, Sheila M., (compiled by), The Kirkyard of Alford, Aberdeen, 1991

Spiers, Sheila M., (compiled by), The Kirkyard of Foveran, Aberdeen, 2005

\section{$\underline{\text { SECONDARY SOURCES }}$}

\section{Published}

\section{Books}

Aitchison, Peter, and Andrew Cassell, The Lowland Clearances: Scotland's Silent Revolution, 1760-1830, East Linton, 2003

Akenson, Donald Harman, Half the World from Home: Perspectives on the Irish in New Zealand, 1860-1950, Wellington, 1990

Alexander, Ruth, Gail Gibson, and Alan J. La Roche, The Royal New Zealand Fencibles, 1847-1852, Auckland, 1997

Arnold, Rollo, The Farthest Promised Land: English Villagers, New Zealand Immigrants of the 1870s, Wellington, 1981

Atkinson, Neill, Trainland: How Railways Made New Zealand, Auckland, 2007

Bade, James N., (ed.), The German Connection: New Zealand and German-speaking Europe in the Nineteenth Century, Auckland, 1993

Bagnall, A.G., Wairarapa: An Historical Excursion, Masterton, 1976

Belich, James, Making Peoples: A History of the New Zealanders from Polynesian Settlement to the End of the Nineteenth Century, Auckland, 1996

Belich, James, Paradise Reforged: A History of the New Zealanders from the 1880s to the Year 2000, Auckland, 2001

Bönisch-Brednich, Brigitte, Keeping a Low Profile: An Oral History of German Immigration to New Zealand, Wellington, 2002 
Brock, Jeanette M., The Mobile Scot: A Study of Emigration and Migration 18611911, Edinburgh, 1999

Brooking, Tom, And Captain of Their Souls: Cargill and the Otago Colonists, Dunedin, 1984

Buchan, James, Capital of the Mind: How Edinburgh Changed the World, London, 2003

Burdon, R.M. The Life and Times of Sir Julius Vogel, Christchurch, 1948

Burns, Patricia, Fatal Success: A History of the New Zealand Company, Auckland, 1989

Butterworth, Susan, Chips off the Auld Rock: Shetlanders in New Zealand, Wellington, 1997

Calder, Jenni, Scots in Canada, Edinburgh, 2003

Calder, Jenni, Scots in the USA, Edinburgh, 2006

Campbell, Felicity, Making Waves: Captain Jock McGregor - Shipmaster, Wanganui Pioneer, Wellington, 2004

Campbell, R.H., The Rise and Fall of Scottish Industry, 1707-1939, Edinburgh, 1980

Campion, M. H., The Road to Mangamahu: A History of the Whangaehu River Valley from Reid's Hill to Mt View, Wanganui, 1988

Carter, Ian, Farm Life in Northeast Scotland 1840-1914: The Poor Man's Country, Edinburgh, 1979

Clapham, Ian, Pukehou: The Frasers of Lower Rangitikei: Family Tree of the Descendants of Duncan and Marjory Fraser, 1795-1995, Feilding, 1996

Clark, Megan J. and John A. Randal, A First Course in Applied Statistics - with Applications in Biology, Business and the Social Sciences, Auckland, 2004

Condliffe, J.B. and Airey, W.T.G., A Short History of New Zealand, Auckland, 1954

Condliffe, J.B., New Zealand in the Making: a Survey of Economic and Social Development, London, 1930

Coppock, J.T., An Agricultural Atlas of Scotland, Edinburgh, 1976

Dalziel, Raewyn, Sir Julius Vogel, Wellington, 1968 
Dalziel, Raewyn, Julius Vogel: Business Politician, Auckland, 1986

Devine, T.M., Scotland's Empire and the Shaping of the Americas 1600-1815, Washington, 2003

Devine, T.M., The Great Highland Famine: Hunger, Emigration, and the Scottish Highlands in the Nineteenth Century, Edinburgh, 1988

Devine, T.M., The Scottish Nation: 1700-2000, London, 1999

Devine, T.M., The Tobacco Lords: A Study of the Tobacco Merchants of Glasgow and Their Trading Activities, c. 1740-90, Edinburgh, 1975

Devine, T.M., The Transformation of Rural Scotland: Social Change and the Agrarian Economy, 1660-1815, Edinburgh, 1994

Dickson, R.J., Ulster Emigration to Colonial America, 1718-1775, London, 1966

Donaldson, Gordon, The Scots Overseas, London, 1966

Dunn, Waldo Hilary, and Ivor L.M. Richardson, Sir Robert Stout: A Biography, Wellington, 1961

Elliott, Bruce S., Irish Migrants in the Canadas: A New Approach, Kingston and Montreal, 2004

Erickson, Charlotte, Invisible Immigrants: The Adaptation of English and Scottish Immigrants in 19th Century America, London, 1972

Flinn, Michael, Scottish Population History from the 17th century to the 1930s, Cambridge, 1977

Fraser, Lyndon, (ed.), A Distant Shore: Irish Migration and New Zealand Settlement, Dunedin, 2000

Fraser, Lyndon, Castles of Gold: A History of New Zealand's West Coast Irish, Dunedin, 2007

Fry, Michael, The Scottish Empire, Edinburgh, 2001

Fry, Michael, Wild Scots: Four Hundred Years of Highland History, London, 2005

Fyfe, Frank and Bebe Douglas, Morvern to Glenmorven, Masterton, 2000

Gardner, W.J., A Pastoral Kingdom Divided: Cheviot, 1889-94, Wellington, 1992 
Gardner, W.J., The Amuri: A County History, 2nd ed, Culverden, 1983

Gillespie, R., Colonial Ulster: The Settlement of East Ulster, 1600-1641, Cork, 1985

Gjerde, Jon, From Peasants to Farmers: The Migration from Balestrand, Norway, to the Upper Middle West, Cambridge, 1985

Glasson, H.A., The Golden Cobweb (A Saga of the Otago Goldfields, 1861-1864), Dunedin, 1957

Gray, Malcolm, Scots on the Move: Scots Migrants 1750-1914, Glasgow, 1990

Griffiths, G.J., (ed.), The Advance Guard, Series 1, Dunedin, 1973

Griffiths, G.J., (ed.), The Advance Guard, Series 2, Dunedin, 1974

Griffiths, G.J., (ed.), The Advance Guard, Series 3, Dunedin, 1974

Grosjean, Alexia and Steve Murdoch (eds), Scottish Communities Abroad in the Early Modern Period, Leiden and Boston, 2005

Hall-Jones, F.G., Historical Southland, Invercargill, 1945

Hall-Jones, F.G., Invercargill Pioneers, Invercargill, 1946

Hall-Jones, John, Martins Bay, Invercargill, 1987

Handley, J.E., The Agricultural Revolution in Scotland, Glasgow, 1963

Handley, J.E., Scottish Farming in the Eighteenth Century, London, 1953

Harper, Marjory, Adventurers and Exiles: the Great Scottish Exodus, London, 2003

Harper, Marjory, and Michael Vance, Myth, Migration and the Making of Memory: Scotia and Nova Scotia, c.1700-1990 Edinburgh, 1999

Harper, Marjory, Emigration from North-East Scotland: Beyond the Broad Atlantic, Aberdeen, 1988

Harper, Marjory, Emigration from North-East Scotland: Willing Exiles, Aberdeen, 1988

Harper, Marjory, Emigration from Scotland Between the Wars, Manchester, 1998

Harvie, Christopher, No Gods and Precious Few Heroes: Scotland 1914-1980, London, 1981

Hawke, G.R., The Making of New Zealand: An Economic History, Cambridge, 1985 
Hewitson, Jim, Far Off In Sunlit Places: Stories of the Scots in Australia and New Zealand, Edinburgh, 1998

Hill, Richard S., Policing the Colonial Frontier: The Theory and Practice of Coercive Social and Racial Control in New Zealand, 1767-1867, Part One, Wellington, 1986

Hilton, George W., The Truck System, Including a History of the British Truck Acts, 1465-1960, Cambridge, 1960

Hocken, T.M., Contributions to the Early History of New Zealand, London, 1898

Holcroft, M.H., Old Invercargill, Dunedin, 1976

Holm, Janet, Nothing But Grass and Wind: The Rutherfords of Canterbury, Christchurch, 1992

Horsman, John, The Coming of the Pakeha to Auckland Province, Wellington, 1971

Howard, Basil, Rakiura: A History of Stewart Island, New Zealand, Wellington and Dunedin, 1940

Hunter, Ian, Age of Enterprise: Rediscovering the New Zealand Entrepreneur 18801910, Auckland, 2007

Hunter, Ian, and Diana Morrow (eds), City of Enterprise: Perspectives on Auckland Business History, Auckland, 2006

Hunter, James, A Dance Called America: The Scottish Highlands, the United States and Canada, Edinburgh, 1995

Hutching, Megan, Long Journey for Sevenpence: Assisted Immigration to New Zealand from the United Kingdom 1947-1975, Wellington, 1999

Ip, Manying, (ed.), Unfolding History, Evolving Identity: the Chinese in New Zealand, Auckland, 2003

Johnstone, J. Laughton, A Kist of Emigrants, Shetland, Forthcoming (2010)

Johnston, Mike, Gold in a Tin Dish: the Search for Gold in Marlborough and Eastern Nelson, Volumes 1 and 2, Nelson, 1992 and 1993

Kamphoefner, Walter, The Westphalians: From Germany to Missouri, Princeton, 1987 
King, Michael, The Penguin History of New Zealand, Auckland, 2003

Knox, W.W., Industrial Nation: Work, Culture and Society in Scotland, 1800Present, Edinburgh, 1999

Laurenson, Graeme, A Kiwi in the Shetland Scattald, New Plymouth, 1980

Lea, K.J., G. Gordon and I.R. Bowler, A Geography of Scotland, Devon, 1977

Leitch, D.B., Railways of New Zealand, Devon, 1972

Leitch, David, and Stott, Bob, New Zealand Railways: the First 125 years, Auckland, 1988

Levitt, Ian, and Christopher Smout, The State of the Scottish Working-Class in 1843:

A Statistical and Spatial Enquiry Based on the Data from the Poor Law Commission Report of 1844, Edinburgh, 1979

Lloyd Prichard, Muriel F., An Economic History of New Zealand to 1939, Auckland, 1970

Macdonald, Charlotte, A Woman of Good Character: Single Women as Immigrant Settlers in Nineteenth-Century New Zealand, Wellington, 1990

MacDonald, Gordon, The Highlanders of Waipu, or, Echoes of 1745: A Scottish Odyssey, Dunedin, 1925

MacKenzie, John M., The Scots in South Africa: Ethnicity, Identity, Gender and Race, 1772-1914, Manchester, 2007

Mackenzie, Mrs Peter, Pioneers of Martins Bay: the Story of New Zealand's Most Remote Settlement, Christchurch, 1952

Macmillan, David S., Scotland and Australia, 1788-1850: Emigration, Commerce and Investment, London, 1967

Marais, J.S., The Colonisation of New Zealand, London, 1968

May, Phillip Ross, Hokitika: Goldfields Capital, Christchurch, 1964

May, Phillip Ross, The West Coast Gold Rushes, Christchurch, 1962

McAloon, Jim, No Idle Rich: The Wealthy in Canterbury and Otago, 1840-1914, Dunedin, 2002 
McCarthy, Angela, (ed.), A Global Clan: Scottish Migrant Networks and Identities Since the Eighteenth Century, London, 2006

McCarthy, Angela, Irish Migrants in New Zealand, 1840-1937: 'The Desired Haven', Woodbridge, 2005

McCarthy, Angela, Personal Narratives of Irish and Scottish Migration, 1921-65: 'For Spirit and Adventure', Manchester, 2007

McDonald, Rob, Dannevirke: The Early Years, Hastings, 2002

McLean, Marianne, The People of Glengarry: Highlanders in Transition, 1745-1820, Montreal and Kingston, 1991

McLeod, Samuel Edward, (compiled by), Idyll of the Shipbuilders: Being a Brief Account of the Life and Migrations of the Families from the Highlands of Scotland that Finally settled at Waipu, North Auckland, Waipu, 1995

McLintock, A.H., The History of Otago: The Origins and Growth of a Wakefield Class Settlement, Dunedin, 1949

McPherson, Flora, Watchman Against the World: The Remarkable Journey of Norman McLeod \& his people from Scotland to Cape Breton Island to New Zealand, Wreck Cove, Cape Breton, 1993

Molloy, Maureen, Those Who Speak to the Heart: The Nova Scotian Scots at Waipu, 1854-1920, Palmerston North, 1991

Morrell, W.P., The Provincial System in New Zealand, 1852-76, Christchurch, 1964

Morrell, W.P., Vogel and his Public Works Policy, Wellington, 1953

Ng, James, Windows on a Chinese Past, Dunedin, 1993

Nolan, Melanie, Breadwinning: New Zealand Women and the State, Christchurch, 2000

Olssen, Erik, A History of Otago, Dunedin, 1984

Olssen, Erik, and Hickey, Maureen, (eds), Class and Occupation: The New Zealand Reality, Dunedin, 2005

Page, Dorothy, Anatomy of a Medical School: A History of Medicine at the University of Otago, 1875-2000, Dunedin, 2008 
Patterson, Brad, (ed.), From Ulster to New Ulster: The 2003 Ulster-New Zealand Lectures, Coleraine, 2004

Patterson, Brad, (ed.), The Irish in New Zealand: Historical Contexts \& Perspectives, Wellington, 2002

Patterson, Brad, (ed.), Ulster-New Zealand Migration and Cultural Transfer, Dublin, 2006

Pearce, G.L., The Scots of New Zealand, Auckland, 1976

Peterson, G.C., Forest Homes: The Story of the Scandinavian Settlements in the Forty Mile Bush, Wellington, 1956

Phillips, Jock, A Man's Country? The Image of the Pakeha Male - A History, Revised Edition, Auckland, 1996

Phillips, Jock, and Terry Hearn, Settlers: New Zealand Immigrants from England, Ireland and Scotland, 1800-1945, Auckland, 2008

Philpott, H.G., A History of the New Zealand Dairy Industry, 1840-1935, Wellington, 1937

Plant, G.F., Oversea Settlement: Migration from the United Kingdom to the Dominions, London, 1951

Platts, Una, The Lively Capital: Auckland 1840-1865, Christchurch, 1971

Pool, Ian, Arunachalam Dharmalingam and Janet Sceats, The New Zealand Family From 1840: A Demographic History, Auckland, 2007

Pooley, Colin, and Jean Turnbull, Migration and Mobility in Britain Since the $18^{\text {th }}$ Century, London, 1998

Prentis, Malcolm D., The Scots in Australia: A Study of New South Wales, Victoria and Queensland, 1788-1900, Sydney, 1983

Ray, Celeste, (ed.), Transatlantic Scots, Tuscaloosa, Alabama, 2005

Ray, Celeste, Highland Heritage: Scottish Americans in the American South, Chapel Hill, North Carolina, 2001

Reed, A. H., The Story of Otago: Age of Adventure, Wellington, 1947

Reeves, William Pember, The Long White Cloud, London, 1924 
Richards, Eric, Britannia's Children: Emigration from England, Scotland, Wales and Ireland Since 1600, London and New York, 2004

Richards, Eric, The Highland Clearances, Edinburgh, 2000

Robinson, Neil, Lion of Scotland: Being an Account of Norman McLeod's Forty Years' Search for a Land Where He and His Followers Could Live as They Wished; of the Voyage, in 1817, From the Western Highlands to Nova Scotia; to Australia in the 1850s; and Finally to New Zealand; and How They Built a Community for Themselves, London, 1952

Robinson, Neil, To the Ends of the Earth: Norman McLeod and the Highlanders' Migration to Nova Scotia and New Zealand, Auckland, 1997

Robinson, Philip S., The Plantation of Ulster: British Settlement in an Irish Landscape, Dublin, 1984

Roxburgh, Irvine, Jacksons Bay: A Centennial History, Wellington, 1976

Runblom, Harald, and Hans Norman (eds). From Sweden to America: A History of the Migration, Minneapolis, 1976

Sansom, Olga, In the Grip of an Island: Early Stewart Island History, Invercargill, 1982

Simkin, C. G. F., The Instability of a Dependent Economy: Economic Fluctuations in New Zealand, 1840-1914, London, 1951

Simpson, Tony, The Immigrants: The Great Migration From Britain to New Zealand, 1830-1980, Auckland, 1997

Sinclair, Keith, A History of New Zealand, Auckland, 2000

Smith, Hance D., Shetland Life and Trade, 1550-1914, Edinburgh, 1984

Sutherland, Alex, Sutherlands of Ngaipu, Wellington, 1947

Thomson, A. G., The Paper Industry in Scotland, Edinburgh, 1974

Thomson, Jane, (ed.), Southern People: A Dictionary of Otago Southland Biography, Dunedin, 1998

Voelkerling, Rex H. and Kevin L. Stewart, From Sand to Papa: A History of the Wanganui County, Wanganui, 1986 
Wagner, Gillian, Children of the Empire, London, 1982

Wainwright, F.T., The Northern Isles, Edinburgh, 1962

Ward, Louis E., Early Wellington, Wellington, 1928

Whatley, Christopher A., The Industrial Revolution in Scotland, Cambridge, 1997

White, Marie, (ed.), Lakes District of Wanganui, Wanganui, 1997

Whittow, J.B. Geology and Scenery in Scotland, Harmondsworth, Middlesex, 1977

Whyte, I.D., Scotland Before the Industrial Revolution, London, 1995

Wilson, James G., Early Rangitikei: A Few Notes, Collected from Various Sources of the Settlement on the Rangitikei River of a Number of Maoris of Different Tribes. A Short History of the Purchase and Colonization of the Land Between the Turakina and Oroua Rivers, and an Account of the Various Pioneers, Christchurch, Wellington and Dunedin, 1914

Wilson, John, Cheviot: Kingdom to County, Cheviot, 1993

Withers, Charles W.J., Gaelic in Scotland, 1698-1981: The Geographical History of a Language, Edinburgh, 1984

Withers, Charles W.J., Urban Highlanders: Highland-Lowland Migration and Urban Gaelic Culture, 1700-1900, East Lothian, 1998

Wright St Clair, R., Caring for People: Wanganui Hospital Board, 1885-1985, Wanganui, 1987

Yska, Redmer, Wellington: Biography of a City, Auckland, 2006

\section{Book Sections}

Akenson, Donald Harman, 'What did New Zealand do to Scotland and Ireland?', in Brad Patterson (ed.), The Irish in New Zealand: Historical Contexts and Perspectives, Wellington, 2002

Basu, Paul, 'Roots tourism as return movement: semantics and the Scottish diaspora', in Marjory Harper, (ed.), Emigrant Homecomings: the Return Movement of Emigrants, 1600-2000, Manchester, 2005 
Bönisch-Brednich, Brigitte, 'Gendering German migration experiences in the 1980s and 1990s', in Lyndon Fraser and Katie Pickles (eds.), Shifting Centres: Women and Migration in New Zealand History, Dunedin, 2002

Bremner, Julie A., 'Charles Suisted', in G.J. Griffiths (ed.), The Advance Guard: Series Two, Dunedin, 1974

Brooking, Tom, “Tam McCanny and Kitty Clydeside' - the Scots in New Zealand', in R.A. Cage (ed.), Scots Abroad, London, 1985

Brooking, Tom, 'Economic transformation', in Geoffrey Rice (ed.), The Oxford History of New Zealand, Second Edition, Auckland, 1992

Brooking, Tom, 'Introduction', in Tom Brooking and Jennie Coleman (eds), The Heather and the Fern: Scottish Migration and New Zealand Settlement, Dunedin, 2003

Brooking, Tom, 'Sharing out the haggis: the special Scottish contribution to New Zealand history', in Tom Brooking and Jennie Coleman (eds), The Heather and the Fern: Scottish Migration and New Zealand Settlement, Dunedin, 2005

Burns, Robert, 'The gloomy night is gath'ring fast,' in James Kinsley (ed.), The Poems and Songs of Robert Burns, Oxford, 1968

Campbell, R.H. and Devine, T.M., 'The rural experience', in W. Hamish Fraser and R. J. Morris (eds), People and Society in Scotland, 1830-1914, Edinburgh, 1990

Campbell, R.H., 'Scotland' in R.A. Cage, (ed.), Scots Abroad, 1750-1914, London, 1985

Catterall, Douglas, 'Scots along the Maas, c.1570-1750', in Alexia Grosjean and Steve Murdoch (eds), Scottish Communities Abroad in the Early Modern Period, Leiden and Boston, 2005

Constantine, Stephen, 'Empire migration and social reform, 1880-1950', in Colin G.

Pooley and Ian D. Whyte (eds), Migrants, Emigrants and Immigrants, London, 1991

Constantine, Stephen, 'Immigration and the making of New Zealand, 1918-1939', in Stephen Constantine (ed.), Emigrants and Empire: British Settlement in the Dominions Between the Wars, Manchester, 1990 
Constantine, Stephen, 'Introduction: Empire migration and imperial harmony', in Stephen Constantine (ed.), Emigrants and Empire: British Settlement in the Dominions Between the Wars, Manchester, 1990

Cook, Len, 'Constraints and conflicts in access to official statistics and statistical records', in New Zealand Archives Futures: Essays in Honor of Michael Hoare, ed. Brad Patterson, Wellington, 1996

Devine, T.M., 'Social responses to agrarian improvement: the Highland and Lowland clearances in Scotland, 1500-1800', in R.A. Houston, and I.D. Whyte (eds), Scottish Society, 1500-1800, Cambridge, 1989

Doherty, J., 'Urbanization in Scotland, 1750-1914', in G. Wittington and I. D. Whyte (eds), An Historical Geography of Scotland, London, 1983

Duncan, J.S., 'The land for the people: land settlement and rural population movements, 1886-1906', in Land and Livelihood: Geographical Essays in Honour of George Jobberns, ed. Murray McCaskill, Christchurch, 1962

Erickson, C.J., 'Who were the English and Scots emigrants to the United States in the late nineteenth century?,' in D.V. Glass and Roger Revelle (eds), Population and Social Change, London, 1972

Fedorowich, Kent, 'The assisted emigration of British ex-servicemen to the dominions, 1914-192', in Stephen Constantine (ed.), Emigrants and Empire: British Settlement in the Dominions Between the Wars, Manchester, 1990

Fitzgerald, Patrick, 'Scottish migration to Ireland in the seventeenth century', in Alexia Grosjean and Steve Murdoch (eds), Scottish Communities Abroad in the Early Modern Period, Leiden and Boston, 2005

Frank, Tim, 'Bread queues and breadwinners: gender in the 1930s', in Caroline Daley and Deborah Montgomerie (eds), The Gendered Kiwi, Auckland, 1999

Gordon, G., 'Industrial development, c. 1750-1980', in G. Wittington and I.D. Whyte (eds), An Historical Geography of Scotland, London, 1983

Gothard, Janice, “The healthy, wholesome British domestic girl': single female migration and the Empire Settlement Act, 1922-1930', in Stephen Constantine (ed.), Emigrants and Empire: British Settlement in the Dominions Between the Wars, Manchester, 1990 
Grosjean, Alexia and Steven Murdoch, 'The Scottish community in seventeenthcentury Gothenburg', in Scottish Communities Abroad in the Early Modern Period, ed. Alexia Grosjean and Steven Murdoch, Leiden and Boston, 2005

Harper, Marjory, 'Introduction', in Marjory Harper, (ed.), Emigrant Homecomings: the Return Movement of Emigrants, 1600-2000, Manchester, 2005

Hearn, Terry, 'Scots miners in the goldfields, 1861-1870', in Tom Brooking and Jennie Coleman (eds), The Heather and the Fern: Scottish Migration and New Zealand Settlement, Dunedin, 2005

Jones, H., 'Population from c. 1600', in G. Wittington and I.D. Whyte (eds), An Historical Geography of Scotland, London, 1983

Linge, G.J.R., 'Manufacturing in New Zealand: four years in a century of growth' in R.F. Watters (ed.), Land and Society in New Zealand: essays in historical geography, Wellington, 1965

Macdonald, Charlotte, 'Too many men and too few women: gender's 'fatal impact' in nineteenth-century colonies', in Caroline Daley and Deborah Montgomerie (eds), The Gendered Kiwi, Auckland, 1999

McAloon, Jim, 'Scots and the colonial economy', in Tom Brooking and Jennie Coleman, (eds) The Heather and the Fern: Scottish Migration and New Zealand Settlement, Dunedin, 2003

McAloon, Jim, 'Scots, networks and the colonial economy: the nineteenth-century business relationships of Sanderson and Murray of Galashiels and Murray, Roberts and Co of Dunedin', in John MacKenzie and Brad Patterson, (eds) Scots Abroad: The New Zealand Scots in International Perspective, forthcoming.

McAloon, Jim, 'The New Zealand economy, 1792-1914', in The New Oxford History of New Zealand, ed. Giselle Byrnes, Melbourne, 2009

McCarthy, Angela, "For spirit and adventure": Personal accounts of Scottish migration to New Zealand, 1921-1961', in Tom Brooking and Jennie Coleman (eds), The Heather and the Fern: Scottish Migration and New Zealand Settlement, Dunedin, 2005 
McCaskill, Murray, 'The South Island goldfields in the 1860s: some geographical aspects', in Land and Livelihood: Essays in Honour of George Jobberns, ed. Murray McCaskill, Christchurch, 1962

McClean, R.R., 'Scottish piety: the Free Church settlement of Otago, 1848-1853', in John Stenhouse and Jane Thomson (eds), Building God's Own Country: History Essays on Religions in New Zealand, Dunedin, 2004

McKenzie, Dorothy, 'Suisted, Charles Eberhard (1810-1860) and Mary Emma (18171860)', in Jane Thomson (ed.), Southern People: A Dictionary of Otago Southland Biography, Dunedin, 1998

Ó Gráda, Cormac, 'Across the briny ocean: some thoughts on Irish emigration to America, 1800-1850', in T.M. Devine and David Dickson (eds), Ireland and Scotland 1600-1850: Parallels and Contrasts in Economic and Social Development, Edinburgh, 1983

Olssen, Erik, 'Lands of sheep and gold: The Australian Dimension to the New Zealand past, 1840-1900', in Keith Sinclair (ed.), Tasman Relations: New Zealand and Australia, 1788-1988, Auckland, 1987

Patterson, Brad, 'A "half Australian, half American" town: the economic foundations of nineteenth century Wellington', in Jack McConchie, David Winchester, and Richard Willis (eds), Dynamic Wellington: a Contemporary Synthesis and Explanation of Wellington, Wellington, 2000

Pederson, Nina Østby, 'Scottish immigration to Bergen in the sixteenth and seventeenth centuries', in Scottish Communities Abroad in the Early Modern Period, ed. Alexia Grosjean and Steve Murdoch, Leiden and Boston, 2005

Pickles, Katie, 'Pink cheeked and surplus: single British women's inter-war migration to New Zealand', in Lyndon Fraser and Katie Pickles (eds), Shifting Centres: Women and Migration in New Zealand History, Dunedin, 2002

Prentis, M. D., 'The settlers: Scots: The condition of Scotland 1788-1860', in James Jupp (ed.), The Australian People: An Encyclopedia of the Nation, its People and Their Origins, North Ryde, New South Wales, 1988 
Riach, Alan, 'Heather and Fern: The Burns effect in New Zealand verse' in Tom Brooking and Jennie Coleman (eds), The Heather and the Fern: Scottish Migration and New Zealand Settlement, Dunedin, 2003

Richards, Eric, 'Running home from Australia: Intercontinental mobility and migrant expectations in the nineteenth century', in Marjory Harper, (ed.), Emigrant Homecomings: The Return Movement of Emigrants, 1600-2000, Manchester, 2005

Scotter, W.H., 'The moderate success of the assisted immigration scheme', in $A$ History of Canterbury Vol.II, ed. W.J. Gardner, 1971

Sprecher, Danielle, 'Good clothes are good business: Gender, consumption and appearance in the office, 1918-1939', in Caroline Daley and Deborah Montgomerie (eds), The Gendered Kiwi, Auckland, 1999

Thomson, Alistair, “My wayward heart': homesickness, longing and the return of the British post-war immigrants from Australia', in Marjory Harper, (ed.), Emigrant Homecomings: The Return Movement of Emigrants, 1600-2000, Manchester, 2005

Thomson, David, 'Marriage and family on the colonial frontier', in Tony Ballantyne and Brian Moloughney (eds), Disputed Histories: Imagining New Zealand's Past, Dunedin, 2006

Treble, J.H., 'The occupied male labour force', in W. Hamish Fraser and R.J. Morris (eds), People and Society in Scotland, 1830-1914, Edinburgh, 1990

Watters, R.F., 'Appendix I: A note on urban growth in New Zealand', in R.F. Watters (ed.), Land and Society in New Zealand: Essays in Historical Geography, Wellington, 1965

Watters, R.F., 'Change and the New Zealand scene', in R.F. Watters (ed.), Land and Society in New Zealand: Essays in Historical Geography, Wellington, 1965

Whyte, I.D., 'Early Modern Scotland: continuity and change', in G. Wittington and I.D. Whyte (eds), An Historical Geography of Scotland, London, 1983

Winder, Gordon, 'Making space: clusters and districts in Auckland manufacturing 1889-1908', in Ian Hunter and Diana Morrow (eds), City of Enterprise: Perspectives on Auckland Business History, Auckland, 2006 
Wittington, G., 'Agriculture and Society, 1750-1870', in G. Wittington and I.D. Whyte (eds), An Historical Geography of Scotland, London, 1983

Young, John R., 'Scotland and Ulster in the seventeenth century: the movement of peoples over the North Channel', in W. Kelly and J.R. Young (eds), Ulster and Scotland 1600-2000: History, Language and Identity, Dublin, 2004

Zickermann, Kathrin, “Briteannia ist mein patria': Scotsmen and the 'British' community in Hamburg', in Alexia Grosjean and Steve Murdoch (eds), Scottish Communities Abroad in the Early Modern Period, Leiden and Boston, 2005

Zirgulis, Rimantas, 'The Scottish community in Kèdainiai c.1630-c.1750', in Alexia Grosjean and Steve Murdoch (eds), Scottish Communities Abroad in the Early Modern Period, Leiden and Boston, 2005

\section{Articles, Working Papers, Conference Proceedings}

'Dr. Gray Hassell', Cyclopaedia of New Zealand, Volume 1, Wellington Provincial District, 1897, pp.357-8

'Mining and Mineral Resources: Coal' in A.H. McLintock, (ed.), An Encyclopaedia of New Zealand, 1966, accessed via Te Ara - the Encyclopedia of New Zealand, updated 18 September 2007

'Mr. James Robertson Thomson', Cyclopaedia of New Zealand, Volume 4, Otago and Southland Provincial Districts, 1905, p.893

'Mr. Robert Scollay', Cyclopaedia of New Zealand, Volume 4, Otago and Southland Provincial Districts, 1905, p.892.

'Onslow settlers of the 1840s: Donald MacDonald', The Onslow Historian: Official Journal of the Onslow Historical Society Inc., Vol.18, No.4, 1988, pp.4-11

Adams, Ian H., and Whyte, I.D., 'The agricultural revolution in Scotland: contributions to the debate', Area, Vol.10, No.3, 1978, pp.198-205

Arnold, Rollo, 'The dynamics and quality of Trans-Tasman migration, 1886-1910', Australian Economic History Review, Vol.26, No.1, 1986, pp.1-20

Arnold, Rollo, 'Yeomen and nomads: New Zealand and the Australasian shearing scene, 1886-1896', NZJH, Vol.18, No.2, 1984, pp.117-142 
Blaustein, Richard, 'Review of The Crooked Stovepipe: Athapaskan Fiddle Music and Square Dancing in Northeast Alaska and Northwest Canada, by Craig Mishler', American Music, Vol.13, No.4, Winter, 1995, pp.492-494

Bönisch-Brednich, Brigitte, 'Being German in Wellington: female perspectives', National Oral History Association of New Zealand Journal, Vol.11, 1999, pp.23-29

Bremner, Julie, 'Old Kaiwarra', The Onslow Historian: Official Journal of the Onslow Historical Society Inc., Vol.10, No.2, 1980, pp.2-3

Bremner, Julie, 'The Kai Warra Road and Khandallah in the 1840s', The Onslow Historian: Official Journal of the Onslow Historical Society Inc., Vol.7, Nos. 3 and 4, 1977, pp.39-42

Bueltmann, Tanja, “'Where the measureless ocean between us will roar”: Scottish emigration to New Zealand, personal correspondence and epistolary practices, c1850-1920', Immigrants \& Minorities Vol.26, No.3, 2008, pp. 242-65.

Campbell, R.J., 'The "Black Eighties": unemployment in New Zealand in the 1880s', Australian Economic History Review, Vol.16, 1976, pp.67-82

Critchfield, Howard J., 'The growth of pastoralism in Southland, New Zealand', Economic Geography, Vol.30, No.4, 1954, pp.283-300

Cumberland, Kenneth B., 'The agricultural regions of New Zealand', The Geographical Journal, Vol.112, No.1/3, Jul-Sep, 1948, pp.43-63

Dalziel, Raewyn, 'The colonial helpmeet: women's role and the vote in nineteenthcentury Auckland', NZJH, Vol.11, No.2, 1977, pp.112-123

Davidson, Allan K., 'Fraser, Philadelphus Bain 1862 - 1940', DNZB, updated 22 June 2007

Davis, Brian R., 'Maclaurin, James Scott 1864 - 1939', DNZB, updated 22 June 2007

Devine, T.M., 'Temporary migration and the Scottish Highlands in the nineteenth century', The Economic History Review, New Series, Vol.32, No.2, August, 1979, pp.344-359

Dowie, J.P., 'Business politicians in action: the New Zealand railway boom of the 1870s', Business Archives and History, Vol.5, 1965, pp.32-56 
Dowie, J.P., 'The course and character of capital formation in New Zealand, 18711900’, New Zealand Economic Papers, Vol.1, 1966, pp.38-58

Dunstall, G., 'Comment on Miles Fairburn's, 'Social mobility and opportunity in nineteenth-century New Zealand', NZJH, Vol.13, No.1, April, 1979, pp.61-2

Elphick, Judith, 'What's wrong with Emma? the feminist debate in colonial Auckland', NZJH, Vol.9, No.2, 1975, pp.126-141

Erickson, Charlotte, 'Emigration from the British Isles to the U.S.A in 1831, Population Studies, Vol.35, No.2, July, 1981, pp.175-197

Erickson, Charlotte, 'Emigration from the British Isles to the U.S.A in 1841, Population Studies, Vol.43, No.2, November, 1989, pp.347-367

Fairburn, Miles, 'Social mobility and opportunity in nineteenth-century New Zealand', NZJH, Vol.13, No.1, April, 1979, pp.43-64

Fairburn, Miles, 'The rural myth and the new urban frontier: an approach to New Zealand social history, 1870-1940', NZJH, Vol.9, No.1, 1975, pp.3-21

Forrest, James, 'Population and settlement on the Otago goldfields, 1861-1870', New Zealand Geographer, Vol.17, No.1, April, 1961, pp.64-86

Galt, Margaret, 'Who came to New Zealand? New light on the origins of British settlers', New Zealand Population Review, Vol.21, No.1 and 2, 1995, pp.50-71

Gandar, John M., 'New Zealand net migration in the latter part of the nineteenth century', Australian Economic History Review, Vol.19, No.2, 1979, pp.151-168, p.161

Gibbons, Peter, 'Cultural colonization and national identity', NZJH, Vol.36, No.1, 2002, pp.5-17

Gibbons, Peter, 'The far side of the search for identity: reconsidering New Zealand history', NZJH, Vol.37, No.1, 2003, pp.38-49

Hamer, David, 'Stout, Robert 1844 - 1930’, DNZB, updated 22 June 2007

Hargreaves, R.P., and T.J. Hearn, 'Special Settlements of the South Island, New Zealand', New Zealand Geographer, Vol.37, No.2, 1981, pp.67-72 
Hawke, G.R., 'Disaggregation of the New Zealand labour force, 1871-1936', VUW Working Papers in Economic History, 79/1, January, 1979

Kennedy, Dane, 'Empire migration in post-war reconstruction: the role of the Oversea Settlement Committee, 1919-1922', Albion: A Quarterly Journal concerned with British Studies, Vol.20, No.3, 1988, pp.403-419

Maxwell, Ian, 'Around the world... The Shetland and Orkney Islands', Your Family Tree, July 2006, pp.54-57

McCarthy, Angela, 'Personal accounts of leaving scotland, 1921-1954', Scottish Historical Review, Vol.83, No.216, October 2004, pp.196-215

McCarthy, Angela, 'Personal letters, oral testimony, and Scottish migration to New Zealand in the 1950s: the case of Lorna Carter', Immigrants and Minorities, Vol.23, No.1, March 2005, pp.59-79

McCaskill, Murray, 'The goldrush population of Westland', New Zealand Geographer, Vol.12, No.1, April, 1956, pp.32-50

McClean, Rosalind, “Writing my history': seven nineteenth-century Scottish migrants to New Zealand revisit their pasts', Migrations and Identities, Vol.1, No.1, 2008, pp.45-73

McDonald, John, and Eric Richards, 'The great emigration of 1841: recruitment for New South Wales in British emigration fields', Population Studies, Vol.51, No.3, November 1997, pp.337-355

Mills, Dennis and Parry, M.L., 'A Scottish agricultural revolution?' Area, Vol.8, No.3, 1976, pp.237-239

Molloy, Maureen, "“No inclination to mix with strangers": marriage patterns among Highland Scots migrants to Cape Breton and New Zealand, 1800-1916', Journal of Family History, Vol.11, 1986, pp.221-243

Nathan, Simon, 'West Coast', Te Ara - the Encyclopedia of New Zealand, updated 2 February 2009

O’Connor, P.S., 'Keeping New Zealand white, 1908-20', NZJH, Vol.2, No.1, 1968, pp.41-65 
Ogilvie Buchanan, R., 'Sheep rearing in New Zealand', Economic Geography, Vol.7, No.4, Oct, 1931, pp.365-379

Parr, Norah, 'Kaiwarra or the village that was', The Onslow Historian: Official Journal of the Onslow Historical Society Inc., Vol.10, No.2, 1980, pp.4-9

Phillips, Jock, 'Who were New Zealand's founding Pakeha?', in Settling the Waikato and Beyond. Proceedings of the New Zealand Society of Genealogists 2006 Conference, Auckland, 2006

Phillips, Jock, 'History of Immigration', Te Ara - the Encyclopedia of New Zealand, updated 21 September 2007

Phillips, Jock, 'Rural Mythologies - Rural Myth Lives On, 1945-1975', updated 1 March 2009

Richards, Eric, 'Ironies of the Highland exodus, 1740-1900', The Journal of Australian Studies, Vol. 'Scatterlings of Empire', No.68, June, 2001, pp.74-85

Senften, Tim, 'Shetland's mining history', The New Shetlander, No.248, 2009, accessed at http://www.laplandica.com/2009/06/18/shetland\%E2\%80\%99smining-history/, 28 July 2009

Sherwood, Alan and Jock Phillips, 'Coal and Coal Mining', Te Ara - the Encyclopedia of New Zealand, updated 4 December 2008

Sinnott, Rex, 'The census and privacy in New Zealand: do privacy concerns justify destruction of name-identified census forms?' Archifacts, April, 2000, pp.25-50

Toynbee, Claire, 'Kinship and the decision to migrate: the experience of Scots migrants to New Zealand', New Zealand Population Review, Vol.26, No.1, May, 2000, pp.23-44

Wilson, John, 'The Voyage Out - Early Steamers', Te Ara - the Encyclopedia of New Zealand, updated 4 March 2009

Whittington, G., 'Was there a Scottish agricultural revolution?' Area, Vol.7, No.3, 1975, pp.204-206 


\section{UNPUBLISHED}

\section{Manuscripts and Unpublished Research}

Lloyd Pritchard Collection, correspondence collected for a book intended to be called 'Scots migrating to New Zealand', held at the New Zealand Society of Genealogists Library, Auckland.

Hearn, Terry and Jock Phillips, “Immigration study findings', unpublished manuscript, c.2007, available at: http://www.nzhistory.net.nz/culture/homeaway-from-home/sources

Maxwell, Val, 'Otago Settlers Pre-1861', New Zealand Society of Genealogists, Auckland, c.1989

\section{Theses and Research Essays}

Bueltmann, Tanja, “Brither Scots Shoulder tae Shoulder': Ethnic Identity, Culture and Associationism among the Scots in New Zealand to 1930', PhD Thesis, Victoria University of Wellington, 2008

Galbraith, Alasdair, 'New Zealand's Invisible Irish: Irish Protestants in the North Island of New Zealand 1840-1900', M.A. Thesis, University of Auckland, 1998

Galt, Margaret Nell, 'Wealth and Income in New Zealand c.1870 to c.1939', PhD Thesis, Victoria University of Wellington, 1985

Gibson, Campbell James, 'Demographic History of New Zealand', PhD Thesis, University of California, Berkeley, 1972.

Gordon, Leslie Geoffrey, 'Immigration into Hawke's Bay, 1856-1876', M.A. Thesis, Victoria University of Wellington, 1965

Hamer, D.A. 'The Law and the Prophet: A Political Biography of Sir Robert Stout (1844-1930)', M.A. Thesis, University of Auckland, 1960

Harland, Jill, forthcoming $\mathrm{PhD}$ Thesis, Otago University

Horn, Gerard, forthcoming PhD Thesis, Victoria University of Wellington.

Hudson, Paul, 'English Emigration to New Zealand, 1839 to 1850: An Analysis of the Work of the New Zealand Company’ PhD Thesis, University of Lancaster, 1996

Jessie M., Annabell, “Caledonia, Stern and Wild': Scottish Identity in Wanganui and Rangitikei, 1880-1918', M.A. Thesis, Massey University, 1995 
Jessie, Annabell, 'Smoke in the Hills? Representations of Turakina's Past', BA (Hons) Thesis, Massey University, 1993

Khan, Latiffa, 'Immigration into Wellington Province 1853-1876', PhD Thesis, Victoria University of Wellington, 1968

Macdonald, Charlotte J., 'Single Women as Immigrant Settlers in New Zealand, 1853-1871', PhD Thesis, University of Auckland, 1986

McClean, Rosalind, 'Scottish Emigrants to New Zealand, 1840-1880: Motives, Means and Background', PhD Thesis, University of Edinburgh, 1990

Morris, John, 'The Assisted Immigrants to New Zealand, 1871-79: a Statistical Study', M.A. Thesis, University of Auckland, 1973

Peden, Robert, 'Pastoralism and the Transformation of the Rangelands of the South Island of New Zealand, 1841 to 1912. Mt Peel Station, a Case Study', PhD Thesis, University of Otago, 2007

Phillips, J.R., 'A Social History of Auckland, 1840-1853', M.A. Thesis, University of Auckland, 1966

Ponton, F.A., 'Immigration restriction in New Zealand: a study of policy from 1908 to 1939', M.A. Thesis, Victoria University of Wellington, 1946

Powell, Debra, “It Was Hard to Die Frae Hame': Death, Grief and Mourning Among Scottish Migrants to New Zealand, 1840-1890', M.A. Thesis, University of Waikato, 2007

Sargison, Pat, “"Essentially a Woman's Work”: A History of General Nursing in New Zealand, 1830-1930', PhD Thesis, University of Otago, 2001

Silcock, R.H., 'Immigration into Canterbury under the Provincial Government', M.A. Thesis, University of Canterbury, 1963

Warburton, G.R., 'The Attitudes and Policies of the New Zealand Labour Movement Towards Non-European Immigration, 1878-1928', M.A. Thesis, University of Canterbury, 1982

Ward, Violet, 'Immigrants and Immigration in the Auckland Province 1792-1876', M.A. Thesis, University of Auckland, 1943 
Wilson, Megan J., 'Myth and Misunderstanding: The Enigma of the Scottish Highland Migrants to Otago/Southland, 1870-1879', M.A. Thesis, University of Otago 1999

\section{Conference Papers, Lectures, Seminars}

McAloon, Jim, 'Scottish Canterbury?', The Jim Gardner Lecture 2007, 5 August 2007

Patterson, Brad, "It Brings to Mind the Wild Valleys of Lovely Glencoe": The Scots in Early Wellington', Workshop on Scottish immigration to New Zealand, December 2005

Phillips, Jock, and Terry Hearn, 'The Peopling of New Zealand project: reflections', Seminar on Ethnic Counting: How Do We Measure Ethnic and Cultural Transfers in the British World?, 2 March 2007

Toynbee, Claire, 'LLooking Forward, Looking Back': Scots Migrants Talk', Nations, Diasporas, Identities, 29 March 2008

\section{Family Histories etc.}

'Higgie Family Tree', provided by Barbara Mariott.

Barnett-Drummuir, Phyllis, 'A Lassie from Lanarkshire', unpublished family history presented by Mrs Barnett-Drummuir

Barnett-Drummuir, Phyllis, 'Notes on the family of William Watson, born Cadder, 1775 ', family history notes prepared by Mrs Barnett-Drummuir

Bolland, Mary and Bruce, 'A Forward Pert Sett: a family history', privately produced family history, 2005, provided by Mary Bolland

Cameron, Tobe, 'Cameron of Kaiwharawhara: the First Three Generations in New Zealand', unpublished family history updated by Peter Hargreaves, provided by Jennifer Cameron

Lambert, Keith N. (compiled by), 'Sutherland Genealogical Tree'

Mulligan, Desiree Margaret, 'Mary Edie's biscuits and other interesting information about: the Edie Family of Edievale', 1996, unpublished family history provided by Desiree Mulligan

Rockel, Eliza, 'When the World was Young', unpublished recollections compiled for her family, provided by Theodora Wickham 
Ulyatt, M. J., 'The Kaiwarra Camerons: The First Fifty Years in New Zealand: 18401890', unpublished family history provided by M.J. Ulyatt

\section{Personal Correspondence}

Bobbie Amyes, 24 February 2009; 5 March 2009; 10 July 2009; 13 July 2009

Nan Bethune, 2 June 2009

Mary Bolland, 3 May 2009

Tanja Bueltmann, 24 July 2009

Jennifer Cameron, March 2006

Linda Dunn, 21 October 2007

Celia Geary, 26 October 2007

Jill Harland, 28 July 2009

Terry Hearn, 6 July 2007

Kae Lewis, 21 October 2007

Craig MacFarlane, June and July 2006

Alexa McPherson, 13 October 2007

Peter Moyes, 26 October; 1 November 2007

Jock Phillips, 21 March 2006

Marilyn Richer, 17 October 2007

Brian Smith, 24 July 2009

Claire Toynbee, 21 May 2009

Marlene Williamson, 30 October 2007

\section{WEBSITES AND ONLINE DATABASES}

\section{Databases}

'NZSG database' compiled by Rebecca Lenihan, based upon the New Zealand Society of Genealogists Scottish Interest Group's Register of New Zealand Immigrants of Scottish Birth Arriving Before 1 January 1921, Volume 1, Parts 1 and 2.

'PNZ database' compiled by Jock Phillips and Terry Hearn, for the 'Peopling of New Zealand' project for the Ministry of Culture and Heritage, New Zealand.

Shetland Family History Society database of Shetland migrants, available at the Shetland Family History Society research rooms Hillhead, Lerwick, Shetland 


\section{Online Databases}

'Shetland Family History Database', compiled by Tony Gott, accessed at http://bayanne.info/Shetland/

'Public Member Trees', available at ancestry.co.uk.

'RootsWeb's WorldConnect Project', available at http://www.rootsweb.ancestry.com/

\section{Family Material}

‘Badbea Families', http://www.badbeafamilies.com/index.html, accessed 6 July 2009

McKenzie, Lynne, 'McKenzie's from Scotland via Nova Scotia to New Zealand', last updated 31 December 2001, http://wc.rootsweb.ancestry.com, accessed 13 January 2009

\section{Passenger Lists}

Passenger list for the Blenheim, arrived Port Nicholas (Wellington), December 1840, http://freepages.genealogy.rootsweb.ancestry.com/ ourstuff/Blenheim.htm, accessed 30 October 2008

Passenger list for the Christian McAusland, arrived Otago, December 1872, http://freepages.genealogy.rootsweb.ancestry.com/ ourstuff/ChristianMcAusland72.h tm, accessed 27 July 2009

Passenger list for the Jessie Readman, arrived Port Chalmers, December 1873, http://freepages.genealogy.rootsweb.ancestry.com/ ourstuff/JessieReadman.htm, accessed 3 April 2009

Passenger list for ships arriving in Port Chalmers between 1897 and 1900, http://freepages.genealogy.rootsweb.ancestry.com/ shipstonz/portchalmers5.html, accessed 13 January 2009

\section{Other}

'Guide to Information Recorded on Birth and Death Entries', available at the Wellington Library website: http://www.wcl.govt.nz/popular/birthanddeath.html 'Highlanders', http://www.highlanders-rugby.co.nz/page.pasp?pageid=2, accessed 13 May 2009

Irish-Scottish Studies Programme, Research, 'Marsden fund Scottish migration to New Zealand project', http://www.victoria.ac.nz/stout-centre/researchunits/issp/projects/projects.aspx, accessed 26 September 2007

McKinlay, Graeme and David, 'McKinlay's of Dunedin, Home Page', http://www.mckinlays.co.nz/index.html, accessed 12 May 2009 
'Undiscovered Scotland: The Ultimate Online Guide: Unst', http://www.undiscoveredscotland.co.uk/unst/unst/index.html, accessed 5 June 2008. 